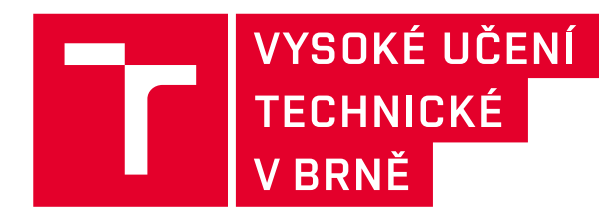

\title{
KONSTRUKCE ELEKTRONICKÝCH ZAŘÍZENÍ
}

\author{
prof. Ing. Kamil Vrba, CSc. \\ Ing. Pavel Hanák, PhD.
}

Vydání elektronické knihy podpořila Fakulta elektrotechniky a komunikačních technologií a Ústřrední knihovna VUT v Brně. Kniha je vydána zdarma a otevřeně pod veřejnou licencí Creative Comons - 4.0 Mezinárodní (CC BY 4.0).
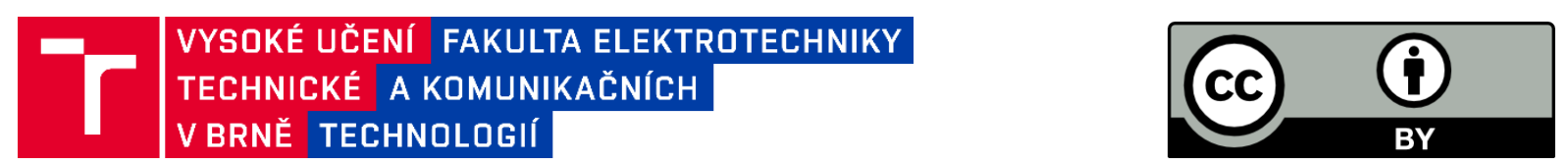
Autoři: prof. Ing. Kamil Vrba, CSc., Ing. Pavel Hanák, PhD.

Název: Konstrukce elektronických zařízení

Vydání: 1. vydání

Druh: e-kniha

Rok a měsíc vydání: 2021/06

Počet stran: 298

Náklad: e-publikace pod veřejnou licencí CC BY 4.0

Vědní obor: Elektrotechnika, elektronika, audio inženýrství, automatizační technika, výpočetní technika, telekomunikace, radioelektronika

Vydavatel: Vysoké učení technické v Brně, Nakladatelství VUTIUM

ISBN: 978-80-214-5957-1

DOI: $10.13164 /$ book.construction.electronic.devices

ANOTACE: Tato elektronická publikace představuje otevřený prrístup k odborným poznatkům a technickým dovednostem potřebným při konstrukci elektronických zařízení či přístrojů. Jsou vysvětleny zásady konstrukce a vlastnosti signálových spojů, doporučení pro rozvod napájení a rozvod zemního vodiče včetně doporučení pro výběr a konstrukci napájecích zdrojů, řešení problémů způsobených zemními smyčkami apod. Jsou uvedeny zásady a možnosti elektrostatického a magnetického stínění a také způsoby ekvipotenciálního stínění proti rušivým signálům. Dále jsou uvedena doporučení pro výběr a aplikační pravidla pro pasivní obvodové prvky jako jsou rezistory, kapacitory, induktory, krystalové rezonátory, nebo pro prvky užívané pro přepětové či nadproudové ochrany. Jsou také uvedeny zkušenosti a doporučení autorů při aplikacích aktivních prvků jako jsou operační zesilovače, vzorkovače a sledovače s pamětí, komparátory, časovače, převodníky $\mathrm{A} / \mathrm{D}$ a $\mathrm{D} / \mathrm{A}$ nebo pro číslicové obvody.

Autoři děkuji za technickou a odbornou pomoc při zpracováni knihy kolegyním Jitce Hoškové a Haně Lukešové. Za konzultace ke kapitole o impulsních zdrojích pak autoři děkuji Ing. Radkovi Tománkovi. 


\section{Obsah}

1 ÚVOD 6

$2 \quad$ KONSTRUKCE SIGNÁLOVÝCH SPOJUீ.......................................................................... 6

\begin{tabular}{|c|c|}
\hline 2.1 & NESYMETRICKÉ VEDENÍ . \\
\hline 2.2 & SYMETRICKÉ VEDENÍ..... \\
\hline 2.3 & VEDENÍ ELEKTRICKY KRÁTKÉ A ELEKTRICKY DLOUHÉ.. \\
\hline 2.4 & ELEKTRICKÉ PARAMETRY SPOJÜ \\
\hline 2.5 & PROVEDENÍ SPOJU゚ \\
\hline 2.5 .1 & Jednodrátové vodiče...... \\
\hline 2.5 .2 & Vícežilové kabely............ \\
\hline 2.5 .3 & 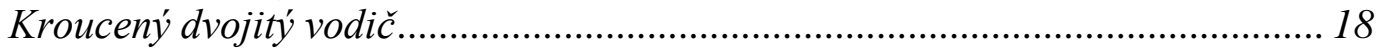 \\
\hline 2.5 .4 & Koaxiální a stíněné kabely ...... \\
\hline 2.5 .5 & 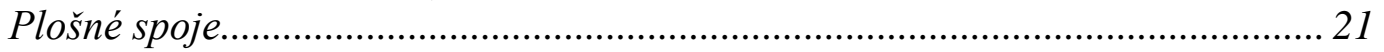 \\
\hline 2.5 .6 & Optické spoje.. \\
\hline
\end{tabular}

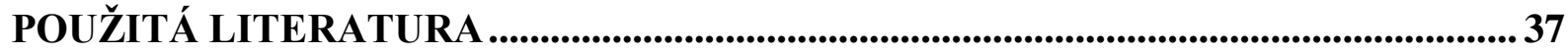

$3 \quad$ KONSTRUKCE NAPÁJECÍCH OBVODÜ............................................................. 38

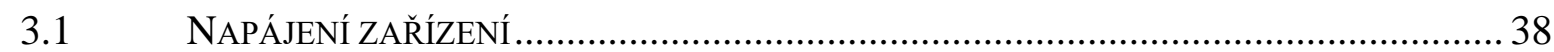

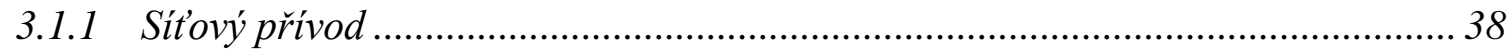

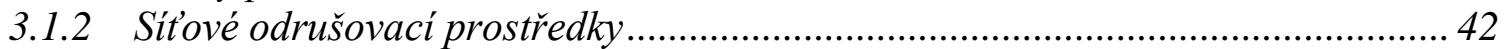

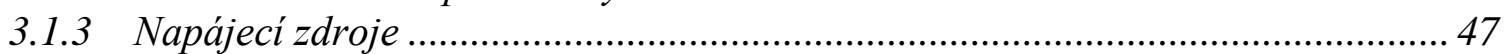

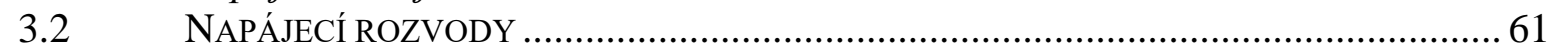

3.2.1 Rozvod napájení od zdroje k jednotlivým systémum ....................................... 61

$3.2 .2 \quad$ Rozvod napájení v jednotlivých částech zařizení ....................................... 64

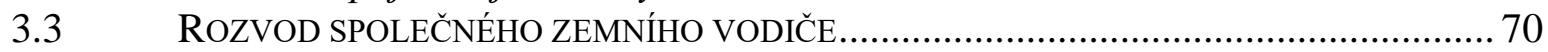

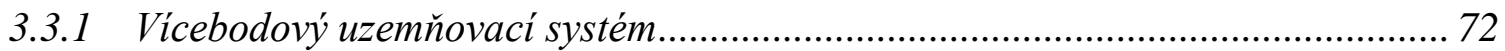

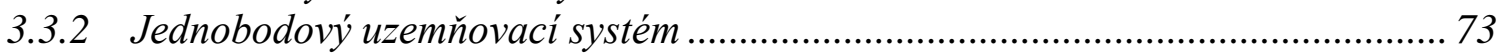

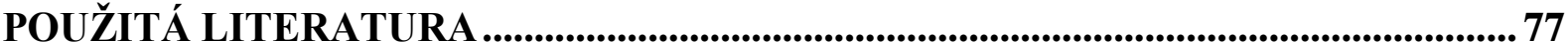

4 ZEMNÍ SMYČKY A ZPƯSOBY GALVANICKÉHO ODDĚLENÍ........................... 78

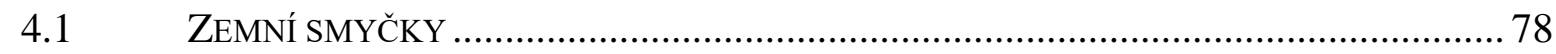

4.2 POTLAČENÍ RUŠIVÉHO NAPĚTÍ ZPU゚SOBENÉHO ZEMNÍ SMYČKOU ............................79

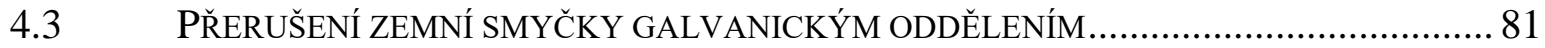

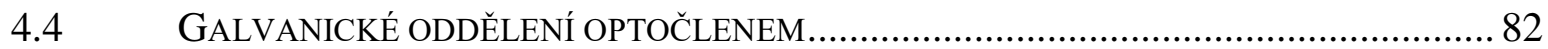

$4.5 \quad$ GALVANICKÉ ODDĚLENÍ IMPULSNÍMI TRANSFORMÁTORY ............................... 87

4.6 GALVANICKÉ ODDĚLENÍ VYSOKONAPĚŤOVÝMI KAPACITORY ..............................99

$4.7 \quad$ GALVANICKÉ ODDĚLENÍ AUDIOSIGNÁLŮ ......................................................... 95

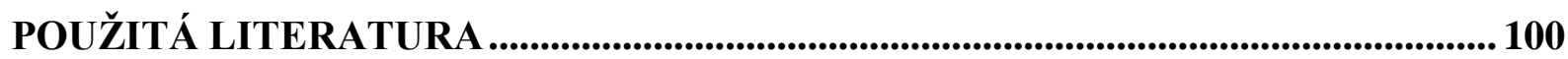

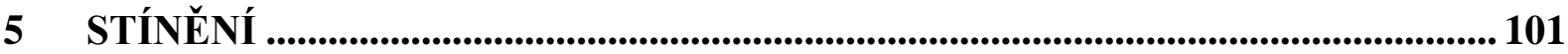

5.1 STÍNĚNÍ ELEKTRICKÉHO POLE .................................................................... 101

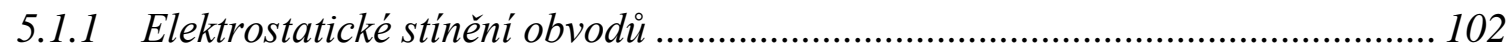

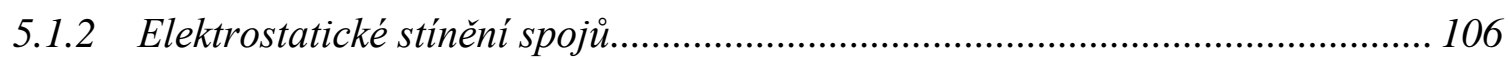

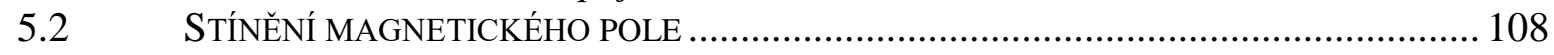

5.2.1 Stíněni obvodů proti rušení magnetickým polem ........................................... 108

5.2.2 Ochrana vodičủ proti vyzařováni magnetického pole ................................... 114

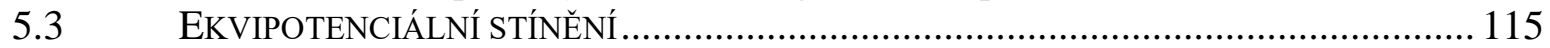


POUŽITÁ LITERATURA ............................................................................................. 118

6 $\quad$ PARAZITNÍ JEVY A JEJICH POTLAČENÍ ....................................................... 119

6.1 POTLAČENÍ RUŠENÍ NA PŘÍVODNÍCH VODIČÍCH................................................. 119

6.1.1 Potlačení rušení na nesymetrickém vedení ................................................... 119

6.1.2 Potlačení rušeni symetrickým vedením .................................................. 123

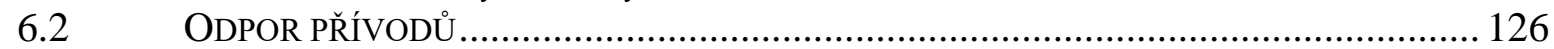

6.2.1 Úbytek napětí na př́vodu k zátěži ............................................................... 126

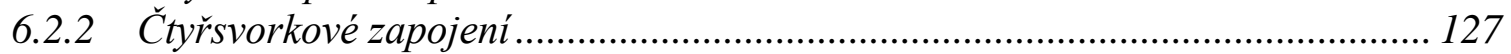

6.2.3 Vazba signálových obvodů na odporu přvivodů ........................................... 128

$6.3 \quad$ TERMOELEKTRICKÉ NAPĚTÍ................................................................ 129

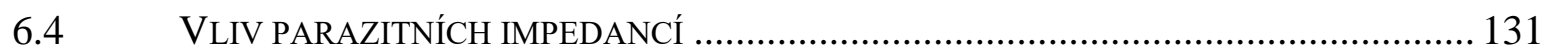

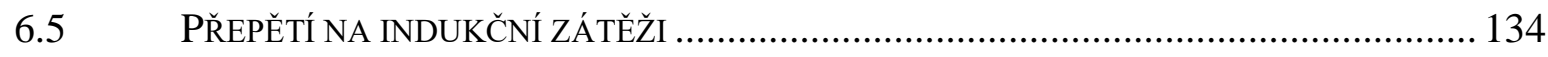

POUŽITÁ LITERATURA .......................................................................................... 136

$7 \quad$ PASIVNÍ OBVODOVÉ PRVKY R, C, L .............................................................. 137

$7.1 \quad$ VYRÁBĚNÉ ŘADY PASIVNÍCH PRVKŮ A JEJICH OZNAČOVÁNÍ ............................... 137

7.2 VÝBĚR REZISTORŮ .............................................................................. 149

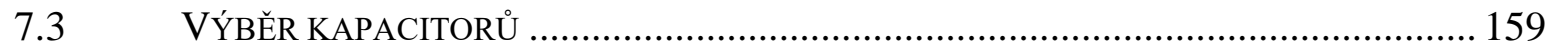

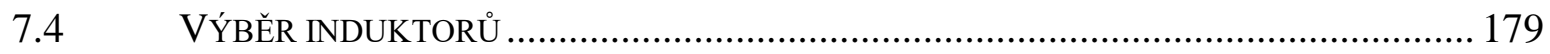

POUŽITÁ LITERATURA ................................................................................................... 196

$8 \quad$ PIEZOELEKTRICKÉ KRYSTALOVÉ REZONÁTORY ..................................... 197

8.1 ZÁKLADNÍ VLASTNOSTI PIEZOELEKTRICKÝCH KRYSTALŮ .............................. 197

PARAMETRY PIEZOELEKTRICKÝCH KRYSTALŮ ................................................. 198

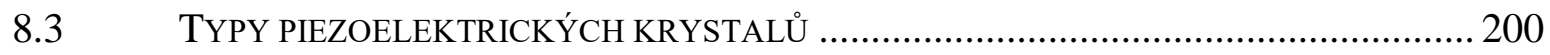

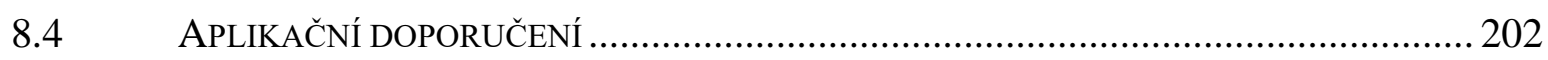

POUŽITÁ LITERATURA .......................................................................................... 206

9 OCHRANA PŘED PŘEPĚTÍM A NADPROUDEM ................................................... 207

9.1 P̌̌EPĚŤOVÉ A NADPROUDOVÉ JEVY ................................................................ 207

9.2 P̌̌EPĚŤOVÉ OCHRANY ............................................................................ 211

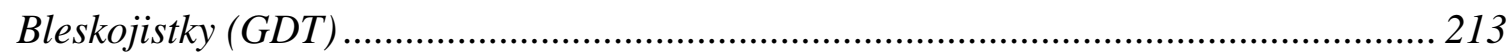

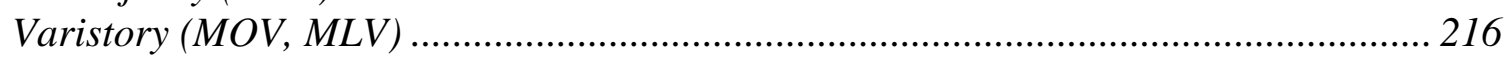

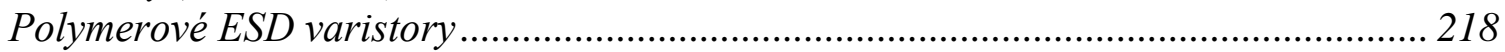

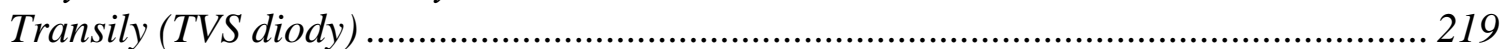

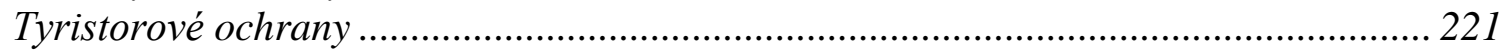

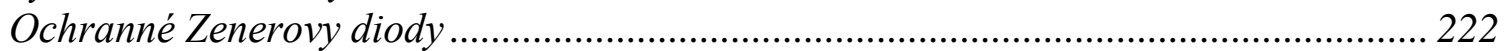

Kapacitory pro prepět'ovou ochranu .................................................................... 222

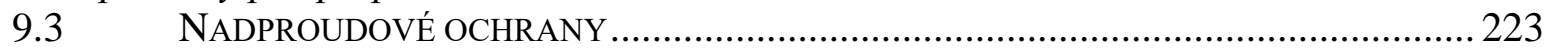

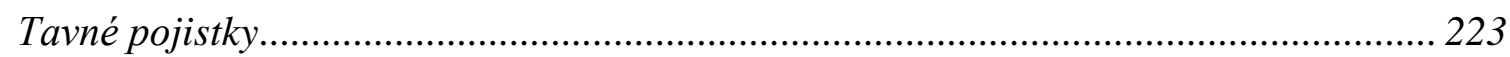

Termistorové vratné pojistky (PPTC) .............................................................. 226

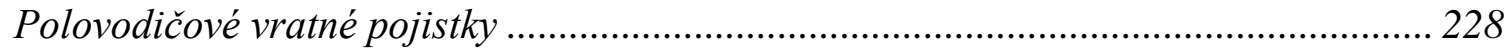

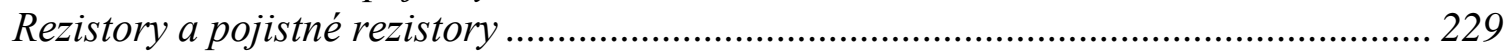

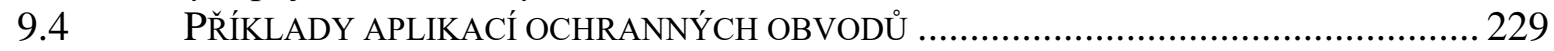

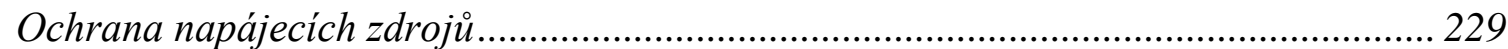

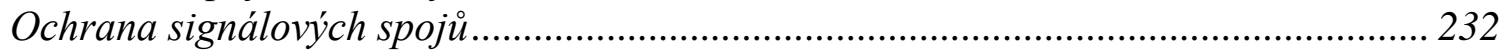

Ochrana datových komunikačních rozhraní a portů............................................. 234

POUŽITÁ LITERATURA ............................................................................................................ 237 


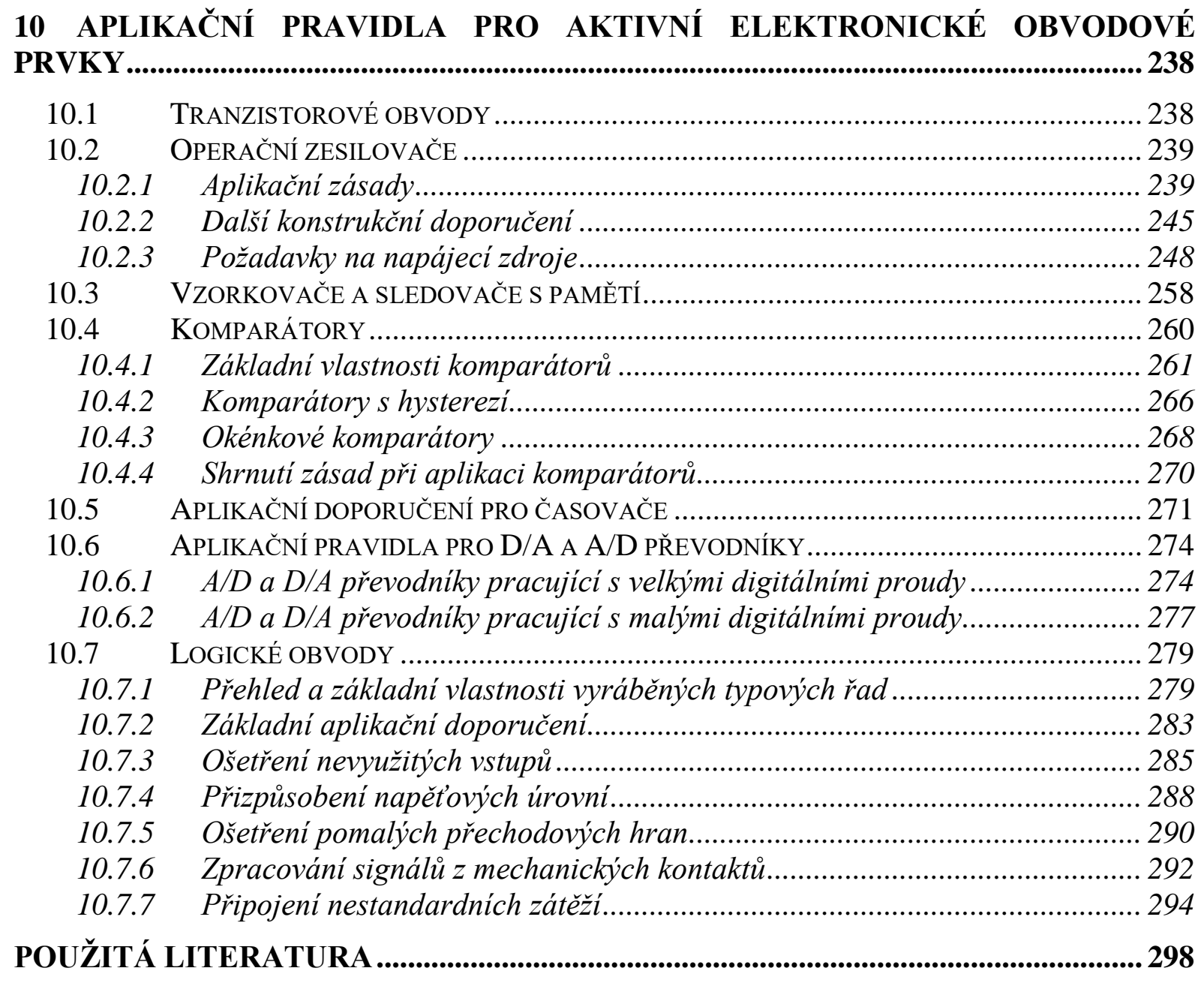




\section{1 Úvod}

Zájemci o problematiku konstrukce elektronických přistrojů či zařízení získají znalosti o konstrukci signálových spojů, napájecích a zemních rozvodů, o zemních smyčkách či o galvanickém oddělení systémů. Budou seznámeni s parazitními jevy a jejich potlačením jako jsou nežádoucí vazby vstupních a výstupních obvodů způsobené parazitními kapacitami a indukčnostmi, termoelektrickými napětími, přepětími na indukční zátěži, odrazy na vedeních či přeslechy. Zájemcům budou vysvětleny principy stínění proti rušivému elektrickému a magnetickému poli, nebo ekvipotenciální stínění proti rušení způsobenému galvanickou vazbou. Budou diskutovány zásady výběru součástek a aplikační doporučení pro pasivní diskrétní prvky, jako jsou rezistory, nejrůznější typy kapacitorů a induktorů, krystalové rezonátory, či součástky pro přep̌etovou a nadproudovou ochranu. Také budou uvedena aplikační pravidla pro operační zesilovače, časové obvody, vzorkovače s pamětí, A/D a D/A převodníky, nebo pro číslicové obvody.

\section{Konstrukce signálových spojů}

V zařízení je možno rozlišit obvykle dvě soustavy spojů - je to soustava signálových spojů a napájecího rozvodu. Na obě soustavy jsou kladeny rozdílné požadavky. Nejprve probereme některé vlastnosti signálových spojů, způsoby jejich realizace a souvisejících doporučení pro jejich užití. Soustavy napájecího rozvodu si povšimneme později v souvislosti s problematikou napájení a jeho rozvodu v zařízení.

Při přenosu signálu používáme v zásadě dva typy přenosových vedení: nesymetrická (jeden vodič je ,živý““ a druhý je uzemněn) a symetrická, která jsou také někdy označována jako diferenční či rozdílová (dva vodiče jsou ,živé“ a třetí je uzemněn).

\subsection{Nesymetrické vedení}

Nesymetrické vedení je konstrukčně jednoduché, nebot' signálová cesta je tvořena jedním vodičem, přičemž signál je vztažen ke společnému vodiči (zemi). Na Obr. 2.1 je nakreslen náhradní model zapojení obvodu pro nesymetrický přenos signálu. Do vedení se mohou dostat

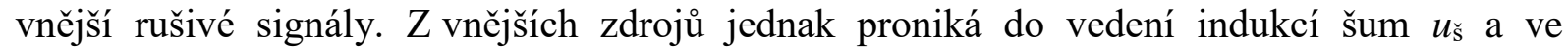
společném vodiči existuje mezi oběma konci vedení potenciální rozdíl $u_{\mathrm{r}}$, vzniklý na odporu zemního vodiče průtokem proudu od dalších obvodů.

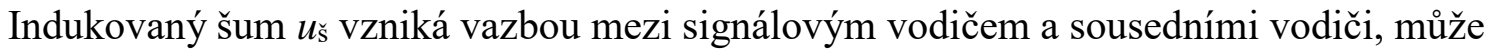
se indukovat $\mathrm{z}$ napájecích zdrojů apod. Tento indukovaný šum se označuje jako přeslech.

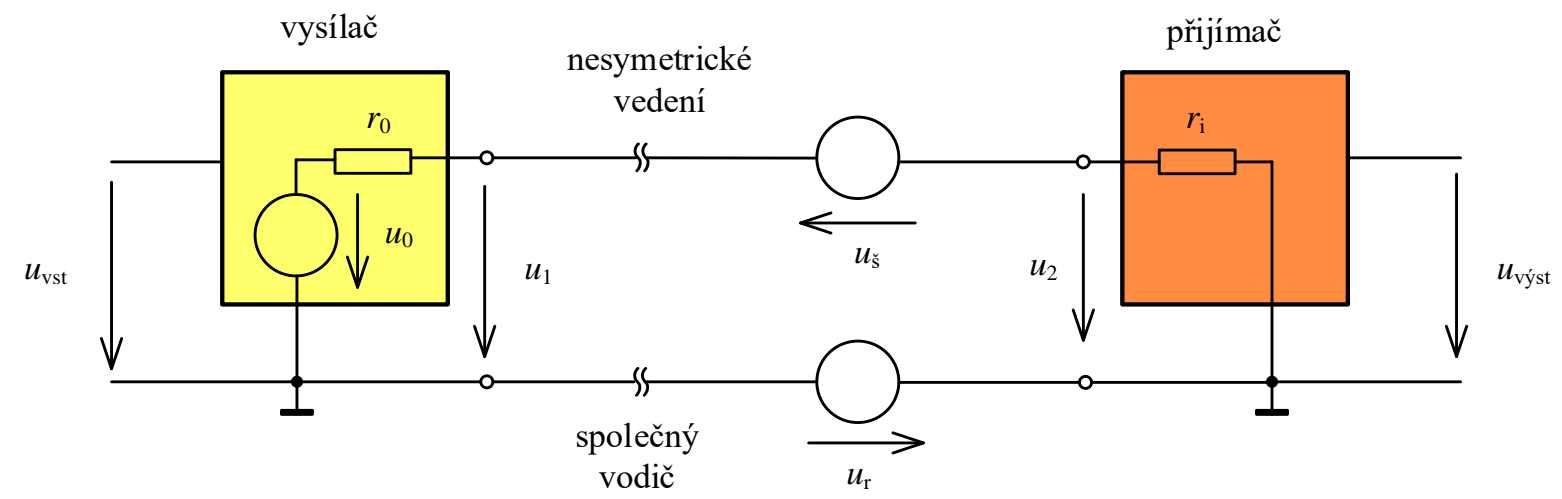

Obr. 2.1: Náhradní model nesymetrického vedení 
Rušivý potenciální rozdíl $u_{\mathrm{r}}$ vzniká průtokem proudu společným zemním vodičem, který má nenulový odpor a nenulovou indukčnost. Tímto vodičem se totiž uzavírají i všechny zemní proudy od dalších (neznázorněných) obvodů. Dominantní složkou napětí $u_{\mathrm{r}}$ je rušivá složka se sít'ovým kmitočtem $50 \mathrm{~Hz}$ nebo s kmitočtem spínaného zdroje (obvykle cca 20 až $40 \mathrm{kHz}$ ). Další významnou složkou jsou změny zemních proudů při překlápění připojených logických členů, které vykazují jiný odběr proudu při výstupní úrovni L a při úrovni $H$.

Vstupní napětí přijímače je tedy dáno superpozicí napětí $u_{2}=u_{1}+u_{\breve{\mathrm{s}}}+u_{\mathrm{r}}$ a je zřejmé, že přijímač nemůže rozlišit užitečný signál $u_{1}$ od rušivých složek $u_{\breve{s}}$ a $u_{\mathrm{r}}$. Podmínkou tedy je, aby odstup signálu od šumu byl co největší. K tomu existuje několik způsobů:

- zkrátit či oddálit paralelně vedené signálové spoje tak, aby se zmenšila možnost prưniku rušivých signálů kapacitními vazbami, popř. vzájemnou induktivní vazbou,

- použít stíněný vodič k potlačení preslechů ze sousednich vodičùu,

- zvětšit úroveň výstupního signálu vysílače $u_{1}$ a tím zvýšit odstup od signálů $u_{\breve{s}}$ a $u_{\mathrm{r}}$

- zmenšit odpor společného zemního vodiče a tím minimalizovat $u_{\mathrm{r}}$,

- dostatečně oddálit signálové vodiče od napájecího rozvodu,

- $\quad$ snižit sklon hran impulsů v okolních vodičich tak, aby se zmenšily přeslechy vzniklé kapacitni vazbou,

- použit přijímačs hysterezní charakteristikou tak, aby přijímač nereagoval na signály $u_{\breve{\mathrm{s}}}+u_{\mathrm{r}}$,

- použit vhodné kombinace předchozích zpưsobi̊.

Každý z uvedených způsobů má však i své nedostatky. Podrobněji bude o této problematice pojednáno později. 


\subsection{Symetrické vedení}

Symetrické vedení využívá k přenosu signálu rozdílový signál dvou vodičů uspořádaných symetricky vůči společnému zemnímu vodiči, který se však na vlastním přenosu informace nepodílí. Princip přenosu signálů symetrickým vedením je naznačen na Obr. 2.2. Vedení je buzeno $\mathrm{z}$ vysílače $\mathrm{s}$ diferenčním výstupem, resp. $\mathrm{z}$ vysílače se dvěma navzájem komplementárními výstupy, přijímač pak pracuje jako rozdílový zesilovač. Rušivé napětí $u_{s}$ se tentokrát indukuje do obou signálových vodičů přibližně stejně a působí proto jako souhlasné napětí, jímž je podložen přenášený signál. Rušivé napětí $u_{r}$ rozdílu zemních potenciálů společného vodiče působí na rozdílových vstupech přijímače díky komplementárním výstupům vysílače rovněž jako souhlasné napětí. Na vstupy rozdílového přijímače jsou přivedena napětí $u_{\mathrm{P}}=u_{1}+u_{\breve{\mathrm{s}}}+u_{\mathrm{r}}, u_{\mathrm{N}}=-u_{1}+u_{\breve{\mathrm{s}}}+u_{\mathrm{r}}$. Na výstupu rozdílového přijímače pak bude napětí $u_{\mathrm{v} y ́ s t}=u_{\mathrm{P}}-u_{\mathrm{N}}=u_{1}+u_{\breve{\mathrm{S}}}+u_{\mathrm{r}}+u_{1}-u_{\breve{\mathrm{S}}}-u_{\mathrm{r}}=2 u_{1}$.

Přijímač s dobrým potlačením souhlasného signálu pak snadno vybere ze směsi vstupních signálů pouze přenášený signál, který jediný je přiváděn jako rozdílový. Pro symetrická vedení se nejčastěji používají zkroucené vodiče nebo ploché a páskové kabely se souběžně vedenými vodiči. To proto, aby se šum z vnějších zdrojů indukoval do obou vodičů přibližně stejně.

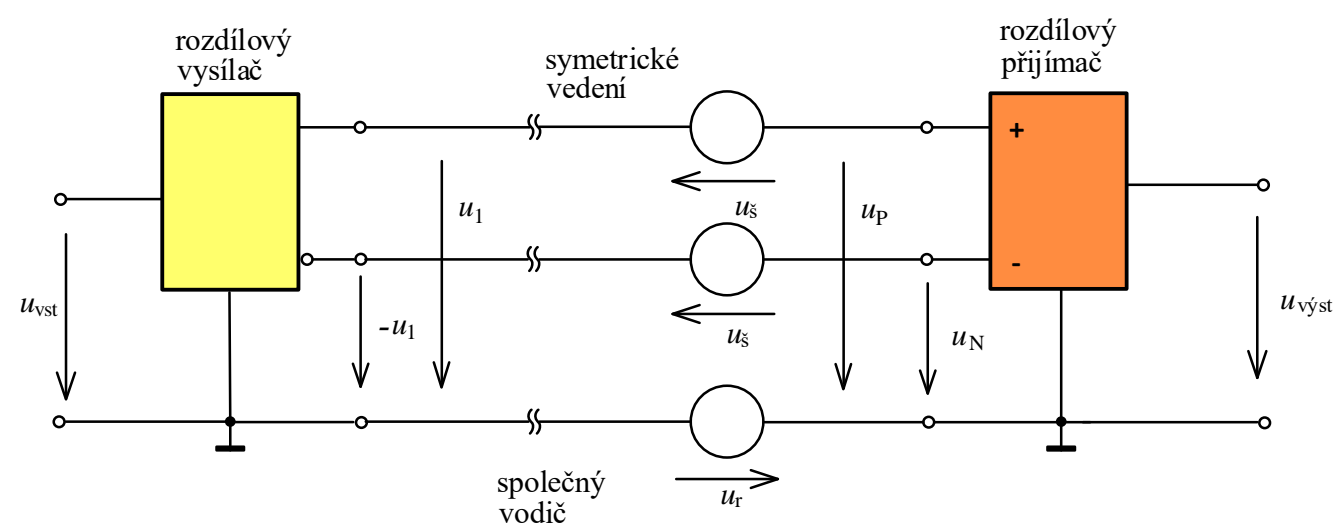

Obr. 2.2: Náhradní model pro vysvětlení přenosu signálu symetrickým vedením

\subsection{Vedení elektricky krátké a elektricky dlouhé}

Pro rozvod signálů se nejčastěji užívají jednodrátové vodiče, ploché kabely, kroucené dvouvodiče (twisted pair), koaxiální kabely či plošné spoje. Pro správný přenos signálu je třeba v konkrétní aplikaci zvolit vhodný druh spoje. Při volbě typu spoje je třeba porovnávat dobu čela a týlu přenášených impulsů s dobou šíření po vedení. Podle toho se signálové spoje dělí na:

a) elektricky krátká vedení

Signál krátkým vedením projde tam a zpět za kratší dobu, než je trvání jeho nástupné či sestupné hrany. Odražený signál dozní se skončením hrany signálu a nezpůsobí proto její zkreslení. Elektricky krátká vedení není nutno impedančně přizpůsobovat. Rychlost šíření signálu vodičem bývá asi $0,22 \mathrm{~m} / \mathrm{ns}$. Jeden metr tedy signál urazí za přibližně $\tau=4,5 \mathrm{~ns}$. Známe-li dobu hrany signálu $t_{\mathrm{hr}}$, pak se obvykle se za krátký spoj považuje spoj takové délky, aby doba šíření tam i zpět byla přibližně rovna době trvání hrany impulsu 
Tab 2.1: Maximální délky elektricky krátkého vedení pro různé typy číslicových obvodů

\begin{tabular}{|l|l|l|l|l|}
\hline Druh & Typ & Napájení (V) & Doba hrany (ns) & Maximální délka (cm) \\
\hline TTL & první série & 5 & 5 & 55 \\
\hline TTL & L & 5 & 15 & 150 \\
\hline TTL & H & 5 & 6 & 66 \\
\hline TTL & S & 5 & 3 & 33 \\
\hline TTL & LS & 5 & 10 & 110 \\
\hline TTL & ALS & 5 & 4 & 44 \\
\hline TTL & F & 5 & 3,5 & 40 \\
\hline TTL & AS & 5 & 2 & 22 \\
\hline TTL & G & 3,3 & 1,5 & 17 \\
\hline CMOS & první série & 10 & 30 & 330 \\
\hline CMOS & HC/HCT & 5 & 9 & 100 \\
\hline CMOS & AC/ACT & 3,3 nebo 5 & 3 & 33 \\
\hline CMOS & AUP & 3,3 & 3,5 & 38 \\
\hline CMOS & AUC & 1,8 & 2 & 22 \\
\hline CMOS & LVC & 3,3 & 3 & 33 \\
\hline CMOS & AHC/AHCT & 5 & 5 & 55 \\
\hline CMOS & CBT/CBTD & 5 & 0,25 & 3 \\
\hline CMOS & CBTLV/CB3T & 3,3 & 0,25 & 3 \\
\hline CMOS & LV1T & 3,3 & 5 & 55 \\
\hline
\end{tabular}

$$
l_{\text {max }} \approx t_{\mathrm{hr}} / 2 \tau .
$$

V tabulce Tab 2.1 jsou pro informaci uvedeny mezní hodnoty elektricky krátkých vedení pro používané číslicové obvody, je-li spojem prostý plošný spoj či izolovaný drát. Je zřejmé, že pro rychlé číslicové obvody jsou kritické vzdálenosti pro přenos signálu nepřizpůsobeným vedením jen několik málo centimetrů.

b) elektricky dlouhá vedení

Signál prochází vedením déle, než je doba trvání jeho hrany. Rušivý signál vzniklý při odrazu na nepřizpůsobeném konci vedení doznívá i po skončení hrany signálu. Tato vedení je třeba pro zamezení odrazů na koncích přizpůsobovat charakteristickou impedancí. Problematika potlačení odrazů při přenosu signálu elektricky dlouhým vedením bude probrána později.

\subsection{Elektrické parametry spojů}

Nejprve je zapotřebí připomenout, že každý vodič vykazuje elektrický odpor

$$
R=\rho \cdot \frac{\ell}{S} ;(\Omega),
$$

kde $\rho$ je měrný odpor materiálu vodiče $\left(\Omega \mathrm{m}^{2} / \mathrm{m}\right)$, popř. $(\Omega \mathrm{m})$, $\ell$ značí délku vodiče $(\mathrm{m}), S$ je plocha průřrezu vodiče $\left(\mathrm{m}^{2}\right)$. Pro vodič kulatého prưřezu pak $S=\pi(d / 2)^{2}$, přičemž $d$ značí průměr vodiče $(\mathrm{m})$. Elektrotechnická měd' má obvykle měrný odpor $\rho=17,24$ až 
$17,86 \mathrm{n} \Omega \mathrm{m}^{2} / \mathrm{m}$ při teplotě $20^{\circ} \mathrm{C}$. Uvažujeme-li $\rho=17,5 \mathrm{n} \Omega \mathrm{m}^{2} / \mathrm{m}$, bude mít např. měděný vodič délky $0,5 \mathrm{~m}$ o průměru $0,5 \mathrm{~mm}$ odpor $45 \mathrm{~m} \Omega$. Plošný vodič tloušt'ky $70 \mu \mathrm{m}$ na desce plošného spoje o délce $10 \mathrm{~cm}$ a šířce $0,5 \mathrm{~mm}$ pak při teplotě $20^{\circ} \mathrm{C}$ vykazuje odpor $50 \mathrm{~m} \Omega$.

Zde poznamenejme, že takovýto odpor vodič vykazuje jen pro stejnosměrný či pomalu se měnící proud protékající vodičem. Při vyšších kmitočtech proudu se začne uplatňovat tzv. povrchový jev (skinefekt), který efektivní hodnotu odporu zvětšuje. Povrchový jev je způsoben tím, že stř́ídavý proud protékající vodičem vyvolá magnetické pole, které „vytlačuje“ nosiče elektrického náboje k povrchu vodiče. Čím vyšší je kmitočet, tím se proud koncentruje do tenčí vrstvy u povrchu vodiče. Protože se takto zmenší efektivní prưř̌z vodiče pro protékající proud, zvětšuje se v závislosti na kmitočtu i ohmický odpor vodiče.

Zvětšení efektivního odporu vodiče kruhového průřezu vlivem skinefektu je uvedeno na obrázku Obr. 2.3. Průběhy jsou normovány vzhledem k odporu pro ss proud. V rozsahu kmitočtů od $10 \mathrm{kHz}$ do 1 až $2 \mathrm{MHz}$ lze skinefekt účinně potlačit použitím vf lanka spleteného $\mathrm{z}$ tenkých drátků. Je to dáno tím, že u velmi tenkých vodičů se skinefekt uplatňuje v daleko menší míře.

Velikost a charakter zkreslení signálů při jejich šíření elektrickým spojem a také úroveň parazitních vazeb mezi sousedními spoji značně závidí na elektrických parametrech montáže: indukčnosti a parazitní kapacitě spoje, charakteristické impedanci, nebo vzájemné indukčnosti a vzájemné kapacitě mezi sousedními vodiči.

Hodnoty elektrických parametrů spojů závisí pak na následujících faktorech: průměru vodičů, jejich délce, způsobu realizace (plošné spoje, drátové vodiče), na vzájemném rozložení sousedních vodičů, fyzikálních parametrech konstrukčních materiálů (relativní permitivitě $\varepsilon_{\mathrm{r}}$, relativní permeabilitě $\mu_{\mathrm{r}}$ ).

Elektrické vlastnosti jednotlivých druhů spojů jako např. indukčnost $L$, kapacitu $C$, nebo charakteristickou impedanci $Z_{0}$, můžeme orientačně určit pomocí dále uvedených vztahů. Vztahy jsou ve většině případů zjednodušené a platí s přesností 10 až $20 \%$. Nejmenší přesnost je u vztahů pro plošné spoje. Cílem je ukázat na jakých parametrech vlastnosti spojů závisí a nikoliv výpočet jejich přesné hodnoty.

V následujících vztazích jsou rozměrové veličiny uvažovány $\mathrm{v}(\mathrm{m}), \varepsilon_{0}$ značí permitivitu vakua $\varepsilon_{o}=8,8 \cdot 10^{-12} \mathrm{~F} / \mathrm{m}, \quad \varepsilon_{r}$ je relativní permitivita, kdy pro většinu dielektrik $\varepsilon_{r}=2$ až 5 , napřr. pro polyetylén $\varepsilon_{r}=2,3$, pro polyvinylchlorid $\varepsilon_{r}=3,1$ až 3,5 a pro nosnou desku plošného spoje je $\varepsilon_{r}=4,4$ až 4,7. Dále $\mu_{0}$ značí permeabilitu vakua $\mu_{o}=1,26 \cdot 10^{-6} \mathrm{H} / \mathrm{m}$ a $\mu_{r}$ je relativní

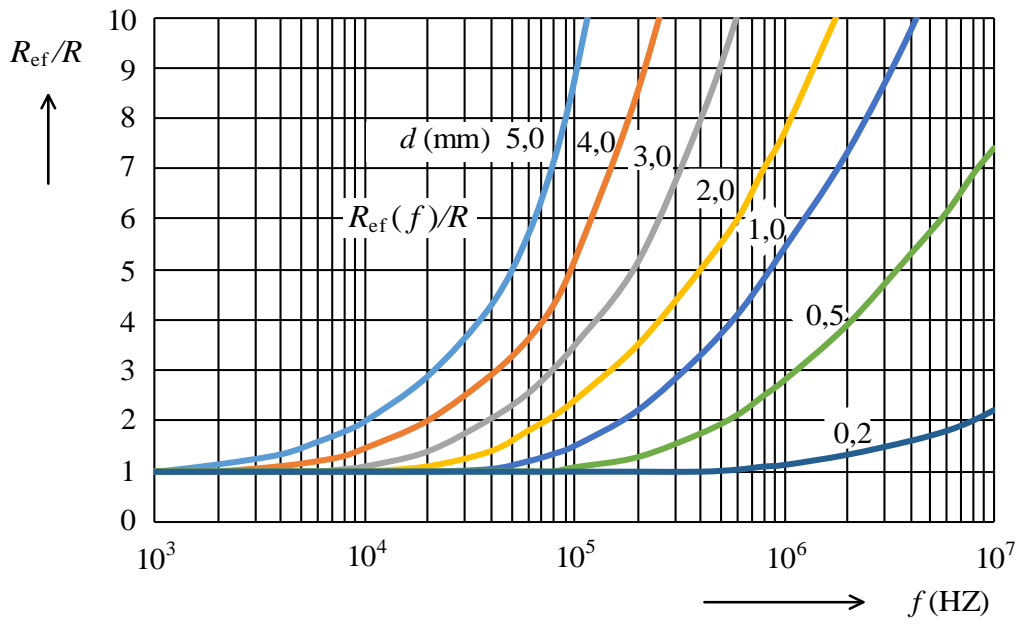

Obr. 2.3: Relativní zvětšení odporu měděného vodiče kruhového průřrezu vlivem povrchového jevu (skinefektu) 
permeabilita, kdy pro vzduch, či pro běžné izolační materiály včetně desky plošného spoje lze přibližně uvažovat $\mu_{r}=1$.

a) Samotný př́mý vodič kruhového průžezu (Obr.2.4)

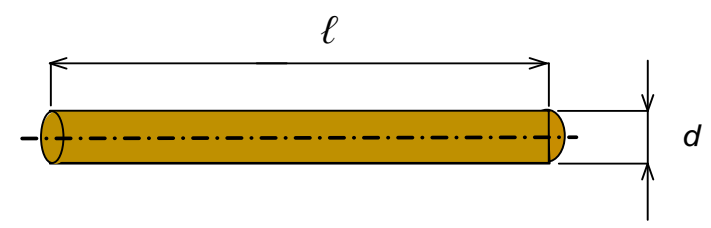

$$
L=\frac{\mu_{0} \mu_{\mathrm{r}}}{2 \pi}\left[\ln \frac{4 \ell}{d}-1\right] \ell ;(\mathrm{H}) .
$$

Obr. 2.4: Samotný vodič vedený dostatečně daleko od vodivé plochy, resp. od kovové kostry př́istroje

Zde předpokládáme, že pokud je vodič veden dostatečně daleko od vodivé plochy, resp. od kovové kostry prŕstroje, nemá smysl uvažovat parazitní kapacitu či jeho charakteristikou impedanci.

b) Vodič nad kovovou plochou Obr. 2.5

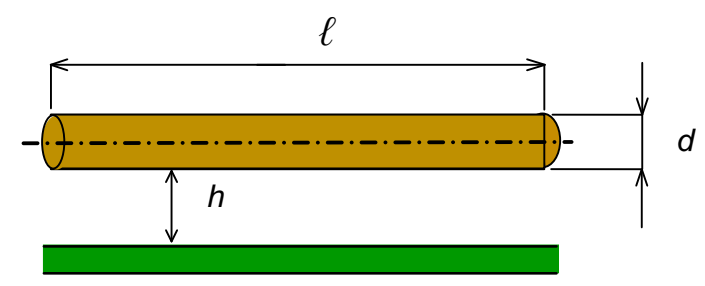

$$
\begin{aligned}
& L=\frac{\mu_{\mathrm{o}} \mu_{\mathrm{r}}}{2 \pi} \ln \left(\frac{4 h}{d}\right) ;(\mathrm{H} / \mathrm{m}) \\
& C=\frac{2 \pi \varepsilon_{o} \varepsilon_{\mathrm{r}}}{\ln \left(\frac{4 h}{d}\right)} ;(\mathrm{F} / \mathrm{m})
\end{aligned}
$$

Obr. 2.5: Vodič nad kovovou deskou resp. nad kovovou kostrou př́ístroje

$$
Z_{0}=\frac{60}{\sqrt{\varepsilon_{\mathrm{r}}}} \ln \left(\frac{4 h}{d}\right) ;(\Omega)
$$

c) Dva vodiče vedle sebe Obr. 2.6

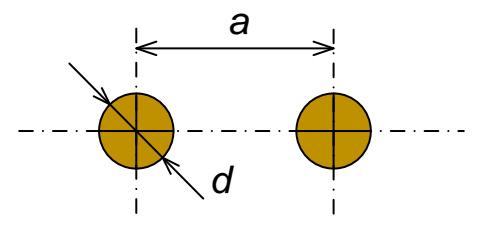

$$
\begin{aligned}
& L=\frac{\mu_{\mathrm{o}} \mu_{\mathrm{r}}}{\pi} \ln \left(\frac{2 a}{d}\right) ;(\mathrm{H} / \mathrm{m}) \\
& C=\frac{\pi \varepsilon_{\mathrm{o}} \varepsilon_{\mathrm{r}}}{\ln \left(\frac{2 a}{d}\right)} ;(\mathrm{F} / \mathrm{m})
\end{aligned}
$$

Obr. 2.6: Dva vodiče vedle sebe, resp.

kroucený dvojitý vodič

$$
Z_{0}=\frac{120}{\sqrt{\varepsilon_{\mathrm{r}}}} \ln \left(\frac{2 a}{d}\right) ;(\Omega)
$$


d) Dva vodiče nad kovovou plochou Obr. 2.7

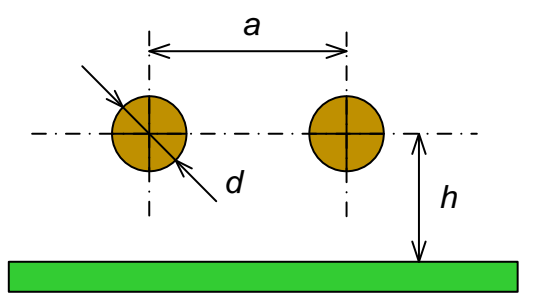

$$
\begin{gathered}
L=\frac{\mu_{\mathrm{o}} \mu_{\mathrm{r}}}{4 \pi} \ln \left[1+\left(\frac{2 h}{a}\right)^{2}\right] ;(\mathrm{H} / \mathrm{m}) \text { pro } d \ll a \\
C=\pi \varepsilon_{\mathrm{o}} \varepsilon_{\mathrm{r}} \frac{\ln \left[1+\left(\frac{2 h}{a}\right)^{2}\right]}{\left[\ln \left(\frac{4 h}{d}\right)\right]^{2}} ;(\mathrm{F} / \mathrm{m}) \text { pro } d \ll 2 h,
\end{gathered}
$$

Obr. 2.7: Dva vodiče resp. dvojitý

kroucený vodič nad kovovou plochou

$$
Z_{0}=\frac{60}{\sqrt{\varepsilon_{\mathrm{r}}}} \ln \left[\frac{4 h}{d} \sqrt{1+\left(\frac{2 h}{a}\right)^{2}}\right] ;(\Omega) .
$$

e) Koaxiální kabel nebo stíněný vodič Obr. 2.8

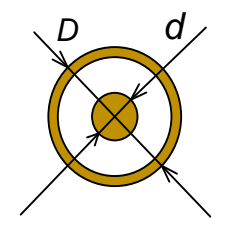

$$
\begin{aligned}
& L=\frac{\mu_{\mathrm{o}} \mu_{\mathrm{r}}}{2 \pi} \frac{D}{d} ;(\mathrm{H} / \mathrm{m}) \\
& C=\frac{2 \pi \mu_{\mathrm{o}} \mu_{\mathrm{r}}}{\ln (D / d)} ;(\mathrm{F} / \mathrm{m})
\end{aligned}
$$

Obr. 2.8: Koaxiální kabel nebo stíněný vodič

$$
Z_{0}=\frac{60}{\sqrt{\varepsilon_{\mathrm{r}}}} \ln (D / d) ;(\Omega)
$$

f) Plošný spoj Obr. 2.9

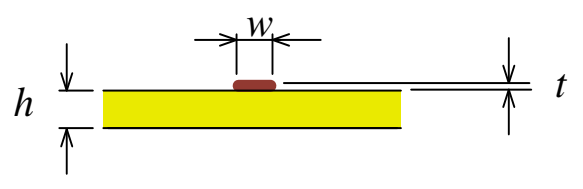

$$
L=\frac{\mu_{0} \mu_{\mathrm{r}}}{2 \pi}\left[0,5+0,224 \frac{t+w}{\ell}+\ln \frac{2 \ell}{t+w}\right] \ell
$$

Obr. 2.9: Přímý plošný vodič 
g) Plošný spoj nad vodivou plochou Obr. 2.10

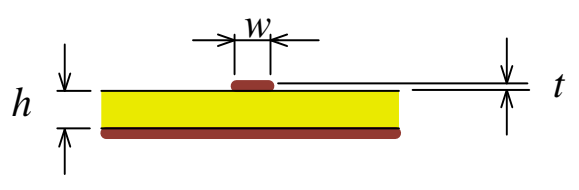

$$
\begin{aligned}
& L=\frac{\mu_{0} \mu_{\mathrm{r}}}{1,5+(w / h)} ;(\mathrm{H} / \mathrm{m}) \\
& C=\varepsilon_{o} \varepsilon_{\mathrm{r}}\left(1+\frac{w}{h}\right) ;(\mathrm{F} / \mathrm{m})
\end{aligned}
$$

Obr. 2.10: Př́mý plošný vodič nad vodivou plochou

$$
Z_{0}=\frac{120 \pi}{\sqrt{\varepsilon_{\mathrm{r}}\left(1+1,5 \frac{h}{w}\right)\left(1+\frac{h}{w}\right)}} \cdot \frac{h}{w} ;(\Omega)
$$

Další konfigurace a parametry spojů lze dohledat např. v publikacích [1] až [4].

Při navrhování elektronických př́strojů a při experimentálním odstraňování parazitních jevů je často třeba rychle odhadnout vlastnosti signálových vodičů. Pro orientaci jsou uvedeny jednoduché tabulky Tab 2.2 až Tab 2.9. ve kterých jsou uvedeny přehledově parametry základních typů signálových vodičů. Při práci suvedenými tabulkami je zapotřebí poznamenat, že odpor vodiče a kapacita ve všech tabulkách jsou přímo úměrné délce vodiče. Indukčnost v tabulkách Tab 2.2 až Tab 2.5 závisí na délce vodiče nelineárně. Pro orientační určení lze však provést lineární aproximaci až do délek překračujících uvedené meze 2 až 3 krát, aniž se dopustíme větší chyby než 10 až $15 \%$. Hodnoty uvedené v tabulkách Tab 2.6 až Tab 2.9 platí s přesností $\pm 20 \%$. Pro zběžný přehled jsou to však údaje dostačující.

Tab 2.2: Odpor a indukčnost přímého měděného vodiče ve volném prostoru

\begin{tabular}{|c|c|c|c|c|}
\hline \multirow{2}{*}{$\begin{array}{c}\text { průměr } \\
\text { vodiče } \\
(\mathrm{mm})\end{array}$} & odpor $(\mathrm{m} \Omega)$ & \multicolumn{3}{|c|}{ indukčnost $(\mathrm{nH})$} \\
\cline { 2 - 5 } & délka vodiče & \multicolumn{3}{|c|}{ délka vodiče } \\
\cline { 2 - 5 } & $100 \mathrm{~mm}$ & $50 \mathrm{~mm}$ & $100 \mathrm{~mm}$ & $200 \mathrm{~mm}$ \\
\hline 0,1 & 219 & 70 & 150 & 330 \\
\hline 0,5 & 8,78 & 50 & 120 & 260 \\
\hline 1,0 & 2,19 & 40 & 100 & 230 \\
\hline 2,0 & 0,55 & 35 & 80 & 200 \\
\hline
\end{tabular}

Tab 2.3: Vlastnosti přímého měděného vodiče nad kovovou deskou, resp. nad kostrou př́istroje

\begin{tabular}{|c|c|c|c|c|c|c|}
\hline \multirow{2}{*}{$\begin{array}{c}\text { průměr } \\
\text { vodiče } \\
(\mathrm{mm})\end{array}$} & \multicolumn{2}{|c|}{ indukčnost $(\mathrm{nH})$ na $100 \mathrm{~mm}$ délky } & \multicolumn{4}{|c|}{ kapacita $(\mathrm{pF})$ na $100 \mathrm{~mm}$ délky } \\
\cline { 2 - 7 } & $1 \mathrm{~mm}$ & $10 \mathrm{~mm}$ & $100 \mathrm{~mm}$ & $1 \mathrm{~mm}$ & $10 \mathrm{~mm}$ & $100 \mathrm{~mm}$ \\
\hline 0,1 & 74 & 116 & 142 & 1,5 & 0,9 & 0,7 \\
\hline 0,5 & 41 & 84 & 110 & 2,7 & 1,4 & 0,8 \\
\hline 1,0 & 28 & 70 & 96 & 4,0 & 1,6 & 0,9 \\
\hline 2,0 & 14 & 56 & 80 & 8,0 & 1,8 & 1,0 \\
\hline
\end{tabular}


Tab 2.4: Vlastnosti dvou paralelních vodičů

\begin{tabular}{|c|c|c|c|}
\hline \multirow{2}{*}{$\begin{array}{c}\text { délka } \\
\text { vodičù } \\
(\mathrm{mm})\end{array}$} & \multicolumn{3}{|c|}{ vzájemná indukčnost $(\mathrm{nH})$} \\
\cline { 2 - 4 } & \multicolumn{2}{|c|}{ vzdálenost vodičů od sebe } \\
\cline { 2 - 4 } & $2 \mathrm{~mm}$ & $10 \mathrm{~mm}$ & $30 \mathrm{~mm}$ \\
\hline 50 & 30 & 15 & 8 \\
\hline 100 & 70 & 40 & 24 \\
\hline 200 & 170 & 110 & 70 \\
\hline
\end{tabular}

\begin{tabular}{|c|c|c|c|}
\hline \multirow{2}{*}{$\begin{array}{c}\text { průměr } \\
\text { vodiče } \\
(\mathrm{mm})\end{array}$} & \multicolumn{3}{|c|}{ kapacita $(\mathrm{pF})$ na $100 \mathrm{~mm}$ délky } \\
\cline { 2 - 4 } & $2 \mathrm{~mm}$ & $10 \mathrm{~mm}$ & $50 \mathrm{~mm}$ \\
\hline 0,1 & 0,75 & 0,5 & 0,04 \\
\hline 0,5 & 1,4 & 0,75 & 0,05 \\
\hline 1,0 & 2,0 & 0,9 & 0,06 \\
\hline 2,0 & 5,0 & 1,3 & 0,07 \\
\hline
\end{tabular}

Tab 2.5: Indukčnost samostatného vodiče na plošném spoji

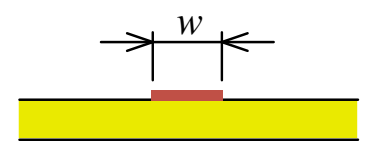

\begin{tabular}{|c|c|c|c|c|}
\hline \multirow{2}{*}{$\begin{array}{c}\text { šǐrka } \\
\text { vodiče } \\
w(\mathrm{~mm})\end{array}$} & \multicolumn{4}{|c|}{ indukčnost $(\mathrm{nH})$} \\
\cline { 2 - 5 } & $10 \mathrm{~mm}$ & $20 \mathrm{~mm}$ & $50 \mathrm{~mm}$ & $100 \mathrm{~mm}$ \\
\hline 0,3 & 9,6 & 22 & 62 & 138 \\
\hline 0,5 & 8,4 & 19,5 & 58 & 130 \\
\hline 1,0 & 7,0 & 16,8 & 51 & 116 \\
\hline 2,0 & 5,6 & 14,0 & 44 & 102 \\
\hline
\end{tabular}

Tab 2.6: Kapacita dvou vodičů na jednostranné desce plošného spoje

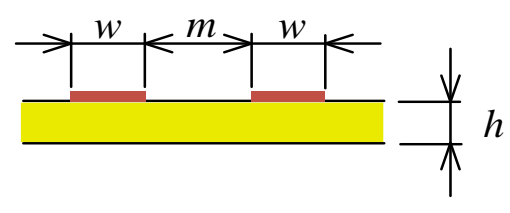

\begin{tabular}{|c|c|c|c|}
\hline \multirow{2}{*}{$\begin{array}{c}\text { šířka } \\
\text { vodiče } \\
w(\mathrm{~mm})\end{array}$} & \multicolumn{3}{|c|}{ kapacita $(\mathrm{pF} / \mathrm{cm})$} \\
\cline { 2 - 4 } & \multicolumn{3}{|c|}{ sířka mezery $m(\mathrm{~mm})$} \\
\cline { 2 - 4 } & 0,5 & 1 & 2 \\
\hline 0,3 & 0,42 & 0,26 & 0,21 \\
\hline 0,5 & 0,47 & 0,38 & 0,28 \\
\hline 1 & 0,6 & 0,47 & 0,38 \\
\hline 2 & 0,7 & 0,6 & 0,47 \\
\hline
\end{tabular}

Tab 2.7: Kapacita mezi vodičem a stíněním na jednostranné desce plošného spoje

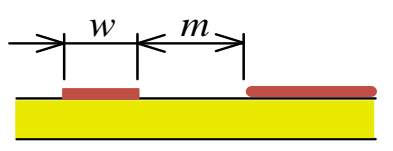

\begin{tabular}{|c|c|c|c|}
\hline \multirow{2}{*}{$\begin{array}{c}\text { šírka } \\
\text { vodiče } \\
w(\mathrm{~mm})\end{array}$} & \multicolumn{3}{|c|}{ kapacita $(\mathrm{pF} / \mathrm{cm})$} \\
\cline { 2 - 4 } & 0,5 & 1,0 & 2,0 \\
\hline 0,3 & 0,53 & 0,42 & 0,32 \\
\hline 0,5 & 0,6 & 0,46 & 0,4 \\
\hline 1,0 & 0,7 & 0,6 & 0,46 \\
\hline 2,0 & 0,81 & 0,7 & 0,6 \\
\hline
\end{tabular}


Tab 2.8: Kapacita dvou vodičů na protilehlých stranách oboustranného plošného spoje

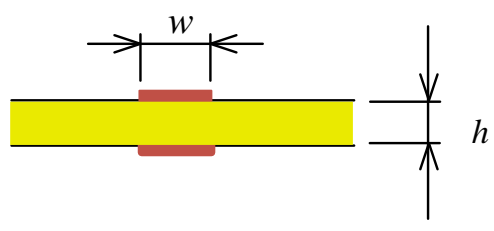

\begin{tabular}{|c|c|c|c|c|}
\hline \multirow{2}{*}{$\begin{array}{c}\text { šírka } \\
\text { vodiče } \\
w(\mathrm{~mm})\end{array}$} & \multicolumn{4}{|c|}{ kapacita $(\mathrm{pF} / \mathrm{cm})$} \\
\cline { 2 - 5 } & \multicolumn{4}{|c|}{ tloušt'ka plošného spoje $h$} \\
\cline { 2 - 5 }$(\mathrm{mm})$ & 0,5 & 1,0 & 1,5 & 2,0 \\
\hline 0,3 & 0,84 & 0,66 & 0,6 & 0,54 \\
\hline 0,5 & 1,08 & 0,75 & 0,72 & 0,63 \\
\hline 1,0 & 1,75 & 1,08 & 0,9 & 0,75 \\
\hline 2,0 & 2,7 & 1,75 & 1,35 & 1,08 \\
\hline
\end{tabular}

Tab 2.9: Vlastnosti vodiče na oboustranné desce plošného spoje, slouží-li druhá strana desky jako stínění

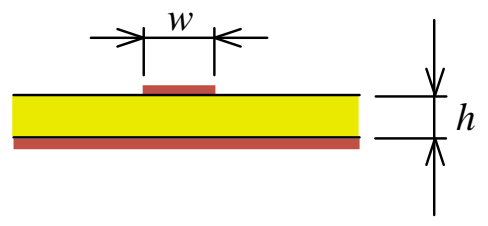

\begin{tabular}{|c|c|c|c|c|}
\hline \multirow{2}{*}{$\begin{array}{c}\text { šírka } \\
\text { vodiče } w \\
(\mathrm{~mm})\end{array}$} & \multicolumn{4}{|c|}{$\begin{array}{c}\text { kapacita }(\mathrm{pF} / \mathrm{cm}) \\
\text { tloušt'ka plošného } \\
\text { spoje } h(\mathrm{~mm})\end{array}$} \\
\cline { 2 - 5 } & 0,5 & 1,0 & 1,5 & 2,0 \\
\hline 0,3 & 1,32 & 0,93 & 0,9 & 0,9 \\
\hline 0,5 & 1,68 & 1,17 & 0,93 & 0,9 \\
\hline 1,0 & 2,4 & 1,68 & 1,38 & 1,17 \\
\hline 2,0 & 3,35 & 2,4 & 1,95 & 1,68 \\
\hline
\end{tabular}

\begin{tabular}{|c|c|c|c|c|}
\hline \multirow{3}{*}{$\begin{array}{l}\text { šíŕka } \\
\text { vodič } w \\
(\mathrm{~mm})\end{array}$} & \multicolumn{4}{|c|}{ indukčnost $(\mathrm{nH} / \mathrm{cm})$} \\
\hline & \multicolumn{4}{|c|}{$\begin{array}{l}\text { tloušt'ka plošného } \\
\text { spoje } h(\mathrm{~mm})\end{array}$} \\
\hline & 0,5 & 1,0 & 1,5 & 2,0 \\
\hline 0,3 & 4,9 & 6,3 & 7,1 & 7,7 \\
\hline 0,5 & 3,9 & 5,3 & 6,1 & 6,7 \\
\hline 1,0 & 2,5 & 3,9 & 4,7 & 5,3 \\
\hline 2,0 & 1,1 & 2,5 & 3,3 & 3,9 \\
\hline
\end{tabular}




\subsection{Provedení spojů}

\subsubsection{Jednodrátové vodiče}

Nejčastěji se používají pro signálové vodiče měděné dráty nebo ohebná splétaná lanka, tzv. lícny Obr. 2.11 a), obvykle průměru 0,3 až $0,5 \mathrm{~mm}$ povrchově krytá pro lepší pájení pocínováním, obalená v izolantu (měkčený PVC, nebo teflon). Jde o nesymetrické vedení, které nemá jednoznačně definovanou charakteristickou impedanci. Její hodnota se obvykle pohybuje od 100 do $1000 \Omega$ a záleží na tom, v jaké vzdálenosti je vodič veden od uzemněné plochy.

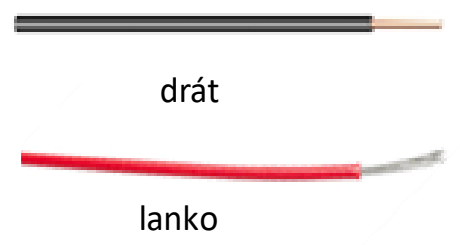

a

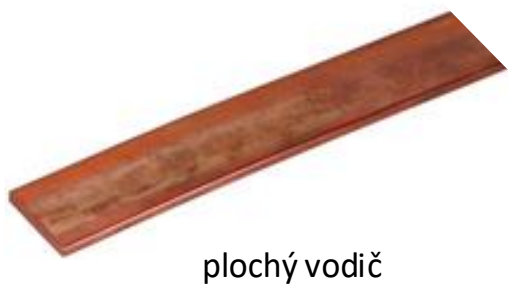

C

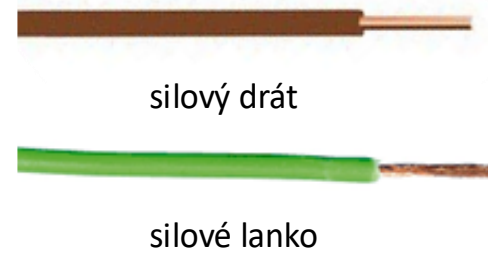

b

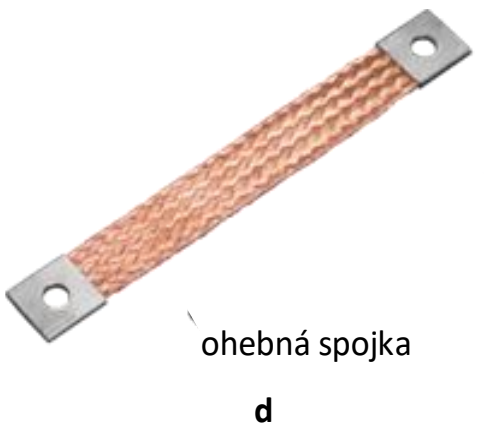

Obr. 2.11: Jednodrátové vodiče: a) signálové vodiče, b) vodiče pro silové rozvody, c) plochý vodič, d) ohebný měděný pásek pro napájecí rozvody

Pro silové rozvody $1 \mathrm{~A}$ až $5 \mathrm{~A}$ se uvnitř zařízení užívají pevné dráty, měděná lanka o průměru $0,75 \mathrm{~mm}$ až $2,5 \mathrm{~mm}$ Obr. 2.11b). Pro silové rozvody 5 A až 50 A se pak používají ploché měděné vodiče Obr. 2.11థ). Důvodem je větší plocha pro odvod tepla, než je tomu u vodiče kruhové průřezu. Pro propojení na pásnicový rozvod napájení jsou také k dispozici ohebné pletené měděné pásky (Obr. 2.11đ).

\subsubsection{Vícežilové kabely}

Typickým provedením vícežilového kabelu, který se užívá pro přenos signálů uvnitř zařízení, jsou dnes ploché ohebné kabely realisované měděným pocínovaným drátem nebo lankem s různým počtem i průřezem vodičů. Vodiče jsou zpravidla kruhového průřrezu. Pro snadnější identifikaci jsou často jednotlivé vodiče (popř. skupiny vodičů) barevně odlišeny Obr. 2.12 ( V V řadě př́ípadů se však z cenových a praktických důvodů od požadavku ohebnosti upouští. Používají se drátové vícežilové kabely, které jsou proti ostrému zlomu chráněny tužší izolací. Jejich výhodou je snadné připojení pomocí zařezávacích kontaktů Obr. 2.12b). 


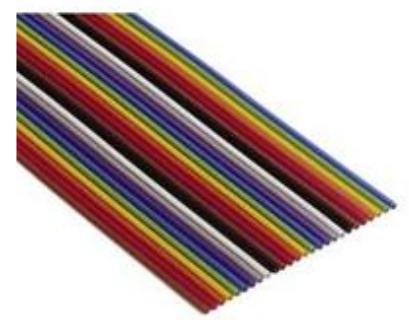

a

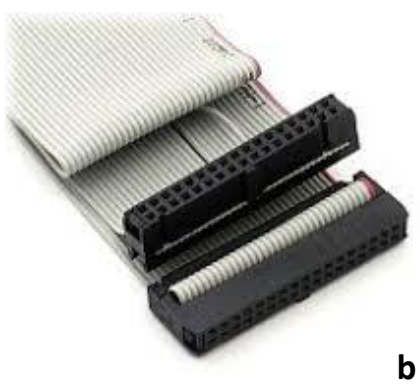

b

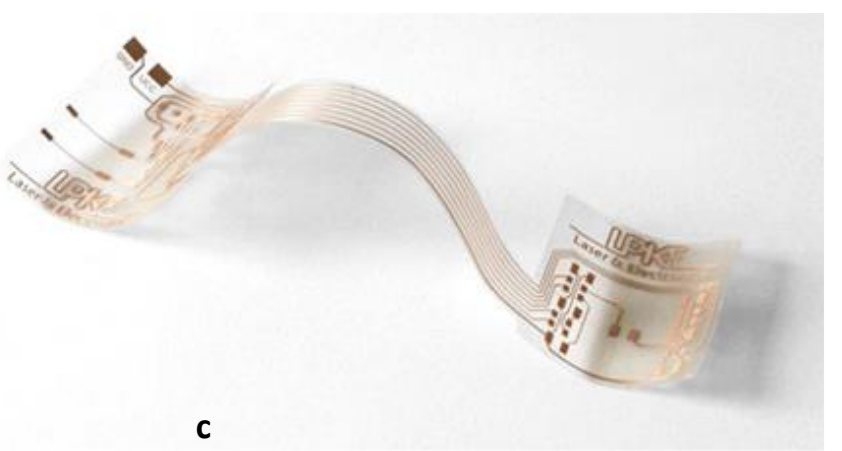

Obr. 2.12: Vícežilový plochý kabel: a) ohebný s lanky, b) drátový ze zařezávacími kontakty, c) realisovaný pomocí ohebného plošněho spoje

Mnohožilové ploché kabely s vodiči kruhového průřezu mají rozsah charakteristických impedancí od $50 \Omega$ do $200 \Omega$, s plochými vodiči na ohebném plošném spoji Obr. 2.12 ) bývá charakteristická impedance $90 \Omega$. Výhodou plochých vodičů na ohebném plošném spoji je lepší chlazení, které dovoluje pro daný proud použít 2 až 3 krát menší prưřez, než u vodičủ o kruhovém průřrezu. Také u kmitočtů nad $1 \mathrm{GHz}$ je plochý vodič výhodnější, má totiž při stejném průřezu asi dvakrát větší povrch než vodič kruhového prưřezu a proto se u něj uplatní tzv. povrchový jev v menší míře.

Přeslechy mezi vodiči plochého kabelu lze snížit použitím zemních vodičů Obr. 2.13 nebo přidáním dalších zemních vodičů Obr. 2.13, Obr. 2.13๕) nebo zvětšením rozestupů mezi trojicemi vodičů, z nichž vždy oba krajní vodiče jsou zemní (Obr. 2.13d). U sdílených zemních vodičů je úroveň přeslechů $1,5 \%$, se dvěma zemními vodiči mezi signálovými vodiči i méně než $1 \%$.

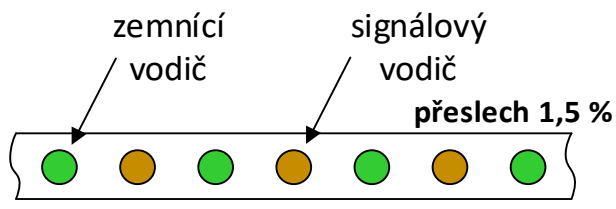

a

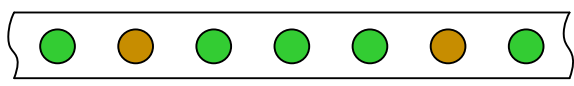

c

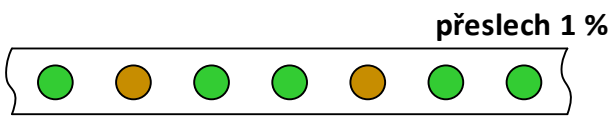

b

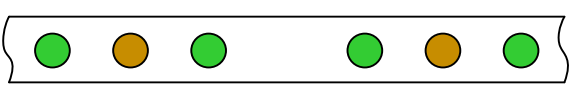

d

Obr. 2.13: Zapojení plochých vícežilových kabelů pro potlačení přeslechů mezi vodiči

Pro přenos telefonních a různých sdělovacích či ovládacích signálů mezi dvěma zařízeními se na větší vzdálenosti používají především kulaté, ale i ploché kabely se dvěma a 
více vodiči. Kabely jsou jak v provedení s pevnými vodiči, tak i s ohebnými lanky. Svazek vodičů může být stíněn opletením tenkými drátky, nebo Al fólií.

Pro rozvody sítě $230 \mathrm{~V}_{\sim}$ se pak užívají měděné ohebné sít'ové kabely dvouvodičové, častěji však třívodičové s ochraným vodičem Obr. 2.14. Fázový, neutrální a ochranný vodič jsou v kabelu vyznačeny barvou izolace. Fázový vodič (L) je vyznačen hnědou popř. černou nebo šedou barvou, pro neutrální (nulový) vodič $(\mathrm{N})$ je vyhrazena světle modrá barva a ochranný (zemní) vodič (PE) se označuje dvoubarevnou kombinací zelené a žluté barvy.

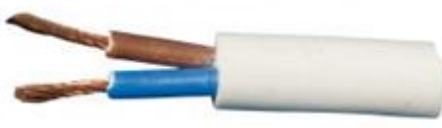

a

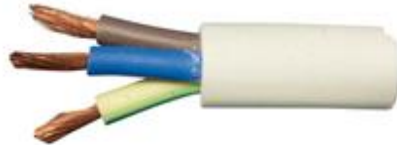

b

Obr. 2.14: Ohebné sít'ové kabely: a) dvouvodičový, b) trrívodičový se zemním vodičem

\subsubsection{Kroucený dvojitý vodič}

Kroucená dvojlinka nebo také kroucený pár (twisted pair), zkráceně twist, je nejuniverzálnější druh vedení používaný pro delší spoje. Je tvořen dvěma souběžnými izolovanými vodiči s průměrem drátu $0,5 \mathrm{~mm}$ nebo zř́d dka $0,3 \mathrm{~mm}$, navzájem kolem sebe zkroucenými tak, že na $1 \mathrm{~m}$ délky připadá 15 až 35 zkrutů (viz Obr. 2.15. Předepsaným mechanickým uspořádáním je zaručena konstantní hodnota charakteristické impedance. Impedanční přizpůsobení je proto snadné a tento typ symetrického vedení může být použit i pro přenos na elektricky dlouhé vzdálenosti.

Symetrické vedení zkroucenými vodiči je odolné proti rušení. Rušivé signály se projevují jako souhlasné napětí a jsou rozdílovým přijímačem potlačeny. Vnější příčné rušivé magnetické pole indukuje do vodičů napětí, které se však zruší díky stř́idající se polaritě elementárních magnetických obvodů tvořenými jednotlivými zkruty (závity). Pokud se používají paralelní nezkroucené vodiče, indukované napětí se nezruší, protože jako elementární magnetický obvod působí celé vedení. Poznamenejme však, že indukované napětí ovlivňuje přenos užitečného signálu jen nepatrně, nebot' $\mathrm{z}$ hlediska vstupů rozdílového přijímače představuje souhlasný signál. Zkroucený dvouvodič je $\mathrm{v}$ mnoha př́padech znamenitou náhradou koaxiálních kabelů především v číslicových systémech.

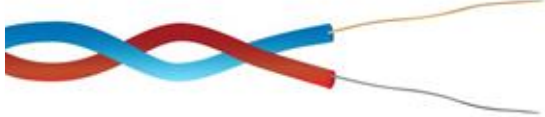

Obr. 2.15: Volně kroucený dvojitý vodič (twist)

Charakteristická impedance vedení s volně zkroucenými vodiči bývá 100 až $130 \Omega$ (někdy 50 až $200 \Omega$ ) při 15 až 35 zkrutech na 1 metr délky. Z konstrukčních důvodů je však obtížné udržet u volně zkroucených vodičů jmenovitou hodnotu v úzké toleranci (cca $8 \%$ v závislosti na utažení smyček). Počet zkrutů na jednotku délky nemá při dobrém dotyku výrazný vliv na charakteristickou impedanci, ovlivňuje hlavně dobu šíření signálu.

Průměrná kapacita volně zkrouceného twistu je $C=30$ až $80 \mathrm{pF}$ na 1 metr délky vedení. Doba šíření je v rozmezí 4 až 5,25 ns/m $\pm 5 \%$. Díky konstantní hodnotě charakteristické impedance jsou takové volně zkroucené vodiče vhodné pro přenosy na vzdálenost kolem 1000 $\mathrm{m}$, mezní kmitočet pro pokles o $3 \mathrm{~dB}$ je $f_{\max } \approx 15 \mathrm{MHz}$. 
Pokud se volně zkroucené vodiče použijí pro konstrukci metalické strukturované kabeláže, pak ostřejší ohyb kabeláže způsobí oddálení vodičů a tím i změnu charakteristické impedance vedení. $Z$ těchto důvodů se kabely kategorie 4 , kde se používaly 4 páry volně zkroucených vodičů, přestaly pro přenos dat používat.

Zlepšení vlastností přineslo zvýšení počtu zkrutů, případně i slepení sousedních vodičů v páru, které znesnadňuje oddálení vodičů při ostrém ohybu kabelu. Přehled kategorií metalických kabelů pro strukturovanou kabeláž včetně základních parametrů je uveden naObr. 2.16. Přeslechy mezi páry jsou v kabelu sníženy tím, že každý pár má jiný počet zkrutů na metr délky nebo má každý pár vlastní stínění. Aby se zabránilo indukci rušení ze sousedních kabelů či silnoproudých rozvodů, mohou být všechny páry opatřeny celkovým stíněním umístěným pod pláštěm kabelu. Použití stínění nepřinese zvětšení šǐřky přenášeného pásma či zvýšení rychlosti přenosu dat, ale potlačí průnik elektromagnetického rušení ze sousedních párů či kabelů a současně snižuje vyzařování rušivých signálů do okolí. Plastový kříž vložený do kabelu kategorie 6 má zabránit ostrým ohybům kabelu, kdy by mohlo dojít ke změně charakteristické impedance. Počínaje kategorií 7 je každý pár vodičů opatřen stíněním a celý kabel má pak ještě jedno stínění, čímž se současně zabraňuje ostrým ohybům kabelu.

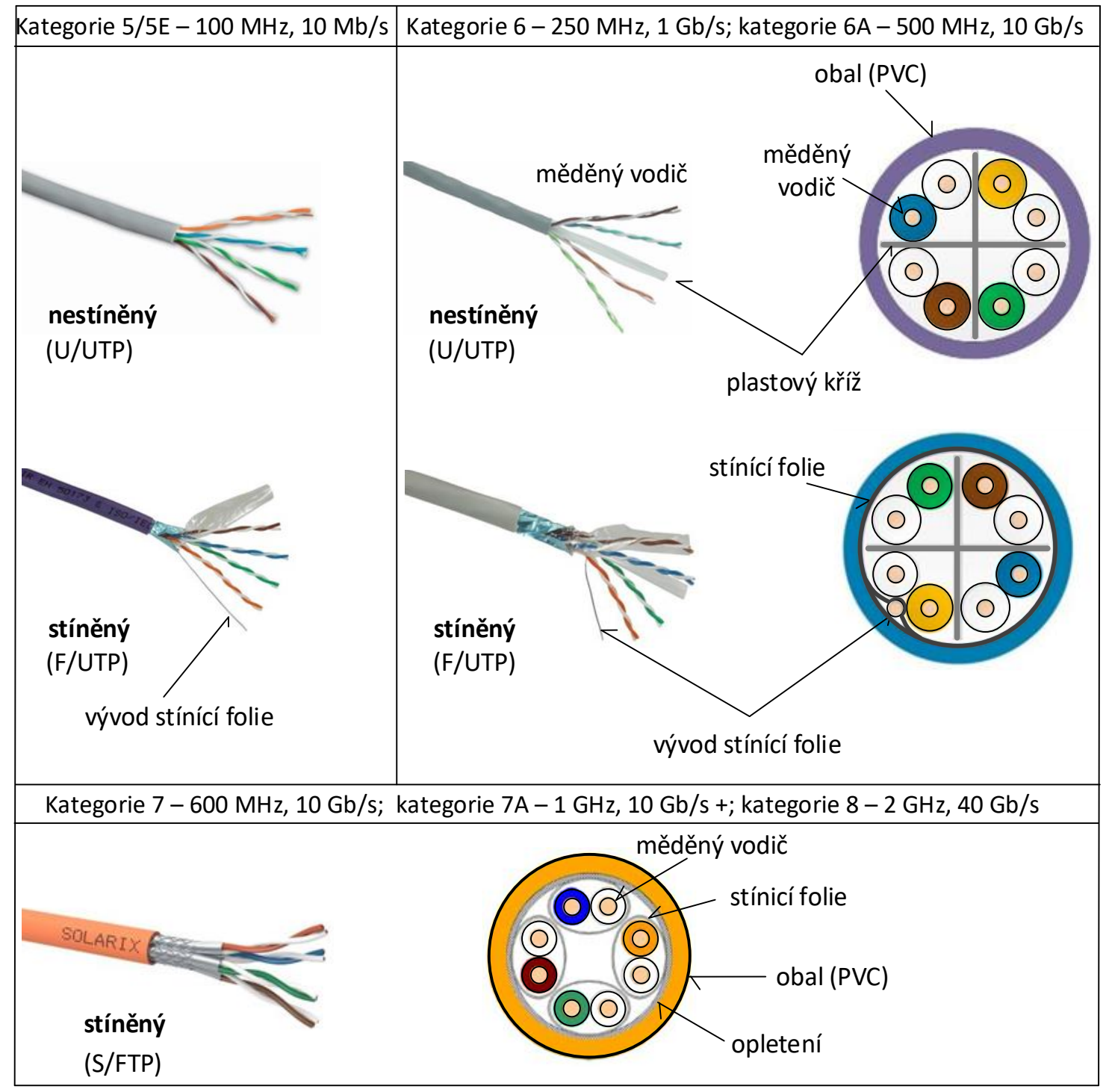

Obr. 2.16: Metalické kabely pro strukturovanou kabeláž 
Vnitřní konstrukce kabelů pro metalickou strukturovanou kabeláž se označují písmenkovými zkratkami ve tvaru zlomku, např. U/UTP, F/UTP, S/FTP. Písmenkové zkratky před zlomkem se týkají kabelu jako celku, kde $U$ = Unshielded značí nestíněný kabel, $F=$ Foil pak kabel stíněný Al fólií, $\mathrm{S}=$ Shielded kabel stíněný opletením. Písmenkové zkratky za zlomkem se týkají jednotlivých párů vodičů, přičemž UTP = Unshielded Twisted Pair značí nestíněný kroucený pár a FTP = Foil Twisted Pair znamená, že každý kroucený pár je stíněn Al fólií.

\subsubsection{Koaxiální a stíněné kabely}

Konstrukce koaxiálního či stíněného kabelu je zřejmá z Obr. 2.17. Středový vodič je obvykle realizován lankem spleteným z tenkých měděných vodičů nebo pevným měděným vodičem. Jako dielektrikum se nejčastěji uživá polyetylén nebo teflon. Stínění může být realizováno opletením ve tvaru sít'ky většinou z měděných drátků, nebo ovinutím hliníkových páskem, popř. kompaktní hliníkovou folií. Pro větší stínicí účinek může být stínění zdvojeno v kombinaci hliníková folie překrytá opletením. Koaxiální kabel se používá jako nesymetrické vedení. Existují však i koaxiální kabely se dvěma stíněními navzájem oddělenými dielektrikem, které jsou určeny pro symetrické vedení.

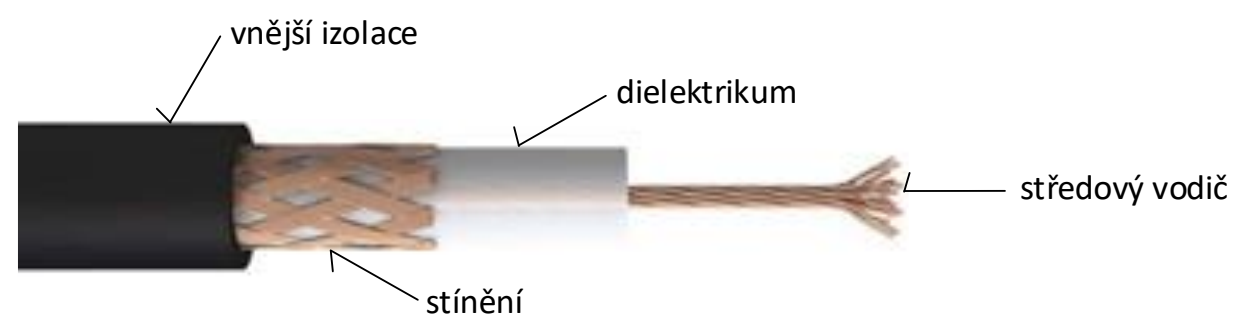

Obr. 2.17: Vnitřní konstrukce stíněného kabelu

Konstrukční uspořádání zajišt'uje minimální citlivost koaxiálního kabelu na rušení kapacitní vazbou. Charakteristická impedance bývá 50 až $200 \Omega$, kapacita 30 až 100 pF/m, doba šíření je 4 až 4,5 ns/m, šířka přenášeného pásma $f_{\max } \approx 1$ až $3 \mathrm{GHz}$.

Zda jde o koaxiální nebo stíněný kabel rozlišujeme podle šířky pásma přenášených kmitočtů. Pro audio-signály se užívá většinou miniaturní (tenký) stíněný kabel o celkovém průměru 3 až 3,5 mm. U tohoto typu kabelu většinou výrobci ani neudávají charakteristickou impedanci, protože jsou určeny pro nízkofrekvenční aplikace do $25 \mathrm{kHz}$ jako např. mikrofonní přívod, př́vody ke sluchátkům apod. Několik příkladů řešení stíněných audiokabelů je uvedeno na Obr. 2.18. Vyšší nároky na šířku kmitočtového pásma a na charakteristickou impedanci pak splňují koaxiální kabely určené pro vysokofrekvenční aplikace, pro rychlé datové přenosy apod. (viz Obr. 2.19.

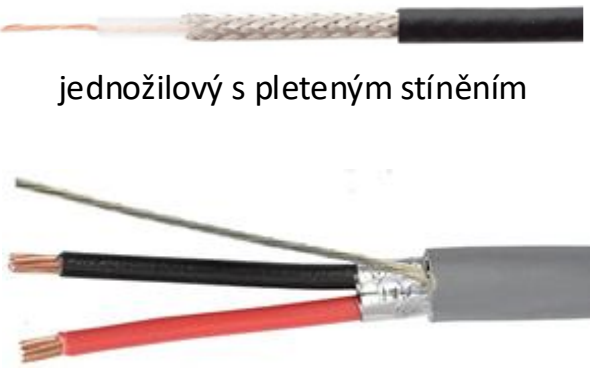

dvoužilový s kompaktním stíněním jednožilový s dvojitým stíněním (stínění vinuté Al folií + pletené)

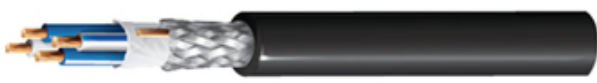

mikrofonní 4 žilový s pleteným stíněním

Obr. 2.18: Několik př́íkladů stíněných audiokabelů 


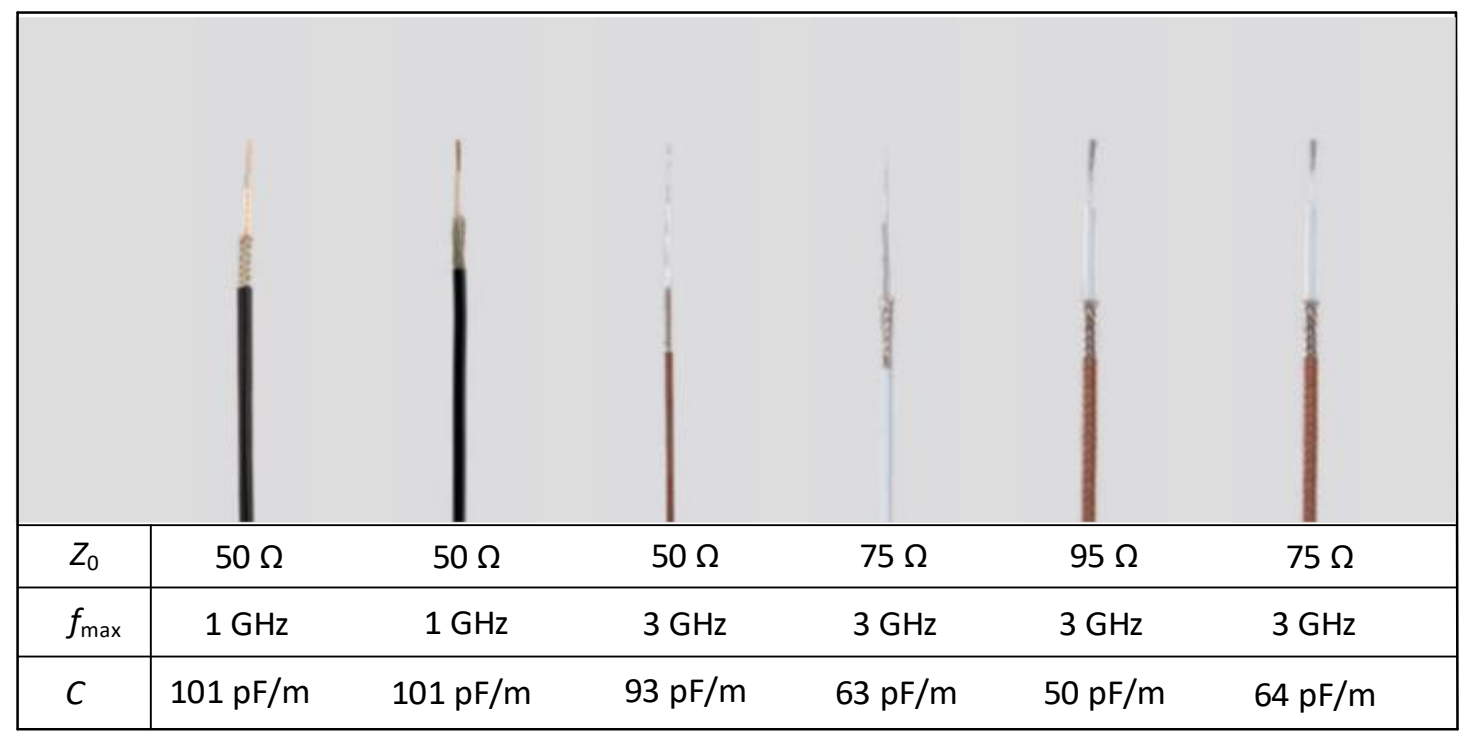

Obr. 2.19: Několik př́kladů koaxiálních kabelů pro vysokofrekvenční aplikace

Koaxiální či stíněné kabely mají však i nevýhody. Zabírají více místa, obtížně se napojují, mají větší hmotnost, jsou dražší a většinou mají poměrně velkou kapacitu, která vyžaduje použít větší budicí proudy. Svoje opodstatnění mají všude tam, kde je zapotřebí dobře odstínit signálový vodič (především při průchodu silně zarušeným prostředím, nebo při vyvazování do svazků) a také v př́padě potřeby definované hodnoty charakteristické impedance v úzkých tolerancích. Pro značnou cenu a problémy s připojováním (nutnost použivat speciální nástroj pro připojení koaxiálního konektoru) se však použivá jen tam, kde je to nezbytně nutné a nelze jej nahradit krouceným dvojitým vodičem. Na dlouhých a extrémně dlouhých přenosových linkách je pak jeho význam potlačen aplikačními možnostmi optických spojů.

\subsubsection{Plošné spoje}

Plošný spoj tvoří kovový (nejčastěji měděný) spojový obrazec na vyztužené izolační podložce. Deska plošného spoje (DPS) plní čtyři základní funkce:

- poskytuje mechanickou oporu součástkám,

- realizuje vodivé spoje,

- slouží k odvodu tepla ze součástek (zejména v provedení SMD)

- většinou obsahuje i popis pro identifikaci součástek.

Vodivý obrazec může být nanesen jen na jedné straně desky, nebo na obou stranách DPS. Propojení vodičů na horní straně s vodiči na spodní straně se provádí pokovenými propojovacími otvory. Uvnitř desky může být i více vrstev vodivého obrazce. Podle toho se DPS dělí na jednostranné, oboustranné a vícevrstvé.

Jednostranné desky plošných spojů mají propojovací vodič pouze na jedné straně DPS a nemají pokovené otvory. Jsou vhodné pro jednodušší aplikace. Na osazování se používají klasické vývodové součástky (osazují se do vyvrtaných otvorů ze strany, kde nejsou vodivé spoje), nebo SMD součástky (osazují se ze strany spojů), v některých př́ípadech se používá kombinace obou způsobů osazování. Vyrábějí se ze základního materiálu, který je jednostranně plátován mědí. 
Dvoustranné desky plošných spojů mají dvě vrstvy propojovacích vodičů v provedení s pokovenými otvory. Používají se pro náročnější aplikace, dosahuje se u nich podstatně vyšší hustoty montáže než u jednovrstvých desek. Na osazování se používají přednostně SMD součástky, ale lze užít i součástky vývodové. Vyrábějí se ze základního materiálu, který je oboustranně plátován mědí.

Vícevrstvé desky plošných spojů (multilayer) mají více než dvě vrstvy propojovacích vodičů. Standardně se vyrábějí v sudém počtu vrstev. Nejběžnějším provedením jsou čtyřvrstvé desky, které mají dvě vrstvy vnější a dvě vrstvy vnitřní. Všechny vrstvy mohou být vzájemně propojeny pokovenými otvory. U těchto typů desek se dosahuje podstatně vyšší propojitelnosti než u dvouvrstvých desek. Osazují se především SMD součástkami méně často pak vývodovými součástkami. Při výrobě vícevrstvých desek se používají tenké základní materiály, na nichž se nejprve vytvoří vodivé obrazce vnitřních vrstev. Dvě sousední vnitřní vrstvy na stejném základním materiálu mohou být vzájemně propojeny pokovenými otvory. Celá sestava se pak slisuje pomocí lepících listů, tzn. prepregů. Nakonec se všechny vrstvy vzájemně propojí prokovenými otvory přes všechny vrstvy.

Základním nosným materiálem DPS je izolační výztuž sycená pryskyřicí tzv. laminát. Na tuto izolační podložku je naplátována z jedné či z obou stran měděná fólie. Jednotlivé typy DPS se odlišují podle použité výztuže (celulozový papír, tkaná nebo netkaná skelná tkanina popř. jejich kombinace) a podle použité pryskyřice (fenelová, epoxidová, polyesterová). Další tř̌́dění DPS je podle mechanických vlastností podložky, kdy rozlišujeme materiály pro neohebné plošné spoje (rigid PCB), pro ohebné plošné spoje (flexible PCB) a pro roztažné plošné spoje SCB (Stretchable Copper Board).

\section{Materiály pro neohebné plošné spoje}

Pro označování materiálu či vlastností použité izolační podložky se užívá několik písmenkových zkratek. FR (Fire Retardent) značí odolnost proti ohni, kdy díky zpomalovačům hoření má materiál podložky samozhášecí vlastnosti. CEM (Composite Epoxy Material) označuje kompositní výztuž, kdy podložka je např. tvořena kombinací papírové výztuže a vrstvy skelné tkaniny. IMS (Insulated Metal Substrate) značí plátované materiály s kovovou podložkou. Zkratka TG (Glass Transition Temperature), někdy Tg nebo $T_{\mathrm{g}}$ označuje tzv. teplotu skelného přechodu (teplota zeskelnění). Pod touto teplotou je materiál podložky tvrdý a křehký a má vysoký modul pružnosti. Nad touto teplotou materiál podložky skokově nabývá kaučovitou pružnost, přičemž modul pružnosti poklesne až o tři řády. Jinak řečeno pod teplotou TG materiál podložky vykazuje menší deformace než nad teplotou TG, kdy dochází k větším deformacím při stejném napětí v tahu.

Materiály pro neohebné plošné spoje, můžeme rozdělit do pěti základních skupin [8]:

- celulózový papír (FR1, FR2, FR3),

- tkaná skelná tkanina (FR4, FR5 a jejich modifikace G10, G11),

- kompositní materiály (CEM1, CEM2),

- materiály pro vysokofrekvenční aplikace (FR6) a pro speciální aplikace (GT, GTX, GPY)

- materiály s kovovou podložkou (IMS).

\section{Materiály na bázi celulózového papíru}

DPS typu FR1 a FR2 mají výztuž z celulózového papíru vytvrzeného fenolovou pryskyřicí. Rozdíl je v teplotě zeskelnění TG. V př́ípadě FR1 je více než $130{ }^{\circ} \mathrm{C}$, kdežto u levnější varianty FR2 je jen $105^{\circ} \mathrm{C}$. Materiály jsou málo odolné vůči vlhkosti a při tepelném 
přetížení dochází ke zuhelnatění podložky a tím i k výraznému poklesu izolačního odporu. Materiál FR3 má také výztuž z celulózového papíru, ale pro vytvrzení je použita epoxidová pryskyřice. Teplota $\mathrm{TG}$ je v tomto př́padě $110^{\circ} \mathrm{C}$. Nejvíce používaným materiálem této kategorie je typ FR2. Materiály s papírovou výztuží jsou levné, ale nejsou příliš rozměrově stálé a jsou poměrně navlhavé. Proto nacházejí uplatnění zejména v různých oblastech spotřební elektroniky pro jednostranné a dvoustranné DPS bez pokovených otvorů.

\section{Materiály na bázi skelných vláken}

Materiály typu FR4, FR5 a jejich modifikace G10, G11 se vyznačují dobrými mechanickými a elektrickými vlastnostmi. Je to díky použití tkané skelné tkaniny jako výztuže. Jsou nehořlavé (samozhášecí), poměrně rozměrově stálé a málo navlhavé.

Nejčastější používaným materiálem z této skupiny je typ FR4 i když má horší vlastnosti než materiál FR5, který má vyšší tepelnou odolnost, ale i cenu. Materiál FR4 má teplotu TG $135^{\circ} \mathrm{C}$, pro materiál FR5 je teplota TG $160^{\circ} \mathrm{C}$. Materiál je určený na výrobu jednostranných, dvoustranných DPS a také na výrobu vícevrstvých DPS s prokovenými otvory. Tento typ materiálu je poměrně levný. Má dobré dielektrické vlastnosti, ale není vhodný na vysokofrekfenční aplikace. Materiál FR4 má poněkud horší rozměrovou stálost, což může hlavně v náročnějších aplikacích způsobit hlavně problémy při osazování součástek s malou roztečí vývodů. V procesu pájení totiž velmi často epoxidová pryskyřice v okolí teploty tavení $\left(120\right.$ až $\left.160^{\circ} \mathrm{C}\right)$ měkne a přitom může dojít ke změně mechanických vlastností. Přes uvedené nedostatky má materiál uplatnění při výrobě spotřební elektroniky, ale především v oblasti náročných aplikací průmyslové elektrotechniky.

\section{Kompositní materiály}

Kompositní materiál CEM1 má podložku tvořenou papírovým jádrem s jednou vrstvou skelné tkaniny. Používá se často jako levnější náhrada materiálu FR4. Teplota skelného přechodu TG je $120{ }^{\circ} \mathrm{C}$. Používá se pro jednostranné či dvoustranné DPS bez pokovených otvorů.

Materiál CEM3 jako podložku využívá kombinaci tkané a netkané skelné tkaniny. Tento materiál se v celé řadě vlastností vyrovná materiálu FR4. Teplota skelného přechodu TG je $130{ }^{\circ} \mathrm{C}$. U DPS s materiálem CEM3 se běžně používají pokovené otvory.

Desky vyrobené z kompositních materiálů mají v porovnání s deskami z materiálu na bázi papíru lepší elektrické i mechanické vlastnosti. Mají lepší izolační vlastnosti a nižší navlhavost. Používají se v méně náročných aplikacích, jako jsou audiozařízení nebo jiná spotřební elektronika.

\section{Materiály pro vysokofrekvenční a speciální aplikace}

Materiál FR6 má podložku tvořenou skelnou tkaninou sycenou polyesterovou pryskyřicí. Vlastnosti tohoto materiálu jsou horší jako FR4, ale lepší než mají materiály na bázi papíru. Materiál má výborné vf vlastnosti i při zvýšené vlhkosti. Díky dobré ceně bývá aplikován ve vf aplikacích telekomunikační a spotřební elektroniky.

Skupina materiálů s označením GT, GTX má podložku na bázi skelné tkaniny a polytetrafluóretylenu (teflon). Mají výborné dielektrické a elektrické vlastnosti. Mají vynikající vf vlastnosti a velmi nízké svodové proudy, materiál je nenavlhavý. Jde o jeden z nejdražších materiálů pro DPS, ale cena odpovídá vynikajícím parametrům. Tento typ materiálu se používá pro vf aplikace $\mathrm{v}$ komunikačních technologiích a také $\mathrm{v}$ přístrojích pracujících $\mathrm{s}$ RTG zářením. 
Materiál s označením GPY má materiál podložky na bázi skelných nebo uhlíkových vláken a polyimidové pryskyřice. Polyimid si zachovává svoje fyzikální vlastnosti v širokém rozmezí teplot (od $-260{ }^{\circ} \mathrm{C}$ do $400{ }^{\circ} \mathrm{C}$ ). Protože materiál je velmi drahý, používá se zejména pro vojenské účely a vysoce náročné průmyslové účely a to i pro výrobu vícevrstvých DPS. Polyimidová fólie známá pod obchodním označením Kapton se také používá pro výrobu ohebných DPS.

\section{Materiály s kovovou podložkou}

Materiály označované zkratkou IMS používají jako podložku kovový materiál (nejčastěji hliník), na které je tenká izolační vrstva (kolem $100 \mu \mathrm{m})$ na kterou je naplátována měd' různé tloušt'ky. Tento typ DPS je určen pro výkonové aplikace, kde se využívá vysoká tepelná vodivost podložky k obvodu tepla ze součástek. Mimo uplatnění v různých výkonových regulačních obvodech nebo k odvodu tepla z číslicových pamětí se v poslední době využívají zejména k odvodu tepla z výkonových LED diod.

\section{Materiály pro ohebné plošné spoje}

Ohebné desky plošných spojů (flexible PCB) se použivají v automobilovém průmyslu, ve fotoaparátech, myčkách nádobí či v pračkách a v celé řadě dalších průmyslových aplikací. V některých př́padech jde skutečně o ohebnou desku plošných spojů, kdy jsou na ohebné desce připájeny i součástky (např. LED pásky) nebo jde jen o ohebné spojení mezi neohebnými deskami plošných spojů nebo ohebné spojení mezi pevnou deskou a součástkou pomocí konektoru.

Materiály pro ohebné plošné spoje jsou většinou bez výztuže. Nejčastěji se užívají materiály na bázi polyesterů a polyimidů. V menší míře se užívají kompositní materiály na bázi aramidového papíru a epoxidových pryskyřic. Nejužívanějším materiálem pro ohebné plošné spoje je polyimidový základní materiál, na kterém je naplátována měděná folie.

\section{Polyetyléntereftalát (PET)}

Základem je polyetyléntereftalátová fólie, na kterou je nalaminována měděná folie. Používá se v membránových spínačích, fóliových klávesnicích, tlačítkových displejích. Nevýhodou je malá tepelná odolnost nepřevyšující $115{ }^{\circ} \mathrm{C}$ a proto se tento materiál nedoporučuje pájet.

\section{Polyetylénnaaftaftalát (PEN)}

Základní materiál je na bázi polyetylénnaftalátové fólie, na který je nalaminována měděná fólie. Mají větší teplotní odolnost než PET fólie a také vykazují lepší elektrické parametry. Ohebné plošné spoje s materiálem PEN se uživají v membránových tlačítkách, fóliových klávesnicích či tlačítkových displejích.

\section{Polyimid (PI)}

Měděná fólie je nalaminována na polyimidovou fólii. Polyimidové podložky jsou schopny pracovat ve velkém rozmezí teplot od kryogenních teplot až po $400{ }^{\circ} \mathrm{C}$. Jejich pájení proto nečiní problémy. Nevýhodou polyimidové podložky je její vysoká navlhavost. 


\section{Materiály pro roztažné plošné spoje}

Roztažné DPS (stretchable PCB) umožňují roztažení plošných spojů, nebo roztažení desky plošných spojů i se součástkami. Pro roztažné plošné spoje SCB (Stretchable Copper Board) se jako základní materiál použivá polyuretan [9], který je nejen roztažný, ale je také velmi prŕíhodný kvůli výborné přilnavosti k mědi. Povolená deformace měděného spoje při roztažení se dociluje provedením plošného spoje v podobě meandru, kdy se natažení plošného spoje projeví v ohybu měděného spoje. Plošný spoj lze roztáhnout do délky až o 30 \% ve směru meandru. Plošný spoj vydrží i příčné zkroucení a ohyb. Nevýhodou takovýchto plošných spojů je menší hustota spojů na desce, protože jeden měděný spoj v podobě meandru zabírá na šířku mnohonásobně více místa než rovný plošný spoj.

Aplikace takového provedení DPS jsou velmi rozsáhlé zejména voblasti tzv. nositelných technologií (wearable technologies), zdravotnictví a sportu (různé monitorovací jednotky) nebo v automobilech (vyhřívání).

\section{Plošné vodiče}

Plošné vodiče se na DPS realizují většinou vyleptáním, méně často vypálením laserem nebo vyfrézováním z měděné fólie naplátované na izolační podložku. DPS jsou zpravidla plátovány jednostranně anebo oboustranně měděnou fólií tloušt'ky $18,35,70$ nebo $105 \mu \mathrm{m}$. V současné době se používají dva základní typy měděné fólie. Galvanickým způsobem vyrobená fólie bývá označena jako typ E popř. ED (electrodeposited). Další typ měděné fólie se vyrábí klasicky válcováním, označuje se jako typ W (wrought) nebo někdy zkratkou RA (rolled annealed).

\section{Typy plošných vodičů}

Z hlediska provedení vlastního spoje se rozeznává soustava jednotných vodičů a soustava jednotných mezer resp. dělicích čar. U soustavy jednotných vodičů mají plošné vodiče převážně jednotnou šířku a mezery mezi plošnými vodiči jsou různě široké (viz Obr. 2.20ł). Při provedení vodivého obrazce soustavou jednotných mezer mají mezery mezi plošnými vodiči převážně jednotnou šiřrku a plošné vodiče jsou různě široké (viz Obr. 2.20b). Každý způsob provedení vodivého obrazce má své výhody a nevýhody.

U soustavy jednotných vodičů jsou velkou výhodou nepatrné vazby mezi jednotlivými spoji a celými obvody. Lze vcelku velmi přesně definovat průřez vodiče, vazbu mezi vodiči a spoje v tomto provedení se vyznačují velmi dobrou přehledností a celkovou ,čtivostí“ daného obrazce. Nevýhodou této metody je, že se musí odleptávat značná část mědi a že spojení úzkých měděných vodičů se základním materiálem je horší a snadněji dochází při jejich zahřátí $\mathrm{k}$ jejich odlepení. Na druhé straně při výrobě dvouvrstvých či vícevrstvých desek s pokovenými propojovacími otvory je malá plocha vodivého obrazce výhodná, protože snižuje spotřebu slitiny cínu a olova nebo zlata potřebného k pokovení. 


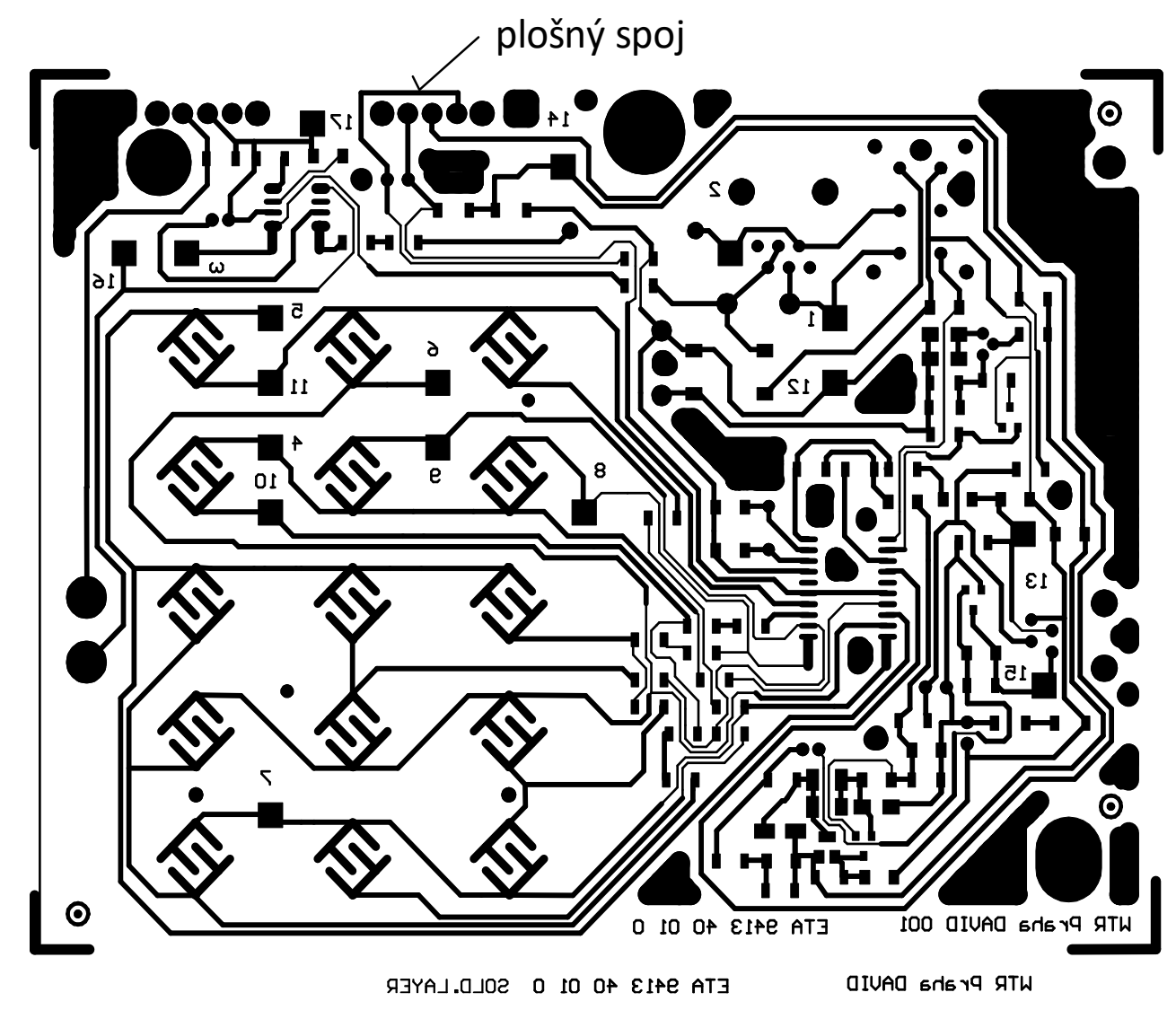

a

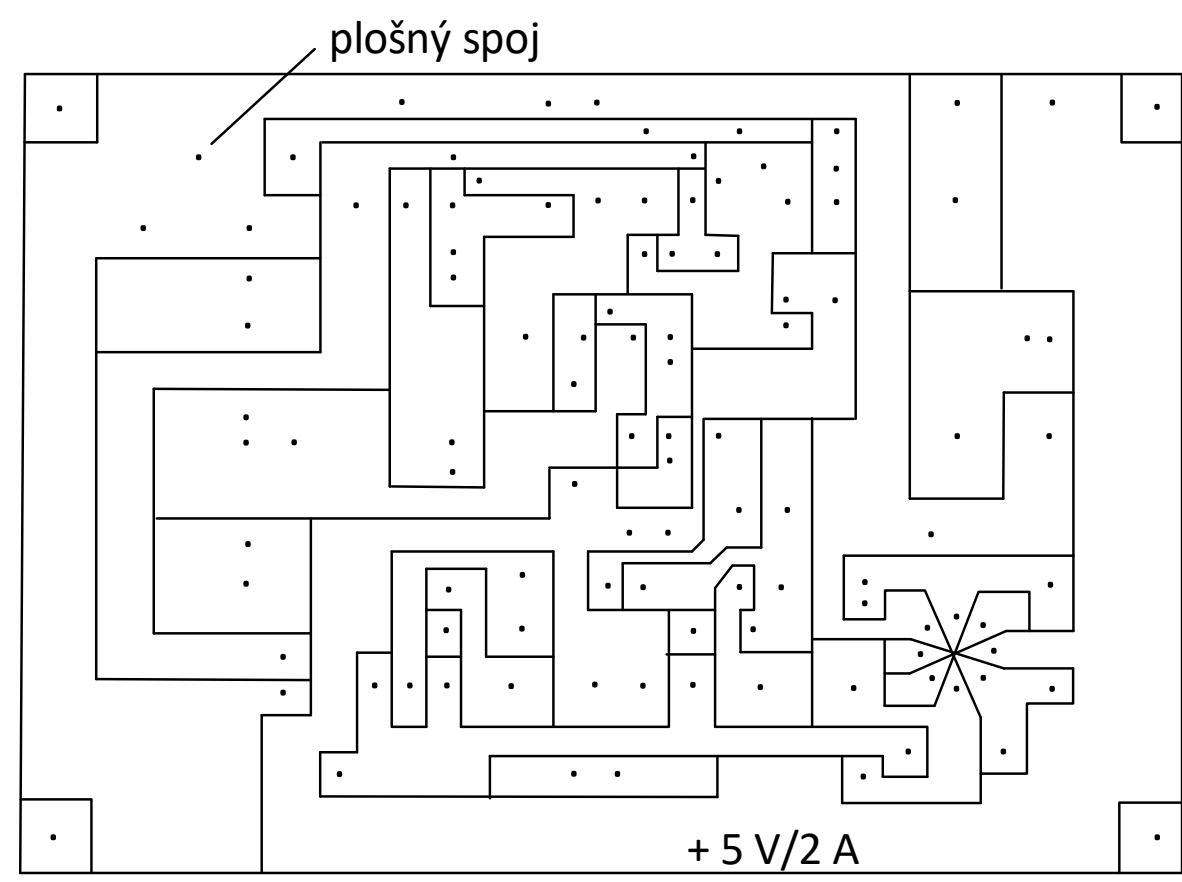

b

Obr. 2.20: Plošné vodiče: a) soustava jednotných vodičů, b) soustava jednotných mezer (dělicích čar) 
U soustavy jednotných mezer (dělicích čar) tvoří spoje celé neodleptané plochy měděné fólie. I když je vodivý obrazec méně přehledný, má tento způsob několik výhod. Při výrobě se totiž odleptává jen minimální množství mědi. Fólie je při pájení méně namáhána tepelně a při opravách se tak snadno neodlepuje. Přerušení spojovací cesty je rovněž méně časté než u prvého způsobu. Značnou nevýhodou jsou velké kapacitní vazby mezi sousedními vodiči. Zcela nevhodný je tento způsob pro realizaci dvouvrstvých či vícevrstvých DPS protože zvyšuje spotřebu slitiny cínu a olova nebo zlata na vytvoření leptuvzdorné masky. Soustava jednotných mezer se proto uživá především u jednoduchých desek plošných spojů a u desek, na kterých jsou realizovány napájecí zdroje.

\section{Třidy konstrukčního provedení}

Při realizaci plošných vodičů je nejprve nutno rozhodnout do jaké konstrukční třídy bude DPS zařazena. Musíme prrihlédnout $\mathrm{k}$ tomu, jaká nejmenší rozteč bude mezi vývody elektrických součástek, jaká bude požadována hustota montáže a zejména jaká může být maximální cena DPS. Jednotlivé tř́́dy (viz Obr. 2.21 jsou charakterizovány jednak minimální šířkou vodičů, minimální šíŕkou izolačních mezer, minimálním přesahem pájecí plošky od otvoru a nejmenším průměrem otvoru $d$. Minimální šířka vodičů, izolačních mezer a přesah pájecí plošky je ve všech třídách shodně $t$.

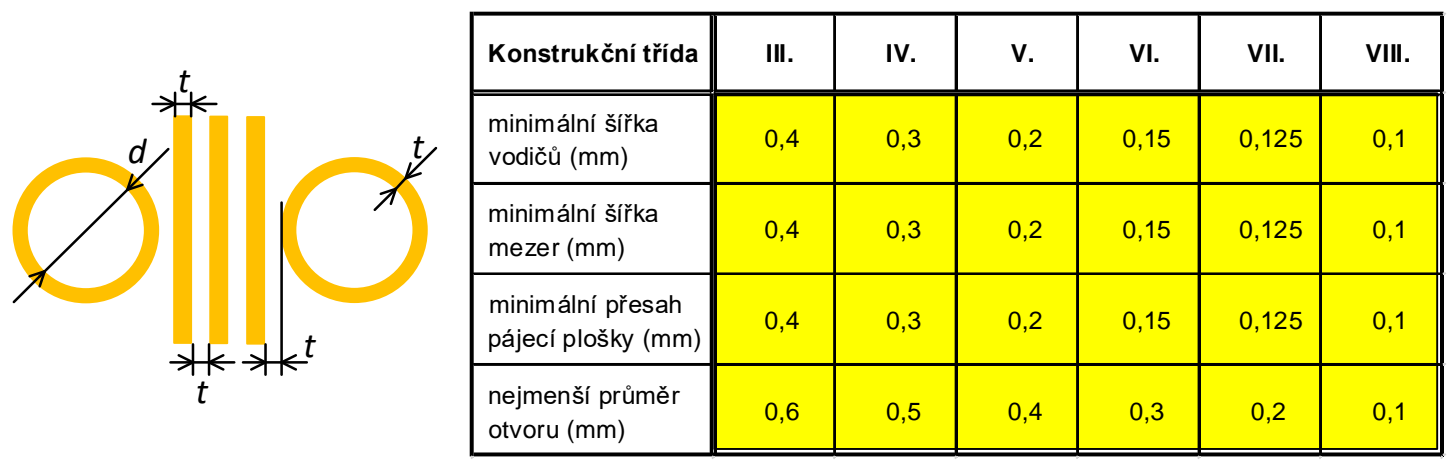

Obr. 2.21: Tř́ídy konstrukčního provedení DPS

Celkem je definováno osm konstrukčních tříd, přičemž nejnižší dvě třridy se dnes prakticky neužívají. Někteří výrobci nabízejí i vyšší třídy, napřs. pro přípustnou šířku spojủ a izolačních mezer $t=0,05 \mathrm{~mm}$. Obecně platí, čím vyšší třída, tím vyšší přesnost technologie výroby a tím i vyšší cena. Poznamenejme ještě, že pokud jen v jediném místě DPS bude použita šířka spojů a izolačních mezer či průměr otvoru patřící do vyšší trř́dy, bude celá DPS zařazena do vyšší kategorie. Výsledná cena pak bude vyšší, protože výrobce musí pro výrobu DPS použít přesnější technologii.

\section{Parametry plošných spojio}

Nejdůležitější vlastností DPS, kterou je třeba před vlastním návrhem plošných spojů přezkoumat, je proudová zatížitelnost plošných vodičů a nutná velikost izolační mezery mezi plošnými vodiči zaručující elektrickou izolaci. Většina plošných vodičů na deskách s integrovanými obvody bude zatížena jen několika miliampéry, avšak přívody napájení, kterými tečou obvykle daleko větší proudy, musí být rozvedeny ke všem obvodům. Na Obr. 2.22 je uvedena proudová zatížitelnost plošných vodičů z mědi o tloušt'ce 35 a $70 \mu \mathrm{m}$ při pokojové teplotě $\vartheta=20^{\circ} \mathrm{C}$ a při teplotě $\vartheta=40^{\circ} \mathrm{C}$. 


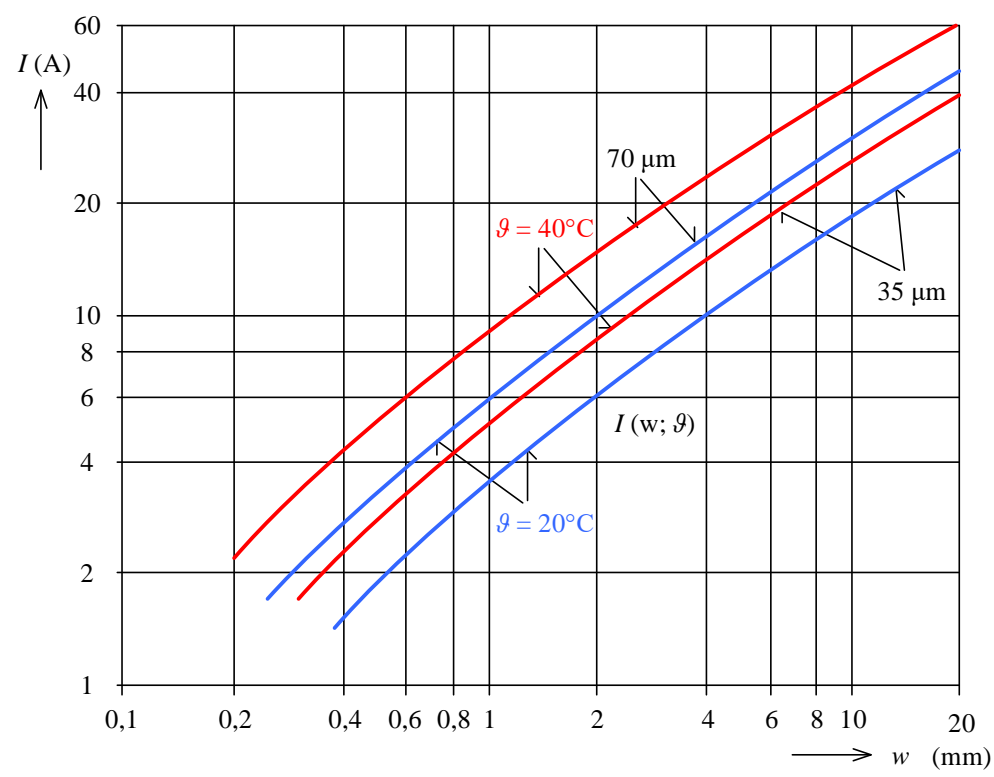

Obr. 2.22: Proudová zatížitelnost plošných vodičů realizovaných měděnou fólií tloušt'ky $35 \mu \mathrm{m}$ a $70 \mu \mathrm{m}$ v závislosti na širřce plošného spoje $w$

Pro desky s pokovenými propojovacími otvory, které byly vyrobeny z laminátu se základní vrstvou mědi $35 \mu \mathrm{m}$, platí údaje pro tloušt'ku $70 \mu \mathrm{m}$ (základní vrstva + pokovení). Z grafu lze např. vyčíst, že uvažujeme-li pokojovou teplotu plošného spoje, je plošný vodič o tloušt'ce $35 \mu \mathrm{m}$ a šířce $w=1 \mathrm{~mm}$ schopen vést proud kolem 4 A. Uvedené údaje jsou pouze orientační. Proudová zatížitelnost totiž závisí ještě na řadě dalších faktorů, jako např. na tepelné vodivosti základního plátovaného materiálu, na odporu plošného vodiče, na dovoleném oteplení vodičů, na tvaru a umístění vodičů na desce, na proudovém zatížení sousedních vodičů. Šíŕka plošného vodiče $1 \mathrm{~mm}$ pro proud $4 \mathrm{~A}$ je proto použitelná pouze při protahování vodiče mezi dvěma sousedícími pájecími body. Jinak musí být šiřka větší, aby se neuplatnil odpor plošného vodiče, a aby se plošný spoj nepřehříval.

Oteplení plošného vodiče $\Delta \vartheta \mathrm{v}$ závislosti na protékajícím proudu $I$ lze určit orientačně z Obr. 2.23. Zde je zapotřebí zdůraznit, že jde o oteplení nad okolní teplotu. Bude-li uvnitř př́stroje teplota $\vartheta$, bude mít plošný spoj teplotu $\vartheta+\Delta \vartheta$.

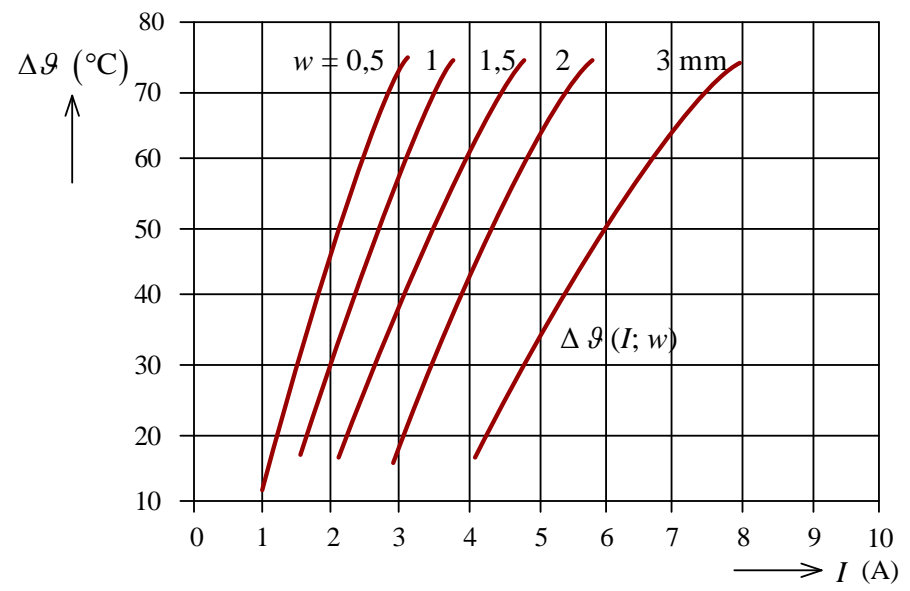

Obr. 2.23: Závislost oteplení plošného vodiče na protékajícím proudu (tloušt'ka fólie $35 \mu \mathrm{m}$ ) 
Znalost odporu plošných vodičů může být důležitá např. u analogových obvodů, u kterých úbytek napětí o několik milivoltů může být kritický. U číslicových obvodů je pak zapotřebí věnovat např. pozornost úbytkům napětí v napájecích rozvodech způsobený odporem plošných vodičů. Na Obr. 2.24 jsou uvedeny závislosti odporu $r$ plošných vodičů na jeho šířce $w$ pro plošné vodiče o tloušt'ce $35 \mu \mathrm{m}$ a $70 \mu \mathrm{m}$ při teplotách $20^{\circ} \mathrm{C}$ a $125^{\circ} \mathrm{C}$.

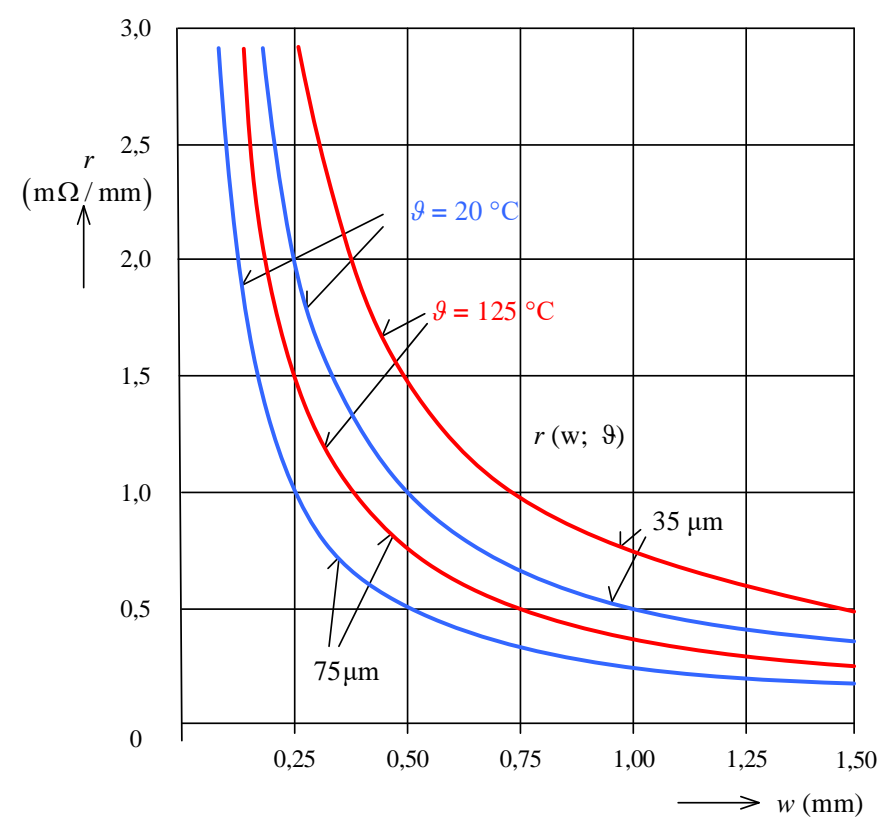

Obr. 2.24: Odpor měděných plošných vodičů v závislosti na šířce plošného vodiče

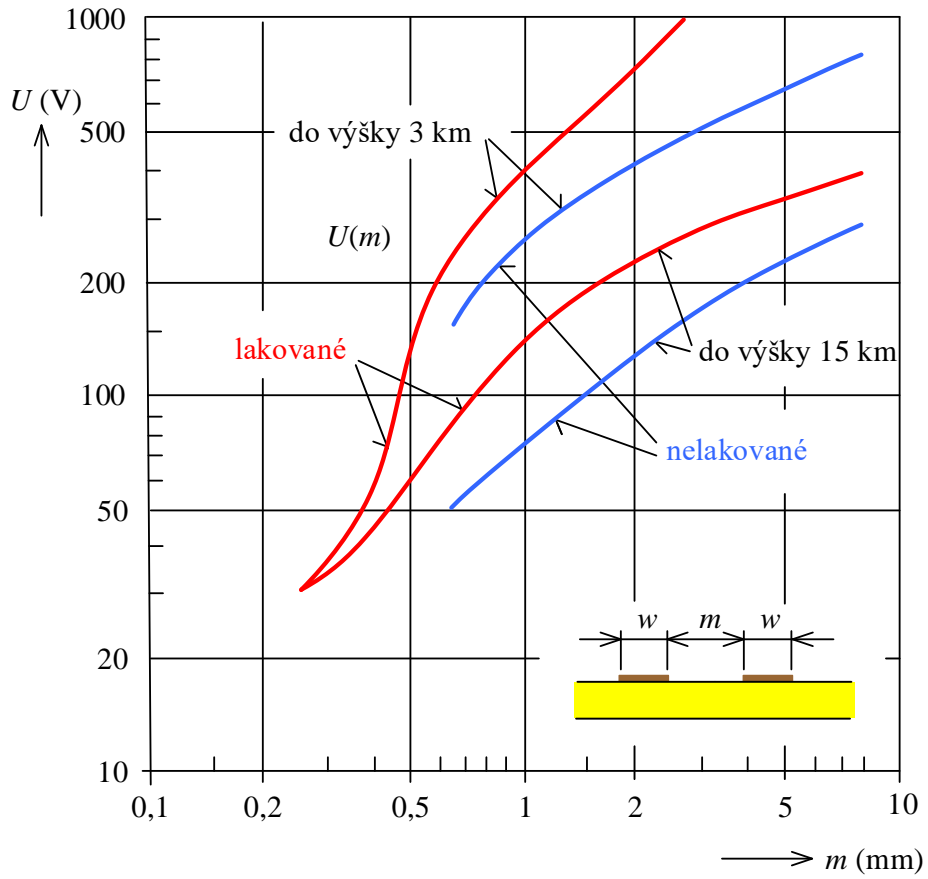

Obr. 2.25: Závislost jmenovitého napětí mezi plošnými spoji na šířce izolační mezery 

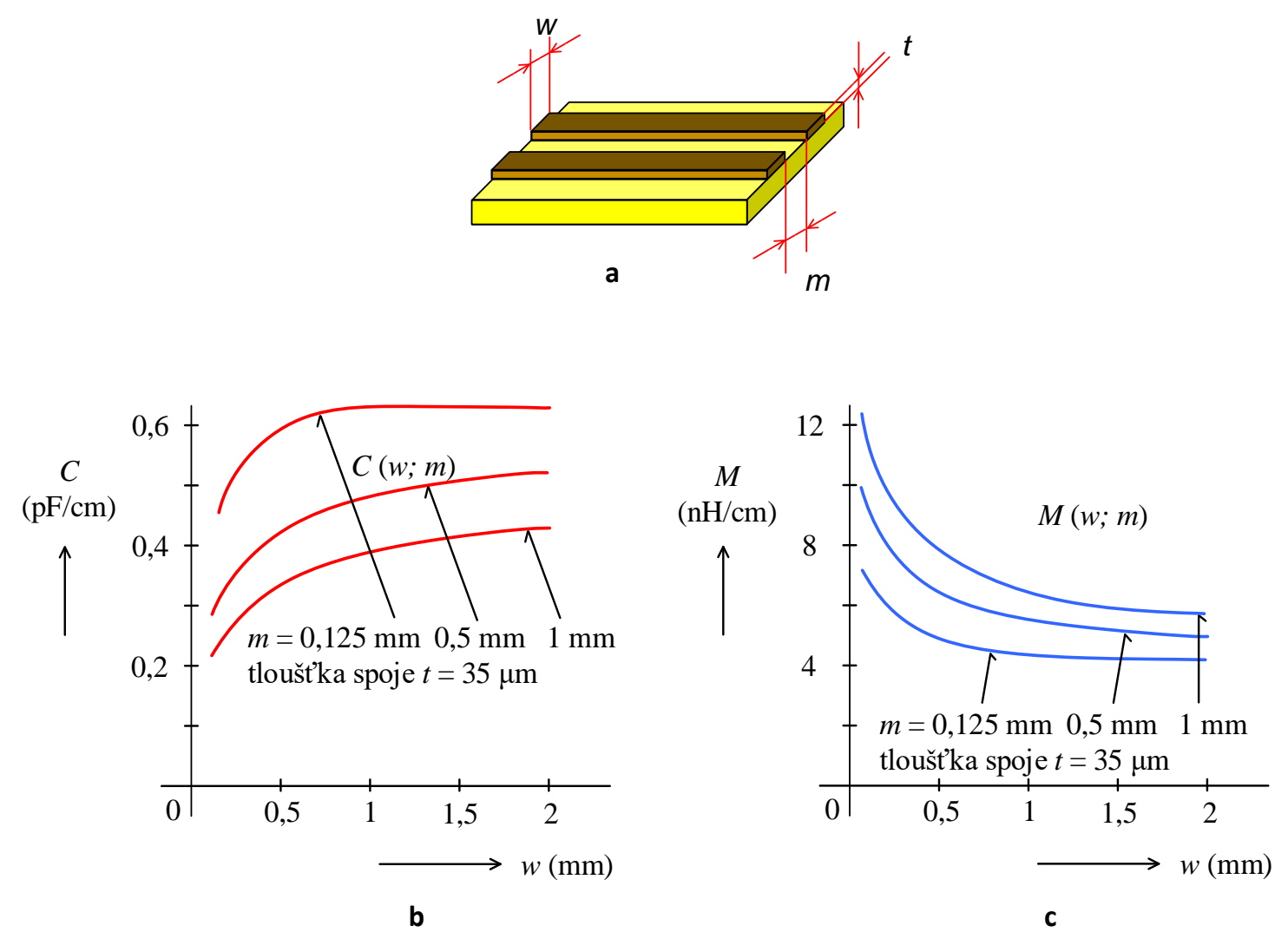

Obr. 2.26: a) Dva plošné vodiče vedle sebe, b) vzájemná kapacita, c) vzájemná indukčnost

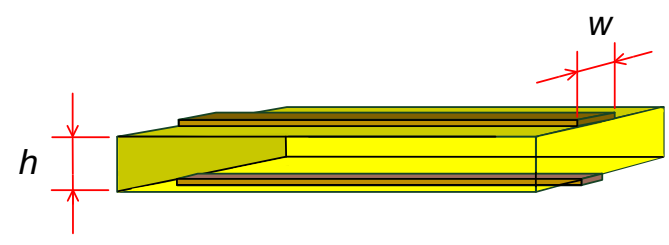

a
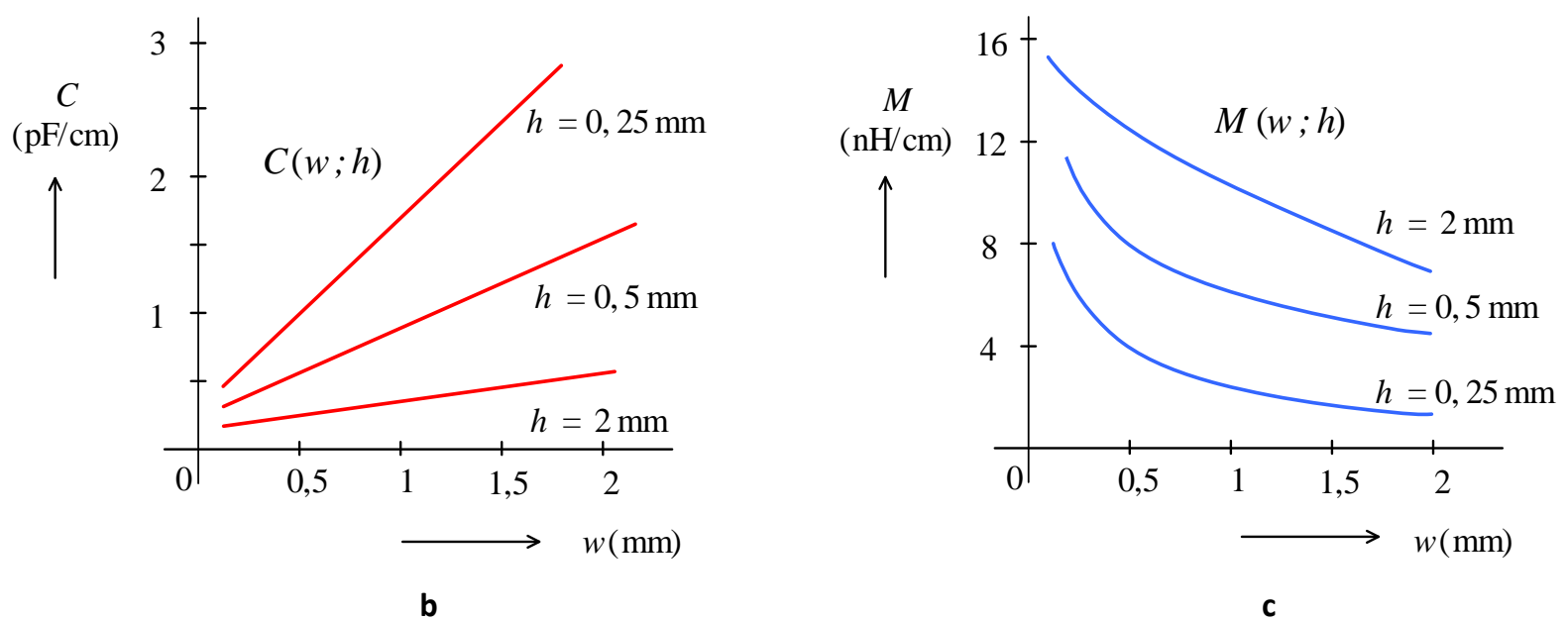

Obr. 2.27: a) Dva plošné vodiče nad sebou, b) vzájemná kapacita, c) vzájemná indukčnost 
Vzhledem k tomu, že u integrovaných obvodů se používají pouze malá napětí, není šířka izolačních mezer kritická. Mezi plošnými vodiči se doporučuje dodržet minimální mezeru $0,1 \mathrm{~mm}$. Pro speciální účely je však nutné přihlížet $\mathrm{k}$ závislosti jmenovitého napětí $U$ mezi plošnými vodiči na šířce izolační mezery $m$ (viz Obr. 2.25. Pro běžné druhy desek se nedoporučuje přikládat mezi dva sousední plošné vodiče vyšší napětí než $500 \mathrm{~V}$.

Vzájemná kapacita a vzájemná indukčnost plošného vodiče závisí na rozložení okolních plošných vodičů nebo na blízkosti zemnicí vrstvy. Př́íklad průběhů vzájemné kapacity $C$ a vzájemné indukčnosti $M$ vztažených k jednotce délky pro případ dvou vodičů šířky $w$ vedených vedle sebe ve vzdálenosti $m$ je uveden na Obr. 2.26. Na Obr. 2.27 jsou pak uvedeny hodnoty pro dva plošné spoje nad sebou ve vzdálenosti $h$.

\subsubsection{Optické spoje}

Spoje popisované v předchozích kapitolách pracují se signály s délkou vlny přibližně do $0,3 \mathrm{~m}$. Pro přenos signálů o kratší vlnové délce se používají rozměrné vlnovody, nebot' klasická vedení s vodiči mají na těchto kmitočtech již velký útlum. Pro vlnové délky kolem $1 \mu \mathrm{m}$ je ale situace zase příznivá, protože k přenosu signálů lze použít světelné vlnovody, tzv. optická vlákna.

Jejich hlavní výhodou je, že se přenášejí shluky fotonů bez elektrického náboje, které nejsou rušeny vnějším elektrickým nebo magnetickým polem. Klasické zdroje šumu či rušení se u optických vláken tedy neuplatní. Zdrojem rušení však mohou být mechanické kmity, které způsobují parazitní modulaci signálu. Vzhledem k tomu, že přenos probíhá na vysokých kmitočtech, dosahuje se velké šířky pásma a vysoké přenosové rychlosti. Vysílač a přijímač jsou galvanicky odděleny a také nedochází k přeslechům mezi vlákny. Vlákna mají malou hmotnost a rozměry.

Optická vlákna se hodí mnohem lépe pro přenos číslicových signálů než analogových. Při přenosu informace optickým spojem se nosný optický kmitočet moduluje přenášenými číslicovými daty.

Dlouhou dobu byl velkým problémem útlum optických vláken. Na počátku to bylo až $1000 \mathrm{~dB} / \mathrm{km}$, ale dnes se dosahuje útlumu 0,2 až $0,55 \mathrm{~dB} / \mathrm{km}$. Díky tomu je možné využít optická vlákna pro přenos na velké vzdálenosti.

\section{Druhy optických vláken}

Základní členění optických vláken vychází z konstrukce vnitřního optického jádra. Průměr jádra a průběh jeho indexu lomu mají rozhodující vliv na výsledné vlastnosti optického spoje. Směrové vedení světla vláknem se totiž uskutečňuje úplnými odrazy na rozhraní vlákna a jeho pláště, který má nižší index lomu. Vláknem se mohou obecně šířit paprsky s různými úhly odrazu. Ty, které se šiří pod malými úhly vzhledem k ose vlákna, se nazývají vidy nízkého řádu, pod větším úhlem vidy vysokého řádu. Pro danou vlnovou délku $\lambda$ existuje určitý počet diskrétních úhlů, u kterých dochází k šíření. Je-li průměr jádra vlákna mnohem větší než $\lambda$, mohou existovat stovky až tisíce vidů a pak hovoříme o tzv. mnohavidových vláknech. U 
gradientních vláken s pozvolnou změnou indexu lomu se sice šíŕi více vidů, ale všechny přibližně stejnou rychlostí. Naopak při použití tenkých vláken (o průměru 8 až $10 \mu \mathrm{m}$ ) se může vláknem šířit pouze jeden vid a tato vlákna označujeme jako jednovidová.

Podle těchto vlastností se optická vlákna třídí do tří základních skupin:

- mnohovidová vlákna se skokovou změnou indexu lomu,

- mnohovidová vlákna s pozvolnou změnou indexu lomu (gradientní vlákna),

- jednovidová vlákna se skokovou změnou indexu lomu.

Průběh indexu lomu, způsob šíření světelných paprsků v jednotlivých typech vláken a průběh vstupního a výstupního impulsu po průchodu jednotlivými typy vláken je názorně dokumentován na Obr. 2.28.
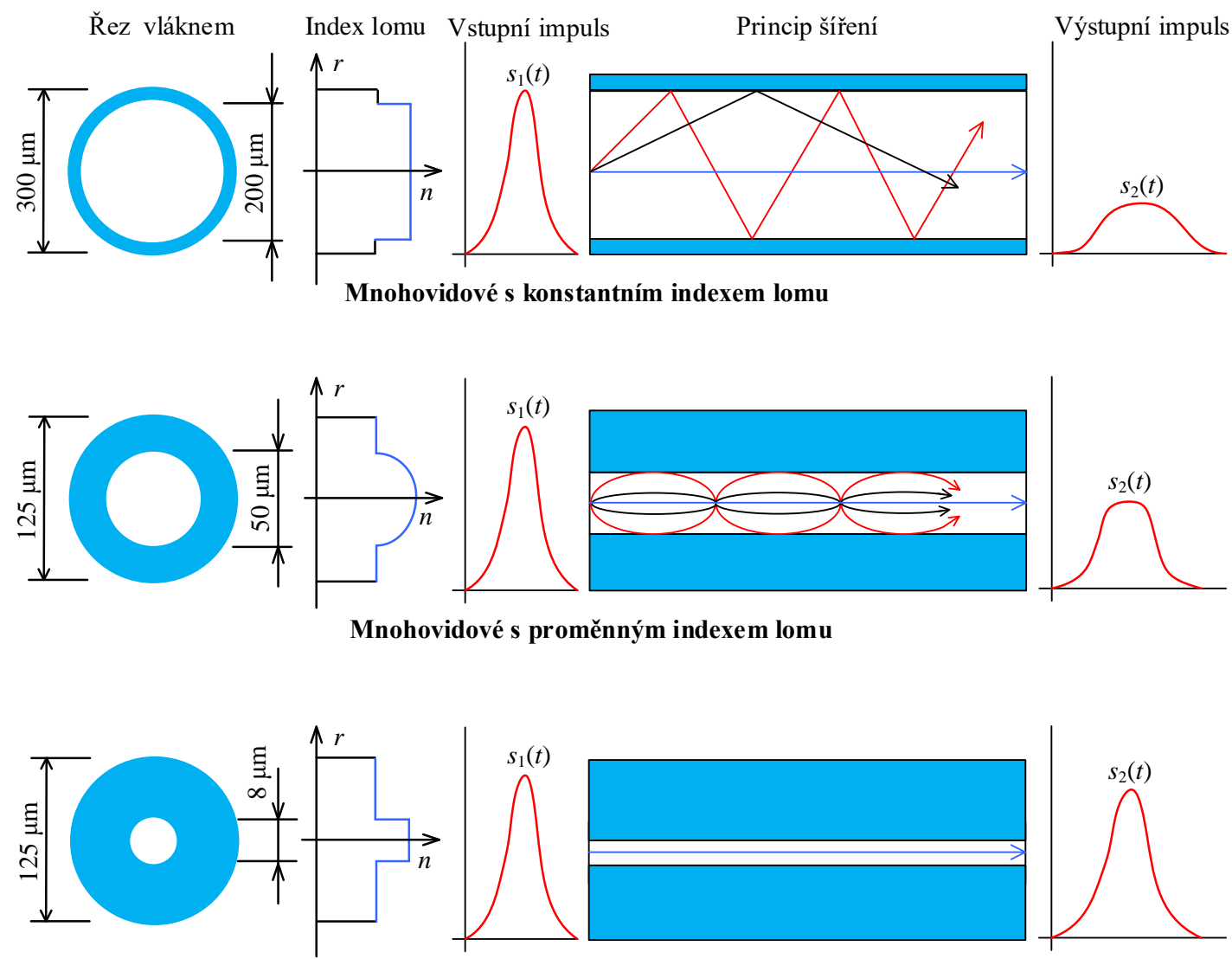

Jednovidové s konstantním indexem lomu

Obr. 2.28: Druhy optických vláken

V př́padě mnohovidového vlákna s průměrem optického jádra 100 až $200 \mu \mathrm{m}$ dochází k mnohačetným odrazům světelných paprsků na rozhraní vlastního optického vlákna a nepropustného pláště. Proto dílčí paprsky (podle délky vlny) postupují vláknem různě rychle. $\mathrm{Z}$ tohoto důvodu dojde na jeho výstupu k rozšiření préenášeného impulsu.

V mnohavidovém vláknu s průměrem jádra vlákna 50 až $130 \mu \mathrm{m}$ s pozvolnou změnou indexu lomu (tzv. gradientní vlákno) všechny dílčí paprsky postupují téměř stejně rychle, což umožňuje dosáhnout menšího rozššřrení přenášených impulsů. 
Nejlepších vlastností se dosahuje u jednovidových vláken s průměrem jádra vlákna 5 až $10 \mu \mathrm{m}$, což je srovnatelné s délkou vlny $\lambda \approx 1 \mu \mathrm{m}$. Vláknem se šíŕi jediný paprsek a proto téměř nedochází k rozšíření přenášeného impulsu a dá se dosáhnout vysokých přenosových rychlostí.

\section{Parametry optických vláken}

Základní informace o vlastnostech optického vlákna poskytuje závislost měrného útlumu na vlnové délce světelného paprsku. Podobně jako u metalických vedení, také v optickém vláknu výkon signálu se vzdáleností od zdroje signálu postupně klesá. Měrný útlum je měřítkem optické energie ve vlákně a udává se zpravidla $\mathrm{v} \mathrm{dB} / \mathrm{km}$. Je definován jako poměr vstupního světelného výkonu $P_{1}$ a výstupního výkonu $P_{2}$ pro danou vlnovou délku $\lambda$ podle vztahu

$$
a(\lambda)=10 \log \left(P_{1} / P_{2}\right)
$$

Hlavní prŕíčinou útlumu světelného signálu voptickém vlákně jsou absorbce a rozptyl světelných paprsků.

Nejstarší typy optických vláken vykazovaly velký útlum, u prvních vláken byl např̀. útlum $1000 \mathrm{~dB} / \mathrm{km}$. Zvyšováním čistoty materiálu se vlastnosti postupně zlepšily na 1 až 3 $\mathrm{dB} / \mathrm{km}$ (viz Obr. 2.29]. U nejstarších typů vláken byla definována tři tzv. optická okna (žlutě, vyznačená vlnová pásma), kdy byl útlum v určitém pásmu nejnižší. První optické okno má sice relativně vysoký útlum, ale světelné zdroje LED z polovodičového materiálu na bázi gáliumarsenid (GaAs) emitující záření $\lambda=0,85 \mu \mathrm{m}$ jsou velmi levné. Obecně totiž platí, čím je vyšší vlnová délka světloemitující zdroje, tím je zdroj dražší.

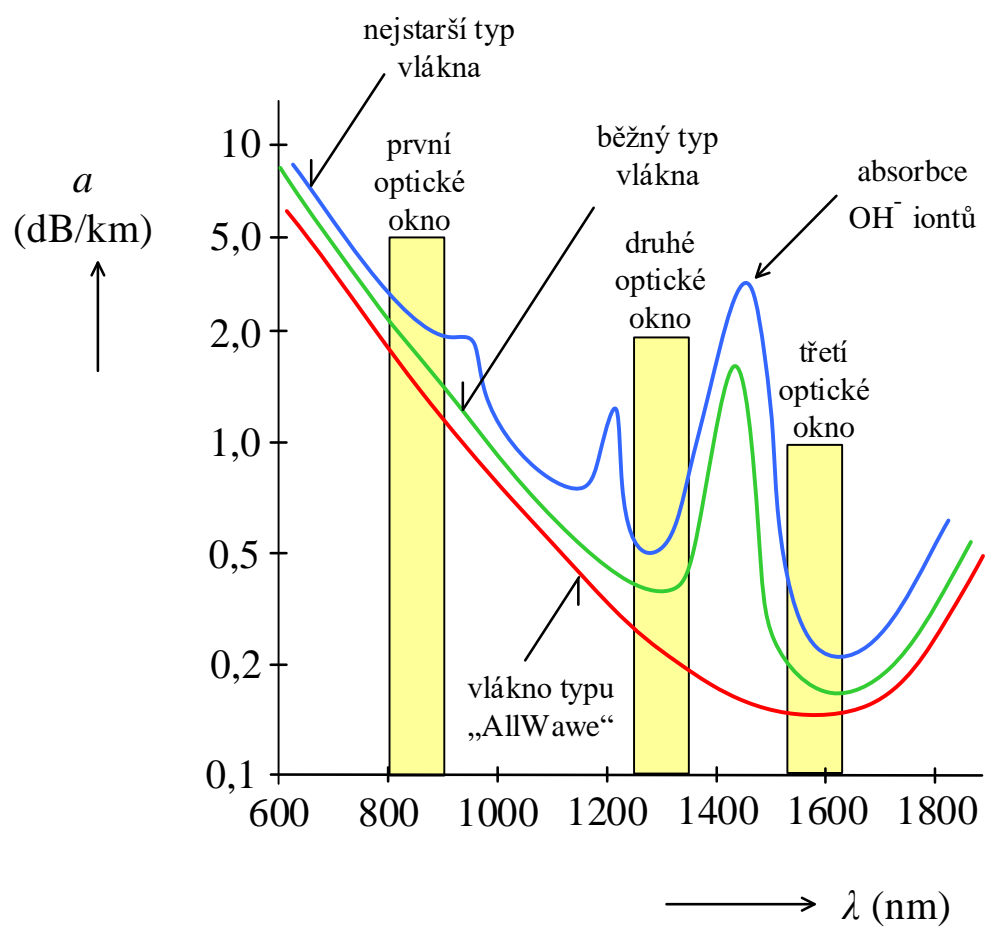

Obr. 2.29: Útlum různých typů optických vláken 
Zvyšování čistoty materiálu vláken vedlo $\mathrm{k}$ tomu, že u běžného typu vlákna zůstal selektivní nárůst útlumu pouze v oblasti vlnových délek kolem $1383 \mathrm{~nm}$ způsobený vysokou koncentrací $\mathrm{OH}^{-}$iontů. Nové metody čištění materiálu vlákna pak vedly ke snížení koncentrace $\mathrm{OH}$ iontů a vlákna označovaná jako „AllWave“ vlákna již žádný selektivní nárůst útlumu nevykazují a mají v této vlnové oblasti útlum 0,2 až $0,3 \mathrm{~dB} / \mathrm{km}$.

Disperse je hned po útlumu nejdůležitějším parametrem při výběru optického vlákna. Disperse způsobuje rozšíření přenášeného impulsu, což omezuje zvyšování opakovací periody signálu. Definuje se jako rozdíl šířky impulsu v polovině jeho výšky na konci a na začátku vlákna (viz Obr. 2.28). Disperse určuje šířku přenášeného pásma kmitočtu a tím i přenosovou rychlost. Šriřka kmitočtového pásma udává nejvyšší kmitočet signálu, který může být ještě spolehlivě přenesen na vzdálenost $1 \mathrm{~km}$ bez nadměrného zkreslení signálu způsobeného dispersí. Šiŕka pásma optického vlákna se uvádí v jednotkách $\mathrm{MHz}-\mathrm{km}$, př́ípadně $\mathrm{GHz}-\mathrm{km}$. Na šiř́ku pásma má velký vliv také použitá vlnová délka světelného zdroje. Např́iklad vlákno, které má na vlnové délce $850 \mathrm{~nm}$ šířku pásma $160 \mathrm{MHz}-\mathrm{km}$, může na vlnové délce $1300 \mathrm{~nm}$ mít šířku pásma $500 \mathrm{MHz}-\mathrm{km}$. S vlnovou délkou optického záření se samozřejmě mění také útlum vlákna.

Výrobci uvádějí i další parametry vlákna, jako je napřr. numerická apretura (NA), která definuje největší úhel, pod kterým může světelný paprsek vstupovat do optického vlákna tak, aby byl ještě vláknem přenášen. Dále se uvádí minimální poloměr ohybu vlákna, což je nejmenší ohyb, který je možné při instalaci vlákna použít. Je závislý na průměru optického vlákna, př́ípadně kabelu a na materiálu, z něhož je vlákno vyrobeno. Čím je průměr vlákna větší, tím je větší i minimální poloměr ohybu.

\section{Základní parametry a možnosti užití jednotlivých typů vláken}

- Mnohovidová vlákna se skokovou změnou indexu lomu:

měrný útlum: 2,6 až $50 \mathrm{~dB} / \mathrm{km}$ při vlnové délce $850 \mathrm{~nm}$

šířka pásma: 6 až $50 \mathrm{MHz}-\mathrm{km}$

použití: pro krátké trasy (v budovách) s malým nárokem na přenosovou rychlost

- Mnohovidová vlákna s gradientním průběhem indexu lomu:

měrný útlum: 2 až $10 \mathrm{~dB} / \mathrm{km}$ při vlnové délce $850 \mathrm{~nm} ; 0,5 \mathrm{~dB} / \mathrm{km}$ při vlnové délce 1300 $\mathrm{nm} ; 0,25 \mathrm{~dB} / \mathrm{km}$ při vlnové délce $1500 \mathrm{~nm}$

šířka pásma: $300 \mathrm{MHz}$ - km až $1,5 \mathrm{GHz}$ - km

použití: lokální počítačové sítě (LAN)

- Jednovidová vlákna se skokovou změnou indexu lomu:

měrný útlum: $0,35 \mathrm{~dB} / \mathrm{km}$ při vlnové délce $1300 \mathrm{~nm} ; 0,2 \mathrm{~dB} / \mathrm{km}$ při vlnové délce $1550 \mathrm{~nm}$ šiřka pásma: při vlnové délce větší než 1300 nm je většinou mnohem větší než $100 \mathrm{GHz}-\mathrm{km}$ použití: pro dlouhé trasy a velké přenosové rychlosti v počítačových sítích

\section{Konstrukční řešení optického vlákna a optického kabelu}

Vlastní optický vlnovod tvoří skleněné jádro optického vlákna (viz Obr. 2.30). Aby se světlo nerozptylovalo do okolí je na jádře obal nepropouštějící světlo. Protože jádro i plášt' jsou velmi křehké, tvoří další vrstvu primární ochrana, která chrání vnitřní části proti poškození a zvyšuje odolnost proti ohybu. Někdy je mezi obalem a primárním povlakem nanesena 
vyrovnávací vrstva silikonu. Sekundární povlak nemusí být vždy součástí vlákna, protože značně zvětšuje průměr vlákna. Vlákno se sekundárním povlakem je však odolnější proti poškození. Pro sekundární ochranu se používají plastické hmoty s vysokou pevností, jako např. polyester, polypropylen, nylon aj. Optická vlákna jsou vyráběna v délkách $1000 \mathrm{~m}$ až do maximálních délek $10000 \mathrm{~m}$.

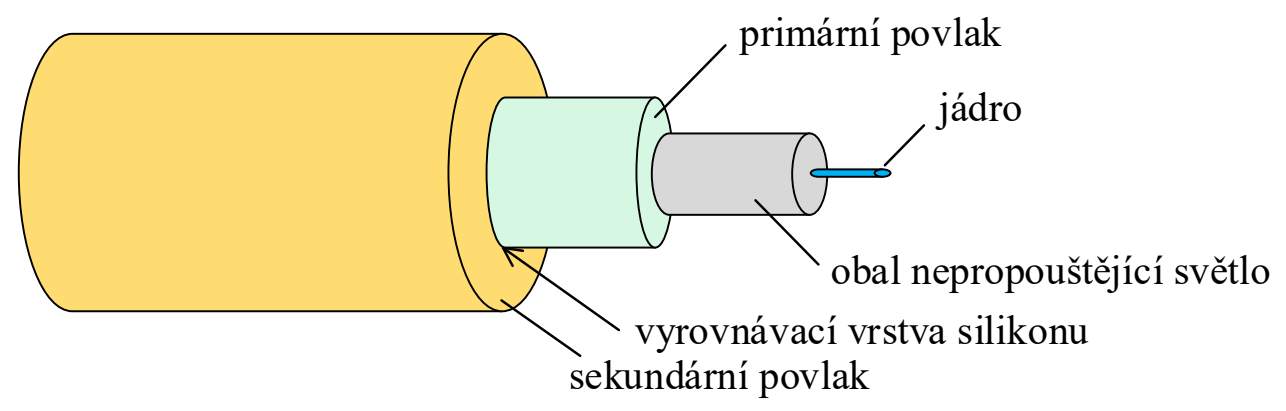

Obr. 2.30: Konstrukce optického vlákna

Optická vlákna určená pro přenosy na větší vzdálenosti jsou obvykle uspořádána do optického kabelu. Nejmenší počet vláken bývá dvě, jedno vlákno pro přenos jedním směrem, druhé vlákno směrem zpět. Př́klad uspořádání dvouvláknového kabelu je uveden na Obr. 2.31 A.

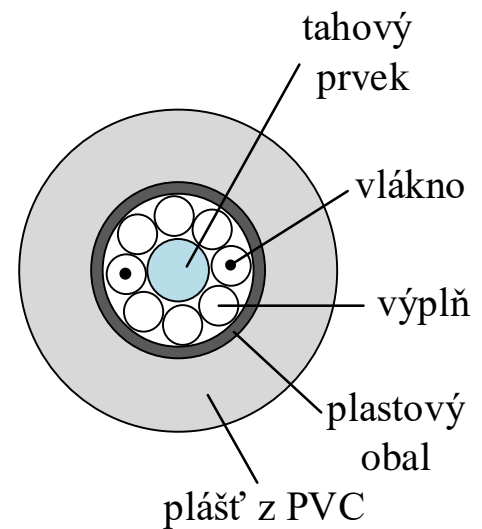

a

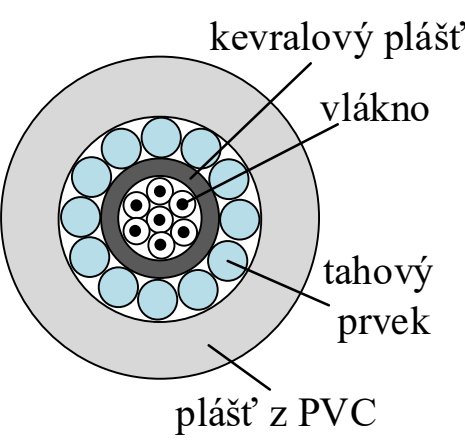

b

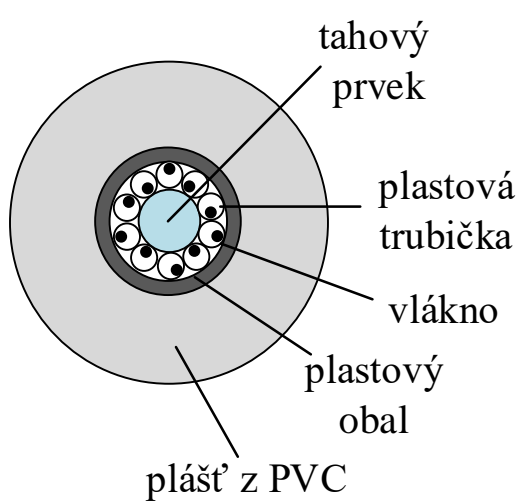

C

Obr. 2.31: Uspořádání optického kabelu: a) dvouvláknový, b) vícevláknový, c) s volným uložením vláken

Jde o klasickou strukturu, kdy ve středu kabelu je tahový prvek (obvykle kevral), další vrstva obsahuje variantně měnitelný počet vláken a výplně. Jedná se o shodnou konstrukci pro různé počty vláken, která se dají vložit do kabelu místo výplní. Je to proto, že vlákna tvoří podstatnou část ceny kabelu a vybere se kabel jen s potřebným počtem vláken. Místo výplní mohou být v kabelu vloženy měděné vodiče sloužící pro napájení opakovačů (opakovač signál přemění na elektrický, zesílí ho a vyšle optický signál do další části vedení). Poslední ochrannou vrstvu tvoří plášt’ z PVC.

Vícevláknový kabel na Obr. 2.31b má jinou koncepci řešení. Vlákna jsou ve středu kabelu, kolem nich je plášt' z kevralu a tahové členy jsou $v$ další vrstvě. Takovéto řešení je určeno pro větší namáhání kabelu na tah. 
Zcela odlišnou konstrukci pak vykazují tzv. kabely s volným uložením vláken, kdy optická vlákna jsou volně uložena do samostatných trubiček, nebo drážek. Protože vlákno je uloženo volně je oproštěno od jakýchkoliv tlakủ. Nevýhodou této konstrukce je však možný posuv vlákna $\mathrm{v}$ trubičce a tím i zvýšení tahů v př́ípadě pokládky kabelu do prudkého svahu. Př́klad takovéto konstrukce kabelu je vyznačen na Obr. 2.31.

$\mathrm{Na}$ Obr. 2.32 jsou uvedeny př́klady řešení vícevláknových kabelů. V kabelu na Obr. 2.32 může být uloženo 2 až 12 optických vláken. Konstrukce kabelu na Obr. 2.32b je určena pro uložení 96 až 144 vláken. Vlákna jsou v obou případech uložena v trubičkách naplněných gelem.

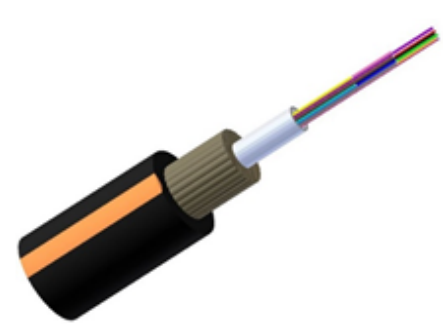

a

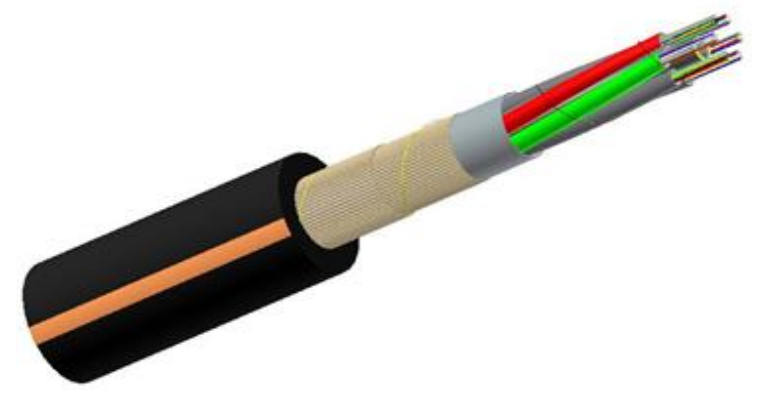

b

Obr. 2.32: Př́klady řešení vícevláknových kabelů 


\section{Použitá literatura}

[1] ZÁHLAVA, V. Metodika návrhu plošných spojů. Skriptum FEL ČVUT, EAN 9788001021934, Praha 2002

[2] JOHNSON, H. W. High-Speed Digital Desing, A Handbook of Black Magic, Prentice Hall, 1993

[3] WALKER, Ch. S. Capacitance, Inductance, and Crosstalk Analysis, Artech House, Boston 1990

[4] DURCANSKY, G. EMV - gerechtes Gerätedesign: Grundlagen der Gestaltung störungsarmer Elektronik, Franzis-Verlag, München 1992

[5] FILKA, M. Optoelektronika pro telekomunikace a informatiku. Skriptum FEKT VUT v Brně, 2008

[6] ŠANDERA, J. Návrh plošných spojů pro povrchovou montáž - SMT a SMD. BEN technická literatura, Praha 2006, ISBN 80-7300-181-0

[7] ZÁHLAVA, V. Návrh a konstrukce desek plošných spojů - principy a pravidla praktického návrhu. BEN - technická literatura, Praha 2010, ISBN 978-80-7300-266-4

[8] HRAŠNA, M. Prehl'ad základných plátovaných materiálov na výrobu DPS. DPS Elektronika, č. 4, 2012.

[9] KLAUZ, M. Roztažné a ohebné plošné spoje. DPS Elektronika, č.3, 2015.

[10] MONTROSE, M. I. Printed Circuit Board Design Techniques for EMC Compliance, IEEE Press, New York 1996.

[11] MONTROSE, M. I. EMC and the Printed Circuit Board, IEEE Press, New York, 1998. 


\section{Konstrukce napájecích obvodů}

Napájecí obvody v zařízení můžeme rozdělit na vlastní napájecí zdroje, které dodávají napájecí napětí potřebné velikosti a na napájecí rozvod, který toto napětí rozvádí k dílčím podsystémům a pak až $\mathrm{k}$ jednotlivým obvodům. Toto uspořádání napájecích obvodů se označuje jako napájení jednostupňové (viz Obr. 3.11). V řadě př́ípadů se však použíá tzv. dvoustupňové či vícestupňové napájení (viz Obr. 3.1b). Při tomto způsobu se používá hrubě stabilizovaného napájecího zdroje, jehož napětí je rozváděno k sekundárním stabilizovaným zdrojům pro napájení jednotlivých subsystémů. Oba uvedené způsoby mají své výhody a nevýhody. Volba mezi oběma řešeními se děje podle hledisek hospodárnosti.

Z hlediska praxe je však při napájení velkých systémů instalovaných ve společném stojanu (RACKu) výhodnější, aby každý blok zařízení, který tvoří konstrukční celek, měl své vlastní zdroje napájené z $230 \mathrm{~V}_{\sim}$. Je to ovlivněno především obtížností realizace napájecího rozvodu v RACKu pro pracovní proudy řádu desítek ampérů. Toto řešení se zejména užívá pro napájení číslicových systémů instalovaných v RACKu.

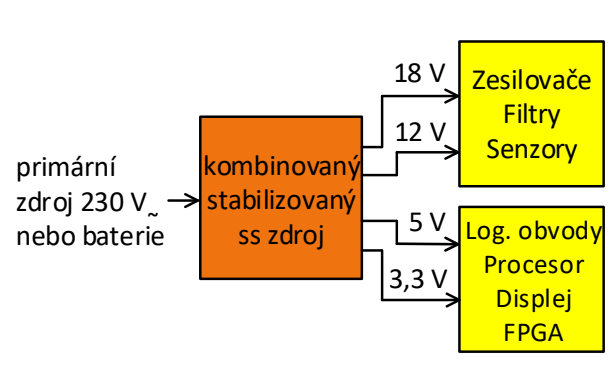

a

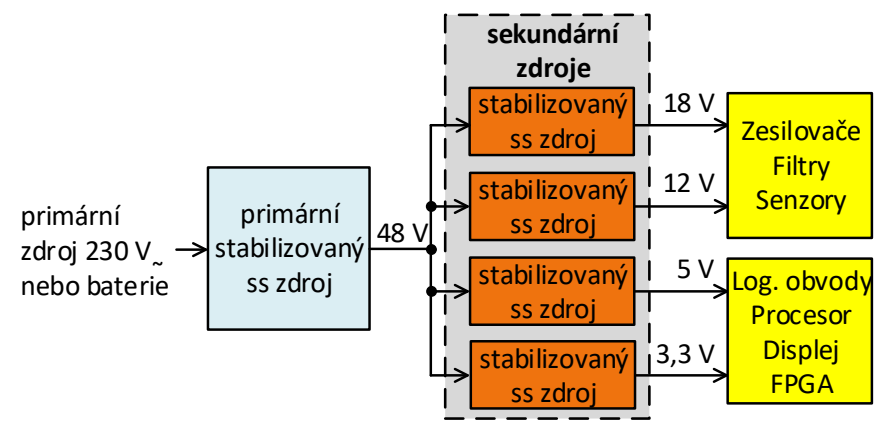

b

Obr. 3.1: a) Jednostupňový rozvod napájení, b) dvoustupňový rozvod napájení

\subsection{Napájení zařízení}

\subsubsection{Sít'ový př́vod}

Př́ivod rozvodné sítě $230 \mathrm{~V}_{\sim}$ do přístroje je třeba řešit $\mathrm{z}$ hlediska bezpečnostních norem, s ohledem na co nejmenší ztráty ve vedení i zhlediska odrušení př́istroje při zaručení požadovaných izolačních vlastností. Přístroje s odběrem do 10 A bývají opatřeny sítovým napájecím konektorem resp. př́strojovou zásuvkou $230 \mathrm{~V}_{\sim}$. Při konstrukci zdrojové části musíme dodržet zásadu, že fázový vodič (L) je přiveden nejprve na přístrojovou pojistku upevněnou v držáku, pak teprve přes sítový vypínač na sítový odrušovací filtr a napájecí zdroj (viz Obr. 3.2 a). Nulový vodič (N) je do přístroje zaveden přes druhý kontakt sít'ového spínače. Úkolem odrušovacího filtru je potlačit nežádoucí jehlové impulsy, které jsou superponovány na sinusový průběh stř̌́davého napětí rozvodné sítě.

Sít’ový vypínač může být přesunut za sít'ový odrušovací filtr jedině v př́ípadě, že odrušovací filtr je umístěn v nerozebíratelné přístrojové zásuvce společně s pojistkou Obr. 3.2b). Na obrázku je současně presentováno uspořádání pro zdravotnické př́ístroje, kdy $\mathrm{z}$ důvodu vyšší bezpečnosti je př́strojová pojistka zařazena i do př́ivodu nulového vodiče $(\mathrm{N})$. Při realizaci sít'ového rozvodu nezapomeneme chránit přetažením vhodné izolační trubičky všechny spoje, které by při dotyku rukou mohly vést $\mathrm{k}$ úrazu elektrickým proudem. Poznamenejme ještě, že u jednodušších zařízení může být sít’ový odrušovací filtr vypuštěn. 
Napájecích sít’ových konektorů resp. př́istrojových zásuvek $230 \mathrm{~V}_{\sim}$ je na výběr celá řada. $\mathrm{K}$ dispozici jsou jednoduché zásuvky, kdy pojistka musí být umístěna v samostatném držáku, dále zásuvky s integrovanou pojistkou či se dvěma pojistkami pro zdravotnické př́stroje, zásuvky s integrovaným odrušovacím filtrem, nebo zásuvky s integrovaným vypínačem Obr. 3.3. Sít’ové konektory jsou konstruovány pro jmenovité napětí $250 \mathrm{~V}_{\sim}$ a pro různá proudová zatížení od $1 \mathrm{~A}$ až do $10 \mathrm{~A}$.
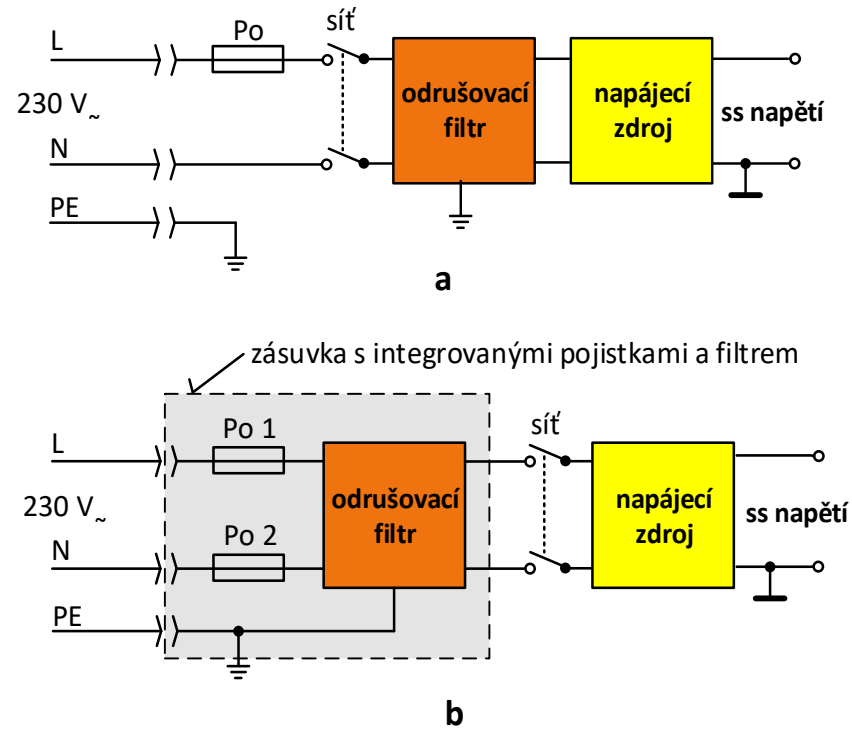

Obr. 3.2: a) Přívod sítě do zařízení, b) variantní řešení přívodu sítě do zařízení

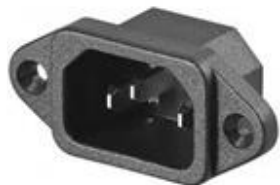

zásuvka

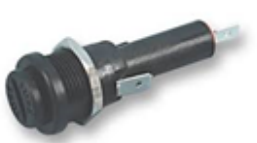

držák pojistky

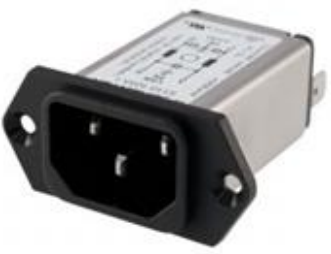

zásuvka s odrušovacím filtrem
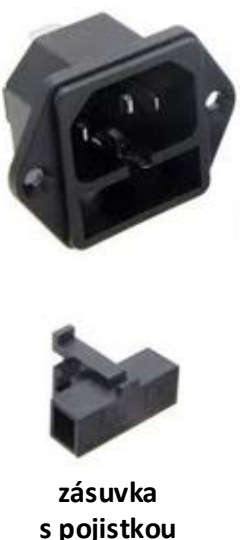

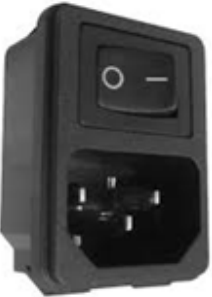

zásuvka s vypínačem

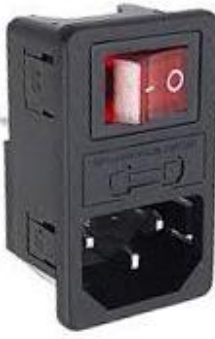

zásuvka s pojistkou a vypínačem

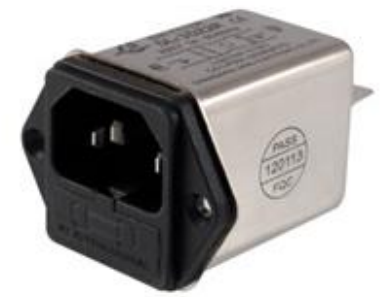

zásuvka s pojistkou a odrušovacím filtrem

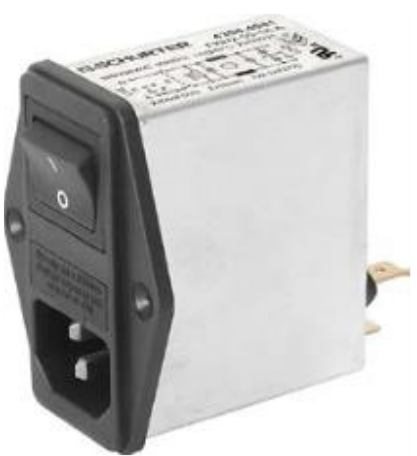

zásuvka s pojistkou, vypínačem a odrušovacím filtrem

Obr. 3.3: Napájecí sít’ové konektory, resp. přístrojové zásuvky 230 V 
Podobně je na výběr i celá řada přistrojových sítových vypínačů. Aby při přepínání vypínače nedocházelo k jiskření, které způsobuje opalování kontaktů, jsou konstrukčně upraveny tak, aby k přepnutí docházelo mžikově. Jako sít'ový vypínač se užívají kolébkové, stiskací nebo páčkové vypínače. $\mathrm{K}$ dispozici je i celá řada sít’ových vypínačů s indikací zapnutí pomocí doutnavky nebo LED indikací. Proti nežádoucímu zapnutí přístroje mohou být vypínače opatřeny klíčkem. Obvykle jsou sít'ové vypínače samostatné, ale mohou být např́íklad i součástí potenciometru nebo sít'ového konektoru. Př́klady provedení přístrojových sít’ových vypínačů jsou pro názornost uvedeny na Obr. 3.4. Přístrojové sít’ové vypínače jsou obvykle konstruovány pro jmenovité napětí $250 \mathrm{~V}_{\sim}$ a pro různá proudová zatížení $1 \mathrm{~A}$ až $10 \mathrm{~A}$.

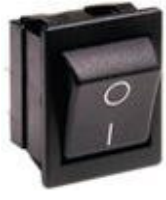

kolébkový

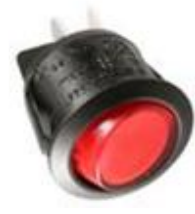

kolébkový s indikací

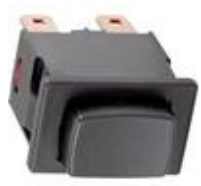

stiskací

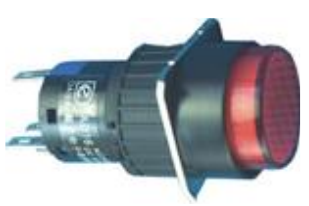

stiskací

s indikací

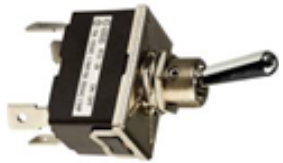

páčkový

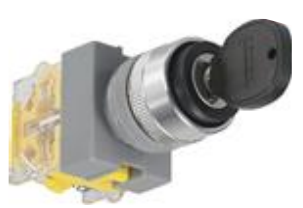

otočný s klíčkem

Obr. 3.4: Přístrojové sít’ové vypínače

Pro rozvod sítě $230 \mathrm{~V}$ uvnitř zařízení vyhoví pro běžné účely i obyčejný sít'ový kabel bez stínění, přičemž rozvod sítě v přístroji se omezuje jen na nejnutnější míru do zdrojové části př́stroje. Pokud se provede odrušení sít’ového přívodu odrušovacím filtrem, nedoporučuje se odrušený sítový př́vod vést paralelně s neodrušeným sít’ovým přívodem, protože odrušení bude ve výsledku neúčinné. Toto řešení je použitelné pro skutečně nejjednodušší zařízení.

Pokud použijeme sít’ový napájecí konektor (zásuvku) s integrovanou pojistkou a odrušovacím filtrem, je možné další rozvod sítě v přístroji provést nestíněným sítovým kabelem Obr. 3.5 ). Při velkých proudových odběrech, nebo při vysokých nárocích na odrušení je obvykle sít'ový odrušovací filtr součástí napájecího zdroje. Pak je nutné realizovat rozvod stíněnými sít'ovými kabely, přičemž stínění kabelů se vzájemně propojí a stínění se připojí na ochranný vodič (PE), tzn. na zemní vodič rozvodné sítě (viz Obr. 3.5b). 


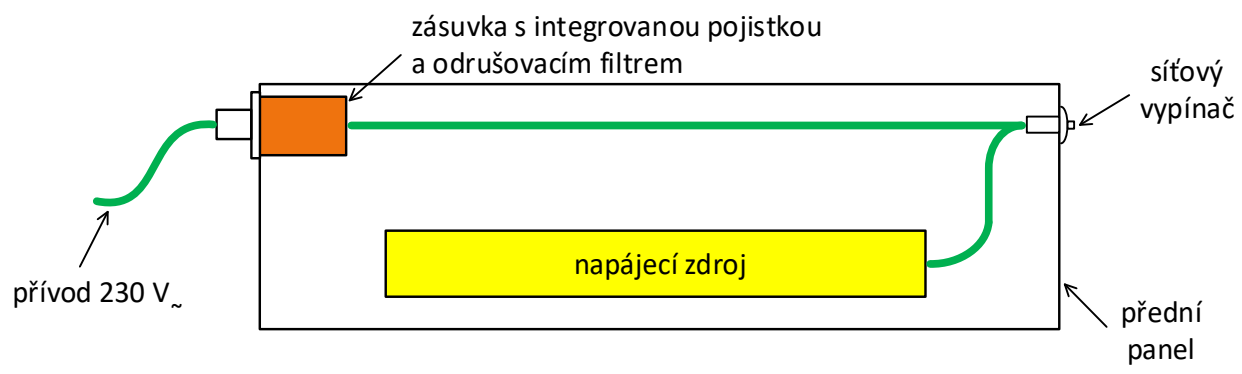

a

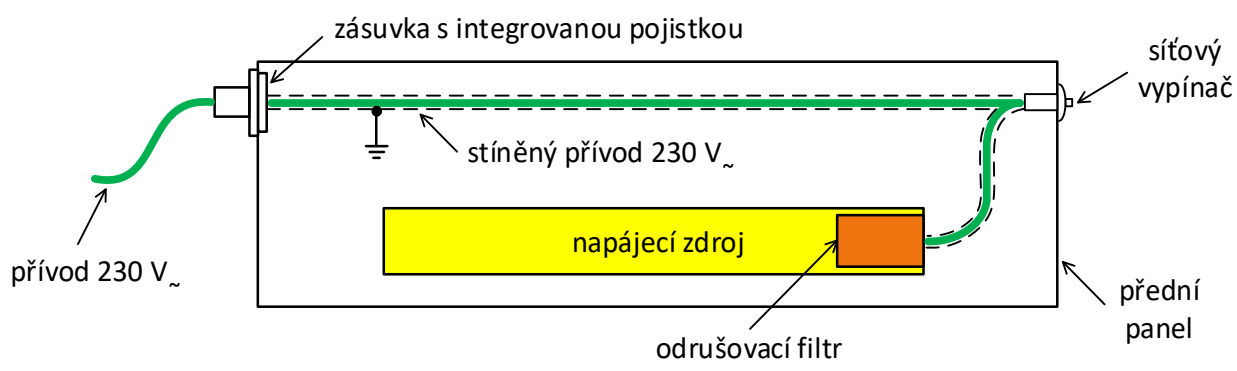

b

Obr. 3.5: Sít'ový prrívod do zařízení se sít’ovým vypínačem na předním panelu: a) odrušovací filtr integrován do sít'ové zásuvky, b) odrušovací filtr součástí napájecího zdroje

Problémy s rozvodem sítě $230 \mathrm{~V}_{\sim}$ uvnitř zařízení se zjednoduší, pokud můžeme použít přístrojovou zásuvku s integrovaným vypínačem, kdy není nutné vést sít'ový přívod $\mathrm{k}$ sít'ovému vypínači na předním panelu Obr. 3.6. V tom případě lze obvykle sít'ový přívod vést nejkratší cestou k napájecímu zdroji. Takových zařízení však není mnoho. Jde o zařízení, která jsou obvykle trvale pod napětím jako např. tiskárny.

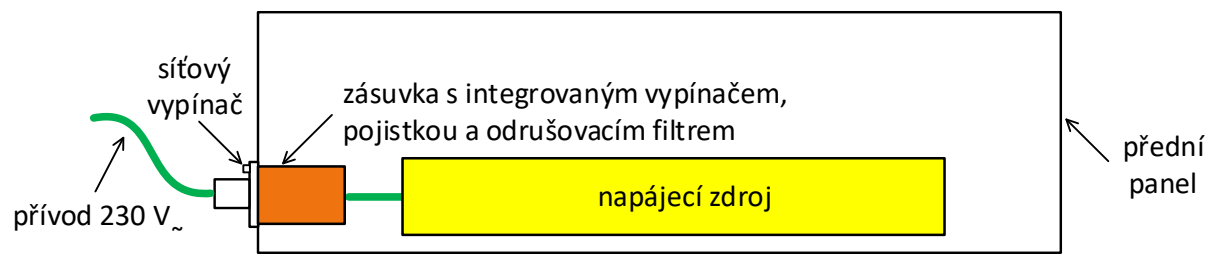

a

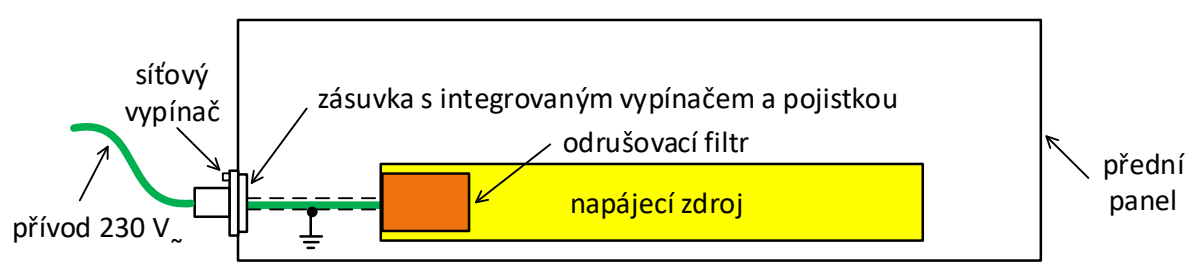

b

Obr. 3.6: Sít'ový přívod do zařízení se sít’ovým vypínačem na zadním panelu: a) odrušovací filtr integrován do sít'ové zásuvky, b) odrušovací filtr součástí napájecího zdroje 


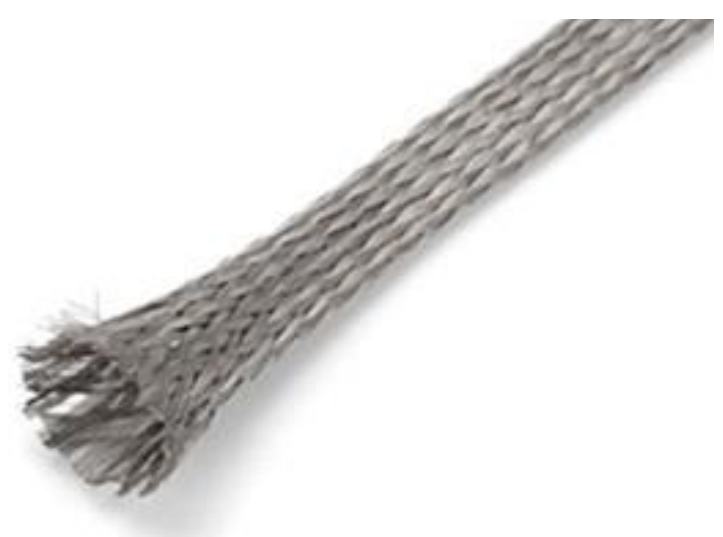

Obr. 3.7: Zemnicí opletení sít’ového kabelu

Pro úplnost ještě uvádíme, že stíněný sít’ový kabel se jako takový nevyrábí, ale $\mathrm{k}$ dispozici je tzv. zemnicí opletení sít’ového př́ivodu Obr. 3.7, které se navlékne na běžný sít'ový př́vod.

Nejlepším způsobem ovšem je, neodpojovat přívod $230 \mathrm{~V}_{\sim}$ př́imo od napájecího zdroje pomocí sít’ového tlačítka. Tento způsob řešení obvykle umožňují spínané AC/DC zdroje, které obsahují pomocný zdroj malého výkonu, který je i při vypnutí zařízení stále v činnosti. S využitím tohoto pomocného zdroje se pak zablokuje spínání hlavního spínaného zdroje. Pro zapnutí zařízení pak dostačuje obyčejné tlačítko a zdroj se zapíná či vypíná pouze běžným řidicím signálem. Takto jsou např. řešeny napájecí zdroje pro stolní PC.

\subsubsection{Sít’ové odrušovací prostředky}

V napájecích zdrojích se odrušovací prostředky používají ke dvěma účelům: jednak $\mathrm{k}$ ochraně zařízení proti rušení, které se do přístroje může dostat přes napájecí sít'ový přívod, jednak k potlačení rušení, které může generovat vlastní zařízení, což by naopak mohlo zvýšit úroveň rušení v samotném sítovém napájecím rozvodu.

V prvém př́padě, kdy se provádí ochrana zařízení proti pronikání rušivých impulsů do př́stroje sítovou napájecí cestou, jde zejména o potlačení průmyslového rušení, které se do sít'ového napájecího rozvodu dostává z ostatních spotřebičů připojených do sítě. Většinou jde o jehlové impulsy superponované na sít'ové napětí $230 \mathrm{~V}_{\sim} / 50 \mathrm{~Hz}$, které jsou způsobeny odpojováním či připojováním spotřebičů, komutátory motorů, špatně odrušenými zařízeními s tyristorovou regulací apod. Pokud tyto impulsy proniknout přes napájecí zdroj do napájecího rozvodu př́stroje, mohou být přidány $\mathrm{k}$ analogovým signálům, mohou způsobit náhodné změny stavu číslicových obvodů, popř. vést ke zničení obvodu překročením povoleného napájecího napětí.

V druhém případě musíme naopak zabránit tomu, aby samo zařízení negenerovalo do sít'ového napájecího rozvodu rušivé signály. Jde zejména o př́istroje s impulsně regulovanými napájecími zdroji, o zařízení s tyristorovou regulací, frekvenční měniče aj. Úroveň rušení, které zařízení může dodávat do rozvodné sítě je definována normou a každé zařízení, které bude vyráběno, ji musí splňovat.

Rušivé signály, které se šíř́ po napájecím vedení jsou většinou v rozmezí kmitočtu 10 $\mathrm{MHz}$ až $30 \mathrm{MHz}$. Rušení se po sít'ovém přívodu šiří bud' symetricky, kdy rušivý proud teče obdobně jako napájecí proud po fázovém vodiči L do zařízení a po nulovém vodiči $\mathrm{N}$ se vrací zpět, nebo asymetricky, kdy se předpokládá, že rušivé proudy zcela shodně naindukované do fázového vodiče $\mathrm{L}$ a do nulového vodiče $\mathrm{N}$ tečou po těchto vodičích do zařízení a zpět jsou ke 
svému zdroji odváděny ochranným vodičem PE. Asymetrické rušení je možno zobecnit na nesymetrické rušení, kdy rušivé proudy ve fázovém a nulovém vodiči jsou rozdílné.

\section{Sit'ové odrušovací kapacitory}

K potlačení rušení ze sít'ového rozvodu se v nejjednodušších případech používá vysokofrekvenční zkrat pomocí tzv. kombinovaného odrušovacího kapacitoru. Zapojení kombinovaného odrušovacího kondenzátoru, které je určeno k potlačení symetrického i nesymetrického rušení v rozvodné síti, je uvedeno na Obr. 3.8 $\mathrm{A}$. Z bezpečnostních důvodů jsou všechny tři kondenzátory obvykle realizovány $\mathrm{v}$ nerozebíratelném pouzdru Obr. 3.8b). Odrušovací kapacitor se užívá pro odrušení jednodušších jednofázových spotřebičů, nebo jako stavební prvek sít'ových odrušovacích filtrů.

V odrušovacích prostředcích se užívají speciálně konstruované kondenzátory třídy $\mathrm{X}$ a Y:

- Kondenzátory třídy $\mathrm{X}$ jsou odrušovací kapacitory určené pro použití v těch př́ípadech, kdy jejich průraz by v bezpečném př́stroji neměl způsobit ohrožení bezpečnosti lidského života elektrickým proudem. Kapacita kondenzátorů typu X bývá v rozmezí 47 až $220 \mathrm{nF}$ někdy i jednotky $\mu \mathrm{F}$. Jsou konstruovány na jmenovité stř́idavé napětí nejméně $250 \mathrm{~V}$ a při výrobě jsou testovány na špičkové pulsní napětí 2 až $4 \mathrm{kV}$ stanovené normou pro jednotlivé třídy či kategorie zařízení.
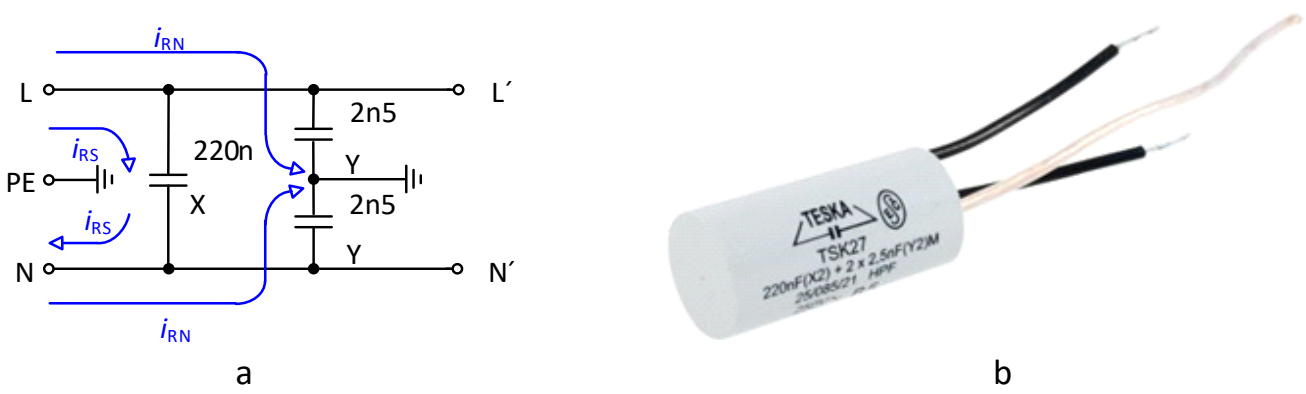

Obr. 3.8: Sít’ový odrušovací kondenzátor: a) zapojení, b) příklad provedení

- Kondenzátory třídy Y jsou pak určeny pro ty př́ípady, kdy by jejich průraz mohl způsobit ohrožení bezpečnosti lidského života elektrickým proudem (např. spojení kostry přístroje na „živý“ vodič). Kapacita kondenzátorů typu Y bývá v rozmezí 2,2 až 4,7 nF. Jsou v bezpečném provedení nejméně na jmenovité stř́ídavé napětí $250 \mathrm{~V}_{\sim}$ a př̀i výrobě jsou taktéž testovány pulsním napětím 2 až $4 \mathrm{kV}$ podle požadované třídy či kategorie zařízení. Kondenzátory třídy Y, protéká při napětí $230 \mathrm{~V}_{\sim} / 50 \mathrm{~Hz}$ tzv. únikový proud, jehož př́ípustná hodnota závisí na bezpečností tř́dě zařízení a jeho použití. Obvykle užívaná hodnota $2,5 \mathrm{nF}$ $\mathrm{s}$ únikovým proudem do $0,5 \mathrm{~mA}$ vyhoví pro všechny přístroje vyjma př́istrojů pro lékařské účely. Přri použití několika kondenzátorů třídy $\mathrm{Y}$ ve vícenásobných filtrech, kde jsou zapojeny paralelně, je nutno si uvědomit, že se sčítají nejen jejich kapacity, ale i hodnoty únikového proudu.

Kondenzátor třídy X tvoří vf zkrat pro symetrické rušení $i_{\mathrm{RS}}$, kondenzátory tř́ídy $\mathrm{Y}$ tvoří vf zkrat pro nesymetrické rušení $i_{\mathrm{RN}}$. V případech, kdy samostatný odrušovací kapacitor nestačí, je zapotřebí použít složitější odrušovací prostředky, tzv. sít’ové odrušovací filtry. 


\section{Sitové odrušovaci tlumivky}

Sít’ové odrušovací tlumivky, někdy také označované jako proudově kompenzované tlumivky, jsou určeny pro kmitočtové pásmo do $30 \mathrm{MHz}$. Většinou jsou vyrobeny na toroidním feritovém jádře s vysokou permeabilitou nebo na monokrystalickém jádře. Tlumivka má dvě souměrné cívky o stejném počtu závitů navinuté na společném jádře. Zapojení odrušovací tlumivky do sít'ového př́ivodu je zřejmé z Obr. 3.9 A. Př́iklad provedení odrušovací tlumivky je

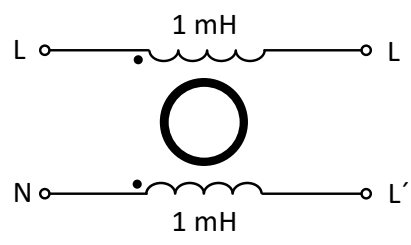

a

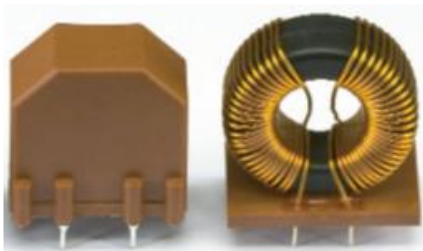

b

Obr. 3.9: Odrušovací tlumivka: a) zapojení, b) příklad provedení

pak na Obr. 3.91. Indukčnost cívek je obvykle v rozmezí 0,1 až $10 \mathrm{mH}$, jsou konstruovány na jmenovité stř́idavé napětí $250 \mathrm{~V}_{\sim}$ s izolační odolností $1500 \mathrm{~V}$.

Při symetrickém buzení se proudově kompenzovaná tlumivka z podstaty své funkce vůči napájecímu proudu $i_{\mathrm{N}}$ o kmitočtu $50 \mathrm{~Hz}$ a tedy i symetrickému rušivému proudu $i_{\mathrm{RS}}$ teoreticky vůbec neuplatní. Tento režim tlumivky se označuje jako diferenční mód. Cívky jsou $\mathrm{v}$ tomto případě provozovány tak, že v jádře vytvoří dílčí magnetická pole, která se navzájem vyruší (viz Obr. 3.10 ). Impedance tlumivky bude zanedbatelná a napájecí napětí se prakticky celé objeví na zátěži. V náročnějších aplikacích můžeme $\mathrm{v}$ praxi přesněji pro tento případ uvažovat př́ípadně i její rozptylovou indukčnost.

Při nesymetrickém buzení (viz Obr. 3.10), kdy oběma cívkami protéká proud $i_{\mathrm{RN}}$ shodným směrem, budou mít dílčí magnetická pole $\mathrm{v}$ toroidním jádře taktéž shodný směr a tlumivka bude pro nesymetrické rušivé proudy představovat velkou indukčnost. Režim tlumivky se pro tento př́ṕpad označuje jako souhlasný mód. Impedance tlumivky bude pro nesymetrické vf rušení velká a rušivé napětí se proto objeví na zátěži zeslabeno.

Odrušovací sít’ové tlumivky se obvykle samostatně nepoužívají, ale nacházejí uplatnění jako stavební prvek sít'ových odrušovacích filtrů.

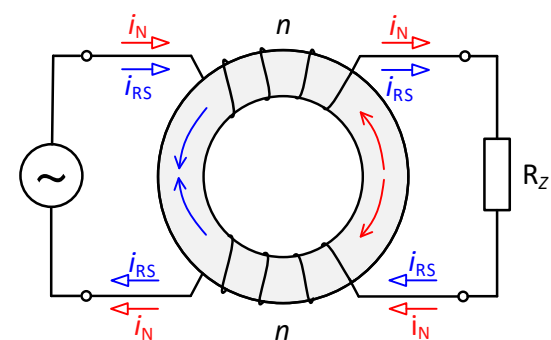

diferenční mód

a

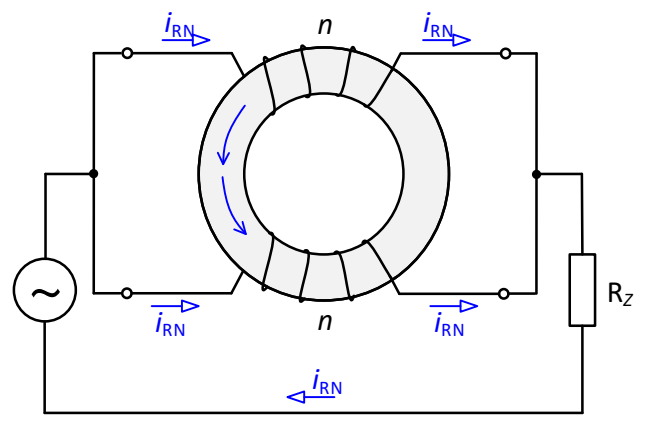

souhlasný mód

b

Obr. 3.10: K vysvětlení diferenčního a souhlasného módu toroidní odrušovací tlumivky 


\section{Sitový odrušovací filtr}

Odrušovací filtry LC jsou určeny především k ochraně jednofázových spotřebičů proti pronikání rušení do přístroje přes sít’ový př́vod. Zároveň ale mohou částečně zabraňovat $\mathrm{i}$ opačně průniku rušení, které by mohlo dodat samotné zařízení do rozvodné sítě. Sít'ový odrušovací filtr musí do zařízení propustit napětí $230 \mathrm{~V}_{\sim} / 50 \mathrm{~Hz}$ prakticky beze změny, ale musí vykazovat vysokou odrušovací účinnost v kmitočtovém pásmu 10 až $30 \mathrm{MHz}$.

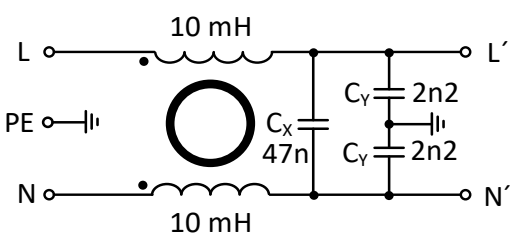

a

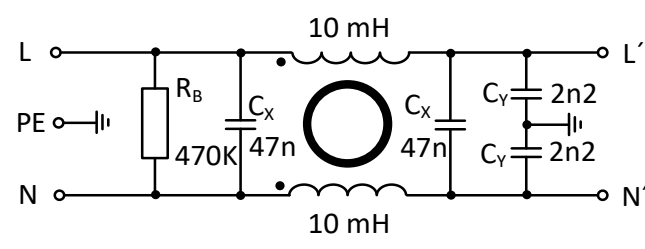

b

Obr. 3.11: Sít’ový odrušovací filtr: a) základní zapojení, b) nejčastěji užívané zapojení

Základní uspořádání sít'ového odrušovacího filtru je uvedeno na Obr. 3.11 A. Odrušovací filtr potlačuje jak symetrické, tak i nesymetrické vysokofrekvenční rušení. Princip odrušení sít’ového napětí osvětlíme s využitím Obr. 3.12. Vlastní pracovní proud $i_{\mathrm{N}}$ o sít’ovém kmitočtu $50 \mathrm{~Hz}$ teče cívkou a zátěží a stejný proud $i_{\mathrm{N}} \mathrm{se}$ vrací zpětným vodičem. V toroidu cívky tento proud vyvolá navzájem opačný magnetický tok a toroidní cívka se pro pracovní proud $i_{\mathrm{N}}$ nechová jako induktor a indukčnost je pro pracovní proud prakticky nulová (tzv. diferenční mód). Protože použité hodnoty kapacitorů představují pro kmitočet $50 \mathrm{~Hz}$ velkou impedanci, pracovní proud projde filtrem do zátěže prakticky bez jakéhokoliv omezení.

Jinak se ovšem filtr chová pro vf rušení. Pokud se bude rušení šiřit po sít'ovém přívodu symetricky (Obr. 3.12 ), tzn. rušivý proud $i_{\mathrm{RS}}$ teče obdobně jako napájecí proud $i_{\mathrm{N}}$ po fázovém vodiči L do zařízení a po nulovém vodiči $\mathrm{N}$ se zpět vrací zpět ke zdroji, tlumivka se ani pro tento př́pad nebude chovat jako induktor, ale vf proud se uzavře přes malou impedanci kapacitoru $C_{X}$ a do zátěže neteče. Ve skutečnosti však můžeme uvažovat, že reálná tlumivka bude pro symetrické rušení vykazovat rozptylovou indukčnost a i když tato je 200 x menší než jmenovitá indukčnost tlumivky, představuje společně s kapacitorem $C_{X}$ vf dolní propust. Kapacitory $\mathrm{C}_{Y}$, jejichž kapacita je řádově menší než kapacita $\mathrm{C}_{X}$, můžeme pro tento př́pad zanedbat.

Pokud se rušivé vf či impulsní proudy $i_{\mathrm{RN}}$ naindukují do obou přívodních vodičů nesymetricky (viz Obr. 3.12b), pak v toroidu tlumivky vyvolají magnetický tok stejného směru, tlumivka se pro tento př́pad chová jako induktor a nesymetrické rušení se v obou vodičích potlačí LC filtry (tzv. souhlasný mód).

$\mathrm{Z}$ předchozího výkladu je zřejmé, že je teoreticky jedno, zda kapacitor $\mathrm{C}_{\mathrm{X}}$ je zapojen před nebo za odrušovací tlumivkou, protože pro symetrické rušení má kapacitor $\mathrm{C}_{X}$ realizovat vf zkrat. Pokud však chceme, aby zařízení samo negenerovalo rušení do rozvodné sítě, lze využít rozptylovou indukčnost odrušovací tlumivky, která společně s kapacitorem $\mathrm{C}_{\mathrm{X}}$ zapojeným před tlumivkou působí jako vf filtr v opačném směru. Nejčastěji užívané zapojení odrušovacího filtru tohoto typu je nakresleno na Obr. 3.11p. 


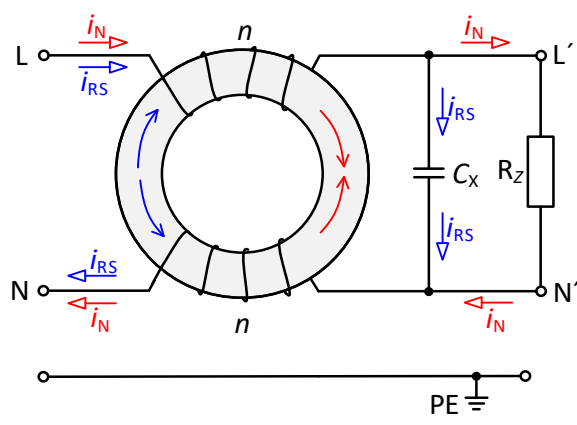

potlačení symetrického vf rušení

a

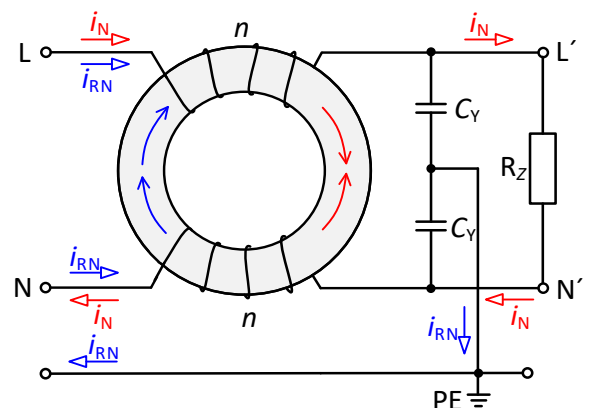

potlačení asymetrického vf rušení

b

Obr. 3.12: K vysvětlení činnosti sit'ového odrušovacího filtru

Ve filtru je doplněn $\mathrm{z}$ bezpečnostních důvodů vybíjecí rezistor $\mathrm{R}_{\mathrm{B}}$ (tzv. Bleeder rezistor). Pokud by se totiž někdo pro odpojení sít’ového př́vodu neočekávaně dotkl kolíků zástrčky zařízení, mohlo by dojít k úrazu elektrickým proudem ze systému odrušovacího filtru. Úkolem vybíjecího rezistoru je proto dostatečně rychlé vybití náboje, který zůstane na kondenzátorech při odpojení zařízení ze sítě. Odpor vybíjecího rezistoru bývá v rozmezí $470 \mathrm{k} \Omega$ až $1 \mathrm{M} \Omega$.

Vlastnosti sít’ového odrušovacího filtru nejlépe popisuje závislost vložného útlumu na kmitočtu. Vlastní měření útlumu se provádí na každém kmitočtu ve dvou krocích, protože útlum závisí na impedanci sít'ového přívodu a na připojené zátěži. V prvém kroku se odrušovací filtr odstraní a změři se napětí $U_{20}$. Při nezměných podmínkách buzení se do měřicí trasy vloží odrušovací filtr a změří se napětí $U_{2}$. Vložný útlum se pak určí podle definice $a=20 \log \left(U_{20} / U_{2}\right)$. Př́klad útlumové charakteristiky sítového odrušovacího filtru je uveden na Obr. 3.13. Pro vzájemné porovnání filtrů je podstatný vložný útlum v rozmezí kmitočtů 10 až $30 \mathrm{MHz}$ (vyznačené žluté pole).

Pro proudy od $1 \mathrm{~A}$ až do $16 \mathrm{~A}$ je $\mathrm{k}$ dispozici řada již hotových odrušovacích filtrů. Několik příkladů odrušovacích filtrů je uvedeno na Obr. 3.14 Z Z bezpečnostních důvodů jsou vždy v nerozebíratelném pouzdře. V nejjednodušších př́padech jsou zastříknuté v izolační hmotě.

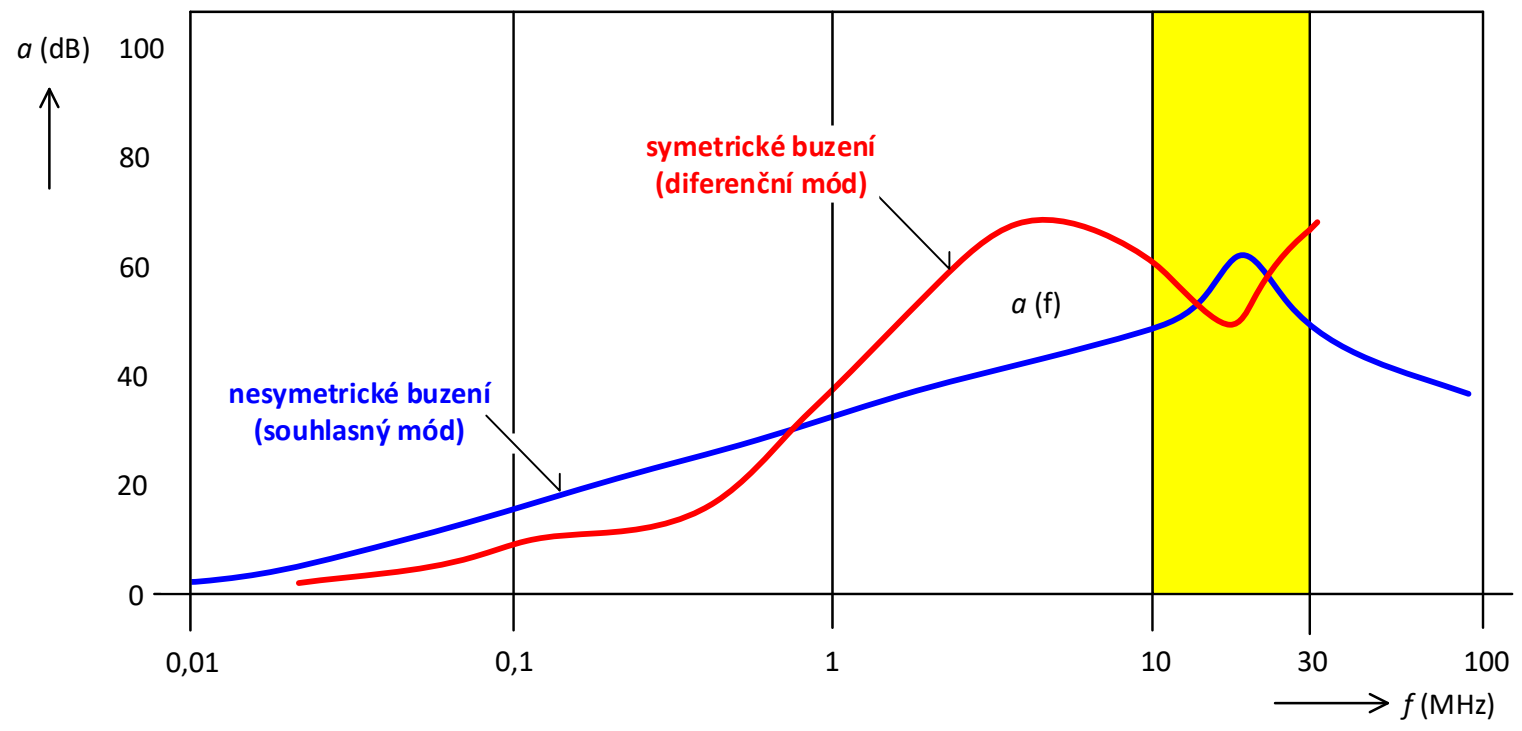

Obr. 3.13: Př́íklad charakteristik vložného útlumu sít’ového filtru 
Protože odrušovací prvky vyzařují do okolí elektromagnetického rušení, jsou kvalitnější odrušovací filtry opatřeny kovovým stíněním, které je připojeno na ochranný vodič PE (zem). Vývody filtru se nedoporučuje prodlužovat, protože se může zhoršit jejich odrušovací účinnost. Pro zachování dobré účinnosti se doporučuje odrušovací filtr umístit co nejblíže k sítové napájecí zásuvce tak, aby k připojení stačila stávající délka vývodů. $Z$ těchto důvodů je nejlepší použít sít’ovou zásuvku s integrovaným odrušovacím filtrem.

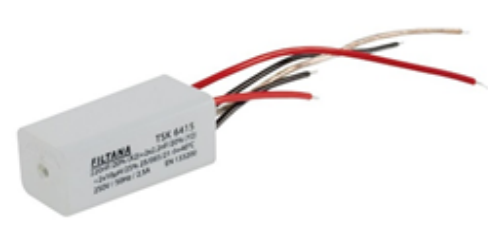

nestíněný

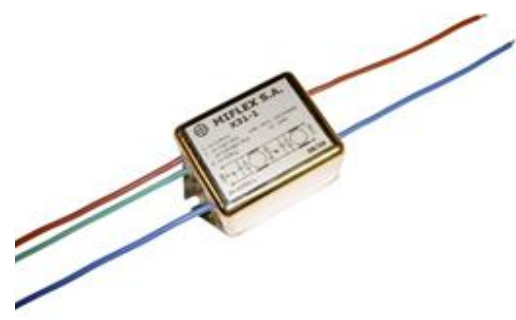

stíněný

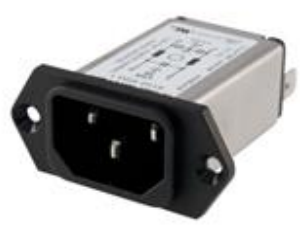

integrovaný do zásuvky

Obr. 3.14: Různá provedení odrušovacích filtrů

\subsubsection{Napájecí zdroje}

Jsou známy dva základní principy, jak realizovat napět’ové zdroje pro napájení zařízení. Napájecí zdroje můžeme rozdělit na dvě základní skupiny:

- spojitě regulované zdroje,

- spínané zdroje s impulsní regulací.

Při konstrukci zařízení je nutno na výběr vhodného typu napájecího zdroje klást velký důraz. Nevhodná volba typu napájecího zdroje může vést ve svém důsledku k tomu, že zařízení bude nepoužitelné pro nízkoúrovňové analogové signály, které by mohly být silně zarušené průnikem vf impulsů z napájecích zdrojů. Špatná volba typu zdroje, také může vést $\mathrm{k}$ tomu, že zařízení bude těžké a rozměrné, navíc s malou účinností napájecích zdrojů.

Cílem této kapitoly není konkrétní návrh napájecích zdrojů, ale zhodnocení jejich vlastností a výběr nejlepšího či kompromisního řešení pro dané použití.

\section{Volba typu napájecího zdroje}

Základní uspořádání klasického napájecího zdroje se spojitou stabilizací je uvedeno na Obr. 3.15 . Sít'ový transformátor nejprve sníží sít'ové napětí $230 \mathrm{~V}_{\sim}$ na potřebnou úroveň. Protože transformátor pracuje na kmitočtu $50 \mathrm{~Hz}$ a výkon přenášený transformátorem závisí na kmitočtu a na prưřezu jádra transformátoru, bude transformátor značně rozměrný. Protože na těchto kmitočtech se většinou užívají jádra složená z železových transformátorových plechů, bude hmotnost transformátoru pro větší výkony značná.

Za transformátorem dochází $\mathrm{k}$ usměrnění střídavého napětí a $\mathrm{k}$ jeho vyhlazení filtračním (střádacím) kondenzátorem $\mathrm{C}_{\mathrm{F}}$. Pro dobré vyhlazení usměrněného napětí je nutno použít velkou kapacitu filtračního kapacitoru, a proto se obvykle užije elektrolytický kondenzátor. Kondenzátor je vybíjen značným proudem tekoucím do zátěže, a pokud je použito dvoucestné usměrnění, musí kondenzátor udržet své napětí po dobu $10 \mathrm{~ms}$. Proto při větších proudech do zátěže vychází tento kondenzátor také značně rozměrný. Např. pro zdroj $10 \mathrm{~V} / 5 \mathrm{~A}$ by byl zapotřebí elektrolytický kondenzátor $22 \mathrm{mF} / 25 \mathrm{~V}$. 
Kapacitu filtračního kapacitoru však nelze volit nekonečně velkou. Abychom zmenšili kolísání napětí a vliv zátěže na toto kolísání, zařazuje se za filtrační kondenzátor spojitý stabilizátor napětí.
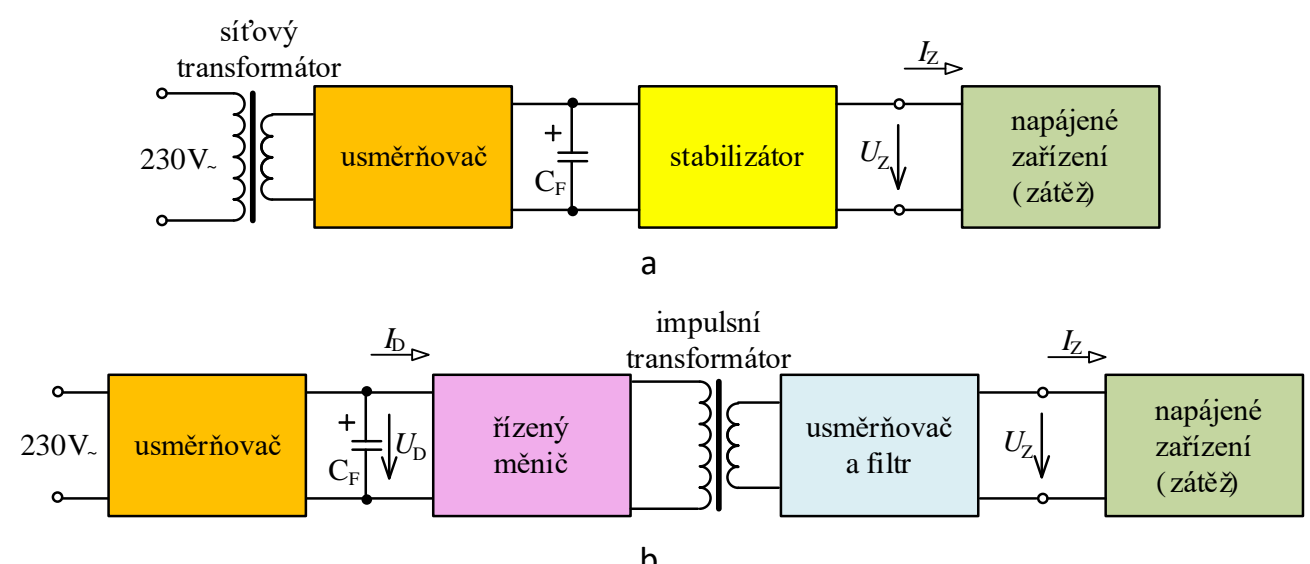

b

Obr. 3.15: a) Klasický spojitý napájecí zdroj napětí, b) spínaný zdroj napětí

Protože v sít'ovém transformátoru a ve stabilizátoru vznikají velké ztráty, je účinnost klasického spojitého zdroje obvykle jen 40 až $50 \%$. Klasický zdroj je přitom díky sít'ovému transformátoru a velkému filtračnímu kondenzátoru značně rozměrný a má velkou hmotnost. Jeho použití je proto omezeno jen pro menší výkony.

Blokové schéma spínaného zdroje je naznačeno na Obr. 3.15b. Sít'ové napětí $230 \mathrm{~V}_{\sim}$ se nejprve usměrní a vyhladí filtračním kondenzátorem. Výhodou je, že kondenzátor nyní není vybíjen přímo proudem do zátěže $I_{Z}$, ale přibližně proudem $I_{\mathrm{D}} \approx U_{\mathrm{Z}} I_{\mathrm{Z}} / U_{\mathrm{D}}$, kde $U_{\mathrm{D}}$ značí střední hodnotu napětí na kondenzátoru $C_{F}$. Pokud je amplituda sít'ového napětí $325 \mathrm{~V}$, lze střední hodnotu zvlněného napětí na kondenzátoru odhadnout na $U_{\mathrm{D}} \approx 310 \mathrm{~V}$. Vybíjecí proud filtračního kondenzátoru bude proto mnohonásobně menší. Pro zdroj $10 \mathrm{~V} / 5 \mathrm{~A}$ bude nyní dostačovat pro stejné procentuální zvlnění napětí kondenzátor o kapacitě pouze $22 \mu \mathrm{F} / 350 \mathrm{~V}$. Rozměry takového kondenzátoru budou ve srovnání s velikostí kondenzátoru v klasickém spojitém zdroji podstatně menší, i když kondenzátor musí být nyní na podstatně vyšší napětí.

Usměrněné a vyhlazené napětí se dále převede pomocí měniče na střídavé napětí, ale o mnohem vyšším kmitočtu. Obvykle se volí kmitočet měniče v rozmezí $25 \mathrm{kHz}$ až $200 \mathrm{kHz}$. Toto stř́́davé napětí se transformuje impulsním transformátorem na požadovanou výstupní úroveň. Vzhledem $\mathrm{k}$ vysokým kmitočtům je $\mathrm{v}$ transformátoru nutno použít feritové jádro. Přitom pro stejný výkon stačí daleko menší transformátor, než u klasického spojitého zdroje.

Nakonec se střídavé napětí ve spínaném zdroji usměrní a vyfiltruje LC filtrem. Stabilizace výstupního napětí se provádí neznázorněnou zpětnou vazbou, kdy se pomocí šířkové pulsní modulace (PWM) ovládá činnost řízeného měniče.

Spínané zdroje napětí dosahují vysoké účinnosti 60 až $95 \%$. Mají malé rozměry i malou hmotnost. Na druhé straně je zapotřebí používat speciální součástky jako jsou rychlé spínací tranzistory a Schottkyho diody. Kapacitor výstupního filtru LC musí pak vykazovat malý parazitní sériový odpor (ESR), malou parazitní indukčnost (ESL) a musí mít povolenu velkou hodnotu maximálního zvlnění proudu (Ripple Current).

Vlastní konstrukce spínaného zdroje je velmi náročná, protože velká část zdroje pracuje s vysokými úrovněmi napětí. Proto se individuální konstrukce spínaných zdrojů pro výkony menší než $25 \mathrm{~W}$ prŕliš nevyplatí. 
Předchozí porovnání vychází jednoznačně ve prospěch spínaných napětových zdrojů. Pokud ale vyhodnotíme vlastnosti obou typů zdrojů z hlediska vf rušení, není situace tak jednoznačná. Výhodou klasického spojitého zdroje je totiž skutečnost, že na jeho výstupu může proniknout pouze zvlnění dvoucestně usměrněného a vyfiltrovaného sít'ového napětí, jehož první harmonická složka je $100 \mathrm{~Hz}$. Pokud z takového zdroje napájíme např. operační zesilovač (viz Obr. 3.16 ), pak pro kmitočty $100 \mathrm{~Hz}$ představují parazitní kapacity koncových tranzistorů $\mathrm{C}_{\mathrm{CE}}$ velkou impedanci a zvlnění napájecího zdroje do výstupu operačního zesilovače téměř nepronikne.

V prŕípadně spínaného zdroje na výstup operačního zesilovače pronikají jehlové impulsy o kmitočtu $25 \mathrm{kHz}$ až $200 \mathrm{kHz}$ velmi snadno. Pro jehlové impulsy představují parazitní kapacity $\mathrm{C}_{\mathrm{CE}}$ malou impedanci (téměř zkrat), a proto tyto impulsy proniknou do signálových cest prakticky nezměněny (viz Obr. 3.16). Takovéto rušení, které pronikne do signálové cesty, se odstraňuje velmi obtížně.

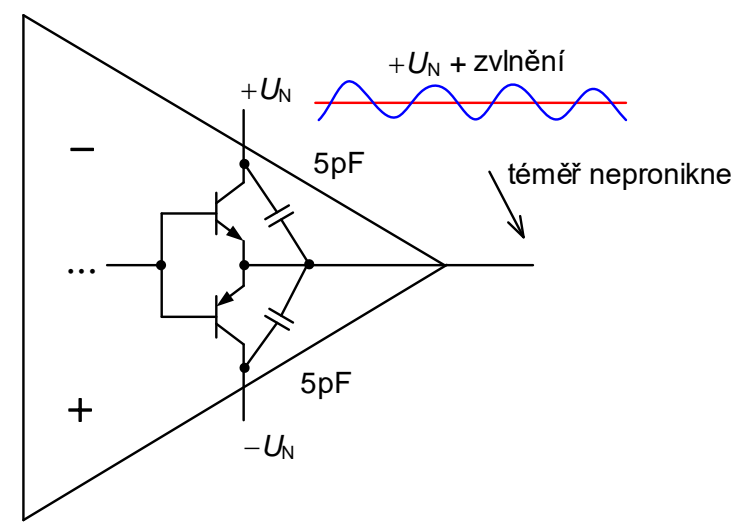

a

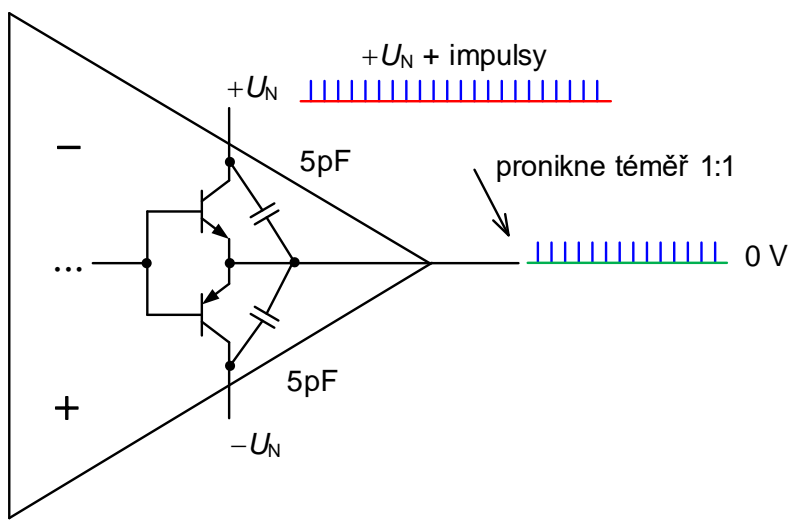

b

Obr. 3.16: Vliv spojitě regulovaného a spínaného zdroje na analogový obvod

Pokud shrneme výhody a nevýhody obou typů napájecích zdrojů, pak zdroje se spojitou regulací mají poměrně malou účinnost (kolem $40 \%$ ) a pokud se použijí pro větší výkony, mají vysokou hmotnost a jsou značně rozměrné. Jejich použití je proto obvykle omezeno jen pro menší výkony (kolem $25 \mathrm{~W}$ ). Na druhou stranu mají řadu výhod, pokud se týká ostatních dosahovaných parametrů. Dosahuje se u nich vysokého stupně integrace, nevykazují impulsní rušení a reagují poměrně rychle na změnu proudu do zátěže. Používají se proto zejména pro napájení malovýkonových analogových zařízení či měřicích přistrojů nebo jejich kritických částí.

Specifika spínaných zdrojů, používaných zejména pro napájení číslicové a výkonové techniky, vyplývají z požadavků značně odlišných od potřeb analogové a měřicí techniky. Typická je potřeba relativně nízkého napětí při velkém výkonu (řádově desítky $\mathrm{W}$ až kW). $Z$ této skutečnosti pak vyplývá důraz na velkou účinnost, kterou nelze dosáhnout spojitou regulací klasických stabilizátorů. Naopak přednosti spojitě regulovaných stabilizátorů, tj. jejich velmi dobré výstupní parametry, nejsou v číslicové či výkonové technice tolik důležité. U spínaných zdrojů se dosahuje vysoké účinnosti (kolem 90 \%). Zvětšení účinnosti je u nich zpravidla provázeno podstatným zlepšením objemového ukazatele, obojí však za cenu zhoršení řady výstupních parametrů jako je např. delší doba přechodového jevu při změně zátěže, nebo vyšší stupeň impulsního rušení. Obvodově je tento typ stabilizátorů oproti předchozímu složitější a potřeba speciálních součástek ztěžuje možnou integraci. 


\section{Spojitě regulované ss napájecí zdroje}

Pro konstrukci spojitě regulovaných napájecích zdrojů se užívají většinou integrované stabilizátory napětí. Bud’ jde o jednoúčelové stabilizátory s pevně nastaveným výstupním napětím, jako napřr. třísvorkové stabilizátory typové řady $78 \mathrm{XX}$, nebo jde o tzv. universální stabilizátory, jejichž výstupní napětí lze nastavit jednoduše pomocí vnějších prvků jako např. čtyřsvorkové stabilizátory typové série $78 \mathrm{G}$, nebo trrísvorkové série 317 . Pro záporná napájecí napětí jsou pak k dispozici komplementární varianty typové série 79XX s pěvně nastaveným napětím, nebo universální stabilizátory typové série 79G nebo série 337. Pro zařízení napájená $\mathrm{z}$ baterí jsou pak $\mathrm{k}$ dispozici stabilizátory $\mathrm{s}$ malým úbytkem napětí mezi vstupem a výstupem označované jako stabilizátory třídy LDO (Low Drop-Out). Všechny typy stabilizátorů jsou $\mathrm{k}$ dispozici v provedení od malovýkonových SMD až po výkonová pouzdra.

\section{Napájecí zdroje s tř́svorkovými stabilizátory}

Nejjednodušší zapojení zdroje napětí se spojitým stabilizátorem typové řady 78XX s pevně nastaveným výstupním napětím je uvedeno na Obr. 3.17 . Úbytek napětí mezi vstupem a výstupem stabilizátoru musí být nejméně $2 \mathrm{~V}$ nejlépe však $3 \mathrm{~V}$, jinak může dojít ke zhoršení stabilizačního účinku. Výrobce doporučuje co nejblíže k vývodům stabilizátoru připojit keramické blokovací kondenzátory. Kondenzátor na vstupu $C_{\mathrm{IN}}$ zabraňuje rozkmitání stabilizátoru parazitní indukčností př́ivodu od filtračního kondenzátoru, pokud je přívod delší než 7,6 cm (3"). Kondenzátor na výstupu $C_{\text {OUT }}$ slouží jako lokální zdroj energie při prudké změně proudu do zátěže. Kapacita kondenzátoru na výstupu menší než 100 nF může způsobit zhoršenou odezvu stabilizátoru.
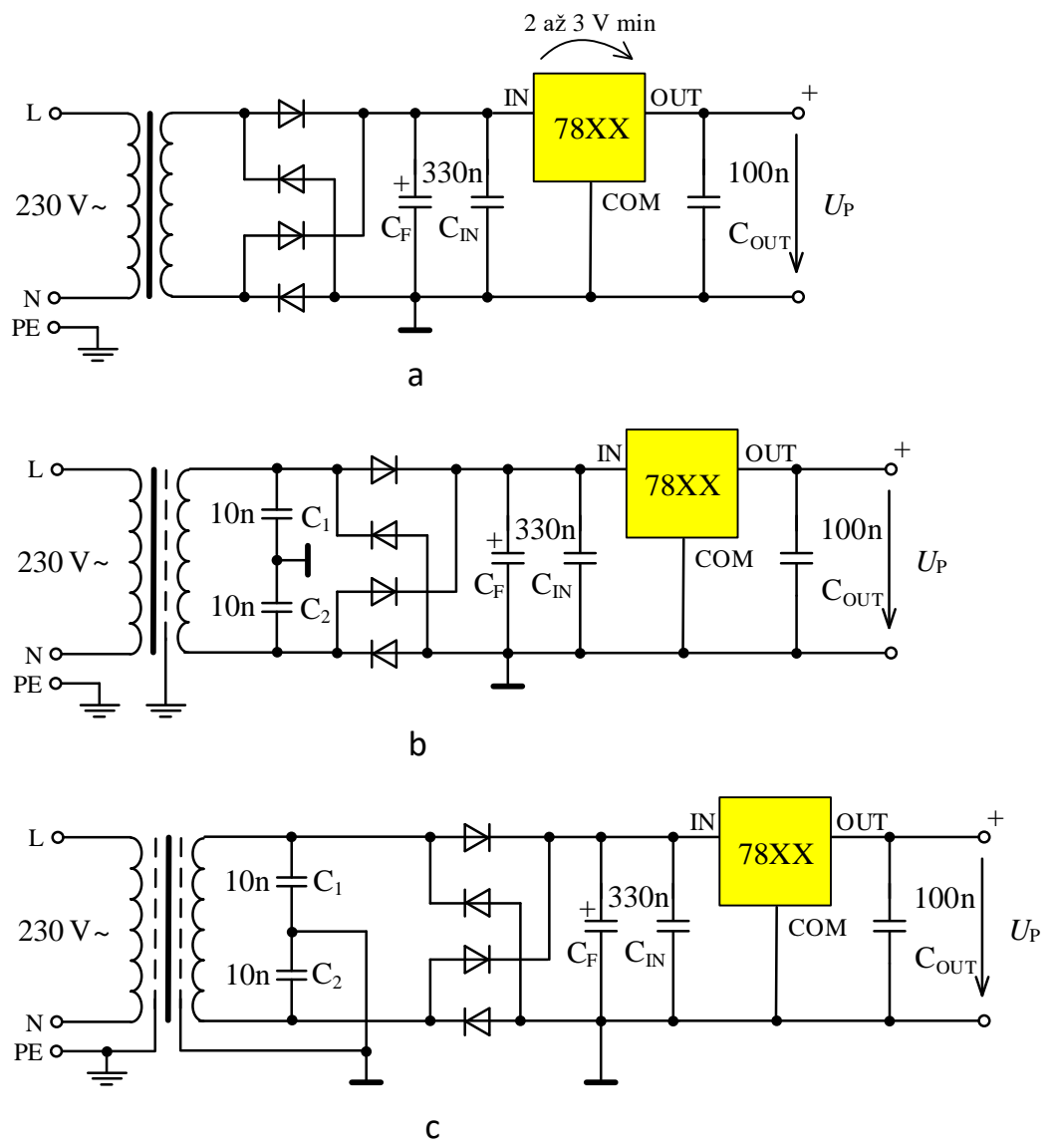

Obr. 3.17: Zapojení spojitého stabilizovaného zdroje s třísvorkovým stabilizátorem 
Ve všech případech sice předpokládáme, že odrušovací filtr zařazený před sít’ovým transformátorem potlačí rušení z rozvodné sítě, ale další účinnou pomocí proti pronikání nebezpečných poruch z rozvodné sítě může být dobré odstínění primárního a sekundárního vinutí tranformátoru zdroje uzemněnou tenkou měděnou folií (viz Obr. 3.17b). Stínicí fólie však nesmí tvořit závit „nakrátko“, překrývající se konce fólie se musí proložit izolační vrstvou. Méně účinným řešením je pak navinutí stínicího vinutí, jehož jeden konec se zaizoluje a druhý konec se spojí se zemí.

Vzniku rušivých impulsů uvnitř zdroje zabraňují také kapacitory $\mathrm{C}_{1}$ a $\mathrm{C}_{2}$ o kapacitě 10 až $100 \mathrm{nF}$ připojené mezi vývody sekundárního vinutí transformátoru a společný zemní vodič (viz Obr. 3.17b). Diody Gratzova můstku totiž vedou proud ještě po určitou dobu, i pokud proud změní svoji polaritu a diody by měly být zavřeny. Diody se zavřou, až jsou z přechodu PN odčerpány všechny menšinové nosiče nábojů nebo zaniknou v důsledku rekombinace. Tento jev se označuje jako závěrná zotavovací doba diody. Závěrný proud se po uplynutí závěrné zotavovací doby skokově zmenší na nulovou hodnotu. Tato rychlá časová změna vyvolá na indukčnostech, které obsahuje každý elektrický obvod, tzv. komutační napětí, které může někdy značně převýšit usměrňované stř́davé napětí. Abychom zabránili zničení diod působením tohoto impulsového přepětí a současně vznik jehlových impulsů omezili, doporučuje se kapacitory $\mathrm{C}_{1}$ a $\mathrm{C}_{2}$ umístit co nejblíže ke Graetzově můstku.

Jedna stínicí vrstva měděné fólie mezi primárním a sekundárním vinutím transformátoru umožňuje zmenšit kapacitu mezi těmito vinutími asi na 10 pF. Další snížení kapacity o 1 až 2 řády je možné dokonalejším provedením stínicích krytů okolo vinutí. Dobré výsledky dává užití dvou stínění (viz Obr. 3.17 ), které se užívá u citlivých přístrojů. Parazitní kapacita mezi vinutími se pak sníží na 1 až $2 \mathrm{pF}$. Obě země, tj. zem sít’ového rozvodu (PE) a zem vlastního zařízení, se pak propojí s ostatními zeměmi v jednom centrálním bodě, obvykle na vstupní nebo výstupní zemní svorce celého zařízení.

Základní uspořádání záporného stabilizovaného napájecího zdroje s obvodem 79XX je naznačeno Obr. 3.18. Protože stabilizátor má jiné vnitřní zapojení než stabilizátor typové řady $78 \mathrm{XX}$, je nutno použít dle doporučení daleko větší kapacity blokovacích kondenzátorů $\mathrm{C}_{\mathrm{IN}} \mathrm{a}$ $\mathrm{C}_{\text {OUT }}$.

Pro získání souměrného zdroje stabilizovaného napětí se používají oba typy trrísvorkových stabilizátorů (viz Obr. 3.18b). Toto zapojení je určeno pro méně náročné účely, protože záporné výstupní napětí nesleduje kladné napájecí napětí tak, jak tomu je u symetrických stabilizátorů typu (viz dále). Pro běžné účely je však zcela dostačující.

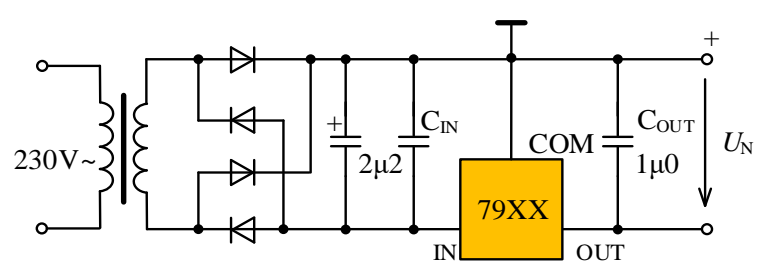

a

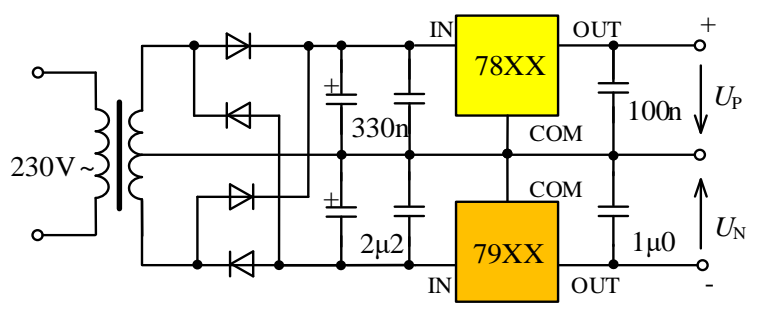

b

Obr. 3.18: a) Zapojení záporného stabilizovaného zdroje s tř́svorkovým stabilizátorem,

b) zapojení pro získání souměrného napájecího napětí 


\section{Symetrické napájecí zdroje sledovacího typu}

Stabilizovaný zdroj symetrického napětí uvedený na Obr. 3.18b se vyznačuje evidentní nevýhodou, protože zapojení není sledovacího typu. Oba stabilizátory jsou zcela nezávislé a kolísání jejich výstupních napětí je tedy také nezávislé. Avšak v řadě případů, zejména pro napájení operačních zesilovačů pracujících s velkým zesílením, je výhodné, aby rozdíl absolutní hodnoty obou napětí byl nulový. To se dá docílit např. tím, že jedno z napětí sleduje absolutní hodnotu druhého napětí. Tento požadavek se dá splnit uspořádáním symetrického stabilizátoru sledovacího typu podle Obr. 3.19 a. Zapojení využívá jako základ třísvorkový stabilizátor $78 \mathrm{XX}$, který vytváří kladné stabilizované napětí $+U_{\mathrm{P}}$. Protože operační zesilovač je zapojen jako invertující, dostane pro $R_{1}=R_{2}$ na jeho výstupu napětí $U_{\mathrm{N}}=-U_{\mathrm{P}}$. Záporné výstupní napětí $U_{\mathrm{N}}$ bude proto sledovat s opačnou polaritou kladné výstupní napětí $U_{\mathrm{P}}$.

Symetrický stabilizátor sledovacího typu lze také sestavit s využitím nastavitelných čtyřsvorkových stabilizátorů $78 \mathrm{G}$ a $79 \mathrm{G}$. Díky tomu, že zpětnovazební sít' je u těchto stabilizátorů vnější, lze oba typy stabilizátorů navzájem provázat (viz Obr. 3.19b). Protože stabilizátor $78 \mathrm{G}$ má vnitřní referenční napětí $+5 \mathrm{~V}$ a $79 \mathrm{G}$ napětí $-2,23 \mathrm{~V}$, nejsou odpory rezistorů $R_{2}$ a $R_{3}$ shodné. Kapacity kapacitorů $C_{1}$ až $C_{4}$ jsou zvoleny podle doporučení výrobce.
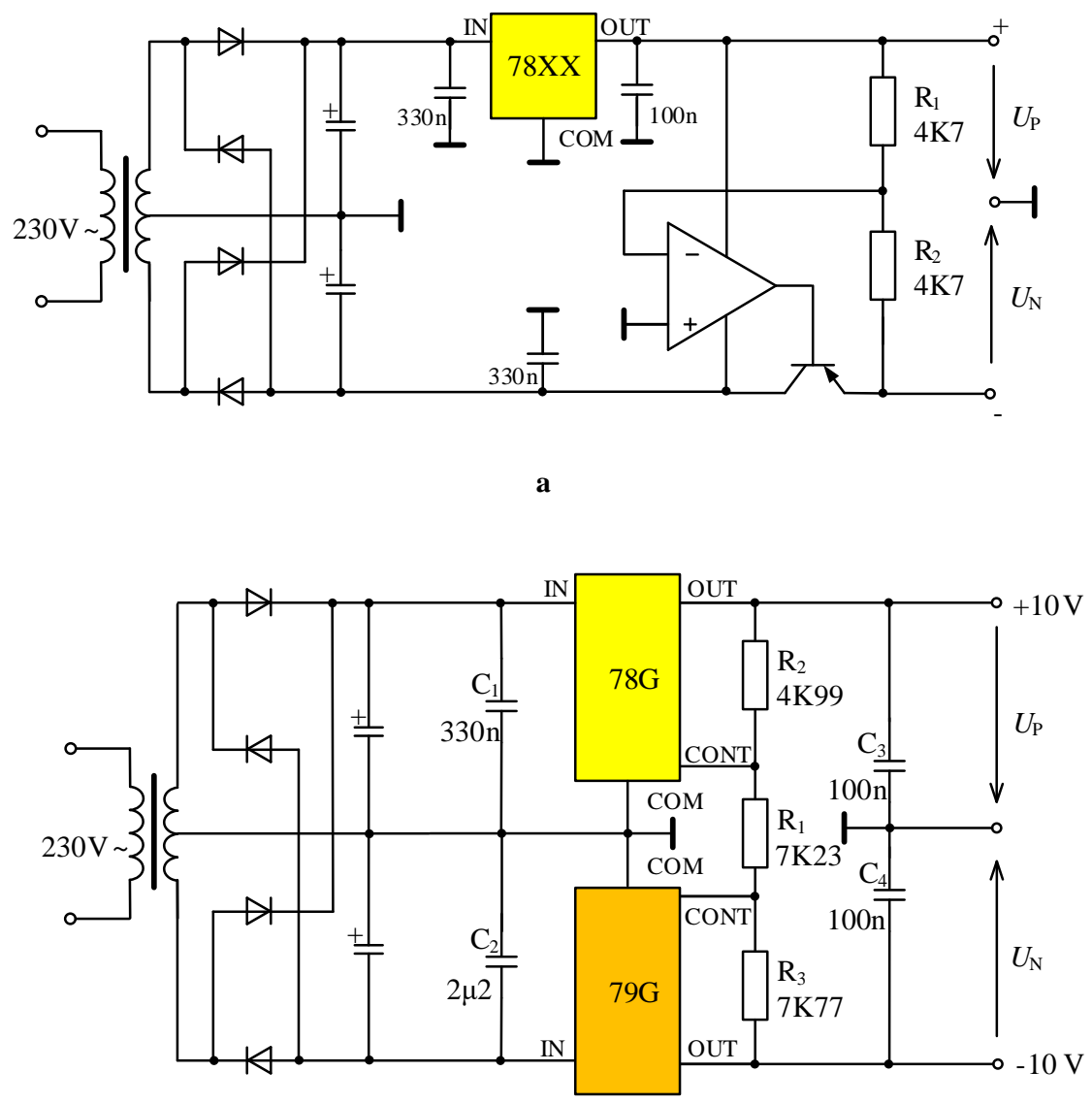

b

Obr. 3.19: Symetrické stabilizátory sledovacího typu: a) s třísvorkovým stabilizátorem a invertujícím zesilovačem, b) s nastavitelnými čtyřsvorkovými stabilizátory $78 \mathrm{G} \mathrm{a}$ $79 \mathrm{G}$ 
Napájecí zdroje se stabilizátory s malým úbytkem napětí.

Stabilizátory s malým úbytkem napětí mezi vstupem a výstupem, označované jako stabilizátory třídy LDO (Low Drop-Out regulator), se vyznačují tím, že mezi vstupním a výstupním napětím stačí pro dobrou stabilizaci úbytek pouze 0,1 až $0,3 \mathrm{~V}$. Pokud stabilizátor srovnáme s konvenčním zapojením integrovaného třísvorkového stabilizátoru, tak ten vyžaduje rozdíl mezi vstupním a výstupním napětím minimálně $2 \mathrm{~V}$, obvykle však více než $3 \mathrm{~V}$.

Stabilizátory třídy LDO jsou $\mathrm{k}$ dispozici s pevně nastaveným výstupním napětím, nebo se jejich napětí nastavuje pomocí vnějšího děliče. Pevně nastavená napětí bývají v typické řadě $1,25 \mathrm{~V} ; 1,5 \mathrm{~V} ; 1,8 \mathrm{~V} ; 2,5 \mathrm{~V} ; 3 \mathrm{~V} ; 3,3 \mathrm{~V} ; 5 \mathrm{~V}$.

Malý úbytek napětí je velkou výhodou u bateriových zařízení, protože baterie se pak může vybít na daleko nižší napětí, než stabilizátor přestane správně fungovat. Napřr. pro stabilizátor s napětím 3,3 V může napětí baterie klesnout až na 3,5 V. To v př́ípadě klasického řešení stabilizátoru není možné.

Určitou nevýhodou stabilizátorů třídy LDO je, že malý úbytek napětí platí pouze pro relativně malé proudy do zátěže. V závislosti na proudu do zátěže úbytek napětí totiž narůstá, a proto tuto vlastnost LDO stabilizátory vykazují většinou jen pro proudy maximálně do 0,5 až $0,8 \mathrm{~A}, \mathrm{kdy}$ je úbytek mezi vstupem a výstupem menší než $1 \mathrm{~V}$.

Při aplikacích stabilizátorů třídy LDO je nutno brát v úvahu jejich náchylnost k rozkmitání, protože př́liš velký nebo př́liš malý ekvivalentní sériový odpor ESR kondenzátoru připojeného k výstupu stabilizátoru může vést k oscilacím (viz Obr. 3.20. Proto je nutno vždy dodržet doporučení výrobce. Někteří přímo uvádějí konkrétní typ blokovacího kondenzátoru (např̀. elektrolytický nebo tantalový) anebo pro doporučenou kapacitu definují rozmezí ekvivalentního sériového odporu ESR pro požadovaný rozsah proudu do zátěže (např. $E S R=0,1$ až $10 \Omega$ pro $I_{\mathrm{OUT}}=0$ až $500 \mathrm{~mA}$ ).

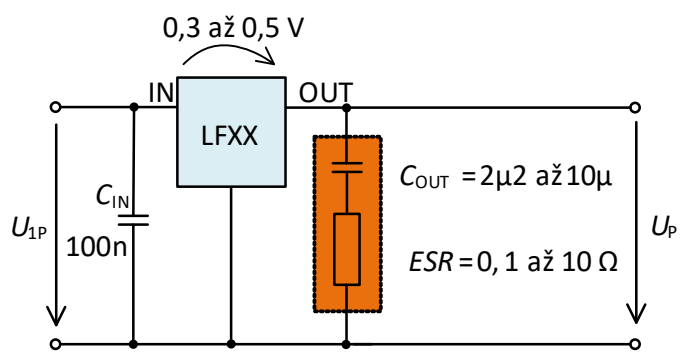

a

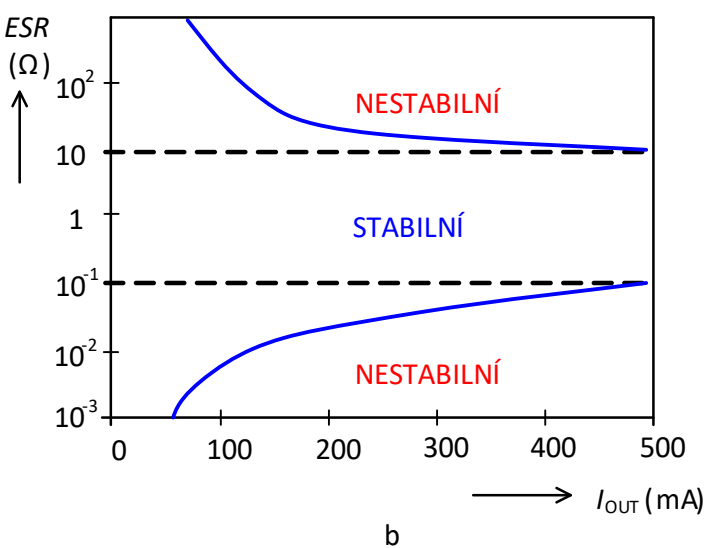

Obr. 3.20: a) Příklad zapojení blokovacích kondenzátorů u stabilizátoru tř́idy LDO,

b) ke kmitočtové stabilitě stabilizátorů tř́́dy LDO

\section{Kombinované klasické napájecí zdroje pro napájení analogových a číslicových systémů}

Pokud je zapotřebí navrhnout pro zařízení stabilizované zdroje pro společné napájení jak analogové, tak i číslicové části př́stroje, je nutno postupovat uvážlivě, abychom se vyhnuli možným problémům s průnikem impulsního rušení z číslicové části do analogové části. Nesprávné řešení, kdy ze spojitého stabilizátoru pro napájení analogové části je odvozeno dalším stabilizátorem napětí pro číslicovou část, je uvedeno na Obr. 3.21 . Je zřejmé, že ke spojení analogové a číslicové země dojde již v napájecím zdroji a k průniku rušení do analogové části bude bezpečně docházet přes tyto propojené země. 
Z těchto důvodů se doporučuje, aby napájení analogové a číslicové části mělo na transformátoru oddělená sekundární vinutí (viz Obr. 3.21b). Pak bude analogová zem oddělena od číslicové a následně je možné tyto země spojit podle potřeby až ve zvoleném centrálním bodě (podle charakteru přístroje např. u vstupní svorky, nebo u výstupní svorky).

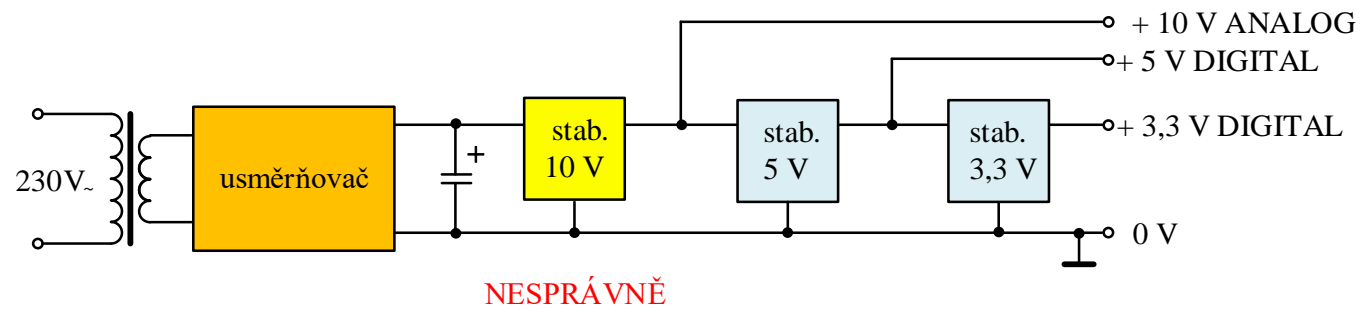

a

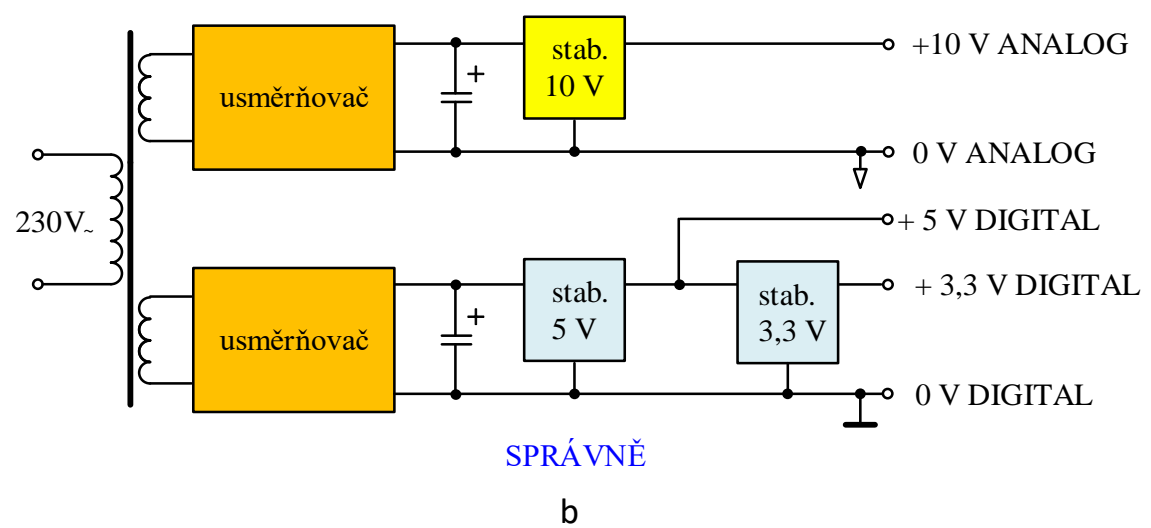

Obr. 3.21: Příklad klasického zdroje pro napájení analogového a číslicového systému

\section{Impulsně regulované ss napájecí zdroje}

Impulsně stabilizovaný napájecí zdroj bývá často uváděn pod názvem sít'ový spínaný zdroj (Switch Mode Power Supply) nebo AC/DC měnič (AC/DC convertor). Spínané zdroje pracují přímo se sítovým napětím $230 \mathrm{~V} / 50 \mathrm{~Hz}$, které se nejprve usměrní a vyfiltruje. Tak získáme ss nestabilizované napětí 310 až $320 \mathrm{~V}$. Toto ss napětí se pomocí měniče převede na střídavé napětí o kmitočtu $25 \mathrm{kHz}$ až $200 \mathrm{kHz}$, ze kterého se po usměrnění a jednoduché filtraci získá stejnosměrné výstupní napětí.

Spínané zdroje užívají ke stabilizaci stejnosměrného výstupního napětí tzv. impulsní regulaci, kdy se v závislosti na okamžité hodnotě výstupního ss napětí mění šířka pravoúhlých impulsů, které rídí činnost spínaného zdroje.

Spínané zdroje mohou být od sít'ového rozvodu galvanicky neodděleny nebo odděleny. Podle toho členíme spínané zdroje na

- neizolované bez galvanického oddělení,

- izolované s galvanickým oddělením.

Výběr typu zdroje závisí na požadované bezpečnosti, na omezení průniku rušení přes zemní smyčky, na složitosti konstrukce a ceně zařízení. 


\section{Neizolované spínané zdroje}

Existuje několik možných řešení jak realizovat spínaný zdroj bez galvanického oddělení od sít'ového rozvodu. Jednotlivá konkrétní řešení však nebudeme rozebírat a poukážeme pouze na výhody či nevýhody, které použití takovéhoto typu zdroje přináší.

Př́klad uspořádání neizolovaného zdroje je uveden na Obr. 3.22. Vstupní střídavé napětí se nejprve usměrní a vyhladí na kondenzátoru $\mathrm{C}_{\mathrm{F} 1}$. Pokud se tranzistor $\mathrm{T}_{1}$ sepne, je proud do kondenzátoru $\mathrm{C}_{\mathrm{F} 2}$ a zátěže $\mathrm{R}_{\mathrm{Z}}$ dodáván přes tlumivku $\mathrm{L}_{1}$. Ta akumuluje energii ve formě magnetického pole. Jakmile se tranzistor $\mathrm{T}_{1}$ rozpojí, tlumivka nakumulovanou energii spotřebovává a snaží se přes sepnutou diodu $\mathrm{D}_{5}$ zachovat směr proudu zátěží $\mathrm{R}_{Z}$. Poznamenejme pro přesnost, že tranzistor je nutno spínat pomocí galvanicky odděleného budiče napět'ových úrovní.

Impulsní regulátor porovná výstupní napětí s referenčním zdrojem napětí. Rozdíl se zesiluje v zesilovači odchylky a tímto napětím se mění šířka pravoúhlých impulsů v modulátoru PWM (Pulse Width Modulation = impulsní šířková modulace). Protože filtr $\mathrm{L}_{1} \mathrm{C}_{\mathrm{F} 2}$ vyhodnocuje střední hodnotu takto modulovaných pravoúhlých kmitů, dochází pomocí této zpětné vazby ke stabilizaci výstupního stejnosměrného napětí.

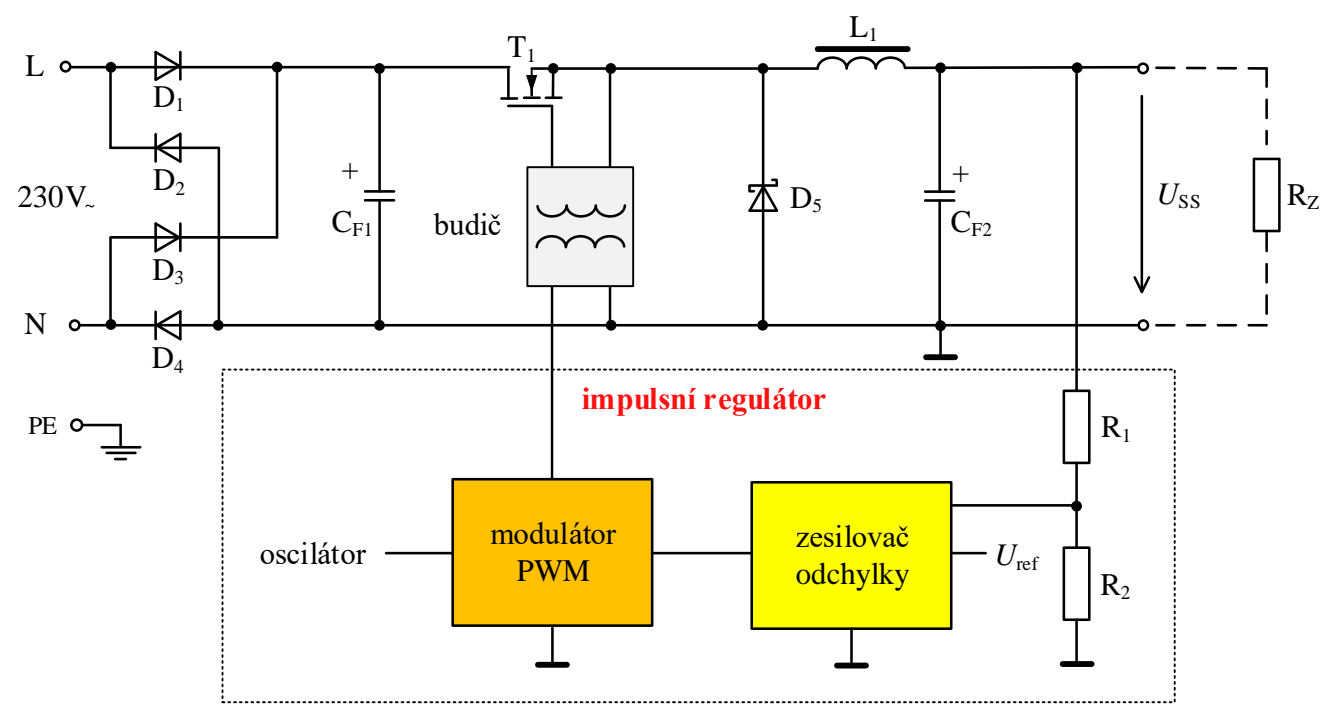

Obr. 3.22: Příklad zapojení galvanicky neizolovaného spínaného zdroje

Nevýhoda takovéhoto typu spínaného zdroje je evidentní. Výstup zdroje není stejnosměrně (galvanicky) oddělen od sítového rozvodu. Vypínání tranzistoru $T_{1}$ způsobuje úzké přepět’ové špičky, které jsou př́íčinou impulsního rušení v ss napájecím rozvodu. Nevýhodou je také omezený rozsah výstupního výkonu, kdy s tímto zapojením se konstruují zdroje do výkonu $50 \mathrm{~W}$. Místo impulsního transformátoru se zde ale vystačí $\mathrm{s}$ jednoduchou tlumivkou bud' na feritovém nebo železoprachovém jádře. Výhodou tohoto zapojení je jednoduchost a nízká cena.

\section{Izolované spinané zdroje}

V případě, že požadujeme galvanické oddělení výstupního napětí od vstupního, případně požadujeme více výstupních napětí navzájem galvanicky oddělených, musíme použít zapojení s impulsním transformátorem. Řešení s transformátorem se použije i v př́padech, kdy rostou požadavky na výstupní výkon. 
Př́iklad zapojení izolovaného spínaného zdroje je na Obr. 3.23. Obvody popíšeme jen stručně pro pochopení principu činnosti. Tranzistory měniče napětí se spínají synchronně. Pokud budou oba sepnuty, teče proud do primárního vinutí transformátoru přes sepnutý tranzistor $T_{1}$ a uzavírá se přes sepnutý tranzistor $T_{2}$. Jakmile se oba tranzistory rozpojí, proud primárním vinutím poteče přes sepnuté diody $\mathrm{D}_{5}$ a $\mathrm{D}_{6}$. Takto vzniknou pravoúhlé napět'ové kmity, jejichž šířka je řízena impulsním regulátorem, resp. modulátorem PWM.

Vzniklé kmity se transformují v potřebné úrovni na sekundární stranu impulsního transformátoru. Zde je signál usměrněn a vyfiltrován LC filtrem. Pokud je dioda $D_{7}$ sepnuta a $D_{8}$ rozpojena, je proud do zátěže dodáván přes tlumivku $L_{1}$. Jakmile se $D_{7}$ rozpojí, sepne se dioda $\mathrm{D}_{8}$ a $\mathrm{v}$ této půlperiodě dodává do zátěže proud stejného směru tlumivka.

Výhodou koncepce zdroje s impulsním transformátorem je, že vstupní a výstupní část jsou stejnosměrně odděleny a zdroj lze tedy z hlediska výstupu považovat za „plovoucí“, tzn. za galvanicky oddělený od sít'ového stř́ídavého proudu. Galvanická izolace obvykle vyřeší problém zemních smyček a také zajistí bezpečné oddělení od rozvodné sítě.

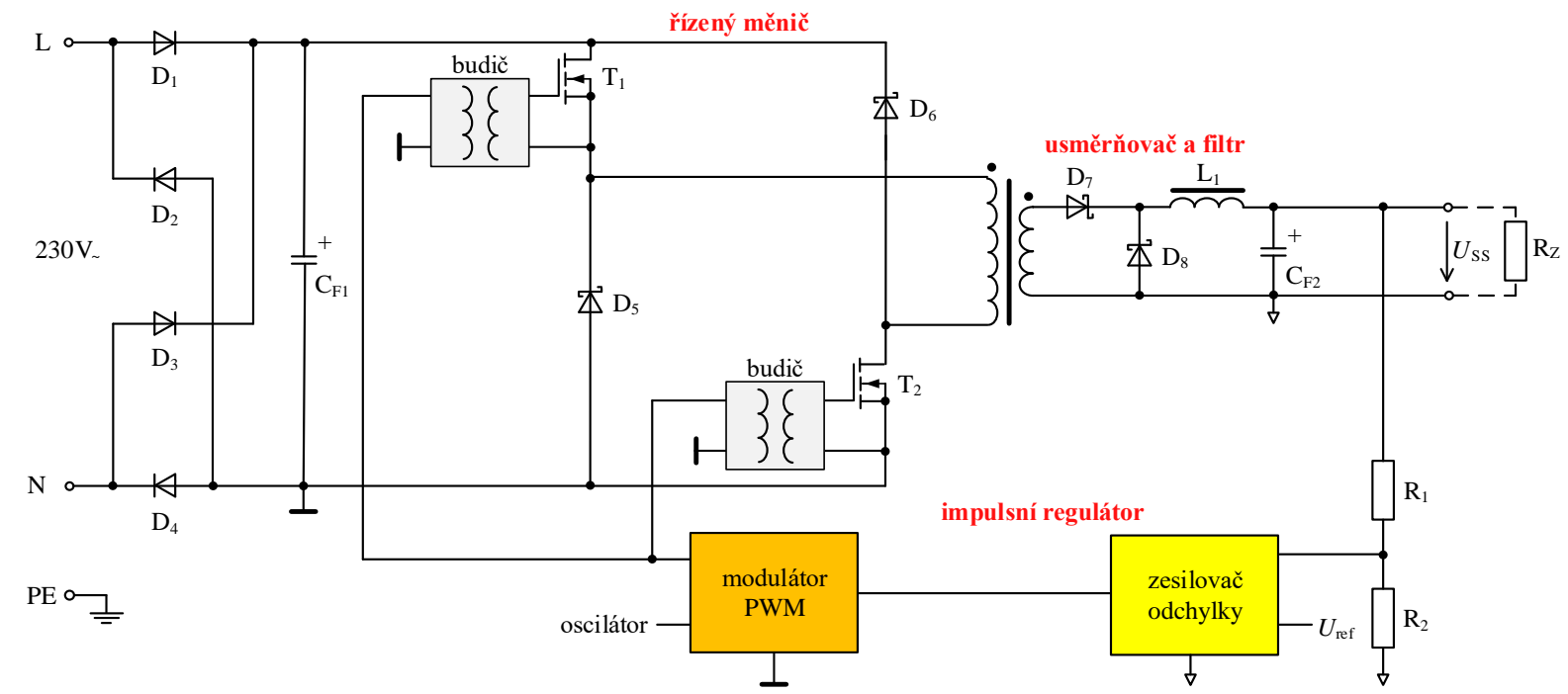

Obr. 3.23: Příklad zapojení galvanicky izolovaného spínaného zdroje

Protože spínaný zdroj pracuje na daleko vyšších kmitočtech, než je kmitočet sítě $50 \mathrm{~Hz}$, musí být jádro impulsního transformátoru feritové. Feritová jádra se i při velkých přenášených výkonech díky vysokým kmitočtům vyznačují malými rozměry. Zapojení s impulsním transformátorem jsou vhodná pro výstupní výkony do $250 \mathrm{~W}$ a některá zapojení jsou použitelná i pro výstupní výkony přesahující $500 \mathrm{~W}$. Naproti tomu galvanická izolace obvykle zvyšuje složitost a cenu spínaného zdroje.

Impulsní transformátor je bohužel významným zdrojem vysokofrekvenčního šumu. Každý transformátor má určitou parazitní kapacitu mezi primárním a sekundárním vinutím 10 až 100 pF. Pokud mezi vstupem a výstupem neexistuje jiné spojení bude to mít za následek vf proudy, které potečou vývody z napájecího zdroje. Vf proudy se budou přes další parazitní kapacity uzavírat zpět na vstup (viz Obr. 3.24 a). Z pohledu rušení je to špatně, protože vývody z napájecího zdroje budou kolem sebe vyzařovat rušivé vf magnetické pole, které může proniknout do dalších obvodů či sousedních vodičů. 
K potlačení vf rušení je zapotřebí vf rušivému proudu poskytnout co nejkratší cestu zpět ke zdroji rušení, tj. k primárnímu vinutí. K tomu se používá odrušovací kondenzátor, který se zapojí mezi vstupní a výstupní stranu spínaného zdroje, s kapacitou, která je podstatně vyšší než je parazitní kapacita mezi primárním a sekundárním vinutím (viz Obr. 3.24b). Tím se účinně zmenší vf rušení a zabrání se tak jeho průniku do zařízení. V principu je ale jedno, ve které části vstupního nebo výstupního obvodu se tímto kondenzátorem realizuje vf zkrat. Proto se můžeme setkat i s jiným zapojením odrušovacího kondenzátoru (viz Obr. 3.24, d).

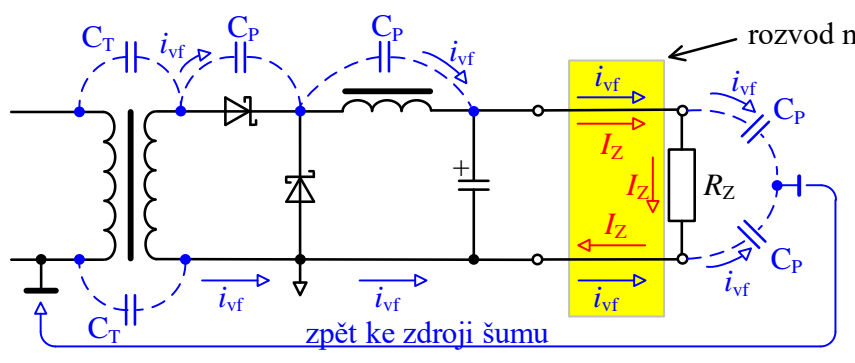

a

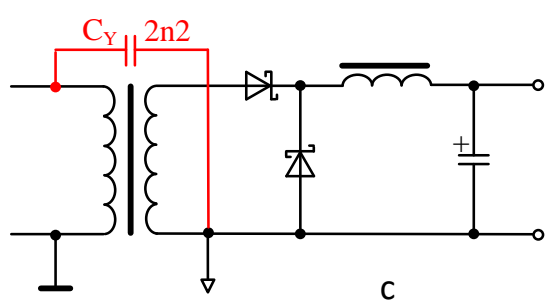

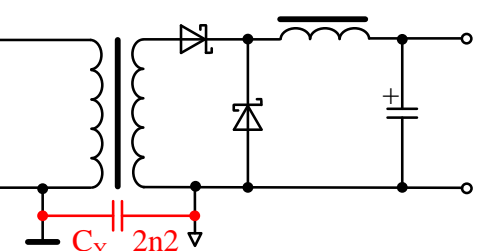

b

Obr. 3.24: K vysvětlení vf rušení impulsního zdroje a způsoby jeho potlačení

Obvykle se volí hodnota kapacity odrušovacího kondenzátoru z rozmezí $1 \mathrm{nF}$ až 4,7 $\mathrm{nF}$. Odrušovací kondenzátor musí být v provedení $\mathrm{Y}, \mathrm{tj}$. v bezpečném provedení, protože jeho průraz by mohl způsobit ohrožení lidského života elektrickým proudem. Kondenzátory musí být minimálně na jmenovité bezpečné stř́ídavé napětí $250 \mathrm{~V}$ (obvykle na $400 \mathrm{~V}_{\sim}$ ) a při výrobě musí být testovány pulsním napětím 2 až $4 \mathrm{kV}$ podle požadované tř́idy či kategorie zařízení. Zde je zapotřebí podotknout, že kondenzátor zvýší tzv. únikový proud zařízení, protože proud tímto kondenzátorem se přičítá $\mathrm{k}$ únikovému proudu kondenzátorů třídy $\mathrm{Y} v$ odrušovacím filtru, který je předřazen spínanému zdroji (anebo je $\mathrm{v}$ řadě př́ípadů jeho součástí).

\section{Kombinované spinané zdroje pro napájení analogových a číslicových systémů}

Pokud v zařízení potřebujeme realizovat větší počet galvanicky oddělených spínaných zdrojů na různá napětí, bylo by řešení samostatných zdrojů příliš drahé. Každý zdroj by totiž vyžadoval užití samostatného impulsního transformátoru včetně celé impulsní regulační smyčky. To by takovýto zdroj prodražilo. Proto se z požadovaných zdrojů vybere ten, který bude do zátěže dodávat největší výkon a tento hlavní zdroj bude stabilizován zpětnou vazbou pomocí spínaného stabilizátoru (viz Obr. 3.25. Z tohoto důvodu nebude stabilizační účinek příliš ovlivňován zatěžovacími proudy méně výkonových zdrojů, které jsou navázány na stejný transformátor. Pro zlepšení stabilizačního účinku celého zdroje jsou filtrační tlumivky navinuty na společném jádře. Protože vedlejší zdroje nejsou tak dobře stabilizovány jako hlavní zdroj, jsou doplněny tř́svorkovými spojitými stabilizátory. Pokud budou proudy do zátěží těchto vedlejších 
zdrojů malé (asi do 0,5 A), použijí se stabilizátory typu LDO s malým úbytkem napětí mezi vstupem a výstupem. Při větších odběrech se užijí klasické třísvorkové stabilizátory.

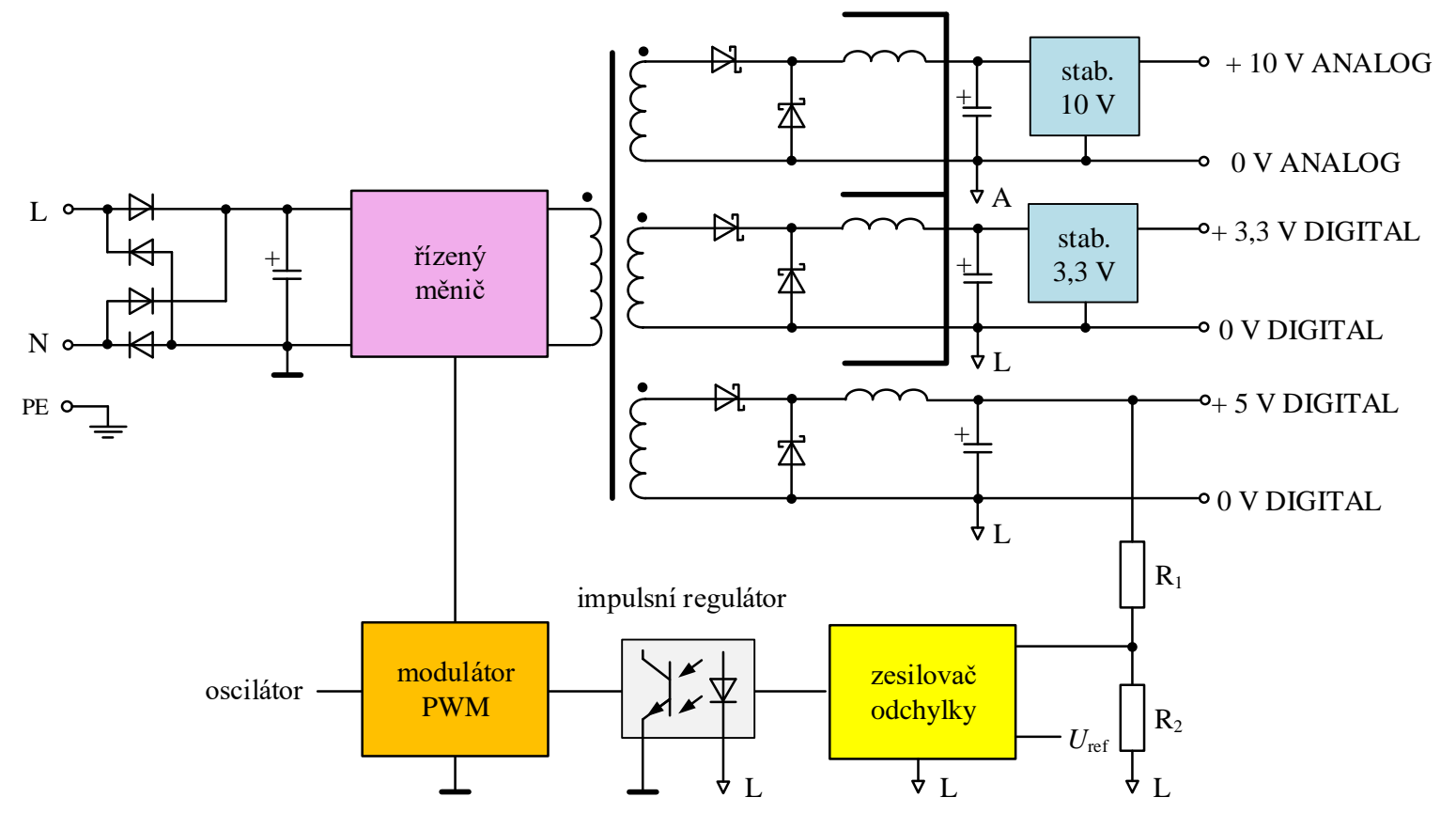

Obr. 3.25: Př́iklad řešení kombinovaného spínaného zdroje

\section{Průmyslově vyráběné spinané zdroje}

K dispozici je celá řada průmyslově vyráběných spínaných sít’ových zdrojů (viz Obr. 3.26. Většinou nedává smysl pokoušet se o vlastní návrh a jejich realizaci, protože je zapotřebí celá řada speciálních znalostí a zkušeností, zejména pokud se týká ochrany spínacích prvků proti průrazu, ochrana proti rušení, požadavky na bezpečnost provozu aj. Důležité je však při jejich výběru věnovat pozornost, jaké parametry a vlastnosti vykazují, tj. zda mají zabudován odrušovací filtr, mají integrovanou ochranu proti přetížení, proti zkratu, proti přepětí, zda je výstup zdroje uzemněný nebo galvanicky oddělený apod. Vstupní napětí spínaných zdrojů bývá obvykle v širokém rozmezí od $85 \mathrm{~V}_{\sim}$ až do $265 \mathrm{~V}_{\text {}}$. Typická výstupní napětí bývají $\mathrm{v}$ řadě $48 \mathrm{~V}, 24 \mathrm{~V}, 18 \mathrm{~V}, 15 \mathrm{~V}, 12 \mathrm{~V}, 5 \mathrm{~V}$, nebo 3,3 V. Nejlépe je spínaný zdroj zakoupit od tuzemského dodavatele, protože takovýto zdroj musí být podroben zkouškám podle platných bezpečnostních norem. 


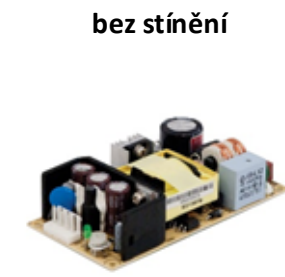

Výstupní napětí: $5 \mathrm{~V}$ Výstupní proud: $6 \mathrm{~A}$ Výkon: $300 \mathrm{~W}$ Účinnost: 78 \% se stíněním

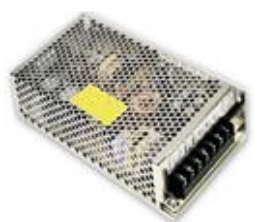

Výstupní napětí: $15 \mathrm{~V}$ Výstupní proud: $10 \mathrm{~A}$ Výkon: $150 \mathrm{~W}$ Účinnost: 84 \% s ventilátorem

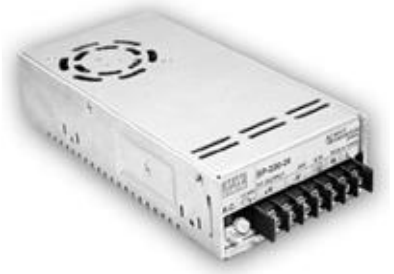

Výstupní napětí: $12 \mathrm{~V}$

Výstupní proud: 16,7 A

Výkon: 200,4 W

Účinnost: 79 \%

Obr. 3.26: Několik příkladů sít’ových spínaných zdrojů

\section{Měniče stejnosměrného napětí}

Měniče ss napětí transformují ss vstupní napětí na vyšší či nižší ss úroveň. V katalozích jsou obvykle uváděny pod označením DC/DC měnič (DC/DC converter). Pracují na stejných principech jako spínané zdroje, ale nároky na obvodové prvky většinou nejsou již tak kritické, protože zpracovávají daleko nižší napětí.

$\mathrm{DC} / \mathrm{DC}$ měniče se užívají nejčastěji pro úpravu napětí $\mathrm{z}$ baterie či $\mathrm{z}$ akumulátoru na požadované napětí, nebo se použijí pro odvození dalších ss napětí z hlavního spínaného sít’ového zdroje. Tento typ měničů doznal takového rozšśřrení, že tvoří samostatnou třídu napájecích zdrojů. Nabízí je celá řada výrobců a proto se omezíme na výběr vhodného typu a na jejich př́ípadné odrušení.

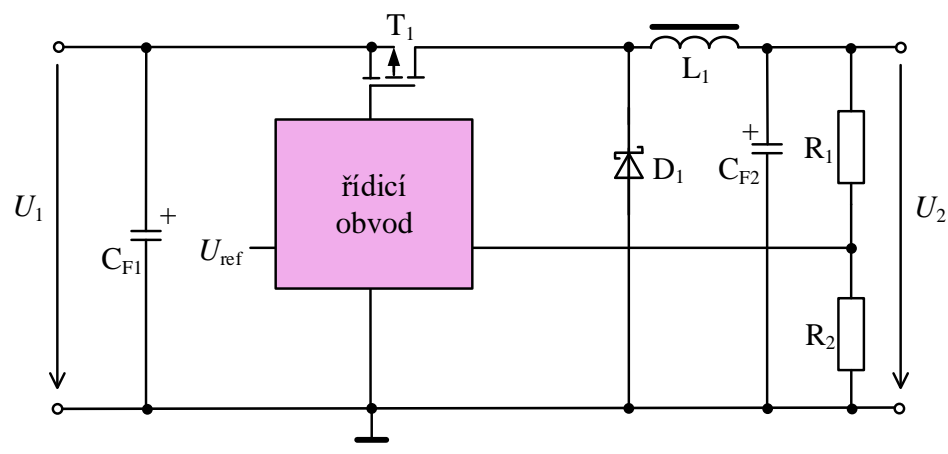

Obr. 3.27: Př́́klad zapojení galvanicky neizolovaného DC/DC měniče

Př́klad zapojení galvanicky neizolovaného měniče je uveden na Obr. 3.27. Je zřejmé, že pokud výstupní napětí budeme odvozovat ze zdroje pro napájení číslicových obvodů, můžeme DC/DC měnič použít zase jen pro napájení číslicových obvodů, protože rušení přes společné zemní smyčky se nevyhneme. Pro úplnost podotkněme, že mimo klasické řešení spínaného měniče se pro menší výkony dají použít i integrované DC/DC měniče, které pracují na principu spínaných kapacitorů. Ty se ale řadí také do kategorie neizolovaných měničů.

Pro napájení analogových obvodů, které musí mít oddělenou zem od země číslicové, nebo napájení galvanicky oddělených částí zařízení, je nutno použít galvanicky izolované měniče DC/DC, které používají pro oddělení vstupní a výstupní části impulsní 
transformátor. I když většina výrobců nabízí neizolované DC/DC měniče, lze dohledat i několik výrobců izolovaných měničů.

Př́klad galvanicky izolovaného DC/DC měniče se symetrickým výstupem je na Obr. 3.28. Protože měnič pracuje s vysokým kmitočtem, dostačuje na sekundární straně pouze jednocestné usměrnění. Impulsní regulací je stabilizováno pouze kladné výstupní napětí. Protože jsou ale obě sekundární vinutí na společném jádře a odběry do zátěže z obou výstupů, jsou většinou symetrické, bude napětí záporného zdroje také stabilní.

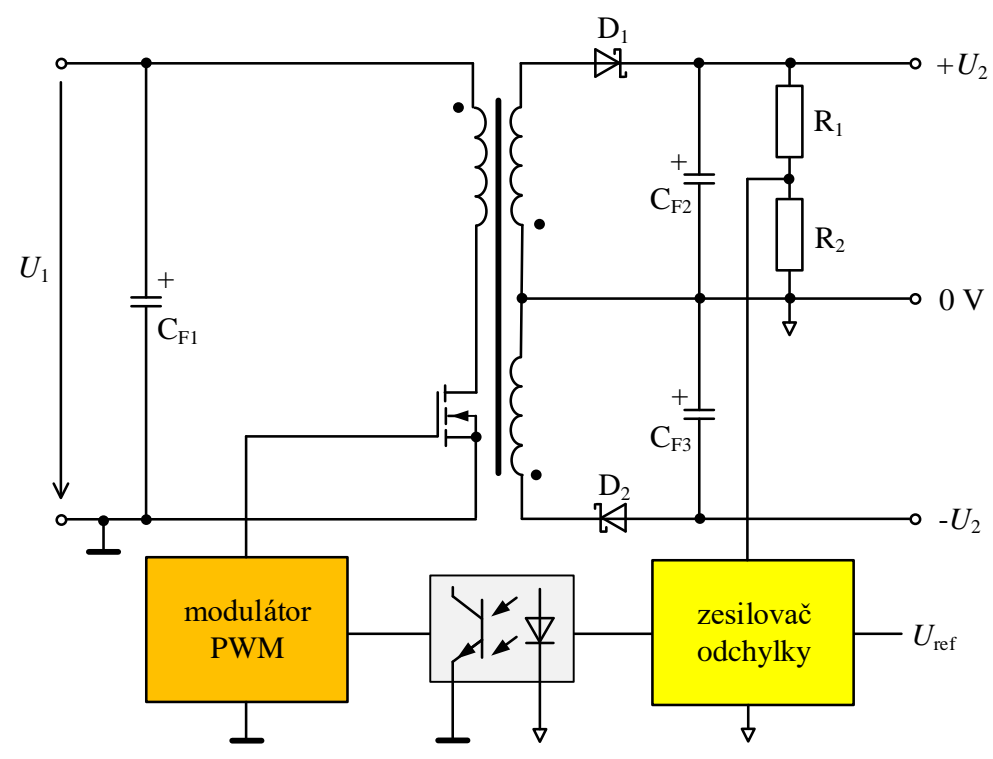

Obr. 3.28: Příklad zapojení galvanicky izolovaného DC/DC měniče

Samozřejmě největším problémem při napájení analogových obvodů z DC/DC měničů je impulsní rušení. Pro potlačení zvlnění výstupního napětí a vf rušení se doporučuje použít LC filtr se dvěma proudově kompenzovanými tlumivkami navinutými na stejném jádře (viz Obr. 3.29 a). Kondenzátor $\mathrm{C}_{1}$ se doporučuje použít tantalový a $\mathrm{C}_{2}$ keramický. V případě, že potřebujeme odrušit symetrický napájecí zdroj, používají se tři odrušovací tlumivky navinuté na společném toroidním jádře (viz Obr. 3.29 ).
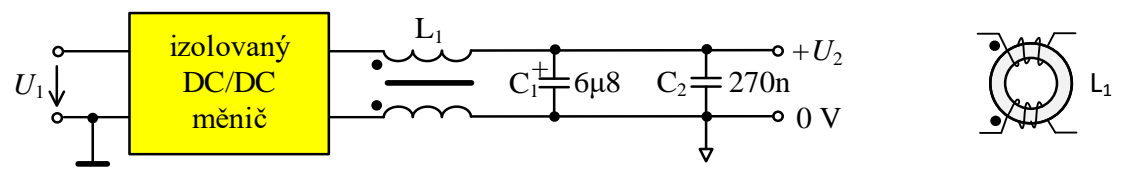

a
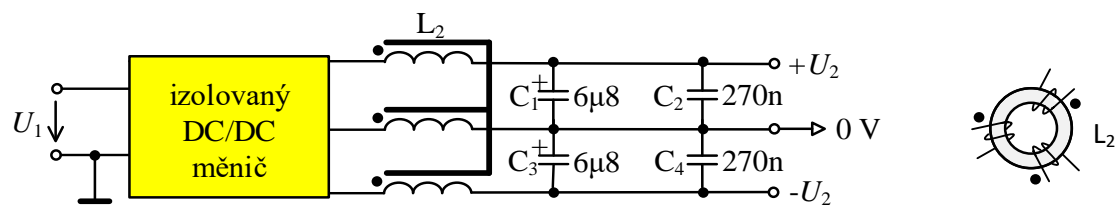

b

Obr. 3.29: Doplňkové odrušení DC/DC zdrojů určených pro napájení analogových obvodů 
Podle požadovaného výkonu dodávaného do zátěže jsou DC/DC měniče vyráběny v integrovaném, hybridním nebo diskrétním provedení. Několik příkladů DC/DC měničů je uvedeno na Obr. 3.30.

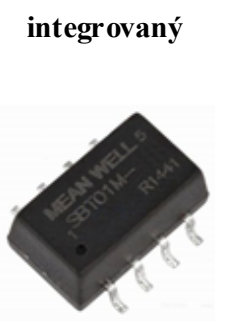

Vstupní napětí DC : 10,8 až 13,2 V dc Výstupní napětí: $9 \mathrm{~V}$

Výstupní proud: 0,111 A

Výkon: $1 \mathrm{~W}$

Účinnost: 75 \%

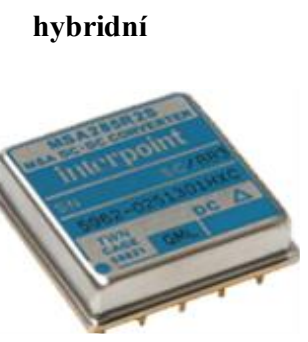

Vstupní napětí DC : 16 až $40 \mathrm{~V}$ Výstupní napětí: + $15 \mathrm{~V}$, - $15 \mathrm{~V}$ Výstupní proud: 0,3 A

Výkon: $5 \mathrm{~W}$

Účinnost: 76 \%

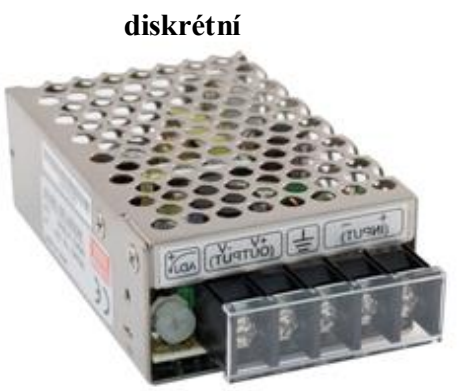

Vstupní napětí DC : $18 . .36 \mathrm{~V}$

Výstupní napětí: $5 \mathrm{~V}$

Výstupní proud: $3 \mathrm{~A}$

Výkon: $15 \mathrm{~W}$

Účinnost: $76 \%$

Obr. 3.30: Př́kklady několika průmyslově vyráběných typů DC/DC měničů

\subsection{Napájecí rozvody}

Př́ivody od ss napájecích zdrojů k vlastnímu spotřebiči mají být krátké, nejvýše asi $0,5 \mathrm{~m}$. U delších vodičů totiž mohou vznikat vlivem přechodových jevů zákmity napětí, které následně pak způsobí ztrátu informace, popř. i poškození některých elektrických součástek. Proto je třeba realizovat napájecí rozvod s minimální indukčností. Také kapacitní vazby s jinými silovými nebo signálními vodiči jsou nežádoucí. Napájecí a zemní sběrnice téhož zdroje napětí se doporučuje vést těsně vedle sebe. Dosáhneme tím malé indukčnosti a navíc příznivé kapacity mezi vodiči. Měděné vodiče napájecího rozvodu musí mít také dostatečný průřez tak, aby na nich průtokem napájecího proudu nevznikal př́liš velký úbytek napětí.

Vlastní rozvod napájení v zařízení se často skládá ze dvou částí. Jednou částí je vedení napájecího napětí od zdroje $\mathrm{k}$ jednotlivým dílům systému nebo $\mathrm{k}$ jednotlivým montážním deskám. Přechod $\mathrm{k}$ těmto částem se obvykle děje pomocí vhodných konektorů, které musí mít zanedbatelný přechodový odpor a musí být dimenzovány tak, aby byly schopny vést značné proudy. Proto se někdy kontakty konektorů spojují paralelně, nebo se užijí konektory pro větší proudové zatížení. Druhou částí je pak vedení napájecího napětí k jednotlivým obvodům.

\subsubsection{Rozvod napájení od zdroje k jednotlivým systémům}

V některých jednodušších př́ipadech se $\mathrm{k}$ rozvodu napájecího napětí od zdroje $\mathrm{k}$ jednotlivým zásuvným jednotkám uživá oboustranně plátovaného plošného spoje s prokovenými otvory Obr. 3.31. Jedna strana spoje se využivá k rozvodu napětí ze zdroje s největším proudovým odběrem, druhá slouží jako zemní vodič. Současně s tím se dosáhne malé indukčnosti rozvodu a navíc takový rozvod představuje př́idavný filtrační kondenzátor. Zbývající část desky plošného spoje se využije pro realizaci signálových spojů mezi jednotlivými zásuvnými deskami, nebo pro rozvod dalších napájecích napětí s menšími proudovými odběry. 


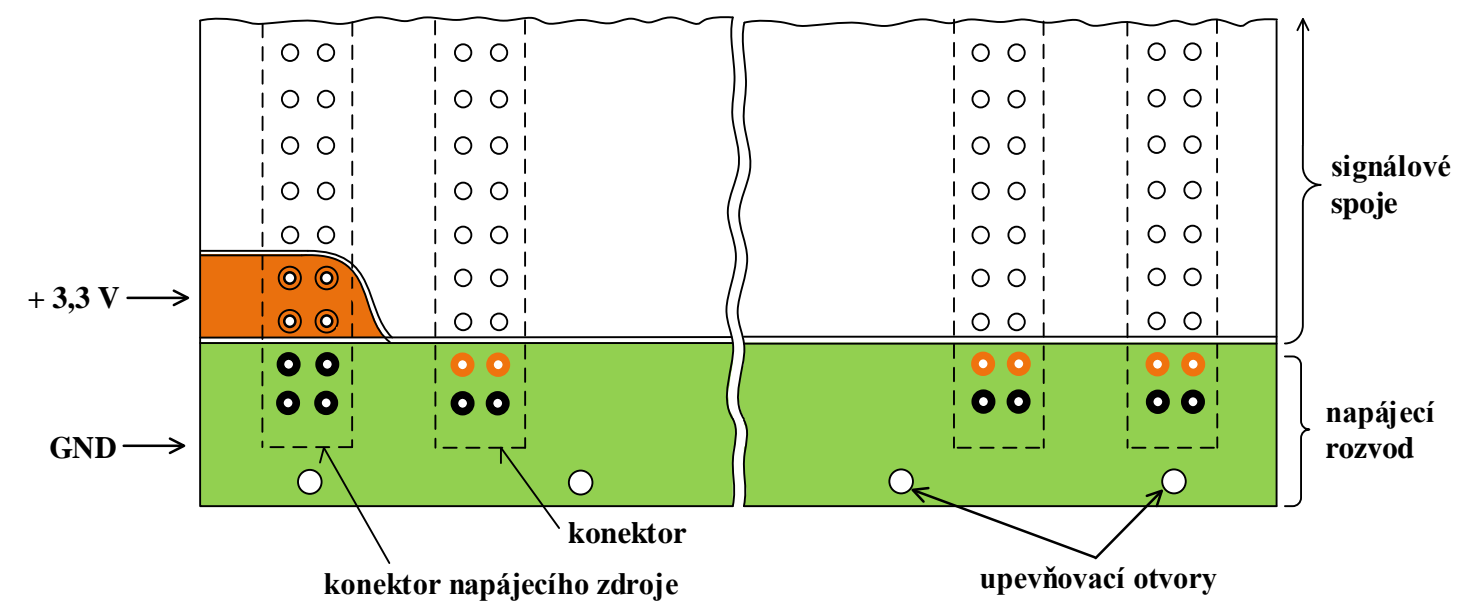

Obr. 3.31: Rozvod napájení pomocí dvoustranné DPS s prokovenými otvory

Při větších proudových odběrech se první část rozvodu realizuje pomocí vícevrstvé desky plošných spojů s prokovenými otvory, kdy se jedna vrstva vyhradí rozvodu napětí s největším proudovým zatížením a druhá sousední vrstva pak rozvodu příslušné výkonové země. Další vrstvy pak slouží k realizaci sběrnic a signálových spojů a k rozvodu dalších př́ípadných napájecích napětí s menšími proudovými odběry. Příklad takového řešení je uveden na Obr. 3.32. Deska plošného spoje je 10-vrstvá, ve vnitřních vrstvách je realizován rozvod ss napětí $3,3 \mathrm{~V}$ a $5 \mathrm{~V}$ a rozvod země. Pro ss prripojení modulu s napájecími zdroji je použit výkonový konektor.

U složitějších zařízení s velkým proudovým odběrem je nutno pro rozvod napájecího napětí použít měděných pásů popř. pletených měděných ohebných spojek. Pro rozvod v př́strojovém stojanu pro větší vzdálenost než $1 \mathrm{~m}$ jsou optimální rozvodové pásnice obdélníkového profilu (viz Obr. 3.33. Pásnicový rozvod má př́znivé parametry nejen proto, že samotný profil zajišt'uje minimalizaci indukčnosti vodičů, ale umožňuje také těsnou montáž

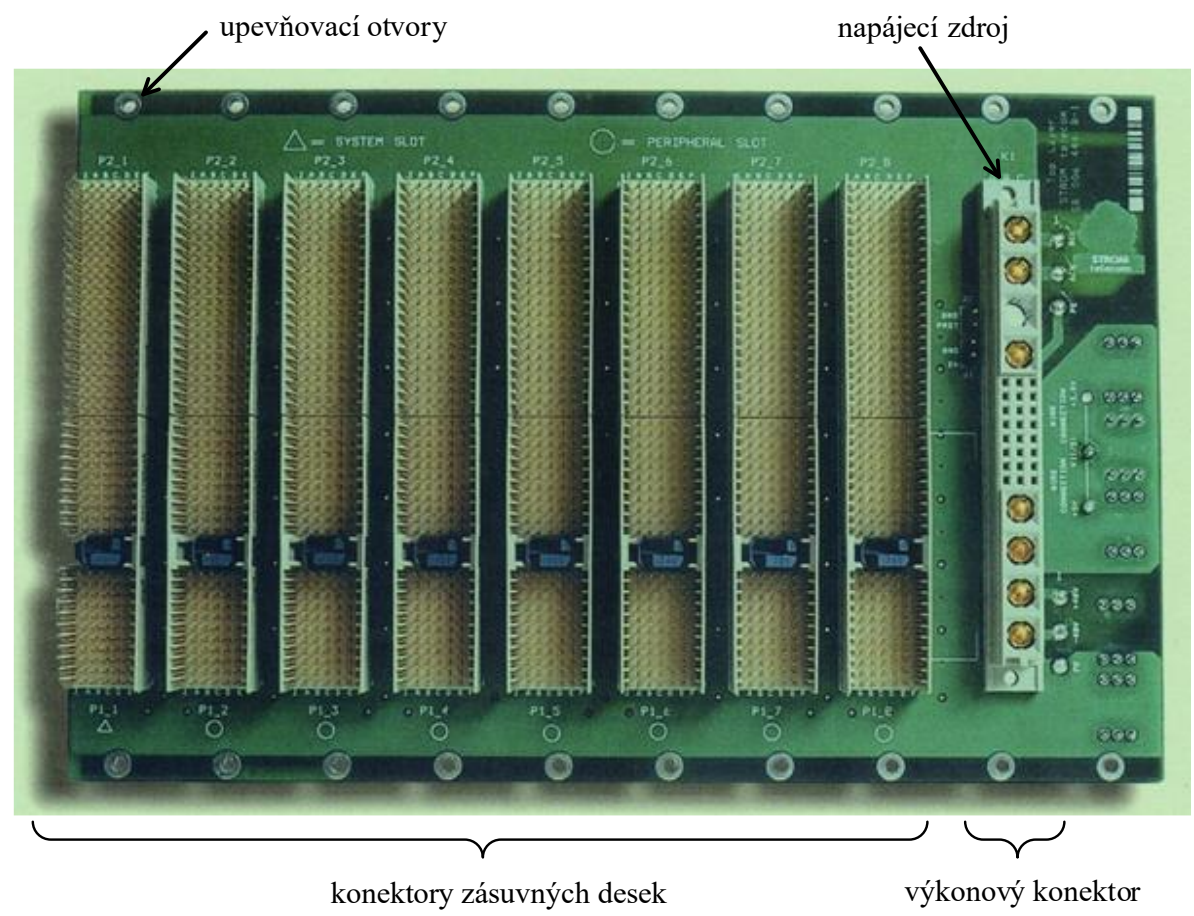

Obr. 3.32: Př́iklad rozvodu napájení pomocí vícevrstvé DPS 
dvojice vodičů, což navíc přispívá k minimalizaci indukčnosti napájecí smyčky rozvodu. Pro homogenní montáž se někdy dvojice pásnic izoluje pouze tenkou izolační vrstvou (tzv. páskové vedení). Takový rozvod má pak velmi malou hodnotu charakteristické impedance a je tedy pro rozvod napájení výhodný. Většinou se však takovému rozvodu snažíme vyhnout a raději dílčí části zařízení napájíme $\mathrm{z}$ menších samostatných napájecích zdrojů a $\mathrm{v}$ prŕístrojovém stojanu rozvádíme sít'ový rozvod $230 \mathrm{~V}$.

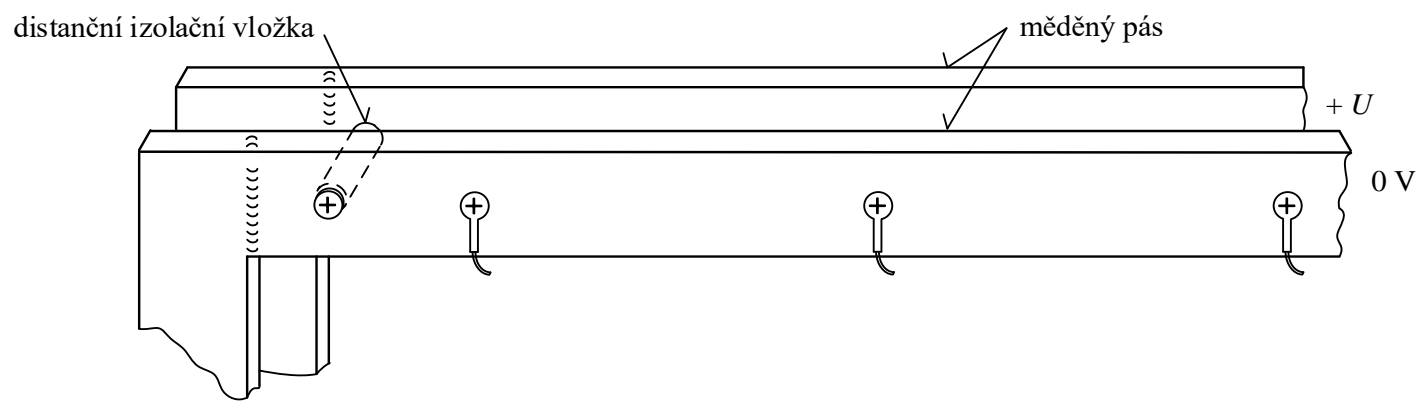

Obr. 3.33: Pásnicový rozvod napájení

Používáme-li pro napájení zařízení impulsně regulovaný zdroj, vyplatí se již v první části rozvodu provést opatření k potlačení pronikání rušivých impulsů do vlastních obvodů. V případě klasického napájecího zdroje to sice tak nutné není, ale ukazuje se, že se opatření vyplatí provést $\mathrm{i} v$ tomto prípadě. Zařazením proudově kompenzované tlumivky $\mathrm{L}_{0}$ účinně potlačíme nesymetrickou složku rušení v napájecím rozvodu (vił Obr. 3.34a).

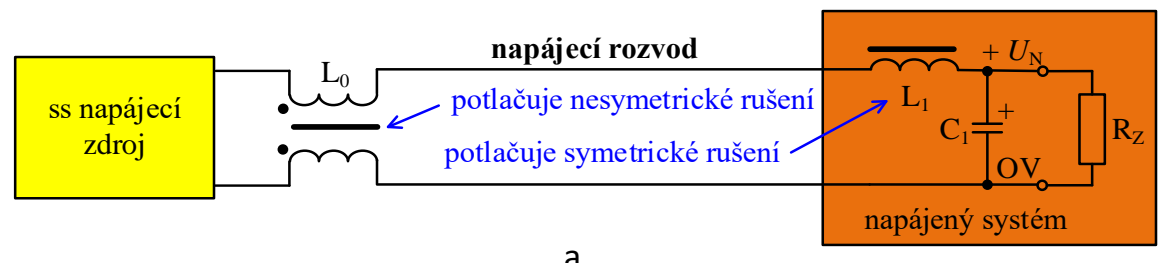

a

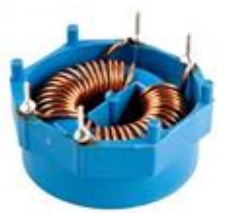

b

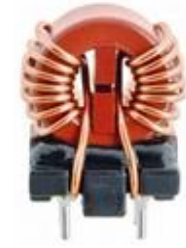

Obr. 3.34: a) Potlačení vf rušení v napájecím rozvodu, b) proudově kompenzovaná tlumivka

Stejně jako u sít'ové odrušovací tlumivky vodič rozvádějící napájecí napětí a zpětný zemní vodič jsou navinuty na společném jádru ve stejném smyslu tak, že pro napájecí proud a pro symetrické rušivé proudy mají jejich magnetické toky opačný směr. Proto se magnetické toky vzájemně vyruší a výsledná indukčnost pro ss napájecí proud a pro symetrické rušení je prakticky nulová. Pro nesymetrické rušivé proudy obou vodičů (tzn. rušivé proudy tekoucí oběma vodiči ve stejném směru) mají magnetické toky souhlasný směr, takže indukčnost tlumivky pro tyto vf rušivé proudy je značná. Proudově kompenzované tlumivky určené pro odrušení napájecího rozvodu jsou stejné koncepce jako odrušovací sítové tlumivky (viz Obr. 3.34 ), ale jsou konstruovány pro větší proudové zatížení a pro provoz s nižším ss jmenovitým napětím (obvykle $50 \mathrm{~V}_{=}$). Někteří výrobci však užití tlumivky nerozlišují a testují všechny na izolační odolnost $1500 \mathrm{~V}$.

Napájecí rozvod může být sám zdrojem vf rušení, které způsobují prudké změny v odběru proudu napájenými systémy. Další rušení se může do napájecího př́vodu naindukovat 
parazitními vazbami mezi signálovými či řídicími vodiči. Toto rušení má charakter symetrické složky rušení, kterou je nutno potlačit na vstupu jednotlivých částí systému (zásuvných desek), tj. na vstupu druhé části rozvodu napájení. K tomu slouží obvykle jednoduchý LC filtr (viz Obr. 3.34 $)$. Konstrukčně může být vf tlumivka $\mathrm{L}_{1}$ provedena jako cívka na otevřeném magnetickém jádru, nebo na toroidním jádru anebo jako vzduchové, tj. s nemagnetickým jádrem. Většinou se užívají vf tlumivky s magnetickým jádrem, protože se dá docílit vyšší indukčnosti při menších rozměrech.

U méně náročných zařízení je LC filtr často nahrazen pouze blokovacím kondenzátorem, který pro vnější rušivé signály slouží jako kapacitní zkrat a současně přispívají k vyrovnání prudkých změn v odběru logických obvodů, ke kterým dochází při jejich př̀klápění.

Odrušení symetrického napájecího rozvodu $\pm U_{\mathrm{N}}$ využívá stejné principy, ale pro potlačení nesymetrického vf rušení je nutno vložit na výstup ze zdroje tzv. „trojfázovou“ proudově kompenzovanou tlumivku se třemi vinutími navinutými ve stejném smyslu na troidním jádře (viz Obr. 3.35. Stejný typ tlumivky se užívá i pro odrušení třífázového sít’ového rozvodu.

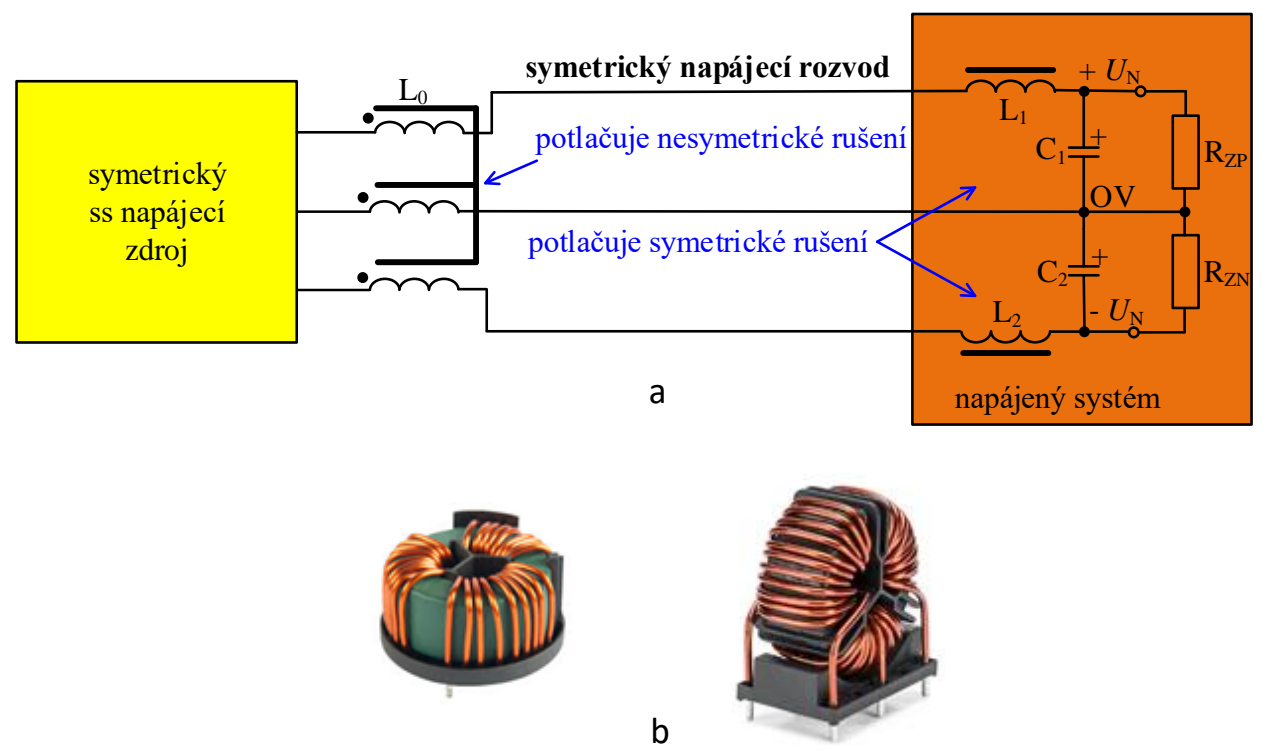

Obr. 3.35: a) Potlačení vf rušení v symetrickém napájecím rozvodu, b) „trojfázová““ proudově kompenzovaná tlumivka

\subsubsection{Rozvod napájení v jednotlivých částech zařízení}

\section{Př́vod napájení do jednotlivých systémových částí zařizení}

Napájecí přívody na vstupu pro napájení dílčí části systému, nebo každé zásuvné desky plošných spojů, se doporučuje zablokovat co nejblíže u vstupního konektoru tantalovým nebo vícevrstvým kondenzátorem o kapacitě $47 \mu \mathrm{F}$ až $100 \mu \mathrm{F}$ a to $\mathrm{v}$ závislosti na proudovém odběru části zařízení. Tento kondenzátor přispívá $\mathrm{k}$ vyrovnání změn $\mathrm{v}$ odběru proudu dílčího systému, ke kterým dochází při překlápění číslicových obvodů a současně slouží jako vf zkrat pro symetrickou složku rušení, která se šírí po napájecích přívodech. Proto je zapotřebí tento kondenzátor v těsné blízkosti přemostit keramickým kapacitorem $100 \mathrm{nF}$ (viz Obr. 3.36ج), nebo v př́ípadě vyšších nároků na odrušení ještě kapacitorem $1 \mathrm{nF}$ (viz Obr. 3.36b). 


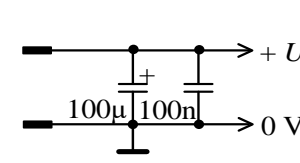

a

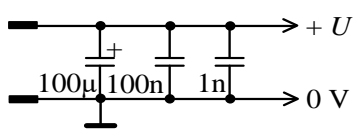

b

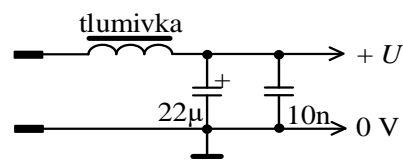

$\mathrm{c}$

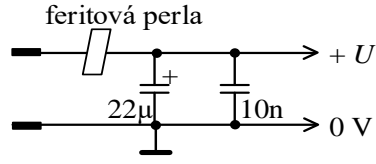

d

Obr. 3.36: Blokování vstupu napájení v jednotlivých částech zařízení: a) b) číslicového systému, c) d) analogového systému

V př́ípadě napájení analogové části nebo zásuvné desky s analogovými obvody jsou obvykle nároky na odfiltrování vf rušení větší. V tom případě se co nejblíže ke vstupnímu konektoru použije LC filtr (viz Obr. 3.36c, d). Protože analogová část vykazuje obvykle méně výrazné změny v odběru napájecích proudů, dostačuje tantalový nebo vícevrstvý kondenzátor $10 \mu \mathrm{F}$ až $47 \mu \mathrm{F}$ přemostěný keramickým kondenzátorem $10 \mathrm{nF}$. Indukčnost tlumivky či feritové perly není uvedena, protože se u těchto prvků většinou ani neuvádí. Při návrhu se proto orientujeme hodnotou modulu impedance tlumivky, kterou výrobce obvykle udává při kmitočtu $100 \mathrm{MHz}$ v závislosti na protékajícím proudu. Většinou se k tomuto účelu používají odrušovací tlumivky určené pro napájecí rozvody a zdroje (Inductors for Power Line), které jsou konstruovány tak, aby vykazovaly malou závislost na ss proudu tekoucího do zátěže, nebo se uživají feritové perly určené pro větší proudové zatížení (Ferrite Beads for Power Line).

Pro blokování napájení se nejčastěji použivají vícevrstvé kondenzátory MLCC (Multilayer Ceramic Capacitors). Elektrolytické kondenzátory jsou totiž většinou rozměrné, tantalové kondenzátory SMD zase často trpí vysycháním dielektrika.

Vnitřní struktura vícevrstvého kondenzátoru je zřejmá z Obr. 3.37. Elektrody dílčích kondenzátorů na vnitřních dielektrických vrstvách střídavě vyčnívají smšrem k vývodům kondenzátoru. Tyto vývody představují parazitní indukčnost, která zhoršuje vlastnosti kondenzátoru a proto se musí mimo vlastní kapacity $\mathrm{C}$ uvažovat i ekvivalentní sériová indukčnost $\mathrm{L}_{\text {par. }}$. Aby se parazitní indukčnost nezvětšila o parazitní indukčnost zemního př́vodu, doporučuje se v př́ípadě užití vícevrstvé DPS uzemněný vývod připojit co nejkratším spojem k vnitřní zemnící vrstvě. Prokovené otvory mají mít průměr 0,3 až $0,4 \mathrm{~mm}$. Větší prokovený otvor totiž vykazuje větší parazitní indukčnost, která zhoršuje vlastnosti kondenzátoru na vysokých kmitočtech.

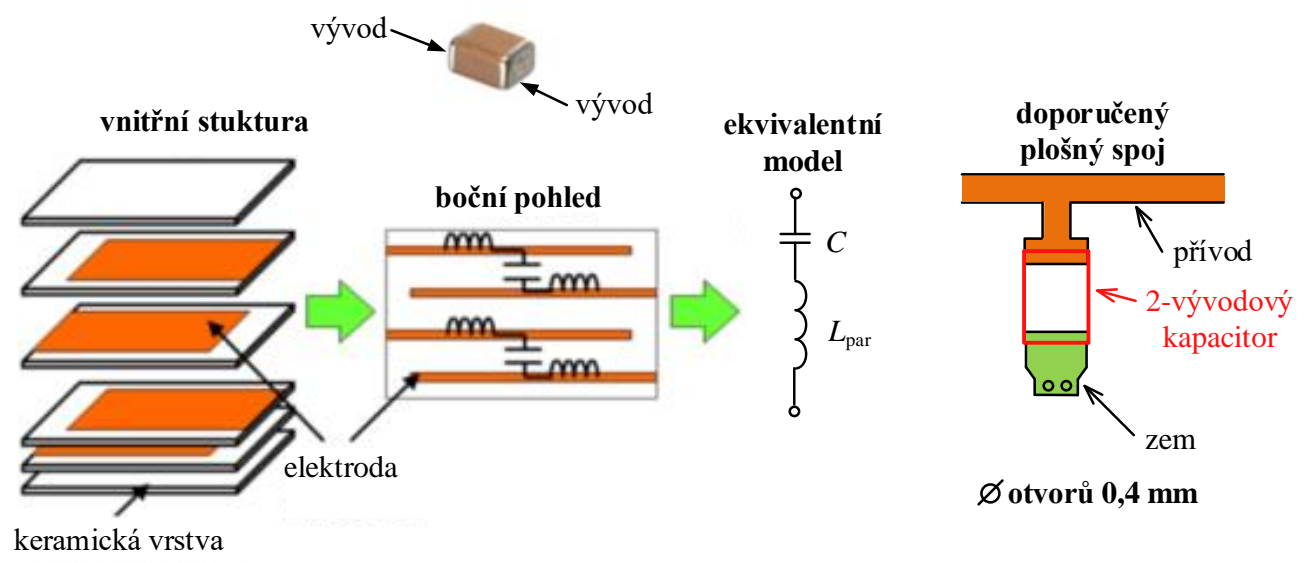

Obr. 3.37: Vícevrstvý MLCC kondenzátor a doporučený plošný spoj

Lepší vlastnosti na vysokých kmitočtech vykazují tzv. tř́vývodové či průchozí blokovací kondenzátory. U těchto kondenzátorů je změněna vnitřní struktura elektrod tak, aby se snížila parazitní indukčnost ovlivňující vlastnosti kondenzátoru na vysokých kmitočtech 
(viz Obr. 3.38. Průchozí a zemní elektrody jsou navzájem proloženy tak, aby vytvořily vícevrstvý kondenzátor. Zemnicí svorka je pak vyvedena na obou bocích součástky.

Jak je vidět z ekvivalentního modelu, indukčnost průchozích elektrod představuje podélné induktory stejně jako je tomu u filtru LC typu T a proto vf vlastnosti LC filtr vylepšují. Zbytková indukčnost zemních prŕvodů $\mathrm{L}_{\text {par }}$ je malá a navíc, protože zemní vrstvy jsou na zem připojeny na obou bočních stranách součástky, jsou zbytkové indukčnosti ve výsledku spojeny paralelně a jejich indukčnost se proto sníží na polovinu. Aby se tyto zbytkové indukčnosti nezvětšily o parazitní indukčnost plošného spoje, je nutné v př́́padě vícevrstvé DPS zemní přívody připojit co nejkratším způsobem do vnitřní zemnicí vrstvy. Doporučuje se použít větší počet prokovených spojů $\emptyset 0,2$ až $\emptyset 0,3 \mathrm{~mm}$ tak, aby parazitní indukčnosti prokovených otvorů byly co nejmenší.

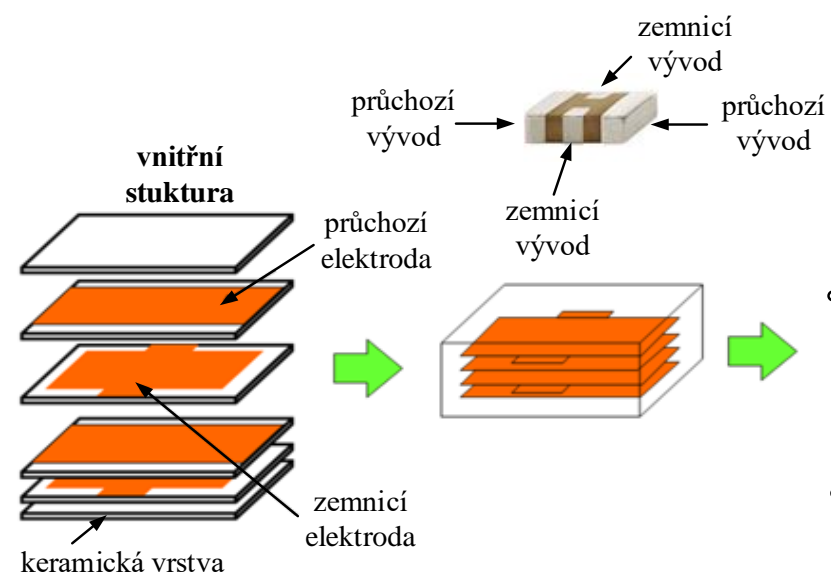

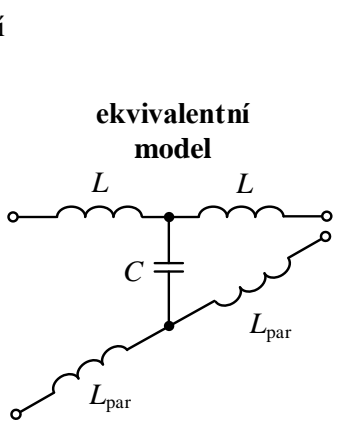

Obr. 3.38: 3-vývodový kondenzátor a doporučený plošný spoj

$\mathrm{Na}$ Obr. 3.39 je uvedeno srovnání několika typů 2-vývodových kondenzátorů se 3vývodovými kondenzátorem. Blokovací vlastnosti se hodnotí pomocí tzv. vložného útlumu (viz Obr. 3.39p)

$$
a=20 \log \left|\frac{U_{20}}{U_{2}}\right|(\mathrm{dB}),
$$

kde $U_{2}$ značí napětí na výstupu filtru (na zátěži $\mathrm{R}_{\mathrm{Z}}$ ) a $U_{20}$ je stejné napětí bez přítomnosti filtru, tedy bez zapojeného kondenzátoru. Aby se daly blokovací schopnosti jednotlivých obvodů či prvků porovnávat, je obvykle odpor budicího generátoru a odpor zátěže shodně $50 \Omega$.

Protože kapacita testovaných kondenzátorů na Obr. 3.39 a byla stejná $10 \mu \mathrm{F} / 6,3 \mathrm{~V}$, mají všechny kondenzátory na nízkých kmitočtech shodné vlastnosti. Účinnost tantalového a polymerového kondenzátoru začíná klesat již po překročení kmitočtu $1 \mathrm{MHz}$ a v př́ípadě 2vývodového vícevrstvého keramického kondenzátoru účinnost klesá po překročení $10 \mathrm{MHz}$. Přitom 3-vývodový kondenzátor je účinný až do $100 \mathrm{MHz}$. Proto jsou 3-vývodové kondenzátory pro potlačení vf rušení velmi účinné. 


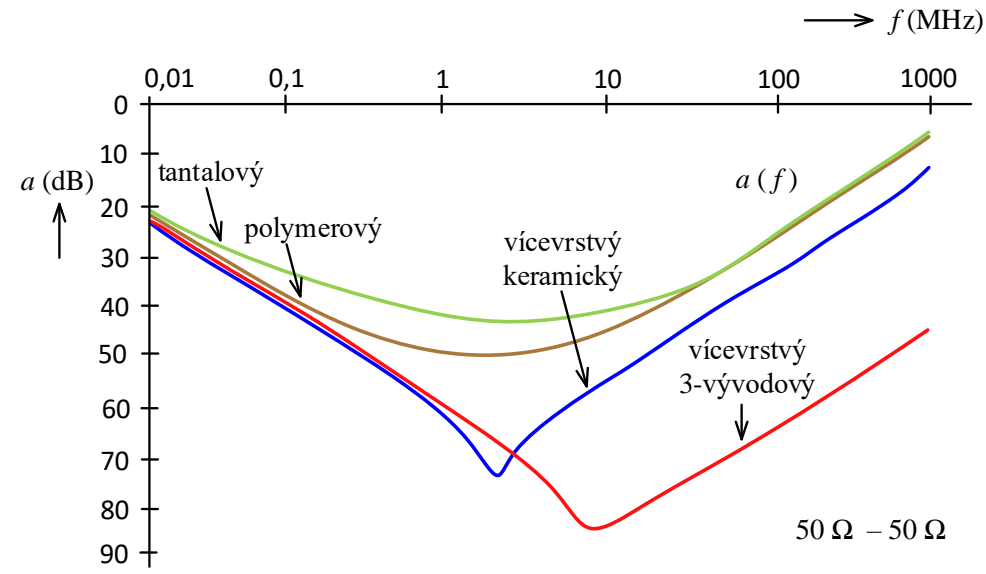

a

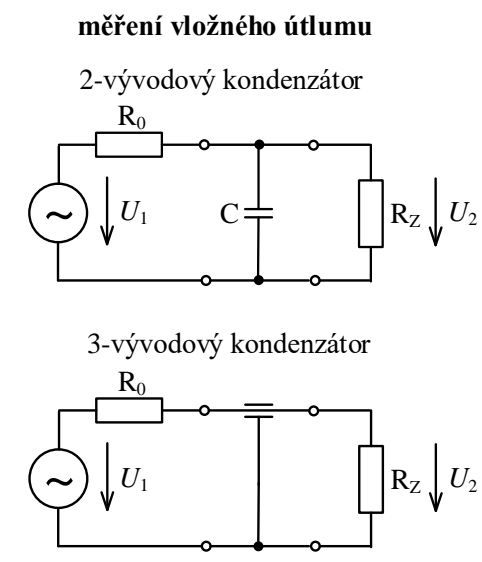

b

Obr. 3.39: a) Srovnání vlastností 2-vývodového a 3-vývodového kondenzátoru $10 \mu \mathrm{F} / 6,3 \mathrm{~V}$,

b) měření vložného útlumu

Tř́vývodové kondenzátory pro blokování napájecích př́ivodů jsou $\mathrm{k}$ dispozici od $1 \mu \mathrm{F}$ až do $10 \mu \mathrm{F}$ a to pro proudy od 0,5 až do 5 A. Používají se pro zablokování napájení bud' na vstupu zásuvné desky plošného spoje, nebo v blízkosti integrovaných obvodů s velkým proudovým odběrem, jako jsou např. centrální procesorové jednotky CPU (Central Processing Unit).

Další možností, jak potlačit vf rušení, je do napájecího přívodu vložit prrídavný odrušovací filtr LC filtr typu - T realizovaný pomocí 3-vývodového vícevrstvého kondenzátoru a tlumivek nebo feritových perel v podélné větvi. Filtr se dodává bud' sestavený z dílčích prvků, nebo jako jedna kompaktní součástky. Př́klad kompaktního odrušovacího filtru určeného do napájecích př́vodů je uveden na Obr. 3.40. Odrušovací filtry jsou obvykle k dispozici pro proudy od 0,5 do $5 \mathrm{~A}$, kapacita 3-vývodového kondenzátoru bývá v rozmezí $100 \mathrm{pF}$ až 4,7 nF. Indukčnost tlumivek resp. feritových perel se obvykle neuvádí. Vlastnosti filtru jsou definovány vložným útlumem. Filtry se často uvádějí pod obchodním označením EMIFIL (Electromagnetic Interference Filters) typu - T. Filtr se zařazuje jako př́davný filtr za blokovací kondenzátor na vstupu zásuvné DPS, nebo v blízkosti kritických obvodů s velkým proudovým odběrem, např. v blízkosti CPU.
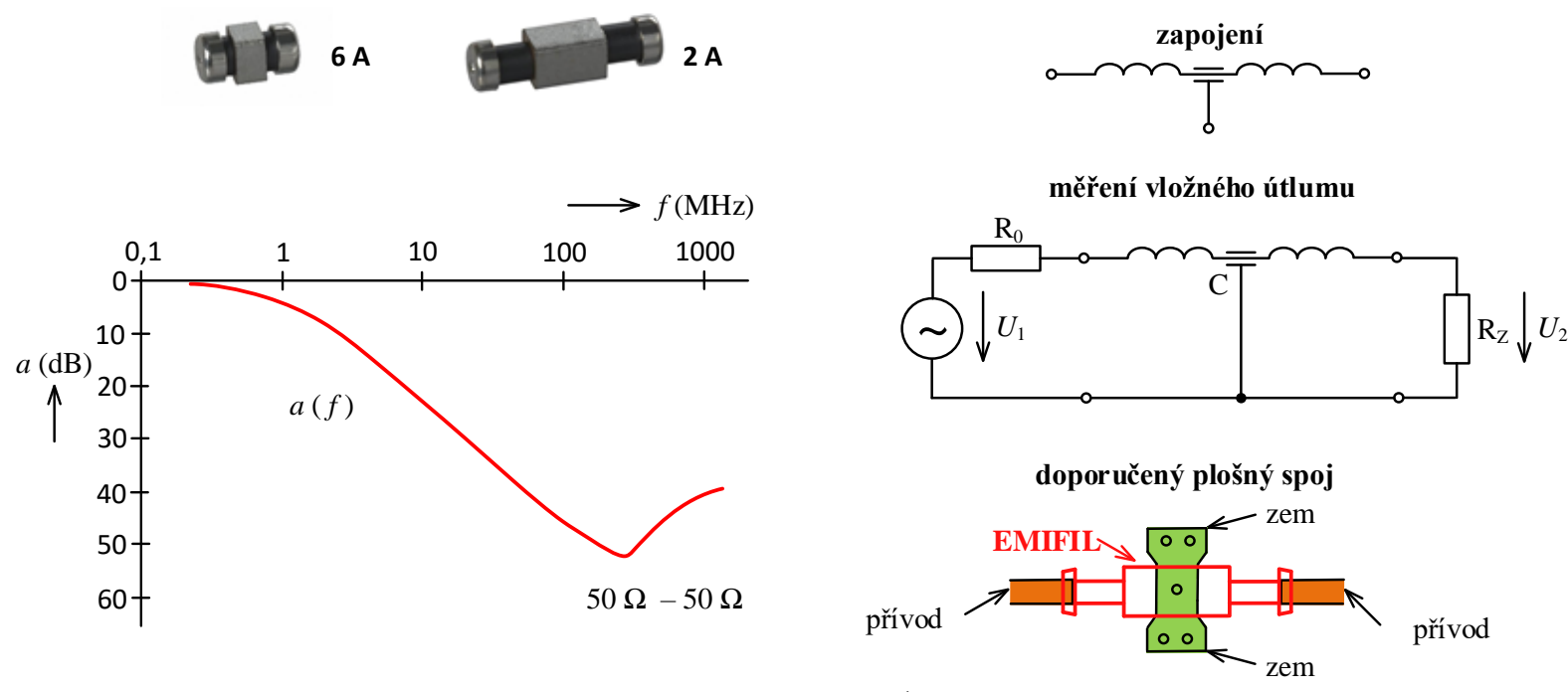

Øotvorů 0,4 mm

Obr. 3.40: Odrušovací filtr typu T do napájecích rozvodů 


\section{Rozvod napájení k jednotlivým součástkám}

Další opatření prováděná ve druhé části napájecího rozvodu jsou obvykle složitější. Vycházejí z hlediska potlačení možných rušivých vlivů, které se, v souvislosti s činností klopných obvodů, nebo změnou zátěže analogových obvodů, mohou projevovat na obou vodičích rozvodu, tj. na rozvodu napájecího napětí a na společném zemním vodiči. Konkrétní opatření se pak liší podle různých typů číslicových obvodů, podle proudových odběrů analogových obvodů či podle jejich náchylnosti k rozkmitání přes parazitní indukčnosti napájecích př́vodů aj.

Na rozvodu napájecího napětí může rušení vznikat působením proudových špiček, které způsobují samotné napájené obvody. Jeden druh těchto špiček vzniká při překlápění logických popř. klopných obvodů. Velikost proudových špiček se úměrně zvětšuje s počtem logických anebo klopných obvodi̊, které pracují synchronně. Nemá-li následkem takto vzniklých proudových změn dojít k rušivým úbytkům napětí na napájecím rozvodu a tím k poklesu napájecího napětí, je třeba v těsné blízkosti logických obvodů připojit do napájení kapacitory, které představují zkrat pro vysoké kmitočty. Doporučená kapacita blokovacího kapacitoru je 1 až $10 \mathrm{nF}$ na jeden klopný obvod. Při návrhu desek plošných spojů pro klasické pomalejší logické obvody se doporučuje, aby napájecí napětí bylo blokováno bezindukčními kondenzátory s kapacitou 47 až $100 \mathrm{nF}$ (keramika) na každých 5 až 10 pouzder integrovaných obvodů (Obr. 3.41 a). V př́padě rychlých logických obvodů a pamětí se pak blokuje každý integrovaný obvod keramickým kondenzátorem 47 až $100 \mathrm{nF}$.

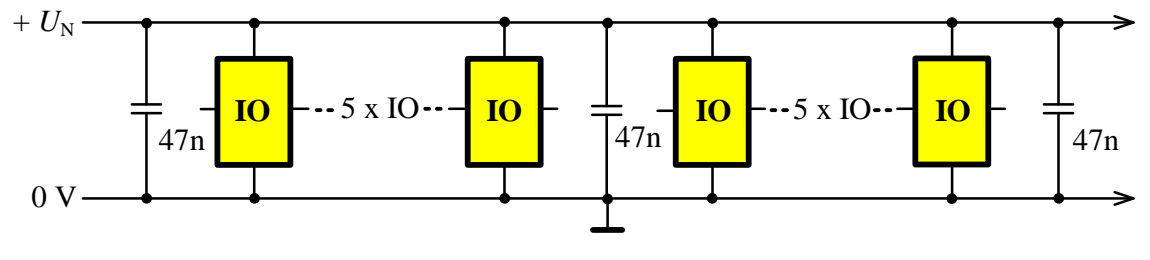

a

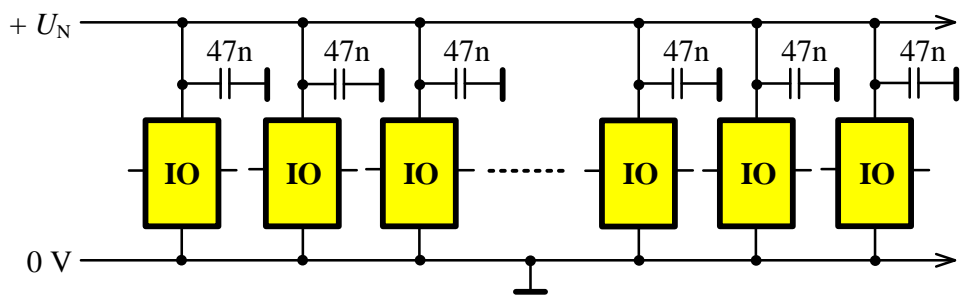

b

Obr. 3.41: Blokování logických integrovaných obvodů: a) pomalé logické obvody, b) rychlé logické obvody a paměti

Blokování číslicových systémů s velkou hustotou integrace se řídíme doporučením výrobců. Většinou je napájecí napětí nutno přivést na větší počet vývodů ze součástky Obr. 3.42. Důležité je samostatné blokování každého páru napájecích přívodů, tj. napájecího př́ivodu a príslušného př́vodu země. Pokud integrovaný obvod obsahuje i analogové obvody nebo $\mathrm{D} / \mathrm{A}$ a $\mathrm{A} / \mathrm{D}$ převodníky je zapotřebí analogové části napájení důsledně oddělit od rušení z číslicového napájecího rozvodu LC filtrem umístěným v blízkosti integrovaného obvodu, nebo tento napájecí vstup napájet ze samostatného spojitě regulovaného zdroje. 


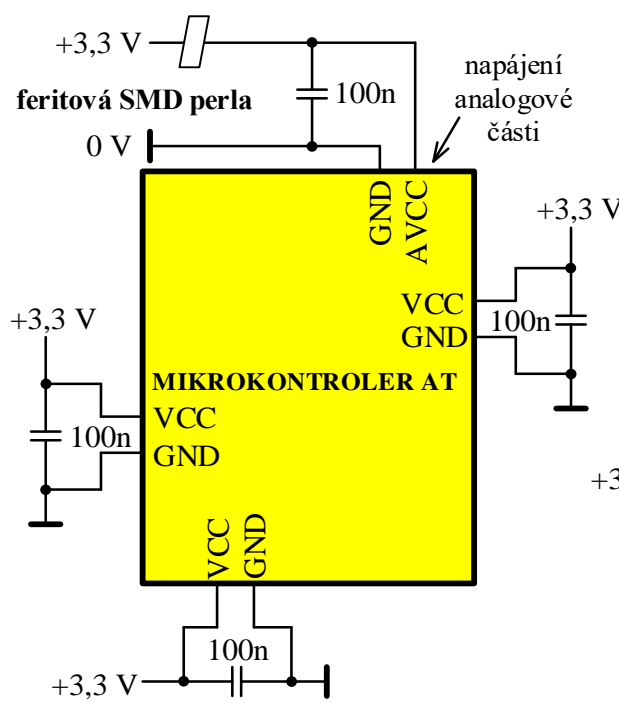

a

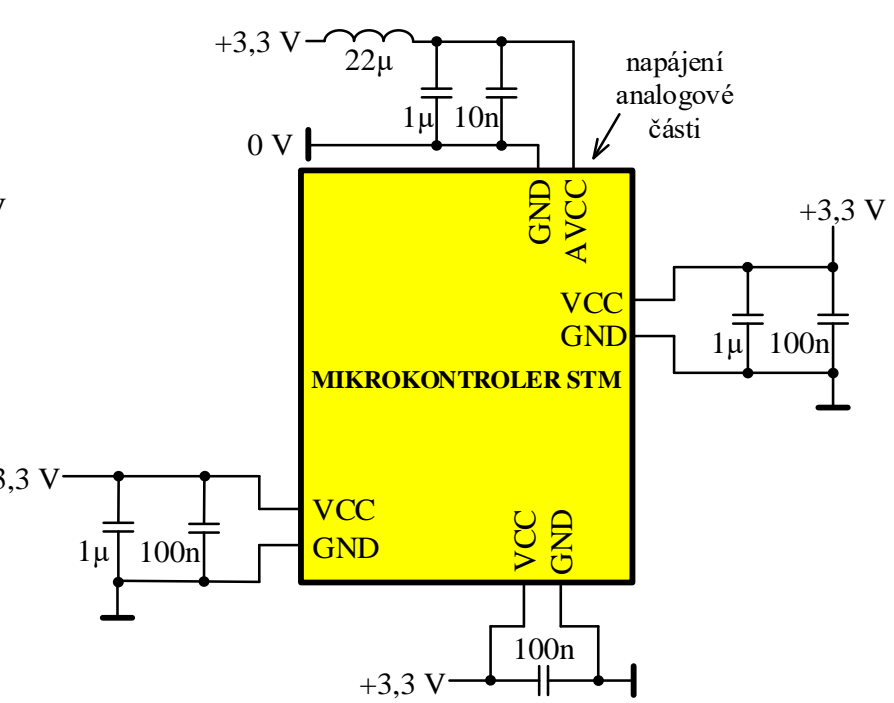

b

Obr. 3.42: Příklad blokování napájení složitějších číslicových integrovaných systémů

U analogových obvodů s operačními zesilovači se doporučuje blokovat napájení co nejblíže vývodům z každého operačního zesilovače keramickými kapacitory s kapacitou $47 \mathrm{nF}$ až $220 \mathrm{nF}$ (viz Obr. 3.43 ). Př́liš malá kapacita $10 \mathrm{nF}$ by mohla vyvolat rezonanci $\mathrm{s}$ indukčnostmi př́vodů v kritické oblasti 1 až $10 \mathrm{MHz}$ a způsobit rozkmitání zesilovače přes napájecí obvody. V př́padě operačních zesilovačů napájených se zdroje jedné polarity Obr. 3.43b) výrobci doporučují zablokovat napájecí přívod kondenzátorem $1 \mu \mathrm{F}$ přemostěný vf kondenzátorem $100 \mathrm{nF}$. Keramický kondenzátor $100 \mathrm{nF}$ zlepšuje blokování napájení pro vf rušení. Umist'uje se co nejblíže k pouzdru OZ.

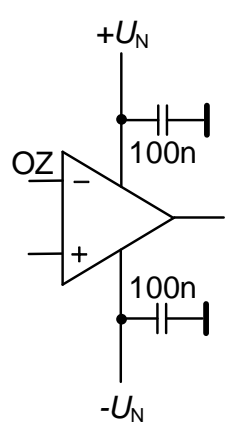

a

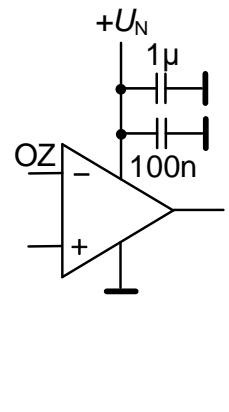

b

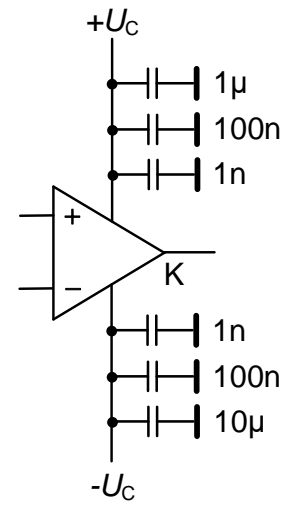

C

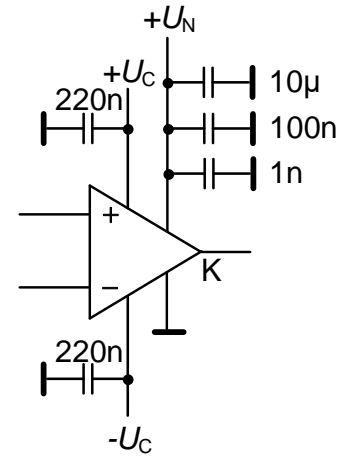

d

Obr. 3.43: Blokování napájení: a) operačních zesilovačů, b) komparátorů

Komparátory se vyznačují prudkými změnami $\mathrm{v}$ odběru proudu z napájení při překlápění svého výstupu. To může vyvolat krátkodobý pokles napájecího napětí vlivem úbytku na př́ivodních vodičích a ovlivnit tak napájení sousedních obvodů. Proto je nutné kvalitní zablokování napájecích př́vodů komparátorů. Zablokování každého napájecího př́vodu se realizuje třemi paralelně řazenými kondenzátory $10 \mu \mathrm{F}, 100 \mathrm{nF}$ a $1 \mathrm{nF}$ Obr. 3.43 ). Keramický kondenzátor $1 \mathrm{nF}$ se umíst'uje co nejblíže k pouzdru komparátoru. Tantalový nebo vícevrstvý kondenzátor $10 \mu \mathrm{F}$ je pak od pouzdra nejdál. Všechny blokovací kondenzátory musí být vždy blízko pouzdra komparátoru. V př́ípadě, že komparátor má oddělené napájení vstupní 
analogové části, blokuje se vstupní část podobně jako je tomu u operačních zesilovačủ Obr. 3.43 d).

Analogové obvody, které se vyznačují velkými proudovými odběry, je nutno pro okamžitou dodávku napájecích proudů vybavit kondenzátory s větší kapacitou. Např. proudový posilovač $\pm 250 \mathrm{~mA}$ se blokuje kondenzátorem $10 \mu \mathrm{F}$ přemostěným kondenzátorem $100 \mathrm{nF}$ Obr. 3.44 ). U výkonových audiozesilovačů se obvykle napájení blokuje elektrolytickými kondenzátory, které jsou pro zlepšení vlastností na vysokých kmitočtech přemostěny keramickými kondenzátory $100 \mathrm{nF}$ Obr. 3.44).

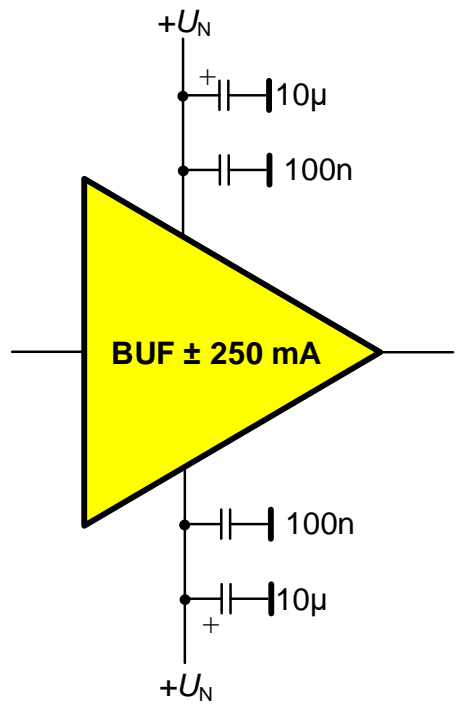

a

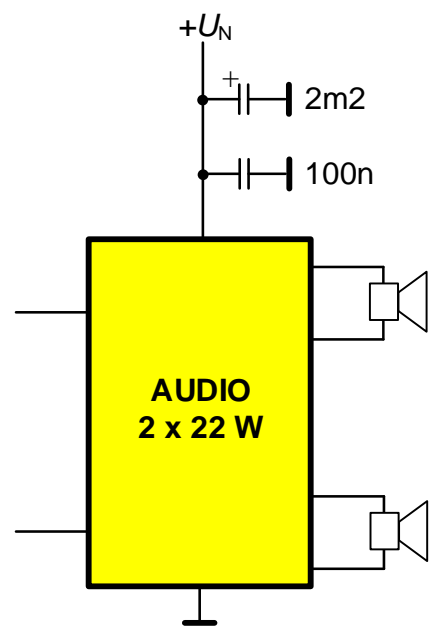

b

Obr. 3.44: Blokování napájecích př́ivodů: a) proudového posilovače, b) výkonového audiozesilovače

\subsection{Rozvod společného zemního vodiče}

Konstrukce rozvodu společného zemního vodiče je v mnoha případech podceňována, ale špatně navržený rozvod zemí může být při uvádění zařízení do chodu zdrojem mnoha nečekaných a často špatně odstranitelných závad. Pro všechny dnešní analogové a digitální obvody je nutné zajistit nízkou impedanci zemního vodiče, tzn. měl by mít co nejmenší odpor a zanedbatelnou indukčnost. Zemní vodič funguje nejen jako nízkoimpedanční zpáteční cesta pro blokování vf proudů způsobených překlápěním digitálních obvodů nebo rychlých komparátorů, ale v př́padě užití zemnicí vrstvy ve vícevrstvé DPS také minimalizuje vnější elektrické rušení (EMI) popř. v radiovém frekvenčním spektru pak radiové rušení (RFI).

Digitální obvody či komparátory se vyznačují tím, že při překlopení obvodu dojde $\mathrm{k}$ prudké změně v odběru proudu v napájecím rozvodu a tedy i v zemním vodiči. Na zemním vodiči může vznikat impulsní rušení ještě z dalších příčin. Při přechodu digitálního obvodu ze stavu H do L se přes zemní vodič vybíjí i parazitní kapacitor, jehož kapacita je dána součtem kapacity spojů a vstupní kapacity členu, který je z toho obvodu buzen. Vybitím tohoto kapacitoru se proud společným zemním vodičem zvětší po dobu asi 10 ns na trojnásobek až čtyřnásobek klidové hodnoty. Přírůstek proudu způsobený vybíjením kapacitoru může být např. až $20 \mathrm{~mA}$ u jednoho logického členu. S počtem synchronně pracujících obvodů se tento proud 
samozřejmě zvětšuje a může pak snadno způsobit nepřijatelný úbytek napětí na společném vodiči.

Použití „drátového“ rozvodu země je proto v dnešní době prakticky nepřijatelné. Např̀. vodič o průměru $5 \mathrm{~mm}$ a délce $25 \mathrm{~mm}$ má přibližně indukčnost $L=10 \mathrm{nH}$. Skoková změna proudu $20 \mathrm{~mA} / \mathrm{ns}$, vyvolaná překlápěním logických obvodů způsobí na tomto zemním vodiči změnu napětí $\Delta u=L(\Delta \mathrm{i} / \Delta \mathrm{t})=10 \mathrm{nH} \cdot(20 \mathrm{~mA} / \mathrm{ns})=200 \mathrm{mV}$. Pro signál s rozkmitem $2 \mathrm{~V}_{\mathrm{pp}}$ to znamená chybu $10 \%$. Pokud se dostane takovýto impuls následně do analogové signálové cesty, dojde ke zhoršení odstupu signálu od šumu. Ve všech digitálních obvodech, které mají některý ze vstupů připojen na tento zemní vodič, pak zcela jistě dojde ke zhoršení jejich šumové imunity. Požadavky na malou impedanci jsou tedy u společného zemního vodiče ještě př́snější než u vedení napájecího napětí.

Kritický je pak rozvod zemního vodiče v zařízení, které obsahuje jak analogové, tak i digitální obvody. Klasickou situaci, kdy zpětný zemní proud digitálních obvodů ovlivňuje zpětný zemní proud analogových obvodů ukazuje Obr. 3.45 části vyvolá ve společné části zemního vodiče chybové (většinou impulsní) napětí, které pak snadno pronikne do analogové části. Aby chybové napětí bylo co nejnižší, je zapotřebí velmi striktně dodržet impedanci zemního rozvodu ve všech jeho částech na co nejnižší úrovni. Toto uspořádání zemí odpovídá konceptu tzv. „vícebodového“ zemnicího systému.
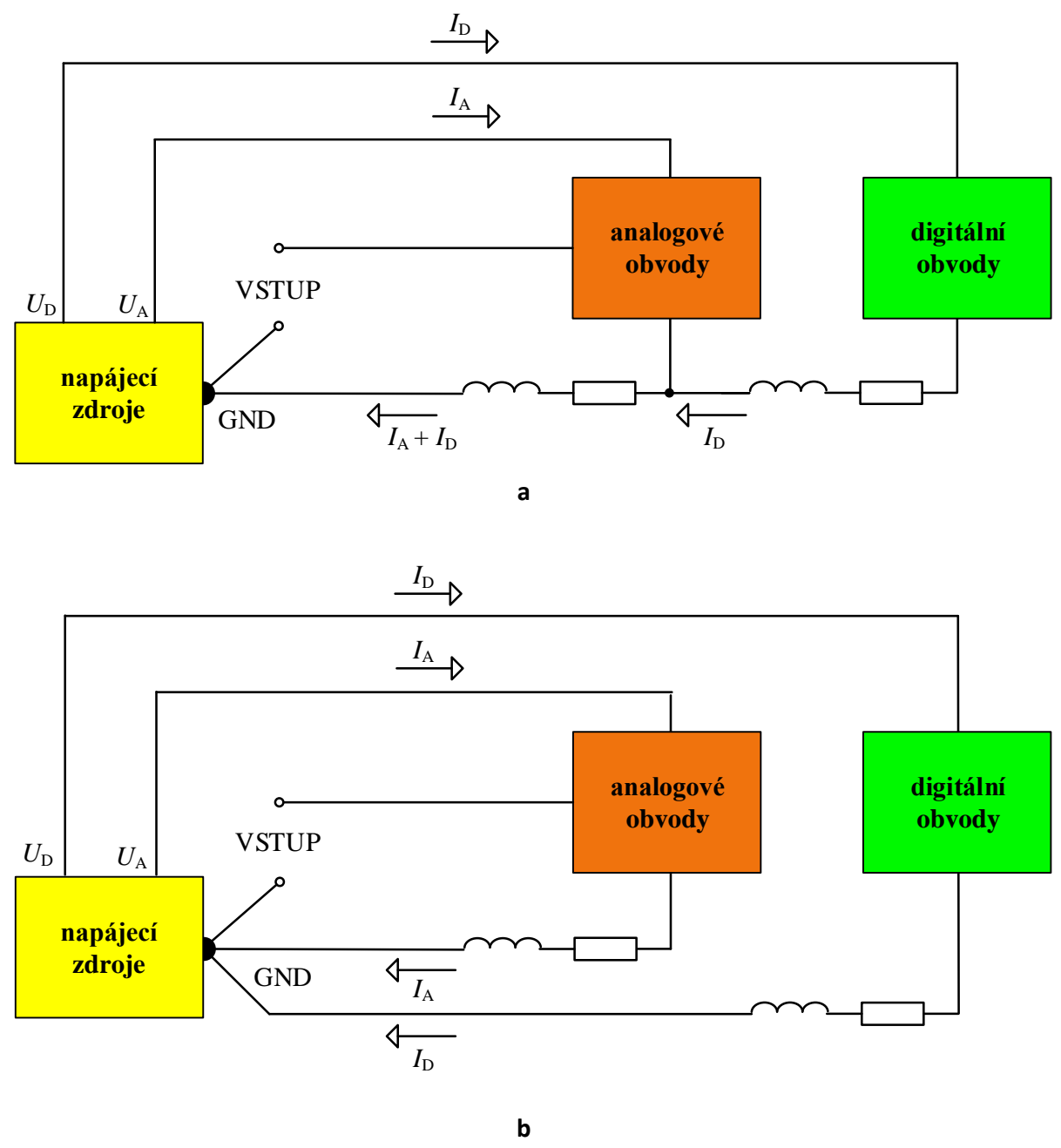

Obr. 3.45: a) Společná část analogového a digitálního rozvodu vyvolá chybové napětí, b) oddělené analogové a digitální zemní rozvody 
Možným řešením je, úplné oddělení analogového zemního vodiče od digitální části (viz Obr. 3.45b) a spojení obou zemí v jednom centrálním bodě. To je základní koncept tzv. „jednobodového“ popř. „hvězdicového“ zemnicího systému. Implementace jednobodového systému s větším počtem zpětných zemních vodičů má však také svá úskalí, protože fyzická délka každého takového zpětného zemního vodiče představuje parazitní odpor a indukčnost a těžko se dá u každého zemního vodiče dodržet požadavek na nízkou impedanci.

\subsubsection{Vícebodový uzemňovací systém}

Nejlepší způsob, jak minimalizovat impedanci zemního rozvodu v zařízení se zásuvnými kartami, je použít pro zapojení mezi kartami vícevrstvou propojovací desku (tzv. blackplane) a v této propojovací DPS vyhradit jednu vrstvu pro rozvod země k jednotlivým kartám (viz Obr. 3.46. Aby se dodržela nízká impedance zemního rozvodu v celém zařízení, jsou zásuvné karty realizovány taktéž na vícevrstvých DPS, kdy jedna vrstva je zde opět vyhrazena zemnímu rozvodu. Propojení zemnicí vrstvy zásuvné karty a propojovací DPS (blackplane) musí být velmi masivní tak, aby se eliminoval přechodový odpor a parazitní indukčnost kolíků konektoru. Konektor zásuvné karty by měl mít alespoň 30 až $40 \%$ kolíků vyhrazen pro propojení země na propojovací DPS. Příklad rozvodu napájecích napětí a zemního vodiče na konektory propojovací DPS je uveden na Obr. 3.47.

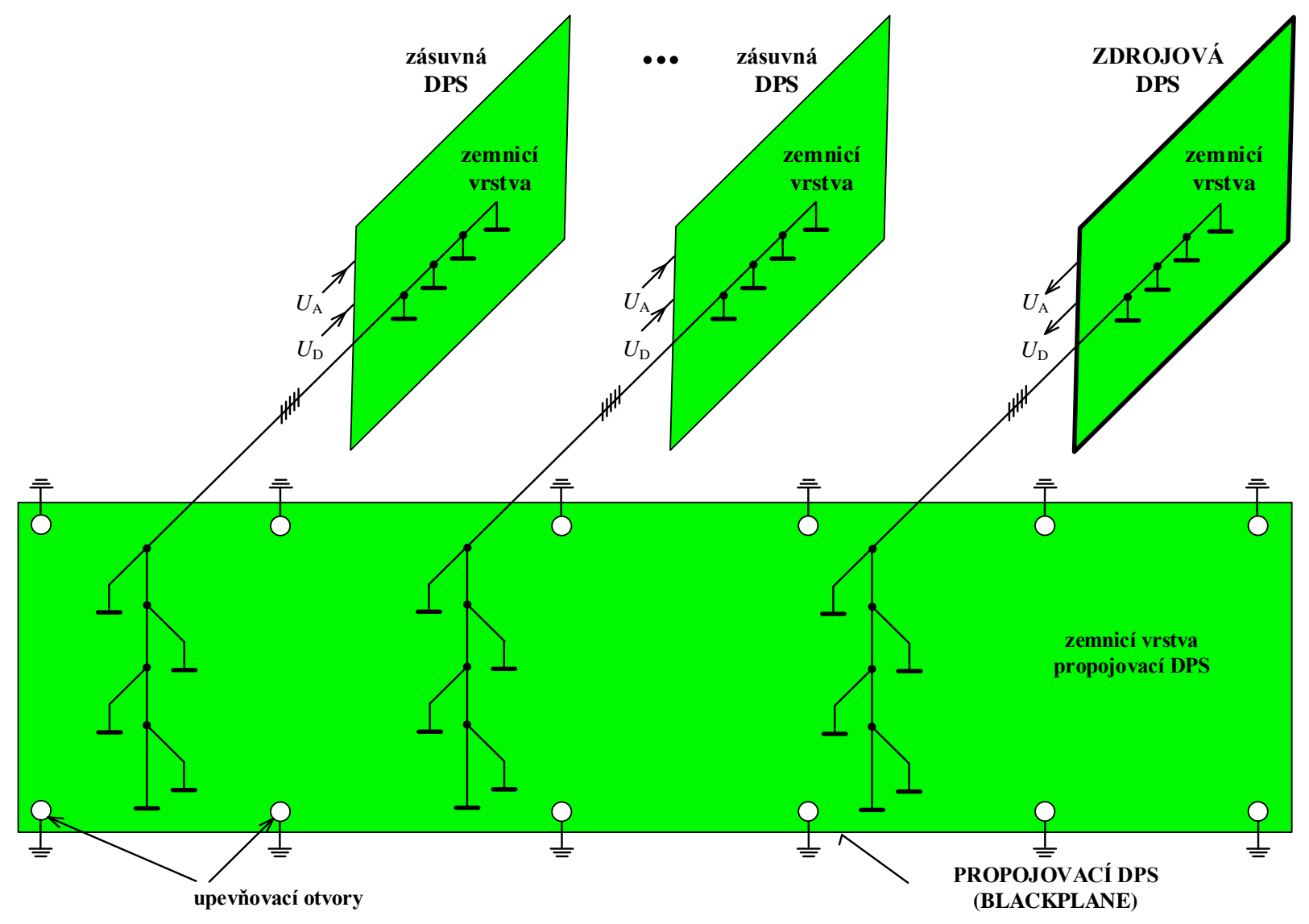

Obr. 3.46: Zařízení se zásuvnými kartami s „vícebodovým“ systémem uzemnění 


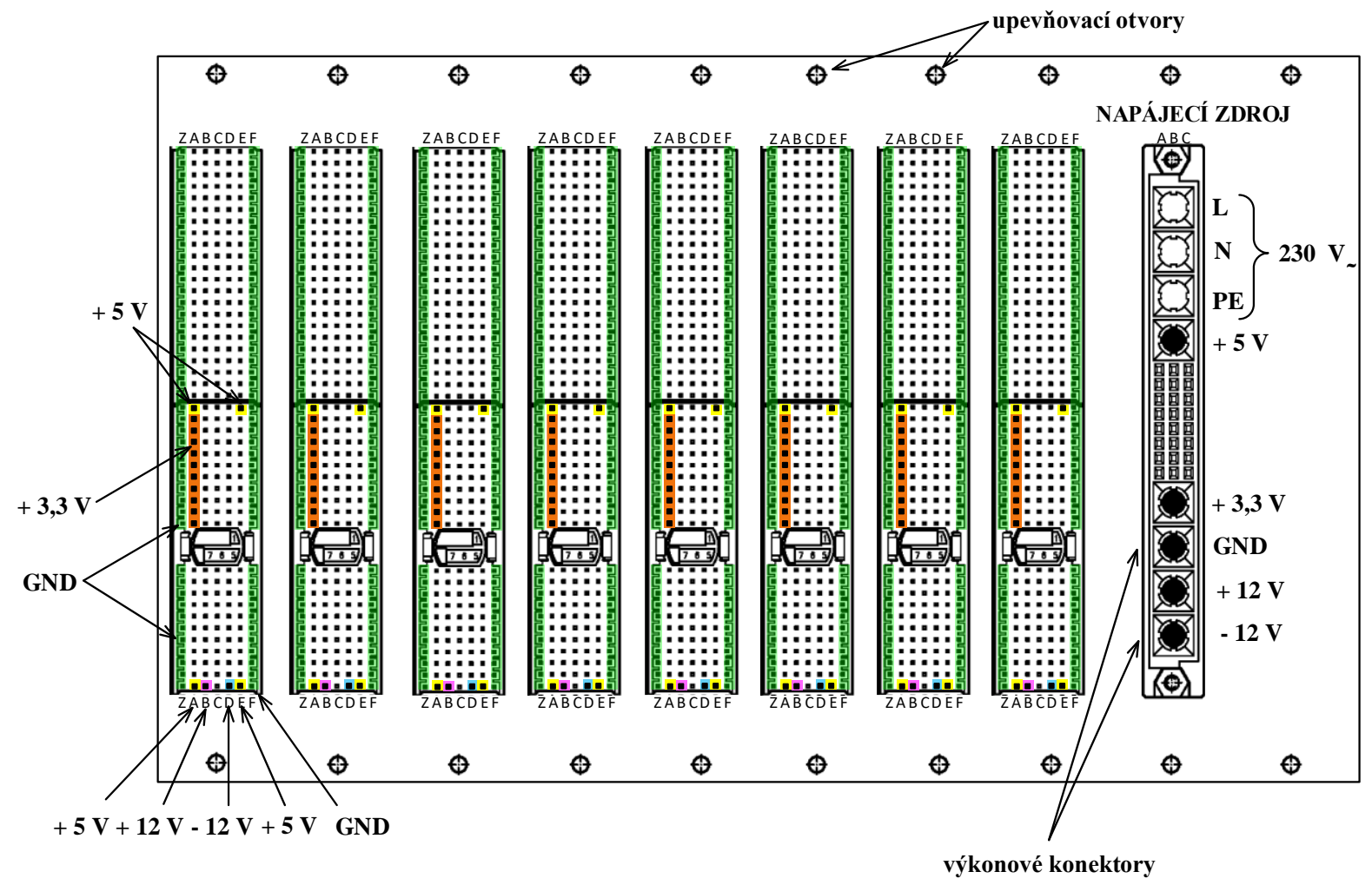

Obr. 3.47: Příklad rozvodu napájecích napětí a zemního vodiče na propojovací desce

Nízká impedance zemního rozvodu musí být dodržena jak na zásuvných kartách, propojovacích konektorech, na propojovací DPS, tak i u připojení na ochranný vodič (PE), tzn. na zemní vodič rozvodné sítě. Protože ochranný vodič je z bezpečnostních důvodů připojen na kovovou konstrukci (kostru) zařízení, je nutno zajistit nízkoimpedanční kontakt zemní vrstvy s kovovou konstrukcí zařízení. Proto se propojovací DPS připevňuje ke kovové konstrukci větším počtem samořezných šroubů za použití tzv. vějířových podložek. Zvláštní pozornost je $\mathrm{v}$ této souvislosti nutno věnovat zoxidovanému nebo eloxovanému hliníku použitému na kovovou konstrukci, protože takovýto povrch má izolační vlastnosti.

Koncepce vícebodového uzemňovacího systému se nejčastěji využívá u digitálních zařízení. Může být použita i ve smíšených systémech, kde jsou jak analogové, tak i digitální obvody, ale jen za předpokladu, že zemní proudy způsobené digitálními obvody jsou dostatečně malé a jsou rovnoměrně rozloženy po celé zemnicí ploše.

\subsubsection{Jednobodový uzemňovací systém}

Striktní rozdělení zemí na analogovou a digitální zem zabrání vzniku rušivých signálů, které by jinak vznikaly na společné části zemního rozvodu. Obě země se pak v jednom bodě spojí s ochranným vodičem (PE), viz Obr. 3.48.

Důležité je v tomto př́ípadě pro každý typ zařízení vybrat ten nejvhodnější bod, kde se všechny země propojí. Pokud budeme např. konstruovat digitální voltmetr, spojíme všechny země u vstupní zemní svorky zařízení, čímž se vyvarujeme vlivu rušivých zemních úbytků, které by se jinak přidaly $\mathrm{k}$ měřenému signálu. Přri konstrukci číslicově řízeného generátoru tvarových kmitů zase nechceme, aby rušivé zemní úbytky byly přidány ke generovanému signálu. Proto jako centrální zemnicí bod zvolíme výstupní zemnicí svorku generátoru. Tam 


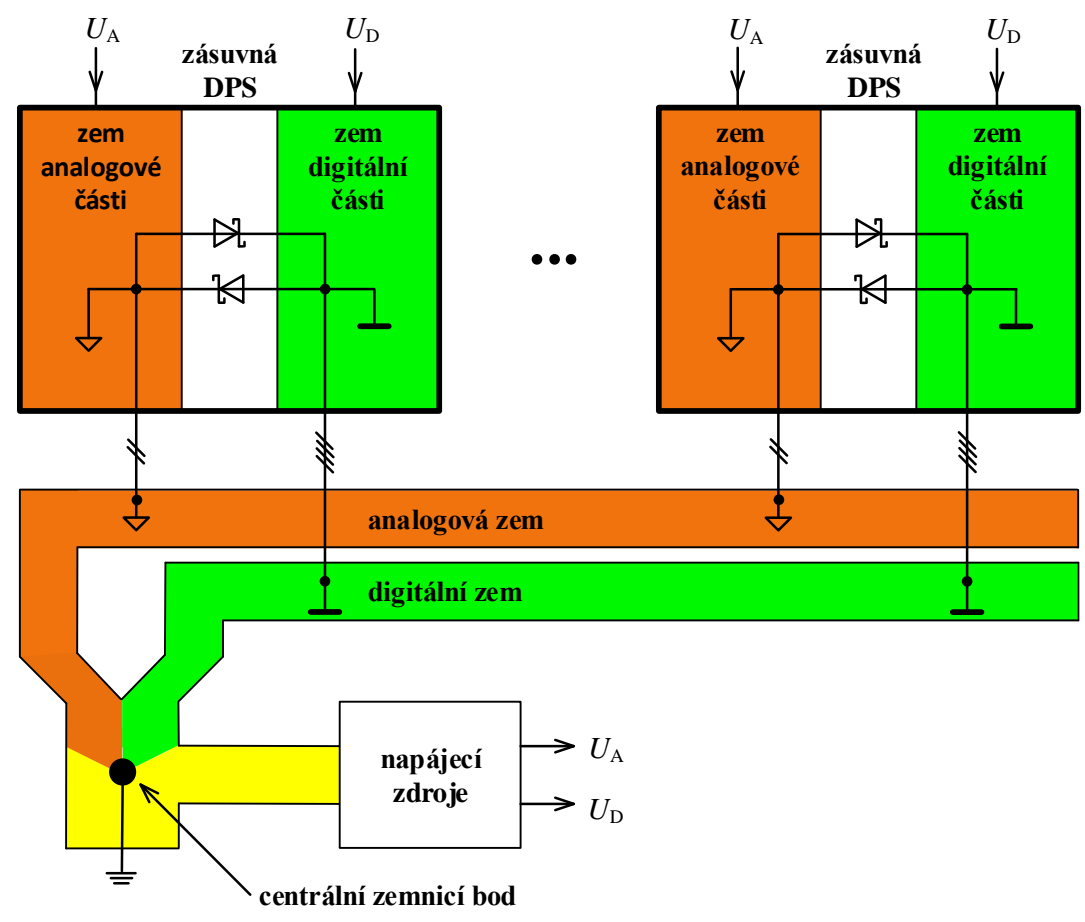

Obr. 3.48: Zařízení se zásuvnými kartami s ,jednobodovým“ zemnicím systémem.

kde nemůžeme rozhodnout, kde se země propojí, volí se jako společný bod zemní svorka výkonově nejvíce namáhaného napájecího zdroje.

Rozdělení na analogovou a číslicovou část zemního rozvodu je samozřejmě nutné i na zásuvných kartách. Někdy je výhodné použít zcela oddělené zemnicí plochy a to zvlášt' pro analogovu a zvlášt' pro digitální část zásuvné karty. Aby se omezila jejich vzájemná parazitní kapacita, neměly by se tyto zemní plochy navzájem překrývat. Na každou zásuvnou kartu se pak mezi zem analogové a zem digitální části zapojí dvě antiparalelně spojené Schottkyho diody. Ty zabraňují vzniku nebezpečného napětí mezi oběma zeměmi při vytažení zásuvné karty z konektoru, které může vést ke zničení některých obvodů. Napětí mezi zeměmi se takto omezí maximálně na $\pm 0,3 \mathrm{~V}$.

Rozdělení zemního rozvodu na více oddělených částí a jejich spojení v jediném centrálním bodě se vyplatí i v jiných př́padech. Např. při konstrukci analogových obvodů předpokládáme, že rozvod společného zemního vodiče je nositelem nulového potenciálu, ale ve skutečnosti tomu tak není. Deset centimetrů plošného spoje tloušt'ky $75 \mu \mathrm{m}$ a šířky $0,5 \mathrm{~mm}$ má odpor $50 \mathrm{~m} \Omega$. Proud $10 \mathrm{~mA}$ na něm vyvolá úbytek $0,5 \mathrm{mV}$. Je-li tento úbytek na výstupní straně, obyčejně nevadí. Zasáhne-li však vstupní obvody zesilovače (viz Obr. 3.49 a), může zemní úbytek $u_{\mathrm{r}}$ vyvolaný průtokem cizího zemního proudu $i$ způsobit obtíže trojího druhu:

- př́davné ss napětí, je-li rušivý úbytek stálý,

- př́davný šum, mění-li se náhodně,

- prrídavnou chybu zesílení, je-li úměrný vstupnímu signálu.

Rušivý napětový úbytek $u_{\mathrm{r}}$, vyvolaný průtokem cizího proudu přes společný zemní vodič, se snadno odstraní vhodným uzemněním signálové zdroje (viz Obr. 3.49b).

Z výše uvedených důvodů se proto vždy vyplatí analogovou zem rozdělit ještě na zem 


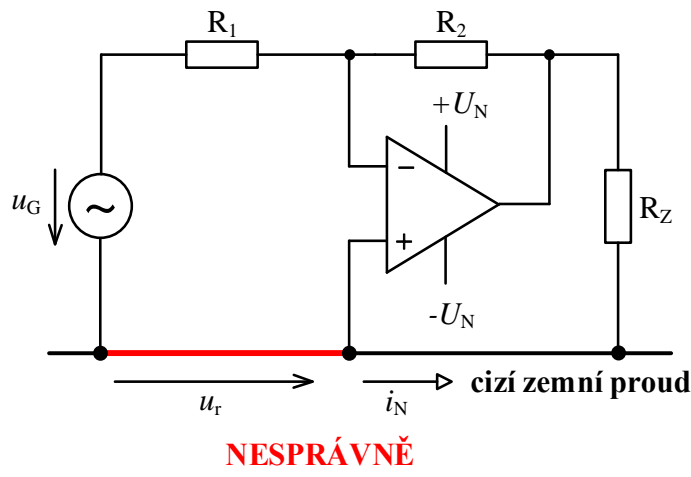

a

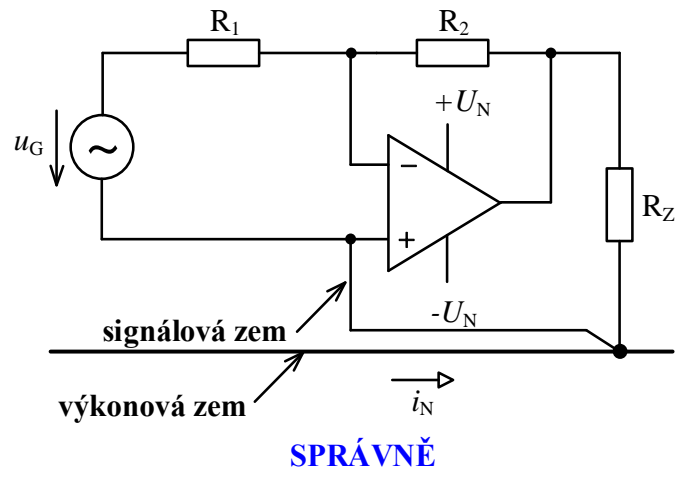

b

Obr. 3.49: a) Rušivý zemní napětový úbytek vyvolaný průtokem cizího zemního proudu,

b) odstranění zemního úbytku jiným způsobem uzemnění signálového zdroje

signálovou a na zem výkonovou. K signálové zemi se připojují všechny signálové či referenční zdroje, nebo body, které mají být připojeny k refenční nule. K výkonové zemi se pak připojí všechny blokovací kondenzátory a zátěže, tzn. obvodové prvky, přes které se uzavírají vf rušivé nebo proudy značné hodnoty. Země se vzájemně propojí až v centrálním zemnicím bodě celého zařízení. Jako př́klad je na Obr. 3.50 uvedeno rozdělení zemí na signálovou (S) a výkonovou (V) u zdroje konstantního proudu 5,0 A. Protože generovanou veličinou je proud tekoucí zátěží $\mathrm{R}_{Z}$, jsou obě země propojeny u výstupní zemnicí svorky.

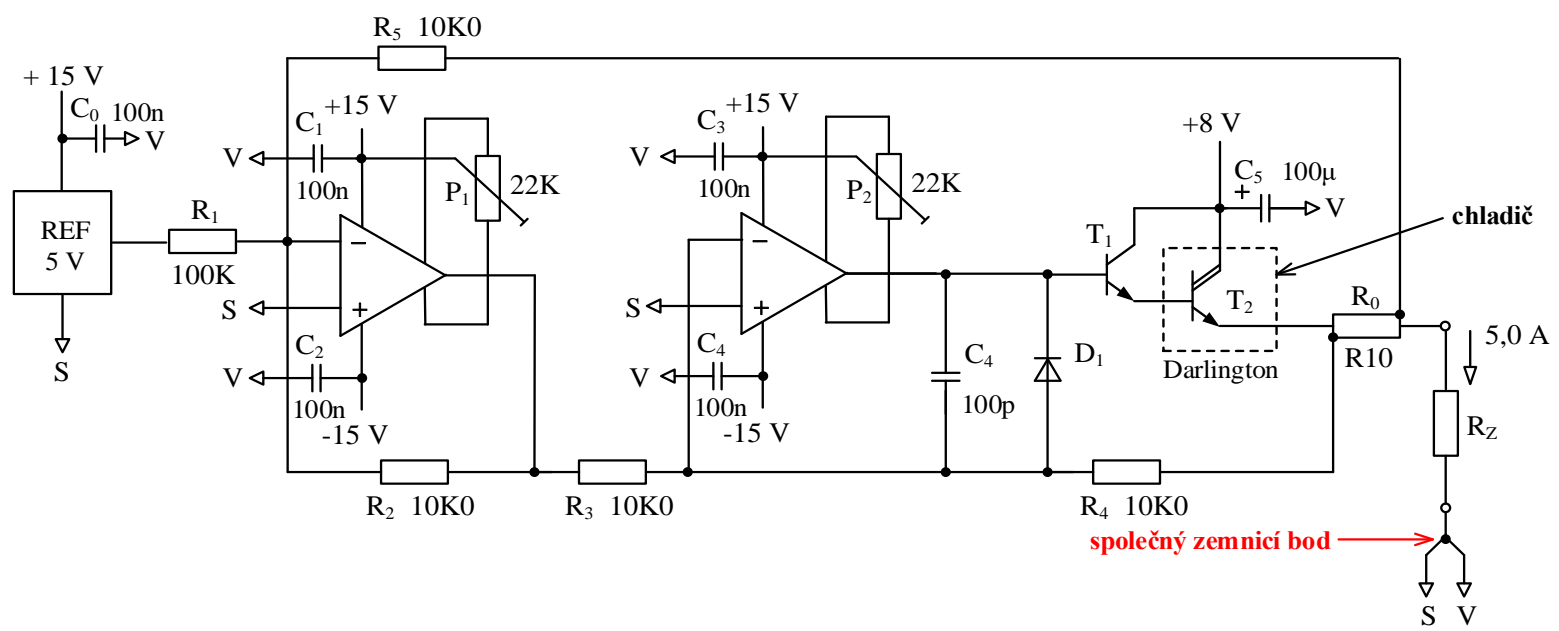

Obr. 3.50: Rozdělení zemí na signálovou a výkonovou zem u zdroje konstantního proudu 5 A

Obdobné problémy přináší spínání výkonových členů připojených k digitálním obvodům. Stačí i jeden tranzistor, který spíná zátěž s velkým proudovým odběrem a vyhledání zdroje rušení bude trvat hezky dlouho. I v tom př́padě se vyplatí rozdělit zem na digitální a výkonovou. Jako př́klad je uvedeno na Obr. 3.51 rozdělení zemí v obvodu pro spínání výkonových LED z řídicího logického obvodu, kdy při sepnutí tranzistoru MOSFET dochází ve zpětném zemním vodiči ke skokové změně proudu (až $100 \mathrm{~mA}$ ). To by mohlo způsobit změnu stavu logických obvodů připojených na stejný zemní vodič. Obě země se pak spojí u zemní svorky napájecího zdroje. 


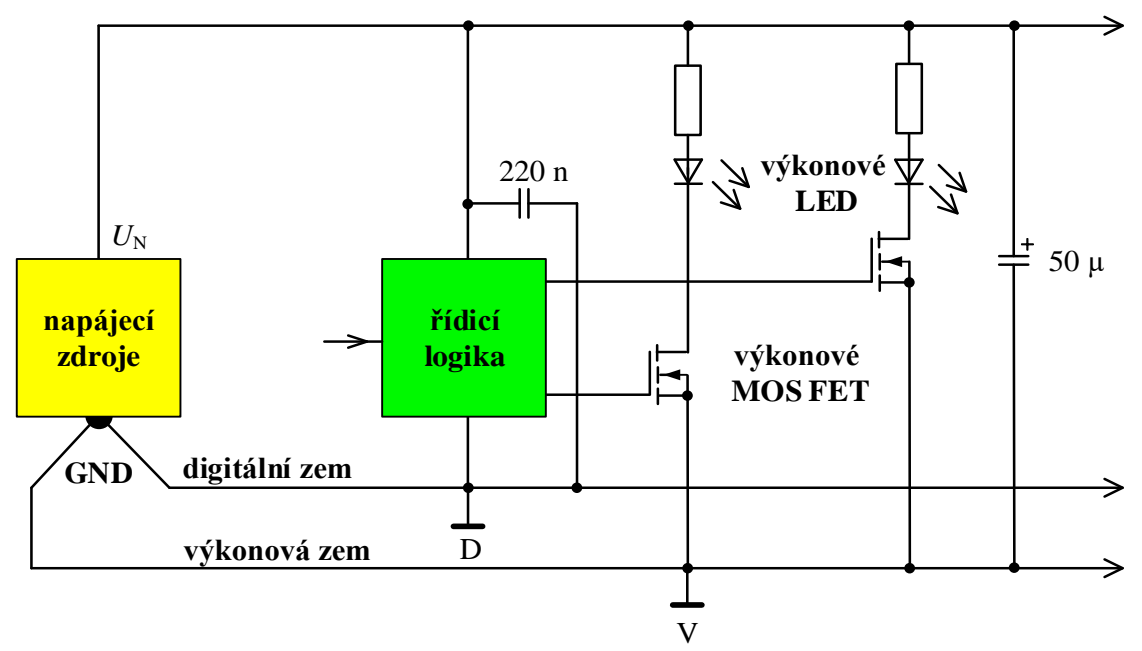

Obr. 3.51: Rozdělení společného zemního vodiče na digitální a výkonovou zem při spínání zátěží s velkým proudovým odběrem

\section{Shrnutí $k$ volbě systému zemního rozvodu}

Každá deska plošných spojů s digitálními nebo se smíšenými analogovými a digitálními obvody by měla mít alespoň jednu celou vrstvu vyhrazenu pro zemní vrstvu. V ideálním př́ipadě by oboustranná DPS měla mít jednu stranu vyčleněnu pro zemní rozvod a druhou stranu pro signálové spoje a rozvod napájecího napětí. V praxi to samozřejmě není možné, protože některé části zemnicí vrstvy musí být odstraněny, aby bylo možno realizovat kř́žžení signálových spojů nebo křižení rozvodu napájecího napětí. V každém případě by mělo vždy zůstat zachováno alespoň 75 \% zemní plochy. DPS s vyšší hustotou montáže integrovaných obvodů budou mít velký počet propojovacích a křížících se spojů a proto je zapotřebí užít minimálně čtyřvrstvou DPS. Dvě vnitřní vrstvy se vyhradí rozvodu země a rozvodu napájecího napětí. Druhé dvě vnější vrstvy pak slouží pro signálové spoje a pro upevnění součástek. Ve většině systémů ani čtyři vrstvy nestačí a je nutno použít vícevrstvé DPS.

Neexistuje žádná jednoznačná metoda, jak v zařízení realizovat rozvod společného zemního vodiče. Pro rychlé digitální obvody je důležité, aby jedna vnitřní vrstva byla vyhrazena zemnicí vrstvě. Pokud jsou na DPS i analogové obvody, vyplatí se již prvotní rozvržení DPS koncipovat tak, aby analogové a digitální systémy byly odděleny a aby se př́ípadné analogové a digitální zemnicí vrstvy nepřekrývaly.

Při vývoji nového zařízení je těžké předem odhadnout, která metoda řešení zemního rozvodu bude nejlepší, zda bude lepší „vícebodový“ zemnicí systém, nebo systém ,jednobodový" s hvězdicovým rozvodem zemních vodičů. Proto se při návrhu nového zařízení doporučuje začít s oddělenými zemnicími systémy, tzn. samostatná zem pro analogové systémy rozdělená navíc na signálovou a výkonovou zem a samostatná zem pro digitální systémy. Jednotlivé země se pak propojí pomocí propojek a experimentálně se ověří, který ze zemnicích systémů bude ten nejlepší. Pokud se nejprve začne s „vícebodovým“ zemním rozvodem, je dodatečné rozdělení zemí prakticky nemožné a většinou se musí všechny díly zařízení nově navrhnout a znovu osadit součástkami. 


\section{Použitá literatura}

[1] SVAČINA, J. Elektromagnetická kompatibilita: principy a poznámky. Vysoké učení technické v Brně, Brno 2001, ISBN 80-214-1873-7

[2] SVAČINA, J. Základy elektromagnetické kompatibility (EMC). Část 3: Způsoby omezování rušení - odrušovací prostředky a elektromagnetické stínění. Elektrorevue, www. elektrotrevue.cz, 2000/41- 28.11.2000

[3] JANSA, J. Potlačení rušení v pásmu $10 \mathrm{kHz}$ až $30 \mathrm{MHz}$. DPS Elektronika, č. 1, 2013

[4] NADLER, A. Application Note: Impact of the layout, components, and filters on the, EMC of modern DC/DC switching controllers. Würth Elektronik, www.weonline.com/anp, 2017-03-23

[5] KOUŘIL, F.; VRBA, K. Teorie nelineárních a parametrických obvodů. SNTL, Praha 1981 ,

[6] TIETZE, U.; SCHENK, CH.; GAMM, E. Electronic Circuits. Hand book for Design 5, and Applications. 2nd edition, Springer - Verlag, Berlin 2008. ISBN 978-3-54000429-5

[7] VRBA.K. Technika analogových obvodů. Elektronické skriptum FEKT VUT v Brně, 2020

[8] ELLIOTT, R. Low Dropout (LDO) Regulators - A short primer on these sometimes difficult devices. Elliott Sound Products, 2017. https://sound-au.com/articles/ldoregulators.htm

[9] DENG, Q. A. LDO Primer-Part I: A Review on Pass Element. Analog and Interface Products Division Microchip Technology Inc., 2019

[10] PATOUX, J. Ask The Applications Engineer 37: Low-Dropout Regulators. Analog Dialogue, 2019

[11] KREJČIŘÍK, A. Napájecí zdroje I, II, III. BEN - technická literatura, Praha 1998

[12] KREJČIŘÍK, A. Spínané napájecí zdroje s obvody TOPSwitch. BEN - technická literatura, Praha 2002

[13] KREJČIŘÍK, A. DC/DC měniče, BEN - technická literature, Praha 2001

[14] PATOČKA, M. Magnetické jevy a obvody ve výkonové elektronice, měřicí technice a silnoproudé elektrotechnice. Akademické nakladatelství VUTIUM, Brno 2011

[15] FAKTOR, Z. Transformátory a tlumivky pro spínané napájecí zdroje. BEN technická literatura, Praha 2002

[16] FAKTOR, Z. Transformátory a cívky. BEN - technická literatura, Praha 1999

[17] WILliAMS, J.; HUFFMAN, B. Some thoughts on DC/DC Converters. Application Note 29, Linear Technology, 1988

[18] MURATA: Basics of Noise Countermeasures, Lesson 1-14, Murata Power Solutions, Inc. 2014.

[19] KESTER, W. ; BRYANT, J. ; BYRNE, M. Grounding Data Converters and Solving the Mystery of "AGND" and "DGND". MT-031 Tutorial, Analog Devices, 2008

[20] FORTUNATO, M. Successful PCB grouding with mixed-signal chips-follow the path of least impedance. Tutorial 5450, Maxim Integrated 2017 


\section{Zemní smyčky a způsoby galvanického oddělení}

\subsection{Zemní smyčky}

V řadě př́padů jsou zemními vodiči signálových spojů navzájem propojena dvě zařízení, která jsou mezi sebou ale také propojena přes zemní vodiče sít'ových přívodů napájecích zdrojů. Stejná situace nastane, když rozsáhlé zařízení rozdělíme na několik sekcí se samostatnými sítovými napájecími zdroji. Spojíme-li takové dílčí sekce zařízení mezi sebou signálovými spoji, vznikne zemní smyčka ze sít’ového rozvodu a zemních spojů v cestě signálu (viz Obr. 4.1. V zemní smyčce vznikají rušivé proudy dvěma hlavními mechanismy:

- Rušivé proudy se do zemní smyčky nejčastěji indukují okolními magnetickými poli, které jsou vždy prrítomny v okolí rozvodu střídavého napětí. Zemní smyčka totiž představuje jeden vodivý závit drátu, který může mít plochu až několik metrů čtverečních. Jakýkoliv magnetický tok vyvolaný střídavým proudem ze sousedních vodičů sítového rozvodu, nebo $\mathrm{z}$ okolních transformátorů či elektromotorů, indukuje v této zemní smyčce rušivý proud (v Obr. 4.1 je zemní smyčka a proud $i_{\mathrm{R}}$ indukovaný okolními magnetickými poli vyznačen červeně). Obecně platí, že čím bude zemní smyčka větší, tím větší budou indukované rušivé proudy.

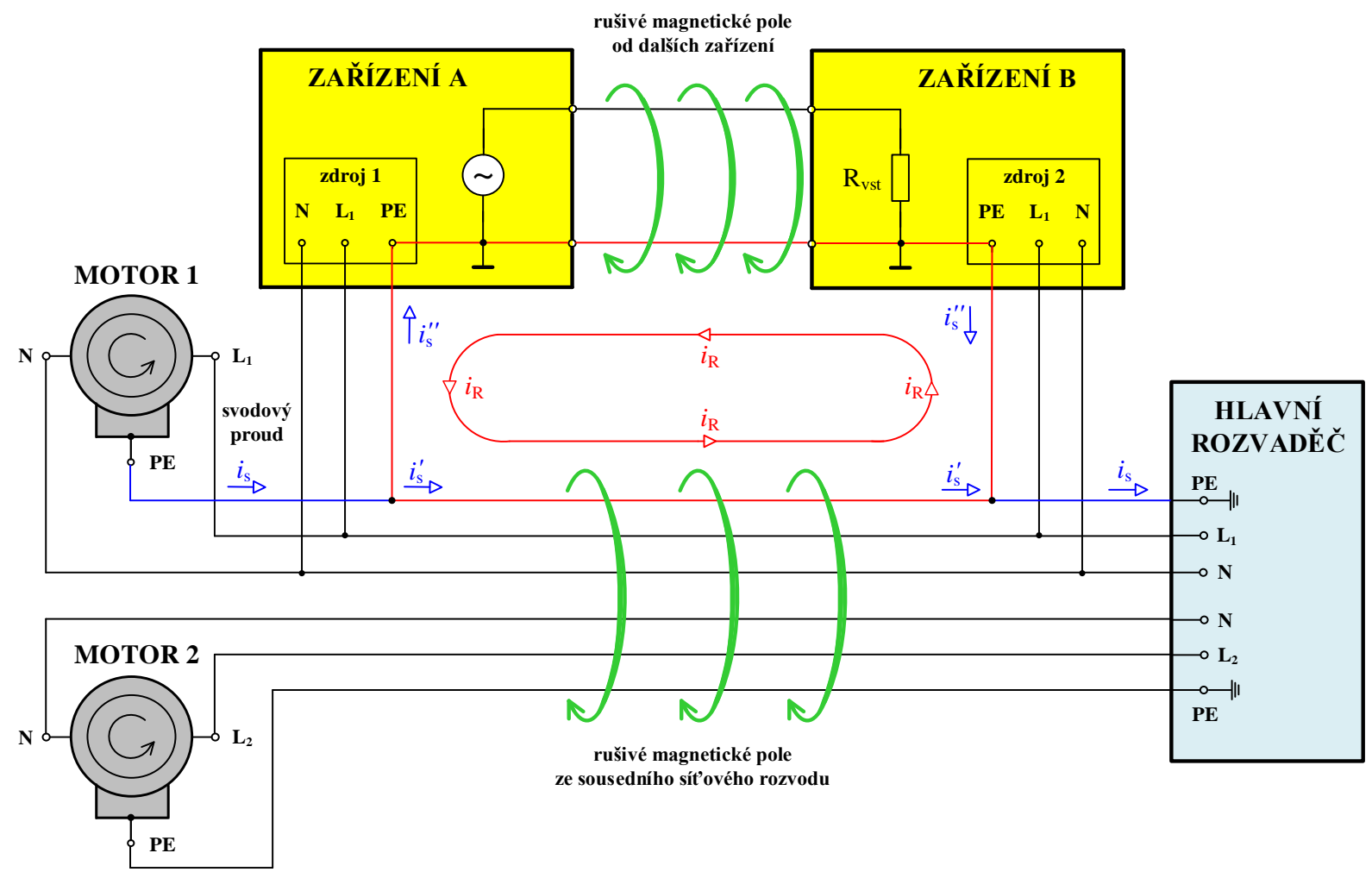

Obr. 4.1: Rušení v zemní smyčce rušivými magnetickými poli a svodovými proudy

- Dalším, ale méně běžným, zdrojem rušení v zemní smyčce mohou být svodové proudy is tekoucí do zemního systému přes nedokonalou izolaci (vObr. 4.1 zakresleny modře), což se projevuje zejména u výkonových motorů. Zemní smyčka mezi zařízením A a zařízením B vytváŕí pro svodové proudy paralelní cestu, kdy část proudu teče zemním vodičem mezi oběma zařízeními a část pak ochranným vodičem PE sít’ového rozvodu. 
Většinou se do zemní smyčky indukuje rušivý proud o kmitočtu $50 \mathrm{~Hz}$, popř. při použití impulsně regulovaných zdrojů pak rušivý proud o kmitočtu řádově desítky kHz. U citlivých zařízení může indukovaný rušivý proud způsobit chybu při přenosu signálů, protože na odporu signálových vodičů vyvolává rušivé napětí. V podstatě existují dva způsoby, jak rušivé proudy, resp. rušivá napětí částečně nebo úplně odstranit:

- potlačit rušivé napětí,

- zařízení galvanicky oddělit.

\subsection{Potlačení rušivého napětí způsobeného zemní smyčkou}

Pokud propojíme dvě zařízení signálovými vodiči, můžeme si účinek rušivých proudů v zemní smyčce namodelovat rušivým napětím $u_{\mathrm{r}}$, které vznikne mezi zemními systémy obou zařízení. Pronikání rušivého napětí lze potlačit vložením tlumivky vinuté stíněným kabelem (viz Obr. 4.2 ), která se zapojí do signálových spojů mezi zařízení A a B způsobem naznačeným na Obr. 4.21. Vinutí stíněným kabelem vytváří vlastně transformátor s převodem $1: 1$, jehož primární vinutí je tvořeno uzemněným pláštěm kabelu (svorky 3-4), sekundární vinutí pak tvoří vnitřní vodič kabelu (svorky 1-2), který přenáší vlastní signál. Rušivé napětí mezi konci primárního vinutí se transformuje ve stejné velikosti do sekundárního vinutí a buzení rušivým signálem se proto mezi svorkami 2-4 v důsledku kompenzace neuplatní. Předpokladem správné funkce je, že reaktance primárního vinutí na kmitočtu rušení je podstatně větší než odpor zemní smyčky.

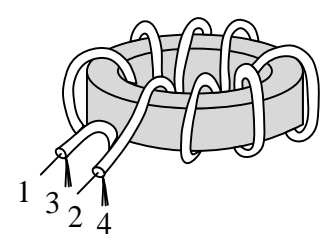

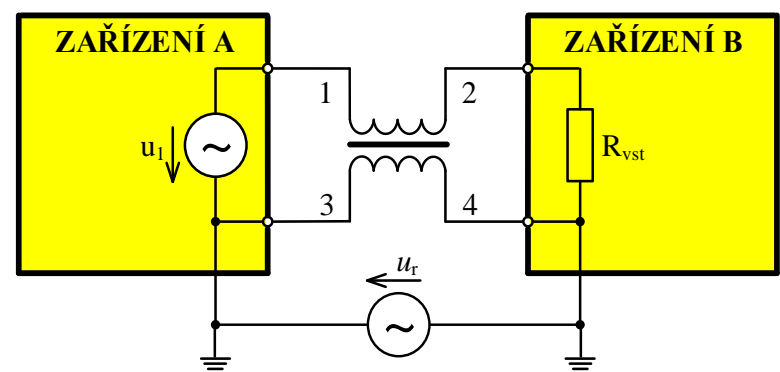

b

Obr. 4.2: a) Provedení souosé tlumivky vinuté stíněným vodičem na toroidním jádru,

b) zařazení souosé tlumivky do signálového vedení pro potlačení rušení způsobeného zemní smyčkou

Jádro tlumivky musí vykazovat velkou magnetickou vodivost. Volba materiálu jádra závisí na kmitočtu rušivých proudů, protékajících zemními spoji. Při sít’ovém nebo nízkofrekvenčním rušení je nejvhodnější toroidní jádro z permalloye. Pro nízké kmitočty (50 $\mathrm{Hz}$ ) jsou však toroidní jádra s velkou permeabilitou obtížně dostupná. Jako náhradu lze použít i transformátorové jádro. Při vyšších kmitočtech rušení vyhoví feritová toroidní jádra.

Pro nižší kmitočty se snažíme navinout na jádro co nejvíce závitů, u vysokých kmitočtů může pomoci i jediný závit nebo jen průvlak feritovým válečkem (viz Obr. 4.3. Feritový váleček se umíst'uje maximálně $10 \mathrm{~cm}$ před oběma konci kabelu. Obdobnou techniku pro potlačení vf rušení, které vnáší do signálu zemní smyčka, lze užít i pro vícežilové kabely Obr. 4.3 . 


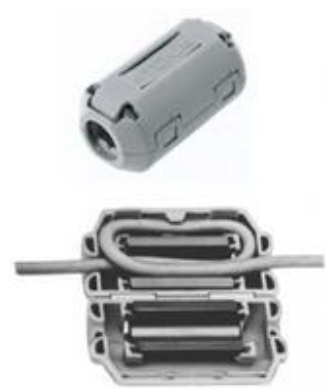

a

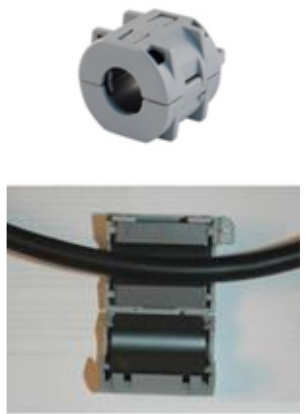

b

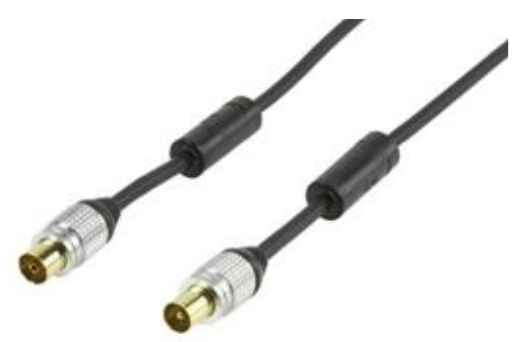

c

Obr. 4.3: a) Feritová tlumivka na koaxiální kabel: a) půlená - s jedním závitem na válečku, b) půlená - pouze průvlak válečkem, c) profesionální kabel s feritovou tlumivkou

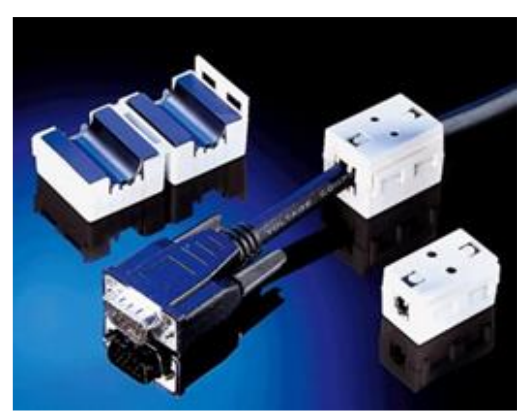

a

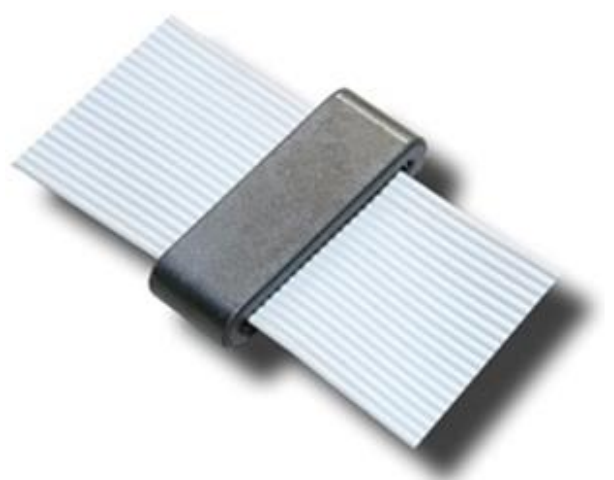

$\mathrm{c}$

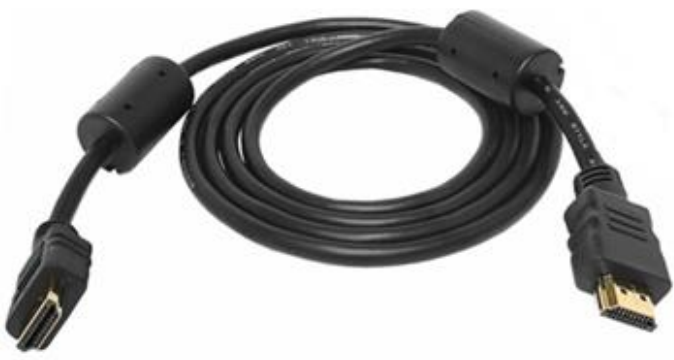

b

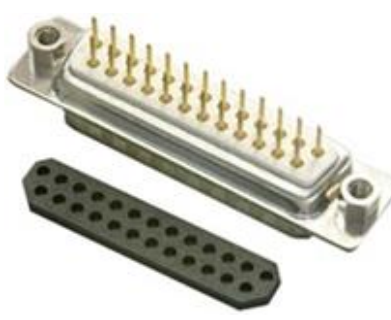

d

Obr. 4.4: Feritové tlumivky na datový vícežilový kabel: a) průvlak půleným feritovým válečkem b) profesionální odrušení vícežilového kabelu, c) feritový návlek, d) feritová vložka do konektoru 
Při aplikaci uvedené metody je však vždy nutno uvážit, že tento princip může pomoci jen tam, kde se uplatňuje rušeni vznikajici ve smyčce s malou impedancí. Je-li např. rušení způsobeno v obvodu s velkou impedancí, je použití takovéto tlumivky neúčinné.

\subsection{Přerušení zemní smyčky galvanickým oddělením}

V řadě případů je účelnější, aby zařízení byla mezi sebou signálově vázána způsobem nevyžadujícím galvanické propojení jejich společných (zemních) vodičů. Signálová vazba je $\mathrm{v}$ těchto př́ípadech obvykle zprostředkována světelnými paprsky (optoelektronické vazební členy), magnetickým polem (nízkofrekvenční popř. impulsní transformátory), nebo kapacitně (oddělovací kondenzátory). Tímto způsobem se za cenu větší složitosti zařízení obcházejí potíže spojené s propojováním zemních vodičů především v soustavách prostorově značně rozlehlých a propojovaných dlouhými signálovými kabely. Každá ze sekcí zpracovávajících signál může přitom být připojena na libovolný „Zemni““ potenciál. Příklad přerušení zemní smyčky mezi dvěma zařízeními je uveden na Obr. 4.5, kdy pro přenos signálu mezi dvěma zařízeními jsou použita optická vlákna.

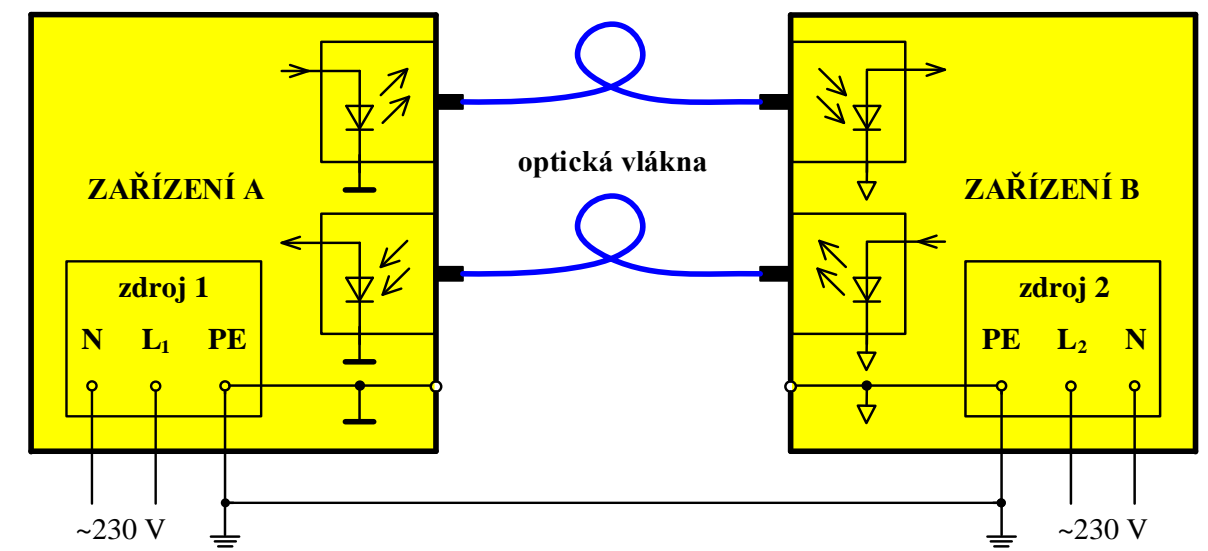

Obr. 4.5: Př́iklad přerušení zemní smyčky pomocí galvanického oddělení signálových vodičů

Obdobný problém nastává, pokud požadujeme, aby vstupní část zařízení byla galvanicky oddělena od dalších uzemněných částí zařízení (viz Obr. 4.6. Samozřejmě galvanicky oddělená část zařízení musí mít vždy vlastní napájecí zdroj taktéž galvanicky oddělený od uzemněné části zařízení. Za tímto účelem se obvykle využije galvanicky izolovaný DC/DC měnič. Pokud nebude překročeno izolační napětí oddělovacích členů nebo izolační napětí DC/DC měniče, bude bezpečnost zařízení zachována. Taková sekce (část) zařízení, která je jak napájením, tak i signálem galvanicky oddělena od ostatních částí zařízení se často označuje jako „plovoucí“ sekce (část).

Volba typu oddělovacího prvku závisí při oddělení digitálních signálů na požadované rychlosti přenosu dat, při oddělení analogových signálů pak na šířce jejich kmitočtového spektra. V této souvislosti poznamenejme, že pro řadu aplikací je př́liš rychlá reakce vazebních prvků spíše na závadu. Např. v automatizační technice se vždy vyplatí používat jen tak rychlé obvody, jak je nezbytně třeba. Pokud je vazební člen pomalý, nepřenese krátké rušivé signály, a tím zvyšuje dynamickou šumovou imunitu. V praxi se ukazuje, že rušivé signály impulsního charakteru trvají nejvýše desítky až stovky ns. Navrhneme-li tedy vazební obvody takovým způsobem, aby se krátké impulsy nepřenášely, podstatně zvýšíme spolehlivost zařízení. 


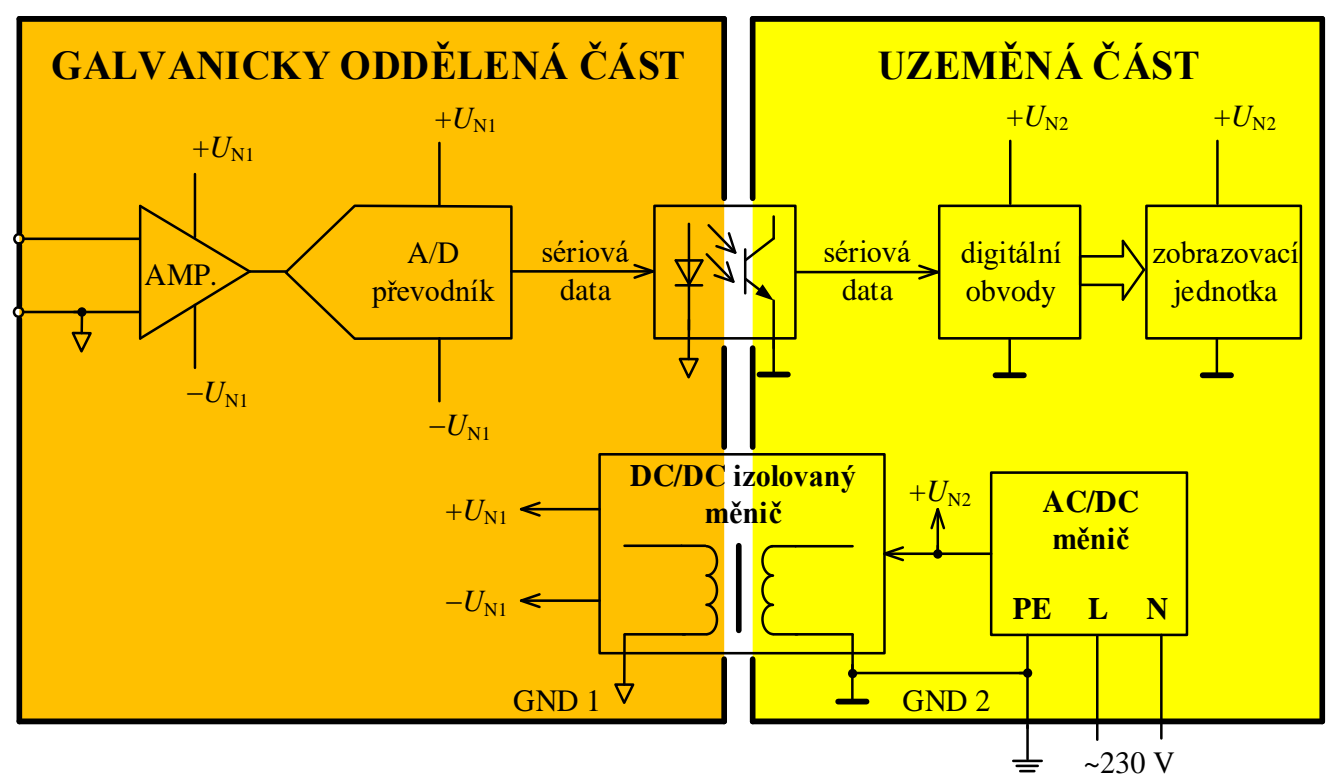

Obr. 4.6: Př́klad galvanického oddělení vstupní části zařízení

\subsection{Galvanické oddělení optočlenem}

Nejčastěji užívanými součástkami pro galvanické oddělení obvodů jsou optoelektrické vazební členy (optocoupler, optoisolator). Obsahují zdroj světelného záření (vysílač) a přijímač záření, které jsou vzájemně vázány optickým prostředím. Zdrojem záření bývá nejčastěji elektroluminiscenční dioda, jako přijímač se nejčastěji užívá fotodioda nebo fototranzistor. Základní vlastností optoelektronických vazebních členů je galvanické oddělení vstupní a výstupní části členu. Optoelektronické vazební členy bývají proto zkráceně nazývány optoizolátory.

Galvanické oddělení používající optoizolátory má za následek vysokou odolnost systémů proti rušení. Optoizolátory nacházejí použití všude, kde je třeba přenést signál (spojitý nebo diskrétní) mezi dvěma galvanicky oddělenými soustavami a slouží tedy k přerušení zemních smyček. Používají se k oddělení zemí výkonových členů, například v průmyslových řídicích systémech, $v$ měřicích zařízeních a jinak prostorově rozlehlých systémech, a to jako vysílač či přijímač signálů přenášených po dlouhých vedeních, pro izolaci digitálních systémů nebo na datových linkách, popřr. pro izolaci v lékařských zařízeních.

Použití optoelektronických vazebních prvků při přenosu datových signálů je jednoduché, a proto zcela běžné. Naproti tomu při použití těchto vazebních členů pro analogové signály musí být řešení podstatně složitější.

\section{Optočleny s fototranzistorem}

Optoelektronický vazební člen s fototranzistorem má velmi malý proudový přenos (poměr kolektorového proudu fototranzistoru ke vstupnímu proudu luminiscenční diodou), takže sám o sobě je pro buzení digitálních obvodů obvykle nepoužitelný a musíme ho doplnit dalším pomocným tranzistorem (viz Obr. 4.7 ). Pro přesnost poznamenejme, že každá část zařízení má svůj vlastní zemnicí systém (GND 1, GND 2) a samostatné galvanicky oddělené napájecí zdroje $\left(U_{\mathrm{N} 1}, U_{\mathrm{N} 2}\right)$. Rychlost přenosu dat při použití optoizolátoru s fototranzistorem bývá obvykle jen $100 \mathrm{~kb} / \mathrm{s}$. Jednotka b/s (někdy bps = bits per second) zde značí počet bitů přenesených za 1 sekundu. Izolační napětí bývá z rozmezí $2,5 \mathrm{kV}$ až $5 \mathrm{kV}$. 
Nižší přenosová rychlost $\mathrm{v}$ řadě případů nevadí a je naopak výhodou, protože oddělovací člen nepřenese rychlé rušivé impulsy. Optočleny s fototranzistorem proto nacházejí použití např. pro oddělení zpětnovazebního signálu v impulsně regulovaných napájecích zdrojích. Některé typy optoizolátorů obsahují pomocný zesilovací tranzistor zapojený s fototranzistorem v Darlingtonově uspořádání (viz Obr. 4.7b). Účinnost tohoto vazebního členu je již značná a stačí vybudit další digitální obvody. Přenosová rychlost takto uspořádaného obvodu je ale poněkud nižší, než v předchozím případě, protože Darlingtonovo zapojení není pro práci ve spínacím režimu př́lišs vhodné.
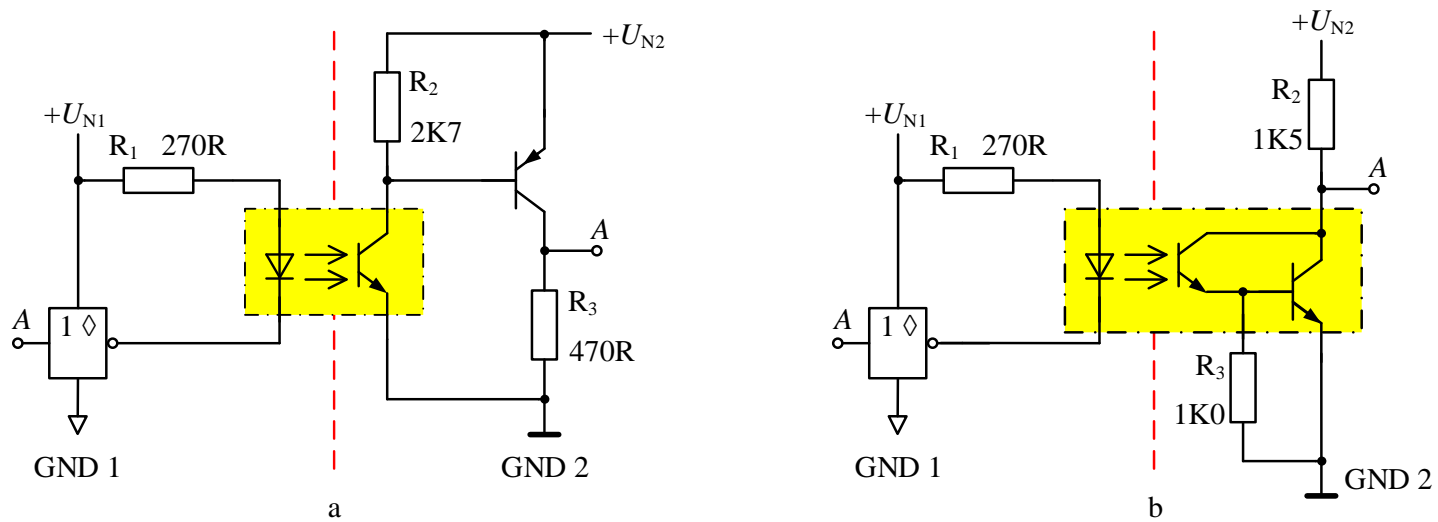

Obr. 4.7: a) Externí ošetření optoizolátoru s fototranzistorem, b) fototranzistor

v Darlingtonově zapojení

\section{Optočleny s fotodiodou}

Použití fotodiody ve spojení s tranzistorem přineslo zrychlení přenosu 10x až 200x. Běžně se dosahuje rychlosti přenosu $1 \mathrm{Mb} / \mathrm{s}$. Př́klad zapojení optoizolátoru s fotodiodou je uveden na Obr. 4.8 . Aby vznikl fotovoltaický jev, je fotodioda PD pólována v závěrném směru. Protože fotodioda pracuje s velmi malými proudy, ale tranzistor pracuje ve spínacím režimu s velkým proudem, doporučuje se v těsné blízkosti optočlenu zapojit kvalitní vf keramický kondenzátor $100 \mathrm{nF}$ (viz Obr. 4.8b). V izolační mezeře mezi vývody vstupní a výstupní části se nesmí ani ve vnitřních vrstvách DPS vést žádné spoje. Izolační napětí bývá $\mathrm{z}$ rozmezí $2,5 \mathrm{kV}$ až $5 \mathrm{kV}$.

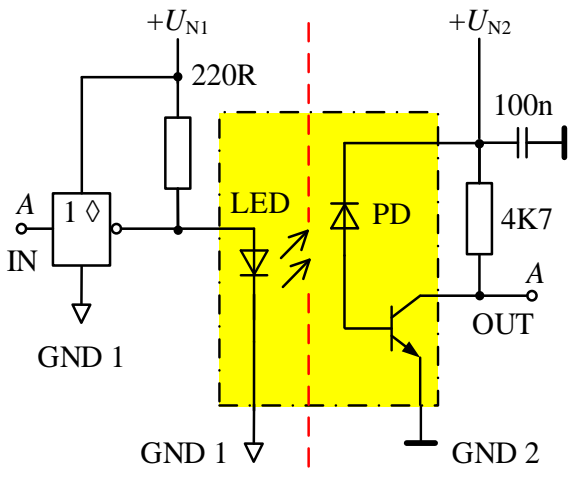

a

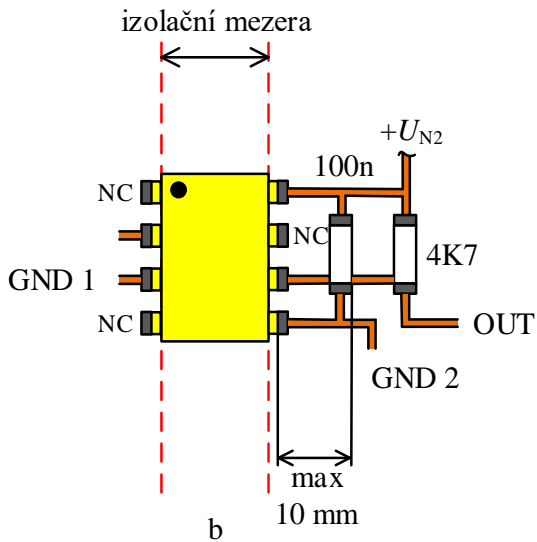

b

Obr. 4.8: a) Př́iklad zapojení optoizolátoru s fotodiodou, b) doporučený plošný spoj 


\section{Digitální optoizolátory}

Digitální optoizolátory se vyznačují vyšším stupněm integrace, kdy výstupní část obvodu je uzpůsobena pro připojení různých typů logických obvodů, nebo má tř́stavový výstup pro připojení na datovou sběrnici. Př́íklad zapojení digitálního optoizolátoru je uveden na Obr. 4.9. Aby se získala dostatečná strmost hran, doporučuje se optoizolátor budit z výkonového hradla, kdy během trvání nástupné či sestupné hrany se navíc odpor $270 \Omega$ přemost'uje přes malou impedanci kapacitoru $33 \mathrm{pF}$ odporem $220 \Omega$. Pro potlačení šumu obsahuje přijímač komparátor s hysterezí $270 \mu \mathrm{A}$. Dosažitelná rychlost přenosu dat je u obvodů tohoto typu až 40 $\mathrm{Mb} / \mathrm{s}$, izolační napětí pak bývá z rozmezí $1,5 \mathrm{kV}$ až $2,5 \mathrm{kV}$.

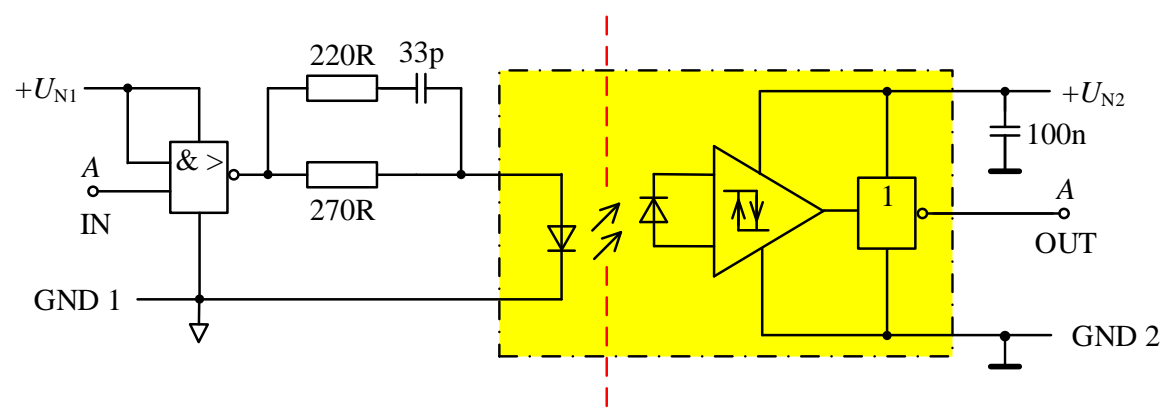

Obr. 4.9: Optoelektronický vazební člen pro digitální signály.

\section{Izolovaný vysílač/přijímač (transciever) pro optické kabely}

Ještě vyšší stupeň integrace mají optoizolátory pro přenos dat mezi dvěma zařízeními pomocí optických kabelů, označované jako vysílač/přijímač pro optické kabely (Fiber Optic Transceiver). Obvod obsahuje většinou integrovanou dvojici optoelektronického vysílače a přijímače pro přenos dat optickými vlákny (viz Obr. 4.10. Aby se potlačilo rušení přes napájecí přívody, má vysílač a přijímač samostatné napájecí a zemnicí přívody. Každý napájecí přívod se doporučuje vybavit LC filtrem a kondenzátor filtru $10 \mu \mathrm{F}$ přemostěný kvalitním vf kondenzátorem $100 \mathrm{nF}$ umístit co nejblíže k vývodům pouzdra. Zemnicí vývody GND1, GND2 nejsou uvnitř obvodu propojeny a tyto vývody se doporučuje co nejkratším způsobem připojit k zemnicí vrstvě DPS.

Diferenční páry datové linky jsou impedančně přizpưsobeny, přičemž provedení plošných spojů musí vyhovovat standardům pro vysokorychlostní přenos. Oddělovací kondenzátory $100 \mathrm{nF}$ jsou dimenzovány pro vysokorychlostní provoz $100 \mathrm{až} 250 \mathrm{Mb} / \mathrm{s}$. Vedení TD a $\overline{\mathrm{TD}}$ musí být zakončeno externě odporem $100 \Omega$. Vedení RD a $\overline{\mathrm{RD}}$ je již interně zakončeno v koncovém stupni odporem $100 \Omega$.

Celý obvod transcieveru je zabudován do optické dvojzásuvky (viz Obr. 4.11 a). Proti přeslechům mezi vysílačem a přijímačem a také, aby se zabránilo průniku vnějšího rušení je dvojzásuvka chráněna kovovým stíněním, které je nutno také připojit nejkratším způsobem k zemnicí vrstvě DPS. Pro vzájemné propojení dvou zařízení je pak dodáván svazek dvou optických vláken s optickými dvojzástrčkami (viz Obr. 4.11\}). 


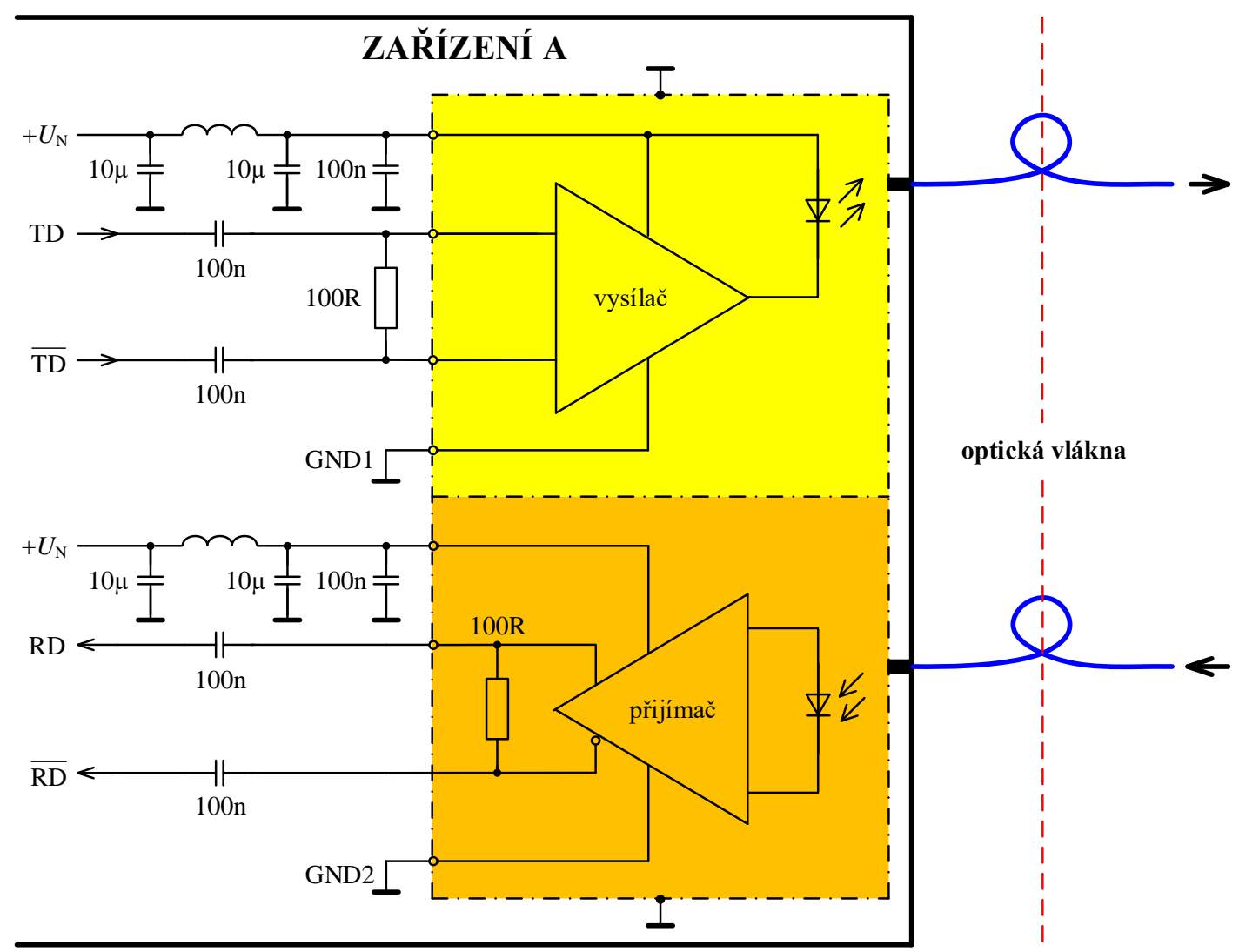

Obr. 4.10: Izolovaný vysílač/přijímač (transciever) pro optické kabely

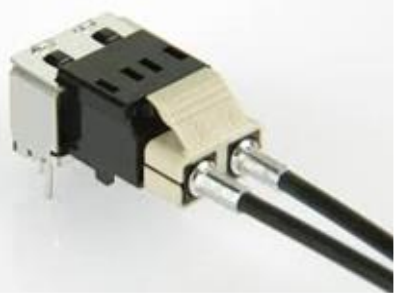

a

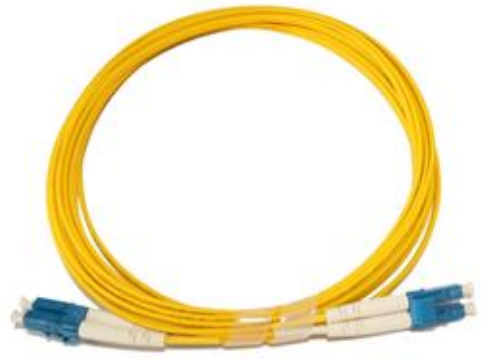

$\mathrm{b}$

Obr. 4.11: a) Digitální vysílač/přijímač zabudovaný do optické dvojzásuvky, b) svazek dvou vláken s dvojzástrčkami

\section{Optočleny pro oddělení analogových signálů}

Použití optoelektronických vazebních členů pro přenos analogových signálů představuje poměrně složitou technickou záležitost. Důvodů $\mathrm{k}$ tomu je několik. V prvé řadě je to nelinearita přenosové funkce běžného optočlenu. Pokud se nevyžaduje velký dynamický rozsah signálu, lze na přenosové funkci najít přibližně lineární úsek. Při malých proudech však převládá šum luminiscenční diody. Při větších nárocích na dynamický rozsah je především nutno kompenzovat vliv nelinearity přenosové funkce vazebního členu. Velmi účinná kompenzace, která potlačuje nelinearitu vazebního členu, se ukázala v možnosti použít dvě fotodiody uspořádané symetricky kolem LED diody (viz Obr. 4.12 a). Jedna fotodioda slouží 
k přenosu signálu a druhá se zapojí jako kompenzační ve zpětnovazební smyčce zesilovače. Na Obr. 4.12b je uvedeno zapojení jedné z možných variant izolačního analogového zesilovače. $\mathrm{O}$ linearitě obvodu nebude nyní rozhodovat absolutní velikost činitele nelinearity vazebního členu, ale pouze hodnota poměru činitelů nelinearit obou vazebních členů v pracovní oblasti.

Takto uspořádaný zesilovač pracuje pouze pro kladné vstupní napětí $u_{\mathrm{IN}}>0$. Aby vznikl fotovoltaický jev, jsou fotodiody $\mathrm{PD}_{1}$ a $\mathrm{PD}_{2}$ pólovány v závěrném směru. Pokud budou fotodiody přibližně shodné, lze očekávat $I_{\mathrm{PD} 1} \approx I_{\mathrm{PD} 2}$. Pro proud fotodiodou $\mathrm{PD}_{1}$ přibližně platí $I_{\mathrm{PD} 1} \approx u_{\mathrm{IN}} / R_{1}$. Protože $u_{\mathrm{OUT}} \approx I_{\mathrm{PD} 2} R_{2}$, bude $u_{\mathrm{OUT}} \approx I_{\mathrm{PD} 1} R_{2} \approx u_{\mathrm{IN}}\left(R_{2} / R_{1}\right)$ a napět'ový přenos zesilovače pak bude $u_{\text {OUT }} / u_{\mathrm{IN}} \approx R_{2} / R_{1}$. Chyba přenosu zesilovače se pohybuje v rozmezí $5 \%$ až $15 \%$.

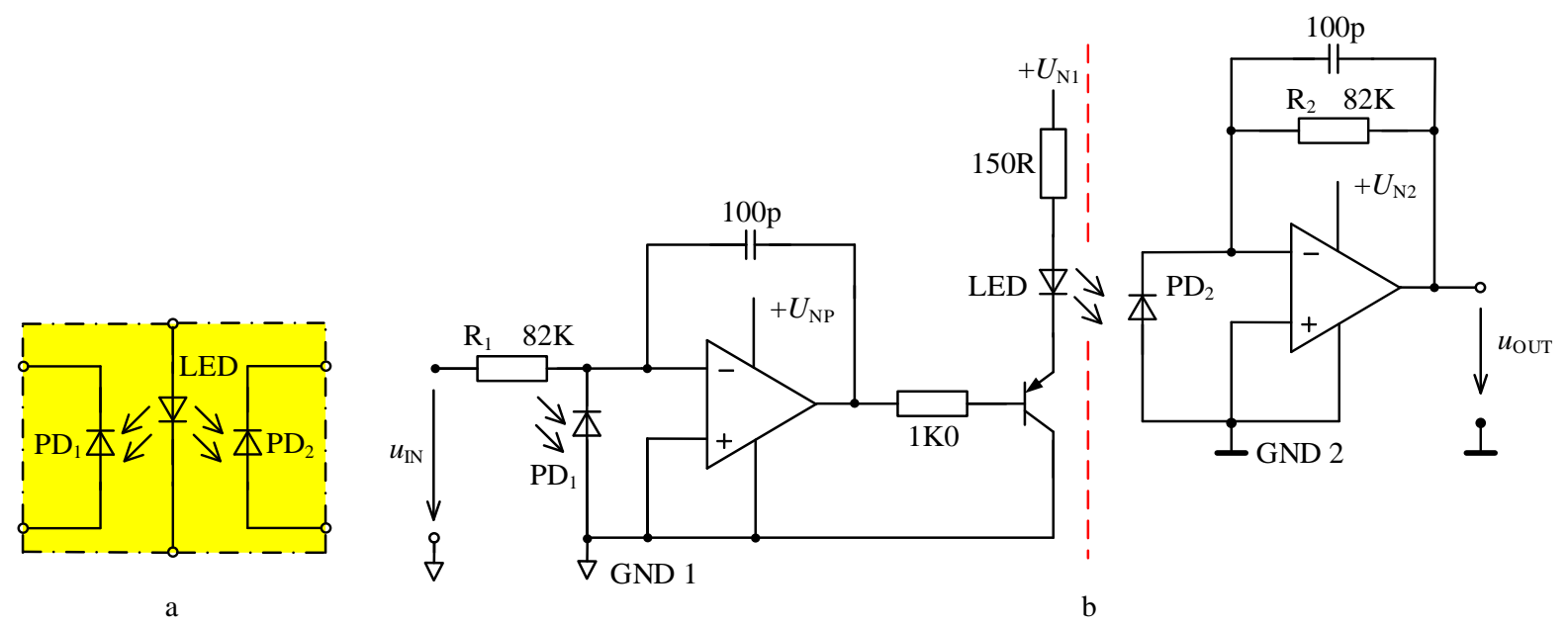

Obr. 4.12: a) Optočlen pro přenos analogového signálu, b) příklad zapojení izolačního analogového zesilovače

\section{Integrovaný izolační analogový zesilovač}

Lepších výsledků při požadavku na galvanické oddělení, pokud se týká linearity převodní charakteristiky a přesnosti přenosu analogového signálu, se dá docílit využitím úplně jiné koncepce řešení. Pokud vstupní analogový signál převedeme převodníkem A/D na data, může být oddělení provedeno na úrovni datového signálu a ten se pak zpět převede $\mathrm{D} / \mathrm{A}$ převodníkem na analogový signál. Přesnost přenosu či linearita převodní charakteristiky je pak určena vlastnostem $\mathrm{A} / \mathrm{D}$ a $\mathrm{D} / \mathrm{A}$ převodníků, nikoliv nelinearitami optočlenu. Obdobně lze využít převod vstupního napětí na kmitočet a po oddělení optočlenem pak převést kmitočet zpět na napětí.

Většina přesných izolačních zesilovačů využívá pro převod analogového signálu na digitální údaj převodníky sigma-delta. Aby se docílilo kvalitních výsledků i v prostředí se silným elektromagnetickým rušením, bývá zapojení izolačního zesilovače plně diferenční (viz Obr. 4.13 ). Chyba přenosu bývá u přesných zesilovačů $\pm 0,1$ až $\pm 1 \%$ a u zesilovačů pro průmyslové aplikace může být chyba max $\pm 5 \%$. Nelinearita přenosové charakteristiky bývá běžně $0,1 \%$, šířka kmitočtového pásma 80 až $100 \mathrm{kHz}$. Izolační napětí je obvykle z rozmezí 1 $\mathrm{kV}$ až $1,5 \mathrm{kV}$. 


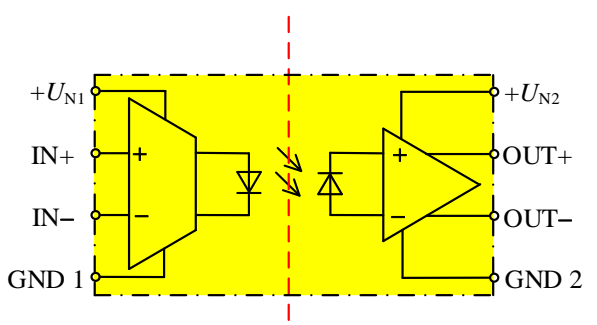

a

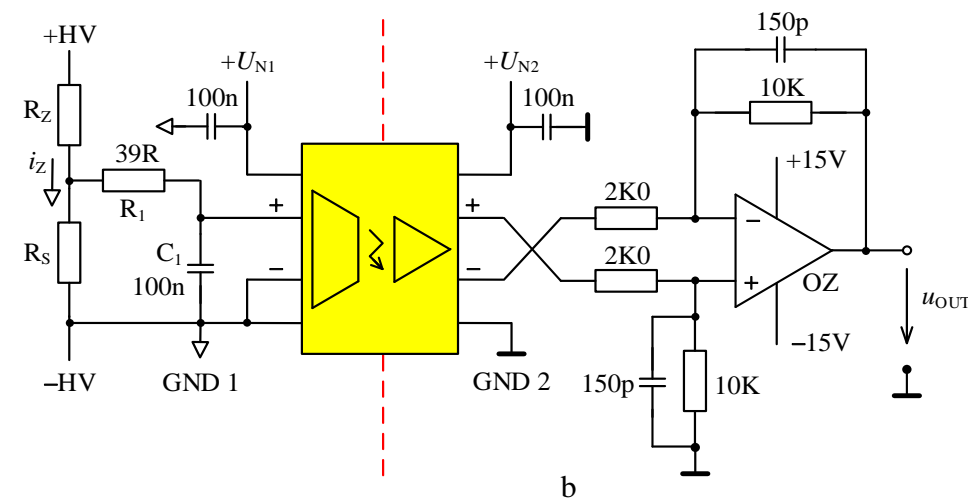

Obr. 4.13: Integrovaný izolační zesilovač, b) př́iklad použití při měření proudu zátěží v okruhu vysokého napětí

Izolační zesilovače se užívají pro měření na živých objektech nebo pro sledování proudu ve vinutí elektrických motorů, které pracují se sít'ovým napětím. $\mathrm{Na}$ Obr. 4.13 b je príklad snímání proudu zátěží $\mathrm{R}_{\mathrm{Z}} \mathrm{v}$ okruhu vysokého napětí pomocí snímacího rezistoru $\mathrm{R}_{\mathrm{S}}$. Dolní propust $\mathrm{R}_{1} \mathrm{C}_{1}$ slouží jako pomocný filtr pro potlačení rušení. Rozdílový zesilovač s operačním zesilovačem slouží k zesílení výstupního napětí a k převedení diferenčního výstupu izolačního zesilovače na jednoduchý výstup vztažený vůči zemi GND 2.

\subsection{Galvanické oddělení impulsními transformátory}

Pro oddělení signálů s rychlým sledem změn úrovní je možné ke galvanickému oddělení dvou obvodů využít také magnetické pole impulsního transformátoru. I když jsou impulsní transformátory ve srovnání s jinými typy oddělovacích členů rozměrnější, jsou schopny bez problémů pracovat i při teplotě $125{ }^{\circ} \mathrm{C}$. Oddělovací impulsní transformátory jsou obvykle realizovány s feritovým jádrem s vysokou permeabilitou. Impulsní transformátory realizované na toroidním jádře Obr. 4.14 kolem sebe sice vyzařují jen velmi slabé vf rušivé magnetické pole, ale protože primární a sekundární vinutí se obtížně odděluje, bývá izolační napětí jen 1 $\mathrm{kV}$. Vyšší izolační napětí až $5 \mathrm{kV}$ se dá docílit u impulsních transformátorů s obdélníkovým jádrem Obr. 4.14b), kdy primární i sekundární vinutí jsou navinuty na feritovém jádře ve tvaru I a magnetický obvod je uzavřen třmenem ve tvaru U. Protože magnetický obvod není uzavřen tak dokonale, jako je tomu u toroidního jádra, má vyzařování vf rušivého magnetického pole vyšší úroveň. Pro různá zapojení lze dohledat transformátorky s řadou variantních provedení primárních a sekundárních vinutí. Několik př́kladů je uvedeno na Obr. 4.14. 

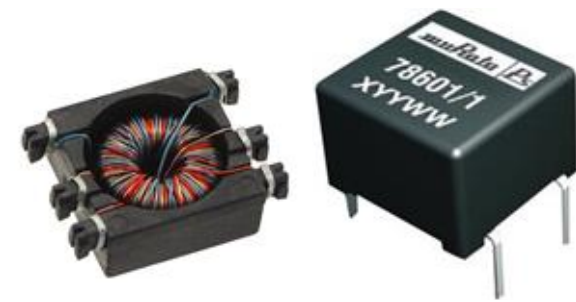

a
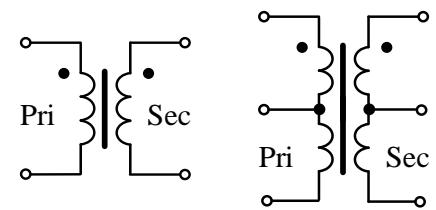
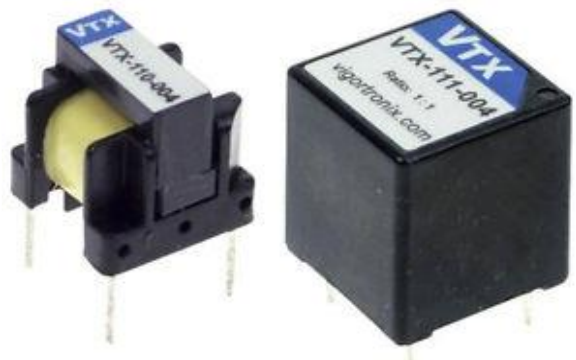

b

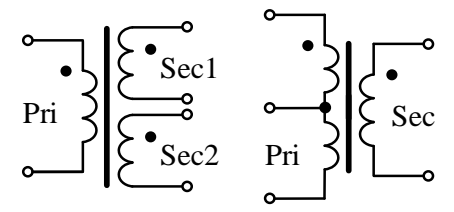

Obr. 4.14: Provedení impulsních transformátorů: a) na toroidním jádře, b) na obdélníkovém jádře, c) zapojení vinutí (př́klady)

Impulsní transformátory se užívají např. pro galvanické oddělení budičů tranzistorových spínačů, nebo pro oddělení ovládacích obvodů tyristorových spínačů. Také se užívají pro oddělení datových signálů v galvanicky oddělených vstupních částech digitálních multimetrů, měřičů činitele přenosu, nebo digitálních spektrálních analyzátorů. Použití ale také nacházejí jako transformátory $\mathrm{v}$ galvanicky izolovaných impulsně řízených zdrojích menších výkonů, nebo pro realizaci galvanicky izolovaných rozhraní RS-422, RS-485 aj.

\section{Galvanické oddělení spínacích obvodi̊}

Př́ḱlad zapojení galvanicky odděleného tyristorového spínače je na Obr. 4.15ł. Pokud na vstup bude přivedena úroveň $\mathrm{H}$, tranzistor $\mathrm{T}_{1}$ se sepne a na sekundárním vinutí se objeví impuls, který sepne diodu $\mathrm{D}_{2}$ a následně se impuls objeví na ř́́dicí elektrodě tyristoru a tyristor se sepne. Odporem rezistoru $\mathrm{R}_{2}$ se nastavuje proud řídicí elektrodou tyristoru. Bude-li na vstup přivedena úroveň $\mathrm{L}$, tranzistor $\mathrm{T}_{1}$ se rozpojí. Protože energie naakumulovaná v magnetickém poli během sepnutí tranzistoru udržuje proud cívkou stejným směrem jako při sepnutém tranzistoru $T_{1}$, sepne se dioda $D_{1}$ a akumulovaná energie je záměrně přeměňována na teplo v Zenerově diodě. Rychlost demagnetizace je určena hodnotou Zenerova napětí $U_{\text {ZD1. Jakmile }}$ se tento děj ukončí, ukončí se i impuls na sekundární straně vinutí. Úkolem rezistoru $\mathrm{R}_{3}$ pak je, aby ve vypnutém stavu ,zkratoval“ rídicí elektrodu s katodou tyristoru, protože řídicí elektroda nesmí zůstat odpojena. Cím je odpor rezistoru $\mathrm{R}_{2}$ menší, tím má tyristor ve vypnutém stavu větší odolnost proti nechtěnému sepnutí.

Galvanicky oddělený spínač s tranzistorem MOS FET může být zapojen podle Obr. $4.15 b$. Vstupní část pracuje shodně jako $\mathrm{v}$ předchozím případě. Jakmile se na sekundárním vinutí objeví napětí, otevřou se diody $\mathrm{D}_{2}$ a $\mathrm{D}_{3}$. Kondenzátory $\mathrm{C}_{1}$ a $\mathrm{C}_{2}$ se nabijí přibližně na napětí $22 \mathrm{~V}$, prričemž jejich napětí se přerozdělí podle napětí paralelně připojených Zenerových diod. Na kolektoru tranzistoru $\mathrm{T}_{2}$ bude maximálně napětí dané součtem napětí na Zenerových 


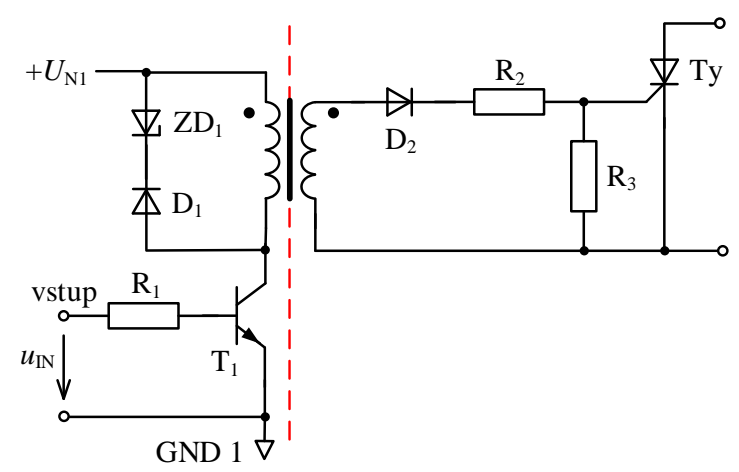

a

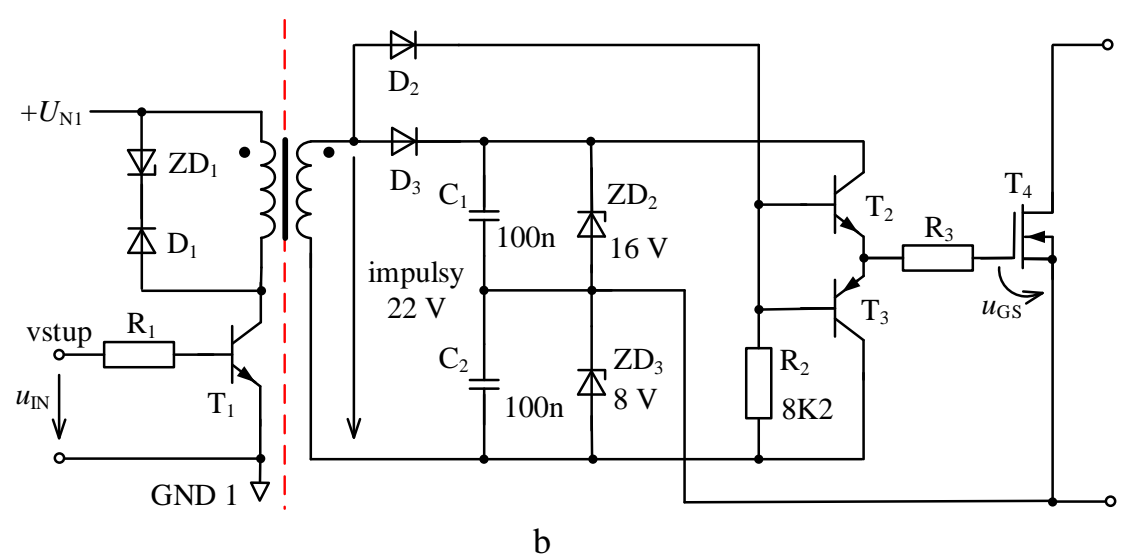

Obr. 4.15: Galvanicky oddělené spínače: a) tyristorový spínač, b) spínač s tranzistorem MOS FET

diodách $\mathrm{ZD}_{1}$ a $\mathrm{ZD}_{2}$, tj. $24 \mathrm{~V}$. Součet napětí obou Zenerových napětí musí být přitom mírně větší než velikost napět'ového impulsu $22 \mathrm{~V}$ na sekundárním vinutí, aby vinutí nepracovalo do zkratu. Proud sepnutou diodou $\mathrm{D}_{2}$ způsobí na rezistoru $\mathrm{R}_{2}$ takové napětí, že se tranzistor $\mathrm{T}_{2}$ sepne a na ř́́dicí elektrodě tranzistoru $\mathrm{T}_{4}$ se přitom vytvoří kladné napětí $u_{\mathrm{GS}} \approx+15 \mathrm{~V}$, které sepne tranzistor MOS FET. Zenerovy diody $Z_{2}$ a $Z_{3}$ slouží k rozdělení celkového sekundárního napětí na dvě definované části. Jakmile impuls $22 \mathrm{~V}$ na sekundární straně skončí, jsou tranzistory $T_{2}$ a $T_{3}$ napájeny pouze $z$ nabitých kondenzátorů $C_{1}$ a $C_{2}$. Tranzistor $T_{2}$ se přitom rozpojí a sepne se naopak tranzistor $\mathrm{T}_{3}$ a na ř́dicí elektrodě tranzistoru $\mathrm{T}_{4}$ bude nyní napětí $u_{\mathrm{GS}} \approx-7 \mathrm{~V}$, které tranzistor MOS FET rozpojí. Parazitní kapacita tranzistoru MOS FET $C_{\mathrm{GS}}$ se přitom vybíjí přes ,zpomalovací“ rezistor $\mathrm{R}_{3}$, jehož odpor v rozmezí $10 \Omega$ až $150 \Omega$ musí vždy doporučit výrobce. $V$ době vypnutí jsou tranzistory $\mathrm{T}_{2}$ a $\mathrm{T}_{3}$ napájeny pouze z nabitých kondenzátorů. Kondenzátory se dobíjejí v době sepnutí spínače.

\section{Galvanické oddělení digitálních signálů}

Pro galvanické oddělení logických signálů se užívají impulsní transformátorky realizované na miniaturním feritovém toroidním jádře s vysokou permeabilitou. Většinou se na primární i sekundární straně vystačí s cívkami s několika málo závity ( 5 až 10 závitů). Příklad galvanického oddělení logických signálů s využitím magnetického pole impulsního transformátorku je uveden na Obr. 4.16ł. Pro vybuzení primárního vinutí se užívá nejčastěji logický člen schopný dodat dostatečný proud do zátěže tvořené ochranným rezistorem $\mathrm{R}_{1} \mathrm{v}$ sérii spojeným s primárním vinutím impulsního transformátorku. Odpor rezistoru $\mathrm{R}_{1}$ se volí tak, aby při úrovni $\mathrm{H}$ na výstupu logického členu nebyl překročen jeho povolený výstupní proud. 
Sekundární vinutí má střed vinutí připojen na dělič $\mathrm{R}_{2}, \mathrm{R}_{3}$, který má výstupní napětí nastaveno na střední úroveň mezi $\mathrm{H}$ a L použitých logických obvodů. Protože impulsní transformátorek přenáši pouze krátké impulsy při změně úrovně budicího číslicového signálu (viz průběhy na Obr. 4.16 ), je pro obnovu signálu za sekundární vinutí zapojen ještě klopný obvod RS. Přitom je samozřejmé, že napájení logického členu budiče a logických obvodů klopného obvodu RS je samostatné, galvanicky oddělené. $V$ některých případech, kdy dostačuje přenášet pouze informaci o nástupné hraně číslicového signálu ve tvaru úzkého jehlového impulsu, je na sekundární straně impulsního transformátorku pouze jednoduché vinutí, ochranná dioda a logický člen.

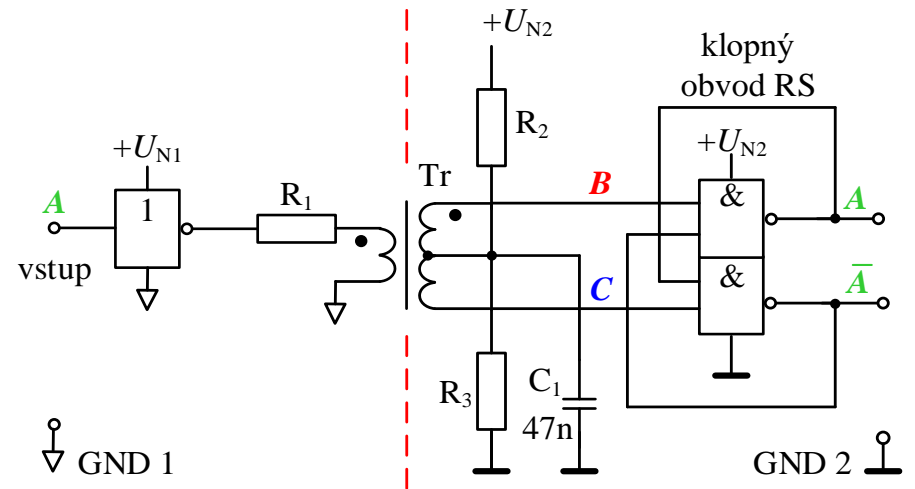

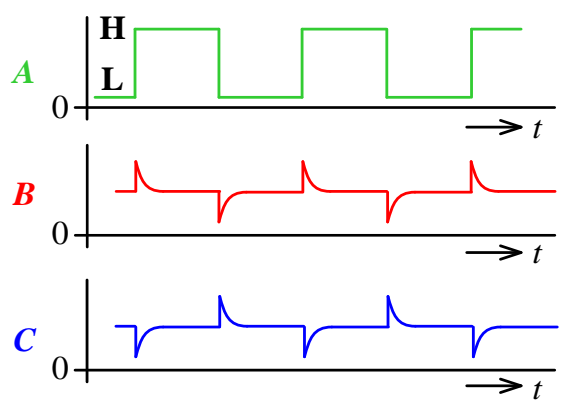

b

Obr. 4.16: a) Galvanické oddělení logického signálu pomocí impulsního transformátorku,

b) časové průběhy

Nevýhodou při užití toroidního jádra způsobu je, že se jen obtížně dociluje prostorové oddělení primárního a sekundárního vinutí tak, aby mezi ně mohlo být přiloženo zkušební napětí řádově několik kilovoltů, což je napětí zcela běžně předepisované normami pro provoz př́strojů se dvěma galvanicky oddělenými částmi. Obtížně se také potlačuje parazitní kapacita mezi primárním a sekundárním vinutím, která snižuje dosažitelný pracovní kmitočet celého uspořádání.

Uvedené nevýhody lze do značné míry odstranit zapojením digitálního oddělovacího členu podle Obr. 4.17 ł. Aktivujeme-li logický obvod budiče, bude kondenzátor $\mathrm{C}_{1}$ představovat pro nástupnou hranu signálu prakticky zkrat a změna výstupní úrovně budiče vyvolá v primárním vinutí impulsního transformátorku krátkodobou změnu magnetického pole. Odběr proudu z výstupu logického členu přitom omezuje rezistor $\mathrm{R}_{1}$. Změna magnetického pole se přenese jediným závitem nakrátko do impulsního transformátorku $\operatorname{Tr}_{2}$ přijímače. Nástupní hrana vstupního digitálního signálu vyvolá proto na sekundárním vinutí impulsního transformátorku $\operatorname{Tr}_{2}$ úzký jehlový impuls kladné polarity. Ten vybudí logický obvod přijímače, přičemž proces je urychlován kladnou zpětnou vazbou vedenou z výstupu logického obvodu před sekundární vinutí zpět na jeho vstup. Díky kladné zpětné vazbě zůstane signál na výstupu přijímače na úrovni $H$. Sestupná hrana vstupního číslicového signálu vyvolá naopak na sekundárním vinutí transformátorku $\operatorname{Tr}_{2}$ záporný jehlový impuls, který vyvolá překlopení logického obvodu přijímače na úroveň L. Přijímač je realizován logickým obvodem s otevřeným kolektorem na výstupu. Protože logický obvod pracuje pro urychlení překlápění jako zesilovač s kladnou zpětnou vazbou, je na jeho výstupu děličem $R_{1}, R_{2}$ nastavena přibližně polovina napájecího napětí. Aby při překlápění logického obvodu přijímače nedocházelo 


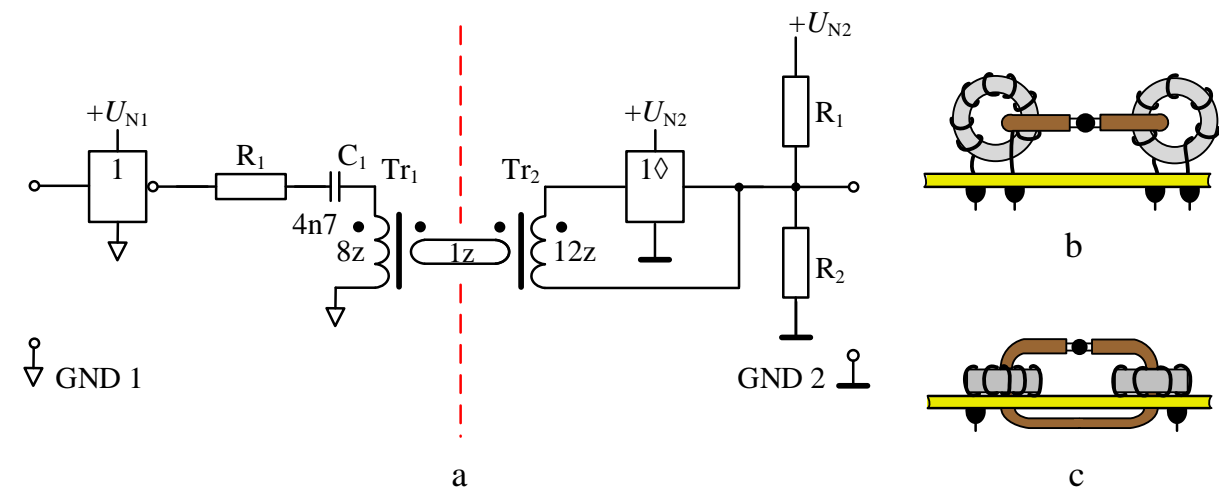

Obr. 4.17: a) Digitální oddělovací člen s velkou elektrickou pevností, b), c) způsob realizace impulsních transformátorků

k zákmitům výstupního napětí, musí být dělič dostatečně „tvrdý“ a proto se odpory rezistorů $\mathrm{R}_{1}$ a $\mathrm{R}_{2}$ volí malé.

Při realizaci lze pro oba impulsní transformátorky použít miniaturní toroidní jádra bez požadavků na elektrickou pevnost. Vysoká elektrická pevnost oddělovacího členu je zaručena jednoduchou vazební smyčkou ve tvaru závitu nakrátko, který lze snadno izolovat od ostatních vinutí. Přitom nedojde ke zmenšení magnetické vazby mezi oběma impulsními transformátorky. Prostorové oddělení budicí a přijímací části má také př́iznivý vliv na zmenšení parazitní kapacity mezi oběma částmi. Pro impulsní transformátorky je příhodné použít miniaturní toroidní jádro 6 až $8 \mathrm{~mm}$. Na primární vinutí impulsní transformátorku $\operatorname{Tr}_{1}$ budiče dostačuje pouze 8 závitů a na sekundární vinutí transformátorku $\operatorname{Tr}_{2}$ pak 12 závitů. Závit nakrátko je vhodné provést např. vodičem s polytetrafluóretylénovou izolací. Elektrická pevnost je pak vyšší než $4 \mathrm{kV}$. Dva příklady řešení takovýchto impulsních transformátorků jsou nakresleny na Obr. 4.17 ,c.

K dispozici jsou i integrované digitální izolátory s impulsními transformátorky. Jsou vyráběny CMOS technologií s monolitickými vzduchovými impulsními transformátorky. Obvykle jsou k dispozici 4 datové kanály v různých konfiguracích. Jeden typ konfigurace je uveden na Obr. 4.18. Výrobce doporučuje oba napájecí př́ivody $U_{\mathrm{N} 1}$ a $U_{\mathrm{N} 2}$ zablokovat co nejblíže k pouzdru keramickými kapacitory $100 \mathrm{nF}$. Přenosová rychlost datových kanálů bývá až $90 \mathrm{Mb} / \mathrm{s}$. Obě napájecí napětí $U_{\mathrm{N} 1}$ a $U_{\mathrm{N} 2}$ mohou být v rozmezí 2,7 V až 5,5 V. Obvod je schopen činnosti i při teplotě $125^{\circ} \mathrm{C}$, kdy jiné typy oddělovacích členů již selhávají. 


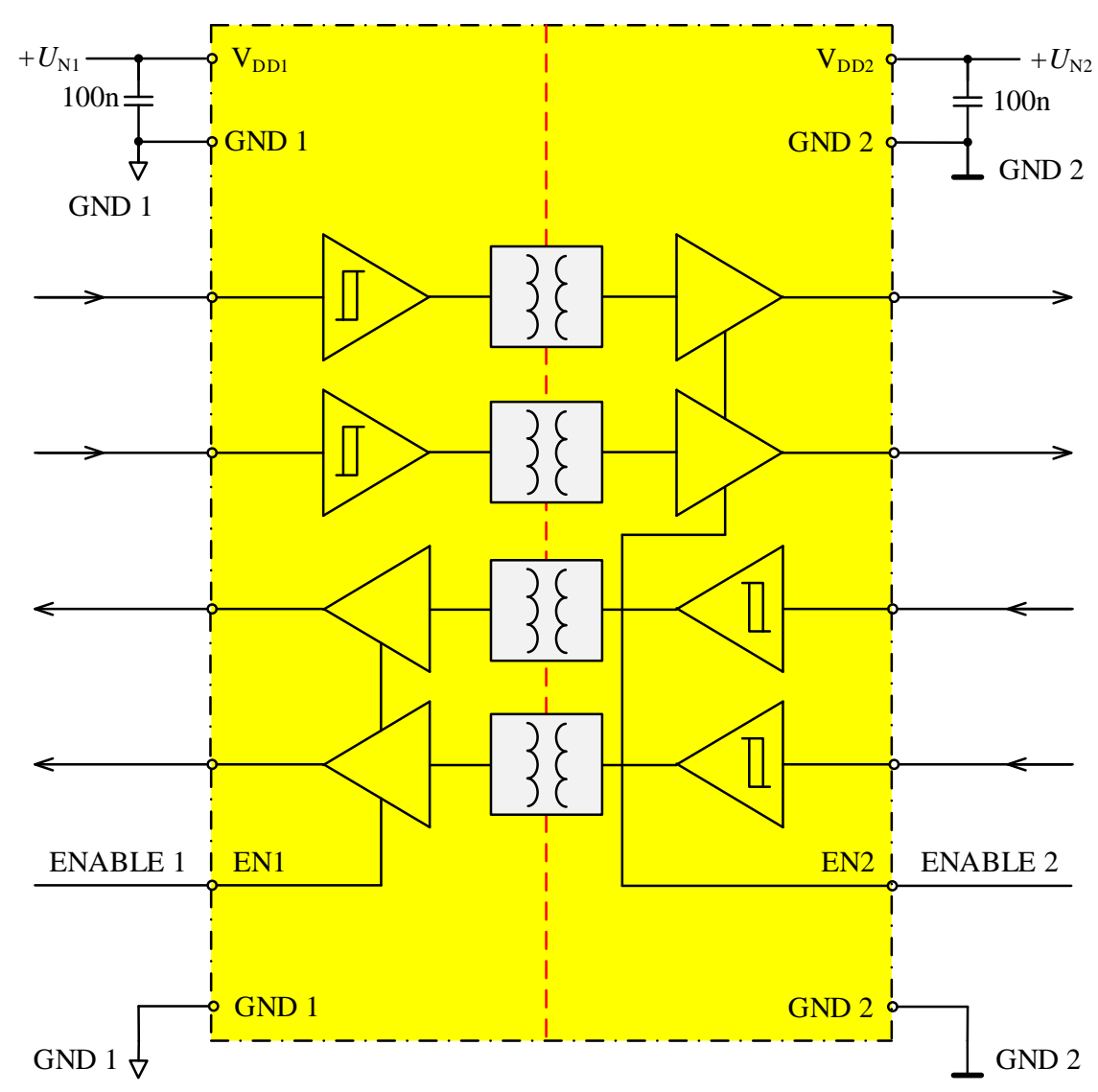

Obr. 4.18: Digitální izolátor s impulsními transformátorky

\subsection{Galvanické oddělení vysokonapět'ovými kapacitory}

Pro galvanické oddělení dvojúrovňových signálů se dají použít také oddělovací či vazební kapacitory. Hlavním problémem při užití kapacitorů je však požadavek na vysoké izolační napětí. Většinou se pro oddělení digitálních signálů užívají vysokonapětové kapacitory na bázi oxidu křemičitého $\left(\mathrm{SiO}_{2}\right)$. Digitální izolátory s vysokonapětovými kapacitory používají dvě základní architektury založené jednak na přenosu hran impulsů a jednat na přenosu harmonického signálu o vysokém nosném kmitočtu modulovaného logickým signálem, tzv. modulace klíčováním.

\section{Digitální izolátory s přenosem hran impulsů}

Koncepce digitálního izolátoru využívajícího k oddělení digitálních signálů přenos hran impulsů je uvedena na Obr. 4.19. Vstupní signál $T X$ se zpracovává ve dvou kanálech. Vysokofrekvenční kanál je schopen přenášet data s rychlostí od $100 \mathrm{~kb} / \mathrm{s}$ až $150 \mathrm{Mb} / \mathrm{s}$. Nízkofrekvenční kanál je určen pro přenos od ss signálů až rychlost přenosu $100 \mathrm{~kb} / \mathrm{s}$.

Ve vf kanále je vstupní signál $T X$ převeden na diferenční signály TXP a TXN. Následují derivační CR články přenesou pouze hrany těchto signálů ve formě jehlových impulsů, které jsou následně do logických úrovní převedeny dvěma komparátory s hysterezí. Z výstupư komparátorů jsou impulsy vedeny na klopný obvod RS, na jehož výstupu získáme obnovený logický signál, který je přiveden na vstup multiplexeru MUX. Současně se u obnoveného signálu v obvodu „vyhodnocení doby trvání impulsu“ měří doba mezi nástupnou a sestupnou branou impulsu. Pokud doba trvání impulsu překročí stanovenou dobu odpovídající vf signálu, 
obvod „vyhodnocení doby trvání impulsu“ dá pokyn multiplexeru MUX, aby se digitální izolátor přepnul na nf kanál.

Protože vstupní signály o nízkém kmitočtu by vyžadovaly oddělovací kondenzátory s nepřiměřeně velkou kapacitou, jsou nf vstupním signálem modulovány pulsní šířkovou modulací (PWM) nosné kmity interního oscilátoru (OSC). Přenos hran impulsů přes derivační články a další zpracování je obdobné jako ve vf kanále. Protože na konci řetězce nf kanálu je zapotřebí odstranit nosné kmity, je před multiplexerem ještě zařazena dolní propust.

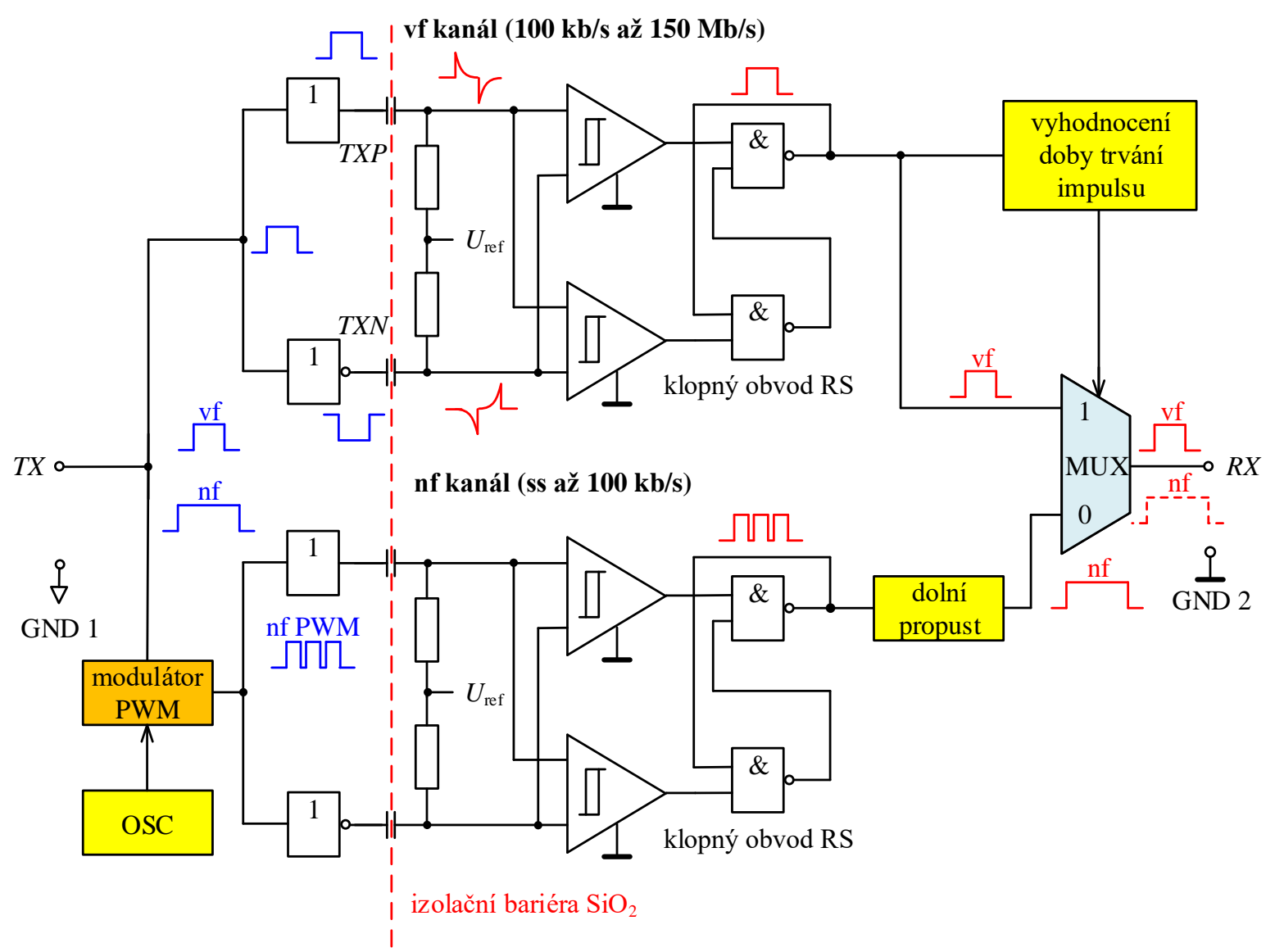

Obr. 4.19: Digitální izolátor s vysokonapět’ovými kapacitory využivající princip přenosu hran impulsů

\section{Digitální izolátory s klíčováním harmonického signálu}

Architektura digitálního izolátoru, ve které je signál interního oscilátoru modulován vstupním logickým signálem metodou označovanou jako klíčování, je naznačena na Obr. 4.20. Logická úroveň H je representována při přenosu signálem o nosném kmitočtu, při úrovni L se pak žádný signál nepřenáší. Modulovaný signál se převede na diferenční signál TXP a TXN a vysílačem je přenesen oddělovacími kapacitory do přijímače. Signál je pak zesílen a v demodulátoru obálky převeden zpět na logický signál $R X$. 

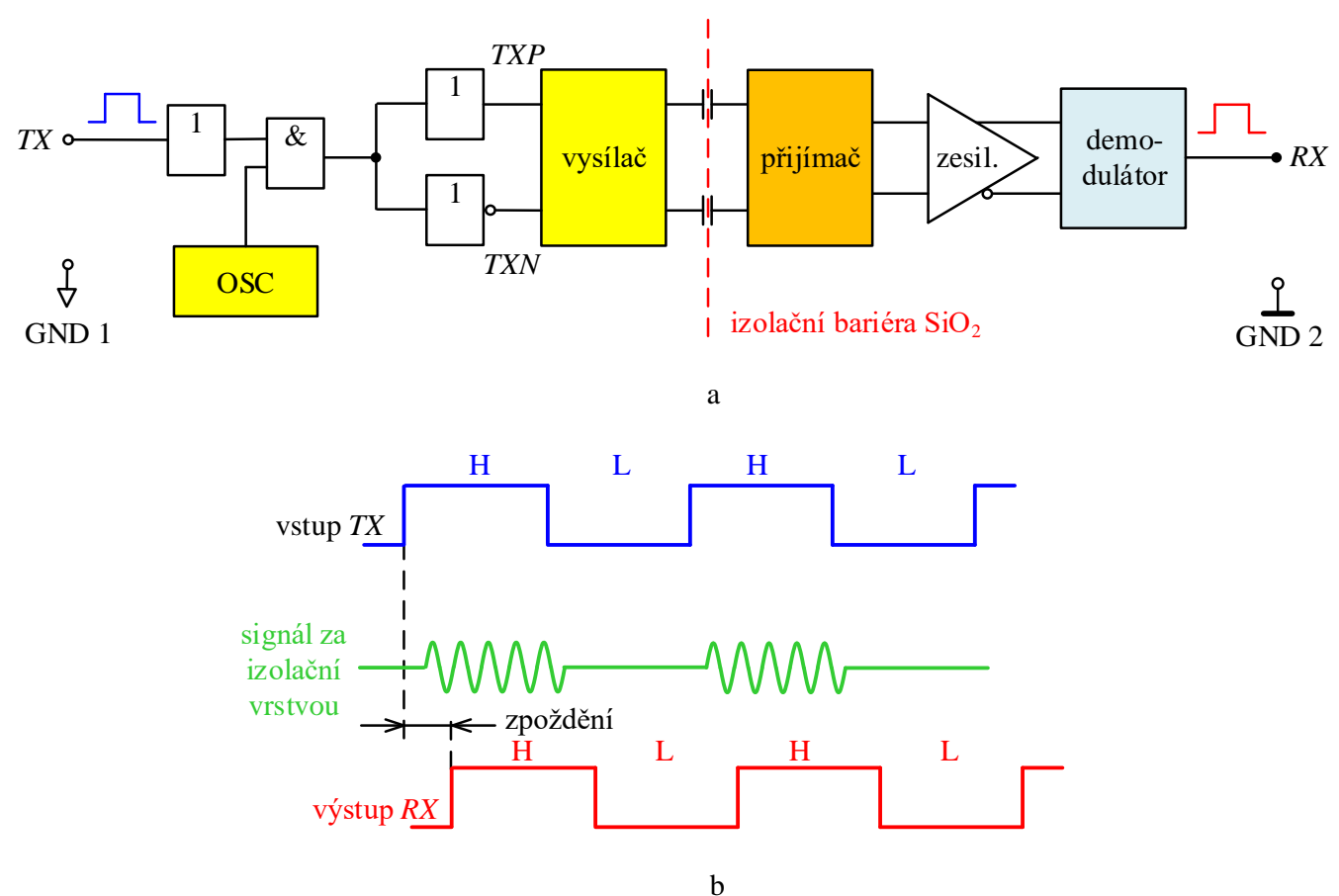

Obr. 4.20: Digitální izolátor s klíčováním vf signálu

\section{Integrované digitální izolátory s vysokonapět’ovými kapacitory}

Digitální izolátory s vysokonapět’ovými kapacitory se dodávají jako integrované obvody. V jednom integrovaném obvodě jsou většinou 4 galvanicky oddělené digitální kanály. K dispozici je celá řada konfigurací datových kanálů. Jedna z možných variant je uvedena na Obr. 4.21, kde je naznačeno zjednodušené schéma digitálního čtyřkanálového izolátoru. Výrobce doporučuje oba napájecí př́vody $U_{\mathrm{N} 1}$ a $U_{\mathrm{N} 2}$ zablokovat co nejblíže u pouzdra kapacitory $10 \mu \mathrm{F}\|1 \mu \mathrm{F}\| 100 \mathrm{nF}$. Vývody EN1 resp. EN2 (Output Enable) umožňují řídit třístavové výstupy digitálních kanálů, tzn. určují zda na výstupech kanálu je úroveň $\mathrm{H}$ či L, nebo výstupy jsou ve stavu s vysokou impedancí. Digitální izolátory s vysokonapětovými kapacitory dosahují přenosovou rychlost až $150 \mathrm{Mb} / \mathrm{s}$. Napájecí napětí bývá z rozmezí $2,25 \mathrm{~V}$ až $5,5 \mathrm{~V}$, izolační napětí bývá z rozmezí $4 \mathrm{kV}$ až $8 \mathrm{kV}$. Používají se $\mathrm{k}$ izolaci datových sběrnic pro průmyslovou automatizaci, pro medicinské systémy, pro izolaci sběrnic RS - 232, $\mathrm{RS}-422, \mathrm{RS}-485$ aj.

\section{Konstrukční doporučení pro digitální izolátory}

Aby se docílilo co nejmenší vf rušení, jsou pro připojení digitálního izolátoru nutné minimálně čtyři vrstvy DPS (viz Obr. 4.22). Skladba vrstev by shora dolů měla být v tomto pořadí: vysokorychlostní spoje, zemnicí vrstva, vrstva rozvodu napájení, nízkorychlostní spoje. Vedení vysokorychlostních spojů po horní straně DPS cíleně zabraňuje použití prokovených otvorů, které do vysokorychlostního spoje vnášejí nežádoucí parazitní indukčnosti. Vložení zemnicí vrstvy pod vrstvu vysokorychlostních spojů umožňuje vytvoření charakteristické impedance pro přenosové vedení. Současně je vytvořena pro zpětný proud krátká cesta s malou indukčností. Vrstva napájecího rozvodu pod zemnicí rovinou vytváŕí přídavnou kapacitu, která působí jako zkrat pro vf rušení. U nízkorychlostních spojů v poslední vrstvě pak nevadí př́padné prokovené otvory. Pod pouzdrem digitálního izolátoru se doporučuje vyfrézovat drážku se šiřkou větší než $1 \mathrm{~mm}$, čímž se zvýší izolační povrchová vzdálenost. Tímto způsobem se sníží pravděpodobnost elektrického výboje na povrchu DPS, nebo v blízkosti jejího povrchu. 


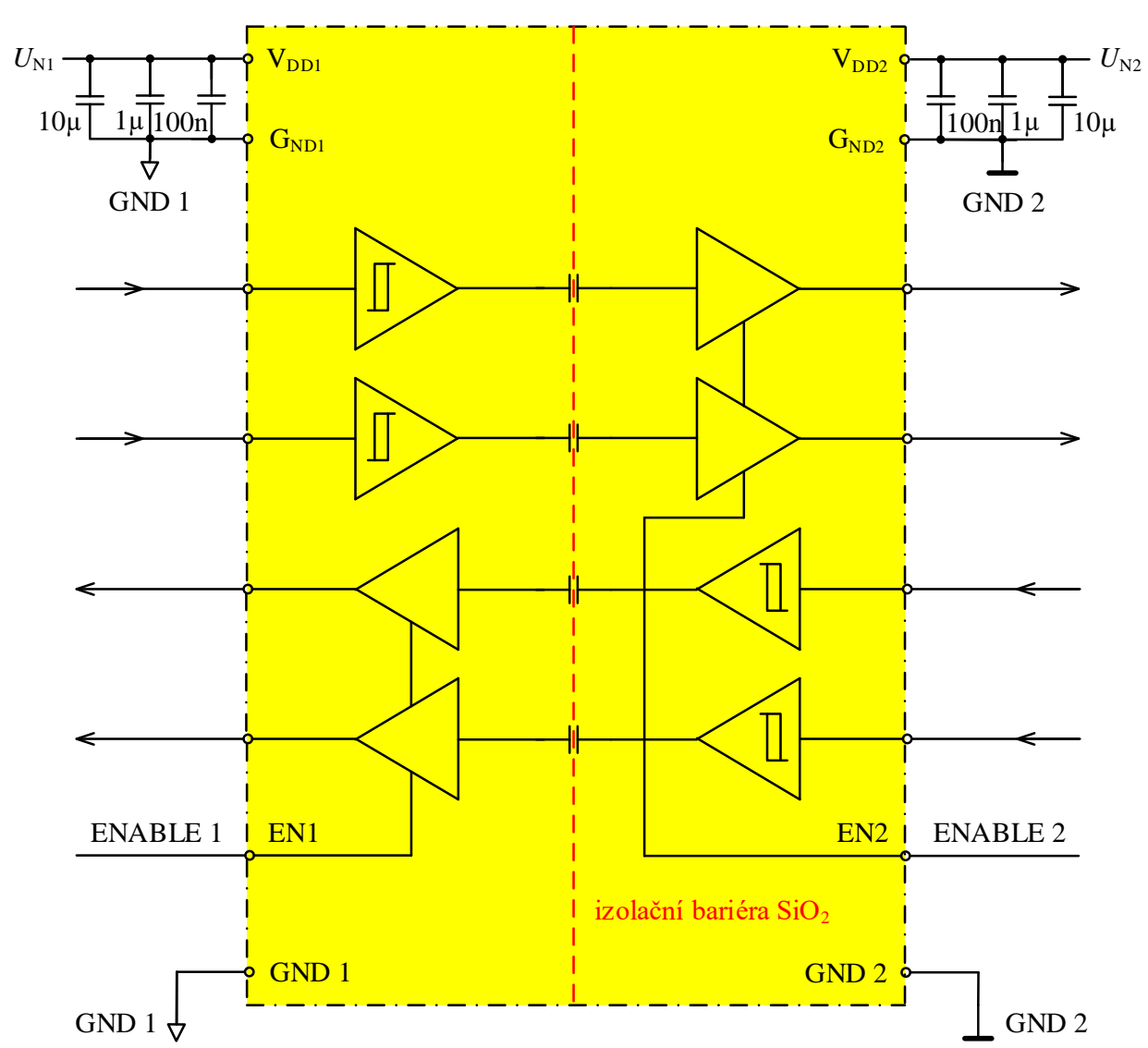

Obr. 4.21: Integrovaný digitální izolátor s vysokonapět’ovými kapacitory (zjednodušené schéma)

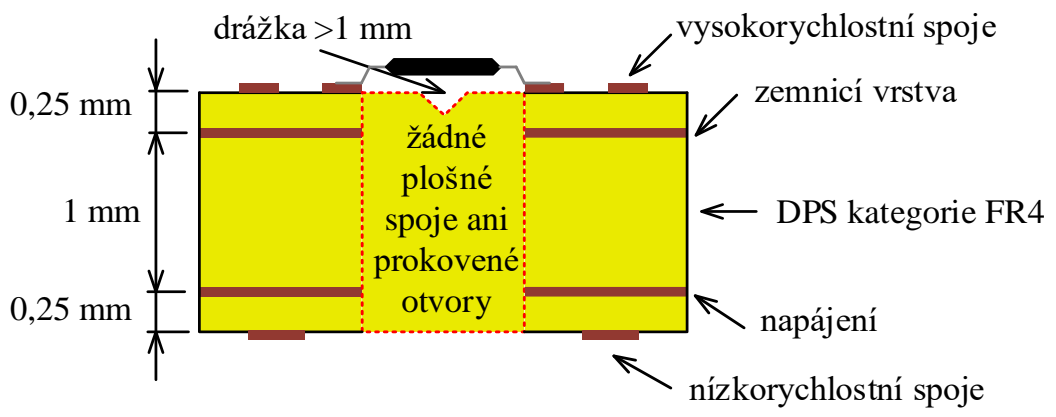

Obr. 4.22: Doporučené provedení DPS pro digitální izolátor s vysokonapět'ovými kapacitory

\subsection{Galvanické oddělení audiosignálů}

Nejčastější příčinou tzv. sít'ového brumu či bzučení je v audiozařízeních zemní smyčka mezi dvěma zařízeními, do které se indukují v části napájecího rozvodu rušivé signály o kmitočtu $50 \mathrm{~Hz}$ a v části signálových vodičů pak rozptylové pole sít'ového transformátoru. Brum (Hum) je v akustických zařízeních hlubokotónový hluk způsobený obvykle průnikem sít'ového kmitočtu $50 \mathrm{~Hz}$ do audiosignálu. Bzučení či pískání (Buzz) je pak způsobeno vyššími harmonickými složkami sít’ového kmitočtu (např. $450 \mathrm{~Hz}, 500 \mathrm{~Hz}, 550 \mathrm{~Hz}$ ). Pro úplnost poznamenejme, že bzučení či pískání audiozařízení může být způsobeno i jinými prŕíčinami, 
např. mechanickou závadou $\mathrm{v}$ reproduktoru. Na rozdíl od analogového šumu, který nemá detekovánu výšku tónu, se brum a bzučení vyznačují výškou tónu.

V zařízeních pro zpracování audiosignálů se pro oddělení dvou zařízení používá nf oddělovací transformátor, který bývá označován obvykle jako audio transformátor. Mimo galvanického oddělení slouží transformátor většinou i k vzájemnému impedančnímu přizpůsobení obou zařízení. Modulová kmitočtová charakteristika audio transformátoru má mít v kmitočtovém pásmu $20 \mathrm{~Hz}$ až $20 \mathrm{kHz}$ zvlnění modulové kmitočtové charakteristiky z(f) maximálně $\pm 1 \mathrm{~dB}$ (viz Obr. 4.23). Činitel nelineárního zkreslení signálu THD (Total Harmonic Distortion) bývá uveden pro referenční kmitočet $30 \mathrm{~Hz}$ nebo $50 \mathrm{~Hz}$ a někdy i $1 \mathrm{kHz}$, kdy činitel nelineárního zkreslení musí být lepší než $1 \%$. Kvalitnější typy oddělovacích nf transformátorů mají v rozmezí kmitočtů $20 \mathrm{~Hz}$ až $30 \mathrm{kHz}$ činitel nelineárního zkreslení pouze $0,0001 \%$.

Podle toho, ve které části zařízení je transformátor užit, rozlišujeme dva typy audio transformátorů: pro oddělení vstupních obvodů se používají malovýkonové transformátory (Line Input Transformers) a pro oddělení výstupu pak výkonové transformátory (Line Output Transformers).

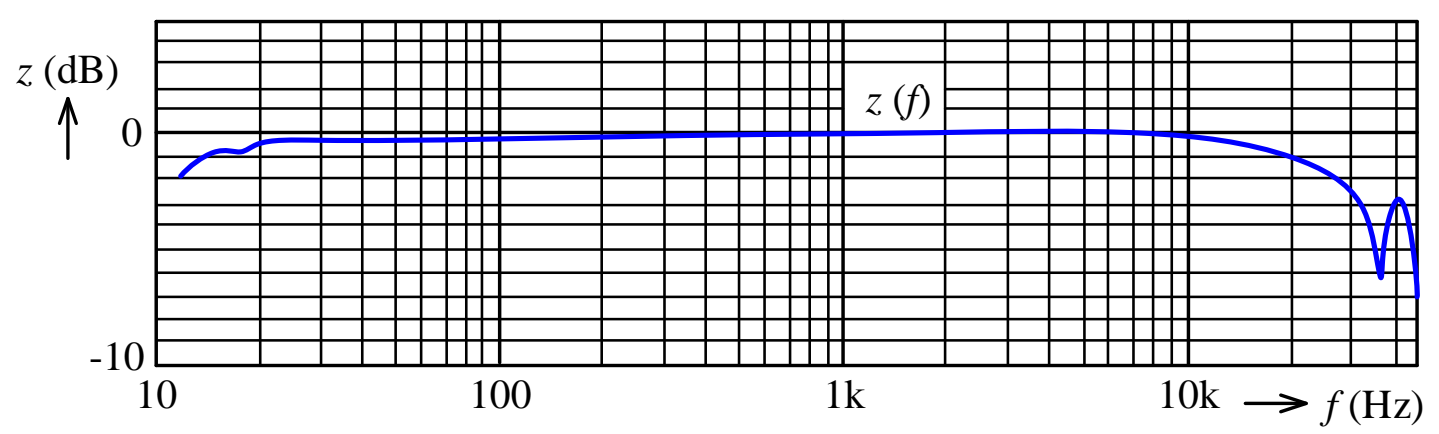

Obr. 4.23: Typická modulová kmitočtová charakteristika audio transformátoru

\section{Vstupní oddělovací nf transformátory}

Pomocí vstupních malovýkonových transformátorů se od vlastního zařízení většinou oddělují akustické snímače zejména pak nízkoimpedanční mikrofony, kdy transfomátor současně slouží k přizpůsobení impedancí. Příklad užití oddělovacího transformátoru v nízkošumovém mikrofonním zesilovači je uveden na Obr. 4.24. Mikrofonní vedení je transformátorem zcela galvanicky odděleno od vlastního zesilovače. Aby pro napájení mikrofonu nebylo nutno vést další vodiče, je použito tzv. „fantomové“ napájení, kdy potřebné ss napájecí napětí je vedeno př́ímo po signálových vodičích vlastního mikrofonního kabelu $\left(\mathrm{R}_{1}, \mathrm{R}_{2}, U_{\mathrm{N} 1}\right)$. Protože je známo, že šum zesilovače je nejmenší, když vstupní impedance zesilovače je rovna impedanci zdroje signálu, je na sekundární straně transformátoru namodelována impedance zdroje signálu pomocí paralelní impedance $R_{3} \|\left(R_{4}+C_{1}\right)$. $V$ př́padě užití nízkoimpedančního mikrofonu je pak nutno impedance na primární a sekundární straně transformátoru navzájem přizpůsobit. Proto transformátor nemusí mít nutně převodní poměr $1: 1$, ale např. $1: 10$. 


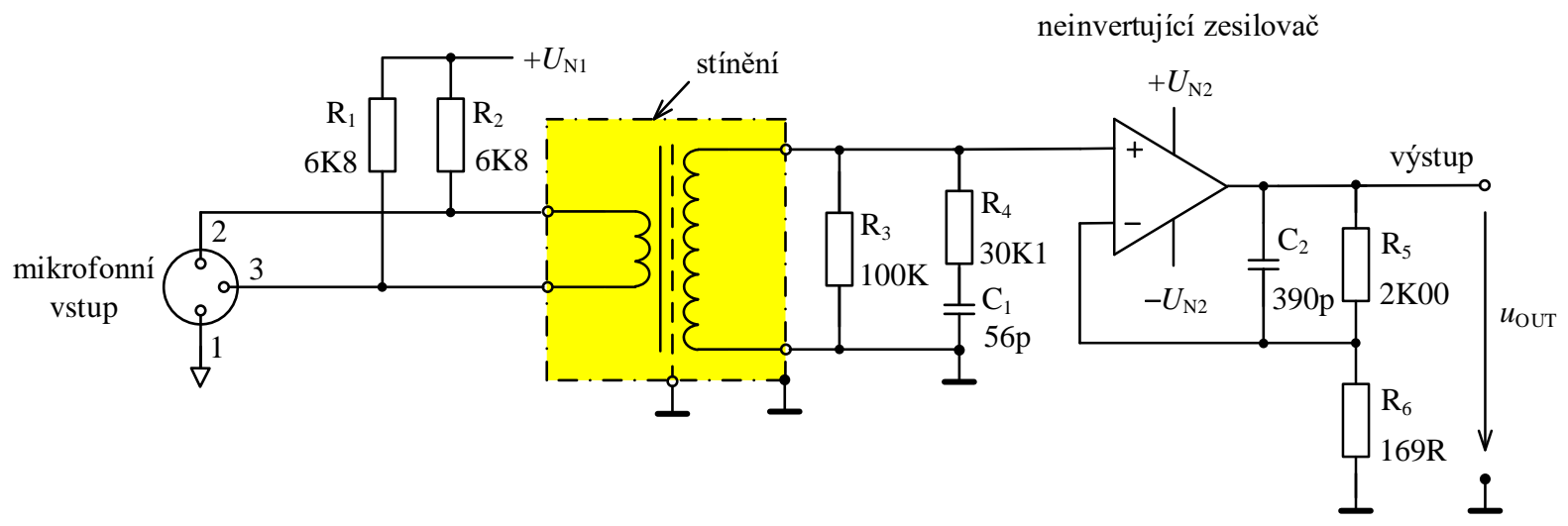

Obr. 4.24: Př́klad použití oddělovacího audio transformátoru v nízkošumovém mikrofonním zesilovači

K dispozici je celá řada malovýkonových audio transformátorů (viz Obr. 4.25 $\mathrm{s}$ různými převodními poměry, nebo na sekundárním vinutí jsou vyvedeny odbočky pro volbu převodního poměru. Pro náročnější aplikace jsou pak určeny oddělovací transformátory označované jako „studiové audio transformátory“, které mají navíc stínění z permaloye, které účinně potlačuje rušivá magnetická pole o sít’ovém kmitočtu $50 \mathrm{~Hz}$ Obr. 4.25b). Některé typy pak pro zmenšení parazitních kapacit mají mezi primární a sekundární vinutí vloženu stínicí fólii, kterou je nutno uzemnit.

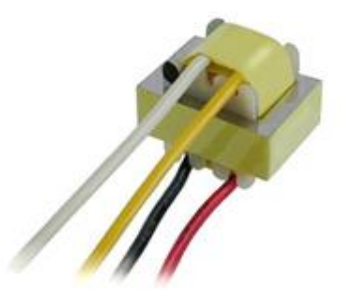

a

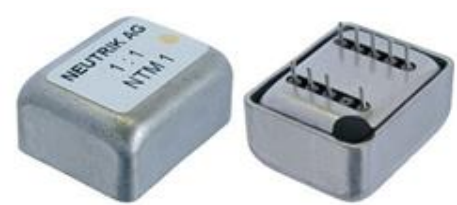

b

Obr. 4.25: Vstupní oddělovací nf transformátory: a) audio transformátor, b) studiový audio transformátor

Pro dodatečné galvanické oddělení stereosignálů, např. pro oddělení radiového přijímače a audiozesilovače, se užívají oddělovací stereotransformátory (viz Obr. 4.26 $)$ ). Bud' se transformátor dodatečně zapojí do propojovacích kabelů Obr. 4.26), nebo je již do propojovacích kabelů zabudován (Obr. 4.264).

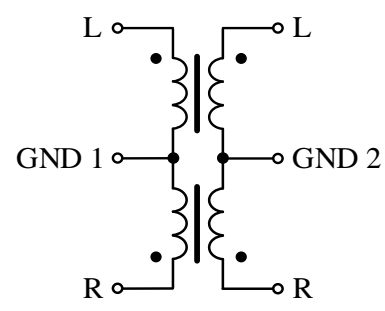

a

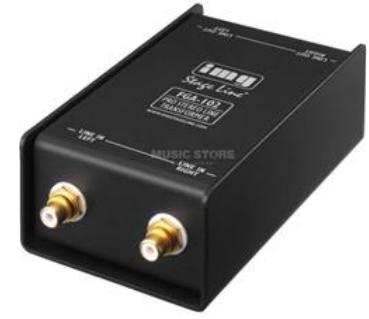

b

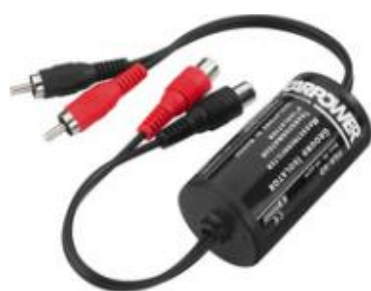

c

Obr. 4.26: Nf transformátor pro oddělení stereosignálů: a) zapojení, b) pro vložení do propojovacích vodičů, c) zabudovaný do propojovacího kabelu 


\section{Výstupní oddělovací nf transformátory}

Výstupní oddělovací transformátor (někdy také reproduktorový transformátor) se používá v audiotechnice k oddělení výkonové zátěže (reproduktoru) od vlastního audiozesilovače. Často je jako součást koncového výkonového stupně audiozesilovače pracujícího v zapojení „push-pull“. Používá se také v případě audiozesilovačủ s výstupním napětím až $100 \mathrm{~V}$, které se užívají při přenosu výkonového signálu do reproduktorové soustavy na vzdálenost až $100 \mathrm{~m}, \mathrm{z}$ důvodu menších ztrát na vodičích. Oddělovací transformátor je pak umístěn až v reproduktorové soustavě.

Užití výstupního oddělovacího audio transformátoru ukážeme na zjednodušeném zapojení výkonového zesilovače v zapojení „push-pull“ (viz Obr. 4.27). Na vstupu koncového stupně je transformátor $\operatorname{Tr}_{1}$, který má uzemněný střed sekundárního vinutí. Proto horní a dolní část sekundárního vinutí generují navzájem inversní signály pro tranzistory $T_{1}$ a $T_{2}$, které jsou oba stejného typu NPN. Aby se zmenšilo tzv. přechodové zkreslení výkonového stupně, je střed vinutí $\operatorname{Tr}_{1}$ připojen na předpětí $+0,8 \mathrm{~V}$, což zajistí, že tranzistory $\mathrm{T}_{1}, \mathrm{~T}_{2}$ se začnou otvírat již při malém kladném napětí na sekundárním vinutí.

Protože tranzistory jsou buzeny inversně, bude $T_{1}$ vést pro kladnou půlvlnu signálu a $T_{2}$ pro zápornou půlvlnu. Výstupní transformátor $\operatorname{Tr}_{2}$ kombinuje kladnou a zápornou část signálu, protože pro kladnou část signálu je $\mathrm{v}$ činnosti horní část primárního vinutí $\operatorname{Tr}_{1}$ a pro zápornou je pak v činnosti dolní část vinutí. Střed primárního vinutí $\operatorname{Tr}_{2}$ je přitom připojen na napájecí napětí $U_{\mathrm{N}}$. Výstupní transformátor současně slouží k impedančnímu přizpůsobení zátěže, kdy např. odpor reproduktoru $4 \Omega$, je na primární straně transformován např. na $1 \mathrm{k} \Omega$.

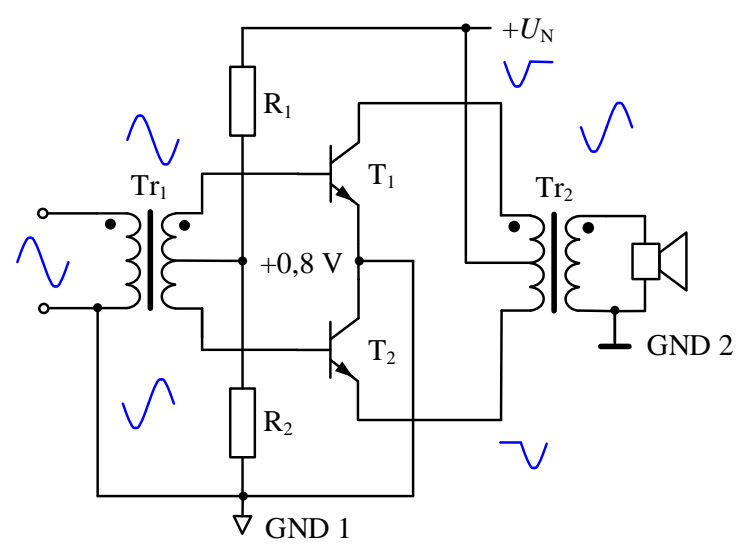

Obr. 4.27: Zjednodušené zapojení výkonového stupně audiozesilovače v zapojení „push-pull““

K dispozici je celá řada nf oddělovacích výkonových transformátorů. Často jsou v univerzálním provedení s odbočkami na sekundární straně, což umožňuje připojit různě velké zátěže (viz Obr. 4.28 l). Běžně jsou v nabídce výrobců oddělovací výkonové audiotransformátory realizované na jádře EI, některé typy jsou i se stíněním Obr. 4.28b). Méně často jsou prozatím v nabídce oddělovací transformátory na toroidních jádrech (Obr. 4.284). 


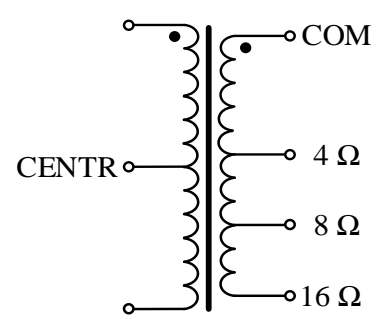

a

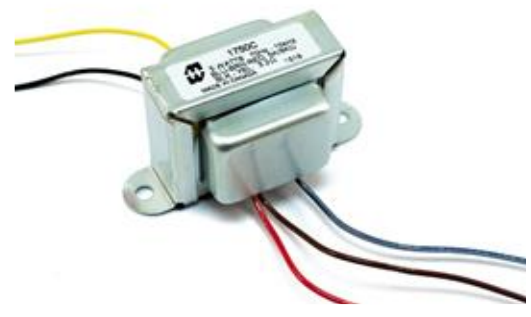

$\mathrm{b}$

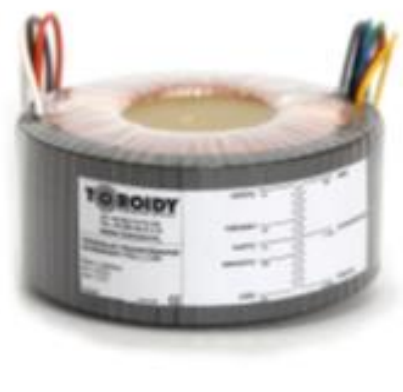

$\mathrm{C}$

Obr. 4.28: Oddělovací výkonové transformátory: a) univerzální s více odbočkami,

b) audiotransformátor na jádře EI se stíněním, c) na toroidním jádře 


\section{Použitá literatura}

[1] LEDOUX, N. Breaking ground loops with functional isolation to reduce data transmission errors. Technical article MS-2256. Analog Devices 2011

[2] AGILENT TECHNOLOGIES: Optocoupler-Designer's Guide. Agilent Technologies, 2002

[3] AVAGO: Overview of High Performance, Analog Optocouplers, Application Note 1157. Avago Technologies, 2011

[4] MURATA: General Purpose Pulse Transformers 786 Series. Murata Power Solutions, Inc. 2020

[5] TEXAS INSTRUMENTS: Digital Isolator Design Guide. Texas Instruments, 2018

[6] TEXAS INSTRUMENTS: ISO77xx Triple-and Quad-Digital Isolator Evaluation Module. Texas Instruments, 2016

[7] TEXAS INSTRUMENTS: ISO 773x High-Speed, Robust-EMC Reinforced TripleChannel Digital Isolator. Texas Instruments, 2016 


\section{Stínění}

V zařízeních pracujících s vyššími pracovními kmitočty je nutno používat různé druhy stínění. Nejčastěji konstruktér stojí před problémem odstínit elektrické nebo magnetické pole, řidčeji se setká se stíněním elektromagnetického pole (pouze v tzv. technice VKV). Metodika jednoduchého inženýrského výpočtu stínění neexistuje. Je to způsobeno jednak malou znalostí problému a především značnou obtížností matematického výpočtu podobných úloh. Pouze pro stínění jednoduchých tvarů existuje přesné řešení. V běžných př́ípadech se spokojujeme $\mathrm{s}$ kvalitativním posouzením jevu a s výsledky experimentu. V náročných prŕpadech se pak používá počítačová simulace založená na metodě konečných prvků.

Stínění je jednou ze základních metod, jak potlačit rušivé signály. Existují dva základní př́istupy jak realizovat stínění. První z nich je založen na myšlence stínit zdroj rušení. Prostor, ve kterém rušení působí, se snažíme omezit a uzavřít tak, aby se rušení nemohlo šírit mimo uzavřenou oblast. Napájecí a signální vodiče vedeme přes odrušovací filtry, které mají zamezit průniku nežádoucího signálu ze stíněné oblasti. Tímto způsobem se především stíní a odrušují různé motory, tyristorové usměrňovače, impulsně regulované zdroje apod. Druhý způsob spočívá na stínění citlivé části zařízení, zejména vstupních dílů. Stínění zamezuje průniku nežádoucích signálů do citlivých vstupních obvodů.

Rušivý signál může pronikat kapacitní nebo induktivní vazbou popř. nežádoucí vodivou drahou. Podle způsobu pronikání rozdělujeme stínění na elektrostatické (elektrické), na magnetické a na ekvipotenciální stínění proti svodovým či plíživým proudům. Při návrhu stínění musí být každý individuální př́pad samostatně pečlivě analyzován. V první frázi je nutno najít zdroje a přijímače rušení a možný způsob parazitní vazby. Nedokonalé či nesprávně provedené stínění, založené na nesprávném pochopení problému, může situaci zhoršit a navíc vyvolat nové problémy.

\subsection{Stínění elektrického pole}

Elektrické (elektrostatické) pole je idealizací. S takovým „čistým polem“ se obvykle nesetkáme, protože elektrické pole je vždy provázeno (i když slabým) magnetickým polem. Charakteristickou vlastností elektrického pole je, že v prostoru obklopeném ze všech stran uzavřenou vodivou plochou pole chybí, i když je tato plocha nabita na vysoký potenciál nebo, i když se taková uzavřená plocha nachází v libovolně silném elektrickém poli. Tento jev se vysvětluje ekvipotenciálními vlastnostmi uzavřené vodivé plochy obklopující daný prostor. Účinek elektrického pole, popřr. elektrické vazby mezi jednotlivými objekty, umístěnými $\mathrm{v}$ prostoru, je dán rozložením elektrických siločar v daném prostředí. Pro kvantitativní hodnocení je však jednodušší a názornější modelování těchto elektrických vazeb pomocí modelových kapacitorů, jejichž kapacity jsou úměrné parazitním elektrickým vazbám mezi objekty v daném prostoru (viz Obr. 5.1). O př́tomnosti této vazby se můžeme přesvědčit napřr. tak, že mezi zdroj rušení (A) a přijímač (B) vložíme kovovou destičku (mnohdy stačí i kapacita vložené ruky), která změní rozložení elektrického pole. Změní-li se takovým zásahem podstatně vlastnosti obvodu, musíme začít uvažovat o elektrostatickém stínění. 

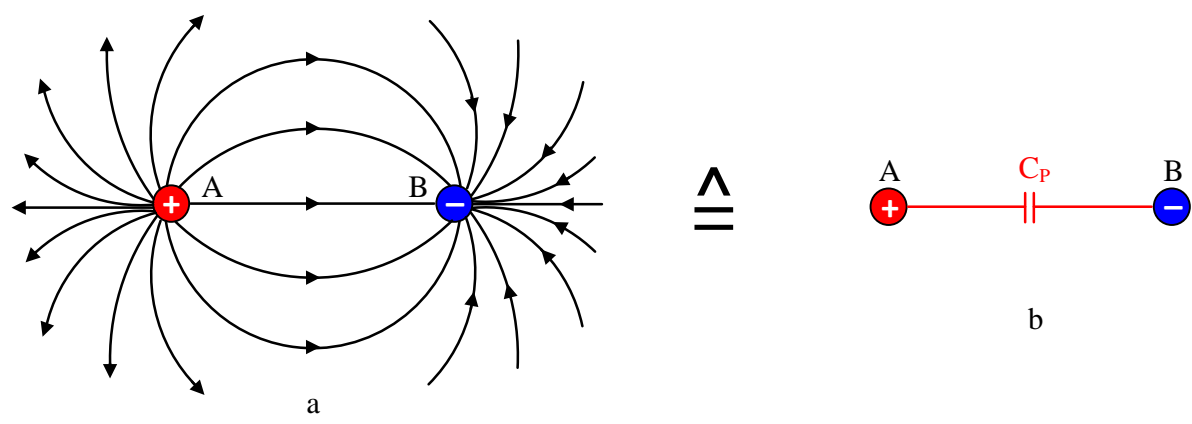

Obr. 5.1: a) Rozložení elektrických siločar mezi dvěma objekty s různými potenciály,

b) modelování elektrické vazby pomocí parazitní kapacity

\subsubsection{Elektrostatické stínění obvodů}

Vazba mezi dvěma obvody A a $B$ je v Obr. 5.2 charakterizována kapacitorem $C_{P}$, kapacitor $\mathrm{C}_{v}$ modeluje kapacitu obvodu $\mathrm{B}$ vǔči uzemněné kovové desce (konstrukci). Princip stínění elektrického pole spočívá ve zmenšení průniku rušivého napětí $u_{\mathrm{R}}$ ze zdroje do přijímače rušení (vodiče nebo obvodové prvky). Jestliže mezi těmito prvky není žádné stínění (viz Obr. 5.2ł), bude parazitní napětí $u$ P vyvolané zdrojem rušení $\mathrm{A} v$ místě přijímače $\mathrm{B}$ mít velikost danou dělicím poměrem kapacitorového děliče $C_{P}, C_{V}$

$$
u_{\mathrm{P}}=\frac{C_{\mathrm{P}}}{C_{\mathrm{V}}+C_{\mathrm{P}}} u_{\mathrm{R}} .
$$

Bude-li přijímač rušení B blíže $\mathrm{k}$ zemnicí ploše než je vzdálenost vysílače $\mathrm{A}$ a přijímače $\mathrm{B}$, bude $C_{\mathrm{V}}>C_{\mathrm{P}}$ a pak

$$
u_{\mathrm{P}} \approx \frac{C_{\mathrm{P}}}{C_{\mathrm{V}}} u_{\mathrm{R}}
$$

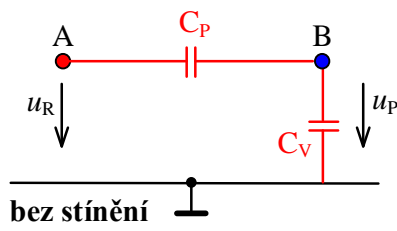

a

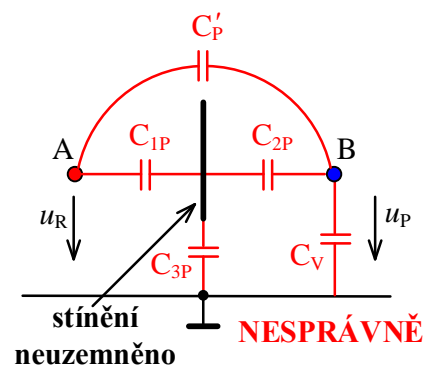

b

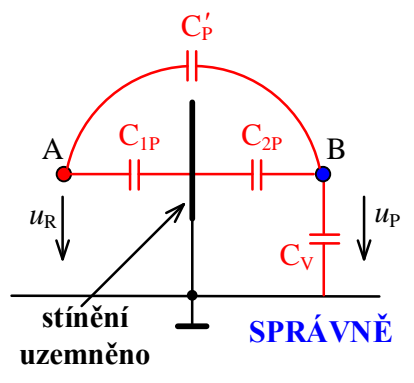

C

Obr. 5.2: Parazitní kapacitní vazby: a) bez stínění, b) s neuzemněným stíněním,

c) s uzemněným stíněním 
Diskuze tohoto vztahu ukazuje, že napětí $u_{\mathrm{P}}$ vyvolané rušivým napětím $u_{\mathrm{R}}$ bude tím menší, čím menší bude vzájemná kapacita $C_{P}$ ( $\mathrm{tj}$. čím dále od sebe budou body $\mathrm{A}$ a $\mathrm{B}$ ) a čím větší bude kapacita $C_{V}$ (tj. čím blíže bude bod $\mathrm{B}$ k uzemněné kovové desce). $\mathrm{Z}$ těchto elementárních úvah vyplývají také základní doporučení pro konstrukci zařízení. Zdroj rušení a citlivé obvody v zařízení se doporučují umístit co nejdále od sebe např. vstupní zesilovače se v zařízení umíst’ují co nejdále od impulsně regulovaného napájecího zdroje. Citlivé obvody se pak umíst'ují co nejblíže ke kovové konstrukci přístroje.

Vložíme-li mezi zdroj rušení A a přijímač B stínicí kovovou přepážku nespojenou se zemnicí plochou Obr. 5.2b), sníží se sice původní parazitní kapacita $C_{\mathrm{P}}$ na parazitní kapacitu $C_{\mathrm{P}}$, která je o řád menší než kapacita $C_{\mathrm{P}}$, ale vzniknou další parazitní kapacity o hodnotě rádově shodné s původní kapacitou $C_{\mathrm{P}}$. Zanedbáme-li parazitní kapacitu $C_{\mathrm{P}}{ }_{\mathrm{P}}$, bude v místě přijímače $\mathrm{B}$ nyní rušivé napětí

$$
u_{\mathrm{P}} \approx \frac{C_{1 \mathrm{P}}}{C_{1 \mathrm{P}}+C_{3 \mathrm{P}}+\frac{C_{2 \mathrm{P}} C_{\mathrm{V}}}{C_{2 \mathrm{P}}+C_{\mathrm{V}}}} u_{\mathrm{R}}
$$

Budou-li nově vzniklé parazitní kapacity přibližně shodné $C_{1 \mathrm{P}} \approx C_{2 \mathrm{P}} \approx C_{3 \mathrm{P}} \approx C_{\mathrm{P}}$ a $C_{\mathrm{V}}>C_{\mathrm{P}}$, bude

$$
u_{\mathrm{P}} \approx \frac{C_{1 \mathrm{P}}}{C_{1 \mathrm{P}}+C_{3 \mathrm{P}}+C_{2 \mathrm{P}}} u_{\mathrm{R}} \approx \frac{1}{3} u_{\mathrm{R}}
$$

K výraznému snížení elektrického rušení tedy nedošlo.

Účinného zmenšení napětí $u_{\mathrm{P}}$ dosáhneme jedině uzemněním stínicí přepážky (Obr. 5.2 ), protože parazitní kapacita $C_{1 \mathrm{P}}$ se nyní neuplatní a kapacita $C_{2 \mathrm{P}}$ bude paralelně s kapacitou $C_{\mathrm{V}}$. Rušivé napětí v místě přijímače bude

$$
u_{\mathrm{P}}=\frac{C_{\mathrm{P}}^{\prime}}{C_{\mathrm{P}}^{\prime}+C_{2 \mathrm{P}}+C_{\mathrm{V}}} u_{\mathrm{R}} \approx \frac{C_{\mathrm{P}}^{\prime}}{C_{2 \mathrm{P}}+C_{\mathrm{V}}} u_{\mathrm{R}} \approx \frac{C_{\mathrm{P}}^{\prime}}{C_{\mathrm{V}}} u_{\mathrm{R}} .
$$

Pokud je napřr. nutné potlačit elektrické rušení mezi dvěma zásuvnými deskami plošných spojů, dostačuje proto mezi ně vložit uzemněnou kovovou stínicí přepážku.

Parazitní vazbu mezi zdrojem rušení a přijímačem můžeme však také účinně zmenšit vložením obou obvodů do kovové stínicí krabičky, přičemž ani není nutné, aby mezi oběma obvody byla stínicí přepážka (Obr. 5.3 ). Přičina spočívá v tom, že kapacitor $C_{1 \mathrm{P}}$ odvádí rušivé signály do stínicího krytu a kapacitor $C_{2 \mathrm{P}}$ přispívá k dalšímu zmenšení parazitního signálu (obdoba situace na Obr. 5.24). Fyzikální smysl stínicího účinku kovového stínění, spojeného se zemí př́istroje, spočívá tedy v připojení velké části parazitních kapacit mezi odstiňovanými body na zem. Z tohoto důvodu se doporučuje montovat citlivé prvky zařízení co nejblíže stínicího krytu. 


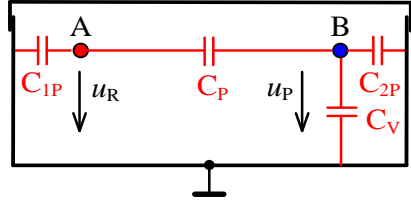

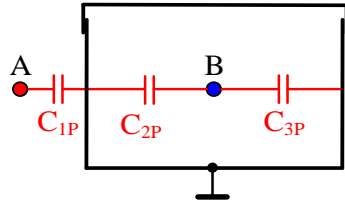

b

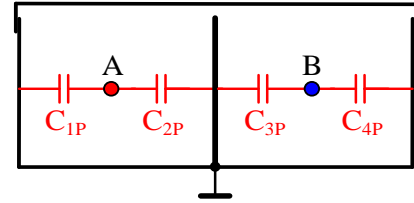

Obr. 5.3: Stínění elektrického pole pomocí uzemněné kovové krabičky: a) zdroj rušení i přijímač uvnitř společného stínění, b) stínění přijímače rušení, c) samostatné stínění zdroje i přijímače rušení

Samozřejmě nejlepší ochranou proti rušivému elektrickému poli je, vložit citlivý obvod do samostatného stínicího krytu Obr. 5.3b). Toto řešení se většinou užije v měřicích př́ístrojích při ochraně vstupních zesilovačŭ. V případě konstrukce vysokofrekvenčních obvodů, kdy může docházet ke vzájemnému ovlivňování jednotlivých částí, se celý obvod umístí do společné stínicí krabičky a dílčí části se navzájem oddělí kovovými přepážkami Obr. 5.34).

Aby bylo stínění proti elektrickému poli účinné, musí se dodržovat několik zásad. Doporučuje se vést všechny vodiče, které přenášejí signál, vnitřkem stíněného prostoru. Stínění musí být připojeno ke společné svorce zapojení. Je-li zdroj signálu spojen jednou svorkou se zemním potenciálem, musí být i stínění spojeno se zemí. V př́padě, že jsou obvody, které chráníme, galvanicky odděleny od uzemněné části zařízení, připojí se stínění na referenční potenciál galvanicky oddělené části. Nesprávné připojení stínění na jiný referenční potenciál (zem) může vést i k nežádoucímu zvětšení rušení.

Pro objasnění těchto tvrzení uvažujme jednoduchý obvod galvanicky oddělený od ochranné zemní svorky (PE) sestávající z budicího externího zdroje napětí a vstupního zesilovače vloženého do neuzemněného stínění (viz Obr. 5.4 a). Budicí zdroj je uzemněn v bodě $\mathrm{A}$, stínění má proti nejbližší zemi kapacitu $C_{\mathrm{BC}}$. Jsou-li body $\mathrm{A}$ a $\mathrm{C}$ od sebe vzdáleny, může se mezi nimi projevit rušivé napětí $u_{\mathrm{R}}$. Toto napětí se na stínění projeví poněkud zmenšené v závislosti na poměru kapacit $C_{\mathrm{AB}}$ a $C_{\mathrm{BC}}$. Přes parazitní kapacitu $C_{\mathrm{BD}}$ se toto napětí následně přenese na vstup zesilovače. Stínění je proto málo účinné. Hrubou chybou by však bylo připojit stínění na jiný referenční potenciál, např̀. na ochrannou zemní svorku PE (čárkovaná spojka mezi body E-F). Veškeré rušení, které by bylo mezi zemí a galvanicky oddělenou částí by pak bylo přes parazitní kapacitor $C_{\mathrm{BD}}$ přivedeno přímo na vstup zesilovače.

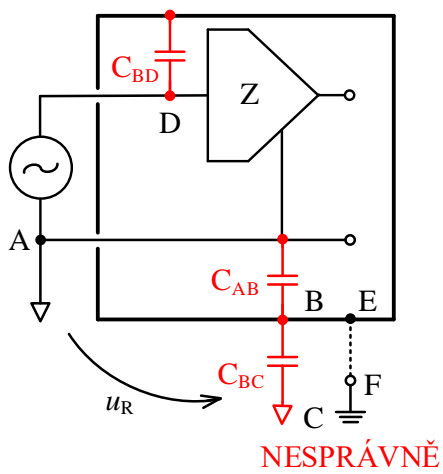

a

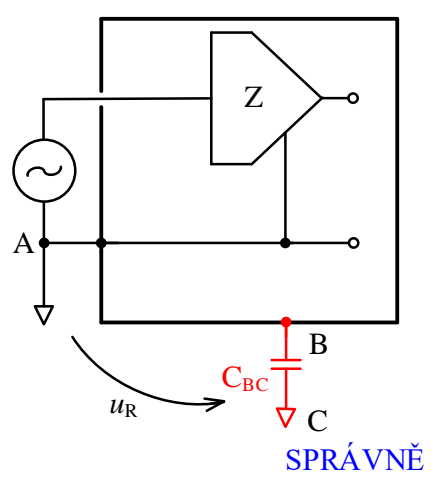

$\mathrm{b}$

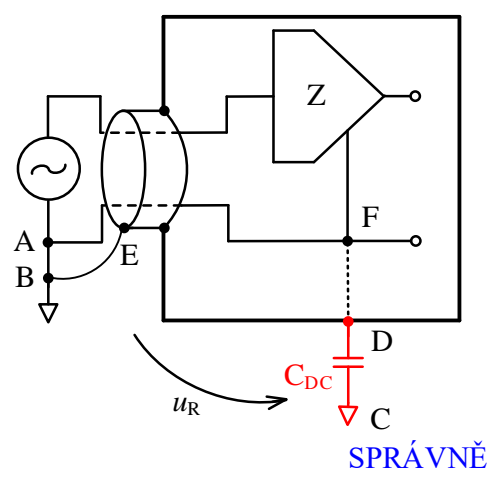

$\mathrm{c}$

Obr. 5.4: a) Neuzemněné elektrostatické stínění má omezený účinek, b) připojení stínění na společný referenční potenciál, c) správný způsob připojení stíněného kabelu ke stínění 
Zkratujeme-li kapacitor $C_{\mathrm{AB}}$ propojením bodů $\mathrm{A}$ a $\mathrm{B}$, odstraníme průnik rušivého napětí přes kapacitory $C_{\mathrm{AB}}$ a $C_{\mathrm{BD}}$. Stínění se připojuje k referenčnímu potenciálu (zemi) na straně zdroje signálu a to pouze $\mathrm{v}$ jednom bodě Obr. 5.4h). V této souvislosti je zapotřebí upozornit, že na jakosti spoje stínění k referenčnímu potenciálu závisí stínicí účinek. Spoj mezi stíněním a referenčním potenciálem nesmí být dlouhý. Impedance takového spoje totiž roste s kmitočtem a stínicí účinek se zhorší. V pásmu krátkých vln a zvláště vln metrových i kratších mohou spoje dlouhé několik centimetrů podstatně zhoršit stínění chráněného obvodu.

Stínicí vodič se nedoporučuje používat jako vodič signálový. Správný způsob používající dvoužilový stíněný kabel je naznačen na Obr. 5.44. Společný vodič signálového obvodu je realizován vnitřním vodičem stíněného kabelu. Stínění je spojeno stínicím pláštěm kabelu s referenčním bodem zapojení (zemí) na vstupu (spoj B - E). Př́ípadný proud ze zdroje rušení $u_{\mathrm{R}}$ se uzavírá obvodem $\mathrm{C}-\mathrm{D}-\mathrm{E}-\mathrm{B}$ a nemůže vyvolat na společném vodiči $\mathrm{A}-\mathrm{F}$ signálového obvodu žádný úbytek napětí. Jestliže však nedodržíme uvedené zásady stínění a propojíme např. společný signálový vodič navíc se stíněním (čárkovaná spojka mezi body D $\mathrm{F}$ ), pak proud vyvolaný zdrojem rušení prochází i společným vodičem $\mathrm{A}-\mathrm{F}$ a vyvolá na něm nežádoucí rušivé napětí.

Malé štěrbiny nebo otvory ve stínicím krytu (ve srovnání s délkou vlny zpracovávaných signálů) prakticky nezmění účinek elektrického stínění. Proto někdy stínění můžeme realizovat jen kovovou mř́žkou. Protože po povrchu stínění tekou jen velice malé proudy, nezávisí jeho účinek na tloušt'ce stínění (stačí i tloušt'ka 10 až $15 \mu \mathrm{m}$ ) a v některých př́padech je stínění možno realizovat izolantem s nanesenou kovovou vrstvou.

Pro elektrostatické stínění se užívají většinou kovové krabičky vyrobené z pocínovaného plechu tloušt'ky $0,5 \mathrm{~mm}$ až $0,9 \mathrm{~mm}$. K dispozici je celá řada již hotových kovových krabiček určených pro elektrostatické stínění. Několik př́íkladů krabiček je uvedeno na Obr. 5.5. Stínicí kryty Obr. 5.5 j) jsou určeny pro montáž na DPS, kdy chybějící stěnu krabičky tvoří souvislá vrstva mědi, nebo mř́žžkování na DPS. Pokud bude zapotřebí v chráněném obvodu provádět nějaká nastavení, použije se stínicí rámeček s odnímatelným víkem Obr. 5.5b). Pro elektrostatické stínění větších konstrukčních celků na DPS se užívají krabičky s oboustranně odnímatelnými víky Obr. 5.54).

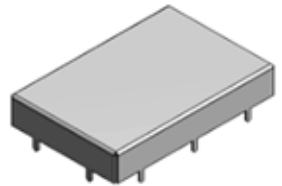

a

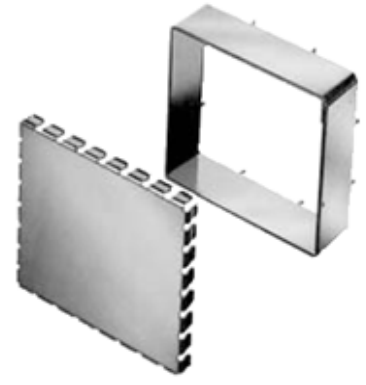

$\mathrm{b}$

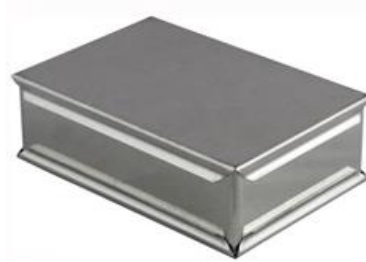

c

Obr. 5.5: Elektrostatické stínění: a) pro montáž na DPS, b) rámeček s odnímatelným víkem pro montáž na DPS, c) krabička s oboustranně odnímatelnými víky

Další možností je, použít plastovou krabičku, která má uvnitř vysoce vodivý povlak provedený nástřikem nebo nátěrem vodivého laku (Obr. 5.6 ). Základem laku jsou částečky mědi, niklu nebo stříbra. Nejlepších výsledků se dosahuje s postříbřenými částečkami mědi. Nástřik vodivým lakem se uživá i pro dodatečné odstínění krytů přístrojů Obr. 5.6b). Povlak 
také zabraňuje hromadění statické elektřiny. Aby bylo takovéto stínění účinné, je nutné jej připojit na zemní potenciál. Vhodným materiálem je měděná stínicí páska, která se přilepí na potažený povrch vodivým lepidlem a přestříká se nebo přetře vodivým lakem.

Pokud je zapotřebí elektrostaticky odstínit větší celky nebo i celé přístrojové skříně, je nutno se vyvarovat dlouhých štěrbin. Odnímatelné části stínění se proto opatřují pružnými kontakty (viz Obr. 5.64). Aby se docílila dobrá vodivost a dlouhodobá pružnost, jsou kontakty vyrobeny z fosforbronzu (slitina mědi, cínu a fosforu).

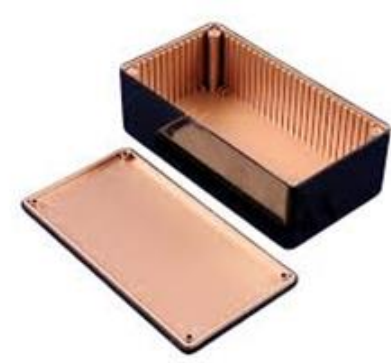

a

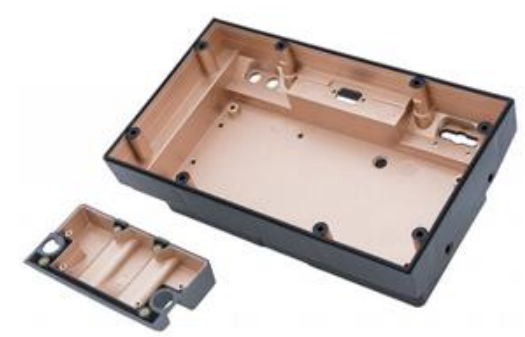

$\mathrm{b}$

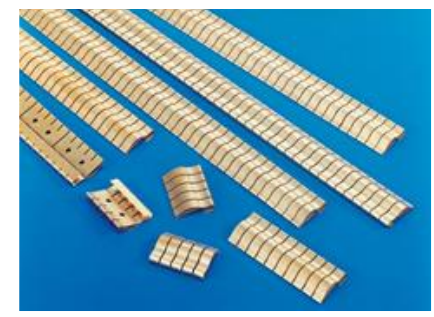

C

Obr. 5.6: a), b) Vodivý povlak jako elektrostatické stínění, c) pružné kontakty pro odnímatelné stínicí kryty

\subsubsection{Elektrostatické stínění spojů}

Podobné zásady jako pro stínění obvodů platí i pro stínění spojů. Stínicí plášt' koaxiálního kabelu musí být spojen s vodičem nesoucím referenční potenciál jen v jednom bodě (Obr. 5.7 ). Jinak by totiž došlo k rozdělení zemního proudu, jehož část by tekla stínicím pláštěm a přes kapacitní vazbu by se rušení přeneslo do stíněného vodiče. Stíněním nemá nikdy protékat proud. Mohl by indukovat napětí ve vodičích rozmístěných ve stíněném prostoru.

Na stínění nemá být žádné napětí proti referenční úrovni Obr. 5.71). Vázalo by se kapacitně do stíněného prostoru (přitom uvažujeme, že zdroj vstupního napětí $u_{\mathrm{G}}$ není ideální a vykazuje vnitřní odpor $R_{\mathrm{G}}$ ). Stínění koaxiálního kabelu musí být vždy připojeno na referenční potenciál, ke kterému je připojen zdroj vstupního napětí.

Skládá-li se stínění z několika po sobě následujících částí, musí být dílčí stínění propojena za sebou a spojena se společnou svorkou pouze v jednom bodě (Obr. 5.74). 

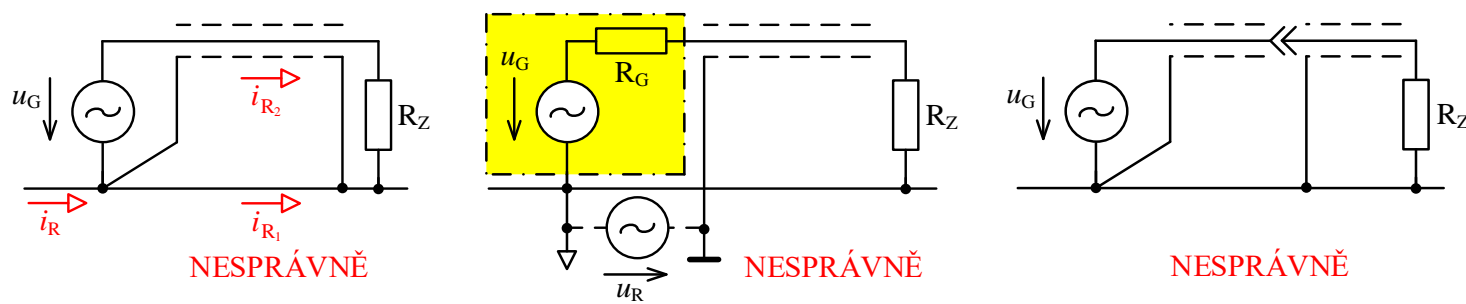

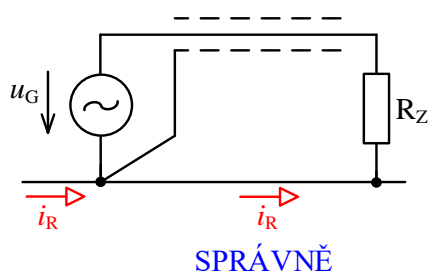

a

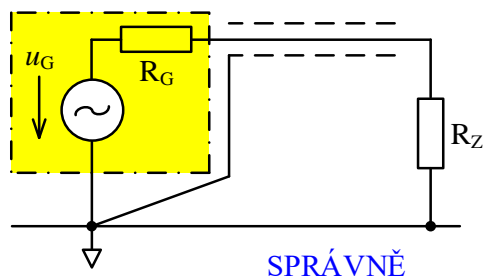

b

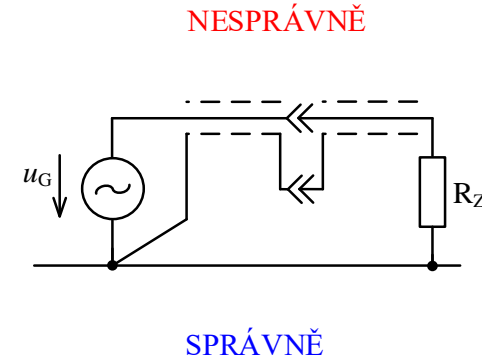

c

Obr. 5.7: Elektrostatické stínění spojů: a) stínění koaxiálního kabelu se na společný vodič připojí jen jedním koncem, b) stínění musí být připojeno na zem vlastního zdroje, c) propojení několika úseků koaxiálního kabelu

Je třeba vždy prověřit, kudy se uzavírá dráha pro rušivý signál mezi stíněním a zemí. $\mathrm{Na}$ Obr. 5.8 je ukázán nesprávný způsob zapojení stíněných kabelů dvou systémů, analogového a číslicového, se zemí. Jsou-li v zařízení přenášeny signály z několika nezávislých zdrojů, je třeba pro každý z nich použít nezávislé stínění, připojené vždy na referenční potenciál príśslušného zdroje Obr. 5.8b).

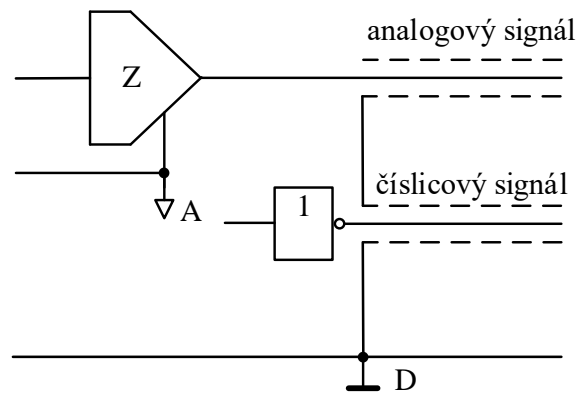

NESPRÁVNĚ

a

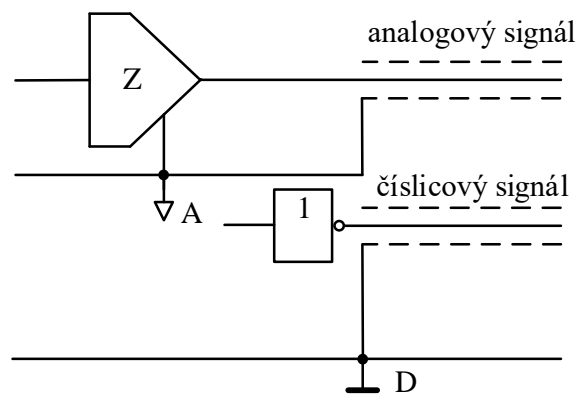

SPRÁVNĚ

$\mathrm{b}$

Obr. 5.8: a) Nevhodným spojením různých stínění může do stíněného vodiče pronikat rušivý signál, b) správný způsob připojení stínění k referenčnímu potenciálu zdroje

Uvedené zásady pro elektrostatické stínění se nesmí aplikovat mechanicky. Každý př́ípad je třeba analyzovat a najít optimální řešení na základě pochopení vlastností a činnosti obvodu. 


\subsection{Stínění magnetického pole}

Pojem ,čistého“ magnetického pole je také idealizací, protože magnetické pole je vždy doprovázeno (i když slabým) elektrickým polem. Charakteristická vlastnost magnetického pole spočívá v tom, že proniká do hloubky kovového materiálu stínění tím méně, čím je větší rychlost jeho změn (vyšší kmitočty) a čím je větší magnetická permeabilita materiálu stínění. Stejnosměrná magnetická pole jsou vytvářena trvalými magnety, např. magnety v reproduktorech. Hlavními zdroji stř́idavých magnetických polí nižších kmitočtů jsou pak sít’ové transformátory a tlumivky, pole vyšších kmitočtů vytvářejí induktory oscilátorů, výstupní transformátory, transformátory impulsních zdrojů apod. Jsou-li v takových polích umístěny magneticky citlivé prvky zařízení, např. vstupní či oddělovací transformátorky, indukují se do nich rušivá napětí, která se ve svém důsledku projeví nežádoucími vazbami, kmitáním nebo brumem. Ve vf obvodech s pracovními kmitočty na $10 \mathrm{MHz}$ mohou být příčinou magnetické vazby i spoje ve tvaru smyčky.

\subsubsection{Stínění obvodů proti rušení magnetickým polem}

Jestliže při stínění elektrického pole je jedno, z jakého vodivého materiálu je provedeno stínění, pak při stínění magnetického pole bude zmenšování pole ve stínění záviset na tom, zda je použito feromagnetických materiálů (železo, permalloy) nebo kovové stínění z nemagnetických materiálů (měd’, hliník). V prvním případě jsou magnetické siločáry jakoby „vstřebávány“ feromagnetickým materiálem a v druhém př́padě jakoby „vytlačovány“. Stínění obvodů proti účinkům magnetického pole je tedy možné realizovat dvojím způsobem.

Stínicí účinek plného kovového materiálu vůči magnetickému poli se charakterizuje hloubkou vniku magnetického pole $\delta$, označující hloubku, ve které se $\mathrm{v}$ př́slušném materiálu zmenší původní magnetická indukce na $1 / \mathrm{e} \approx 37 \% \mathrm{z}$ indukce ve volném prostoru. $\mathrm{V}$ tabulce Tab 5.1 je pro představu uvedena hloubka vniku pro nejběžnější materiály.

Materiály s velkou magnetickou permeabilitou (ocel, permalloy, Mu-metal) se užívají pro stínění ss magnetického pole až do akustických kmitočtů. Stínicí materiály s velkou elektrickou vodivostí (měd', mosaz, hliník) jsou pak výhodnější při vyšších kmitočtech a jejich účinnost se zvyšuje s kmitočtem.

Tab 5.1: Hloubka vniku magnetického pole pro běžné materiály

\begin{tabular}{|c|c|c|c|c|}
\hline \multirow{2}{*}{$\begin{array}{c}\text { Kmitočet } \\
f[\mathrm{~Hz}]\end{array}$} & ocel & permalloy & měd' & hliník \\
\cline { 2 - 5 } & 1,54 & 0,38 & 6,70 & 8,80 \\
\hline $10^{2}$ & 0,49 & 0,12 & 2,10 & 2,75 \\
\hline $10^{3}$ & 0,15 & 0,04 & 0,67 & 0,88 \\
\hline $10^{4}$ & 0,05 & 0,01 & 0,21 & 0,28 \\
\hline $10^{5}$ & - & - & 0,07 & 0,09 \\
\hline $10^{6}$ & & & & \\
\hline
\end{tabular}

Při navrhování nového zařízení dbáme na to, aby př́istroj nebyl zdrojem nežádoucího rušení a byl vǔči cizím magnetickým polím necitlivý. Proto je nutno dodržovat několik zásad. Citlivé obvody umíst'ujeme co nejdále od zdrojů rušivých magnetických polí (sít’ových 
transformátorů, impulsně regulovaných zdrojů aj.). Citlivé vodiče vedeme tak, aby do nich indukované napětí bylo co nejmenší. Proto volíme jejich směr rovnoběžně s magnetickými siločarami. Indukované napětí je totiž úměrné ploše smyčky a závisí na její orientaci vůči zdroji rušení. Plochu smyčky omezíme co nejvíce zmenšováním rozměrů a vzdáleností použitých vodičů. Orientaci pole můžeme ovlivnit umístěním vedení a zdrojů rušení (natočením transformátoru o $90^{\circ}$ apod.).

Při konstrukci magnetických stínění je nutné brát v úvahu možnost vzniku bludných proudů (různá délka dráhy proudu v přímém a zpětném směru oslabuje účinek stínění). Je žádoucí, aby stínicí kryt, po kterém se uzavírají dráhy vírivých proudů, byl pokud možno z jednoho homogenního materiálu, dráha nesmí být přerušená a musí mít co nejmenší odpor. Není-li totiž dokonalý styk mezi jednotlivými částmi krytu (např. spojení dvou částí kovového krytu) vznikne mezi těmito částmi mezera, která je sice z mechanické stránky zanedbatelná, ale pro vf proudy se vytvoří překážka, která jim nedovolí uzavřít dokonale obvod v místě spoje. Tyto víŕivé proudy se pak uzavírají bludnými cestami a způsobují nežádoucí vazby.

Malé otvory téměř nezhoršují účinnost magnetického stínění. Dlouhé úzké štěrbiny, př́pustné v elektrickém stínění, jsou v magnetickém stínění nebezpečné svým zářením, pokud jsou kolmé na směr vírivých proudů Obr. 5.9. Při stínění složitějších elektrických obvodů, v nichž jsou magnetické toky orientovány nejrůznějším způsobem, se dlouhým štěrbinám raději vyhýbáme. Je proto žádoucí spojit jednotlivé díly stínění tak, aby možné štěrbiny nebyly delší než 0,25 až $1 \%$ vlnové délky.

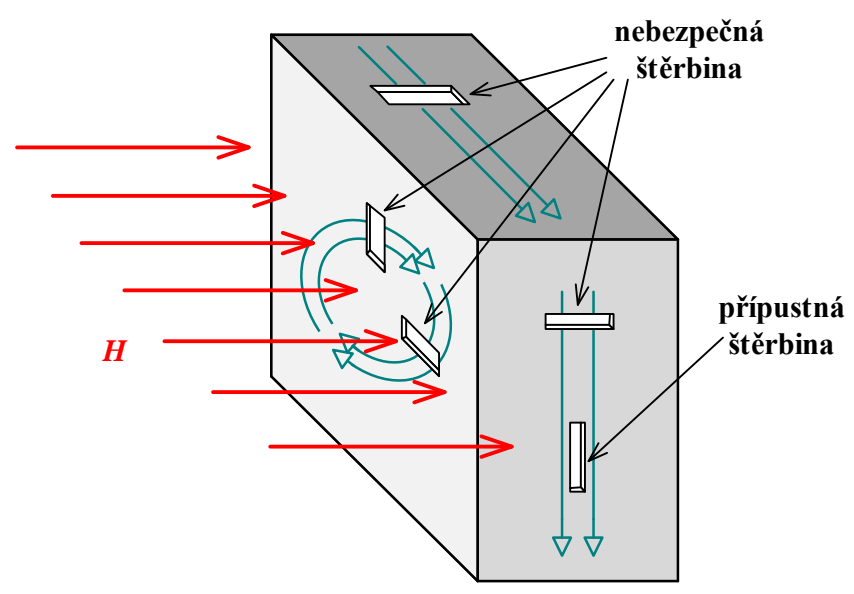

Obr. 5.9: Umístění dlouhých štěrbin na magnetickém stínicím krytu

Je zajímavé porovnat vlastnosti stínění elektrického a magnetického pole. Jestliže při stínění elektrického pole účinek stínění závisí na propojení stínění s uzemněnou vodivou plochou (kovovou konstrukcí) popř. s referenčním potenciálem, pak při stínění magnetického pole spojení stínění se zemí nemá na účinek stínění vliv. Změna kmitočtu nemá na účinnost elektrického stínění prakticky vliv, účinnost magnetického stínění však závisí na kmitočtu (čím je kmitočet nižší, tím je problematika stínění složitější). Účinnost elektrického stínění závisí na specifickém odporu materiálu jen málo, kdežto účinnost magnetického stínění velmi závisí na permeabilitě materiálu. Realizace stínění proti magnetickému poli je podstatně obtížnější než stínění proti vlivu elektrických polí. Dále plášt' stíněného vodiče uzemněný na jedné straně má dobrý stínicí účinek proti elektrickému poli, ale má malý nebo žádný proti poli magnetickému. 


\section{Stínění ss a nf magnetického pole}

Před účinky stejnosměrného a pomalu se měnícího magnetického pole chráníme zařízení pomocí stínění zhotoveného z feromagnetických materiálů s velkou relativní permeabilitou. Ve stínění bude docházet ke zkratu magnetického pole Obr. 5.9. Stínění tedy pracuje podobně jako magnetický bočník. Účinek stínění bude tím větší, čím bude větší tloušt'ka stínění a čím méně je v něm spár a švů.

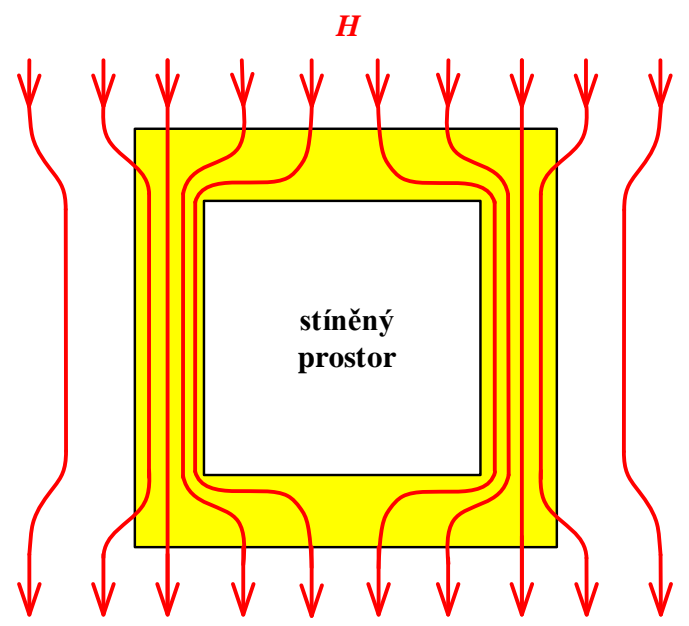

Obr. 5.10: „Vstřebávání“ magnetického pole pomocí feromagnetického stínění

Pro méně náročné účely se pro stínění magnetického pole dají užít krabičky vyrobené z pocínovaného ocelového plechu (viz Obr. 5.11 l), tzn. stejné, jako se užívají pro elektrostatické stínění. Jejich účinnost na sítových kmitočtech je však již nevyhovující. Lepší účinnost má permalloy, což je magnetická slitina 80 \% niklu a $20 \%$ železa, nebo supermalloy (79 \% niklu, $16 \%$ železa, $5 \%$ molybdenu). Zatímco ocel má permeabilitu několik tisíc, mají tyto materiály permeabilitu kolem 100 000. Jejich nevýhodou je nesnadné tvarování při výrobě magnetického stínění. Tvárnější a tažnější je materiál známý pod obchodním označením Mumetal ( $\mu$ - kov), což je 80 \% niklu, $5 \%$ molybdenu, 12 až $15 \%$ železa a malé množství dalších prvků jako je křemík. Slitina Mu-metal má obvykle hodnotu relativní permeability 80000 až 100000 . Umožňuje snadné tvarování do tenkých plechů vhodných pro magnetické stínění ss polí až do kmitočtů kolem $30 \mathrm{kHz}$ (viz Obr. 5.11p,c).

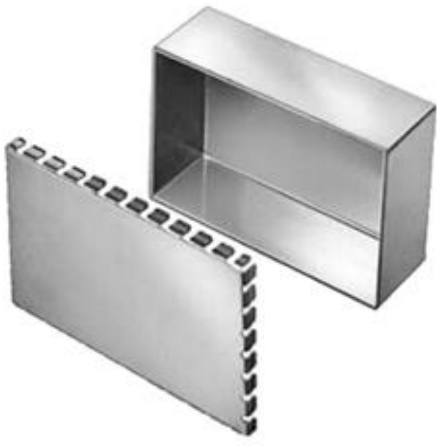

a

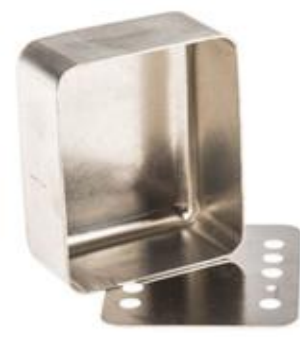

b

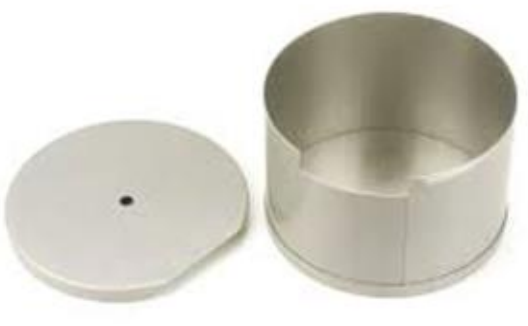

$\mathrm{C}$

Obr. 5.11: Stínění ss a nf magnetického pole: a) stínění z ocelového plechu pro méně náročné účely, b) stínění pro audiotransformátory (Mu-metal), c) stínění pro toroidní transformátory (Mu-metal) 
Pokud je nutné proti elektromagnetickému poli odstínit větší celek zařízení je nutné jej umístit do kovové stínicí skříně (viz Obr. 5.12 ). Konstrukce takové skříně vyžaduje pro dosažení kvalitního stínicího účinku dodržet několik zásad. Jednotlivé díly skříně musí mít dostatečný přesah v místě spojení s jinými částmi. Větrací otvory či průchody v kovovém stínění musí být realizovány na bázi „podkritických“ dutých kovových vlnovodů ve tvaru trubiček, které zatlumí i nejvyšší předpokládaný kmitočet elektromagnetického rušení. Dviřka skříně je nutno utěsnit pružinovými kontaktními lištami z nerezové oceli Obr. 5.12b), nebo pro utěsnění použít elastomery (těsnění z vodivé pryže).

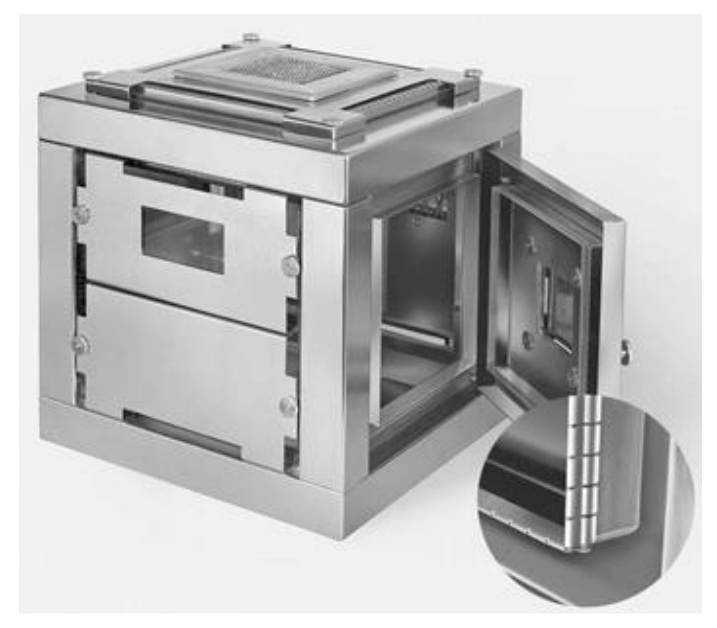

a

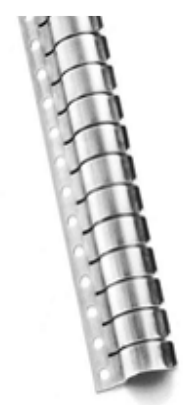

b

Obr. 5.12: a) Elektromagneticky odstíněná skříň, b) lišta s pružinovými kontakty z nerezové oceli

\section{Stínění vf magnetického pole}

Vysokofrekvenční magnetické pole stíníme nejčastěji kovovými kryty z nemagnetického materiálu. Princip stínění objasníme na kovovém stínění obdélníkového prưřezu vloženého do časově proměnného magnetického pole Obr. 5.13 đ). Ve stínění se časově proměnným magnetickým polem (červené šipky) indukují stř́idavé proudy, tzv. vířivé nebo též Foucaltovy proudy (modré šipky). Magnetické pole, které vyvolá tento proud je uzavřené, přičemž uvnitř válce je orientováno proti budicímu poli (červené čárkované šipky) a vně válce souhlasně s budicím polem (tzv. Lenzovo pravidlo). Intenzita výsledného pole uvnitř válce je proto mnohem menší a vně válce větší - pole je ze stínění „vytěsňováno“ (viz Obr. 5.13b). Proto vodivé nemagnetické materiály pro vf magnetické pole vykazují stínicí účinek. Je zřejmé, že účinek je tím větší, čím větší je intenzita pole vyvolaná válcem, tzn. čím větší jsou viŕrivé proudy. 


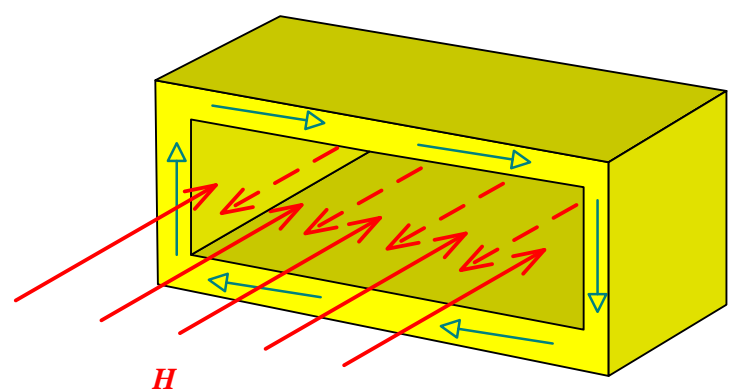

a

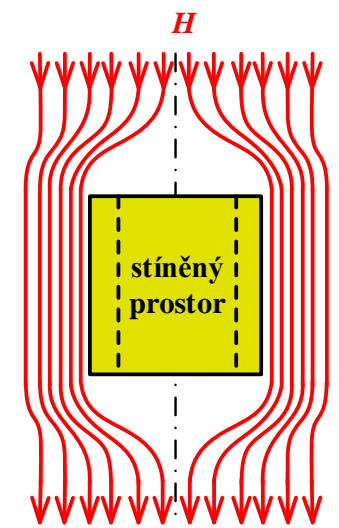

b

Obr. 5.13: a) K vysvětlení stínicího účinku neferomagnetického vodivého stínění,

b) „vytěsňování“"vf magnetického pole

Uvedený princip se nejčastěji užívá pro stínění vf cívek. Obvykle jsou stínící kryty cívek provedeny $\mathrm{z}$ hliníku nebo $\mathrm{z}$ mědi. Na Obr. 5.14 je př́klad soupravy pro výrobu vf cívky $\mathrm{s}$ hliníkovým krytem, na Obr. 5.14 pak souprava s krytem z pocínované mědi.

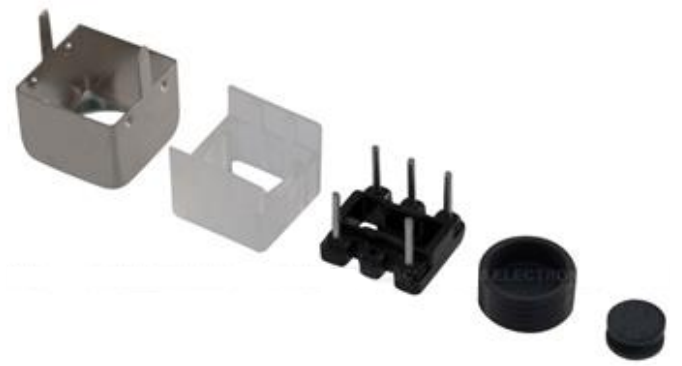

$\mathrm{a}$

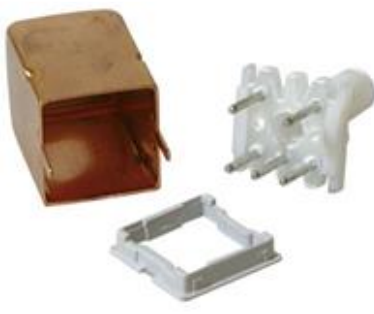

b

Obr. 5.14: Soupravy pro výrobu vf cívek: a) s hliníkovým stínicím krytem,

b) s krytem z pocínované mědi

\section{Mikrovlnné absorpční materiály}

Mikrovlnné absorpční fólie (Microwave Absorber Sheets) vyrábí celá řada firem. Většinou jsou samolepicí, takže práce s nimi nepřináší větší potíže. Dodávají se v různých tloušstkách a formátech (Obr. 5.15 ). Fólie absorbující mikrovlny využívají dva odlišné principy.

První typ potlačuje mikrovlny s využitím magnetických ztrát v materiálu (viz Obr. 5.15 ). V tomto prípadě je do silikonu, nebo do jiného gumového materiálu vmíchán magnetický materiál (většinou ferit). Č́st energie vstupujících mikrovln se v absorpční feritové vrstvě přemění $v$ teplo díky viŕivým proudům. Zahřívání je však minimální a odvod tepla není nutný. Potlačené spektrum kmitočtů se $\mathrm{v}$ tomto př́padě liší pouze podle použitých magnetických materiálů. Materiál jako takový je nevodivý a lze jej proto prímo nalepit na pouzdra integrovaných obvodů. Tento typ absorpčních fólií je účinný pro široký frekvenční rozsah od několika stovek MHz až jednotky GHz. 


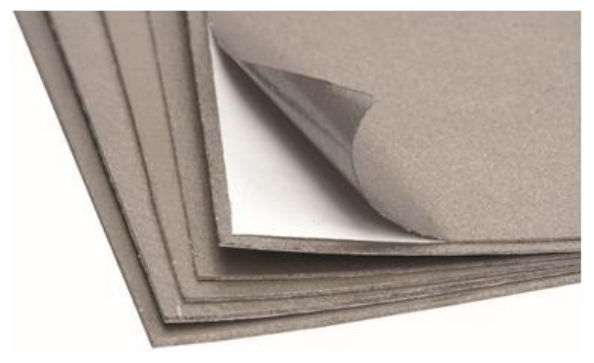

$\mathrm{a}$
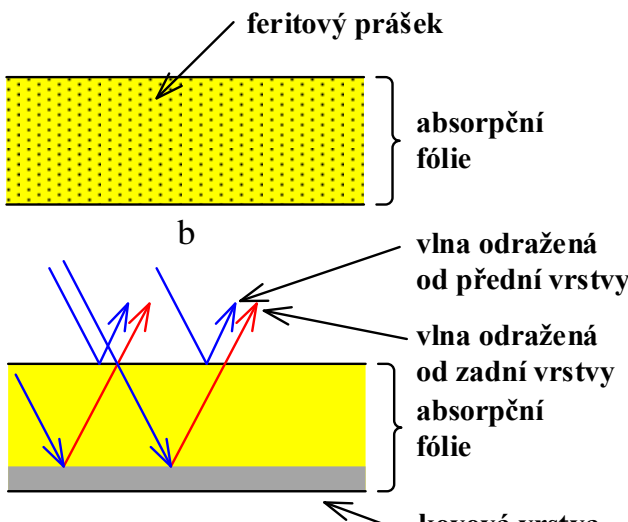

$\mathrm{c}$

Obr. 5.15: a) Samolepicí mikrovlnná absorpční fólie, b) absorpce mikrovln feritovým práškem, c) potlačení mikrovlnného rušení odrazem

Druhý typ absorpčního materiálu pracuje na odlišném principu. Absorpční fólie odráží mikrovlny jak z přední, tak i ze zadní vrstvy fólie Obr. 5.15Æ). Dvě odražené vlny se navzájem překrývají, ale v důsledku rozdílu ve vzdálenosti uražené každou z vln. Pokud budou fáze vln odražených předním a zadním povrchem navzájem posunuty o $180^{\circ}$, obě vlny se vzájemně vyruší a mikrovlnné vlnění je potlačeno. Ve skutečnosti nejsou amplitudy ani kmitočty odražených vln úplně stejné, takže část energie rušivého vlnění zůstane nepotlačena. Výsledkem je, že tento typ absorpční fólie velmi účinně potlačí mikrovlny v okolí určitého kmitočtu a ostatní kmitočty zůstanou nepotlačeny. Tento typ absorpční vrstvy je účinný pro kmitočtové pásmo od jednotek $\mathrm{GHz}$ až do několika desítek $\mathrm{GHz}$.

Mikrovlnné absorpční fólie na bázi feritu mohou být vlepeny dovnitř př́strojových skříní, nebo se připevní jako stínění mezi dvě desky plošných spojů. Některé absorpční fólie vykazují vysokou tepelnou vodivost a mohou být aplikovány př́mo na pouzdra integrovaných obvodů (Obr. 5.16 ).

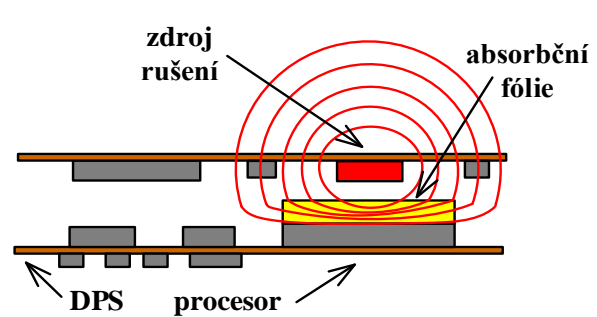

a

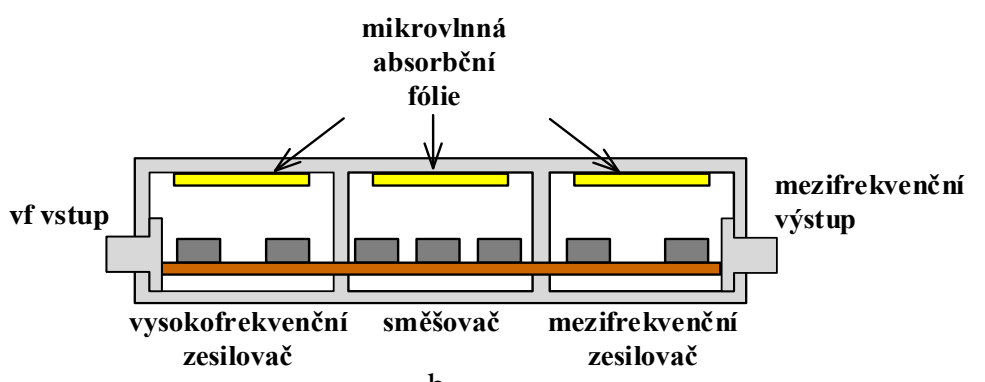

b

Obr. 5.16: Příklady použití mikrovlnné absorpční fólie: a) potlačení vf rušení mezi sousedními DPS pomocí absorbční fólie na bázi feritu, b) potlačení vazeb v satelitním prijímači absorbční fólií na bázi odrazu vln 
Typy absorpčních materiálů, které potlačují rušení na bázi odrazu vln, jsou účinné jen vůči omezenému okruhu kmitočtů. $\mathrm{Na}$ Obr. 5.16b je uveden př́klad použití tohoto typu materiálu pro zamezení interferencí mezi jednotlivými stupni satelitního přijímače, který mikrovlnný signál zesiluje a současně transformuje do nižšího kmitočtového pásma. Nalepená absorpční fólie účinně zabraňuje oscilacím zesilovacího obvodu v důsledku rezonance dutin a potlačuje parazitní vazby mezi jednotlivými obvody.

\subsubsection{Ochrana vodičů proti vyzařování magnetického pole}

Výkonové vedení k zátěži, které může být zdrojem rušivého magnetického pole, je vhodné vést zkrouceným dvouvodičem (tzv. twist). Nesmí však být vytvořena žádná jiná paralelní vodivá cesta. $\mathrm{Na}$ Obr. 5.17 đe uvedeno nesprávné provedení. Spojením bodů X a Y vznikne nesymetrie, zemním vodičem teče proud $i_{3}=i_{1}-i_{2}$ a kompenzační účinek zkroucených vodičů se zmenší. Správný způsob připojení je naznačen na Obr. 5.17b. Vzájemně opačný proud v obou vodičích a zkroucení vodičủ vyvolá kompenzaci magnetického pole. Poznámka: Spojení v bodech $\mathrm{X}$ a $\mathrm{Y}$ nemusí být jen přímé, podobně působí např. i nesymetrie kapacity zátěže. Ke zmenšení parazitních nesymetrií se doporučuje vést zkroucené vodiče těsně podél zemní plochy a dodržovat minimální velikost plochy možných parazitních smyček.

Pro vedení signálů o velkých úrovních je výhodnější užít souosý kabel. V tomto př́ípadě se nejedná o stínění, jak bylo popisováno dříve, ale o kompenzaci magnetického pole, vznikajícího průchodem proudu vnitřním vodičem souosého kabelu. Př́iklad nesprávného užití souosého kabelu, které nemá na potlačení magnetického pole prakticky žádný účinek je uveden na Obr. 5.17๕. Správný způsob použití souosého vedení pro stínění a kompenzaci rušení je uveden na|Obr. 5.17 đ. Vně souosého kabelu pak nevzniká žádné rušivé pole.

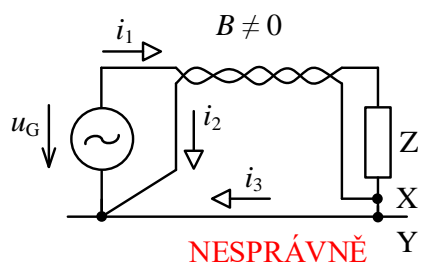

a

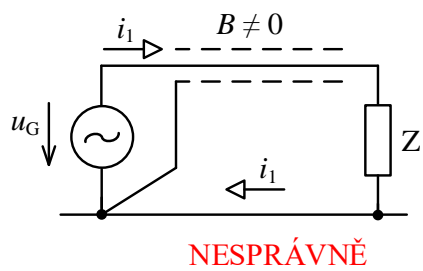

c

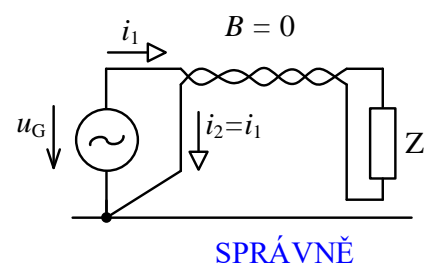

b

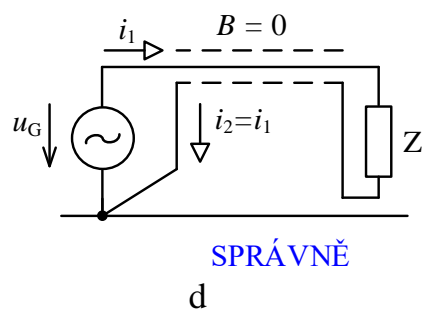

Obr. 5.17: a) Neúplná kompenzace magnetického pole, b) správné připojení zátěže ke zdroji nevyvolává rušivé magnetické pole, c) d) nesprávné a správné užití souosého kabelu pro potlačení rušivého magnetického pole 


\subsection{Ekvipotenciální stínění}

V náročných aplikacích může být na závadu pronikání rušivého signálu nežádoucí vodivou drahou do vodiče nesoucího užitečný signál. Svodové proudy, které se plíží po povrchu plošného spoje, přesáhnou snadno úroveň vstupního proudu řídicí elektrody unipolárního tranzistoru. Vliv svodových proudů se uplatňuje především u unipolárních tranzistorových zesilovačů, nebo u operačních zesilovačů s unipolárními tranzistory na vstupu. Svodový odpor $10^{12} \Omega$ mezi napájecím rozvodem a vstupem operačního zesilovače, ve všeobecné elektronice považovaný spíše za izolant, vyvolá na DPS svodový vstupní proud $15 \mathrm{pA}$. To je o jeden řád nad vstupním klidovým proudem běžného unipolárního zesilovače. Pro dovršení obtíží mají svodové proudy nestálou povahu, protože jsou neseny elektrony i pomalými ionty. Každá změna elektrostatického pole (např. po zapnutí) se projeví pomalým přerozdělováním iontů a odpovídajícími dlouhými, až hodinovými přechodnými ději spojenými s ustalováním přenášeného náboje. Nosným prostředím svodových proudů je elektrolytická kaše na povrchu součástek, vzniklá z prachu, z otisků prstů a ze zbytků pájecích tavidel, která se aktivuje poutanou vlhkostí nebo orosením.

Pasivní ochrana, která vede k přerušení cesty nepravého vstupního klidového proudu, je umístění kritického uzlu na dobrý izolant. Nejčastěji se $\mathrm{k}$ tomuto účelu použivá teflonem izolovaná pájecí svorka (viz Obr. 5.18 a, b). Teflonové tělísko se zamáčkne do otvoru v DPS a do něj se zalisuje střední pájecí svorka Obr. 5.18๕). Na pájecí svorku se pak připájí všechny kritické vývody. Tento způsob ochrany je však značně pracný a proto se užívá jen v nejnáročnějších př́padech.

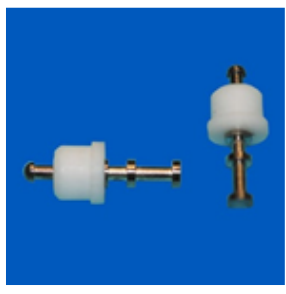

a

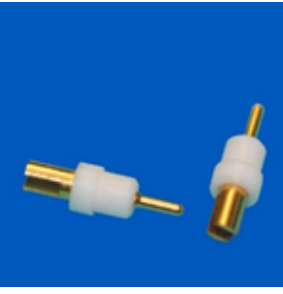

$\mathrm{b}$

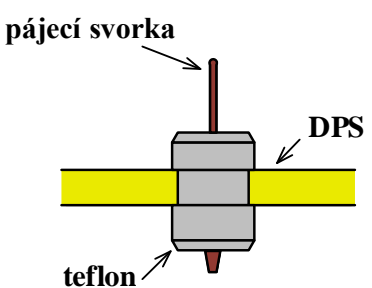

c

Obr. 5.18: Pasivní ochrana proti svodovým proudům pomocí pájecí svorky zalisované $\mathrm{v}$ teflonovém tělísku

Druhý způsob řeší uvedený problém aktivně pomocí tzv. aktivní izolace. Jeho zvláštním případem je izolace zemí, kterou vysvětlíme na příkladu zapojení fotodetektoru na Obr. 5.19a. Vzhledem k tomu, že se na napětí převádí velmi malé proudy tekoucí fotodiodou, je použit operační zesilovač se vstupními proudy jednotek fA. Protože neinvertující vstup OZ je připojen na nulový potenciál, bude se díky záporné zpětné vazbě invertující vstup udržovat také přibližně na nulovém potenciálu (tzv. virtuální nula). Aby do tohoto bodu netekly svodové proudy, obkrouží se kritické místo na DPS uzemněným prstencem (viz Obr. 5.19b). Vnější povrchové proudy, které směřují do kritických vnitřních bodů, jsou tímto prstencem zachyceny a svedeny k zemi. Protože napětí na invetujícím vstupu OZ je při provozu velmi malé (řádově desítky $\mu \mathrm{V})$, je izolace mezi vnitřními body a prstencem namáhána jen tímto malým zbytkovým napětím.

Pokud je pro realizaci obvodu použit oboustranný plošný spoj doporučuje se shodný prstenec realizovat i na druhé straně plošného spoje. V př́ípadě vícevrstvé DPS se ve vnitřní vrstvě doporučuje pod kritickým místem realizovat vodivou plochu, která se připojí na stejný 
potenciál jako prstenec. Pokud je DPS chráněna izolačním lakem, nesmí být tímto lakem prrekryt spoj realizující ochranný prstenec.

Povrchová aktivní izolace však nechrání kritický uzel proti vnitřním, resp. objemovým svodům proudům $\mathrm{v}$ desce plošného spoje. Jestliže tyto svody vadí, je nutno pro výrobu DPS užít materiály s označením GT, GTX vyrobené na bázi skelné tkaniny sycené polytetrafluoretylenem (teflon), které se vyznačují velmi nízkými povrchovými i objemovými svodovými proudy.

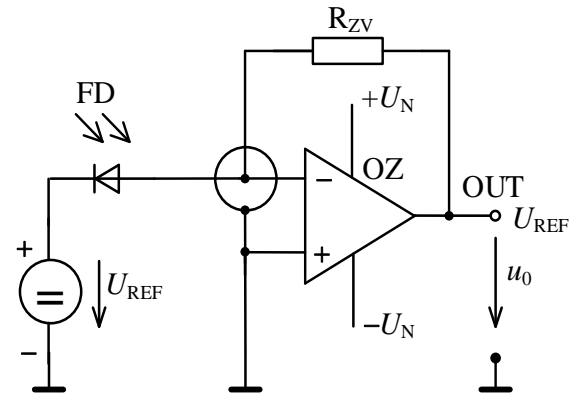

a

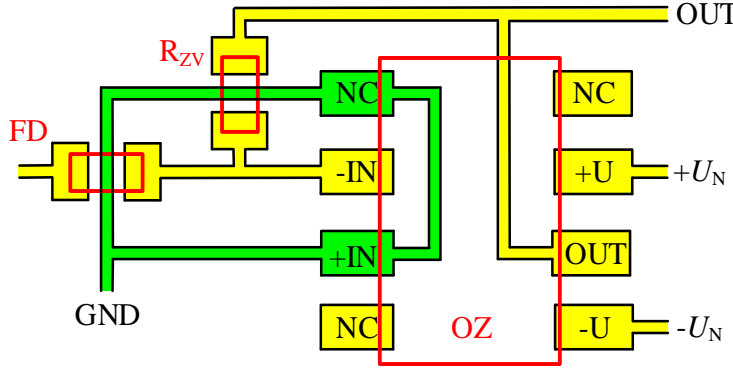

$\mathrm{b}$

Obr. 5.19: Ekvipotenciální stínění: a) Ochrana citlivého vstupu OZ izolačním prstencem,

b) doporučený plošný spoj

$\mathrm{Na}$ Obr. 5.20 je ukázáno rozvinutí techniky ekvipotenciálního stínění na jiné př́ípady. Napět'ový sledovač (Obr. 5.20 ) je připojen k vysokoimpedančnímu napětovému zdroji. Plášt' koaxiálního kabelu a izolační prstenec kolem neinvetujcího vstupu OZ jsou připojeny k výstupu OZ. Protože zesilovač $\mathrm{v}$ tomto uspořádání má jednotkový přenos, tj. $u_{0} \approx u_{\mathrm{G}}$, budou neinvertující vstup a střední vodič vstupního kabelu při jakémkoli signálovém buzení obklopeny nulovým elektrostatickým polem (obdoba techniky bootstrap). Povrchové iontové proudy, vyvolané vstupní signálovou změnou, odvádí výstup OZ. Protože stíněný kabel představuje pro OZ kapacitní zátěž, což by mohlo vést k jeho rozkmitání, je pro oddělení této zátěže použit rezistor o odporu $100 \Omega$. Protože proudy tekoucím tímto rezistorem jsou zanedbatelně malé, nevznikne na rezistoru téměř žádný úbytek napětí.

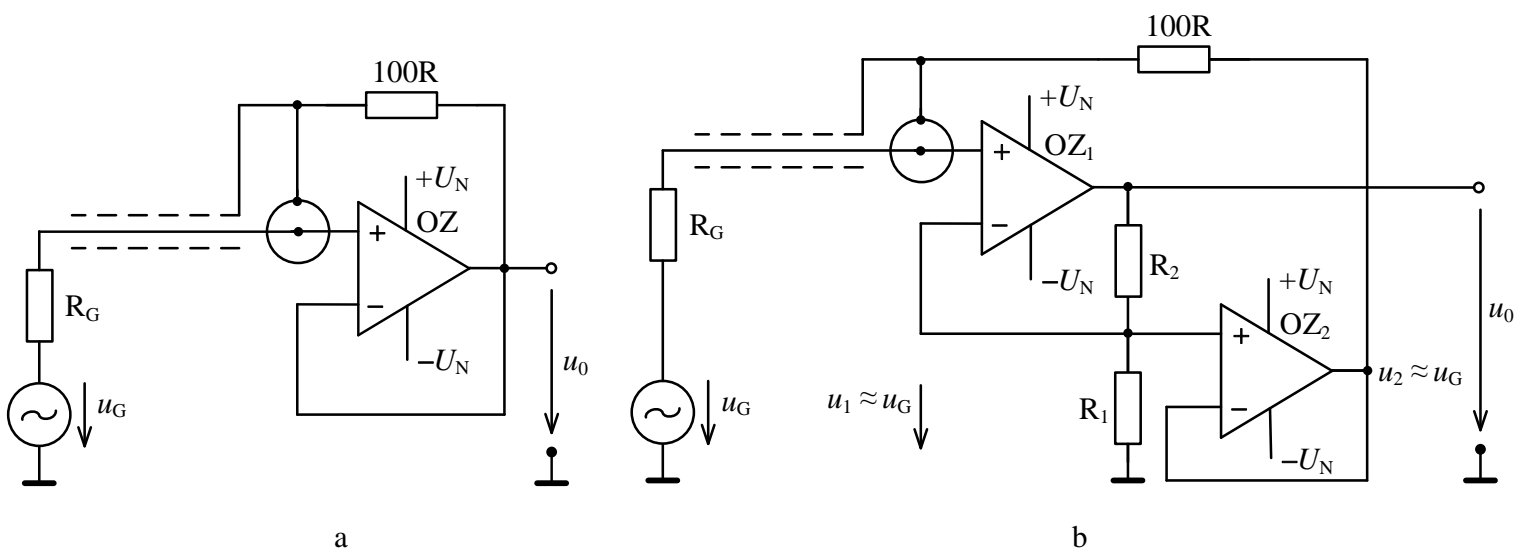

Obr. 5.20: Aktivní izolace: a) izolace vstupu napětového sledovače, b) izolace vstupu neinvertujícího zesilovače 
Aktivní izolace vstupu zesilovače s velkým vstupním odporem ekvipotenciálním stíněním je naznačena na Obr. 5.20b. Dobrého stínicího účinku vůči nežádoucím vlivům je dosaženo tím, že zdroj pomocného napětí se zesilovačem $\mathrm{OZ}_{2}$, na jehož výstup je stínění připojeno, vytvoří přibližně stejné napětí, jako je na středovém vstupním vodiči. Díky $100 \%$ záporné zpětné vazbě má zdroj pomocného napětí s $\mathrm{OZ}_{2}$ velmi malý výstupní odpor (pod $1 \Omega$ ) a zesilovač se tedy chová jako „tvrdý“ zdroj napětí. Rezistor o odporu $100 \Omega$ slouží i zde jako ochrana proti rozkmitání velkou kapacitní zátěží, kterou představuje pro $\mathrm{OZ}_{2}$ stíněný kabel. 


\section{Použitá literatura}

[1] BRANDER, T., GERFER, A., RALL, B. Trilogy of Magnetics. Würth Elektronik, Waldenburt 2009, ISBN 978-3-89929-157-5

[2] SVAČINA, J. Elektromagnetická kompatibilita. Vysoké učení technické v Brně, Brno 2001, ISBN 80-214-1873-7

[3] SVAČINA, J. Základy elektromagnetické kompatibility (EMC). Část 3: Způsoby omezování rušení - odrušovací prostředky a elektromagnetické stínění. Elektrorevue, www. elektrotrevue.cz, 2000/41- 28.11.2000

[4] CHATTERTON, P.A., HOULDEN, M.A. EMC - Electromagnetic Theory to Practical Design. John Wiley, New York 1992

[5] HABIGER, E. Elektromagnetische Verträglichkeit. Hüthig Buch Verlag, Heidelberg 1992

[6] RODEWALD, A. Elektromagnetische Verträglichkeit - Grundlagen, Experimente, Praxis. Vieweg Verlag, Wiesbaden 1995

[7] PEIER, D. Elektromagnetische Verträglichkeit - Problemstellung und Lösungsansätze. Hüthig Buch Verlag, Heidelberg 1990

[8] KEISER, B. Principles of Electromagnetic Compatibility. Artech House, Norwood 1987

[9] VACULÍKOVÁ, P., VACULÍK, E. aj. Elektromagnetická kompatibilita elektrotechnických systémi̊. Grada Publishing, Praha 1998

[10] PAUL, C. R. Introduction to Electromagnetic Compatibility. John Wiley, New York 1992

[11] SCHWAB, A. J. Elektromagnetische Verträglichkeit. Springer Verlag, Berlin 1991

[12] LINEAR TECHNOLOGY. LTC 6268-10/LTC 6269-10: 4 GHz Ultra-Low Bias Current FET Input Op Amp. Data Sheet. Linear Technology Corporation

[13] TEXAS INSTRUMENTS. LMP7721 3-Femtoampere Inpu Bias Current Precision Amplifier. Data Sheet. Texas Instruments Incorporated 


\section{Parazitní jevy a jejich potlačení}

\subsection{Potlačení rušení na přívodních vodičích}

Rušivé signály $\mathrm{v}$ zásadě do zařízení pronikají třemi způsoby: elektromagnetickým zářením, kontaktně po vedení nebo kolem vedení, kdy na vedení musíme pohlížet jako na vf vedení, v němž se energie šiří elektromagnetickým polem kolem vodičů. Přitom je třeba mít na zřeteli, že při vhodných podmínkách může rušivý signál šířený po vedení využít toto vedení jako vysílací anténu a pokračovat ve formě elektromagnetického pole. Obdobně může nastat i opačný jev, kdy rušivé elektromagnetické pole může být zachyceno vedením nebo další částí zařízení jako přijímací anténou a dále se šířit „po vedení“. O tom, zda rušivý signál přijde k chráněnému zařízení po vedení, nebo polem, rozhoduje především konkrétní konfigurace zdroje a přijímače rušení, charakter prostředí, vzájemná vzdálenost, způsob propojení apod.

\subsubsection{Potlačení rušení na nesymetrickém vedení}

Vysokofrekvenčnímu rušení je tradičně vymezena oblast nad $9 \mathrm{kHz}$, často se však uvažuje oblast až od $150 \mathrm{kHz}$ výše. Rušení nad $150 \mathrm{kHz}$ bývá zpravidla také označováno jako rádiové rušení. V méně náročných případech se na vstupu citlivých zařízení buzených nesymetricky užívají RC filtry. Na vyšších kmitočtech je však na závadu sériová parazitní indukčnost kapacitoru, která způsobuje zvyšování impedance kapacitoru na vysokých kmitočtech. Lepších výsledků se dociluje s LC filtry osazenými tř́vývodovými průchozími kapacitory, které mají parazitní indukčnost podstatně nižší (viz Obr. 6.1 a). Na místě induktoru se pak užije tzv. feritová perla, realizovaná obvykle jako SMD vícevrstvový induktor (viz Obr. 6.1b). Odrušovací filtry LC se vkládají jak do signálových přívodů, tak i do napájecích přívodů Obr. 6.1 ). Do napájecích přívodů je však nutno vybrat součástky, které snesou prríslušné proudové zatížení.
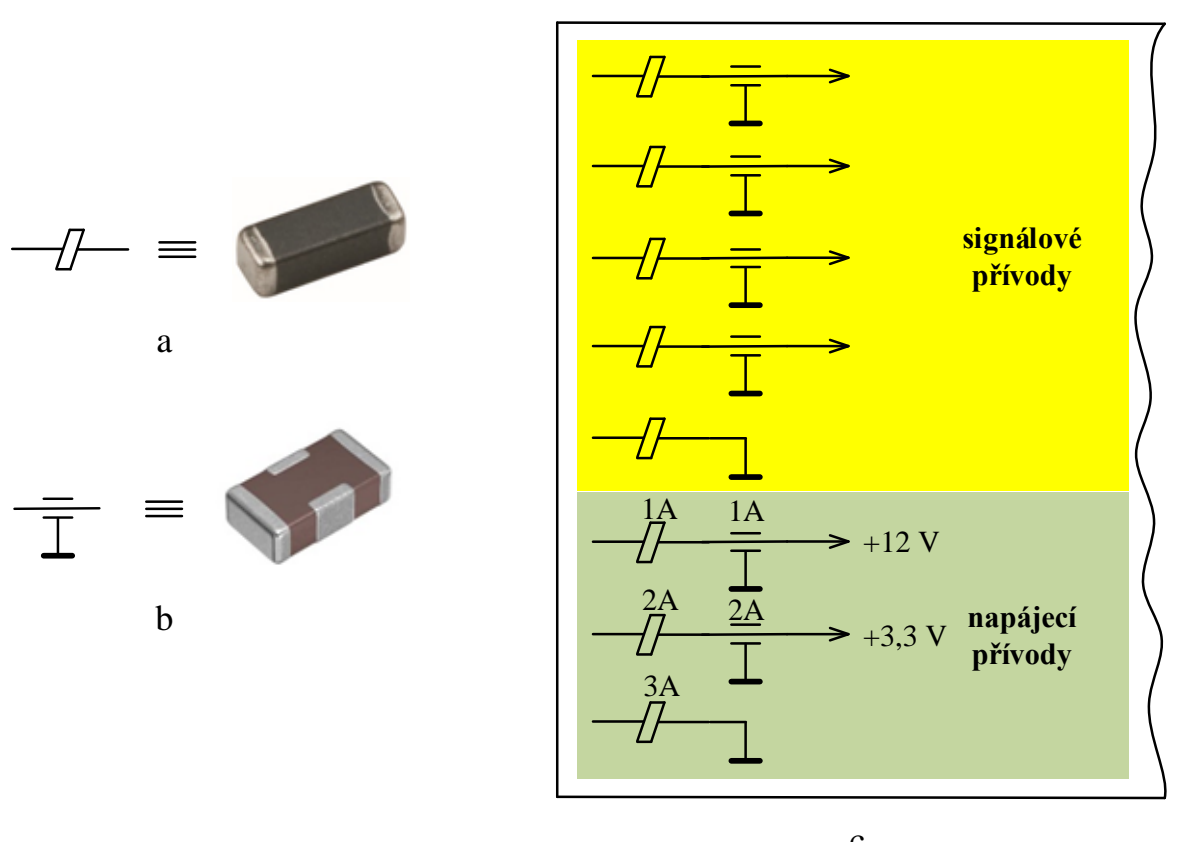

Obr. 6.1: a) Feritová perla (vícevrstvový SMD induktor), b) třívývodový průchozí kapacitor, c) odrušovací filtry na vstupních prrívodech 
Př́klad konstrukčního řešení zásuvné karty do PC s odrušenými signálovými je uveden na Obr. 6.2. Signálové vodiče přiváděné do zásuvné karty konektorem jsou ihned na vstupu odrušeny LC filtry s feritovými perlami a třívývodovými kapacitory. Zásuvná karta má na čelní straně kovový držák, který je šrouby spojen na zemní vodič zásuvné jednotky. To proto, aby vf impedance zemního spoje k zemnicí vrstvě zůstala nízká. Připojení držáku k zemnicí vrstvě vodičem by totiž vneslo do zemního spoje nežádoucí parazitní indukčnost. Kovový držák je pak dalším šroubem vodivě spojen s kovovou skříní zařízení. Každý signálový vodič je ošetřen LC filtrem s feritovou perlou a tř́vývodovým průchozím kapacitorem. Boční vývody kapacitorů jsou co nejkratším způsobem spojeny prokovenými otvory s vnitřní zemnicí vrstvou desky plošných spojů.

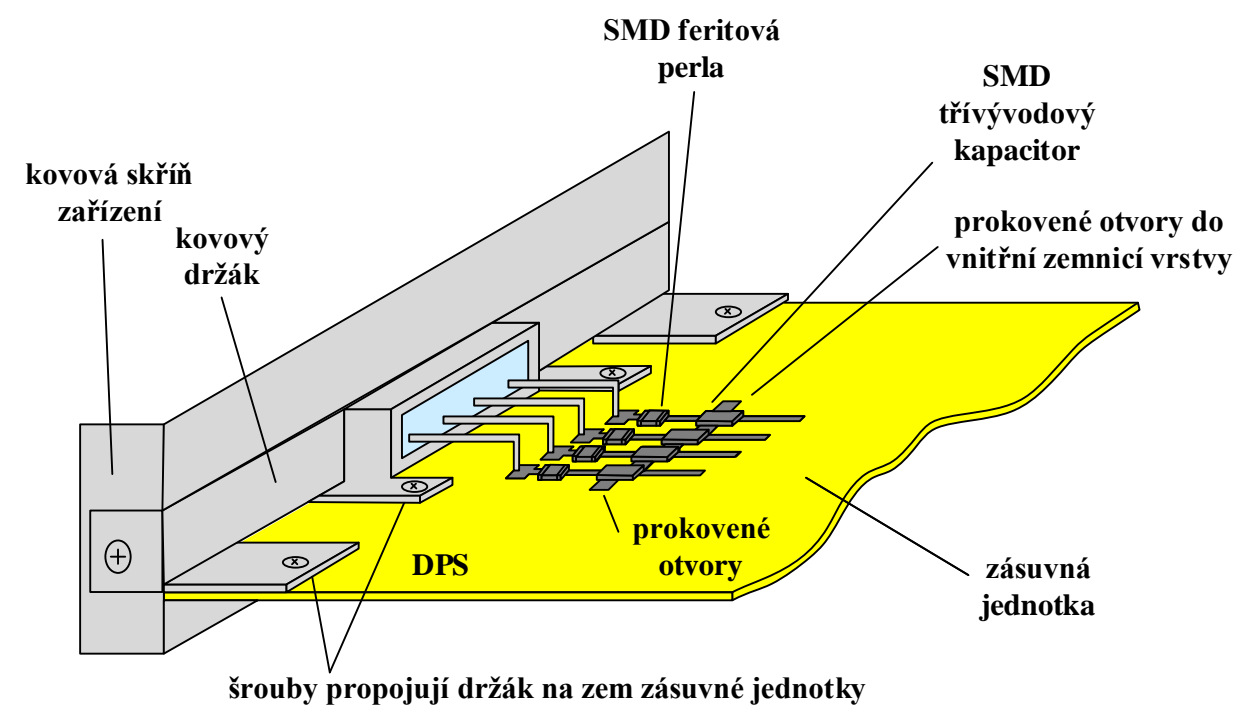

Obr. 6.2: Př́iklad konstrukčního řešení zásuvné jednotky do PC s odrušenými signálovými př́vody

V náročnějších případech musíme na vstupní vedení pohlížet jako na vf vedení, v němž se energie širrí elektromagnetickým polem kolem vodičů. Jakákoliv nehomogenita vedení, napřr. prosté zablokování př́ívodů kapacitorem mezi sebou nebo se zemním vodičem, způsobí odrazy vf energie a její šíření v různých formách do celého obvodu. Je třeba podotknout, že stejnou pozornost je nutno věnovat i napájecím př́vodům.

K potlačení vf rušení se v tomto případě užívají průchodkové kapacitory upevněné v uzemněné kovové stínicí přepážce (viz Obr. 6.3. Pro zlepšení filtračních vlastností je možno na průchozí vodič průchodkového kapacitoru navléknout jednootvorovou feritovou perlu. Stínicí přepážku je možno, na rozdíl od elektrostatického stínění, uzemnit ve více bodech. 


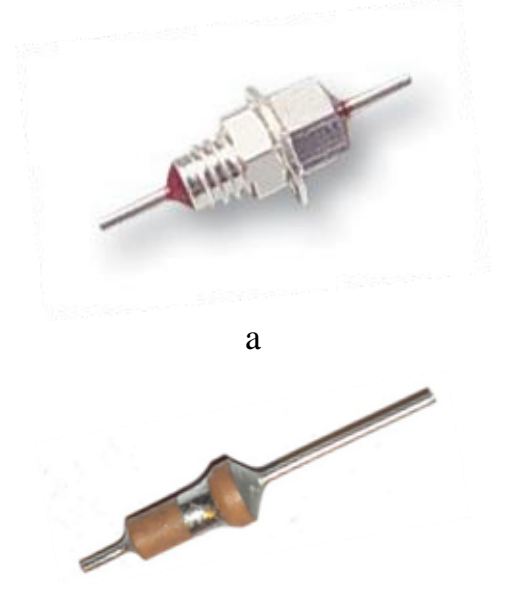

b

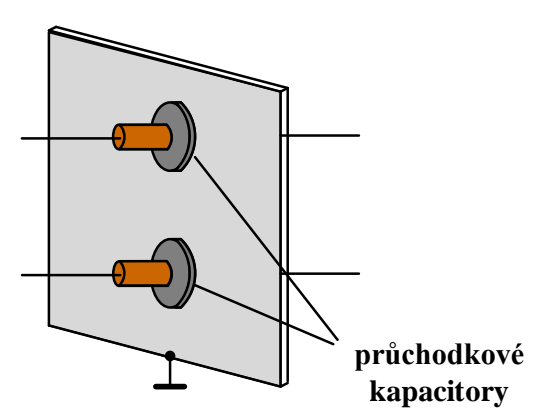

c

Obr. 6.3: Odrušení signálových spojů: a) průchodkový kapacitor se šroubením, b) na připájení nízkotavnou pájkou, c) stínicí kovová přepážka s průchodkovými kapacitory

Stínicí přepážka, ve které jsou upevněny průchodkové kapacitory, se nemá používat současně k zamezení šiřrení vf rušení a k elektrostatickému stínění signálu. Správné je použít dva paralelní stínicí systémy, první proti pronikání vf rušení a druhý pro elektrostatické stínění. $\mathrm{Na}$ Obr. 6.4 je uveden příklad uspořádání filtru zamezujícího pronikání vf rušení přes napájecí přívody do elektrostaticky odstíněného vstupního zesilovače, který je od hlavní části zařízení galvanicky oddělen. Stínicí přepážka je se stínicím krytem vodivě spojena šrouby s navlečenými distančními trubičkami. Připomeňme, že pokud je zesilovač galvanicky oddělen, musí být stínicí kryt připojen k zemi galvanicky oddělené části. Jinak může dojít i ke zhoršení rušení. Charakteristické impedance napájecích a vstupních vedení bývá $50 \Omega$ až $1 \mathrm{k} \Omega$. Pro 1 $\mathrm{MHz}$ se proto obvykle volí $\mathrm{L}=10 \mu \mathrm{H}$ a C $=1 \mathrm{nF}$.

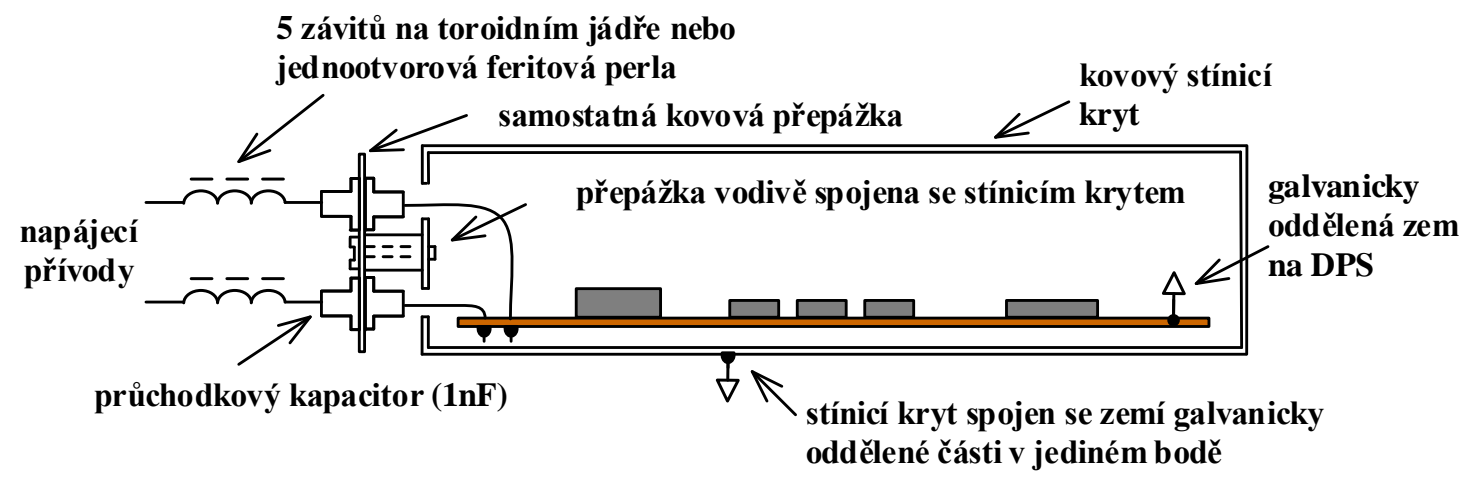

Obr. 6.4: Odrušení napájecích př́vodů elektrostaticky stíněného zesilovače

Pro různé účely je $\mathrm{k}$ dispozici celá řada průchodkových kapacitorů. Pro signálové spoje se užívají kapacitory s průměrem průchozího vodiče $0,5 \mathrm{~mm}$ s kapacitou $100 \mathrm{pF}$ až $6,8 \mathrm{nF}$, pro napájecí př́vody s proudy až $10 \mathrm{~A}$ jsou $\mathrm{k}$ dispozici kapacitory s průměrem vnitřního vodiče 0,8 mm o kapacitách $1 \mathrm{nF}$ až $8,2 \mathrm{nF}$ a pro výkonové přívody s proudy $16 \mathrm{~A}$ až 200 A se používají kapacity $1 \mu \mathrm{F}$ až $4,7 \mu \mathrm{F}$.

I když průchodkové kondenzátory představují nejúčinnější způsob odrušení, užívají se stále méně. Tento způsob odrušení je totiž velmi náročný na ruční práci, což zvyšuje finální cenu zařízení. Proto je velká snaha konstruktérů potlačit rušení již na úrovni desek plošných 
spojů. K tomuto účelu se nejčastěji užívají třívývodové průchozí kapacitory $\mathrm{SMD}$, poprr. tř́ivývodové SMD filtry LC typu T nebo П. Př́klad takového řešení je naznačen na Obr. 6.5. Tř́ivývodový SMD kapacitor, popř. tř́ivývodový LC filtr s průchozím kapacitorem se vloží do plošného vodiče v místě průchodu do stínicího krytu. Pětistranný vodivý stínicí kryt je přitom umístěn na plošný spoj realizovaný po celém obvodu stínicího krytu, který je po celém obvodu elektricky spojen se souvislou zemnicí vrstvou uvnitř DPS pomocí většího počtu prokovených otvorů. Výsledkem je šestistranný vodivý kryt, jehož šestá strana je tvořena zemnicí vrstvou. Veškeré štěrbiny mezi stínicím krytem a plošným spojem po obvodu stínicího krytu a také mezi souvislou zemnicí vrstvou musí být menší než $5 \%$ vlnové délky $\lambda$.

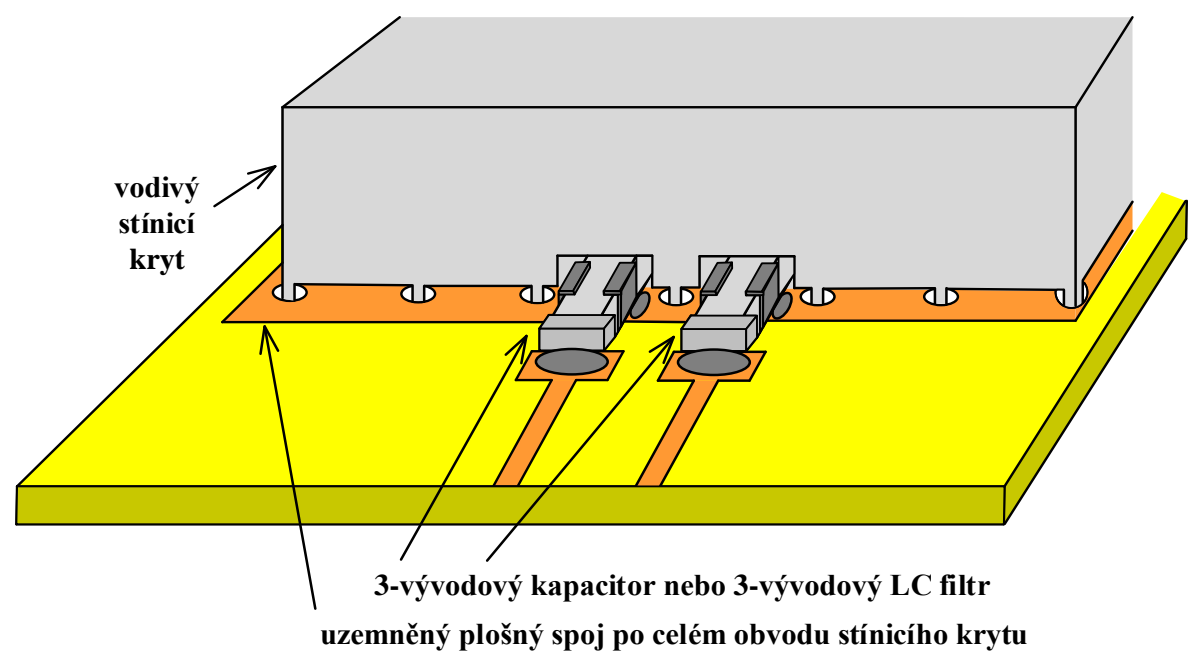

Obr. 6.5: Odrušení signálu na úrovni DPS

Třívývodový kapacitor nebo třívývodový filtr musí být připájen středovým vývodem k uzemněnému plošnému spoji realizovanému po obvodu stínicího krytu (viz Obr. 6.6). Každý tř́vyývodový prvek má být umístěn symetricky vůči prokoveným otvorům, které propojují obvodový plošný spoj a stěnu stínicího krytu s vnitřní zemnicí vrstvou. Vzdálenost prokovených otvorů po obvodu stínění musí být také menší než $5 \%$ vlnové délky.

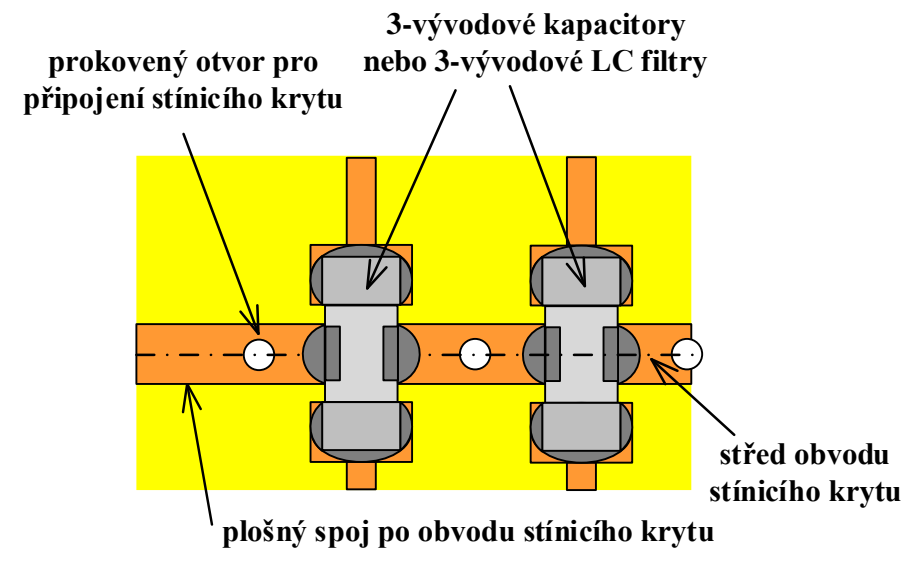

Obr. 6.6: Způsob umístění třívývodových odrušovacích prvků v místě průchodu do stínicího krytu 
Je však třeba konstatovat, že i trrívývodové odrušovací prvky jsou o hodně dražší než např. feritové perly. Aby bylo možné během testování obvodu nalézt nejlevnější řešení a zároveň se vyhnout novému návrhu DPS, vytvářejí se v přívodních plošných spojích universální pájecí plošky, které umožní připojení jakéhokoliv odrušovacího prvku, jako např́iklad:

- rezistoru s nulovým odporem, což se obvykle využije pro prvotní testování bez odrušení,

- rezistoru nebo feritové perly v sérii se signálem,

- jednoduchého RC nebo LC filtru,

- 3-vývodového průchozího kapacitoru,

- 3-vývodového průchozího LC filtru.

\subsubsection{Potlačení rušení symetrickým vedením}

Nízkofrekvenční šum či rušení, jehož kmitočtové pásmo leží v blízkosti užitečného pásma, se filtrací odstraňuje obtížně, protože obvykle dojde k částečnému narušení kmitočtového spektra užitečného signálu. V případě nf šumu se proto vyplatí raději použít symetrické vedení.

Mnoho obtíží lze totiž na nižších i vyšších kmitočtech odstranit užitím symetrického vedení signálu a rozdílových resp. diferenčních zesilovačů. Nesymetrický analogový signál se pro potřeby přenosu převede pomocí zesilovače s diferenčním výstupem na dva navzájem inversní signály (viz Obr. 6.7). Protože oba vodiče procházejí stejným zarušeným prostorem, lze předpokládat, že se do obou vodičů rušivý signál naindukuje souhlasně. Tento souhlasný signál bude potlačen $\mathrm{v}$ diferenčním přijímači. Diferenční přijímač současně zdvojnásobí dynamický rozsah užitečného signálu ve srovnání s přijímačem s asymetrickým vstupem. Vf rušivé signály, které nemají souhlasný charakter, se případně potlačí jednoduchými RC články na vstupu diferenčního přijímače.

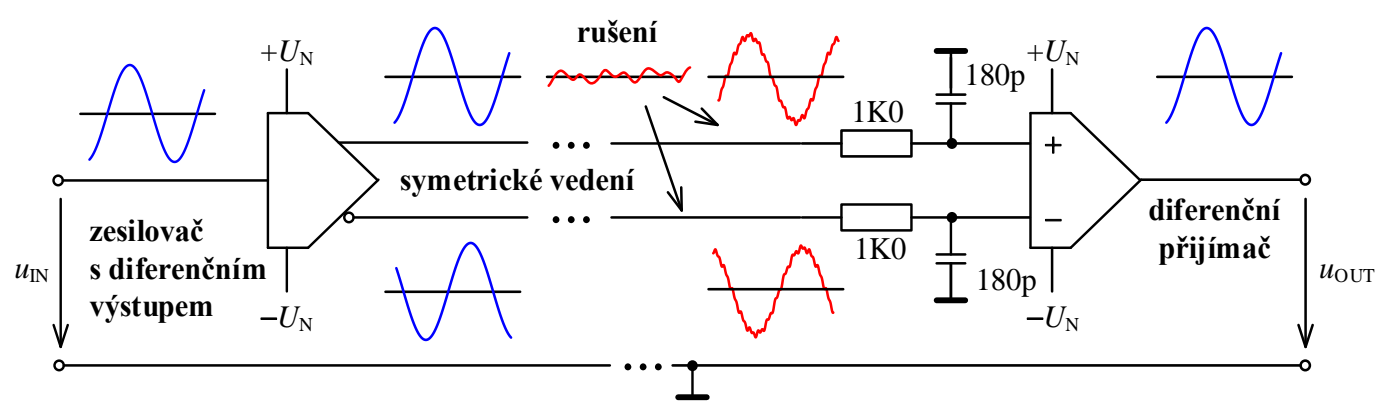

Obr. 6.7: Potlačení rušení v analogovém signálu pomocí symetrického vedení

Symetrická vedení se uživají i pro potlačení rušení ve vysokorychlostním přenosu dat. Pokud totiž použijeme pro přenos logického signálu nesymetrické vedení (viz Obr. 6.8 a a do přenášeného signálu se naindukuje impulsní rušení, není možné použití filtru, protože by se snížila strmost nástupních či sestupných hran logického signálu. Naindukovanými impulsy pak může dojít na výstupu přijímače k nežádoucímu překlopení logického signálu. Při symetrickém přenosu logického signálu se vstupní signál vztažený vůči zemnicímu vodiči převede vysílačem s diferenčním výstupem na diferenční logický signál Obr. 6.8). V symetrickém vedení se impulsní šum sečte s diferenčními signály. Protože impulsní šum má nyní charakter souhlasného signálu, bude tento šum v diferenčním přijímači potlačen. 


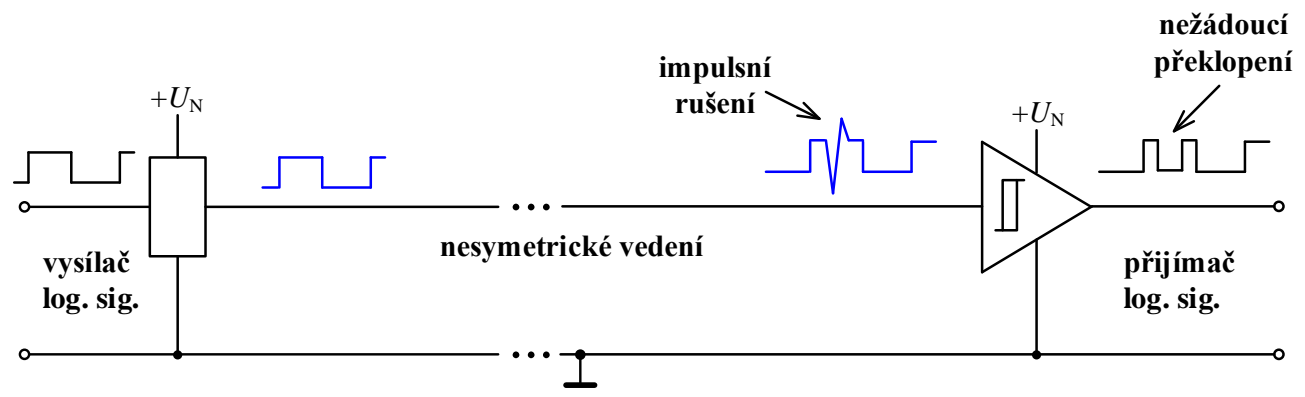

a

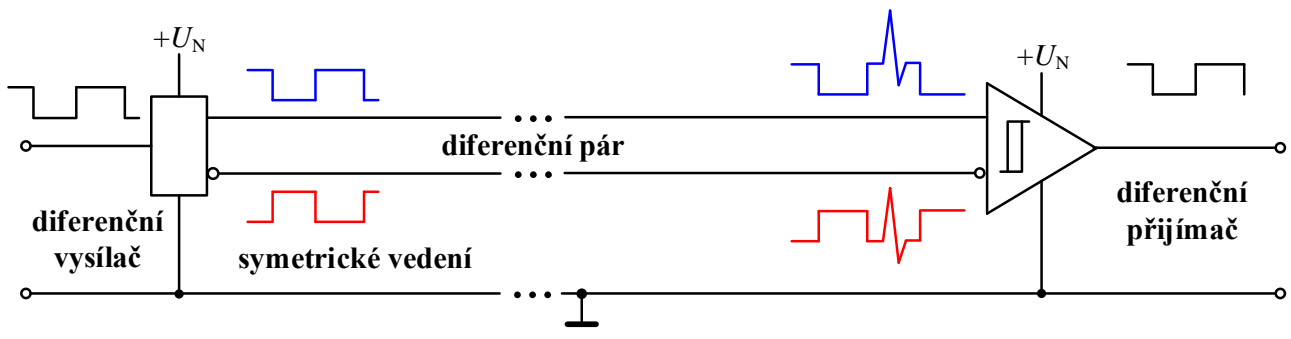

$\mathrm{b}$

Obr. 6.8: Srovnání vlivu impulsního rušení na nesymetrické a symetrické vedení

Z hlediska výstupu diferenčního přijímače se sice rušivý signál potlačí, ale z hlediska jeho vstupu se souhlasné rušivé signály z obou vodičů navzájem posilují a na diferenční vstup působí signál s dvojnásobným rozkmitem. V př́ípadě, kdy velký rozkmit signálu způsobuje na vstupu přijímače problémy, doporučuje se před diferenční přijímač do přenosového vedení zařadit symetrickou proudově kompenzovanou tlumivku (viz Obr. 6.9). Dva př́klady signálových symetrických tlumivek v provedení SMD jsou na Obr. 6.10, kde jsou také uvedeny jejich vlastnosti pro souhlasný a diferenční mód. Zatímco diferenční signál prochází tlumivkou beze změny, souhlasný šum je potlačen. Ve skutečnosti je diferenční signál částečně také symetrickou tlumivkou utlumen (viz Obr. 6.10£). Útlum diferenčního signálu však nastává až při kmitočtech o řád vyšších než je tomu u souhlasných signálů.

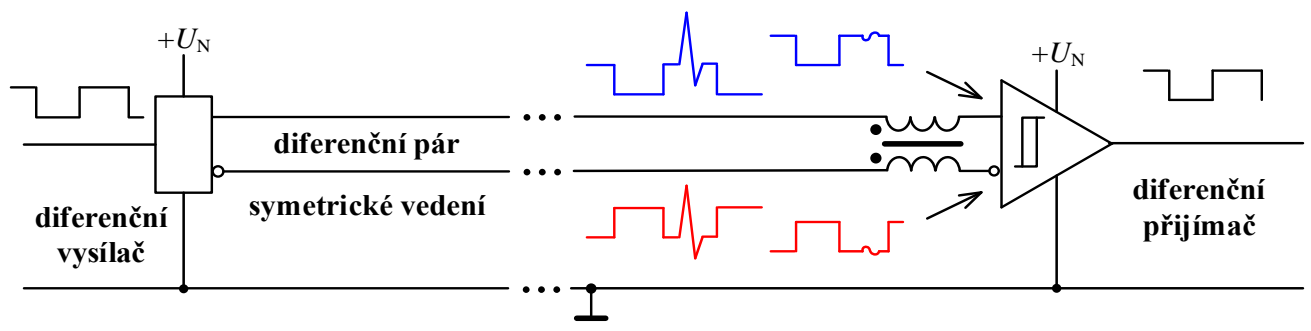

Obr. 6.9: Symetrická tlumivka vložená na konec symetrického vedení snižuje nároky na vstup diferenčního přijímače 


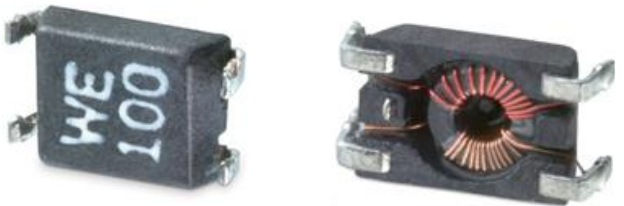

a

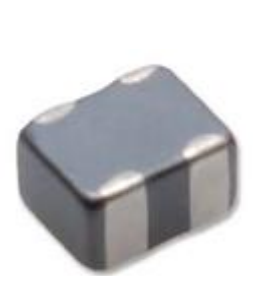

b

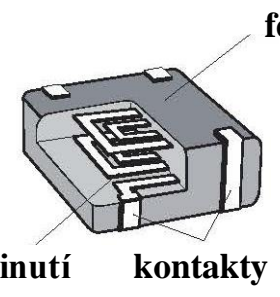

souhlasný mód

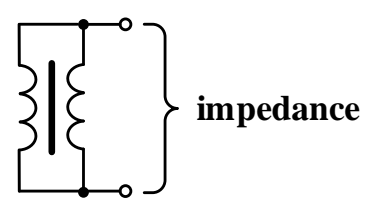

diferenční mód

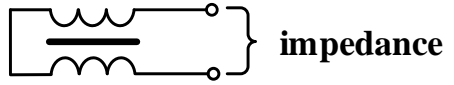

c
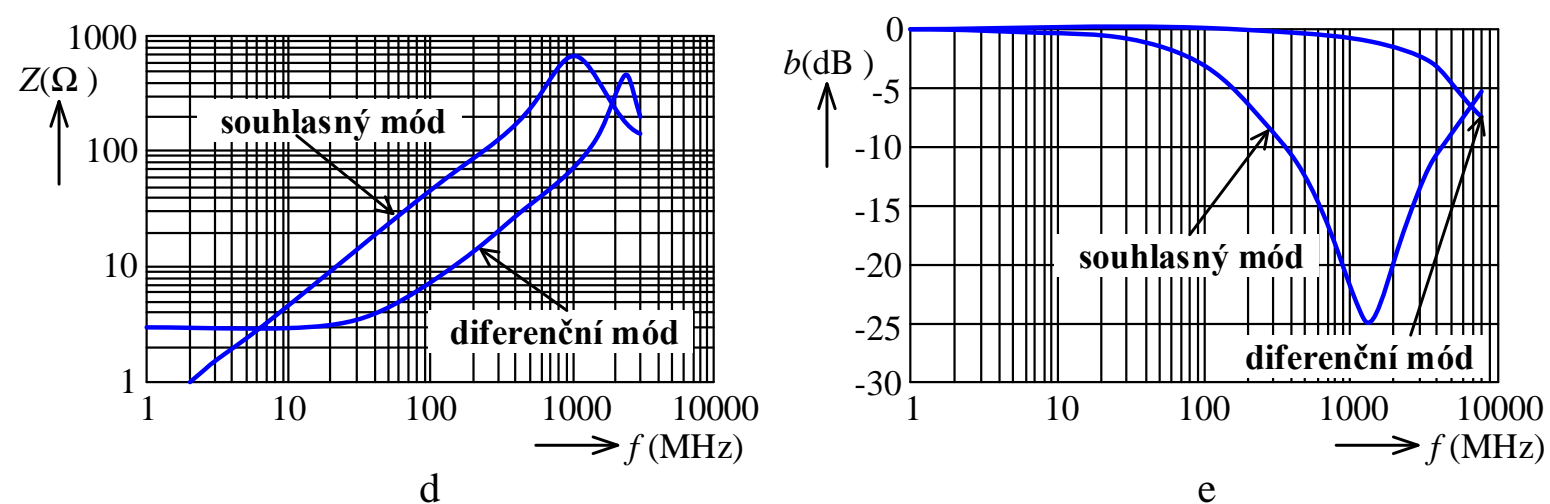

e

Obr. 6.10: a) b) SMD symetrická tlumivka, c) d) impedance pro souhlasný a diferenční mód,

e) útlumové charakteristiky pro souhlasný a diferenční mód

I když hlavním důvodem pro použití symetrické tlumivky je potlačení souhlasného šumu, nacházejí použití v symetrickém vedení i pro eliminaci zpoždění mezi diferenčními signály. Diferenční vysílač je sice konstruován tak, aby zpoždění přímého a inversního logického signálu bylo minimální, ale výrobní tolerance logických obvodů způsobují jejich vzájemné zpoždění. Pokud bude sled náběžných a sestupných hran na výstupu diferenčního vysílače nevyvážený, symetrická tlumivka díky navzájem opačnému magnetickému toku způsobí sladění hran a zmenší jejich vzájemné zpoždění (Obr. 6.11)). Podobné zpoždění způsobuje v diferenčním páru i nestejná délka jednoho z vodičů. Proto se doporučuje tlumivku vložit i na začátku vedení (Obr. 6.11b). 


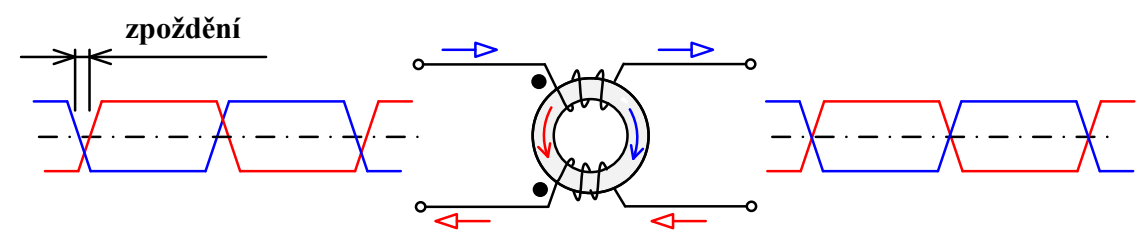

a

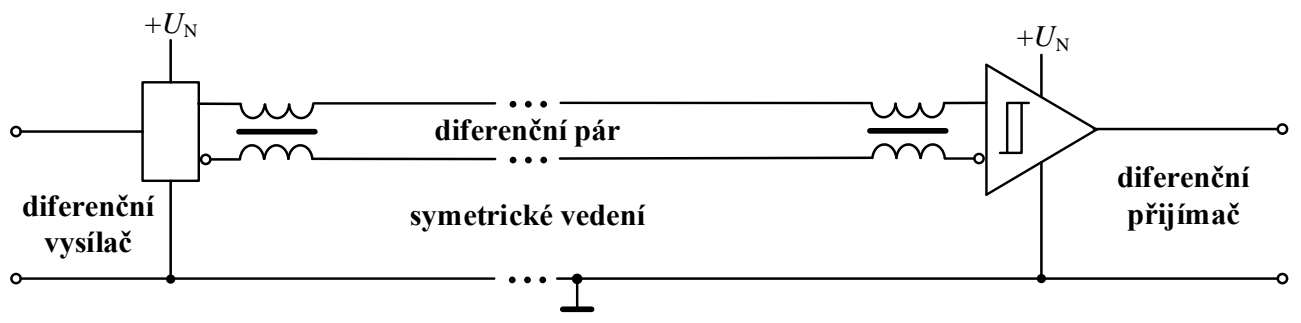

b

Obr. 6.11: a) Použití symetrické tlumivky pro eliminaci zpoždění v diferenčním páru,

b) symetrickou tlumivku se doporučuje vložit na začátku i na konci symetrického vedení

\subsection{Odpor př́vodů}

Obvykle odpor měděných vodičů zanedbáváme, protože vodiči tečou relativně malé proudy a úbytek napětí na odporu vodiče je zanedbatelný. V některých prŕípadech, např. při větších proudech, nebo při větších délkách vodičů anebo při velmi přesných měřeních, nelze úbytek napětí zanedbat. Odpor prŕívodů je pak nutno eliminovat změnou zapojení, jiným uspořádáním vodičů apod.

\subsection{1 Úbytek napětí na př́ívodu $k$ zátěži}

Na výstupní straně zařízení je často zpětnovazební zesilovač se zápornou zpětnou vazbou. Úbytek napětí na odporu př́ívodu $\mathrm{k}$ zátěži můžeme ovlivnit vhodnou volbou místa připojení obvodu zpětné vazby. První situace je znázorněna na Obr. 6.12 a, kde je naznačen invertující zesilovač s proudově posíleným výstupem. Proudový posilovač (booster) je schopen dodat do zátěže proud např. až 10 A. Pokud budeme zpětnovazební signál odebírat hned Z výstupu proudového posilovače, musíme do výstupního odporu zesilovače zahrnout i odpor vodiče $R_{\mathrm{P}} \mathrm{k}$ zátěži $\mathrm{R}_{\mathrm{Z}}$. Výstupní odpor zesilovače včetně odporu př́vodu k zesilovači je možno

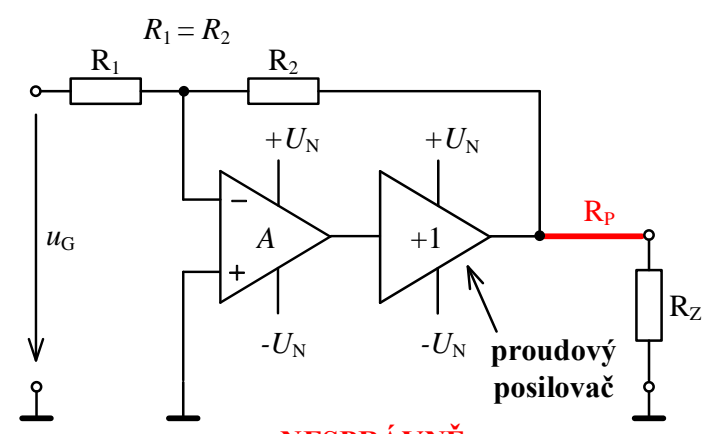

NESPRÁVNĚ

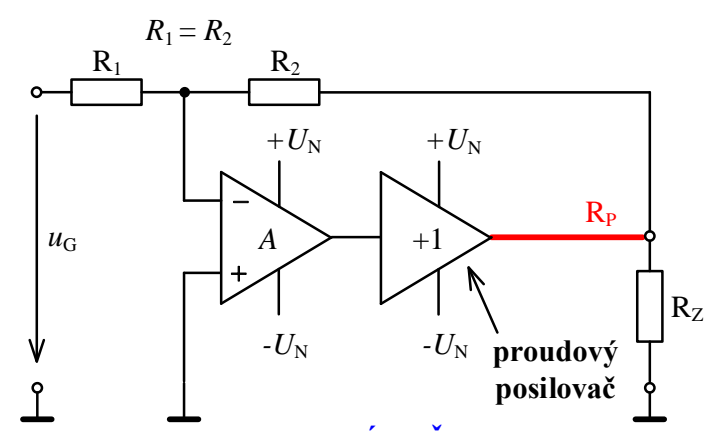

SPRÁVNĚ

b

Obr. 6.12: a) Nevhodný způsob zapojení, b) zapojení potlačující vliv impedance př́ívodu k zátěži 
pro nezatížený obvod na Obr. 6.12 $\left(R_{\mathrm{Z}}=\infty\right)$ přibližně určit dle vztahu

$$
R_{\mathrm{OUT}} \approx R_{\mathrm{P}}+\frac{R_{1}+R_{2}}{R_{1}} \frac{R_{0}}{A}
$$

kde odpor přívodu $R_{\mathrm{P}} \approx 1 \Omega, R_{0} \approx 10 \Omega$ značí výstupní odpor posilovače, $A \approx 150000$ zesílení operačního zesilovače bez zpětné vazby. Uvažujeme-li jednotkový přenos zesilovače, tj. $R_{1}=$ $R_{2}=10 \mathrm{k} \Omega$, bude výstupní odpor zesilovače $R_{\mathrm{OUT}} \approx 1 \Omega$. Na zátěži pak bude napětí snížené o úbytek na př́ivodním vodiči.

Pokud budeme zpětnovazební signál odebírat př́mo na zátěži (Obr. 6.12), situace bude mnohem prŕznivější. Odpor přívodu $R_{\mathrm{P}}$ bude nyní zahrnut do výstupního odporu posilovače a výstupní odpor obvodu tedy

$$
R_{\mathrm{OUT}} \approx \frac{R_{1}+R_{2}}{R_{1}} \frac{R_{0}+R_{\mathrm{P}}}{A} .
$$

Výstupní odpor zesilovače bude $\mathrm{v}$ tomto případě podstatně nižší $R_{\mathrm{OUT}} \approx 0,15 \mathrm{~m} \Omega$. Úbytek napětí na odporu př́vodu zůstane sice stejný, ale na napětí na zátěži nebude mít prakticky vliv. Vliv impedance přívodů je nyní potlačen velkým zesílením zesilovače bez zpětné vazby.

Uvedený způsob snímání zpětnovazebního signálu př́ímo na zátěži se užívá u zdrojů přesného napětí nebo i u napájecích zdrojů v případě, kdy vlastní stabilizátor je značně vzdálen od zátěže, a na dlouhém př́ivodním vodiči by mohly vzniknout úbytky napětí. Má-li však být zachován výstupní signál s velkým odstupem rušivých napětí, musí být plocha smyčky tvořená př́vodem $\mathrm{k}$ zátěži a zpětnovazebním vodičem malá, aby nevznikla vazba rušivým magnetickým polem z vnějších a vnitřních zdrojů rušení. Každá změna magnetického pole procházejícího smyčkou je totiž zesilovačem zpracována jako vstupní signál. Proto se má vést zpětnovazební vodič blízko, nejlépe koaxiálně (souose) s př́vodem k zátěži.

\subsection{2 Čtyřsvorkové zapojení}

V případě měření či snímání napětí na rezistorech s malým odporem, kdy odpory př́vodů nebo přechodové odpory svorek mají srovnatelné odpory s odporem měřeného rezistoru, je zapotřebí pro připojení rezistoru použít tzv. čtyřsvorkové zapojení a takovou metodu měření, která vliv odporu př́vodů a vliv přechodových odporů svorek eliminuje. Př́klad čtyřsvorkového měření rezistoru je uveden na Obr. 6.13ł. Měřený rezistor je napájen ze zdroje proudu. Protože napětí je snímáno voltmetrem přímo na rezistoru, není měření ovlivněno úbytky napětí na odporech př́vodů $R_{\mathrm{P} 1}, R_{\mathrm{P} 2}$, ani úbytky napětí na přechodových odporech proudových svorek. Napětové svorky jsou v sérii s voltmetrem a jejich přechodový odpor lze vůči vstupnímu odporu voltmetru většinou zanedbat.

Rezistory s malým odporem (řádově od $0,001 \Omega$ do $1 \Omega$ ) jsou vyráběny většinou ve čtyřsvorkovém provedení (viz Obr. 6.13b). Díky odděleným proudovým a napět'ovým svorkám je vliv přechodových odporů a odporů prrívodních vodičů eliminován. Konkrétní prríklad využití čtyřsvorkového snímacího rezistoru ve zdroji proudu řízeného napětím je uveden na Obr. 6.13飞. Zpětnovazební obvod s operačním zesilovačem reguluje proud do zátěže $\mathrm{R}_{\mathrm{Z}}$ tak, aby na snímacím rezistoru byl konstantní úbytek napětí bez ohledu na změny odporu zátěže $\mathrm{R}_{Z}$. Úbytky napětí na proudových přívodech snímacího rezistoru $\mathrm{R}_{\mathrm{S}} \mathrm{se} \mathrm{v}$ tomto př́ípadě neprojeví, protože napětí na snímacím rezistoru se snímá na samostatných svorkách. 


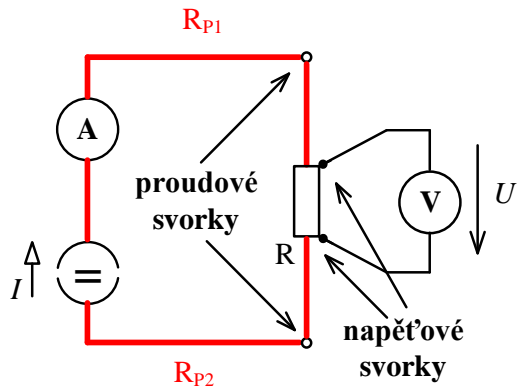

a

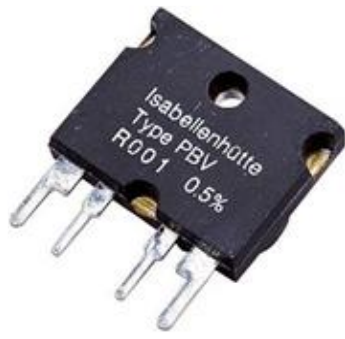

b

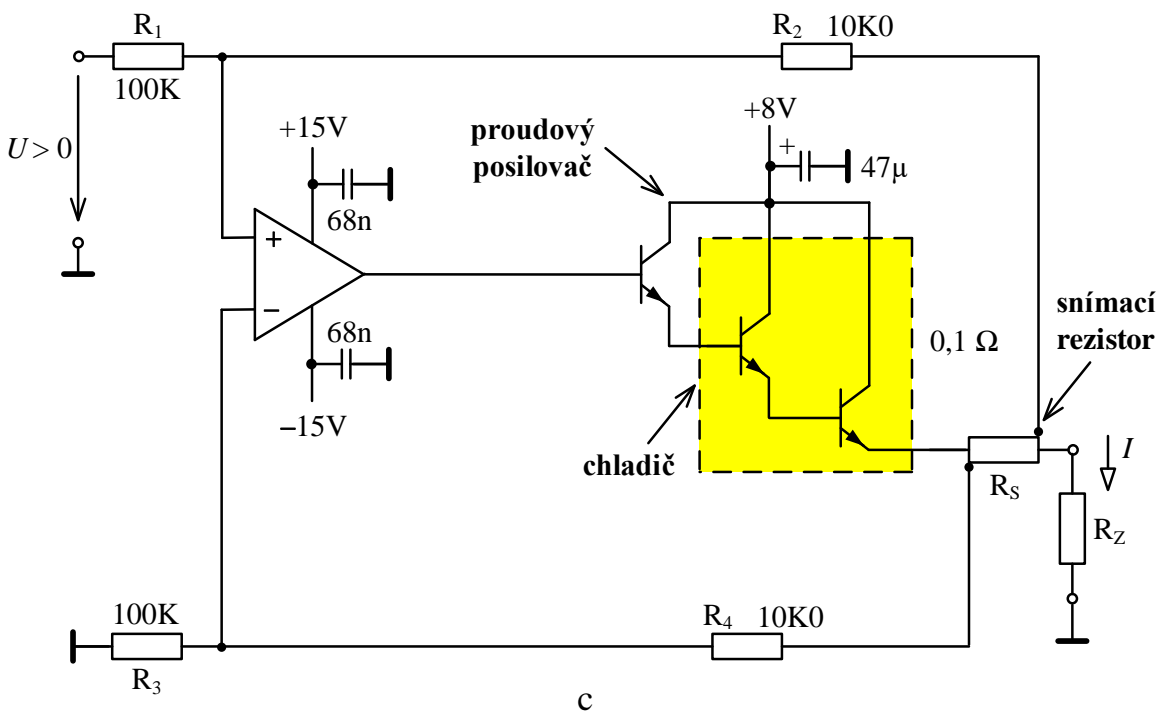

Obr. 6.13: a) Čtyřsvorkové měření rezistoru, b) čtyřsvorkový rezistor, c) využití čtyřsvorkového rezistoru ve zdroji proudu

\subsubsection{Vazba signálových obvodů na odporu přívodů}

Je-li část zemního vodiče společná jak pro vstupní, tak pro výstupní obvod zesilovače, vznikne na něm vlivem procházejícího výstupního proudu úbytek napětí vyvolávající v obvodu zpětnou vazbu. Tato vazba mezi výstupem a vstupem je obvykle způsobena uzemněním zátěže do nevhodného bodu Obr. 6.14, kdy na úseku $R_{P}$, který je společný pro vstupní i výstupní obvod, vzniká zpětná vazba.

Přenosová funkce obvodu uvedeného na Obr. 6.14je dána vztahem

$$
\frac{u_{O}}{u_{G}}=\frac{A\left(R_{\mathrm{P}}+R_{\mathrm{Z}}\right)}{R_{\mathrm{Z}}+R_{\mathrm{P}}(1-A)} \approx \frac{A R_{\mathrm{Z}}}{R_{\mathrm{Z}}+R_{\mathrm{P}}(1-A)} .
$$

Je-li zesílení zesilovače $A$ kladné (zesilovač je neinvertující), pak tato zpětná vazba zvětšuje vstupní signál a tedy i zesílení obvodu. Pro invertující zesilovač se zesílením $A<0$ zpětná vazba způsobuje zmenšení zesílení obvodu. V obvodu bez vazby mezi vstupním a výstupním obvodem zesilovače bude $R=0 \Omega$ a $u_{\mathrm{O}} / u_{\mathrm{G}}=A$. Obdobně pro $R_{\mathrm{Z}}=\infty$ je také $u_{\mathrm{O}} / u_{\mathrm{G}}=A$.

Nemá-li se vlivem parazitní zpětné vazby na odporu přívodu změnit zesílení o více než 1 $\%$, pak se dá z předchozího vztahu odvodit podmínka

$$
1,01 A \leq \frac{A R_{\mathrm{Z}}}{R_{\mathrm{Z}}+R_{\mathrm{P}}(1-A)}, \text { resp. } R_{\mathrm{P}} \leq \frac{R_{\mathrm{Z}}}{101(1-A)} .
$$


Předpokládáme-li typicky $A=-200$ a $R_{\mathrm{Z}}=1 \mathrm{k} \Omega$, pak pro odpor př́vodu dostaneme hodnotu $R_{\mathrm{P}} \leq 50 \mathrm{~m} \Omega$. Odpor prrivodu pouhých $50 \mathrm{~m} \Omega$ (např. $10 \mathrm{~cm}$ plošného spoje tloušt'ky $70 \mu \mathrm{m}$ o šířce $0,5 \mathrm{~mm}$ ) tedy změní zesílení zesilovače o $1 \%$. Vliv odporu přívodu se však neprojeví pouze na změně zesílení, ale změní se i výstupní impedance zesilovače. Předpokládáme-li, že v probíraném př́kladu by byla výstupní impedance bez zpětné vazby nulová, vliv společného odporu $R_{\mathrm{P}}=50 \mathrm{~m} \Omega$ ji zvětší při invertujícím zesilovači na $R_{\mathrm{OUT}}=(1-A) R_{\mathrm{P}} \approx 10 \Omega$.

U neinvertujícího zesilovače $(A>1)$ je vlivem zpětné vazby výstupní odpor záporný. To znamená, že se připojením zátěže výstupní napětí zvětší. Zesilovač je potenciálně nestabilní. Z uvedeného rozboru je zřejmé, že konstrukci musíme cíleně volit tak, aby vstupní a výstupní proud zesilovače neprocházel společným vodičem. To je také jeden z důvodu, proč analogovou zem je př́hodné rozdělit na signálovou a výkonovou zem a spojit je až v centrálním zemnicím bodě celého zařízení.

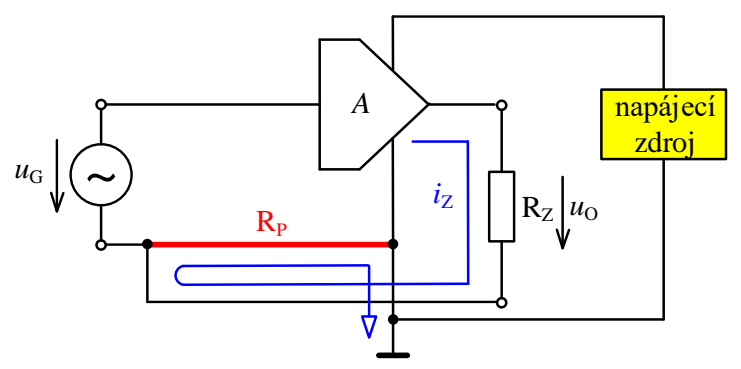

Obr. 6.14: Vazba signálových obvodů na odporu přívodů

\subsection{Termoelektrické napětí}

Při vedení spojů k jednotlivým součástkám se nevyhneme propojení vodičů z různých kovi̊. Takový spoj, který je vystaven nestejným místním teplotám, je zdrojem tzv. termoelektrického napětí. Velikost tohoto napětí závisí na konkrétní kombinaci dvou spojených kovi̊ a na rozdílu jejich teplot

$$
U_{\mathrm{TH}}=a_{\mathrm{AB}}\left(T_{2}-T_{1}\right) .
$$

Materiálová (termoelektrická) konstanta $\alpha_{\mathrm{AB}}$ závisí na konkrétní kombinaci kovů A, B. VTab 6.1 jsou uvedeny konstanty některých materiálů proti mědi. Zde slitina $\mathrm{Cd} / \mathrm{Sn}$ je nízkoteplotní pájka, $\mathrm{Pb} / \mathrm{Sn}$ je obyčejná cínová pájka, spoj $\mathrm{Cu}-\mathrm{CuO}$ př́sluší oxidované měděné svorce. $\mathrm{Na}$ styku dvou stejných kovů termoelektrické napětí nevznikne $\left(\alpha_{\mathrm{AA}} \approx 0\right)$.

Tab 6.1: Termoelektrické konstanty některých materiálů proti mědi

\begin{tabular}{|l|c|}
\hline $\begin{array}{c}\text { Materiály } \\
\mathbf{A}-\mathbf{B}\end{array}$ & $\begin{array}{c}\text { Termoelektrická } \\
\text { konstanta } \boldsymbol{\alpha} \mathbf{A B}\left(\boldsymbol{\mu V} /{ }^{\circ} \mathbf{C}\right.\end{array}$ \\
\hline $\mathrm{Cu}-\mathrm{Cu}$ & $<0,2$ \\
\hline $\mathrm{Cu}-\mathrm{Ag}$ & 0,3 \\
\hline $\mathrm{Cu}-\mathrm{Au}$ & 0,3 \\
\hline $\mathrm{Cu}-\mathrm{Cd} / \mathrm{Sn}$ & 0,3 \\
\hline $\mathrm{Cu}-\mathrm{Pb} / \mathrm{Sn}$ & $1 \mathrm{až} 3$ \\
\hline $\mathrm{Cu}-\mathrm{Si}$ & 400 \\
\hline $\mathrm{Cu}-\mathrm{Kovar}$ & 40 \\
\hline $\mathrm{Cu}-\mathrm{CuO}$ & 1000 \\
\hline
\end{tabular}


Z uvedené rovnice vyplývají dvě konstrukční zásady pro potlačení nežádoucích termoelektrických napětí: použití jediného kovu, nebo úplné vyrovnání teplot.

První zásada je nepoužitelná v systémech obsahujících různorodé elektronické součástky (viz Obr. 6.15 ). Nechtěné termoelektrické spoje vznikají v samotných součástkách, v jejich styku s mědí a pájkou plošného spoje, v signálových prrívodech vedených přes konektor, na vstupních svorkách apod.

Ani druhá zásada není snadno realizovatelná v soustavě, která mění elektrickou energii v teplo. K potlačení nežádoucích termoelektrických napětí jsou nutné promyšlenější postupy. Teplotní rozdíly ve vstupní části zesilujícího obvodu musí být co nejmenší. Působení sálavého tepla a volně cirkulujících vzdušných proudů zabrání masivní uzavřená kovová krabice. Teplo přiváděné po signálových a napájecích přívodech se omezí zmenšením jejich průřrezu a teplotním zkratem do kostry (masivní měděné vstupní svorky). Teplo generované uvnitř krabice musí být malé. Klidový prríkon aktivních součástek se volí co nejmenší. Výkonové členy je lépe umístit mimo teplotně chráněnou oblast. Teplotní rozdíly nelze zcela vyloučit, ale je možné je usměrnit tak, aby nevadily. Pokud je to možné, navrhne se zařizení obvodově souměrné a symetrie se vyjádří konstrukčně i topologicky, viz náčrt uvedený na Obr. 6.15b. Kritické párové součástky se umístí podle osy tepelné symetrie. Aktivní součástky (operační zesilovače, tranzistory) a další zdroje tepla se uloží na osu symetrie nebo souměrně podle ní, jsou-li v páru. Vyvolané teplotní pole zasáhne citlivé párové součástky stejnou měrou a jejich termoelektrická napětí se vyruší. To je samozřejmě ideální př́ípad, ke kterému je možno pouze se přiblížit. Rovnoměrnému rozložení teploty na DPS napomáhá i horní souvislá vrstva měděné fólie plošného spoje, která vytváří tepelný zkrat.

Odhalení a potlačení termoelektrických napětí v hotovém přístroji vyžaduje dost úsilí, trpělivosti a zkušeností. Na výsledek každého zákroku teplou pájkou je nutno čekat až hodinu, až se obnoví tepelná rovnováha. Poznamenejme však, že se uvedené zásady nemají přeceňovat a v běžných př́padech se termoelektrická napětí mohou zanedbat. Stačí je vyhledat, když se objeví obtíže.

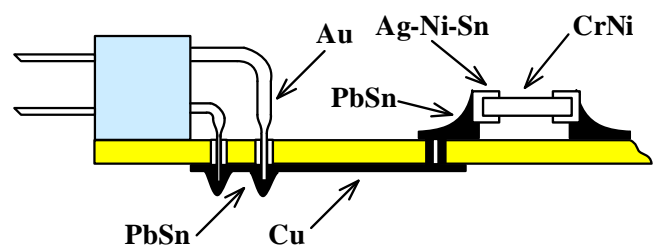

a

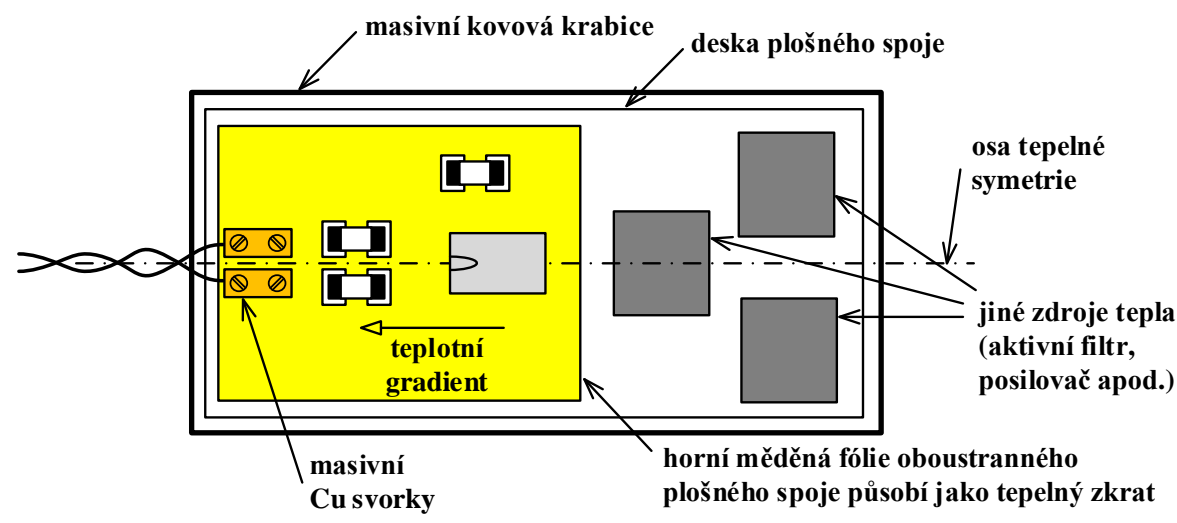

b

Obr. 6.15: a) Nežádoucí termoelektrické spoje v systému obsahujícím různorodé součástky, b) symetrická konstrukce cílená na potlačení termoelektrického napětí 


\subsection{Vliv parazitních impedancí}

Otázkou potlačování nežádoucích vazeb mezi jednotlivými obvody se zabývala kapitola o stínění obvodů. U každého reálného obvodu se však setkáváme s řadou dalších vnitřních kapacitních nebo induktivních vazeb. Mohou to být vnitřní kapacity nebo indukčnosti použitých součástek, nebo kapacity a vzájemné indukčnosti mezi libovolnými body zapojení. Vliv těchto parazitních impedancí se uplatňuje obecně od tím nižších kmitočtů, čím větší jsou impedance a zisky zesilovacích stupňů ve sledovaném obvodu. V této kapitole si povšimneme některých důsledků, které parazitní impedance způsobují ve vlastním obvodu.

\section{Millerova kapacita}

Pokud při návrhu plošných spojů bude výstupní vodič invertujícího zesilovače veden v blízkosti vstupního přívodu, může vzniklá parazitní kapacita $C_{\mathrm{P}}$ značně ovlivnit šířku kmitočtového pásma zesilovače Obr. 6.16 ). Parazitní kapacita $C_{\mathrm{P}}$ mezi vstupem a výstupem se v tomto prŕípadě jeví mezi vstupem zesilovače a zemním vodičem jako tzv. Millerova kapacita $C_{\mathrm{M}}=(1-A) C_{\mathrm{P}}$ Obr. 6.16). Tato kapacita tvoří společně s vnitřním odporem $R_{\mathrm{G}}$ budicího generátoru dolní propust s mezním kmitočtem $f_{\mathrm{m}}=1 / 2 \pi R_{\mathrm{G}} C_{\mathrm{M}}$, kdy nastává pokles zisku o $3 \mathrm{~dB}$. Např. pro zesilovač se zesílením $A=-200, C_{\mathrm{P}}=50 \mathrm{pF}, R_{\mathrm{G}}=1 \mathrm{k} \Omega$ bude mezní kmitočet takovéhoto zesilovače jen $16 \mathrm{kHz}$.

Podobným způsobem se projevuje i vnitřní parazitní kapacita $C_{\mathrm{BC}}$ přechodu mezi kolektorem a bází tranzistoru, která prakticky znemožňuje použití zapojení tranzistoru se společným emitorem jako vf zesilovače.

Parazitní kapacita $C_{\mathrm{BC}}$ (viz Obr. 6.17 la) se totiž jeví na vstupu tranzistoru v zapojení SE, který má napětové zesílení $A_{\mathrm{U}} \approx-g_{\mathrm{m}} R_{\mathrm{C}}$ (zde $g_{\mathrm{m}}$ je strmost tranzistoru), jako daleko větší Millerova kapacita $C_{\mathrm{M}}=\left(1-A_{\mathrm{U}}\right) C_{\mathrm{BC}}, A_{\mathrm{U}}<0$. Tato kapacita tvoří společně s vnitřním odporem $R_{\mathrm{G}}$ budicího zdroje dolní kmitočtovou propust Obr. 6.17b), která omezuje kmitočtové pásmo zpracovaného signálu. Např́. pro $C_{\mathrm{BC}}=5 \mathrm{pF}, R_{\mathrm{G}}=1 \mathrm{k} \Omega, A_{\mathrm{U}}=-200$, bude $C_{\mathrm{M}} \approx 1 \mathrm{nF}$ a k omezení kmitočtového pásma začne docházet již od kmitočtu $f_{\mathrm{m}}=1 / 2 \pi R_{\mathrm{G}} C_{\mathrm{M}} \approx 160 \mathrm{kHz}$.

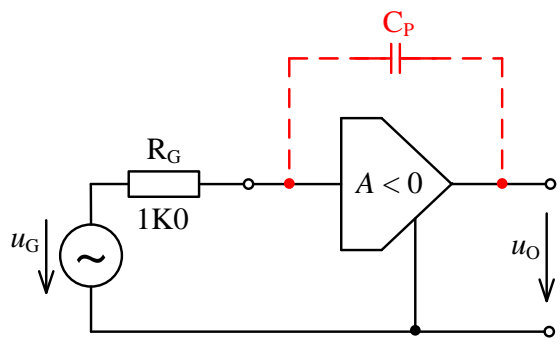

a

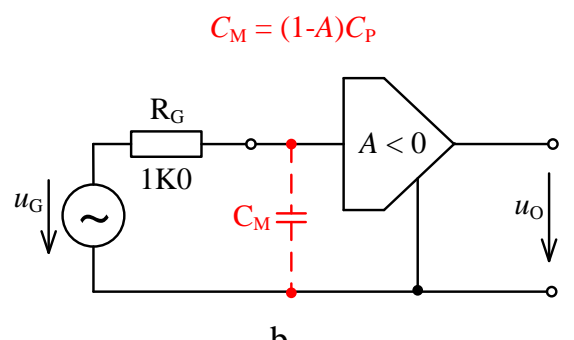

$\mathrm{b}$

Obr. 6.16: a) Parazitní kapacita mezi vstupem a výstupem invertujícího zesilovače,

b) náhradní model s Millerovou kapacitou

Snaha zmenšit tuto nežádoucí kapacitu vedla k vývoji nových aktivních prvků jako např́klad tranzistorů řízených polem se dvěma řídicími elektrodami, speciálních typů bipolárních tranzistorů se zmenšenou kapacitou přechodu kolektor-báze, nebo k návrhu zapojení, u nichž je vliv nežádoucí kapacity potlačen. Jako př́klad uvedeme kaskodové zapojení tranzistorů na Obr. 6.17. Tranzistor $\mathrm{T}_{1}$ zde pracuje v zapojení se společným emitorem (SE) a tranzistor $\mathrm{T}_{2} \mathrm{v}$ zapojení se společnou bází (SB). V kolektoru tranzistoru $\mathrm{T}_{1}$ je zde místo kolektorového odporu použit vstupní odpor zapojení $\mathrm{SB}$, který má hodnotu $R_{\mathrm{vst}} \approx 1 / g_{\mathrm{m}}$. Proto 
bude zesílení signálu na kolektoru $\mathrm{T}_{1}$ jednotkové $A_{\mathrm{U} 1}=-g_{\mathrm{m}} R_{\mathrm{vst}}=-g_{\mathrm{m}} / g_{\mathrm{m}}=-1$ a Millerův efekt se prakticky neuplatní. Napět'ové zesílení kaskódového zesilovače na kolektoru $T_{2}$ zůstává stejné $A_{\mathrm{U} 2} \approx-g_{\mathrm{m}} R_{\mathrm{C}}$. Na vstupu $\mathrm{T}_{1}$ bude nyní Millerova kapacita $C_{\mathrm{M}}=2 C_{\mathrm{BC}}$.

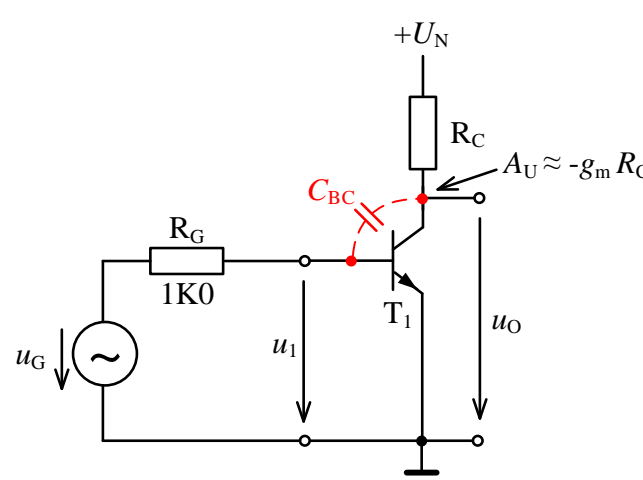

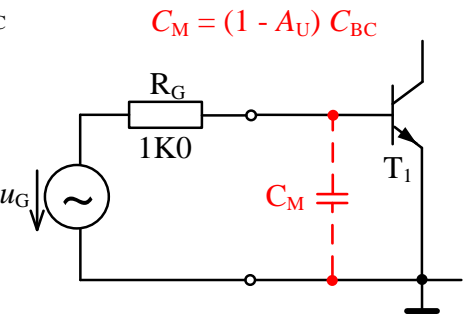

b

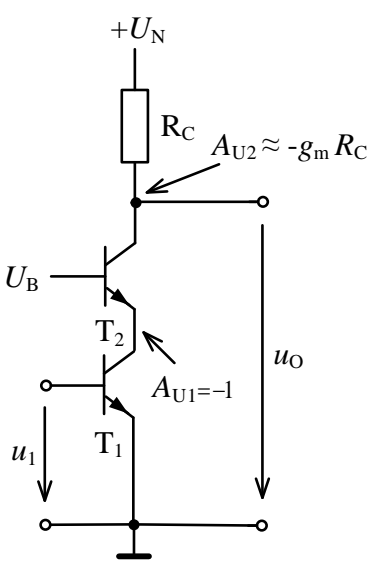

c

Obr. 6.17: a) Vliv parazitní kapacity na zapojení SE, b) k vysvětlení Millerova jevu,

c) kaskódové zapojení

\section{Vliv parazitních kapacit a indukčností na vlastnosti zesilovače}

Jak malá parazitní kapacita již může zhoršit vlastnosti zesilovače, ukážeme na př́ikladu obvodu naznačeného na Obr. 6.18. Uvažujme zesilovač, který má zpracovat vstupní signál $10 \mathrm{mV}$ s odstupem od ostatních signálů alespoň o $60 \mathrm{~dB}$. Odpor zdroje signálu uvažujme např. $R_{\mathrm{G}}=1 \mathrm{k} \Omega$. Odstupu $60 \mathrm{~dB}$ od $10 \mathrm{mV}$ odpovídá $1000 \mathrm{x}$ menší př́ípustný rušivý signál, tj. $10 \mu \mathrm{V}$. Pokusme se určit, jaká může být největší parazitní kapacita mezi vstupem zesilovače a zdrojem rušení o napětí $10 \mathrm{~V} / 50 \mathrm{~Hz}$. Z předchozí úvahy vyplývá, že zdroj rušení smí vyvolat na rezistoru $\mathrm{R}_{\mathrm{G}}$ úbytek napětí nejvýše $10 \mu \mathrm{V}$. Úbytku $10 \mu \mathrm{V}$ na $1 \mathrm{k} \Omega$ odpovídá proud $10 \mathrm{nA}$. Reaktance kapacitoru $X_{\mathrm{C}}=1 / \omega C_{\mathrm{P}}$, kterým protéká při kmitočtu $50 \mathrm{~Hz}$ proud $10 \mathrm{nA}$, může mít maximálně hodnotu $X_{\mathrm{C}} \approx 10 \mathrm{~V} / 10 \mathrm{nA}=10^{9} \Omega$. Z toho vyplývá, že kapacita $C_{\mathrm{P}}=1 /\left(\omega X_{\mathrm{C}}\right)$ smí být pouze $3 \mathrm{pF}$ ( $\mathrm{tj}$. např. sousední plošné spoje vedené paralelně v délce $5 \mathrm{~cm}$ ). Vidíme, že př́ípustná parazitní kapacita je velmi malá i u zesilovače s běžnými středními impedancemi vstupních obvodů. Proto se většinou v náročnějších vstupních obvodech neobejdeme bez speciálních opatření, jako jsou stíněné vodiče, proložení sousedních plošných spojů uzemněným plošným spojem, oddálení sousedících vodičů apod.

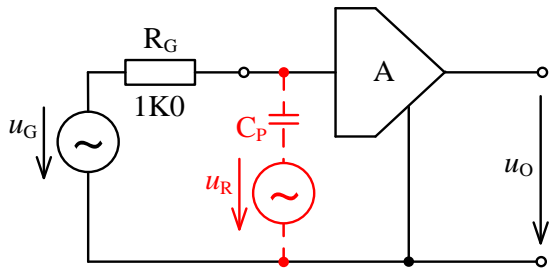

Obr. 6.18: K určení vlivu parazitních kapacit sousedících vodičů na vlastnosti zesilovače

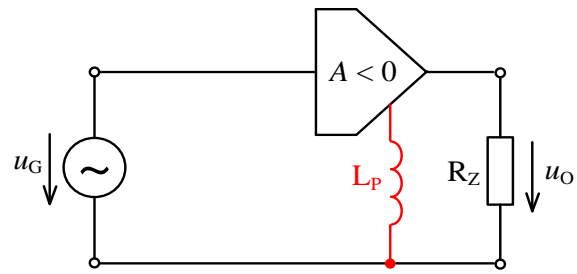

Obr. 6.19: K určení vlivu parazitní indukčnosti společného př́vodu vstupní a výstupní části zesilovače 
Ani ve zdánlivě nízkofrekvenčních obvodech nelze vliv parazitních impedancí podceňovat. Vysvětlíme tvrzení na základě rozboru vlivu parazitní indukčnosti $L_{P}$ na činnost obvodu zesilovače nakresleného na Obr. 6.19. Protože parazitní indukčnost je společná vstupnímu i výstupnímu obvodu zesilovače, vznikne proudová kmitočtově závislá zpětná vazba. Reaktance parazitní indukčnosti $X_{\mathrm{L}}=\left|\bar{Z}_{\mathrm{L}}\right|=\omega L_{\mathrm{P}}=2 \pi f L_{\mathrm{P}}$ ovlivní modul přenosu obvodu takto

$$
\frac{u_{O}}{u_{G}}=\frac{A R_{\mathrm{Z}}}{R_{\mathrm{Z}}+X_{\mathrm{L}}(1-A)} .
$$

Pokud se vlivem parazitní zpětné vazby na indukčnosti přívodu nemá zesílení změnit o více než $1 \%$, lze z předchozího vztahu odvodit podmínku

$$
X_{\mathrm{L}} \leq \frac{R_{\mathrm{Z}}}{101(1-A)} .
$$

Předpokládáme-li typicky $A=-1000, R_{\mathrm{Z}}=1 \mathrm{k} \Omega$, pak reaktance parazitní indukčnosti $X_{\mathrm{L}} \leq 0,01 \Omega$. Požadujeme-li, aby se kmitočtová charakteristika zesilovače nezměnila do kmitočtu $10 \mathrm{kHz}$ o více než $1 \%$, parazitní indukčnost nesmí být větší než $L_{\mathrm{P}}=X_{\mathrm{L}} / 2 \pi f=$ $=0,01 / 2 \pi \cdot 10^{4} \approx 160 \mathrm{nH}$. Takovou parazitní indukčnost vykazuje např. plošný spoj o délce $130 \mathrm{~mm}$, tloušt'ce $70 \mu \mathrm{m}$ a šířce $0,5 \mathrm{~mm}$. Při návrhu plošných spojů je proto nutno zajistit, aby vodič společné vstupní a výstupní části byl vždy co nejkratší.

\section{Vliv vzájemných parazitních impedancí na digitální obvody}

U digitálních obvodů mohou parazitní impedance mezi sousedícími vodiči způsobovat nežádoucí překlopení sousedních digitálních obvodů. Ačkoliv se zdálo, že hodnoty vzájemné kapacity i vzájemné indukčnosti plošných spojů jsou relativně malé, je třeba vzít v úvahu, že čím delší bude společná dráha vodičů, tím budou jejich hodnoty vyšší a navíc dochází $\mathrm{k}$ interakci se všemi dalšími sousedními vodiči. Proto je nutno se zabývat při návrhu plošných spojů pro digitální obvody i těmito parazitními vlastnostmi.

Parazitní galvanická vazba mezi vodiči vzniká při nedokonalé vzájemné izolaci vodičů, např. při nedokonalém odleptání mědi mezi plošnými spoji při výrobě DPS. Galvanickou vazbu si můžeme zjednodušeně modelovat pomocí parazitního rezistoru $R_{P}$ Obr. 6.20 a). Signál $\mathrm{z}$ prvního vodiče se do sousedního přenese v dělicím poměru děliče $R_{\mathrm{P}}$ a $\mathrm{R}_{\mathrm{G} 2} \| \mathrm{R}_{\mathrm{Z} 2}$.

Vliv vzájemné kapacity plošných vodičů si můžeme zjednodušeně namodelovat pomocí parazitního kapacitoru $C_{\mathrm{P}}$ (viz Obr. 6.20 $)$ ), který se zátěží sousedního vodiče $\mathrm{R}_{\mathrm{P}}$ a $\mathrm{R}_{\mathrm{G} 2} \| \mathrm{R}_{\mathrm{Z} 2}$ tvoří derivační RC článek. Napět'ové změny v prvním vodiči vyvolávají v parazitním kapacitoru proud $i(t)=C_{\mathrm{P}} \mathrm{d} u(t) / \mathrm{d} t$, který se na zátěži sousedního vodiče převede na napět'ové změny. Pokud v prvním vodiči bude docházet ke skokovým změnám napětí, pak se v sousedním vodiči objeví, tzv. derivační špičky. Čím bude parazitní kapacita $C_{\mathrm{P}}$ větší, tím větší bude i výška těchto impulsů. V reálném př́ípadě, kdy na DPS je celá řada dalších obvodů, je indukovaný proud v daném obvodu ve skutečnosti superpozici všech vzájemně kapacitně spojených obvodů působících na daný plošný vodič.

Kromě vzájemné kapacity existuje ještě další, často i důležitější mechanismus interakce sousedících plošných vodičů a to vzájemná parazitní indukčnost $M_{\mathrm{P}}$. Vzájemná indukčnost je přítomna všude tam, kde jsou dvě smyčky proudu. Tyto proudové smyčky vytvářejí magnetická pole, která vzájemně reagují úměrně rychlosti změnám proudu ve smyčce. Vzájemnou indukčnost si můžeme představit jako impulsní transformátorek vložený mezi sousední vodiče (viz Obr. 6.20b). Proudové změny v prvním vodiči vyvolají v sousedním vodiči napětí $u(t)=M_{\mathrm{P}} \mathrm{d} i(t) / \mathrm{d} t$. Proto budou rychlé proudové změny $\mathrm{v}$ prvním vodiči přeneseny 
do sousedního vodiče opět jako derivační špičky. V reálném př́ípadě je účinek na daný vodič dán superpozicí vlivu vzájemných indukčností od všech ostatních sousedních obvodů.

Derivační špičky způsobují v prrípadě analogových obvodů impulsní rušení, v př́padě číslicových obvodů pak mohou způsobovat tzv. hazardní stavy, kdy může dojít k nežádoucímu překlopení sousedních digitálních obvodů. Vzájemnou parazitní kapacitu či indukčnost lze potlačit vzájemným oddálením sousedních vodičů, zkrácením délky paralelně vedených vodičů, nebo vložením zemního vodiče mezi sousední vodiče. V př́ípadě vícevrstvých DPS se pak doporučuje vložit vnitřní zemnicí vrstvu.

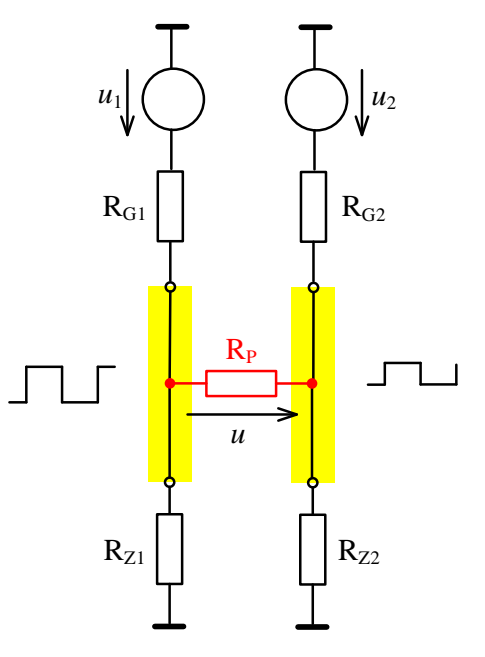

a

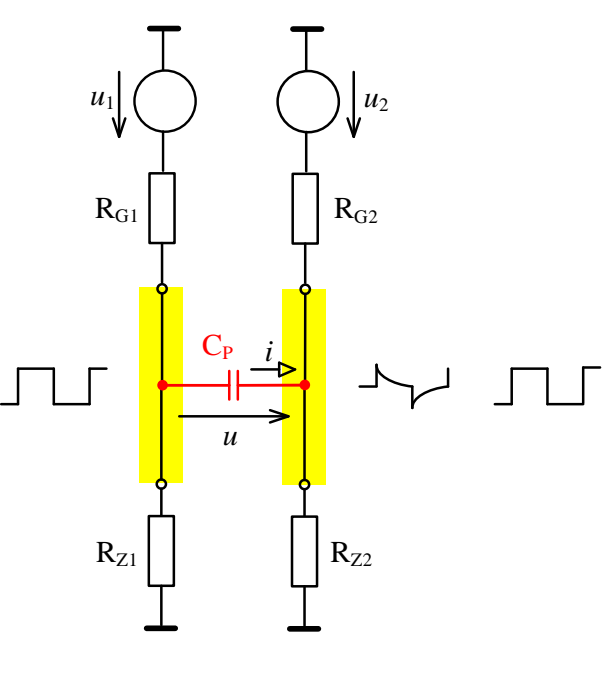

b

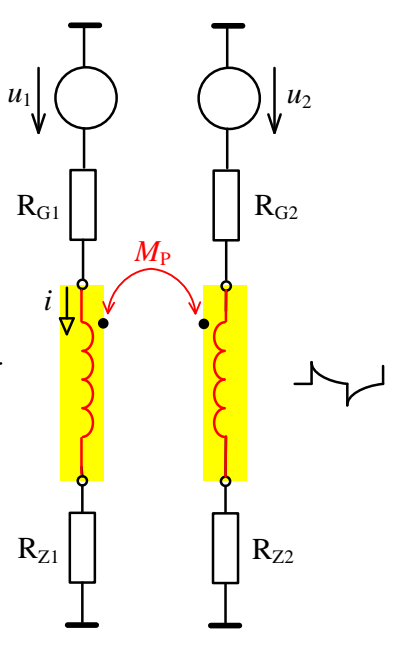

Obr. 6.20: Účinek vzájemných impedancí mezi sousedními vodiči na digitální obvody:

a) galvanická vazba, b) vzájemná kapacita, c) vzájemná indukčnost

\subsection{Přepětí na indukční zátěži}

Relé, reproduktory a ostatní zařízení s elektromagnety mají impedanci indukčního charakteru. Při vypnutí proudu by bez ochranných obvodů na vinutí těchto součástek vznikla velká přepětí. Velikost napět'ových špiček je ve většině případů větší než maximální př́ípustné napětí $U_{\text {CEmax }}$ tranzistoru. Obvykle tyto špičky neodstraní ani stabilizátor napájecího napětí, protože většina stabilizátorů je př́liliš pomalá a nestačí včas tyto rázy omezit. Přepětové rázy je třeba potlačit přímo $\mathrm{v}$ místě vzniku připojením paralelního členu $\mathrm{k}$ cívce. $\mathrm{K}$ tomuto účelu se dají použít diody, rezistory, nelineární rezistory, referenční diody, kapacitory a jejich kombinace.

Pro běžné použití je nejvhodnější dioda Obr. 6.21 ), která je zapojena vzhledem k napájecímu napětí vždy v závěrném směru. Po odpojení napájecího zdroje se indukčnost vinutí snaží zachovat původní velikost a směr proudu přes diodu, která je v tomto okamžiku pólována v propustném směru. Tím je zamezeno vzniku přepětí, ale zpožd’uje se tím poněkud odpad kotvy relé vlivem procházejícího proudu.

Dobu odpadu lze zkrátit rezistorem zapojeným v sérii s diodou Obr. 6.21b), čímž se zvětší odpor diody v propustném směru. Zde ovšem připouštíme napětovou špičku nad napětí zdroje $U_{\mathrm{N}}$ a to o velikost $I_{\mathrm{C}} R+U_{\mathrm{P}}$, přičemž $U_{\mathrm{P}}$ značí tzv. prahové napětí na diodě v propustném směru a $I_{\mathrm{C}}$ proud, který tekl cívkou před rozpojením tranzistoru a cívka se tento proud snaží udržet na stejné hodnotě a ve stejném směru i po jeho rozpojení. Protože po rozpojení tranzistoru $U_{\mathrm{CE}}=U_{\mathrm{N}}+I_{\mathrm{C}} R+U_{\mathrm{P}}$ musíme odpor rezistoru $\mathrm{R}$ dimenzovat tak, aby vyhovoval podmínce 


$$
R \leq \frac{U_{\mathrm{CEmax}}-U_{\mathrm{N}}-U_{\mathrm{P}}}{I_{\mathrm{C}}} .
$$

Jsou-li k dispozici různá napájecí napětí, můžeme též použít zapojení podle Obr. 6.21氏, v němž je dioda připojena na pomocné napětí $U$, přičemž musí platit $U>U_{\mathrm{N}}$ a $U_{\mathrm{CEmax}}>U+$ $U_{\mathrm{P}}$

Podobně je nutno ochránit koncový stupeň audiozesilovače Obr. 6.21, protože reproduktor představuje induktivní zátěž a přepětí, které na reproduktoru může vzniknout při vypnutí zesilovače, může zničit jeho koncové tranzistory. Protože není známo, v jaký okamžik dojde k vypnutí zesilovače, je nutno chránit zesilovač jak pro kladné, tak i záporné vybuzení výstupu. K tomu slouží dvě diody $\mathrm{D}_{1}, \mathrm{D}_{2}$, které za běžného provozu jsou pólovány v závěrném směru. Do propustného směru jsou diody otevřeny až v okamžiku vypnutí zesilovače.

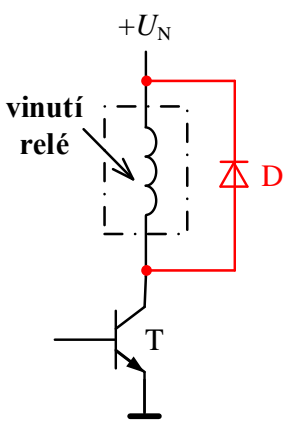

a

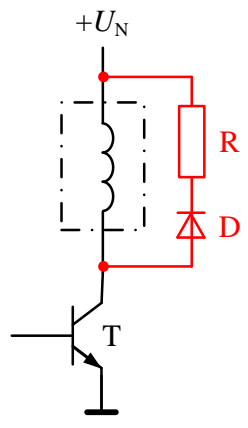

b

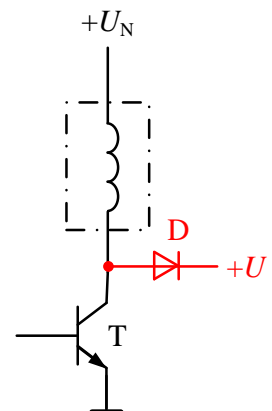

$\mathrm{c}$

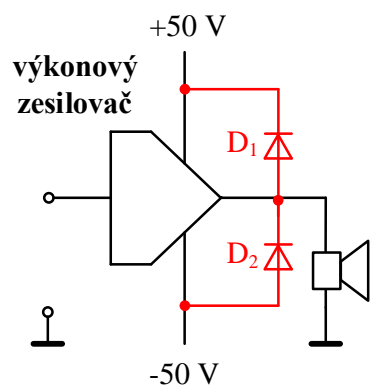

d

Obr. 6.21: Odstranění přepětových špiček na indukční zátěži pomocí diod 


\section{Použitá literatura}

[1] ŽÁČEK, J.; KÜNZEL, K. EMC v technické praxi IV: Omezování rušení v oblasti vysokých kmitočtů. Automa, 2006, roč. 12, č. 7, s. 64-67.

[2] ŽÁČEK, J.; KÜNZEL, K. EMC v technické praxi II: Rušivé signály, jejich zdroje a šíření. Automa, 2006, roč. 12, č. 3, s. 102-105.

[3] SVAČINA, J. Základy elektromagnetické kompatibility 1 - 6. Elektrorevue, 20002001. Dostupné na http://www.urel.feec.vutbr.cz/EncyklopedieEMC/index.php

[4] SVAČINA, J. Elektromagnetická kompatibilita: principy a poznámky. Vysoké učení technické v Brně, Brno 2001, ISBN 80-214-1873-7

[5] ARMSTRONG, K. Advanced PCB design and layout for EMC. Part 2 - Segregation and Interface Suppression, UK EMC Journal, 2010

[6] ARMSTRONG, K. Design Techniques for EMC, Part 4: Shielding. UK EMC Journal, 2007

[7] ARMSTRONG, K. Design Techniques for EMC and signal integrity, Part 5: PCB design and layout. UK EMC Journal, 2007

[8] MURATA: Noise suppression filter guide: Characteristics of common mode choke coils for signal lines and now to choose one, Murata, 2016 


\section{Pasivní obvodové prvky $\mathrm{R}, \mathrm{C}, \mathrm{L}$}

Při konstrukci elektronických zařízení se obyčejně věnuje hlavní pozornost zapojení, volbě a návrhu vhodných obvodů, vnitřnímu uspořádání prvků uvnitř zařízení a zapomíná se přitom na jednu z hlavních podmínek pro správnou funkci zařízení, tj. na uvážený výběr vhodných součástek pro konstruované zařízení. Jedním ze základních požadavků na vlastnost stavebních prvků pro elektroniku jsou stabilita jejich elektrických parametrů, mechanická pevnost a provozní spolehlivost. Splnění těchto požadavků však může zajistit pouze vhodně, pro daný způsob provozu a dané zařízení, vybraný prvek. Dodržení aplikačních pravidel je nezbytnou podmínkou úspěchu každé konstrukce. Respektování aplikačních zásad ušetř́ celou řadu hodin hledání, proč je obvod náchylný ke kmitání, proč je zvýšená úroveň šumu na výstupu nebo proč je zařízení náchylné ke vzniku tzv. hazardních stavů apod.

Podrobné údaje o jednotlivých součástkách poskytují př́slušné katalogy výrobců či jejich internetové stránky. Zde se zmíníme pouze o některých jejich obecných vlastnostech, jejich označování a konstrukčních zásadách při aplikaci v zařízení.

\subsection{Vyráběné řady pasivních prvků a jejich označování}

Nejčastěji užívané pasivní prvky tj. rezistory, kapacitory (kondenzátory) a popřr. induktory (cívky, tlumivky) se vyrábějí pouze v řadě jmenovitých hodnot odporů popř. kapacit či indukčností. Užívá se posloupnost hodnot odvozených z čísel geometrické řady. Jde o číselnou řadu, jejímiž krajními členy jsou čísla 1 a 10 a poměr mezi sousedními členy řady je vždy přibližně stejný. Hodnoty řady rostou geometricky podle vztahu $R=\sqrt[n]{10^{m}}$, kde $n$ značí počet členů řady v jedné dekádě a $m$ je $m$-tý prvek v řadě $m=0,1,2, \ldots n$. Pro hodnoty pasivních prvků byla zvolena stupnice, která dělí interval 1 až 10 na $n=3,6,12,24, \ldots, 192$ dílů. Důvodem jsou základní tolerance $\pm 40, \pm 20, \pm 10, \pm 5, \pm 2, \pm 1, \pm 0,5 \%$ tak, aby se sousední hodnoty odlišovaly nejvýše o danou toleranci. Tyto řady čísel se značí $\mathrm{E}$ a jsou definovány normou IEC 60063. Označují se E3 ( $\pm 40 \%)$, E6 ( $\pm 20 \%)$, E12 ( $\pm 10 \%)$, E24 $( \pm 5 \%)$, E48 $( \pm 2 \%)$, E96 $( \pm 1 \%)$, E192 $( \pm 0,5 \%)$, a to podle toho, kolik členů je obsaženo v jedné dekádě řady. Základní řada jmenovitých hodnot E12, je pro dvě dekády graficky znázorněna na Obr. 7.1 a. $\mathrm{Na}$ Obr. 7.11 je pak zobrazena povolená tolerance hodnot $\mathrm{v}$ jedné dekádě řady E12. V poslední době se pro hodnoty kapacitorů nejčastěji užívá řada E12, pro hodnoty rezistorů pak řada E24. Pro přesné a velmi přesné hodnoty součástek se pak ještě užívají řady E48, E96, E192. Řady jmenovitých hodnot $v$ rozmezí jedné dekády jsou pro jednotlivé řady uvedeny v Tab 7.1. Řada E192 se používá i pro přesné odchylky hodnoty $\pm 0,2 \%$ a $\pm 0,1 \%$. 


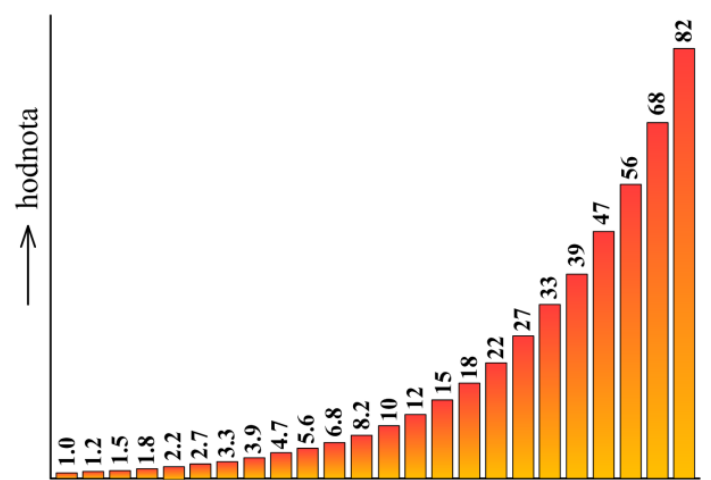

a

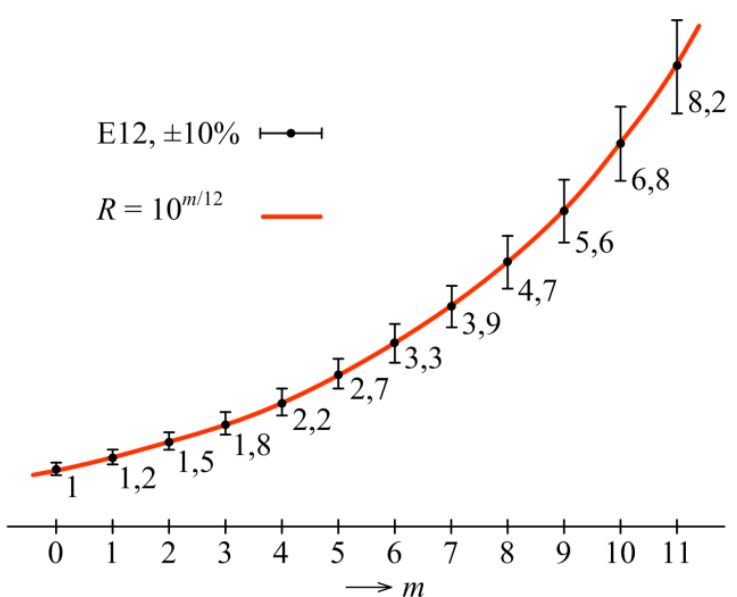

b

Obr. 7.1: a) Dvě dekády hodnot řady E12, b) povolené tolerance hodnot v jedné dekádě řady E12

Používání řad se odlišuje podle druhů pasivních součástek. Nejčastěji užívanou řadou pro odpory rezistorů je řada E24 s tolerancí $\pm 5 \%$. Pro přesné aplikace se pak nejčastěji používají rezistory s odpory v řadě E96 $( \pm 1 \%)$. Je však evidentní, že držet několik řad rezistorů skladem by bylo značně náročné, jen řada E96 v rozmezí odporů $1 \Omega$ až $10 \mathrm{M} \Omega$ představuje téměř 600 různých hodnot odporů. $Z$ těchto důvodů se většinou skladem drží řada odporů $E 24$, ale $\mathrm{s}$ přesností $\pm 1 \%$ odpovídající řadě E96. Keramické kondenzátory bývají v řadách E12 nebo E24. Elektrolytické kondenzátory popř. kondenzátory fóliové větších kapacit (řádu mikrofaradů) mají jmenovité hodnoty obvykle k dispozici $v$ řadě E6. Některé typy potenciometrů jsou $\mathrm{k}$ dispozici jen $\mathrm{v}$ řadě $\mathrm{E} 3$, nebo mají $\mathrm{i}$ hodnoty $\mathrm{v}$ odlišné řadě $1,2,5,5$. Induktory (cívky, tlumivky) se vyrábějí v řadách E12 nebo E24.

Ke zkrácenému označování jmenovitých hodnot pasivních součástek jako jsou rezistory, kapacitory a induktory se užívá hned několik kódových systémů lišících se podle toho, zda jde o označení jmenovité hodnoty ve schématu nebo na součástce nebo o značení používané výrobcem. V některých případech se označení hodnoty používané ve schématech použije i pro označení na součástce. 
Tab 7.1: Řady jmenovitých hodnot pasivních součástek

\begin{tabular}{|c|c|c|c|c|c|c|c|c|c|c|c|}
\hline \multicolumn{12}{|c|}{ К̌ada E3 $\pm 40 \%$} \\
\hline \multicolumn{4}{|c|}{1,0} & \multicolumn{4}{|c|}{2,2} & \multicolumn{4}{|c|}{4,7} \\
\hline \multicolumn{12}{|c|}{ Řada E6 $\pm 20 \%$} \\
\hline \multicolumn{2}{|c|}{1,0} & \multicolumn{2}{|c|}{1,5} & \multicolumn{2}{|c|}{2,2} & \multicolumn{2}{|c|}{3,3} & \multicolumn{2}{|c|}{4,7} & \multicolumn{2}{|c|}{6,8} \\
\hline \multicolumn{12}{|c|}{ Řada E12 $\pm 10 \%$} \\
\hline 1,0 & 1,2 & 1,5 & 1,8 & 2,2 & 2,7 & 3,3 & 3,9 & 4,7 & 5,6 & 6,8 & 8,2 \\
\hline \multicolumn{12}{|c|}{ Řada E24 $\pm 5 \%$} \\
\hline 1,0 & 1,1 & 1,2 & 1,3 & 1,5 & 1,6 & 1,8 & 2,0 & 2,2 & 2,4 & 2,7 & 3,0 \\
\hline 3,3 & 3,6 & 3,9 & 4,3 & 4,7 & 5,1 & 5,6 & 6,2 & 6,8 & 7,5 & 8,2 & 9,1 \\
\hline \multicolumn{12}{|c|}{ Řada $E 48 \pm 2 \%$} \\
\hline 100 & 105 & 110 & 115 & 121 & 127 & 133 & 140 & 147 & 154 & 162 & 169 \\
\hline 178 & 187 & 196 & 205 & 215 & 226 & 237 & 249 & 261 & 274 & 287 & 301 \\
\hline 316 & 332 & 348 & 365 & 383 & 402 & 422 & 442 & 464 & 487 & 511 & 536 \\
\hline 562 & 590 & 619 & 649 & 681 & 715 & 750 & 787 & 825 & 866 & 909 & 953 \\
\hline \multicolumn{12}{|c|}{ Řada E96 $\pm 1 \%$} \\
\hline 100 & 102 & 105 & 107 & 110 & 113 & 115 & 118 & 121 & 124 & 127 & 130 \\
\hline 133 & 137 & 140 & 143 & 147 & 150 & 154 & 158 & 162 & 165 & 169 & 174 \\
\hline 178 & 182 & 187 & 191 & 196 & 200 & 205 & 210 & 215 & 221 & 226 & 232 \\
\hline 237 & 243 & 249 & 255 & 261 & 267 & 274 & 280 & 287 & 294 & 301 & 309 \\
\hline 316 & 324 & 332 & 340 & 348 & 357 & 365 & 374 & 383 & 392 & 402 & 412 \\
\hline 422 & 432 & 442 & 453 & 464 & 475 & 487 & 499 & 511 & 523 & 536 & 549 \\
\hline 562 & 576 & 590 & 604 & 619 & 634 & 649 & 665 & 681 & 698 & 715 & 732 \\
\hline 750 & 768 & 787 & 806 & 825 & 845 & 866 & 887 & 909 & 931 & 953 & 976 \\
\hline \multicolumn{12}{|c|}{ Řada E192 $\pm 0,5 \%$} \\
\hline 100 & 101 & 102 & 104 & 105 & 106 & 107 & 109 & 110 & 111 & 113 & 114 \\
\hline 115 & 117 & 118 & 120 & 121 & 123 & 124 & 126 & 127 & 129 & 130 & 132 \\
\hline 133 & 135 & 137 & 138 & 140 & 142 & 143 & 145 & 147 & 149 & 150 & 152 \\
\hline 154 & 156 & 158 & 160 & 162 & 164 & 165 & 167 & 169 & 172 & 174 & 176 \\
\hline 178 & 180 & 182 & 184 & 187 & 189 & 191 & 193 & 196 & 198 & 200 & 203 \\
\hline 205 & 208 & 210 & 213 & 215 & 218 & 221 & 223 & 226 & 229 & 232 & 234 \\
\hline 237 & 240 & 243 & 246 & 249 & 252 & 255 & 258 & 261 & 264 & 267 & 271 \\
\hline 274 & 277 & 280 & 284 & 287 & 291 & 294 & 298 & 301 & 305 & 309 & 312 \\
\hline 316 & 320 & 324 & 328 & 332 & 336 & 340 & 344 & 348 & 352 & 357 & 361 \\
\hline 365 & 370 & 374 & 379 & 383 & 388 & 392 & 397 & 402 & 407 & 412 & 417 \\
\hline 422 & 427 & 432 & 437 & 442 & 448 & 453 & 459 & 464 & 470 & 475 & 481 \\
\hline 487 & 493 & 499 & 505 & 511 & 517 & 523 & 530 & 536 & 542 & 549 & 556 \\
\hline 562 & 569 & 576 & 583 & 590 & 597 & 604 & 612 & 619 & 626 & 634 & 642 \\
\hline 649 & 657 & 665 & 673 & 681 & 690 & 698 & 706 & 715 & 723 & 732 & 741 \\
\hline 750 & 759 & 768 & 777 & 787 & 796 & 806 & 816 & 825 & 835 & 845 & 856 \\
\hline 866 & 876 & 887 & 898 & 909 & 920 & 931 & 942 & 953 & 965 & 976 & 988 \\
\hline
\end{tabular}




\section{Označování jmenovité hodnoty ve schématech}

Nejprve uvedeme zkrácené označování jmenovitých hodnot pasivních obvodových prvků používané ve schématech elektrických obvodů. Základní jednotkou pro písmenový kód pro jmenovité odpory rezistorů je $1 \mathrm{ohm}(\Omega)$. Písmenový kód pro násobitele je uveden v Tab 7.2. kde jsou také uvedeny př́íklady označení odporů rezistorů tímto systémem.

Tab 7.2: Označování jmenovitých hodnot odporů rezistorů ve schématech

\begin{tabular}{|c|c|}
\hline \multicolumn{2}{|c|}{ Základní jednotka $1 \Omega$} \\
\hline Násobitel & Kód \\
\hline 1 & $\mathrm{R}$ \\
\hline $10^{3}$ & $\mathrm{~K}$ \\
\hline $10^{6}$ & $\mathrm{M}$ \\
\hline $10^{9}$ & $\mathrm{G}$ \\
\hline $10^{12}$ & $\mathrm{~T}$ \\
\hline
\end{tabular}

\begin{tabular}{|c|c|}
\hline \multicolumn{2}{|c|}{ Příklady označování odporů rezistorů } \\
\hline Jmenovitý odpor & Kódové označení \\
\hline $0,47 \Omega$ & $\mathrm{R} 47$ \\
\hline $2,2 \Omega$ & $2 \mathrm{R} 2$ \\
\hline $100 \Omega$ & $100 \mathrm{R}$ \\
\hline $1 \mathrm{k} \Omega$ & $1 \mathrm{~K} 0$ \\
\hline $4,7 \mathrm{k} \Omega$ & $4 \mathrm{~K} 7$ \\
\hline $220 \mathrm{k} \Omega$ & $220 \mathrm{~K}$ \\
\hline $3,3 \mathrm{M} \Omega$ & $3 \mathrm{M} 3$ \\
\hline $100 \mathrm{M} \Omega$ & $100 \mathrm{M}$ \\
\hline
\end{tabular}

Základní jednotkou písmenového kódu pro jmenovité kapacity kapacitorů je 1 Farad (F). Písmenové symboly pro násobitele základní jednotky včetně prríkladů jejich použití jsou uvedeny v Tab 7.3.

Tab 7.3: Označování jmenovitých hodnot kapacit kapacitorů ve schématech

\begin{tabular}{|c|c|}
\hline \multicolumn{2}{|c|}{ Základní jednotka $1 \mathrm{~F}$} \\
\hline Násobitel & Kód \\
\hline $10^{-12}$ & $\mathrm{p}$ \\
\hline $10^{-9}$ & $\mathrm{n}$ \\
\hline $10^{-6}$ & $\mu$ \\
\hline $10^{-3}$ & $\mathrm{~m}$ \\
\hline 1 & $\mathrm{~F}$ \\
\hline
\end{tabular}

\begin{tabular}{|c|c|}
\hline \multicolumn{2}{|c|}{ Př́klady označování kapacit kapacitorů } \\
\hline Jmenovitá kapacita & Kódové označení \\
\hline $5,6 \mathrm{pF}$ & $5 \mathrm{p} 6$ \\
\hline $47 \mathrm{pF}$ & $47 \mathrm{p}$ \\
\hline $1 \mathrm{nF}$ & $1 \mathrm{n} 0$ \\
\hline $3,3 \mathrm{nF}$ & $3 \mathrm{n} 3$ \\
\hline $4,7 \mu \mathrm{F}$ & $4 \mu 7$ \\
\hline $100 \mu \mathrm{F}$ & $100 \mu$ \\
\hline $1 \mathrm{~F}$ & $1 \mathrm{~F} 0$ \\
\hline
\end{tabular}

Základní jednotkou pro písmenový kód používaný pro označování jmenovité indukčnosti induktorů je 1 Henry $(\mathrm{H})$. Kódy užívané pro násobitele základní jednotky jsou pro tento případ uvedeny v Tab 7.4. 
Tab 7.4: Označování jmenovitých hodnot indukčností induktorů ve schématech

\begin{tabular}{|c|c|}
\hline \multicolumn{2}{|c|}{ Základní jednotka $1 \mathrm{H}$} \\
\hline Násobitel & Kód \\
\hline $10^{-9}$ & $\mathrm{n}$ \\
\hline $10^{-6}$ & $\mu$ \\
\hline $10^{-3}$ & $\mathrm{~m}$ \\
\hline 1 & $\mathrm{H}$ \\
\hline
\end{tabular}

\begin{tabular}{|c|c|}
\hline \multicolumn{2}{|c|}{ Př́iklady označování indukčností induktorů } \\
\hline Jmenovitá indukčnost & Kódové označení \\
\hline $1 \mathrm{nH}$ & $1 \mathrm{n} 0$ \\
\hline $8,2 \mathrm{nH}$ & $8 \mathrm{n} 2$ \\
\hline $5,6 \mu \mathrm{H}$ & $5 \mu 6$ \\
\hline $270 \mu \mathrm{H}$ & $270 \mu$ \\
\hline $1 \mathrm{mH}$ & $1 \mathrm{~m} 0$ \\
\hline $47 \mathrm{mH}$ & $47 \mathrm{~m}$ \\
\hline $1 \mathrm{H}$ & $1 \mathrm{H} 0$ \\
\hline
\end{tabular}

\section{Označování jmenovité hodnoty odporu na součástce}

Dnes nejpoužívanější SMD rezistory se vyrábějí s popisem nebo rozměrově nejmenší provedení i bez popisu. Pokud je na nich hodnota uvedena, je tvořena třemi resp. čtyřmi číslicemi, z nichž první dvě resp. tři udávají hodnotu $\mathrm{v}$ ohmech a poslední číslice násobitel podle tabulky Tab 7.5. Čtyřčíselné označení se využívá u precizních rezistorů s tolerancí $1 \% \mathrm{a}$ lepší, trríčíselné pak u rezistorů s tolerancí $5 \%$ a horší.

Tab 7.5: Hodnoty násobitelů udávaných poslední číslicí na pouzdře SMD rezistorů a př́klady značení

\begin{tabular}{|c|c|c|c|}
\hline \multicolumn{4}{|c|}{ Základní jednotka $1 \Omega$} \\
\hline Kód & Násobitel & Kód & Násobitel \\
\hline $\mathbf{0}$ & $10^{0}$ & $\mathbf{5}$ & $10^{5}$ \\
\hline $\mathbf{1}$ & $10^{1}$ & $\mathbf{6}$ & $10^{6}$ \\
\hline $\mathbf{2}$ & $10^{2}$ & $\mathbf{7}$ & $10^{7}$ \\
\hline $\mathbf{3}$ & $10^{3}$ & $\mathbf{8}$ & $10^{-2}$ \\
\hline $\mathbf{4}$ & $10^{4}$ & $\mathbf{9}$ & $10^{-1}$ \\
\hline
\end{tabular}

Př́klady označení jmenovitého odporu na SMD rezistorech

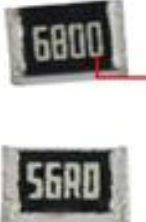

$680 \times 10^{\circ}=680 \Omega$

\section{2} $270 \times 10^{2}=27 \mathrm{k} \Omega$ B203 $820 \times 10^{3}=820 \mathrm{k} \Omega$ $56 \times 10^{\circ}=56 \Omega$ $390 \times 10^{4}=3,9 \mathrm{M \Omega}$

K uvedené hodnotě připíšeme tolik nul, kolik udává poslední číslice (s výjimkou kódu násobitele 8 a 9, které značí setinu a desetinu) a získáme výslednou hodnotu odporu v ohmech. Rezistory s odporem menším než $100 \Omega$ mají někdy v popisu písmeno „R“ udávající pozici desetinné čárky. Jde však o značení převzaté z jiného systému značení (viz dále).

Př́klady značení SMD rezistorů: $473=47000 \Omega ; 335=3300000 \Omega ; 479=4,7 \Omega ; 2201$ $=2200 \Omega ; 101=100 \Omega ; 821=820 \Omega ; 1000=100 \Omega ; 8 \mathrm{R} 2=8,2 \Omega ; 0 \mathrm{R} 56$ nebo R56 = 0,56 $\Omega$, někdy ale také $47 \mathrm{R} 0=47 \Omega$ (viz dále). 
Někteří výrobci, zejména přesných rezistorů SMD, používají pro vyznačení hodnoty odporu rezistoru kombinaci čísel a písmen tak, jak je to uvedeno v Tab 7.6. Písmeno označuje násobitel a případně zastupuje i desetinnou čárku. Písmenový kód pro označení rádu odporu se užívá i u rezistorů na větší výkony (metaloxidové, drátové).

Tab 7.6: Hodnota odporu vyjádřená kombinací čísel a písmen

\begin{tabular}{|c|c|c|c|}
\hline \multicolumn{2}{|c|}{ Odpor rezistoru } & \multicolumn{2}{c|}{ Př́klady } \\
\hline Kód & Rozmezí odporů & Označení & Hodnota \\
\hline OR & 0 & $0 \mathrm{R}$ & zkrat \\
\hline \multirow{2}{*}{ XRXX } & 1 až $9,76 \Omega$ & $1 \mathrm{R}$ & $1 \Omega$ \\
\cline { 3 - 4 } & & $9 \mathrm{R} 5$ & $1,5 \Omega$ \\
\hline \multirow{2}{*}{ XXRX } & \multirow{2}{*}{10 až $97,6 \Omega$} & $10 \mathrm{R}$ & $10 \Omega$ \\
\cline { 3 - 4 } & & $97 \mathrm{R} 6$ & $97,6 \Omega$ \\
\hline XXXR & 100 až $976 \Omega$ & $100 \mathrm{R}$ & $100 \Omega$ \\
\hline \multirow{2}{*}{ XKXX } & \multirow{2}{*}{1 až $9,76 \mathrm{k} \Omega$} & $1 \mathrm{~K}$ & $1 \mathrm{k} \Omega$ \\
\cline { 3 - 4 } & & $9 \mathrm{~K} 76$ & $9,76 \mathrm{k} \Omega$ \\
\hline \multirow{2}{*}{ XMXX } & \multirow{2}{*}{1 až $9,76 \mathrm{M} \Omega$} & $1 \mathrm{M}$ & $1 \mathrm{M} \Omega$ \\
\cline { 3 - 4 } & & $9 \mathrm{M} 76$ & $9,76 \mathrm{M} \Omega$ \\
\hline
\end{tabular}

Z nedostatku místa pro popis na SMD rezistorech začínají někteří výrobci používat nový kódovací systém vycházející z 1\% řady E96. Způsob kódování je znám jako kódovací metoda EIA-96 a je založen na tom, že se hodnoty z řady E96 očíslují od 01 do 96 tak, jak je to uvedeno v Tab 7.7. Za tento údaj se pak uvede písmenový kód násobitele uvedený v Tab 7.8. Např. 22A značí odpor $165 \Omega 1 \%, 68 \mathrm{C}$ je 49,9 k $\Omega 1 \%$ nebo $43 \mathrm{E}$ je $2,74 \mathrm{M} \Omega$. 
Tab 7.7: Č́íselné kódy EIA-96 pro SMD rezistory řady E96

\begin{tabular}{|c|c|c|c|c|c|c|c|c|c|c|c|}
\hline \multicolumn{10}{|c|}{ E96 $\mathbf{1 1 \%}$} \\
\hline kód & hodnota & kód & hodnota & kód & hodnota & kód & hodnota & kód & hodnota & kód & hodnota \\
\hline $\mathbf{0 1}$ & 100 & $\mathbf{1 7}$ & 147 & $\mathbf{3 3}$ & 215 & $\mathbf{4 9}$ & 316 & $\mathbf{6 5}$ & 464 & $\mathbf{8 1}$ & 681 \\
\hline $\mathbf{0 2}$ & 102 & $\mathbf{1 8}$ & 150 & $\mathbf{3 4}$ & 221 & $\mathbf{5 0}$ & $\mathbf{3 2 4}$ & $\mathbf{6 6}$ & $\mathbf{4 7 5}$ & $\mathbf{8 2}$ & 698 \\
\hline $\mathbf{0 3}$ & 105 & $\mathbf{1 9}$ & 154 & $\mathbf{3 5}$ & 226 & $\mathbf{5 1}$ & 332 & $\mathbf{6 7}$ & $\mathbf{4 8 7}$ & $\mathbf{8 3}$ & 715 \\
\hline $\mathbf{0 4}$ & 107 & $\mathbf{2 0}$ & 158 & $\mathbf{3 6}$ & 232 & $\mathbf{5 2}$ & 340 & $\mathbf{6 8}$ & 499 & $\mathbf{8 4}$ & 732 \\
\hline $\mathbf{0 5}$ & 110 & $\mathbf{2 1}$ & 162 & $\mathbf{3 7}$ & 237 & $\mathbf{5 3}$ & 348 & $\mathbf{6 9}$ & 511 & $\mathbf{8 5}$ & 750 \\
\hline $\mathbf{0 6}$ & 113 & $\mathbf{2 2}$ & 165 & $\mathbf{3 8}$ & 243 & $\mathbf{5 4}$ & 357 & $\mathbf{7 0}$ & 523 & $\mathbf{8 6}$ & 768 \\
\hline $\mathbf{0 7}$ & 115 & $\mathbf{2 3}$ & 169 & $\mathbf{3 9}$ & 249 & $\mathbf{5 5}$ & 365 & $\mathbf{7 1}$ & 536 & $\mathbf{8 7}$ & 787 \\
\hline $\mathbf{0 8}$ & 118 & $\mathbf{2 4}$ & 174 & $\mathbf{4 0}$ & 255 & $\mathbf{5 6}$ & 374 & $\mathbf{7 2}$ & 549 & $\mathbf{8 8}$ & 806 \\
\hline $\mathbf{0 9}$ & 121 & $\mathbf{2 5}$ & 178 & $\mathbf{4 1}$ & 261 & $\mathbf{5 7}$ & 383 & $\mathbf{7 3}$ & 562 & $\mathbf{8 9}$ & 825 \\
\hline $\mathbf{1 0}$ & 124 & $\mathbf{2 6}$ & 182 & $\mathbf{4 2}$ & 267 & $\mathbf{5 8}$ & 392 & $\mathbf{7 4}$ & 576 & $\mathbf{9 0}$ & 845 \\
\hline $\mathbf{1 1}$ & 127 & $\mathbf{2 7}$ & 187 & $\mathbf{4 3}$ & 274 & $\mathbf{5 9}$ & 402 & $\mathbf{7 5}$ & 590 & $\mathbf{9 1}$ & $\mathbf{8 6 6}$ \\
\hline $\mathbf{1 2}$ & 130 & $\mathbf{2 8}$ & 191 & $\mathbf{4 4}$ & 280 & $\mathbf{6 0}$ & 412 & $\mathbf{7 6}$ & 604 & $\mathbf{9 2}$ & 887 \\
\hline $\mathbf{1 3}$ & 133 & $\mathbf{2 9}$ & 196 & $\mathbf{4 5}$ & 287 & $\mathbf{6 1}$ & 422 & $\mathbf{7 7}$ & 619 & $\mathbf{9 3}$ & 909 \\
\hline $\mathbf{1 4}$ & 137 & $\mathbf{3 0}$ & 200 & $\mathbf{4 6}$ & 294 & $\mathbf{6 2}$ & 432 & $\mathbf{7 8}$ & 634 & $\mathbf{9 4}$ & 931 \\
\hline $\mathbf{1 5}$ & 140 & $\mathbf{3 1}$ & 205 & $\mathbf{4 7}$ & 301 & $\mathbf{6 3}$ & 442 & $\mathbf{7 9}$ & 649 & $\mathbf{9 5}$ & 953 \\
\hline $\mathbf{1 6}$ & 143 & $\mathbf{3 2}$ & 210 & $\mathbf{4 8}$ & 309 & $\mathbf{6 4}$ & 453 & $\mathbf{8 0}$ & 665 & $\mathbf{9 6}$ & 976 \\
\hline
\end{tabular}

Tab 7.8: Kód násobitele pro kód EIA-96

\begin{tabular}{|c|c|c|c|c|c|c|c|c|c|c|c|}
\hline Kód & $\mathbf{A}$ & $\mathbf{B}$ & $\mathbf{C}$ & $\mathbf{D}$ & $\mathbf{E}$ & $\mathbf{F}$ & $\mathbf{G}$ & $\mathbf{H}$ & $\mathbf{X}$ & $\mathbf{Y}$ & $\mathbf{Z}$ \\
\hline Násobitel & $10^{0}$ & $10^{1}$ & $10^{2}$ & $10^{3}$ & $10^{4}$ & $10^{5}$ & $10^{6}$ & $10^{7}$ & $10^{-1}$ & $10^{-2}$ & $10^{-3}$ \\
\hline
\end{tabular}

Podobný způsob kódování se používá pro řady E48, E24, E12, kdy se použije společné číslování těchto řad od 01 do 84 tak, jak je to uvedeno v Tab 7.9. Kód násobitele se však pro tyto př́ipady zapíše před číselný kód. Např. podle tohoto schématu A55 značí $180 \Omega \pm 5 \%, C 31$ je odpor $42,2 \mathrm{k} \Omega \pm 2 \%$ a D18 je $226 \mathrm{k} \Omega \pm 2 \%$.

Tab 7.9: Č́selné kódy EIA-96 pro SMD rezistory řady E12 až E48

\begin{tabular}{|c|c|c|c|c|c|c|c|}
\hline \multicolumn{7}{|c|}{ E48 $\mathbf{2} \%$} \\
\hline kód & hodnota & kód & hodnota & kód & hodnota & kód & hodnota \\
\hline $\mathbf{0 1}$ & 100 & $\mathbf{1 3}$ & 178 & $\mathbf{2 5}$ & 316 & $\mathbf{3 7}$ & 562 \\
\hline $\mathbf{0 2}$ & 105 & $\mathbf{1 4}$ & 187 & $\mathbf{2 6}$ & 332 & $\mathbf{3 8}$ & 590 \\
\hline $\mathbf{0 3}$ & 110 & $\mathbf{1 5}$ & 196 & $\mathbf{2 7}$ & 348 & $\mathbf{3 9}$ & 619 \\
\hline $\mathbf{0 4}$ & 115 & $\mathbf{1 6}$ & 205 & $\mathbf{2 8}$ & 365 & $\mathbf{4 0}$ & 649 \\
\hline $\mathbf{0 5}$ & 121 & $\mathbf{1 7}$ & 215 & $\mathbf{2 9}$ & 383 & $\mathbf{4 1}$ & 681 \\
\hline $\mathbf{0 6}$ & 127 & $\mathbf{1 8}$ & 226 & $\mathbf{3 0}$ & 402 & $\mathbf{4 2}$ & 715 \\
\hline $\mathbf{0 7}$ & 133 & $\mathbf{1 9}$ & 237 & $\mathbf{3 1}$ & 422 & $\mathbf{4 3}$ & 750 \\
\hline $\mathbf{0 8}$ & 140 & $\mathbf{2 0}$ & 249 & $\mathbf{3 2}$ & 442 & $\mathbf{4 4}$ & 787 \\
\hline $\mathbf{0 9}$ & 147 & $\mathbf{2 1}$ & 261 & $\mathbf{3 3}$ & 464 & $\mathbf{4 5}$ & 825 \\
\hline $\mathbf{1 0}$ & 154 & $\mathbf{2 2}$ & 274 & $\mathbf{3 4}$ & 487 & $\mathbf{4 6}$ & 866 \\
\hline $\mathbf{1 1}$ & 162 & $\mathbf{2 3}$ & 287 & $\mathbf{3 5}$ & 511 & $\mathbf{4 7}$ & 909 \\
\hline $\mathbf{1 2}$ & 169 & $\mathbf{2 4}$ & 301 & $\mathbf{3 6}$ & 536 & $\mathbf{4 8}$ & 953 \\
\hline
\end{tabular}




\begin{tabular}{|c|c|c|c|c|c|}
\hline \multicolumn{5}{|c|}{ E24 $\mathbf{5 \%} \%$} & \multicolumn{2}{c|}{ E12 $\mathbf{\pm 1 0 \%}$} \\
\hline kód & hodnota & kód & hodnota & kód & hodnota \\
\hline $\mathbf{4 9}$ & 100 & $\mathbf{6 1}$ & 330 & $\mathbf{7 3}$ & 100 \\
\hline $\mathbf{5 0}$ & 110 & $\mathbf{6 2}$ & 360 & $\mathbf{7 4}$ & 120 \\
\hline $\mathbf{5 1}$ & 120 & $\mathbf{6 3}$ & 390 & $\mathbf{7 5}$ & 150 \\
\hline $\mathbf{5 2}$ & 130 & $\mathbf{6 4}$ & 430 & $\mathbf{7 6}$ & 180 \\
\hline $\mathbf{5 3}$ & 150 & $\mathbf{6 5}$ & 470 & $\mathbf{7 7}$ & 220 \\
\hline $\mathbf{5 4}$ & 160 & $\mathbf{6 6}$ & 510 & $\mathbf{7 8}$ & 270 \\
\hline $\mathbf{5 5}$ & 180 & $\mathbf{6 7}$ & 560 & $\mathbf{7 9}$ & 330 \\
\hline $\mathbf{5 6}$ & 200 & $\mathbf{6 8}$ & 620 & $\mathbf{8 0}$ & 390 \\
\hline $\mathbf{5 7}$ & 220 & $\mathbf{6 9}$ & 680 & $\mathbf{8 1}$ & 470 \\
\hline $\mathbf{5 8}$ & 240 & $\mathbf{7 0}$ & 750 & $\mathbf{8 2}$ & 560 \\
\hline $\mathbf{5 9}$ & 270 & $\mathbf{7 1}$ & 820 & $\mathbf{8 3}$ & 680 \\
\hline $\mathbf{6 0}$ & 300 & $\mathbf{7 2}$ & 910 & $\mathbf{8 4}$ & 820 \\
\hline
\end{tabular}

Ke zkrácenému označování jmenovitých hodnot miniaturních vývodových rezistorů se pak téměř výhradně použivá barevný kód podle normy IEC 63 Tab 7.10. Barevný kód se nejčastěji vyjadřuje proužky po obvodu součástky válcového tvaru. První proužek je vždy blíže k okraji tělesa součástky. Pokud je vynechán poslední proužek, je tolerance odporu $\pm 20 \%$.

Tab 7.10: Označování jmenovitých hodnot a odchylek odporů barevným kódem dle IEC 63

\begin{tabular}{|c|c|c|c|c|c|}
\hline & $5600=$ & 560 & $\cdot 10^{1}$ & $\rightarrow \pm 5$ & $\%$ \\
\hline pruh & 1. číslo & 2. číslo & 3. číslo & násobitel & tolerance \\
\hline černá & 0 & 0 & 0 & $\times 10^{0}$ & \\
\hline hnědá & 1 & 1 & 1 & $\times 10^{1}$ & $\pm 1 \%$ \\
\hline červená & 2 & 2 & 2 & $\times 10^{2}$ & $\pm 2 \%$ \\
\hline oranžová & 3 & 3 & 3 & $\times 10^{3}$ & \\
\hline žlutá & 4 & 4 & 4 & $\times 10^{4}$ & \\
\hline zelená & 5 & 5 & 5 & $\times 10^{5}$ & $\pm 0.5 \%$ \\
\hline modrá & 6 & 6 & 6 & $\times 10^{6}$ & $\pm 0.25 \%$ \\
\hline fialová & 7 & 7 & 7 & $\times 10^{7}$ & $\pm 0.1 \%$ \\
\hline šedá & 8 & 8 & 8 & $\times 10^{8}$ & $\pm 0.05 \%$ \\
\hline bílá & 9 & 9 & 9 & $\times 10^{9}$ & \\
\hline zlatá & - & - & - & $\times 0.1$ & $\pm 5 \%$ \\
\hline Stříbrná & - & - & - & $\times 0.01$ & $\pm 10 \%$ \\
\hline
\end{tabular}

\section{Označování jmenovité hodnoty kapacity na součástce}

Rozsah kapacity vyráběných kapacitorů je velmi široký - od jednoho pikofaradu do několika Faradů. Tomu odpovídá i daleko rozmanitější systém značení, než tomu je u rezistorů. Navíc napřr. keramické kapacitory v malých SMD pouzdrech bohužel často nenesou žádný číselný kód, a tak je identifikace jejich hodnoty často možná jen měřením. 
Starší značení kapacitorů používá jako základ $1 \mathrm{~F}$ a užívají se hodnoty jako pikofarad, nanofarad nebo mikrofarad a je v podstatě shodné s uváděním kapacity na schématech (viz Tab 7.3 . Toto značení se stále užívá u rozměrnějších kapacitorů, jako jsou např. elektrolytické kondenzátory, kdy se užívají jednotky $1 \mu \mathrm{F}, 1 \mathrm{mF}$ či F.

Dnes je, zejména u kapacitorů menších rozměrů, běžnější systém značení pomocí trojice čísel, z nichž první dvě udávají hodnotu v pF a třetí násobitel (počet nul za touto hodnotou). Tabulka násobitelů je shodná jako u rezistorů, výsledná kapacita je v pikofaradech, viz Tab 7.11. U SMD kondenzátorů (pokud je údaj uveden) se používá většinou tohoto způsobu značení.

Tab 7.11: Označování kapacit na SMD kondenzátorech číselným kódem

\begin{tabular}{|c|c|c|c|}
\hline \multicolumn{4}{|c|}{ Základní jednotka $1 \mathrm{pF}$} \\
\hline Kód & Násobitel & Kód & Násobitel \\
\hline $\mathbf{0}$ & $10^{0}$ & $\mathbf{5}$ & $10^{5}$ \\
\hline $\mathbf{1}$ & $10^{1}$ & $\mathbf{6}$ & $10^{6}$ \\
\hline $\mathbf{2}$ & $10^{2}$ & $\mathbf{7}$ & $10^{7}$ \\
\hline $\mathbf{3}$ & $10^{3}$ & $\mathbf{8}$ & $10^{-2}$ \\
\hline $\mathbf{4}$ & $10^{4}$ & $\mathbf{9}$ & $10^{-1}$ \\
\hline
\end{tabular}

Př́íklady označení jmenovité kapacity na SMD kapacitoru

\begin{tabular}{|c|l|}
\hline Kódové označení & Jmenovitá kapacita \\
\hline 479 & $4,7 \mathrm{pF}$ \\
\hline 120 & $12 \mathrm{pF}$ \\
\hline 681 & $680 \mathrm{pF}$ \\
\hline 152 & $1500 \mathrm{pF}=1,5 \mathrm{nF}$ \\
\hline 104 & $100000 \mathrm{pF}=100 \mathrm{nF}$ \\
\hline
\end{tabular}

Můžeme se však setkat i s jiným označením kapacity, kdy se popis skládá z označení výrobce (není povinné), písmenového kódu označujícího hodnotu a číselný kód násobitele.

Tab 7.12: Kód pro označování hodnoty kapacity kapacitoru pomocí písmen a číslic

\begin{tabular}{|c|c|c|c|c|c|c|c|}
\hline \multicolumn{7}{|c|}{ Základní jednotka $1 \mathrm{pF}$} \\
\hline kód & hodnota & kód & hodnota & kód & hodnota & kód & hodnota \\
\hline $\mathbf{A}$ & 1,0 & $\mathbf{J}$ & 2,2 & $\mathbf{S}$ & 4,7 & $\mathbf{a}$ & 25 \\
\hline $\mathbf{B}$ & 1,1 & $\mathbf{K}$ & 2,4 & $\mathbf{T}$ & 5,1 & $\mathbf{b}$ & 35 \\
\hline $\mathbf{C}$ & 1,2 & $\mathbf{L}$ & 2,7 & $\mathbf{U}$ & 5,6 & $\mathbf{d}$ & 40 \\
\hline $\mathbf{D}$ & 1,3 & $\mathbf{M}$ & 3,0 & $\mathbf{V}$ & 6,2 & $\mathbf{e}$ & 45 \\
\hline $\mathbf{E}$ & 1,5 & $\mathbf{N}$ & 3,3 & $\mathbf{W}$ & 6,8 & $\mathbf{f}$ & 50 \\
\hline $\mathbf{F}$ & 1,6 & $\mathbf{P}$ & 3,6 & $\mathbf{X}$ & 7,5 & $\mathbf{m}$ & 60 \\
\hline $\mathbf{G}$ & 1,8 & $\mathbf{Q}$ & 3,9 & $\mathbf{Y}$ & 8,2 & $\mathbf{n}$ & 70 \\
\hline $\mathbf{H}$ & 2,0 & $\mathbf{R}$ & 4,3 & $\mathbf{Z}$ & 9,1 & $\mathbf{t}$ & 80 \\
\hline & & & & & $\mathbf{y}$ & 90 \\
\hline
\end{tabular}


Kódy hodnot jsou uvedeny v Tab 7.12, číselný kód násobitele je shodný s Tab 7.11. Pokud bude na součástce uveden zápis J3, znamená to hodnotu kapacity $2,2 \cdot 10^{3}=2200 \mathrm{pF}$. Zápis ve tvaru KJ3 má na místě prvního znaku symbol výrobce. V tomto případě je to KEMET a kapacita je opět $2200 \mathrm{pF}$.

Na některých elektrolytických a fóliových kapacitorech výrobci uvádějí hodnotu kapacity jako číslo bez jednotky, a to v mikrofaradech pokud je kapacita větší než $0,01 \mu \mathrm{F}$, pokud je menší, tak je v pikofaradech. Správnou jednotku můžeme vydedukovat podle velikosti kondenzátoru a jeho provedení. U kondenzátorů miniaturních jde řádově o $\mathrm{pF}$, u rozměrnějších či elektrolytických jde o $\mu \mathrm{F}$.

Používala se ještě řada jiných systémů označování - například barvami tělíska a barevnými tečkami. Pokud na takový kondenzátor narazíme, je lepší jeho kapacitu změřit. K měření přistoupíme i v prrípadě pochybností, zda je kondenzátor označen starým nebo novým způsobem - např́iklad trojčíslí 470 může znamenat 470 pF i 47 pF.

\section{Označování jmenovité hodnoty indukčnosti na součástce}

Značení hodnoty indukčnosti na SMD induktorech resp. na cívkách či tlumivkách je prozatím značně nejednotné a je nutno vždy pracovat s informacemi poskytovanými výrobcem pro danou součástku.

$\mathrm{V}$ případě rozměrnějších součástek se indukčnost na nich uvádí shodně jako ve schématech tak, jako je uvedeno v Tab 7.4. kdy základní jednotkou je $1 \mathrm{H}$. Ve většině prrípadů se pak používá dvouciferný číselný kód doplněný číslem násobitele (viz Tab 7.13), kdy ovšem je základní jednotkou $1 \mu \mathrm{H}$. Někteří výrobci pro označení indukčnosti induktory používají kód sestávající s číslic a písmen. Způsob značení je zřejmý z Tab 7.14.

Tab 7.13: Označování indukčností na induktoru číselným kódem

\begin{tabular}{|c|c|c|c|}
\hline \multicolumn{4}{|c|}{ Základní jednotka $1 \mu \mathrm{H}$} \\
\hline Kód & Násobitel & Kód & Násobitel \\
\hline $\mathbf{0}$ & $10^{0}$ & $\mathbf{5}$ & $10^{5}$ \\
\hline $\mathbf{1}$ & $10^{1}$ & $\mathbf{6}$ & $10^{6}$ \\
\hline $\mathbf{2}$ & $10^{2}$ & $\mathbf{7}$ & $10^{7}$ \\
\hline $\mathbf{3}$ & $10^{3}$ & $\mathbf{8}$ & $10^{-2}$ \\
\hline $\mathbf{4}$ & $10^{4}$ & $\mathbf{9}$ & $10^{-1}$ \\
\hline
\end{tabular}

\begin{tabular}{|c|l|}
\hline \multicolumn{2}{|c|}{ Př́klady označení jmenovité indukčnosti } \\
\hline Kódové označení & Jmenovitá indukčnost \\
\hline 569 & $5,6 \mu \mathrm{H}$ \\
\hline 120 & $12 \mu \mathrm{H}$ \\
\hline 681 & $680 \mu \mathrm{H}$ \\
\hline 152 & $1,5 \mathrm{mH}$ \\
\hline 104 & $100 \mathrm{mH}$ \\
\hline
\end{tabular}


Tab 7.14: Označování indukčností na induktorech číselným a písmenovým kódem

\begin{tabular}{|c|c|}
\hline Kódové označení & Jmenovitá indukčnost \\
\hline $3 \mathrm{~N} 3$ & $3,3 \mathrm{nH}$ \\
\hline $33 \mathrm{~N}$ & $33 \mathrm{nH}$ \\
\hline $\mathrm{R} 33$ & $0,33 \mu \mathrm{H}$ \\
\hline $3 \mathrm{R} 3$ & $3,3 \mu \mathrm{H}$ \\
\hline 330 & $33 \mu \mathrm{H}$ \\
\hline 331 & $330 \mu \mathrm{H}$ \\
\hline
\end{tabular}

Značení indukčností tlumivek s drátovými axiálními vývody je shodné jako barevné značení odporu na rezistorech s drátovými vývody. Protože se však tyto součástky nevyrábějí v tak přesných řadách jako rezistory, vystačí se se dvěma proužky pro číselnou hodnotu a jedním proužkem pro násobitele. Čtvrtý proužek pak vyznačuje toleranci indukčnosti. Pokud je poslední proužek vynechán, je tolerance indukčnosti $\pm 20 \%$. Barevné označování indukčností je uvedeno v Tab 7.15.

Tab 7.15: Označování jmenovitých hodnot a odchylek indukčností barevným kódem

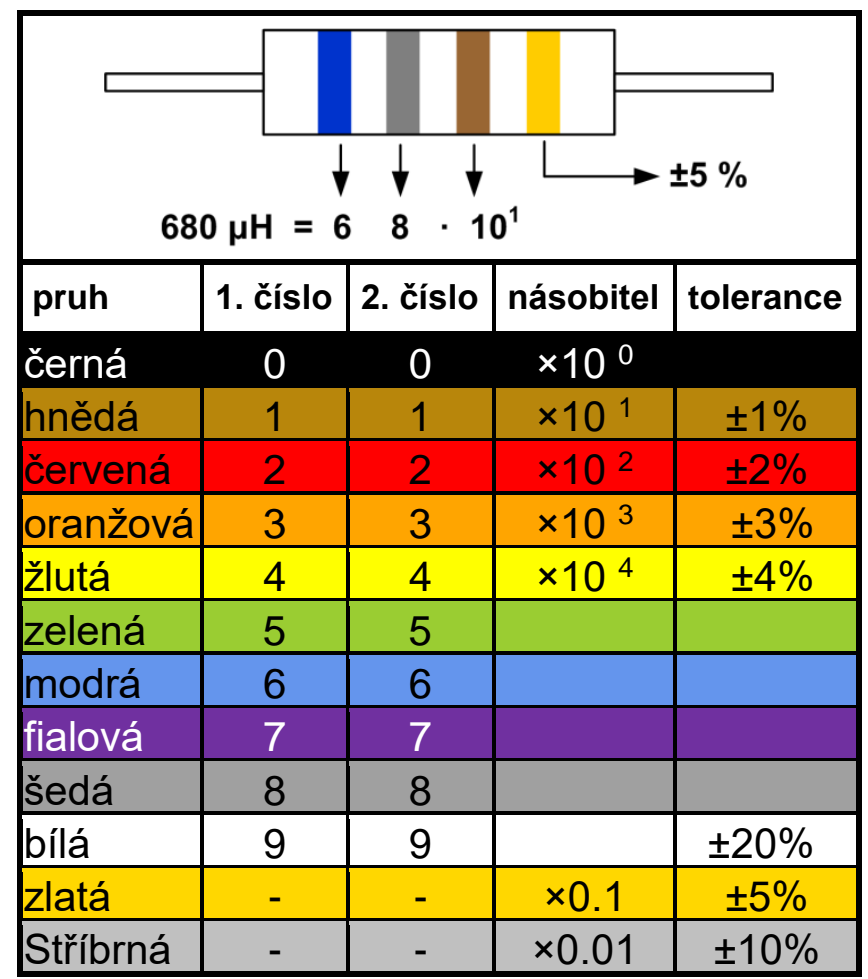

\section{Označování tolerance jmenovité hodnoty na součástce}

$\mathrm{Za}$ jmenovitou hodnotou odporů rezistorů bývá někdy uvedeno i označení tolerance písmenovým kódem, nejčastěji ve formátu podle Tab 7.16. Odchylky jsou v př́ípadě rezistorů obvykle souměrné kolem jmenovité hodnoty (např. $\pm 5 \%$ ). Dovolené odchylky, pro něž není v 
Tab 7.16 stanoveno písmeno kódu, se označují písmenem A a jsou blíže specifikovány výrobcem součástky (popř. v dohodě se zákazníkem).

$\mathrm{V}$ Tab 7.17 jsou uvedena kódová označení tolerance jmenovité hodnoty kapacitorů. Odchylky mohou být i nesouměrné kolem jmenovité hodnoty (např. $-20 \%$ a $+50 \%$ ). Nesouměrné odchylky se vyskytují zejména u elektrolytických a některých keramických kondenzátorů. $\mathrm{V}$ př́padě malých hodnot kapacity se místo tolerance někdy uvádí povolená odchylka v absolutní hodnotě (např. $\pm 0,1 \mathrm{pF}$ ).

Tab 7.16: Kódové označení dovolených odchylek rezistorů a prŕílady označení odchylky

\begin{tabular}{|l|l|c|l|}
\hline Kód & Tolerance & Kód & Tolerance \\
\hline B & $\pm 0,1 \%$ & $\mathbf{G}$ & $\pm 2 \%$ \\
\hline $\mathbf{C}$ & $\pm 0,25 \%$ & $\mathbf{J}$ & $\pm 5 \%$ \\
\hline $\mathbf{D}$ & $\pm 0,5 \%$ & $\mathbf{K}$ & $\pm 10 \%$ \\
\hline $\mathbf{F}$ & $\pm 1 \%$ & $\mathbf{M}$ & $\pm 20 \%$ \\
\hline
\end{tabular}

\begin{tabular}{|c|c|}
\hline $\begin{array}{c}\text { Kódové } \\
\text { označení }\end{array}$ & $\begin{array}{c}\text { Jmenovitý odpor } \\
\text { a dovolená odchylka }\end{array}$ \\
\hline 2R2J & $2,2 \Omega \pm 5 \%$ \\
\hline $2 \mathrm{M} 2 \mathrm{G}$ & $2,2 \mathrm{M} \Omega \pm 2 \%$ \\
\hline $4 \mathrm{~K} 7 \mathrm{~K}$ & $4,7 \mathrm{k} \Omega \pm 10 \%$ \\
\hline $102 \mathrm{R} 5 \mathrm{~A}$ & $102,5 \Omega \pm 0,2 \%$ \\
\hline
\end{tabular}

Tab 7.17: Kódového označení dovolených odchylek kapacitorů a př́klady označení odchylky

\begin{tabular}{|l|l|c|l|}
\hline Kód & Tolerance & Kód & Tolerance \\
\hline $\mathbf{B}$ & $\pm 0,1 \mathrm{pF}$ & $\mathbf{L}$ & $\pm 15 \%$ \\
\hline $\mathbf{C}$ & $\pm 0,25 \mathrm{pF}$ & $\mathbf{M}$ & $\pm 20 \%$ \\
\hline $\mathbf{D}$ & $\pm 0,5 \mathrm{pF}$ & $\mathbf{N}$ & $\pm 30 \%$ \\
\hline $\mathbf{E}$ & $\pm 0,5 \%$ & $\mathbf{P}$ & $-0+100 \%$ \\
\hline $\mathbf{F}$ & $\pm 1 \%$ & $\mathbf{Q}$ & $-10+30 \%$ \\
\hline $\mathbf{G}$ & $\pm 2 \%$ & $\mathbf{S}$ & $-20+50 \%$ \\
\hline $\mathbf{H}$ & $\pm 3 \%$ & $\mathbf{T}$ & $-10+50 \%$ \\
\hline $\mathbf{J}$ & $\pm 5 \%$ & $\mathbf{X}$ & $-20+40 \%$ \\
\hline $\mathbf{K}$ & $\pm 10 \%$ & $\mathbf{Z}$ & $-20+80 \%$ \\
\hline
\end{tabular}

\begin{tabular}{|c|c|}
\hline Kódové označení & $\begin{array}{c}\text { Jmenovitá kapacita } \\
\text { a dovolená odchylka }\end{array}$ \\
\hline $479 \mathrm{~J}$ & $4,7 \mathrm{pF} \pm 5 \%$ \\
\hline $120 \mathrm{D}$ & $12 \mathrm{pF} \pm 0,5 \mathrm{pF}$ \\
\hline $681 \mathrm{~N}$ & $680 \mathrm{pF} \pm 30 \%$ \\
\hline $152 \mathrm{~S}$ & $1,5 \mathrm{nF}-20+50 \%$ \\
\hline $104 \mathrm{Z}$ & $100 \mathrm{nF}-20+80 \%$ \\
\hline
\end{tabular}

Podobně za jmenovitou hodnotou indukčnosti může být na induktoru uvedena písmenovým kódem její tolerance. Značení tolerancí indukčností však nemusí být vždy zcela shodné se značením tolerancí v případě rezistorů a kapacitorů. Kódové označení dovolených odchylek indukčnosti a př́iklady označení odchylky na součástce jsou uvedeny v Tab 7.18. 
Tab 7.18: Kódové označení dovolených odchylek jmenovité indukčnosti a př́íklady označení odchylky

\begin{tabular}{|l|l|c|l|}
\hline Kód & Tolerance & Kód & Tolerance \\
\hline B & $\pm 0,15 \mathrm{nH}$ & $\mathbf{H}$ & $\pm 3 \%$ \\
\hline $\mathbf{C}$ & $\pm 0,2 \mathrm{nH}$ & $\mathbf{J}$ & $\pm 5 \%$ \\
\hline $\mathbf{S}$ & $\pm 0,3 \mathrm{nH}$ & $\mathbf{K}$ & $\pm 10 \%$ \\
\hline $\mathbf{D}$ & $\pm 0,5 \mathrm{nH}$ & $\mathbf{L}$ & $\pm 15 \%$ \\
\hline $\mathbf{F}$ & $\pm 1 \%$ & $\mathbf{M}$ & $\pm 20 \%$ \\
\hline $\mathbf{G}$ & $\pm 2 \%$ & $\mathbf{V}$ & $\pm 25 \%$ \\
\hline
\end{tabular}

\begin{tabular}{|c|c|}
\hline Kódové označení & $\begin{array}{c}\text { Hodnota indukčnosti } \\
\text { a dovolená odchylka }\end{array}$ \\
\hline $120 \mathrm{~J}$ & $12 \mu \mathrm{H} \pm 5 \%$ \\
\hline $681 \mathrm{G}$ & $680 \mu \mathrm{H} \pm 2 \%$ \\
\hline $104 \mathrm{M}$ & $100 \mathrm{mH} \pm 20 \%$ \\
\hline $152 \mathrm{~K}$ & $1,5 \mathrm{mH} \pm 10 \%$ \\
\hline
\end{tabular}

\section{Označování povoleného napětí na součástkách}

$\mathrm{Na}$ rezistorech a induktorech se většinou povolené napětí na součástce neuvádí. Nejjednodušší je označování povoleného napětí u rozměrnějších elektrolytických kondenzátorů, kdy se hodnota napětí uvede vedle či pod údajem o jmenovité hodnotě. Např. údaj $47 \mu \mathrm{F} 10 \mathrm{~V}$ (někdy jen $4710 \mathrm{~V}$ ) značí hodnotu $47 \mu \mathrm{F}$ na $10 \mathrm{~V}$.

Někteří výrobci pro kondenzátory použivají značení kódem sestávajícím z písmene a tří číslic. Písmeno z Tab 7.19 označuje povolené napětí, dvě číslice velikost a poslední číslice násobitel. Např. označení A476 znamená: A značí napětí, 47 je číslo a 6 exponent násobitele $10^{6}$. Základní jednotkou je zde pikofarad, takže hodnota kapacity je $47 \cdot 10^{6} \mathrm{pF}=47 \mu \mathrm{F}$, kondenzátor je na $10 \mathrm{~V}$. Je užíván i jiný kód pro povolené napětí, který se uvádí až za kódem sestávajícím z tří číslic, které udávají jmenovitou kapacitu. Způsob kódového označení je uveden v Tab 7.20. Existují však i další systémy a je proto nutno vždy sledovat katalogový list př́slušného výrobce.

Tab 7.19: Písmenový kód pro označení povoleného napětí na kondenzátorech (před číselným kódem)

\begin{tabular}{|l|c|c|c|c|c|c|c|c|c|}
\hline Kód & e & G & J & A & C & D & E & V & H \\
\hline Napětí (V) & 2,5 & 4,0 & 6,3 & 10 & 16 & 20 & 25 & 35 & 50 \\
\hline
\end{tabular}

Tab 7.20: Kód pro označení povoleného napětí na kondenzátorech (za číselným kódem)

\begin{tabular}{|l|c|c|c|c|c|c|c|c|c|c|c|c|c|}
\hline Kód & $\mathbf{6 R 3}$ & $\mathbf{0 1 0}$ & $\mathbf{0 1 6}$ & $\mathbf{0 2 5}$ & $\mathbf{0 3 5}$ & $\mathbf{0 5 0}$ & $\mathbf{M}$ & $\mathbf{P}$ & $\mathbf{R}$ & $\mathbf{S}$ & $\mathbf{U}$ & $\mathbf{V}$ & $\mathbf{Y}$ \\
\hline Napětí (V) & 6,3 & 10 & 16 & 25 & 35 & 50 & 63 & 100 & 200 & 250 & 350 & 400 & 450 \\
\hline
\end{tabular}

\subsection{Výběr rezistorů}

Rezistor (Resistor) představuje základní stavební prvek všech elektronických zařízení. Jeho vlastnost je definována jmenovitým odporem (Rated Resistance) vyjádřeným jednotkou Ohm $(\Omega)$. Konstruktér elektronického zařízení obvykle stojí před otázkou, jaký typ rezistoru 
pro dané použití volit. Žádný z vyráběných rezistorů není totiž univerzální a je třeba vždy posoudit, která jeho vlastnost je pro aplikaci primární. Kromě jmenovitého odporu a jeho tolerance je u rezistorů důležitá elektrická zatížitelnost, vliv okolní teploty na stálost odporu, změna parametrů vlivem připojeného napětí, šum, odolnost proti vnějším klimatickým vlivům.

\section{Parametry rezistori̊} $+25^{\circ} \mathrm{C}$

Jmenovitý odpor (Nominal Resistance) je odpor rezistoru zjištěný při pokojové teplotě

Tolerance odporu (Resistor Tolerance) vyjadřuje výrobní odchylku odporu od jeho jmenovité hodnoty a udává se jako maximální a minimální odchylka odporu $\pm \Delta R$ vztažená ke jmenovitému odporu $R$ v procentech

$$
\delta R=\frac{ \pm \Delta R}{R} \cdot 100 \quad[\%]
$$

Tolernace rezistorů je obvykle souměrná kolem jmenovité hodnoty (např. $\pm 10 \%$ ).

Jmenovité zatížení (Nominal Dissipation) rezistorů je hodnota udávaná výrobcem pro daný druh rezistoru. Platí až do teploty okolního prostředí (vzduchu) udávané výrobcem, obvykle $40^{\circ} \mathrm{C}$. Protože se však rezistor při provozu zahřívá procházejícím proudem, nelze při větších teplotách okolí zatěžovat rezistory plným jmenovitým výkonem. Proto je pro každý typ rezistoru obvykle udávána závislost tzv. provozního zatížení na teplotě (Power Derating Curve), viz Obr. 7.2 . V obrázku značí $P$ provozní zatížení, $P_{0}$ jmenovité zatížení a $T$ teplotu okolí. Jmenovitá okolní teplota $T_{\mathrm{A}}$ (Rated Ambient Temperature) pak udává nejvyšší trvalou teplotu okolí rezistoru, při které může rezistor bez poškození pracovat při jmenovitém zatížení

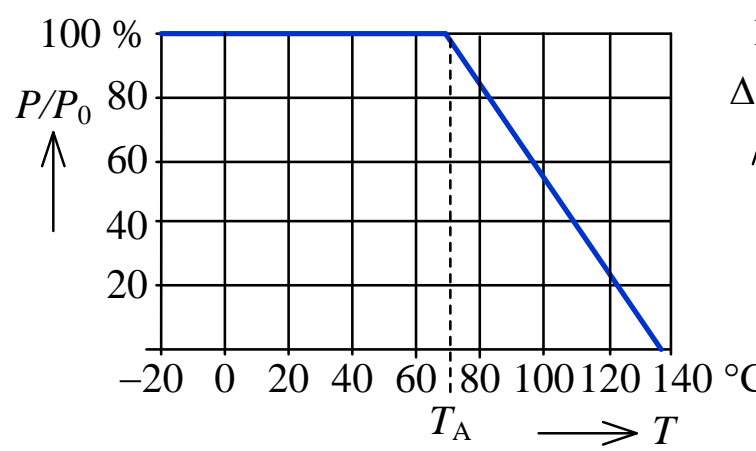

$\mathbf{a}$

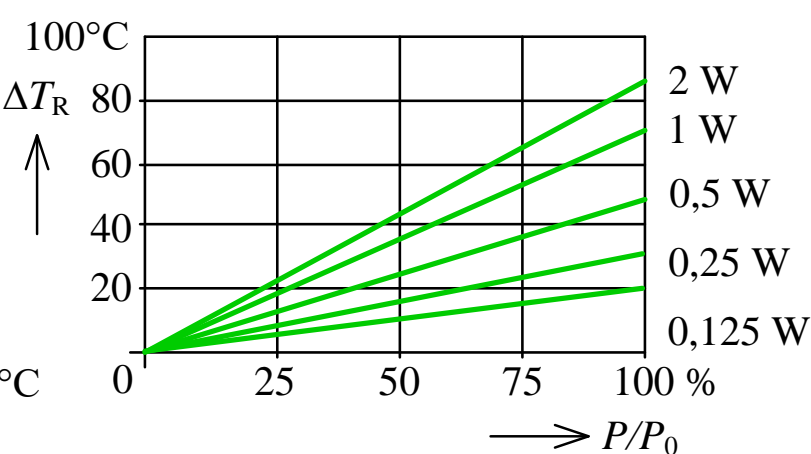

b

Obr. 7.2: a) Př́́klad závislosti zatížení rezistoru na teplotě okolí, b) příklad závislosti oteplení povrchu rezistoru na jeho zatížení pro rezistory s různými jmenovitými výkony

(viz čárkovaná čára vObr. 7.2 ). U některých typů rezistorů je uváděna závislost oteplení povrchu (Surface Temperature Rise) rezistoru $\Delta T_{\mathrm{R}}$ na jeho poměrném zatížení $P / P_{0}$ pro různá provedení rezistoru určená pro různé jmenovité výkony, viz Obr. 7.2b. Někteří výrobci ještě uvádějí grafy pro určení hustoty montáže rezistorů vedle sebe na DPS tak, aby nedošlo $\mathrm{k}$ přehřátí DSP. Chceme-li dlouhodobě zachovat velkou spolehlivost a stabilitu rezistorů nebo prodloužit dobu bezporuchové činnosti, využíváme často jejich jmenovité zatížení jen z 20 \% i méně. 
Vratnou změnu odporu rezistoru vlivem teploty, vztaženou na $1 \mathrm{~K}$ popř. $1{ }^{\circ} \mathrm{C}$, udává tzv. teplotni koeficient odporu (Temperature Coefficient of Resistance)

$$
T R=T C R=\frac{R_{1}-R_{0}}{R_{0}\left(T_{1}-T_{0}\right)} \cdot 10^{6},\left[\cdot 10^{-6} /{ }^{\circ} \mathrm{C}\right], \text { resp. }\left[\mathrm{ppm} /{ }^{\circ} \mathrm{C}\right]
$$

kde $R_{0}$ je odpor rezistoru při počáteční teplotě $T_{0}\left(\right.$ obvykle $+20 \pm 5^{\circ} \mathrm{C}$ ) a $R_{1}$ je odpor rezistoru naměřený při teplotě $T_{1}$ (obvykle $-55^{\circ} \mathrm{C}$ nebo $+125^{\circ} \mathrm{C}$ ). Velikost teplotního koeficientu odporu je důležitý údaj pro konstruktéra přístrojů, nebot' mu dovoluje vypočítat skutečný odpor rezistoru s ohledem na provozní teplotu rezistoru $T$ podle vztahu

$$
R=R_{0}\left[1+\left(T-T_{0}\right) T C R \cdot 10^{-6}\right] .
$$

Hodnotu teplotního koeficientu odporu TCR je nutno zejména zkoumat při výběru přesných rezistorů do zpětných vazeb operačních zesilovačů. Za velmi kvalitní lze považovat rezistory s teplotním koeficientem $\pm 15 \mathrm{ppm} /{ }^{\circ} \mathrm{C}$ a lepším. Pokud se týká teplotních vlastností SMD rezistorů, můžeme je seřadit od nejlepších k nejhorším takto:

1) rezistory metalizované (Metal Foil) založené na tzv. Z-technologii mají TCR asi $-0,1 \mathrm{ppm} /{ }^{\circ} \mathrm{C}$,

2) rezistory tenkovrstvé (Thin-Film) mají $T C R$ asi $+4 \mathrm{ppm} /{ }^{\circ} \mathrm{C}$,

3) rezistory tlustovrstvé (Thick-Film) mají $T C R$ asi $+42 \mathrm{ppm} /{ }^{\circ} \mathrm{C}$,

4) nejhorší jsou rezistory uhlíkové (Carbon) mají $T C R$ v rozmezí $+350 \mathrm{ppm} /{ }^{\circ} \mathrm{C}$ až $-2000 \mathrm{ppm} /{ }^{\circ} \mathrm{C}$.

Obecně se odpor kovů s oteplením zvětšuje, jejich teplotní koeficient je kladný. Uhlíkové rezistory mají obvykle teplotní koeficient záporný a jejich odpor se s oteplením zmenšuje, avšak některé uhlíkové rezistory (s odporem do několika set ohmů) vykazují kladný teplotní koeficient. Tato skutečnost je dána odlišným způsobem jejich výroby.

Jmenovité napětí (Rated Voltage) je trvalé maximální napětí na rezistoru při jmenovité okolní teplotě, které rezistor ještě nepoškodí.

Největši př́pustné napětí (Maximum Overload Voltage) se udává především u rezistorů s velkým odporem, přičemž se rozlišuje, zda se jedná o napětí stejnosměrné, střídavé či impulsové. Udaná hodnota platí jen pro určité rozmezí atmosférického tlaku.

Napětový součinitel odporu (Voltage Coefficient) udává vratnou změnu odporu rezistoru $\mathrm{v}$ závislosti na připojeném napětí. Udává se jako poměr relativní změny odporu udané $\mathrm{v}$ procentech k odpovídající změně napětí (např. 0,05 \%/V). Napět'ový součinitel odporu se stanoví ze vzorce

$$
K_{u}=\frac{R_{2}-R_{1}}{R_{2}\left(U_{1}-U_{2}\right)} \cdot 100 \%
$$

kde $R_{1}$ je odpor rezistoru při napětí $U_{1}$ a $R_{2}$ je odpor rezistoru při napětí $U_{2}$, přičemž $U_{1}$ odpovídá jmenovitému napětí a $U_{2} \approx U_{1} / 10$.

Šum (Noise) je považován za typickou vlastnost všech druhů vrstvových rezistorů. Při zatížení rezistoru stejnosměrným proudem lze pozorovat zvýšení hladiny šumového napětí, způsobené tzv. ,proudovým šumem“ (Current Noise). Tento šum nebyl zjištěn v kovech nebo slitinách s malým odporem (drátové rezistory), ale je nežádoucí vlastností všech vrstvových rezistorů, i když odporová vrstva byla napařena z materiálu, který ve tvaru drátu proudový šum nevykazuje. Šumové napětí se udává $v \mu V / V$, tzn. vztažené $\mathrm{k} 1 \mathrm{~V}$ přiloženého napětí. Velikost šumu se podle jakosti napařené odporové vrstvy pohybuje od 0,05 do $10 \mu \mathrm{V} / \mathrm{V}$. Tlustovrstvé 
(Thick-Film) a uhlíkové (Carbon) rezistory jsou známé svým zvýšeným šumem zejména na nízkých kmitočtech. Je to dáno značnou nehomogenitou jejich odporové vrstvy. Drátové, tenkovrstvé (Thin-Film) a metalizované (Metal Foil) mají lepší šumové vlastnosti.

Impedance rezistorů se v ideálním případě s kmitočtem nemění. U reálných rezistorů se ale uplatňuje parazitní kapacita příp. parazitní indukčnost, viz náhradní schéma reálného rezistoru na Obr. 7.3. Zde $\mathrm{R}$ je samotný rezistor, prvky $\mathrm{C}_{\mathrm{P}}$ a $\mathrm{L}_{\mathrm{P}}$ modelují jeho parazitní kapacitu a indukčnost.

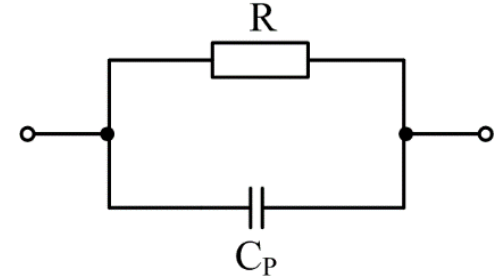

$\mathbf{a}$

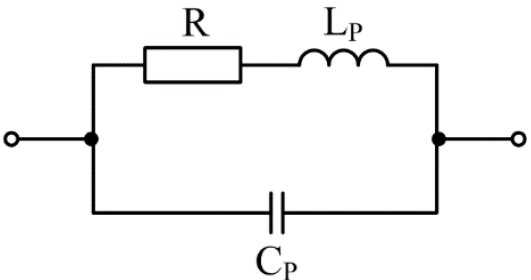

b

Obr. 7.3: a) Zjednodušený náhradní model, b) náhradní model rezistoru.

Pro velké odpory (ř́ádově nad desítky $\mathrm{k} \Omega$ ) vystačíme se zjednodušeným modelem rezistoru na Obr. 7.3 द, kdy se parazitní kapacita začíná výrazně uplatňovat již od kmitočtů nad $1 \mathrm{MHz}$. Pro malé odpory (ř́ádově pod desítky $\mathrm{k} \Omega$ ) je zapotřebí uvažovat přesnější model rezistoru na Obr. 7.3p. Informativní průběh závislosti modulu impedance rezistoru na kmitočtu je uveden na Obr. 7.4 A. Nad kmitočtem $1 / 2 \pi R C_{\mathrm{P}}$ se začíná již výrazně uplatňovat parazitní kapacita $C_{\mathrm{P}}$ a na nejvyšších pak i parazitní indukčnost $L_{\mathrm{P}}$.

Čím menší je odpor rezistorů, tím se vliv parazitní kapacity uplatňuje od vyšších kmitočtů. Nemá proto smysl používat $\mathrm{v}$ obvodech pracujících na vysokých kmitočtech rezistory neúměrně velkých odporů. U malých hodnot odporů naopak převažuje na vyšších kmitočtech induktivní charakter. Pro názornost jsou na Obr. 7.4 uvedeny př́íklady závislostí modulu impedance na kmitočtu u SMD rezistorů pro různé hodnoty odporu. Je zřejmé, že pro vf obvody je vhodné užívat rezistory s odporem řádově stovek $\Omega$ až $1 \mathrm{k} \Omega$.

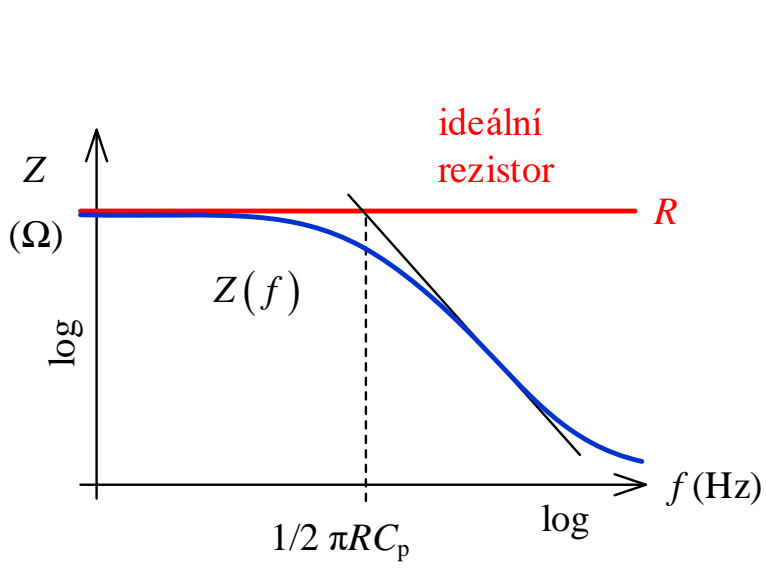

a

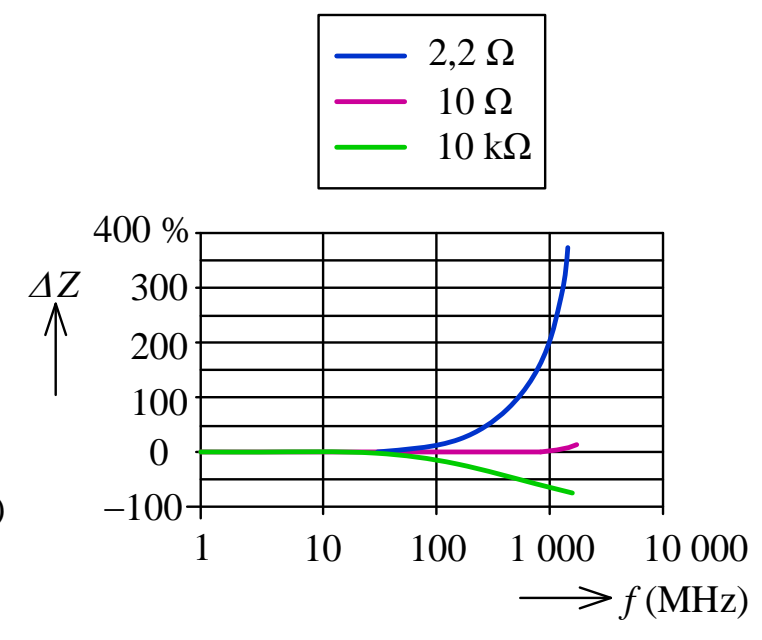

b

Obr. 7.4: a) Kmitočtová závislost impedance rezistoru na kmitočtu, b) př́klad frekvenční závislosti modulu impedance SMD rezistorů s různými odpory 
Kmitočtovou závislost rezistorů nesmíme opomenout při konstrukci rezistorových děličů s velkými hodnotami odporů (vstupní obvody osciloskopů, střídavých voltmetrů aj.). V tomto př́padě je třeba vliv parazitní kapacity $C_{\mathrm{p}}$ rezistoru s velkým odporem kompenzovat přidáním dodatečného kapacitoru $\mathrm{C}_{\mathrm{k}} \mathrm{k}$ rezistoru s menším odporem (viz Obr. 7.5ł), tzn. dělič musíme kmitočtově korigovat. Dělič bude optimálně korigován, bude-li splněna podmínka $R_{1} C_{\mathrm{p}}=R_{2} C_{\mathrm{k}}$, resp. $R_{1} / R_{2}=C_{\mathrm{k}} / C_{\mathrm{p}}$. To znamená, že dělicí poměr rezistorového děliče $\mathrm{R}_{1}, \mathrm{R}_{2}$ musí být stejný jako dělicí poměr kapacitorového děliče $C_{k}, C_{p}$. Experimentální ověření správné kompenzace nežádoucích kapacitních vlivů u rezistorového děliče je snadné (viz Obr. 7.5b). Pravoúhlé signály musí takovýto korigovaný dělič přenášet bez zkreslení (kontroluje se širokopásmovým osciloskopem). Př́klad řešení kmitočtově korigovaného rezistorového děliče je naznačen na Obr. 7.54. Vliv parazitních indukčností a kapacit prŕivodů potlačujeme vhodnou montáží a provedením spojů.

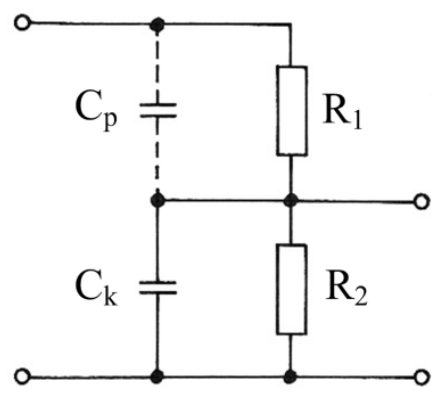

a

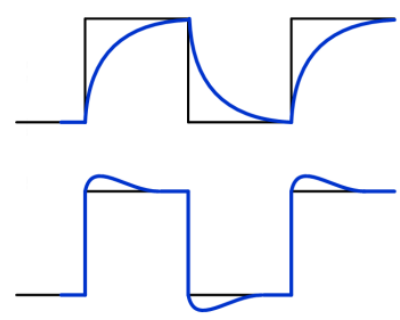

b

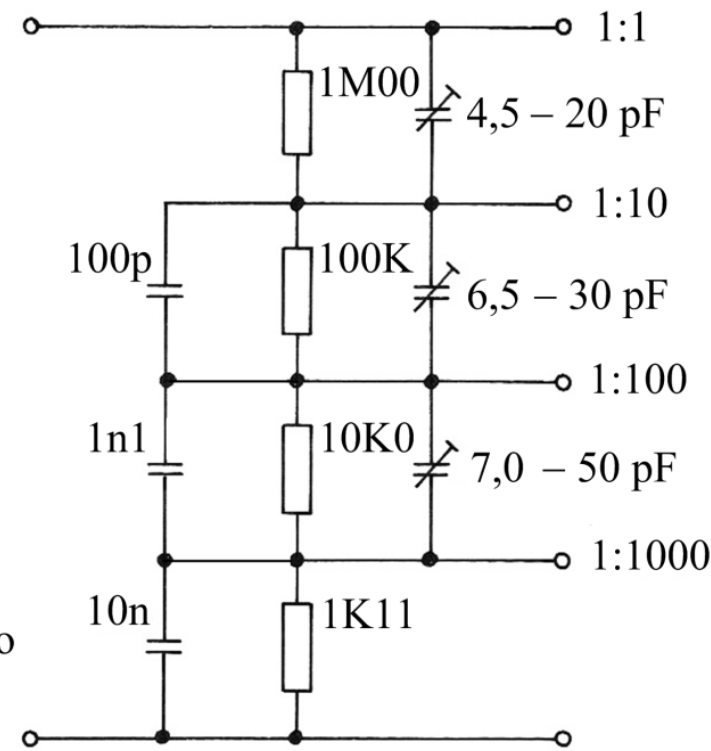

nedokompenzováno

Obr. 7.5: a) Kompenzace parazitní kapacity v rezistorovém děliči, b) experimentální ověření kompenzace, c) př́klad řešení kmitočtově korigovaného rezistorového děliče

\section{Typy rezistori̊}

Podle výrobní technologie a elektrické zatížitelnosti můžeme rezistory rozdělit do dvou skupin na vrstvové a drátové. Vrstvové rezistory tvoří vrstva čistého uhlíku nebo odporového laku obsahujícího saze (uhlíkové rezistory), odporové keramiky (tlustovrstvé a tenkovrstvé rezistory), kovu nebo odporové slitiny (metalizované rezistory). Odporový materiál je nanesen na keramickém tělísku (u SMD rezistorů nejčastěji na hranatém, u vývodových na válcovém). U rezistorů SMD pro větší zatížení je odporový materiál nanesen na keramické trubičce. Vzhled SMD rezistoru a řez jeho strukturou je uveden na Obr. 7.6 a, b, vzhled válcového SMD rezistoru pak na Obr. 7.64. 


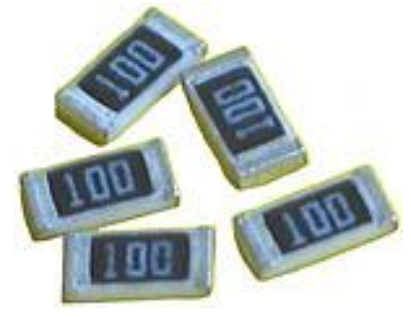

a

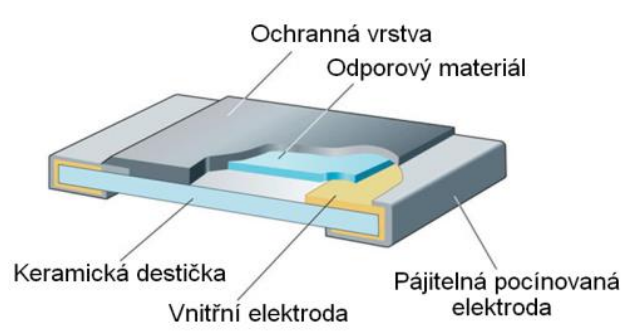

b

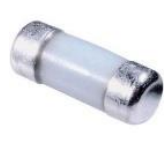

c

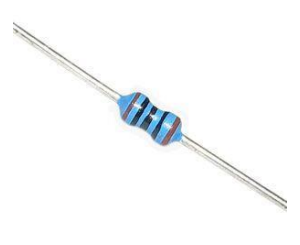

d

Obr. 7.6: a) Př́iklad provedení SMD rezistoru, b) řez jeho strukturou, c) SMD rezistor válcový, d) vývodový axiální válcový

Většina dnešních běžných SMD rezistorů je vyráběna tzv. tlustovrstvou technologií. Odporová vrstva je nanášena sítotiskovou technologií na horní stranu keramické destičky a poté zapečena při teplotě kolem $850^{\circ} \mathrm{C}$. Přesné rezistory $(0,1 ; 0,2 ; 0,5$ a $1 \%)$ jsou vyráběny tenkovrstvou technologií. Odporová vrstva se v tomto př́ípadě nanáší naprašováním a následně je v ní vyleptána vodivá cestička určující odpor rezistoru. Výsledný odpor tenko i tlustovrstvých rezistorů se nastaví broušením nebo laserovým trimováním. Odporovým materiálem bývá keramický substrát, např. nitrid tantalu $(\mathrm{TaN})$, oxid rutheničitý $\left(\mathrm{RuO}_{2}\right)$, oxid olovnatý $(\mathrm{PbO})$, nichrom (NiCr) či jejich kombinace.

Standardně se užívají SMD rezistory v pravoúhlých pouzdrech ve velikostech $0805 \mathrm{a}$ 1206. Nákresy těchto pouzder spolu s rozměry v mm jsou uvedeny na Obr. 7.7 a , b, způsob balení v páscích pak na Obr. 7.74. Název pouzdra označuje rozměry stran v setinách palce $(8 \mathrm{x}$ $0,254=2 \mathrm{~mm}$ atd.). Tlak na zvyšování užitných vlastností př́strojů bez požadavku na zvýšení jejich objemu vede na stále menší pouzdra 0402 nebo 0201.

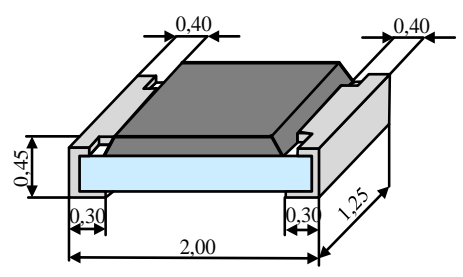

$\mathbf{a}$

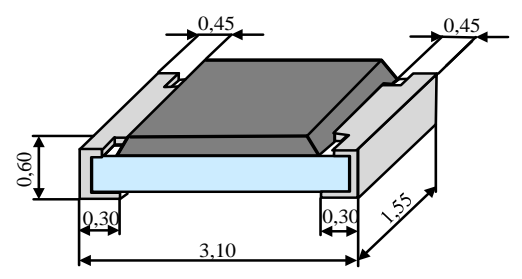

b

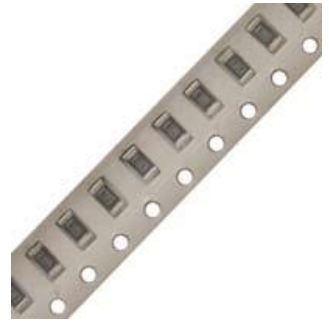

c

Obr. 7.7: Rozměry pouzder SMD v mm a) 0805, b) 1206; c) způsob balení SMD pasivních součástek

Odpor vývodových válcových vrstvových rezistorů se nastavuje při výrobě vybroušením šroubovité drážky do odporové vrstvy, čímž se zvětší délka odporové dráhy a tím i hodnota odporu. Tím ale vzniká určitá parazitní indukčnost, která se může za jistých podmínek nepř́iznivě projevit jako nežádoucí impedance při vyšších kmitočtech. Z tohoto důvodu se běžné vývodové rezistory nehodí do vysokofrekvenčních obvodů pro kmitočty nad $10 \mathrm{MHz}$. Pro tyto obvody se uživají rezistory SMD nebo vývodové rezistory s potlačenou indukčností, u kterých se výsledný odpor dostavuje obrušováním tloušt'ky odporové vrstvy podobně jako u SMD.

Pro vyšší jmenovitá zatížení (nad $1 \mathrm{~W}$ ) se užívají drátové smaltované, popř. tmelené rezistory. Drátové rezistory tvoří odporový drát, navinutý v jedné vrstvě na keramické trubičce, 
u typů pro zatížení 50 až $100 \mathrm{~W}$ také na ploché keramické destičce. Vinutí je chráněno keramickým pouzdrem, viz Obr. 7.8 . Protože vinutí tvoří v podstatě cívku, vykazují drátové rezistory velkou parazitní indukčnost. Tato okolnost se musí při aplikacích drátových rezistorů vždy respektovat. Vývody rezistorů na menší zatížení jsou realizovány ve směru podélné osy rezistoru, tzv. axiální vývody. Rezistory pro větší zatížení a některé další druhy mají vývody páskové nebo sponkové, směřující $\mathrm{k}$ ose rezistoru tzv. radiální vývody. Některé typy jsou pro lepší odvod tepla zatmeleny do pouzdra s chladičem (viz Obr. 7.8b). K dispozici jsou i výkonové rezistory realizované kompaktním odporovým materiálem, které se vyznačují zanedbatelnou parazitní indukčností Obr. 7.8\&,d). Jsou určeny pro obvody pracujícími na vysokých kmitočtech nebo pro pulsní aplikace.

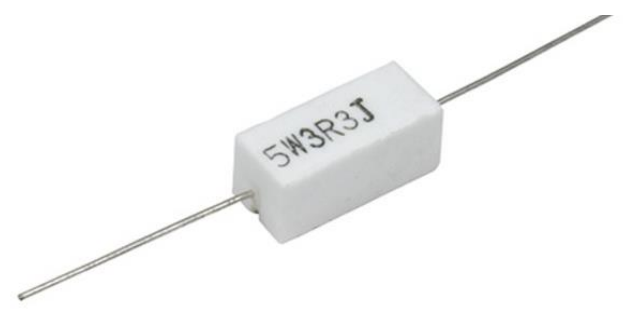

$\mathbf{a}$
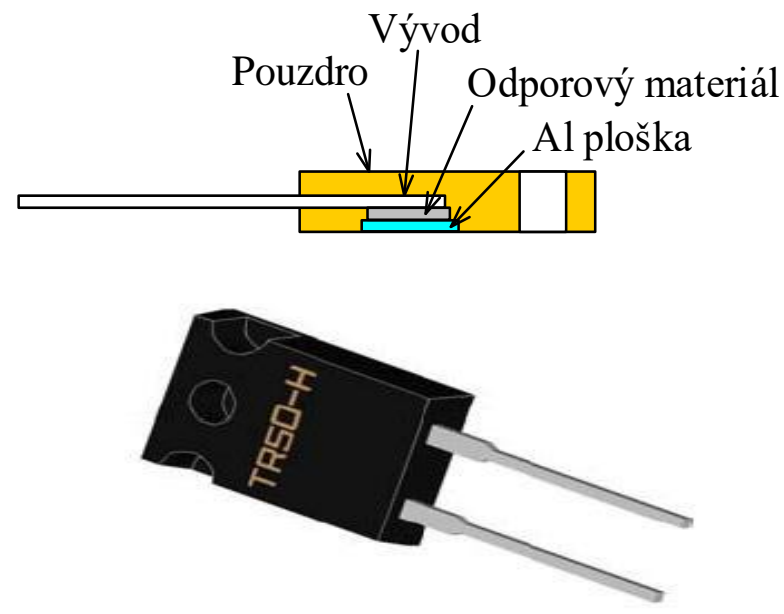

c

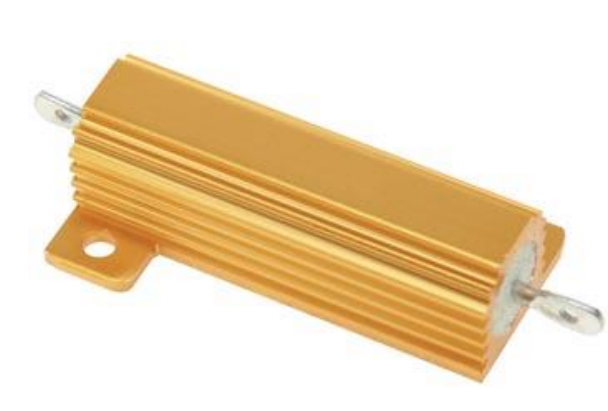

b
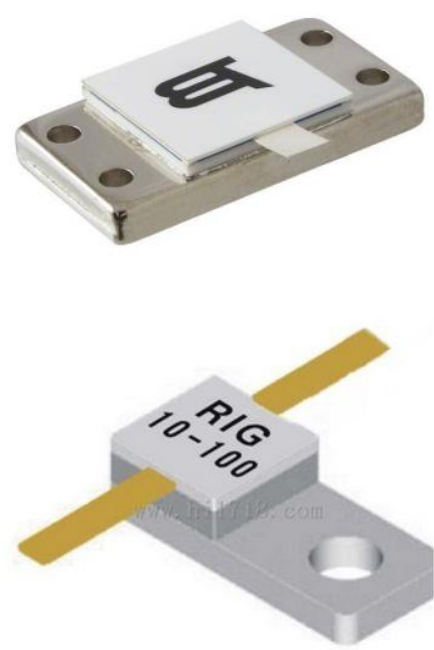

d

Obr. 7.8: Výkonové rezistory: a) v keramickém pouzdru, b) s chladičem, c) bezindukční v plastovém pouzdru, d) bezindukční na chladič

Samostatný problém tvoří aplikace rezistorů s malými odpory. Př́vody a přechodové odpory při připojení rezistoru představují parasitní rezistory zapojené v sérii $\mathrm{s}$ vlastním rezistorem. V běžných případech lze tento vliv zanedbat. Požadujeme-li však rezistor s malým (a přesným) odporem, může být připojení zdrojem značných nepřesností. Např. pro rezistor $\mathrm{s}$ odporem $10 \Omega$ je pro přesnost $0,1 \%$ povolen odpor př́vodů a připojení pouhých $10 \mathrm{~m} \Omega$. V takovém př́ípadě se snažíme připojovat rezistor čtyřsvorkově, abychom vliv přívodů odstranili. Při nevhodném návrhu se může do vlivu př́vodů rezistorů s malým odporem započítávat $\mathrm{i}$ 
odpor prŕslušného plošného spoje a výsledný odpor může být mimo toleranci i při použití přesného rezistoru.

\section{Potenciometry a potenciometrické trimry}

Kromě pevných rezistorů se $\mathrm{v}$ elektronice používají i rezistory s plynule nastavitelným odporem, a to obvykle ve formě tzv. potenciometrů či potenciometrických trimrů. Potenciometr je určen k častému ovládání obsluhou, a proto je jeho konstrukce robustnější a jeho ovládání je vyvedeno ze zařízení ven. Potenciometrický trimr je obvykle určen k nastavení parametrů, které uživatel často nemění a proto je jej možno nastavit pouze po okrytování př́stroje. Potenciometr či potenciometrický trimr má tři vývody: jsou vyvedeny oba konce odporové dráhy a vývod sběrače, který se posunuje po odporové dráze. Z toho plynou jeho vlastnosti, jako menší stabilita nastaveného odporu, zvýšený šum při nastavování hodnoty, možnost změny odporu nebo tzv. mikrofoničnost při mechanickém chvění.

Obvykle jsou oba konce odporové dráhy připojeny na napětí, jehož žádaná část se má odebírat ze sběrače. Zdroj je tedy zatěžován stále stejně velkým odporem. Zatížení potenciometrů se udává pro celou odporovou dráhu. Provozujeme-li potenciometr jako proměnný rezistor ( $\mathrm{tj}$. využíváme pouze odporovou dráhu mezi jedním koncem odporové dráhy a sběračem), je nutno zmenšit přípustné zatížení úměrně odporu zapojené části dráhy. $Z$ obdobných důvodů bývá jmenovité zatížení potenciometrů s logaritmickým a exponenciálním průběhem odporové dráhy přibližně poloviční než u potenciometrů stejných rozměrů $s$ lineárním průběhem.

Potenciometry se převážně upevňují na ovládací panel centrální maticí (otočné $\mathrm{s}$ vyvedeným hř́ídelem) nebo dvěma šrouby (posuvné) anebo v prrípadě potenciometrických trimrů se pájejí př́mo do plošných spojů.

Při použivání potenciometrů jako děličů napětí nebo v př́strojových měřicích obvodech se vyžaduje, aby změna odporu byla přímo úměrná natočení nebo posunutí sběrače, tj. aby odporová dráha měla lineární průběh. Pokud je potenciometr používán pro regulaci hlasitosti zvuku, mívá odpor dráhy logaritmický průběh, aby byla regulace přizpůsobena subjektivní citlivosti sluchu. Těmto potenciometrům se říká logaritmické potenciometry (označeny písmenem $\mathrm{A}$, dříve $\mathrm{G})$. Vyrábějí se i další průběhy drah pro různé charakteristiky ovládání, např̀. exponenciální (označeny písmenem $\mathrm{C}$, dříve $\mathrm{E}$ ), logaritmické s různým rozsahem regulace, s potlačenou částí dráhy (kolem středu nebo počátků) apod.

Odporové hmoty potenciometrů a potenciometrických trimrů jsou v podstatě stejné jako u pevných rezistorů, tj. uhlíková vrstva, odporový lak nebo u druhů pro větší zatížení odporový drát. Kromě těchto materiálů se stále častěji uplatňuje cermetová vrstva, která je tvořena tenkou vrstvičkou skla s rozptýlenými částicemi kovů. Nosným materiálem bývá nejčastěji tvrzený papír, u kvalitnějších potenciometrů keramická destička. Obecně lze říci, že potenciometry s uhlíkovou odporovou dráhou na tvrzeném papíru lze použít jen v klimaticky nenáročném prostředí. Pro vyšší nároky je třeba užívat uhlíkové potenciometry na keramické podložce nebo nejlépe potenciometry s odporovou dráhou typu cermet.

V současné době se vyrábí celá řada potenciometrů a potenciometrických trimrů. Výčet všech typů by přesáhl rámec této publikace, a proto si pouze uvedeme některé charakteristiky základních typů.

Jednoduché potenciometry se dodávají jednak otevřené bez krytu (např. drátové potenciometry, Obr. 7.9 a) a jednak v prachotěsném či plastovém pouzdru Obr. 7.9đ), které chrání vnitřek před pronikáním prachu. Pro speciální účely se vyrábějí tzv. těsné potenciometry, kde vlastní systém potenciometrů je neprodyšně uzavřen, což zvyšuje jeho stálost a odolnost proti klimatickým vlivům. K jednoduchým potenciometrům patří i posuvné (tahové) potenciometry Obr. 7.9 d), které našly velké uplatnění především ve spotřební elektronice. 
Tento potenciometr je složen ze základní desky, ke které je pevně uchycen pásek z izolantu, na němž je nanesena odporová dráha $\mathrm{z}$ odporového laku (lak s uhlíkem). Ta může mít průběh odporu lineární i logaritmický apod.

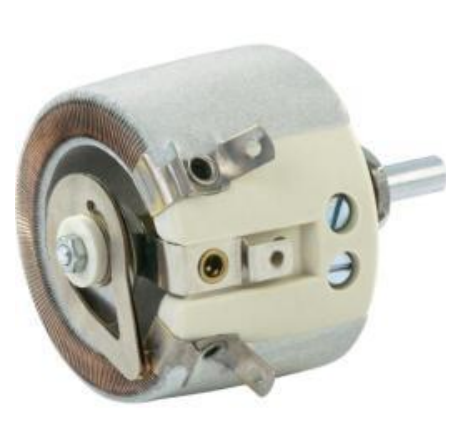

a

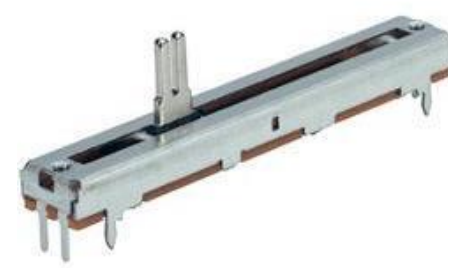

d

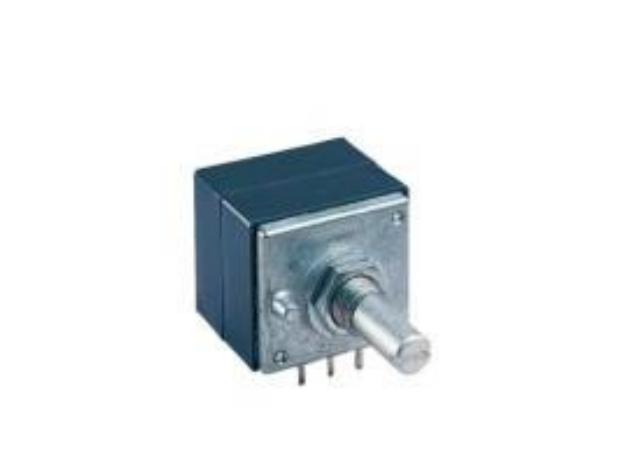

b

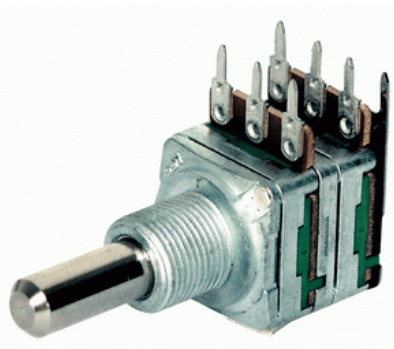

$\mathbf{e}$

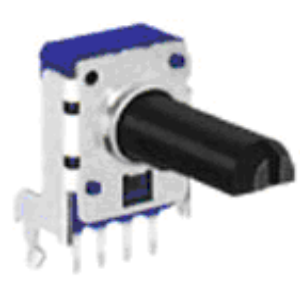

c

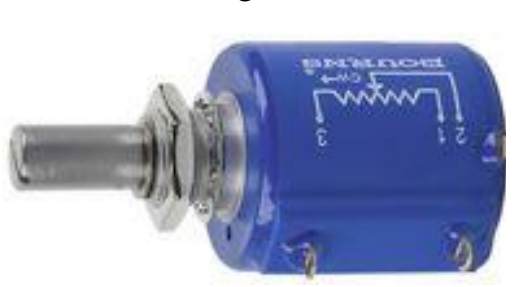

$\mathbf{f}$

Obr. 7.9: Různé druhy potenciometrů: a) drátový, b) v prachotěsném pouzdru, c) v plastovém pouzdru, d) posuvný, e) tandemový, f) víceotáčkový

Tandemové potenciometry Obr. 7.9b,e) jsou vytvořeny spojením dvou potenciometrů, ovládaných současně společným hř́delem, popř. společným hmatníkem u potenciometrů posuvných. Jsou vhodné tam, kde je zapotřebí řídit shodně změnu odporu dvou potenciometrů. Široké uplatnění nachází především v obvodech pro stereofonní práci se zvukem. Pro takovéto účely musí mít oba potenciometry pokud možno stejný průběh. Např. u otočných potenciometrů s lineárním průběhem zaručuje výrobce souběh $3 \mathrm{~dB}$, u posuvných dokonce $2 \mathrm{~dB}$ (pro stejné jmenovité hodnoty odporů).

Pro velmi přesné prrístrojové aplikace jsou pak $\mathrm{k}$ dispozici víceotáčkové potenciometry, které mívají 3, 5 nebo 10 otáček (Obr. 7.9f).

Dvojité potenciometry se vzhledově podobají tandemovým. V tomto případě se však každý potenciometr ovládá samostatně pomocí dvojitého hřídele. Vnější hřídel je dutý a kratší než hř́idel vnitřní. Každý z obou potenciometrů může mít nejen jinou jmenovitou hodnotu odporu, ale i jiný průběh odporové dráhy. Užívají se především ke zmenšení zastavěného prostoru na ovládacím panelu, kdy by pro samostatné potenciometry byla na ovládacím panelu zapotřebí dvakrát větší plocha.

Stejná snaha ke zmenšení zastavěného prostoru na ovládacím panelu vede k používání potenciometrů se zabudovaným vypínačem. Některé typy mají zabudován dvoupólový sít'ový vypínač pro napětí do $250 \mathrm{~V}$ a proud $1,5 \mathrm{~A}$, jiné mají zabudován spínač pro napětí do $24 \mathrm{~V}$ a proud $0,5 \mathrm{~A}$.

Potenciometrické trimry jsou potenciometry uzpůsobené pro montáž do plošných spojů. Průběh odporové dráhy je u všech typů lineární. Jezdec (běžec) je obvykle na obou stranách 
trimru opatřen drážkou pro šroubovák nebo je možno na něj nasunout ovládací knoflík. Pro běžné aplikace a pro menší provozní zatížení se používají potenciometrické trimry s odporovou vrstvou z polovodivého laku. Podložka je bud' z tvrzeného papíru, nebo keramiky. Pro nejlevnější zařízení se užívají potenciometrické trimry uhlíkové na podložce s tvrzeného papíru. Pro přesnější účely se pak užívají potenciometrické trimry s cermetovou vrstvou, které jsou většinou na keramické podložce. Výrobců potenciometrických trimrů je celá řada, na Obr. 7.10 jsou uvedeny jen př́klady provedení jednootáčkových vývodových potenciometrù pro ležatou či stojatou montáž (Obr. 7.10 ) nebo SMD provedení (Obr. 7.10巾).

Je-li požadováno velmi jemné nastavení odporu, je možno použít víceotáčkový potenciometrický trimr Obr. 7.10£, d). Celek je uzavřen v pouzdru z termoplastické hmoty. Jezdec na unašeči je veden hř́́delem se závitem. K dispozici jsou potenciometrické trimry s 5 až 20 otáčkami. Výběru typu víceotáčkového potenciometru je nutno věnovat péči, protože u nejlevnějších typů dochází někdy při seřizování k odskočení závitu a pak je jeho použití pro přesné dostavení hodnoty odporu zcela zbytečné.

K ovládání miniaturních elektronických zařízení, především přenosných přijímačů, zesilovačů a různých měřicích prŕístrojů se užívají také vrstvové knoflíkové potenciometry. Potenciometrický trimr je vestavěn do knoflíku z termoplastu. Pro snazší manipulaci je knoflík vroubkován. Pro větší jmenovité zatížení $(2 \mathrm{~W})$ se vyrábějí i potenciometrické trimry drátové.
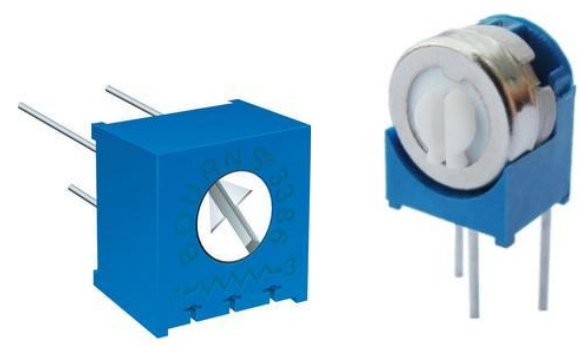

$\mathbf{a}$

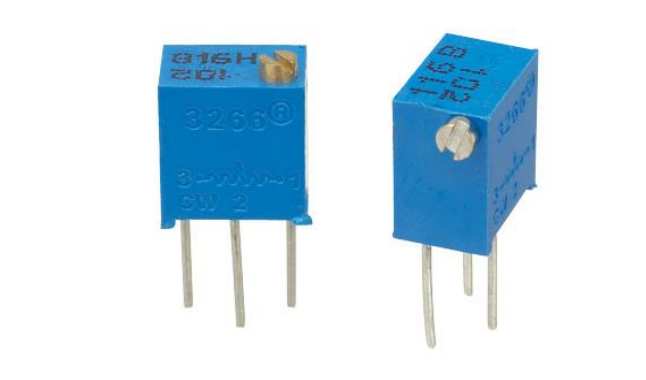

C

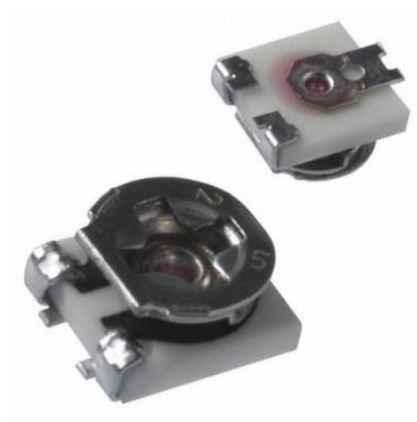

b
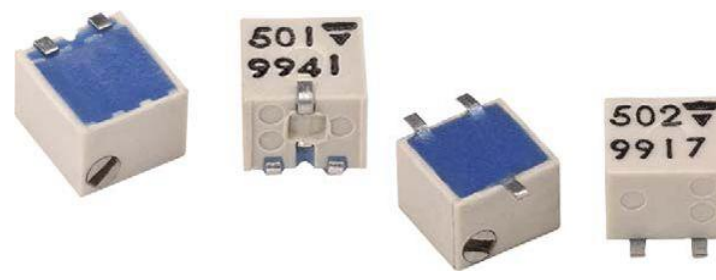

9917

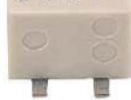

d

Obr. 7.10: Př́klady provedení potenciometrických trimrů: a) jednootáčkový vývodový, b) jednootáčkový SMD, c) víceotáčkový vývodový, d) víceotáčkový SMD. 


\subsection{Výběr kapacitorů}

Vedle rezistorů jsou v elektronice nejčastěji používanou pasivní součástkou kapacitory různých druhů a vlastností. Používají se jako vazební členy mezi obvody, v laděných obvodech, vysokofrekvenčních i nízkofrekvenčních filtrech, ale také jako filtrační k vyhlazení usměrněného stř́davého napětí $\mathrm{v}$ napájecích zdrojích nebo jako blokovací v rozvodech napájecího napětí.

Kapacitory (Capacitors) jsou tvořeny nejen dvěma elektrodami (polepy), mezi nimiž je př́slušné dielektrikum (keramika, nebo izolační fólie z polyesteru, polypropylenu, polystyrenu, polyetylenu, slídy aj.), ale jsou ještě zalisovány bud' do pouzdra z izolantu, nebo zastř́íknuty do termoplastu, anebo opatřeny vrstvou ochranného laku nebo tmelu (např. keramické vývodové kapacitory). Ani samotné dielektrikum není elektricky dokonalé a jeho vlastnosti ještě zhoršuje použitý povrchový materiál. V kapacitoru tak vznikají ztráty, které si můžeme modelovat jako rezistor vykazující tzv. izolační nebo svodový odpor, připojený paralelně ke kapacitoru. Při vyšších kmitočtech se pak přidávají ještě dielektrické ztráty a indukčnost elektrod (zvláště u svitkových kapacitorů), při velmi vysokých kmitočtech popř. i sériová indukčnost a odpor př́vodů k elektrodám. Tyto nepříznivé vlivy zahrnujeme pod izolační odpor a ztrátový činitel kapacitorů.

\section{Parametry kapacitorů}

Na kapacitorech je vyznačena jmenovitá kapacita (Nominal Capacitance), která odpovídá kapacitě zjišsěné měřením při určitém kmitočtu $(50$ nebo $100 \mathrm{~Hz}$ někdy $120 \mathrm{~Hz}$ u filtračních kondenzátorů, $1 \mathrm{kHz}$ nebo $1 \mathrm{MHz}$ u ostatních typů). Jmenovitá kapacita je volena v řadách E6, El2 a E24, nejčastěji se užívá řada E12. Na SMD kapacitorech však většinou nebývá jmenovitá kapacita vůbec vyznačena.

Tolerance kapacity (Capacitance Tolerance) udává výrobní odchylku kapacity od její jmenovité hodnoty a obvykle se vyjadřuje jako maximální a minimální odchylka $\pm \Delta C$ vztažená ke jmenovité kapacitě $C$ v procentech

$$
\delta C=\frac{ \pm \Delta C}{C} \cdot 100[\%] .
$$

Tolerance kapacitorů bývají ve většině případů nesouměrné (např. $-10 \% \mathrm{a}+50 \%$ ). $\mathrm{V}$ případě malých kapacit (menších než $100 \mathrm{pF}$ ) se uvádí povolená absolutní odchylka $\pm \Delta \mathrm{C}$ $\mathrm{v}$ pikofaradech (např. $\pm 0,5 \mathrm{pF}$ ).

Jmenovité napětí (Rated Voltage) kapacitoru $U_{\mathrm{R}}$ je největší přípustná hodnota součtu stejnosměrného napětí a vrcholové hodnoty střídavého napětí, které může být přiloženo na kapacitor v celém rozsahu pracovních teplot. U keramických a foliových kapacitorů lze hodnotu jmenovitého napětí bez poškození kapacitoru krátkodobě překročit. U elektrolytických či tantalových kapacitorů se nesmí toto napětí překročit ani za nejnepř́źznivějších okolností (např. při sít'ovém přepětí), jinak dochází $\mathrm{k}$ dalšímu formování kapacitoru spojenému s vývinem plynu a tepla, které může vést ke zničení kapacitoru. Skutečné provozní napětí se volí vždy menší než napětí jmenovité. Zmenšením provozního napětí lze nejen zmenšit zbytkový proud (viz dále), ale dosáhnout i prodloužení životnosti kapacitoru. 


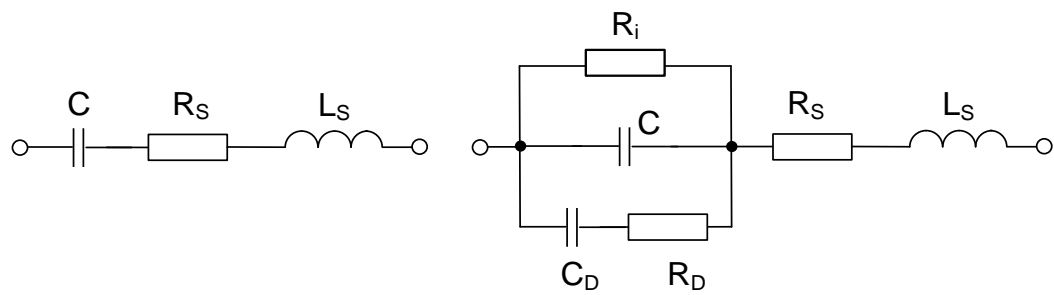

$\mathbf{a}$

b

Obr. 7.11: a) Náhradní model kapacitoru, b) náhradní model zahrnující dielektrickou absorbci a svodový odpor

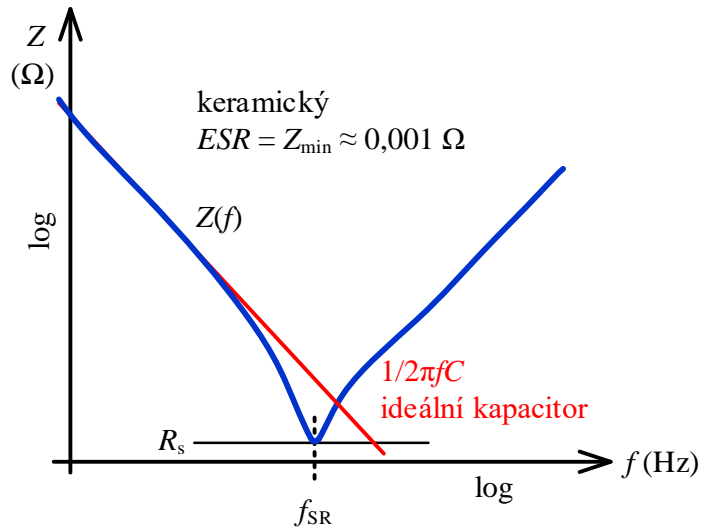

$\mathbf{a}$

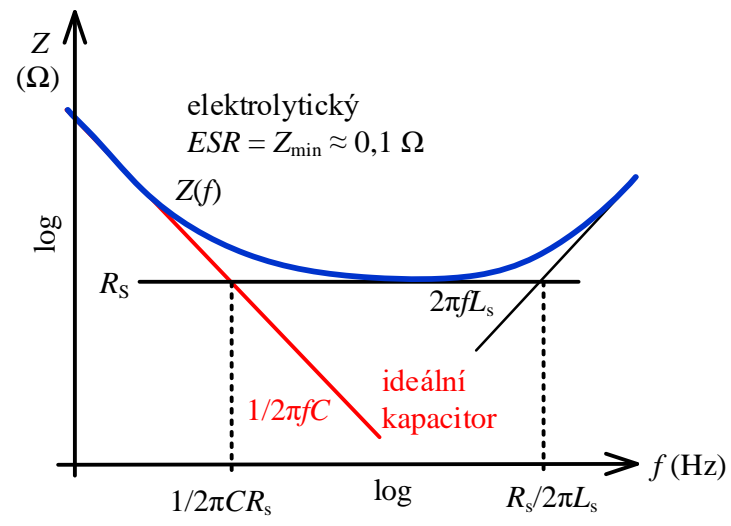

b

Obr. 7.12: a) Kmitočtová závislost impedance keramického kapacitoru, b) elektrolytického kapacitoru

Impedance kapacitoru v ideálním př́padě s kmitočtem neustále klesá. Každý reálný kapacitor vykazuje mimo jmenovité kapacity další parazitní vlastnosti. V řadě př́padů vystačíme s modelem podle Obr. 7.12 a. V obrázku značí C vlastní kapacitor se jmenovitou kapacitou $C, \mathrm{R}_{\mathrm{S}}$ ekvivalentní sériový rezistor o odporu $R_{\mathrm{S}}(E S R=$ Ekvivalent Series Resistance) daném součtem všech sériových odporů (napřr. odpor elektrolytu, anodové a katodové fólie a obou prřivodů), Ls ekvivalentní sériový induktor s indukčností $L_{\mathrm{S}}(E S L=$ Ekvivalent Series Inductance) danou součtem všech sériových indukčností (indukčnost elektrod a obou př́ivodů). V některých katalogových listech lze ekvivalentní sériový odpor $R_{\mathrm{s}}$ dohledat pod zkratkou $E S R$ a podobně ekvivalentní sériovou indukčnost pod zkratkou ESL. Modul impedance uvedeného modelu kapacitoru uvedeného na Obr. 7.12 je dán vztahem

$$
Z(\omega)=\sqrt{R_{S}^{2}+\left(\omega L_{S}-\frac{1}{\omega C}\right)^{2}} .
$$

Informativní průběhy závislosti modulu impedance na kmitočtu pro keramický a elektrolytický kapacitor jsou uvedeny na Obr. 7.12. Ze vzájemného srovnání je zřejmé, že z hlediska filtračních vlastností jsou lepší keramické kapacitory, protože vykazují podstatně menší hodnoty sériového odporu $R_{\mathrm{S}}$. U elektrolytických kapacitorů se však dá docílit daleko větší kapacity než u kapacitorů keramických. Odpor $R_{\mathrm{S}}$ je obvykle teplotně závislý - se snižující se teplotou vzrůstá viskozita elektrolytu a tím i specifický odpor. Minimální prakticky 
dosažitelný odpor $R_{\mathrm{S}}$ je dán odporem kontaktních spojů a elektrod, a proto obvykle nelze u elektrolytického kondenzátoru realizovat modul impedance $Z<0,1 \Omega$. U vícevrstvých keramických kapacitorů lze docílit až $Z \approx 0,001 \Omega$. Je zřejmé, že modul impedance skutečného kapacitoru se s kmitočtem nezmenšuje neomezeně a nemusí tedy znamenat, že kapacitor s větší kapacitou má na vyšších kmitočtech menší impedanci než kapacitor s menší kapacitou.

$\mathrm{Z}$ rovnosti reaktancí $X_{\mathrm{C}}$ a $X_{\mathrm{L}}$

$$
X_{\mathrm{C}}=X_{\mathrm{L}}, \operatorname{resp} \cdot \frac{1}{\omega C}=\omega L_{\mathrm{S}}
$$

můžeme určit vlastní rezonančni kmitočet kapacitoru $f_{\mathrm{SR}}(\mathrm{viz}$ Obr. 7.124)

$$
f_{\mathrm{SR}}=\frac{1}{2 \pi \sqrt{L_{\mathrm{S}} C}}
$$

Závislosti impedance kapacitoru na kmitočtu pro různé druhy dielektrik jsou uvedeny na Obr. 7.13. Umístění a šířka zlomů závisí na konstrukci kapacitoru, použitého dielektrika a kapacity kondenzátoru. Nejlepší vlastnosti vykazují keramické vícevrstvé kondenzátory (MLCC). Jejich maximální kapacita je však omezena jen na řádově stovky mikrofaradů.

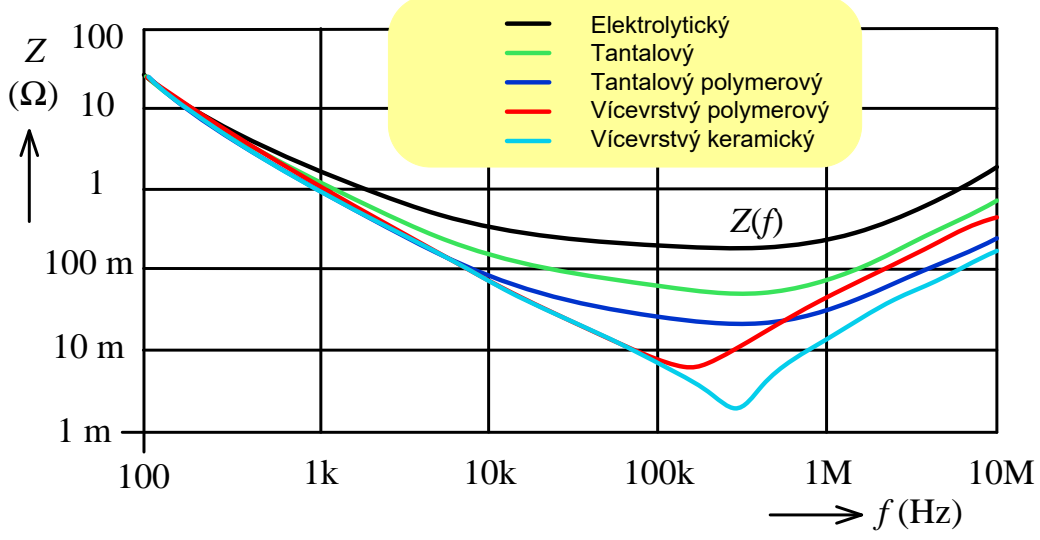

Obr. 7.13: Závislost modulu impedance různých typů kondenzátorů s kapacitou $100 \mu \mathrm{F}$ na kmitočtu

Ztrátový činitel $\left(D F=\right.$ Dissipation Factor) je definován jako poměr odporu $R_{\mathrm{S}}$ sériového rezistoru k reaktanci vlastního kapacitoru $X_{\mathrm{C}}$

$$
D F=\operatorname{tg} \delta=\frac{R_{\mathrm{S}}}{X_{\mathrm{C}}}=\omega C R_{S} .
$$

Ztrátový činitel je udáván při kmitočtu 50 popř. $100 \mathrm{~Hz}$ (u elektrolytických kapacitorů) nebo podle předpokládaného použití při kmitočtech $1 \mathrm{kHz}, 10 \mathrm{kHz}, 100 \mathrm{kHz}$ a $1 \mathrm{MHz}$ (u keramických či fóliových kapacitorů). Čím je menší jeho hodnota, tím kvalitnější je dielektrikum a tím i kapacitor. Ztrátový činitel polystyrenových, polyesterových a keramických kapacitorů (z tzv. vysokofrekvenční keramiky) je řádově $10^{-4}$ až $10^{-3}$, u kapacitorů metalizovaných asi $10^{-2}$, kdežto u elektrolytických kapacitorů bývá $10^{-1}$. S rostoucím kmitočtem se ztrátový činitel $\operatorname{tg} \delta$ obvykle zvětšuje. Ztrátový činitel elektrolytických kapacitorů vykazuje značnou teplotní závislost (vyplývá to z teplotní závislosti odporu $R_{\mathrm{S}}$ ). Informativní průběh ztrátového činitele nízkovoltového elektrolytického kapacitoru v závislosti na kmitočtu pro dvě mezní teploty je naznačen na Obr. 7.14. Někdy se udává také jakost kapacitoru ( $Q F=$ Quality Factor) 


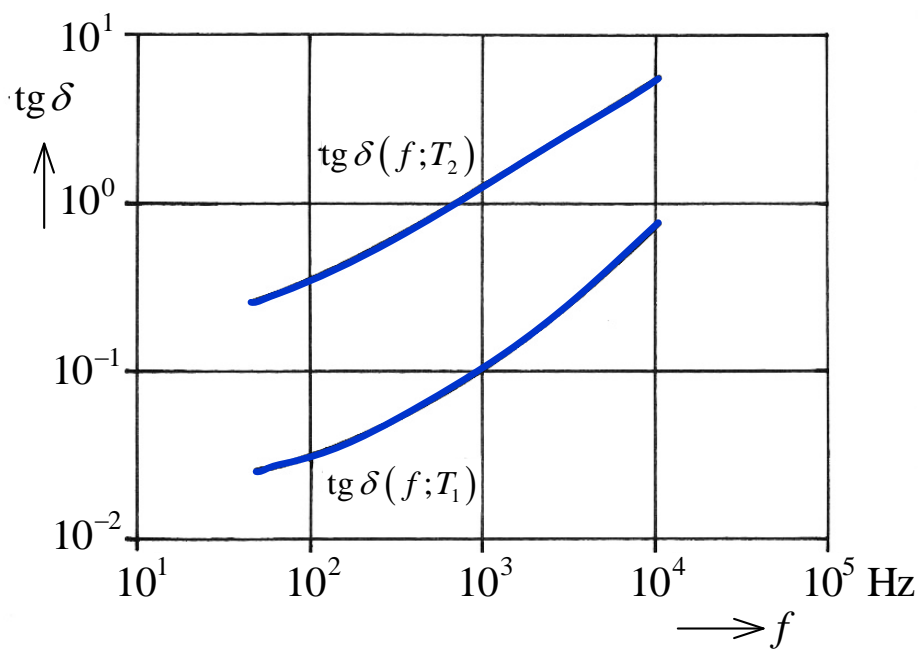

Obr. 7.14: Kmitočtová závislost ztrátového činitele nízkovoltového elektrolytického kapacitoru pro dvě mezní teploty

$$
Q_{\mathrm{C}}=\frac{1}{\operatorname{tg} \delta}=\frac{X_{\mathrm{C}}}{R_{\mathrm{S}}}=\frac{1}{\omega C R_{\mathrm{S}}} .
$$

V některých př́padech s jednoduchým modelem nevystačíme. U kapacitorů, které jsou provozovány jako analogová pamět' (např. ve vzorkovačích s pamětí) nebo určují parametry časovacích obvodů, se musí uvažovat paralelní izolační odpor (Insulation Rezistance), který je v náhradním schématu na Obr. 7.12b reprezentován modelovým rezistorem $R_{\mathrm{i}}$. Odpor se zjišstuje měřením ss zbytkového proudu $I_{\mathrm{LC}}$ (DC Leakage Currnet) mezi vývody kapacitoru. Je výsledkem součtu odporu vlastního dielektrika a povrchového odporu kapacitoru. Izolační odpor se poněkud mění s teplotou, přiloženým napětím a klimatickými vlivy (některá dielektrika při zvětšené relativní vlhkosti částečně navlhají a jejich izolační odpor se zmenšuje). Izolační odpor metalizovaných kapacitorů bývá minimálně $10^{8}$ až $10^{9} \Omega$, keramických řádově $10^{10} \Omega$, u terylenových, polyesterových a polystyrenových až $10^{11} \Omega$. U polarizovaných kondenzátorů (elektrolytických, tantalových) se spíše udává ss zbytkový proud $I_{\mathrm{LC}}$. Protože zbytkový proud značně závisí na teplotě, uvádí se v katalozích velikost zbytkového proudu ve tvaru např. $I_{\mathrm{LC}}<0,01 C U$, kde $C$ znamená kapacitu kapacitoru $\mathrm{v} \mu \mathrm{F}$ a $U$ přiložené napětí ve voltech, výsledná hodnota je v $\mu \mathrm{A}$. Takže např. kapacitor o jmenovité kapacitě $100 \mu \mathrm{F}$ má při přiloženém napětí $10 \mathrm{~V}$ zbytkový proud $I_{\mathrm{LC}}<0,01 \cdot 100 \cdot 10=10 \mu \mathrm{A}$.

Dielektrická absorbce (Dielectric Absorption) je málokdy uvažovanou vlastností kapacitorů. Tento jev se však uplatňuje nejvíce u kapacitorů, použitých v různých časovacích obvodech, analogových integrátorech nebo ve vzorkovačích s pamětí $(\mathrm{S} / \mathrm{H}, \mathrm{T} / \mathrm{H}), \mathrm{v}$ nichž se kapacitory nabíjejí a vybíjejí na přesnou hodnotu. V náhradním zapojení na Obr. 7.12b je tento jev modelován prvky $C_{D}, R_{D}$. Nabije-li se kapacitor na určité napětí, část náboje se váže $s$ dielektrikem a nelze ho odstranit krátkodobým vybitím. Vliv dielektrické absorbce vysvětlíme na modelovém obvodu na Obr. 7.15 Ar. Připojíme-li na vnější svorky stejnosměrné napětí (spínačem $S_{1}$ ), pak se po dostatečně dlouhé době kapacitory $C$ a $C_{D}$ nabijí na toto napětí. Zkratujeme-li pak po odpojení ss napětí vnější svorky (spínač $\mathrm{S}_{2}$ ), vybije se vlastní kapacitor $\mathrm{C}$ rychle, kdežto rychlost vybíjení modelového kapacitoru $C_{D}$ je omezena velkým odporem rezistoru $\mathrm{R}_{\mathrm{D}}$. Rozpojíme-li zkrat před vybitím kapacitoru $\mathrm{C}_{\mathrm{D}}$, pak se část náboje $\mathrm{z}$ kapacitoru 
$\mathrm{C}_{\mathrm{D}}$ přenese zpět na kapacitor $\mathrm{C}$ a na vnějších svorkách kapacitoru pozorujeme část původního napětí přiloženého na kapacitor Obr. 7.15b). Poměr obou napětí je funkcí nabíjecího a vybíjecího času, použitého napětí a teploty. Proto má pouze srovnávací význam. Nejlepším materiálem z hlediska dielektrické absorbce je polystyren a polypropylen se součinitelem dielektrické absorbce cca $0,02 \%$. Polyester dosahuje hodnot 0,2 až $0,25 \%$, keramika Z5U 2 až $2,5 \%$ a keramika X7R kolem 0,8\%. Nevhodný výběr kapacitoru s velkou dielektrickou absorbcí může způsobit velkou chybu zapamatovaného napětí o desítky nebo dokonce stovky $\mathrm{mV}$.

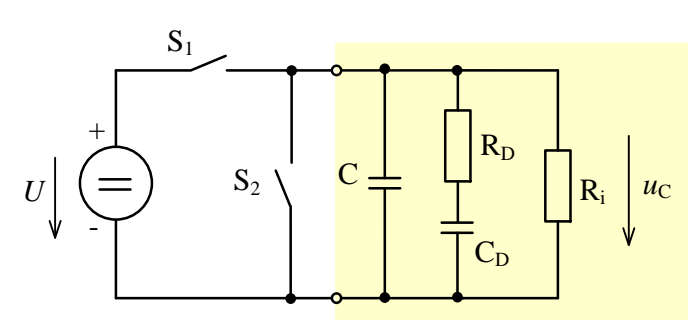

$\mathbf{a}$

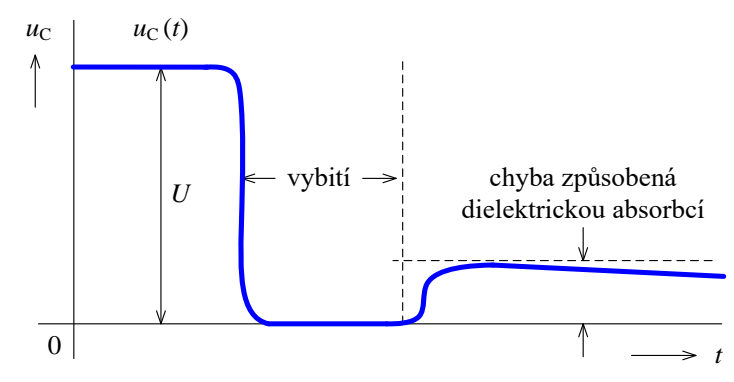

b

Obr. 7.15: a) Model dielektrické absorbce, b) chyba způsobená dielektrickou absorbcí

Kapacita kapacitorů je závislá na teplotě. Změny vlivem oteplení se udávají podobně jako u rezistoru teplotnim koeficientem kapacitoru (Temperature Coefficient of Capacitance)

$$
T C C=T C=\frac{C_{2}-C_{1}}{C_{1}\left(T_{2}-T_{1}\right)} \cdot 10^{6},\left[10^{-6} / \mathrm{K} \operatorname{resp} .10^{-6} /{ }^{\circ} \mathrm{C}\right],
$$

kde $C_{1}$ značí kapacitu kapacitoru při dolní měřicí teplotě $T_{1}\left(25 \pm 10^{\circ} \mathrm{C}\right)$ a $C_{2}$ kapacitu při horní měřicí teplotě $T_{2}\left(85 \pm 3^{\circ} \mathrm{C}\right.$ popř. $100 \pm 3^{\circ} \mathrm{C}$ podle kategorie). Teplotní koeficient kapacitoru určuje maximální změnu jeho kapacity ve stanoveném rozmezí teplot. Teplotní koeficient kapacitoru se často vyjadřuje lineárně v miliontinách změny na stupeň Celsia $\left(\mathrm{ppm} /{ }^{\circ} \mathrm{C}\right)$, nebo jako procento změny $\mathrm{v}$ určitém rozmezí teplot. Podle použité hmoty dielektrika může být závislost teplotního koeficientu kladná (P-positive) nebo záporná ( $\mathrm{N}$-negative). Např. P100 značí $100 \mathrm{ppm} /{ }^{\circ} \mathrm{C}$ nebo $\mathrm{N} 200$ je $-200 \mathrm{ppm} /{ }^{\circ} \mathrm{C}$. Teplotní koeficient je lineární závislostí teploty pouze u některých typů kapacitorů (některé typy keramických kapacitorů a některé druhy fóliových kapacitorů). $\mathrm{O}$ dalších parametrech specifických pro určité typy kapacitorů se zmíníme dále.

Pro všeobecné použití se nejčastěji užívají kapacitory s keramickým dielektrikem, zkráceně keramické, a to v provedení SMD. Tyto kapacitory jsou velmi stabilní a mají malý ztrátový činitel. Hodí se proto i pro velmi vysoké kmitočty. Mají minimální rozměry a díky tomu i malou parazitní indukčnost. Některé druhy keramických kapacitorů mají značný záporný teplotní součinitel kapacity, a proto se z nich vyrobené kapacitory někdy používají ke kompenzaci teplotních změn obvodů. 


\section{Typy kapacitori̊}

Keramické kapacitory jsou v současné době na trhu s různými hmotami dielektrika. Tyto hmoty se mezi sebou liší hlavně různými závislostmi kapacit na teplotě a přiloženém napětí a také hodnotami ztrátového činitele.

Keramické kapacitory třídy 1 (EIA Class 1) jsou kapacitory s malými ztrátami. Vyznačují se velkou stálostí kapacity, malým ztrátovým činitelem (max. $\left.5 \cdot 10^{-3}\right)$ i při vysokých kmitočtech, lineárním teplotním součinitelem (závislost kapacity na teplotě je lineární, a to bud' pozitivní, nebo negativní a je vratná), vysokým izolačním odporem, malou tolerancí kapacity, dlouhodobou stabilitou parametrů bez napětové závislosti. Užívají se ve vf laděných obvodech, filtrech, časovacích obvodech, k teplotní kompenzaci rezonančních obvodů a filtrů, jako vf vazební a oddělovací kapacitory. Nejznámější hmota dielektrika kapacitorů třídy 1 je NP0 (př́padně $\mathrm{C} 0 \mathrm{G}$ ), která má nejmenší ztráty a především nulový teplotní koeficient, resp. minimální změnu kapacity v běžném rozmezí teplot. Vynikající teplotní vlastnosti mají také kapacitory se slídovým dielektrikem. Kapacitory s touto hmotou jsou rozměrově větší a dražší. Hmoty s větší ale stále přibližně lineární závislostí kapacity na teplotě jsou napřr. N80, N150, N220, N330, N470, N750.

Př́klad teplotní závislosti kapacitorů typu $1 \mathrm{~s}$ negativním teplotním součinitelem je nakreslen na Obr. 7.16. Jako referenční je brána kapacita kapacitoru při pokojové teplotě $25^{\circ} \mathrm{C}$.

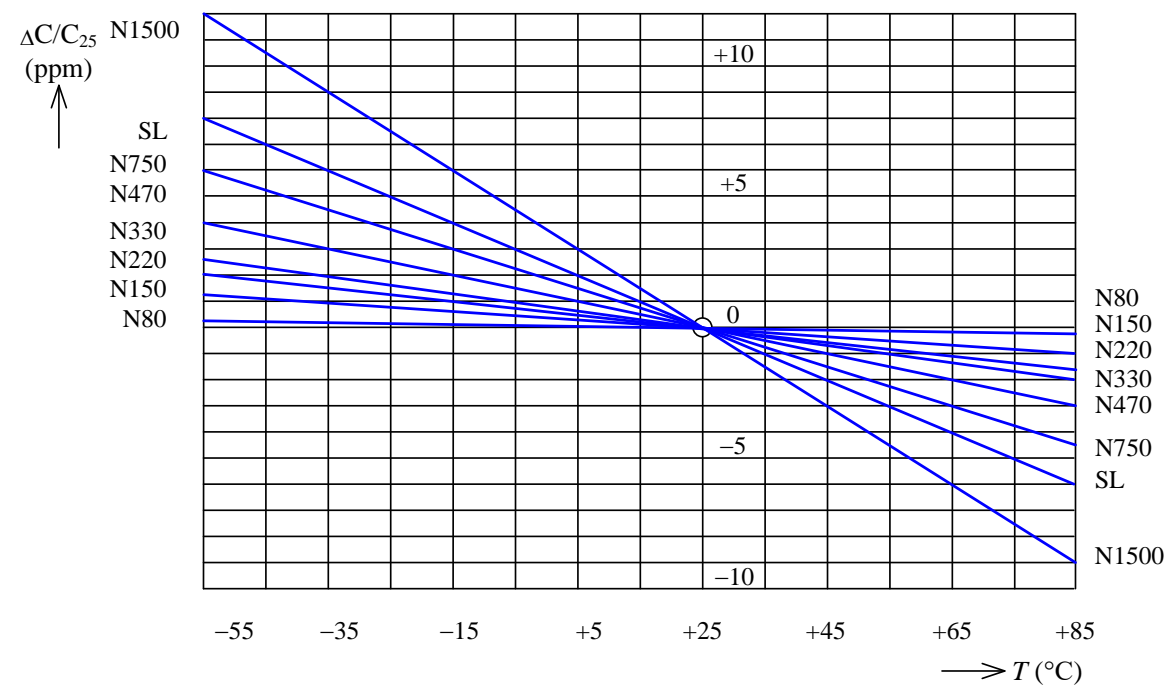

Obr. 7.16: Teplotní závislost kapacitorů typu $1 \mathrm{~s}$ negativním teplotním koeficientem pro různé hmoty dielektrika

$\mathrm{V}$ př́padě, že je zapotřebí kapacitor s teplotním koeficientem $T C C$, který není ve vyráběných typech kapacitorů $\mathrm{k}$ dispozici, můžeme jej získat paralelním nebo sériovým spojením kapacitorů s různými teplotními koeficienty. Pro výpočet teplotního koeficientu dvou kapacitorů $\mathrm{C}_{1} \mathrm{~s} T C C_{1} \mathrm{a} \mathrm{C}_{2} \mathrm{~s} T C C_{2}$ platí pro př́pad paralelního zapojení

$$
T C=\frac{C_{1} \cdot T C_{1}+C_{2} \cdot T C_{2}}{C_{1}+C_{2}}
$$

a pro sériové zapojení

$$
T C=\frac{C_{2} \cdot T C_{1}+C_{1} \cdot T C_{2}}{C_{1}+C_{2}}
$$


Je-li zapotřebí kapacitor o kapacitě $C \mathrm{~s}$ určitým teplotním koeficientem $T C$, určíme kapacity dílčích kapacitorů paralelního zapojení podle vztahů

$$
C_{1}=C \frac{T C-T C_{2}}{T C_{1}-T C_{2}}, \quad C_{2}=C-C_{1}
$$

a v př́ípadě sériového spojení

$$
C_{1}=C \frac{T C_{1}-T C_{2}}{T C-T C_{2}}, \quad C_{2}=\frac{C \cdot C_{1}}{C_{1}-C} .
$$

Určitou opatrnost, založenou na znalostech vlastností kapacitoru a obvodu, v němž bude použit, je třeba zachovávat při užití keramických kapacitorů třídy 2 (EIA Class 2). Tyto typy vykazují sice vyšší kapacity při malých rozměrech, ale mají menší stabilitu a větší ztrátový činitel (10 až $\left.35 \cdot 10^{-3}\right)$, nelineární závislost kapacity a ztrátového činitele na teplotě, na napětí a na kmitočtu. Užívají se převážně pro blokovací, vazební a odrušovací účely. Mezi nejznámější hmoty dielektrika kapacitorů třídy 2 patř́ X7R (pro kapacitory s kapacitou 1 až $330 \mathrm{nF}$ v rozmezí teplot $-55 \mathrm{a}+125^{\circ} \mathrm{C}$ vykazuje změnu kapacity $\pm 15 \%$ ), Y5P, Y5V, Z5U apod.Tab 7.21 vysvětluje význam těchto označení.

Tab 7.21: Význam označení hmot dielektrika kapacitorů (EIA Class 2) s nelineární závislostí teplotního součinitele

\begin{tabular}{|l|l|l|l|l|l|}
\hline \multicolumn{2}{|c|}{ teplota $T_{1}$} & \multicolumn{2}{l|}{ teplota $\boldsymbol{T}_{\mathbf{2}}$} & \multicolumn{2}{l|}{$\begin{array}{l}\text { změna kapacity } \\
\text { mezi } \boldsymbol{T}_{\mathbf{1}} \text { a } \boldsymbol{T}_{\mathbf{2}}\end{array}$} \\
\hline kód & teplota & kód & teplota & kód & procenta \\
\hline $\mathrm{X}$ & $-55^{\circ} \mathrm{C}$ & 4 & $+65^{\circ} \mathrm{C}$ & $\mathrm{A}$ & $\pm 1.0 \%$ \\
\hline $\mathrm{Y}$ & $-30^{\circ} \mathrm{C}$ & 5 & $+85^{\circ} \mathrm{C}$ & $\mathrm{B}$ & $\pm 1.5 \%$ \\
\hline $\mathrm{Z}$ & $+10^{\circ} \mathrm{C}$ & 6 & $+105^{\circ} \mathrm{C}$ & $\mathrm{C}$ & $\pm 2.2 \%$ \\
\hline & & 7 & $+125^{\circ} \mathrm{C}$ & $\mathrm{D}$ & $\pm 3.3 \%$ \\
\hline & & 8 & $+150^{\circ} \mathrm{C}$ & $\mathrm{E}$ & $\pm 4.7 \%$ \\
\hline & & 9 & $+200^{\circ} \mathrm{C}$ & $\mathrm{F}$ & $\pm 7.5 \%$ \\
\hline & & & & $\mathrm{P}$ & $\pm 10 \%$ \\
\hline & & & & $\mathrm{R}$ & $\pm 15 \%$ \\
\hline & & & & $\mathrm{S}$ & $\pm 22 \%$ \\
\hline & & & & $\mathrm{U}$ & $+22 \%$ až $-56 \%$ \\
\hline & & & & $\mathrm{V}$ & $+22 \%$ až $-82 \%$ \\
\hline
\end{tabular}

Nelineární závislost kapacity na teplotě pro dva různé dielektrické materiály jsou uvedeny na Obr. 7.17. Je zřejmé, že kapacitory s těmito materiály budou použitelné pouze jako blokovací nebo oddělovací kapacitory v nf technice. 


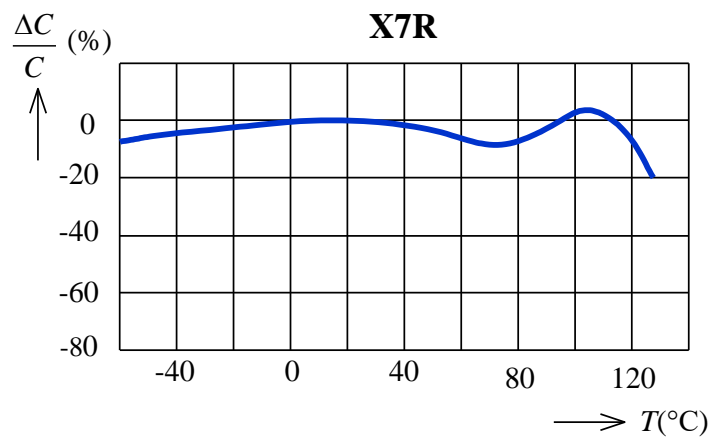

a

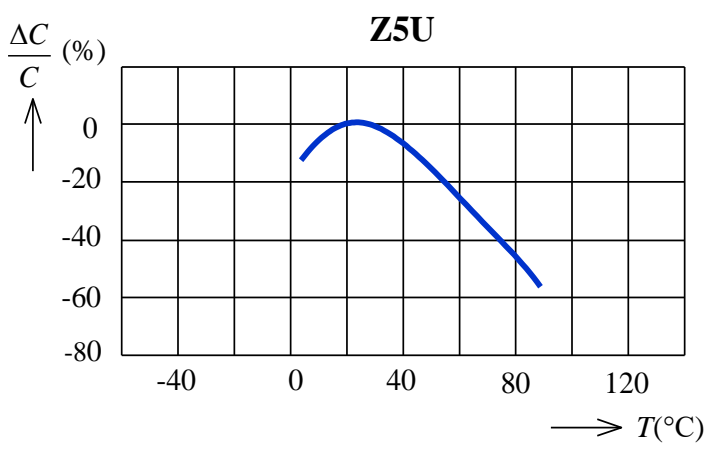

b

Obr. 7.17: Teplotní závislosti kapacitoru třídy 2 s hmotou dielektrika a) X7R, b) Z5U

U kapacitoru tř́idy 1 nezávisí kapacita téměř na přiloženém napětí. Závislost změny kapacity kapacitoru třídy 2 na přiloženém napětí je však značná. Změna kapacity v závislosti na přiloženém napětí může dosáhnout až $-80 \%$ vůči hodnotě zjištěné při napětí 0,5 nebo $1 \mathrm{~V}$. Tyto skutečnosti dokumentují závislosti na Obr. 7.18, kdy na Obr. 7.18丸 jsou uvedeny změny kapacity na přiloženém napětí v závislosti na použitém dielektriku a na Obr. 7.181 pak v závislosti na jmenovitém napětí pro hmotu X7R. Tyto nelineární změny kapacity kapacitorů trrídy 2 mohou vadit u přesných filtrů, či v jiných analogových aplikacích. V audioaplikacích může způsobovat zvětšení harmonického zkreslení.

Většina diskrétních kapacitorů vykazuje také ve větší či menší míře závislost kapacity na kmitočtu. U keramických kapacitorů tř́dy 2 a u fóliových kapacitorů se kapacita průkazně snižuje s rostoucím kmitočtem. Tyto okolnosti dokumentují charakteristiky nakreslené na Obr. 7.19 pro hmotu X7R a Y5V. Keramické kapacitory třídy 2 jsou spíše vhodné pouze pro nízká provozní napětí do $40 \mathrm{~V}$. Používají se proto jen jako kapacitory vazební, blokovací a filtrační v nízkofrekvenční technice (do $25 \mathrm{kHz}$ ).

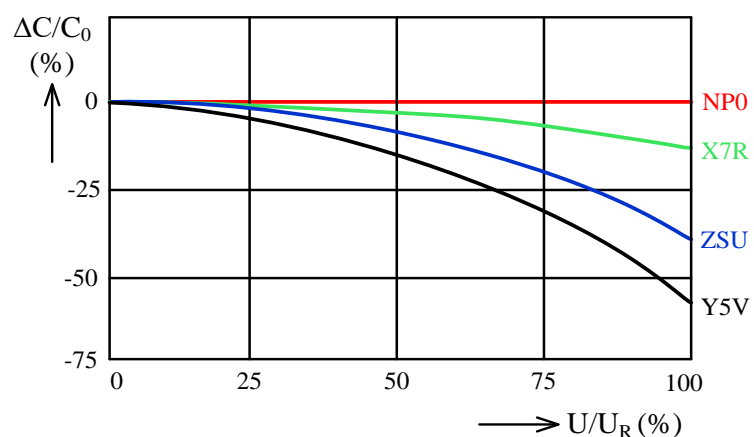

$\mathbf{a}$

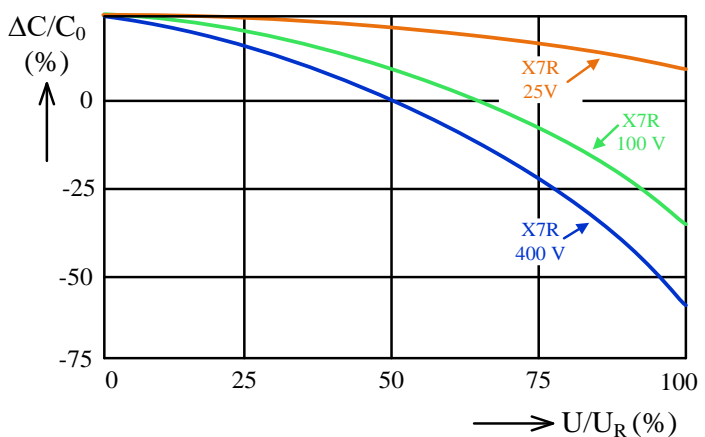

b

Obr. 7.18: Závislost kapacity kapacitorů tř́dy 2 na přiloženém napětí: a) pro keramické kapacitory se jmenovitým napětím $25 \mathrm{~V}$ pro různá dielektrika (NPO tř́́dy 1 uvedeno pro srovnání), b) pro keramické kapacitory X7R s různými jmenovitými napětími 


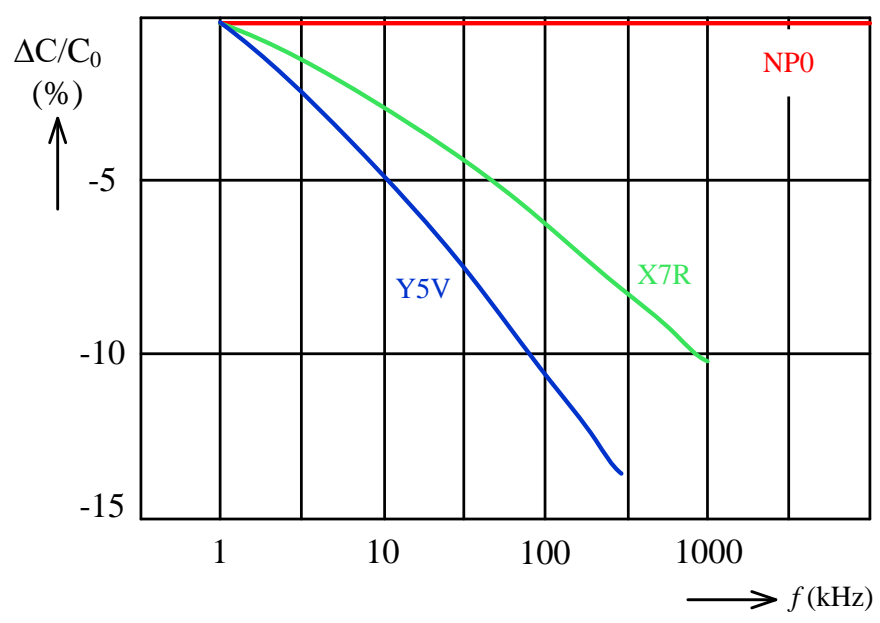

Obr. 7.19: Kmitočtová závislost kapacity pro keramické kondenzátory X7R a Y5V třídy 2 (NPO třídy 1 uvedena pro srovnání)

Keramické kapacitory tř́́dy 2 se vyznačují při stejných rozměrech podstatně vyšší kapacitou než kapacitory tř́dy 1. Jejich nelineární vlastnosti v závislosti na teplotě, přiloženém napětí či na kmitočtu je ale předurčují k použití jako vazební, blokovací či filtrační kapacitory v audio technice nebo maximálně do jednotek MHz. Doporučuje se je provozovat pro nižší napětí, než je jejich jmenovité napětí.

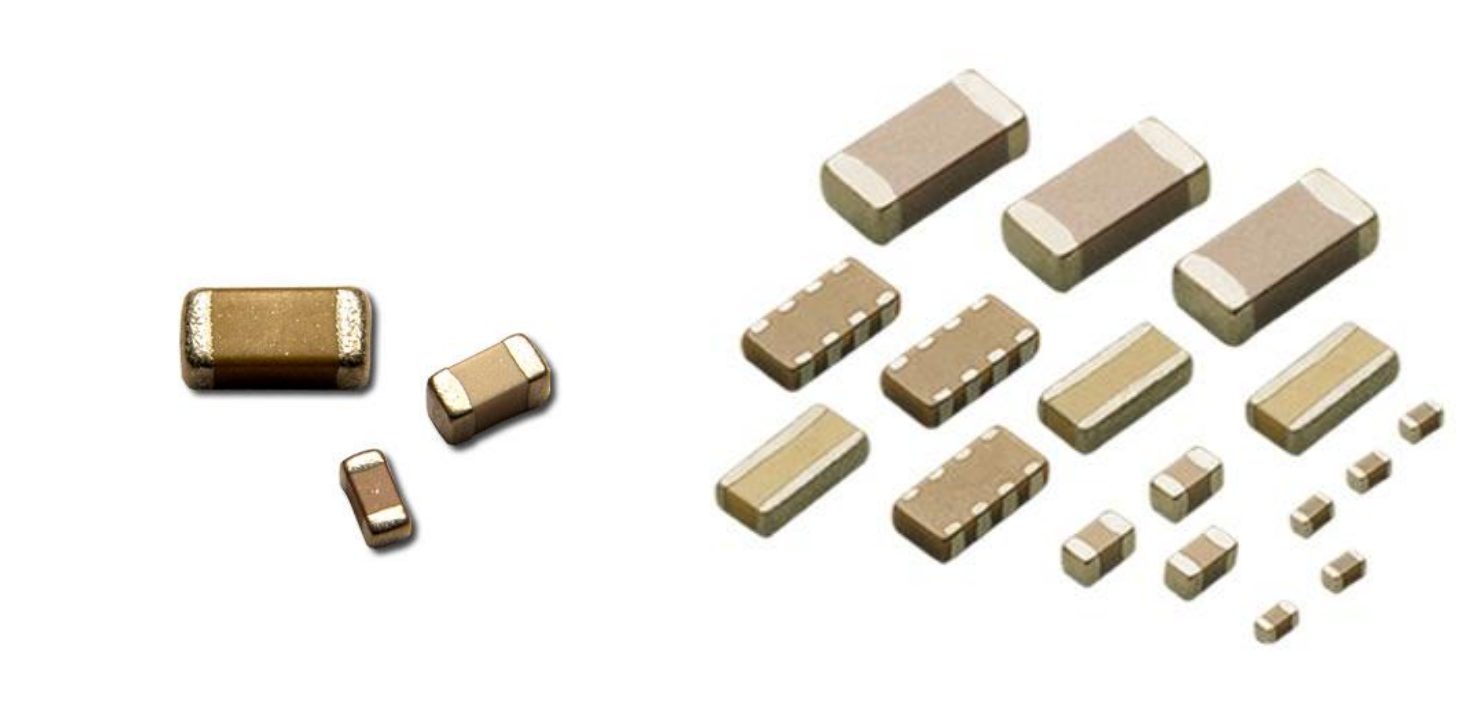

$\mathbf{a}$

b

Obr. 7.20: Kapacitory SMD: a) jednovrstvé, b) vícevrstvé, vícevrstvé s potlačenou indukčností a kapacitorová pole

Podle konstrukce se keramické či polymerové kapacitory dělí na jednovrstvé (Single Layer Capacitor) a vícevrstvé (MLCC = Multilayer Ceramic Capacitor). Jednovrstvé kapacitory SMD sestávají pouze ze dvou elektrod, mezi kterými je dielektrikum. Díky velmi nízké parazitní sériové indukčnosti a malému sériovému odporu nacházejí zejména použití ve vysokofrekvenčních a mikrovlnných obvodech pracujících řádově na gigahertzových kmitočtech. Vnější vzhled jednovrstvých kapacitorů SMD je zřejmý Obr. 7.20a). Vícevrstvé 
kapacitory umožňují při relativně malých rozměrech realizovat velké hodnoty kapacit, jejich vysokofrekvenční vlastnosti jsou však horší. Vyrábějí se i vícevrtsvé kapacitory SMD s potlačenou indukčností (na Obr. 7.20ß pouzdra s vývody na delší straně pouzdra) a kapacitorová pole (na Obr. 7.20b pouzdra s více vývody). Nejběžnější jsou vícevrstvé kapacitory MLCC, jejichž vnitřní konstrukce v SMD provedení je naznačena na Obr. 7.21.

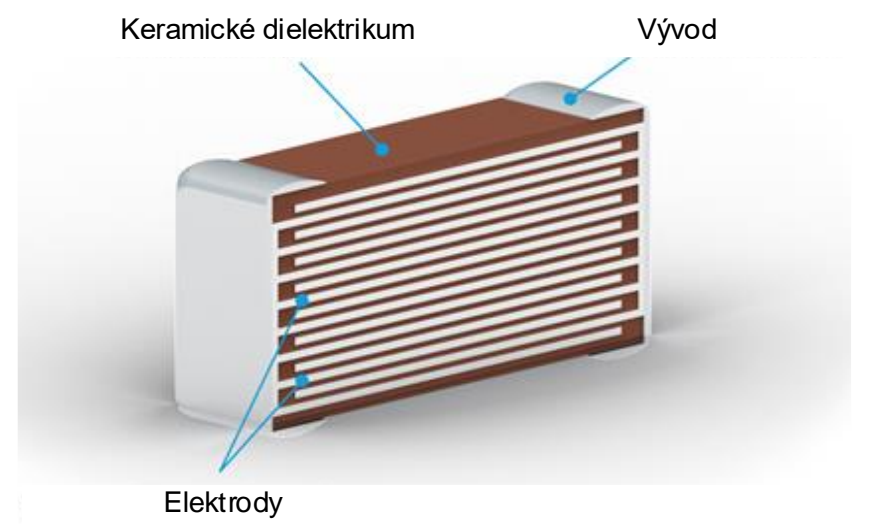

Obr. 7.21: Konstrukce vícevrstvého keramického SMD kapacitoru MLCC

Průchodkové kapacitory (Feedthrough Capacitors) jsou zvláštním druhem kapacitorů a používají se zejména $\mathrm{k}$ blokování signálových či napájecích přívodů vysokofrekvenčních zařízení, která jsou uzavřena ve stínicím kovovém krytu. Průchodkové kapacitory (viz Obr. 7.23 ) jsou v podstatě trubičkové kapacitory s vnitřní (průchozí) a vnější (zemní) elektrodou. Vnitřní elektroda je realizována průchozím drátem, jehož jeden konec se spojí s př́vodem budicího obvodu (zdroj signálu, napájecí zdroj) a druhý konec se připojí k obvodu uvnitř stínicího krytu. Vnější elektroda se spojí s uzemněnou kovovou stínící přepážkou.

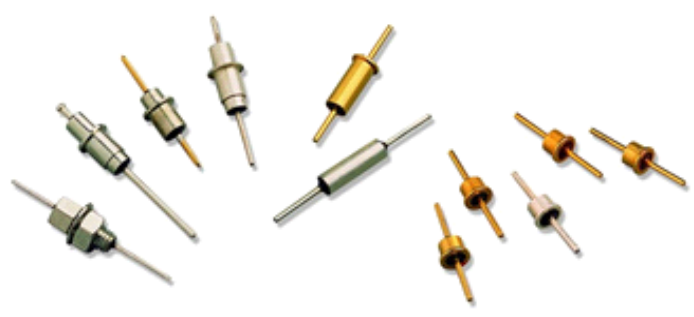

$\mathbf{a}$

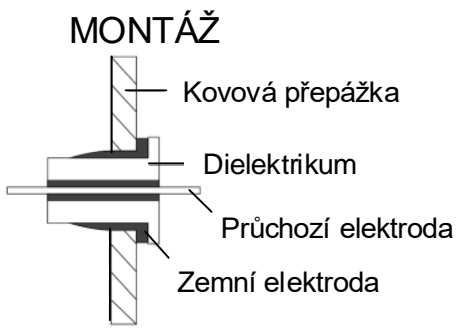

b

Obr. 7.22: a) Průchodkové kapacitory, b) montáž průchodkového kapacitoru do kovové přepážky

Tyto kapacitory se jako vývodové vyrábějí ve dvojím provedení: bud' je vnější elektroda opatřena kovovou armaturou se závitem k upevnění maticí na kovovou stínicí přepážku, nebo je vnější elektroda bez armatury a př́mo se zapájí nízkotavnou pájkou (teplota pájení $\leq 170^{\circ} \mathrm{C}$ ) do otvoru v kovové přepážce, kterou kapacitor prochází. Průchodkové kapacitory určené pro napájecí přívody mají větší průměr průchozího vodiče. Pro výkonové napájecí zdroje existují speciální typy pro proudy 16 A a více. 
Třivývodové kapacitory (3-terminal Capacitors) jsou SMD vícevrstvé MLCC kapacitory se dvěma průchozími elektrodami a se dvěma stínicími uzemněnými elektrodami (viz Obr. 7.23b). Používají se k velmi účinnému potlačení rušení, protože na vysokých kmitočtech vykazují impedanci daleko nižší než běžné dvouvývodové kapacitory. Tř́vývodový kapacitor se pro potlačení rušení v nejjednodušším případě použije tak, že se průchozími elektrodami vloží do přívodního vodiče a zemní elektrody se spojí se zemí. Aby se na vysokých kmitočtech nezhoršily jejich vlastnosti parazitní indukčností plošných vodičů, doporučuje se propojení zemnicích elektrod s vnitřní zemnicí vrstvou DPS větším počtem prokovených otvorů ( $\varnothing$ max $0,3 \mathrm{~mm}$ ) co nejblíže ke kapacitoru. Lepších výsledků se dosáhne však v př́ipadech, kdy tř́vyývodový kapacitor se použije v LC filtru ve spojení s feritovou perlou. Typy s maximálním proudem 50 až $100 \mathrm{~mA}$ jsou určeny pro signálové spoje, do napájecích př́vodů jsou k dispozici typy pro proudy až $5 \mathrm{~A}$.

\section{MONTÁŽ NA DPS}
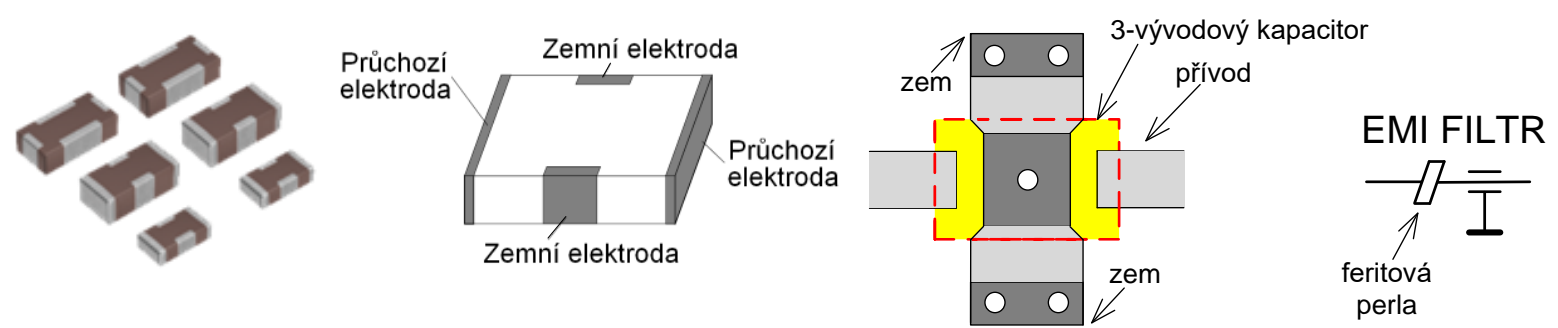

O prokovené otvory ø max $0,3 \mathrm{~mm}$

$\mathbf{a}$

b

c

d

Obr. 7.23: a) Třívývodový kapacitor SMD, b) zapojení elektrod, c) doporučený plošný spoj,

d) př́iklad zapojení v odrušovacím filtru

Kapacitory fóliové jsou dalšími často používanými kapacitory (někdy označované jako svitkové). Dielektrikum těchto kapacitorů je nejčastěji z plastů (polyester, polypropylen, polystyren, polyetylentereftalát, polykarbonát) nebo u nejlevnějších typů papírové (napuštěné impregnační látkou). Elektrody jsou tvořeny hliníkovou fólií s vývody. Někdy jsou hliníkové elektrody nahrazeny pokovením dielektrické fólie. Takový typ je označován jako kapacitor metalizovaný (MP).

Podle typů dielektrika a provedení lze fóliové kapacitory dělit do několika skupin označovaných zkratkami:

- FKS, KT - polyesterová fólie,

- MKS, MKT - polyesterová fólie, metalizovaný,

- FKP, KP - polypropylenová fólie,

- MKP - polypropylenová fólie, metalizovaný,

- MKC - polykarbonátová fólie, metalizovaný,

- KS - polystyrenová fólie.

Dielektrikum včetně elektrod je obvykle svinuto do válce nebo elipsoidu. Svinutí do elipsoidu se užívá u miniaturních a SMD provedení. Průřez svitkovým kapacitorem s radiálními vývody ukazuje Obr. 7.24. 


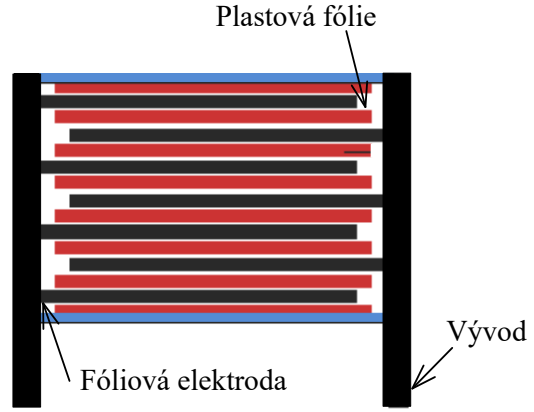

a

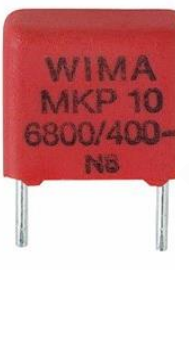

b
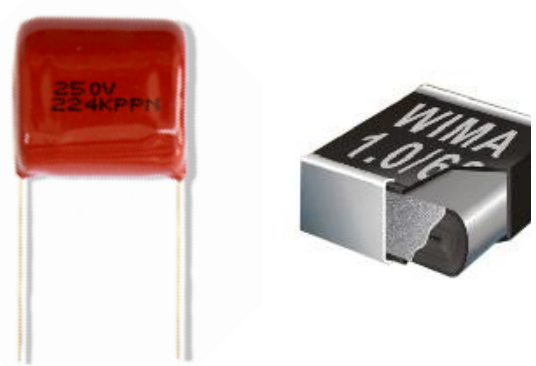

c d

Obr. 7.24: Fóliové svitkové kapacitory: a) vnitřní provedení) b) radiální zalisovaný v plastovém hranatém pouzdře, b) radiální zalitý v epoxidové pryskyřici, c) SMD fóliový kapacitor

Fóliové kapacitory jsou $\mathrm{k}$ dispozici v hodnotách kapacit od asi $5 \mathrm{pF}$ do $100 \mu \mathrm{F} v$ závislosti na provedení a maximálním napětí. Jsou vyráběny $\mathrm{v}$ různých provedeních a pouzdrech, viz např. Obr. 7.25. Aby do svitku nevnikala vlhkost, je bud' zalit epoxidovou pryskyřicí, nebo zalisován do plastické hmoty, takže svitek je neprodyšně uzavřen a je odolný vůči klimatickým vlivům.

Některé typy fóliových kapacitorů se vyrábějí s potlačenou indukčností. Alespoň jedna kovová fólie je u nich širší a vyčnívá po celé délce ze svitku; její závity se nakonec spojí nakrátko pájením. Zkratovaná fólie bývá ve vrchní vrstvě a působí tak jako elektrické stínění kapacitorů. Její vývod bývá bud' delší, nebo je na kapacitoru označen proužkem, natištěným po obvodu obalu svitku vlevo od nátisku typu a hodnoty kapacitoru. Tento vývod se má připojovat na nulový potenciál (kostru), popř. do bodu s nejmenším odporem proti zemi.

Kapacitory s foliemi z plastických hmot jsou kvalitnější než s papírovým dielektrikem. Kapacitory s polystyrenovou fólií mají teplotní součinitel kapacity záporný, kapacitory s polyesterovou fólií kladný, což umožňuje $\mathrm{v}$ nutných př́padech volit vhodnou kombinaci $\mathrm{k}$ dosažení určité nebo malé teplotní závislosti. Pro kapacity větší než $100 \mathrm{nF}$ jsou svitkové kapacitory značně rozměrné. Menší rozměry mají kapacitory s pokovenou dielektrickou fólií. Tyto tzv. kapacitory s metalizovanou fólií mají obvykle regenerační schopnost, tzn. jednotlivý krátkodobý průraz nevede ke zničení kapacitoru. Užití kapacitorů s metalizovanou fólií $\mathrm{v}$ obvodech s malým šumem je nutno pečlivě zvážit, protože mikroprůrazy na nedokonalostech použité fólie mohou způsobit zvětšený šum kapacitorů.

Kapacitory elektrolytické jsou zcela odlišné od dosud popisovaných kapacitorů jak složením a výrobní technologií, tak i použitím. Nejčastěji se používají levnější hliníkové, pro náročnější účely také tantalové kapacitory, které se vyznačují malou parazitní indukčností. Oba druhy jsou polarizované, tj. mají na rozdíl od jiných druhů kapacitorů kladný a záporný pól. Elektrolytické kapacitory se proto používají jen $\mathrm{v}$ obvodech, kde je na ně připojeno stejnosměrné polarizační napětí, např. $\mathrm{v}$ sít'ových zdrojích pro filtraci stejnosměrné složky z usměrněného střídavého napětí, k blokování napájení, nebo v nf technice jako oddělovací. Musí být vždy správně pólovány (vývod označený + se připojuje na vyšší potenciál), jinak hrozí nebezpečí exploze kapacitorů. Jestliže na kapacitoru není vyznačena polarita, je záporný pól na vnějším krytu a vývod, který se připojuje na kladný pól, prochází izolační průchodkou. Pro 
střídavé napětí se elektrolytické kapacitory sice nehodí, ale stejnosměrné napětí může mít přidánu určitou střídavou složku.

Pro vysoké kmitočty vykazuje elektrolytický kapacitor ve srovnání s keramickým velkou impedanci (viz Obr. 7.12), takže do vysokofrekvenčních obvodů elektrolytické kapacitory nejsou vůbec vhodné. Je to způsobeno vlivem parazitních parametrů $L_{\mathrm{S}}$ a $R_{\mathrm{S}}$ (viz vztah (7.6)). $\mathrm{V}$ důsledku toho nebude modul impedance kapacitorů nikdy menší než jednotky nebo desetiny ohmu. Proto se obvykle ve filtračních obvodech přidává paralelně k elektrolytickému ještě kapacitor keramický nebo svitkový s menší kapacitou. Při nevhodné kombinaci se však může stát, že př́idavný kapacitor vytvoří s indukčností elektrolytického kapacitoru paralelní rezonanční obvod a modul impedance blokovacího obvodu pro rezonanční kmitočet tohoto obvodu se zvětší. Př́iklady různých typů elektrolytických kapacitorů jsou uvedeny na Obr. 7.25.

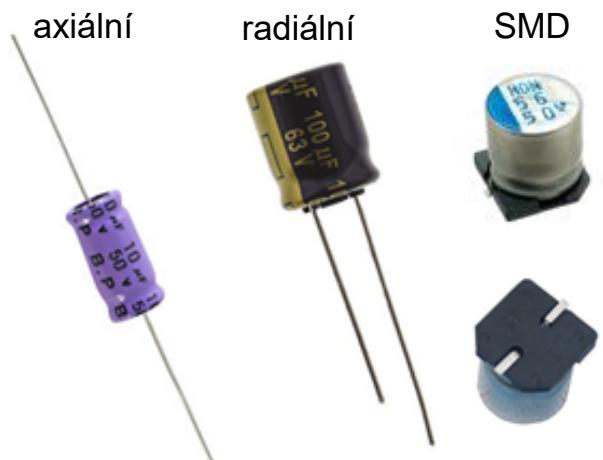

HLINÍKOVÝ

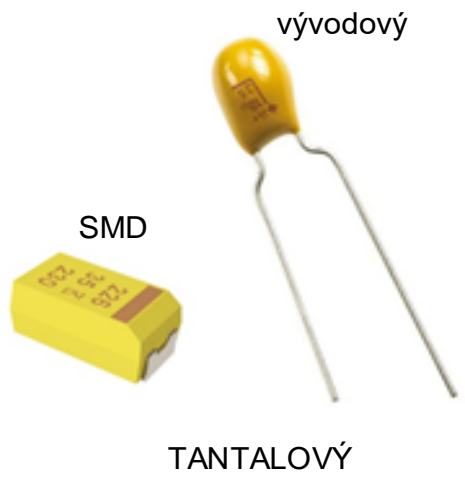

b

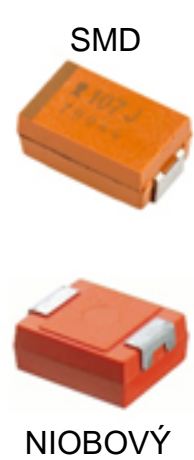

C

Obr. 7.25: Elektrolytické kondenzátory: a) hliníkové, b) tantalové, c) niobové

Použití vodivého elektrolytu způsobuje značné zvětšení ztrátového činitele a trvalý průchod tzv. zbytkového stejnosměrného proudu (DC Leakage Current), který protéká elektrolytickým kapacitorem i při delším připojení na stejnosměrné napětí. Hodnotu zbytkového proudu lze považovat za měřítko kvality kapacitoru. V okamžiku připojení kapacitorů na napětí a zejména po delším beznapět'ovém skladování je zbytkový proud velký (až stonásobek hodnoty při trvalém provozu), ale již po několika minutách provozu klesne na předepsanou nebo nižší hodnotu (viz Obr. 7.26a).

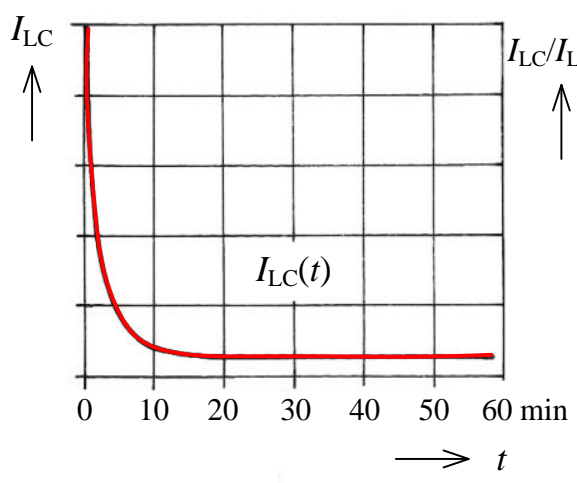

$\mathbf{a}$

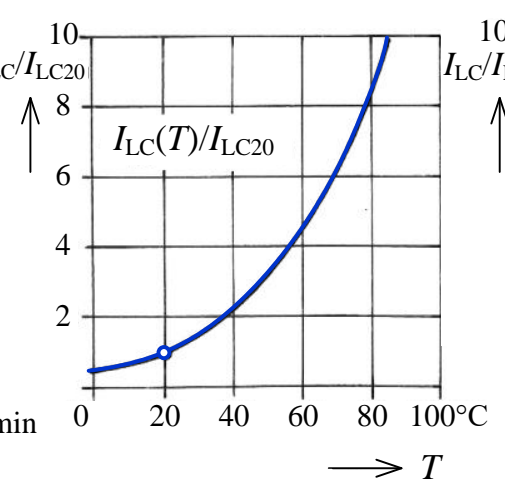

b

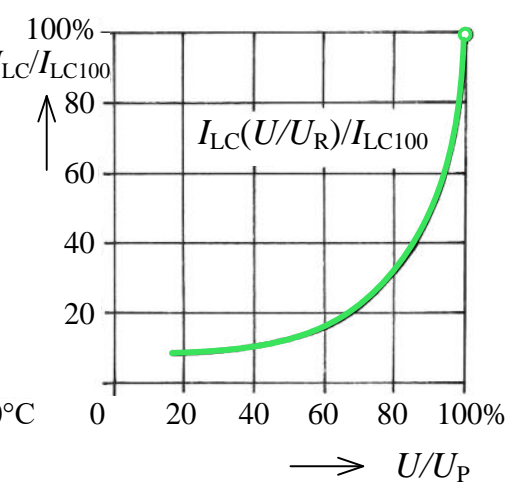

c

Obr. 7.26: Zbytkový proud elektrolytického kapacitoru: a) časová závislost, b) teplotní závislost, c) napět’ová závislost 
Kapacitory, které byly skladovány déle než 30 dnů bez napětí, mají být před montáží polarizovány (formovány) přiložením stejnosměrného napětí přes sériový rezistor s odporem cca $100 \Omega$ u kapacitorů se jmenovitým napětím $U_{\mathrm{R}}<100 \mathrm{~V}$, popřr. přes rezistor s odporem cca $1,5 \mathrm{k} \Omega$ u kapacitorů s $U_{\mathrm{R}}>100 \mathrm{~V}$, a to po dobu 1 hod. Zbytkový proud má taktéž velkou teplotní závislost, která je nejlépe patrna z grafu na Obr. 7.26b. V rozsahu pracovních teplot se zbytkový proud může změnit až o řád. Provozování kapacitorů při nižší teplotě, než je nejvyšší povolená teplota, příznivě působí i na prodloužení životnosti kapacitoru. Při každém snížení teploty o $7^{\circ} \mathrm{C}$ až $10^{\circ} \mathrm{C}$ lze počítat s prodloužením životnosti přibližně na dvojnásobek. Snížíme-li např. pracovní teplotu $\mathrm{z} 85^{\circ} \mathrm{C}$, při které je udána trvanlivost 2000 hod. na $43^{\circ} \mathrm{C}$, bude pravděpodobná očekávaná životnost 128000 hod. Volbou kapacitoru s několikanásobně větším jmenovitým napětím $U_{\mathrm{R}}$, než je provozní napětí $U$, dosáhneme podstatného zmenšení zbytkového proudu (viz Obr. 7.26థ). Např. je-li provozní napětí 40 \% ze jmenovitého, zmenší se zbytkový proud na $10 \%$. Bohužel toto zmenšení zbytkového proudu resp. volba vyššího jmenovitého napětí než by bylo nutné, je na úkor větších rozměrů kapacitoru. Se zbytkovým proudem musíme počítat tam, kde elektrolytický kapacitor není přemostěn rezistorem o malém odporu. Neuplatní se tedy u blokovacích a filtračních obvodů. Významnou roli může však hrát u vazebních kapacitorů, kdy může způsobit změnu nastavení pracovního bodu v následujícím stupni.

Pro výběr filtračních kapacitorů do impulsně regulovaných napájecích zdrojů je nejdůležitějším parametrem maximální zvlnění zatěžovacího proudu (Ripple Current). Při impulsním zatěžování proudovým odběrem totiž dochází k ohřevu kondenzátoru způsobených výkonovou ztrátou na parazitním sériovém odporu (ESR), resp. na vyšších kmitočtech i na parazitní sériové impedanci (ESL). Výrobci proto uvádějí efektivní hodnoty (R.M.S.) takovéhoto proudu, které způsobí oteplení kapacitoru např. o $85^{\circ} \mathrm{C}$ při kmitočtu $100 \mathrm{~Hz}, 10 \mathrm{kHz}$ popř. i $100 \mathrm{kHz}$.

Elektrolytické kapacitory dodávají výrobci v několika typových řadách. Kromě základní řady jsou $v$ obvykle v nabídce i typy s menšími rozměry či pro zvýšené požadavky, např. vyšší teplotní rozsah. Většina dnešních typů elektrolytických kapacitorů jsou tzv. suché kapacitory s kašovitým elektrolytem mezi hliníkovými fóliemi. Svitek je vložen do utěsněného pouzdra z hliníkového plechu nebo plastu. Póly elektrod jsou vyvedeny pocínovanými měděnými dráty nebo pásky. U kovových druhů bývá záporný pól spojen s pouzdrem. Proto se tyto elektrolytické kapacitory dodávají také s izolačním povlakem z PVC nebo jsou zalisovány do plastu. Vyrábějí se také vícenásobné kapacitory, obsahující dva až tři oddělené kondenzátory ve společném pouzdře. Vývody (pájecí špičky) mají normalizovanou rozteč pro zapájení do plošných spojů.

Nevýhody hliníkových elektrolytických kapacitorů, tj. poměrně malý rozsah pracovních teplot a malá časová stálost, jsou $\mathrm{z}$ větší části odstraněny u tantalových popř. u niobových kapacitorů. Jejich největší výhodou pak je, že vykazují jen velmi malou parazitní indukčnost a jsou tedy vhodným blokovacím prostředkem k omezení rozkmitání obvodů přes napájecí zdroje nebo pro potlačení špiček v napájecím rozvodu. Rozeznáváme tantalové kapacitory s tekutým a tuhým elektrolytem. Tantalové elektrolytické kapacitory mají obecně menší rozsah provozních napětí než kapacitory hliníkové. Tantalové kapacitory s pevným i s kapalným elektrolytem se vyrábějí do 35 a $50 \mathrm{~V}$.

V současnosti jsou k dispozici SMD tantalové a tantalové polymerové nebo niobové kapacitory. Kapacitor je označen svojí hodnotou kapacity většinou v $\mu \mathrm{F}$ a jmenovitým napětím ve V. Dovolená odchylka jmenovité kapacity bývá obvykle $\pm 20 \%$.

Předností tantalových a niobových kapacitorů jsou velmi malé rozměry, velký rozsah pracovních teplot, malý zbytkový proud, dobré kmitočtové vlastnosti, výhodné teplotní závislosti kapacity, ztrátového činitele, impedance a zbytkového proudu. Některé typy 
tantalových kapacitorů však trpí vysycháním elektrolytu spojené se ztrátou funkčnosti. Proto se všude, kde to je možné, raději nahrazují vícevrstvými kapacitory nebo niobovými.

\section{Výběr kapacitoru podle uvažované aplikace}

Výběr kondenzátoru (elektrolytický, tantalový, keramický, fóliový aj.) se vždy řídí dle konkrétní aplikace:

Časovaci kapacitory (Timming Capacitors) určují kmitočet nebo dobu překlopení časovacích obvodů, jako jsou astabilní či monostabilní multivibrátory, kmitavé okruhy, vf laděné obvody, analogové generátory trojúhelníkových kmitů, nebo převodníky napětí na kmitočet. Do této kategorie patří i kapacitory, které určují časové konstanty nejrůznějších pasivních či aktivních filtrů a to jak nízkofrekvenčních, tak i vysokofrekvenčních. Je zřejmé, že změna kapacity může $\mathrm{v}$ těchto př́padech způsobit rozladění obvodu, prodloužení časového impulsu časovače, nebo u filtrů může dojít ke změnám průběhu kmitočtové charakteristiky a nebo k prodloužení odezvy filtru na skokové změny. Časovací kapacitory se proto musí volit přesné a stabilní kapacitory tř́́dy 1 . Nejlepší jsou s polystyrenovým dielektrikem, následované polykarbonátovým a polyesterovým dielektrikem. Pro malé hodnoty kapacity se použijí keramické kapacitory s nulovým teplotním součinitelem (COG/NPO apod.).

Pamětové kapacitory (Hold Capacitors) se používají ve vzorkovačích či sledovačích s pamětí (S/H, T/H circuits). Pro tyto aplikace je nutno vybrat kapacitory s velkým izolačním odporem a malou dielektrickou absorbcí, jinak může docházet ke změně zapamatované hodnoty napětí. Kapacitory s malou dielektrickou absorbcí je nutno také použít pro analogvé filtry ve fázových závěsech, kdy součástí zpětnovazební smyčky závěsu je filtr smyčky zařazený za kmitočtově fázový detektor. Nesprávná volba typu kapacitoru může nevyhovujícím způsobem ovlivnit dobu ustalování fázového závěsu a tím i celého generátoru. $Z$ hlediska dielektrické absorbce je nejlepším materiálem pro diektrikum polystyren a polypropylen s hodnotou $0,02 \%$. Stejné vlastnosti vykazuje i teflon, který má navíc dobré teplotní vlastnosti. Za ještě vyhovující se pro méně náročné aplikace považuje polyesterové dielektrikum s hodnotou $0,2 \%$.

Vazebni kapacitory (Coupling Capacitors) se používají v nízkofrekvenčních i vysokofrekvenčních obvodech. V nízkofrekvenčních obvodech se používají primárně pro oddělení ss složky od stř́davé složky signálu. $Z$ tohoto důvodu bývají někdy také označovány jako oddělovaci kondenzátory. V nízkofrekvenčních obvodech (viz Obr. 7.27ł) vazební kapacitor tvoří společně se vstupním odporem následujícího stupně horní propust 1 . řádu s mezním kmitočtem $f_{\mathrm{m}}=1 / 2 \pi C_{\mathrm{V}} R_{\mathrm{i}}$. Při mezním kmitočtu $f_{\mathrm{m}}$ dojde k poklesu zisku o $3 \mathrm{~dB}$, resp. k poklesu zesílení na hodnotu 0,707 , ale při tomto kmitočtu již dojde $\mathrm{k}$ natočení fáze signálu o $45^{\circ}$. To by mohlo mít vliv na vlastnosti přenášeného signálu, a proto se $f_{\mathrm{m}}$ volí 5 až $15 \mathrm{krát}$ nižší než je nejnižší kmitočet přenášeného signálu. Přesnost či stabilita takového kapacitoru není tedy kritická. V nf obvodech vazební kapacitor mívá kapacitu řádově desítky až stovky mikrofaradů a proto se obvykle volí vícevrstvé nebo elektrolytické kondenzátory. Musíme však volit kapacitor s malým zbytkovým proudem, protože jinak by mohlo dojít k posunutí pracovního bodu následujícího stupně. 


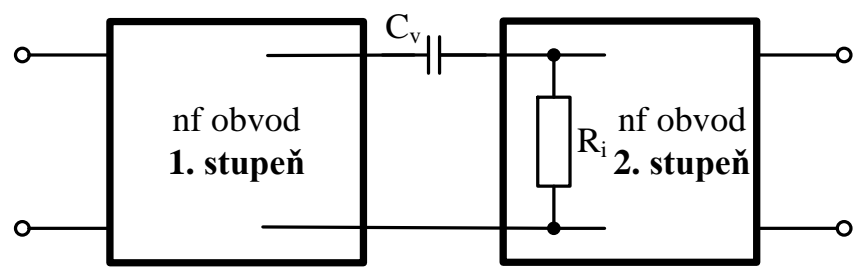

$\mathbf{a}$

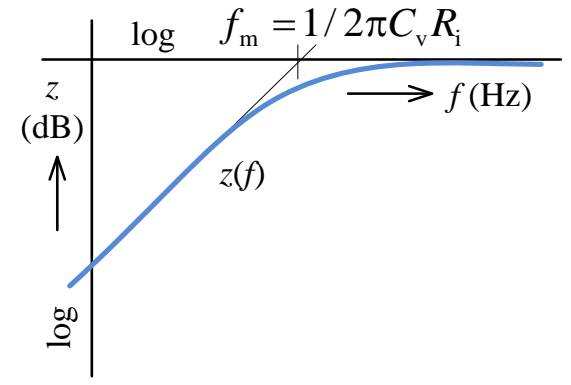

b

Obr. 7.27: Vazební kapacitor v nf obvodech

Filtrační kapacitory (Filtering Capacitors) v klasických napájecích zdrojích zajišt'ují dvě funkce. Primárně jsou určeny k vyhlazení dvoucestně usměrněného napětí. Proto někdy tento kapacitor bývá označován jako vyhlazovaci kondenzátor. Zároveň ale slouží jako okamžitý zdroj energie pro pokrytí proudových špičkových odběrů vyvolaných činností připojeného zařízení. S výjimkou malých napájecích zdrojů do výkonu cca $20 \mathrm{~W}$ jsou do výkonnějších zdrojů zcela nevhodné radiální a axiální kondenzátory s drátovými vývody. Přestože mohou mít pro tento účel vhodnou kapacitu i provozní napětí, nejsou dimenzovány pro větší nabíjecí a vybíjecí proudy. Při jejich použití ve spojení s výkonným transformátorem a usměrňovačem dojde velmi brzy $\mathrm{k}$ poškození tenkých vnitřních př́vodů ke svitku a úplné ztrátě kapacity. Vyhovující jsou radiální kondenzátory s vývody typu snap-in Obr. 7.28ł). Pro napájecí zdroje velkých výkonů jsou pak nejlepší elektrolytické kondenzátory se šroubovými vývody Obr. 7.28b) určené přímo pro výkonové zdroje či zdroje spínané, frekvenční měniče a další průmyslová použití. Jsou konstruovány na velké nabíjecí i vybíjecí proudy, vnitřní př́vody i celková konstrukce je daleko robustnější a kvalitnější, než u kondenzátorů pro spotřební elektroniku. Jejich životnost je při teplotách kolem $50^{\circ} \mathrm{C}$ několik desítek tisíc hodin, aniž by se projevovala nárůst svodového proudu, vnitřního odporu či pokles kapacity. Jistou nevýhodou, ovšem vyváženou vynikajícími vlastnostmi, mohou být nepoměrně větší rozměry těchto kondenzátorů oproti standardním. To je ovšem dáno jejich robustní vnitřní konstrukcí.

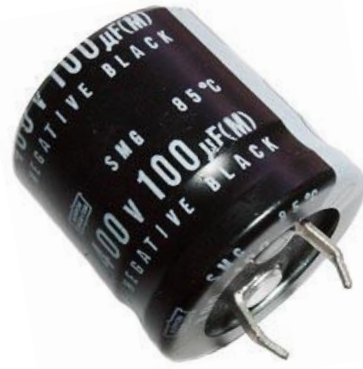

$\mathbf{a}$

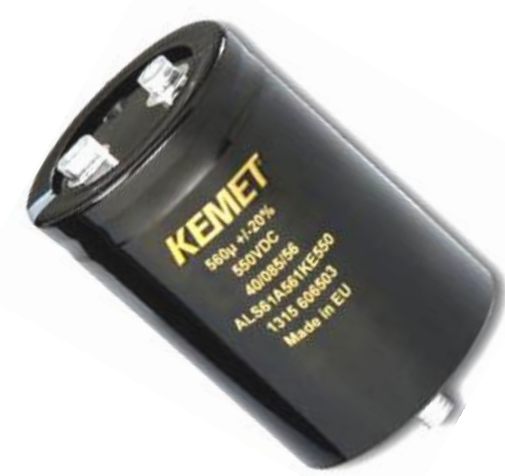

b

Obr. 7.28: Filtrační elektrolytické kondenzátory pro napájecí zdroje: a) s vývody snap-in, b) se šroubovacími vývody 
Filtračni kapacitory pro impulsní či spínané napájecí zdroje se používají na pozici výstupního kondenzátoru zdroje. Zde má jejich výběr zcela zásadní význam, protože ze spínaného výstupního průběhu musí vytvořit napětí konstantní. Většinou je tento kapacitor součástí výstupního LC filtru impulsně řízeného zdroje. Filtrační kapacitor se vybírá podle těchto dvou hlavních parametrů: 1) musí vykazovat malý parazitní sériový odpor $(E S R)$ a malou parazitní indukčnost $(E S L), 2)$ musí mít povolenu velkou hodnotu maximálního zvlnění proudu (Ripple Current). Jinak se bude kapacitor přehřívat. Pokud není možné požadované vlastnosti realizovat jediným vhodně vybraným kapacitorem zapojí se několik kapacitorů paralelně. Používají se elektrolytické kondenzátory s potlačenou indukčností nebo polymerové elektrolytické kondenzátory.

Blokovaci kapacitory (Bypass Capacitors) se umíst'ují na DPS hned u vstupního konektoru napájecího napětí (viz Obr. 7.29). Tím se eliminuje parazitní odpor a indukčnost př́vodního napájecího vedení. V prŕípadě rychlé změny proudového odběru slouží jako zdroje energie, který je schopen krátkodobě takovýto proud dodat. Jinak by mohlo dojít k úbytku napětí na napájecích rozvodech vyvolaném průtokem proudu parazitním odporem přívodního napájecího vedení a k ovlivnění napájení sousedních DPS. Současně slouží k odstranění části rušivých složek v napájecím rozvodu (zvlnění, šum, rušení). V př́padě analogové části napájené z impulsně regulovaného zdroje bývá tento kapacitor součástí filtru LC anebo místo induktoru se použije feritová perla (Ferrite Bead), viz Obr. 7.30. Úkolem tohoto filtru je potlačit pronikání jehlových špiček se základním kmitočtem $20 \mathrm{kHz}$ až $200 \mathrm{kHz}$ z impulsně regulovaného zdroje. $\mathrm{V}$ př́padě napájení analogové desky z klasických zdrojů lze tlumivku či feritovou perlu vypustit. Pro zlepšení impedančních vlastností se používá často kombinace elektrolytického a vícevrstvého keramického kapacitoru. Obvykle se volí tantalové nebo vícevrstvé kondenzátory $100 \mu \mathrm{F}$ a doplňují se vf kapacitorem $100 \mathrm{nF}$. Při menších proudových odběrech desky se elektrolytický kapacitor vypouští a blokování desky se realizuje pomocí vícevrstvého keramického kapacitoru. Často se po ploše DPS rozmístí rovnoměrně i další keramické vícevrstvé blokovací kapacitory jako lokální zásobníky energie.

Skupinové blokovací kapacitory (Bulk Capacitors) slouží jako lokální zdroj, jehož úkolem je zásobovat menší blokovací kapacitory např. u součástek, které mají napájecí napětí přivedeno a zablokováno na více pinech, jako jsou napřr. mikrokontroléry či hradlová pole (viz Obr. 7.30). Jako skupinový kapacitor se obvykle užívá tantalový, niobový nebo vícevrstvý keramický kapacitor SMD.

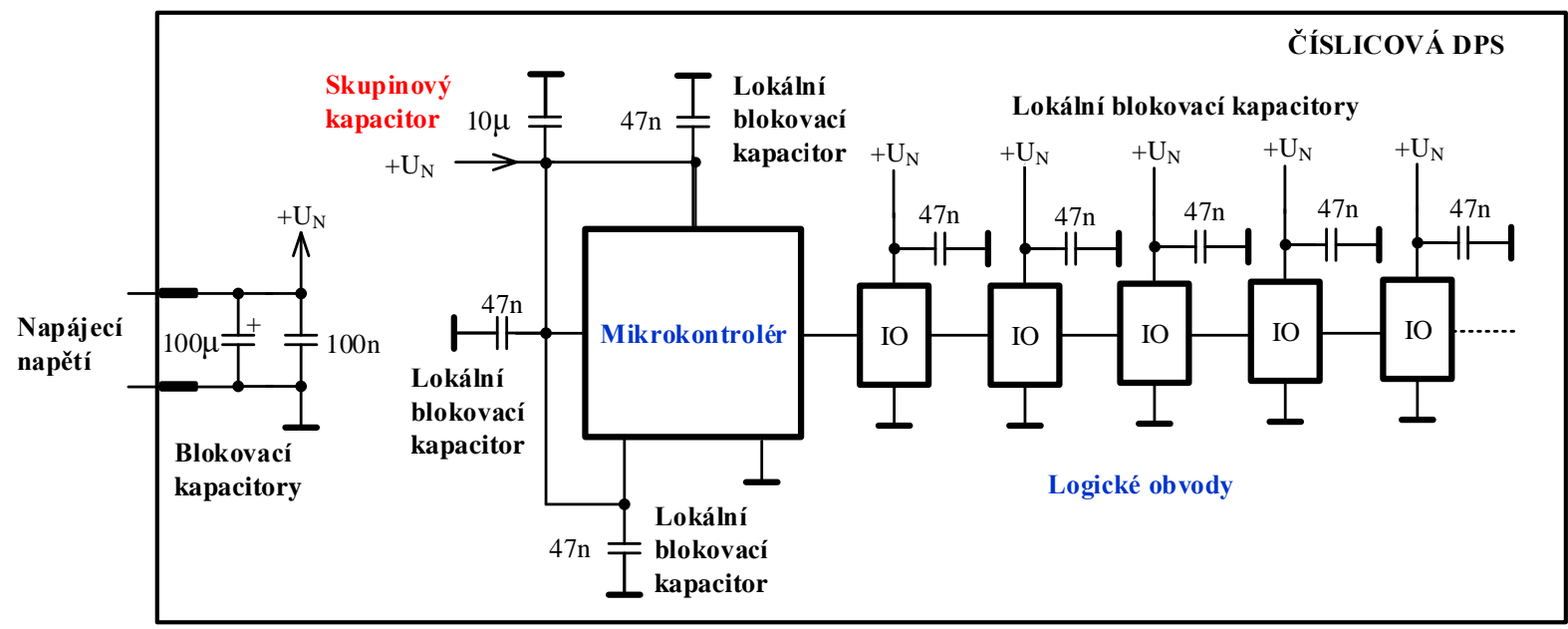

Obr. 7.29: Rozmístění filtračních a blokovacích kapacitorů na desce plošných spojů osazené číslicovými obvody 


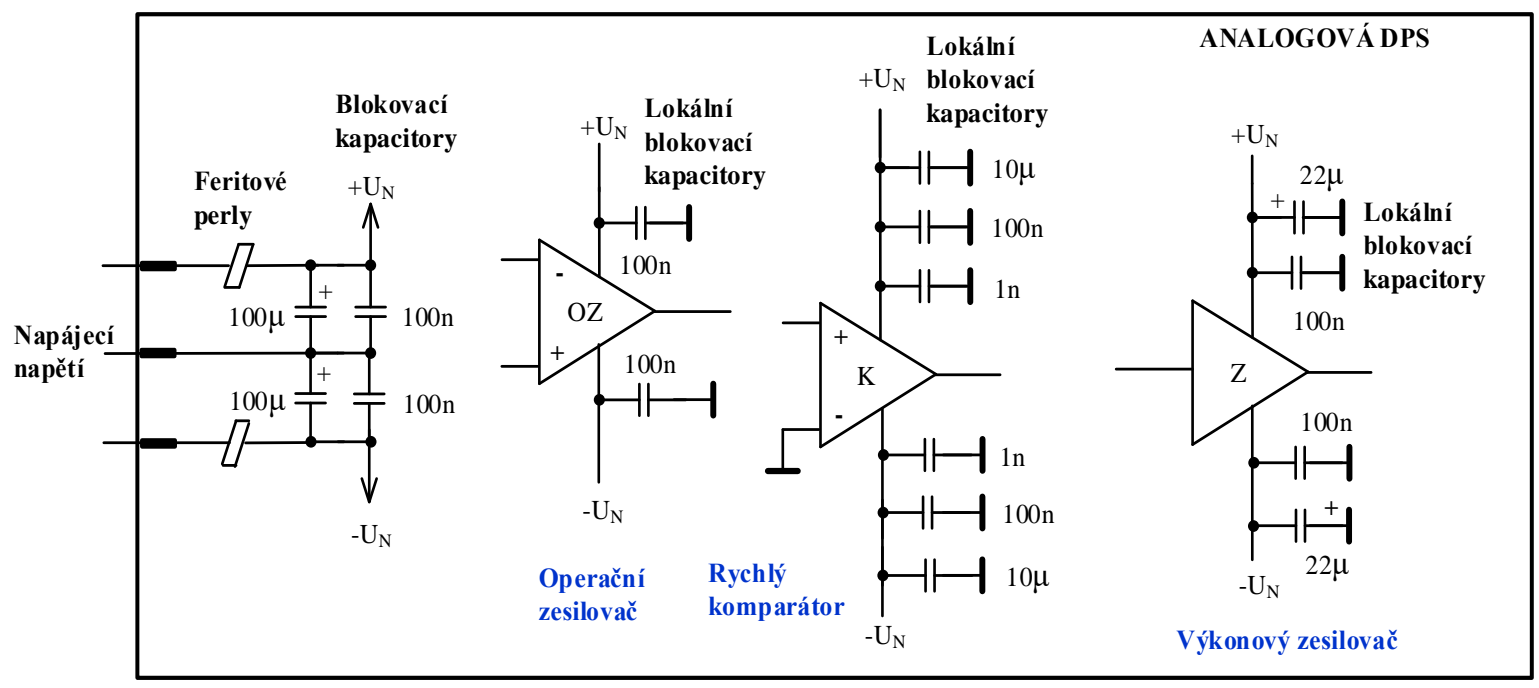

Obr. 7.30: Rozmístění filtračních a blokovacích kapacitorů na DPS osazené analogovými obvody

Lokální blokovaci kapacitory (Decoupling Capacitors) se pak zapojují co nejblíže napájecím vývodům číslicových obvodů Obr. 7.29]. U složitějších obvodů jako jsou mikrokontroléry či hradlová pole se těchto blokovacích kapacitorů zapojuje podle doporučení výrobců hned několik. Tím se zabrání šíření proudových impulsů, způsobených činností logických obvodů nežádoucími cestami po napájecích vodičích. V okamžiku proudových špiček je proud dodáván těmito kapacitory. Ze stejného důvodu se v případě rychlých logických obvodů doporučuje zablokovat každý integrovaný obvod keramickým kapacitorem 10 až $47 \mathrm{nF}$ co nejblíže u pouzdra. Zde jsou kapacitory zejména zapotřebí pro potlačení proudových špiček, které vznikají při nabíjení parazitních kapacit vedení připojených $\mathrm{k}$ výstupům integrovaných obvodů. Jako lokální blokovací kondenzátory je vhodné použít SMD keramické vysokofrekvenční kapacitory z důvodu velmi malých parazitních indukčností a schopnosti blokovat kmitočty vyšší než $10 \mathrm{MHz}$.

U analogových integrovaných obvodů, jako jsou např. operační zesilovače, lokální blokovací kapacitory slouží k oddělení jednotlivých zesilovačů navzájem tak, aby nedošlo k rozkmitání zesilovačů $\mathrm{v}$ důsledku zpětných vazeb přes parazitní indukčností napájecích přívodů (viz Obr. 7.30. K blokování stačí v tomto případě běžné keramické kondenzátory 100 až $150 \mathrm{nF}$.

U rychlého analogového komparátoru je však situace náročnější, protože při překlopení komparátoru doje ke značné velké a značně rychlé změně v odběru proudu z napájecího rozvodu. Pro blokování je zapotřebí v tomto případě na místě lokálního blokovacího kapacitoru využít více než jeden kapacitor. Tím lze zajistit nízkou impedanci na požadovaném frekvenčním rozsahu vůči zemi na blokovaných napájecích pinech. Blokovací kondenzátory se v tomto př́ipadě zapojují paralelně (viz komparátor na Obr. 7.30). Pro rychlé komparátory se doporučují kapacitory s kapacitou $10 \mathrm{nF}, 100 \mathrm{nF}$ a $1 \mu \mathrm{F}$. Př́i výběru vhodného blokovacího kondenzátoru je nutné brát ohled na kapacitu a výběr pouzdra každého z nich. Pokud by bylo použito více blokovacích kondenzátorů $\mathrm{v}$ pouzdře stejných rozměrů, nedojde $\mathrm{k}$ žádnému zlepšení na blokovaném napájecím pinu, protože impedanční křivky jednotlivých kondenzátorů se budou překrývat tak, jako je to vidět na Obr. 7.31, kde jsou zobrazeny závislosti impedance na frekvenci pro blokovací kondenzátory v pouzdře 0805 s různými kapacitami. Výsledná impedanční charakteristika je shodná s charakteristikou jediného kondenzátoru (na obrázku jde 


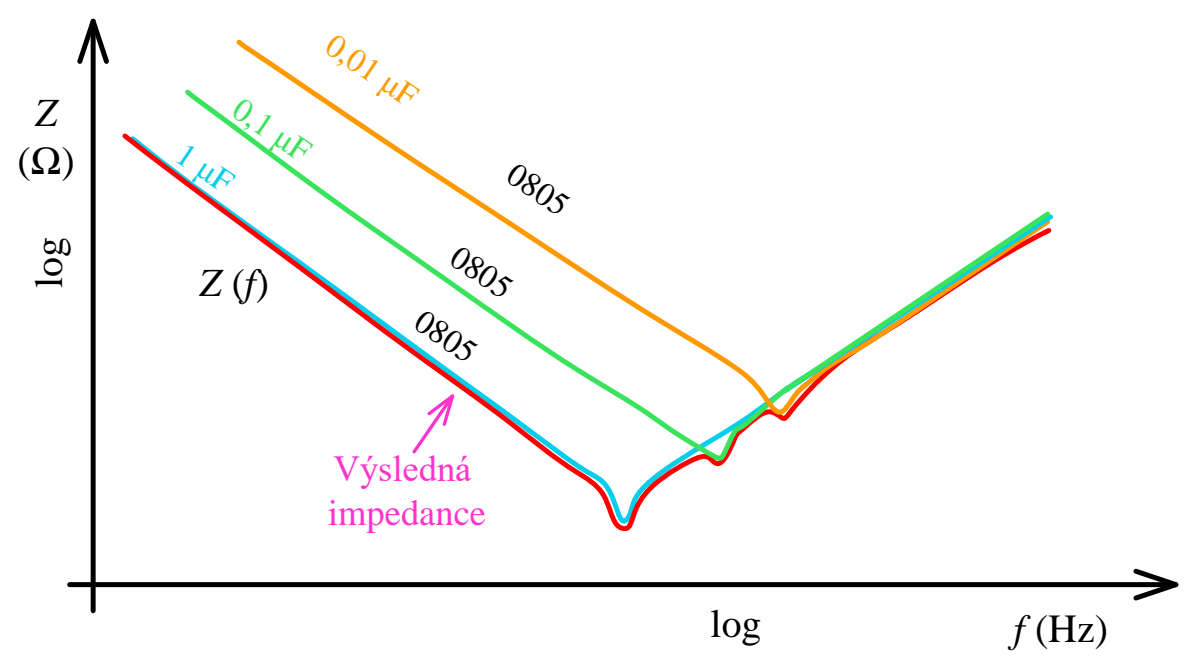

$\mathbf{a}$

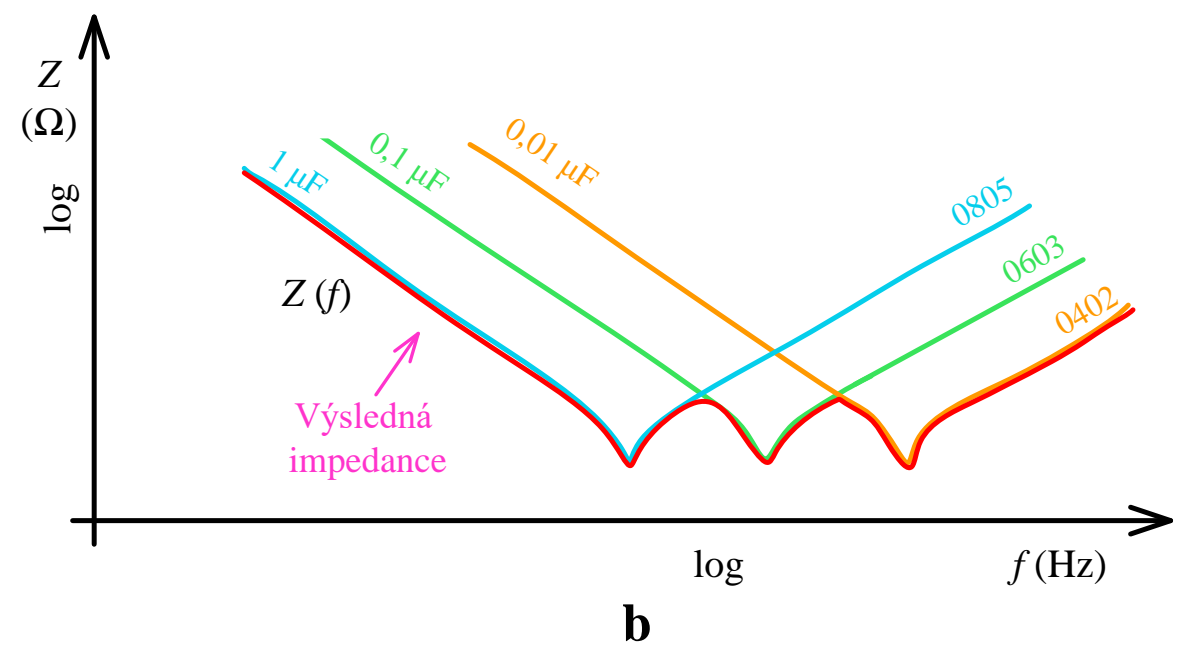

Obr. 7.31: Výsledná impedance tř́ paralelně zapojených SMD kapacitorů s různou kapacitou ve stejném pouzdře $(0805)$, b) v pouzdrech různých velikostí $(0805,0603,0402)$

o kondenzátor s kapacitou $1 \mu \mathrm{F}$ ). Jinými slovy, zbylé dva kondenzátory s menší kapacitou by byly na plošném spoji zcela zbytečné.

Správné řešení spočívá ve výběru typů pouzder pro jednotlivé kapacitory. Je známo, že nejmenší SMD pouzdra mají nejmenší parazitní indukčnost a tedy mají i nejlepší vf vlastnosti. $\mathrm{Z}$ tohoto důvodu je nutné vybrat kapacitor s nejmenší kapacitou v nejmenším pouzdře a kapacitor s největší kapacitou pak v pouzdře největším. Výsledná impedance všech tří paralelně spojených kapacitorů bude mít př́íhodnější průběh (vizObr. 7.32 a). Aby se nezvětšila parazitní indukčnost o indukčnost př́vodů, umístí se vf kapacitor s nejmenší kapacitou co nejblíže integrovanému obvodu (viz Obr. 7.32 b). Ze stejného důvodu se uzemnění kapacitorů provede co nejkratším způsobem do vnitřní vrstvy vícevrstvé DPS vyhrazené zemnění. 


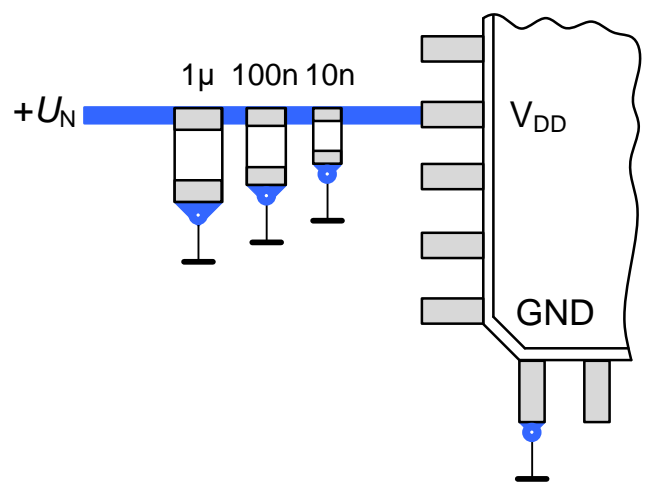

Obr. 7.32: Zapojení tří lokálních blokovacích kapacitorů SMD k integrovanému obvodu

V případě výkonového zesilovače (viz Obr. 7.30 se napájecí přívody také ošetří blokovacími kapacitory. Při zpracování audiosignálů, které se vyznačují velkou dynamikou, musí zesilovač zpracovat i dynamické špičky signálu. To samozřejmě způsobí i proudové špičky v napájecím rozvodu. Blokovací kapacitor musí být proto schopen tyto proudové špičky krátkodobě pokrýt. $Z$ tohoto důvodu jsou nároky na blokovací kondenzátor podobné jako na filtrační kapacitory ve spínacích zdrojích. Používají se elektrolytické kondenzátory s potlačenou indukčností nebo polymerové elektrolytické kondenzátory anebo se použije běžný elektrolytický kondenzátor a přemostí se vícevrstvým keramickým kapacitorem.

Ladicí kapacitory (Tunning Capacitor) se používají pro nastavení kmitočtu v přijímačích nebo v oscilátorech vysílačů. Dříve se vyráběly otočné kapacitory se vzduchovou mezerou mezi elektrodami. Nyní se užívají především miniaturní kapacitory s proměnnou kapacitou s dielektrikem z plastické folie, ovšem s mnohem lepšími vlastnostmi než někdejší kapacitory. Př́iklad provedení ladicího kapacitoru s polyetylenovým dielektrikem je uveden na Obr. 7.33 Kapacitu ladicích kapacitorů je obvykle možné nastavit v rozmezí 2,5 pF až 60 pF. Nastavení capacity se provádí knoflíkem upevněným na hřídel.
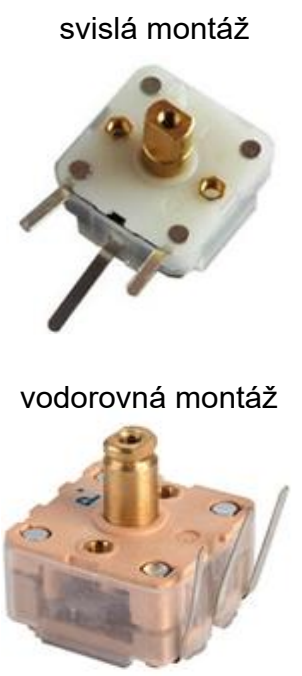

LADICÍ KONDENZÁTORY
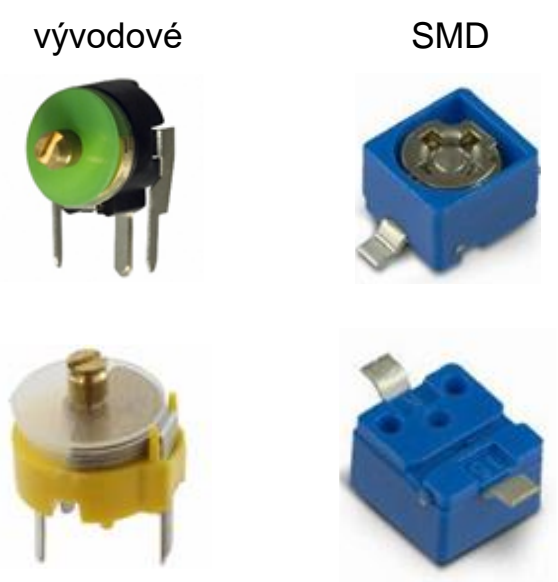

KAPACITNÍ TRIMRY
SMD miniaturní

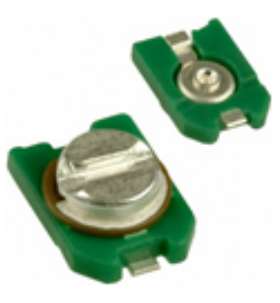

Obr. 7.33: Kapacitory s proměnnou kapacitou: a) ladicí kondenzátory, b) kapacitní trimry fóliové vývodové a SMD kapacitní trimry , c) kapacitní trimr SMD 
Kapacitní trimry (Trimmer Capacitor) jsou nastavitelné proměnné kapacitory o menší kapacitě, které se používají k doladění ladicích obvodů přijímačů a oscilátorů, nastavení stupně vazby mezi obvody, k neutralizaci parazitních kapacit atd. Kapacitní trimry jsou realizovány jako otočné elektrody tvaru půlkruhu oddělené dielektrikem (polypropylen, polykarbonát). Vzájemně se střídají otočné elektrody připojené $\mathrm{k}$ jednomu vývodu a elektrody stabilní fixované na plastovém tělísku, které jsou připojeny ke druhému vývodu kapacitoru. Změna kapacity je však velmi malá: minimální kapacita cca $1-4$ pF maximální cca $5-50$ pF. Těleso kapacitorů je $\mathrm{z}$ termoplastické hmoty, kapacita se nastavuje pomocí šroubováku. Kapacitor je přizpůsoben k připájení do plošných spojů. Př́íklady kapacitních trimrů jsou uvedeny na Obr. 7.33 .

\subsection{Výběr induktorů}

Induktor (Inductor) je pasivní elektronický prvek, který má schopnost při průchodu elektrického proudu vytvářet magnetické pole a akumulovat jeho energii. Jeho vlastnost je definována indukčností (Inductance) vyjádřenou jednotkou Henry $(\mathrm{H})$. Nejčastěji je indukčnost vyjádřena $\mathrm{v} \mu \mathrm{H}$ nebo $\mathrm{nH}$. Podle použití, nebo podle provedení bývá také označován jak cívka, vf cívka, indukční cívka, tlumivka ad. Indukčnost induktoru ovlivňuje materiál jádra, jeho tvar a velikost, počet závitů a provedení cívky.

\section{Parametry induktoru}

Jmenovitá indukčnost (Rated Inductance) je nejdůležitější parametr popisující základní vlastnost induktoru. Protože je tento parametr závislý na okolních vlivech, udává se tato hodnota pro konkrétní frekvenci (napřx. pro nf aplikace při kmitočtu $1 \mathrm{kHz}$, nebo pro vf aplikace při kmitočtu $25 \mathrm{MHz}$ či $100 \mathrm{MHz}$ ), pro jmenovitý ss proud či pro určitou teplotu. Jmenovitá indukčnost je výrobci volena v řadách E12 a E24, nejčastěji se užívá řada E12.

Tolerance jmenovité indukčnosti (Inductance Tolerance) udává maximální odchylku od jmenovité indukčnosti. Obvykle se vyjadřuje v \%, ale u některých přesných induktorů se udává absolutní odchylka od jmenovité indukčnosti, např. $\pm 0,15 \mathrm{nH}$ nebo $\pm 0,5 \mathrm{nH}$.

Stejnosměrný odpor (DC Resistance, DCR) představuje odpor cívky změřený stejnosměrně bez střídavé složky proudu. V podstatě představuje odpor vodiče, kterým je cívka realizována. Obvykle se uvádí maximální hodnota tohoto odporu (DCR max). Stejnosměrný odpor je důležitým parametrem při návrhu spínaných zdrojů.

Impedance induktoru $\mathrm{v}$ ideálním případě $\mathrm{s}$ kmitočtem narůstá lineárně. V reálném př́padě však díky parazitním kapacitám těsně před tzv. rezonančním kmitočtem narůstá rychleji a po překročení tohoto kmitočtu díky i dalším parazitním vlastnostem induktoru prudce klesá (viz Obr. 7.34). 


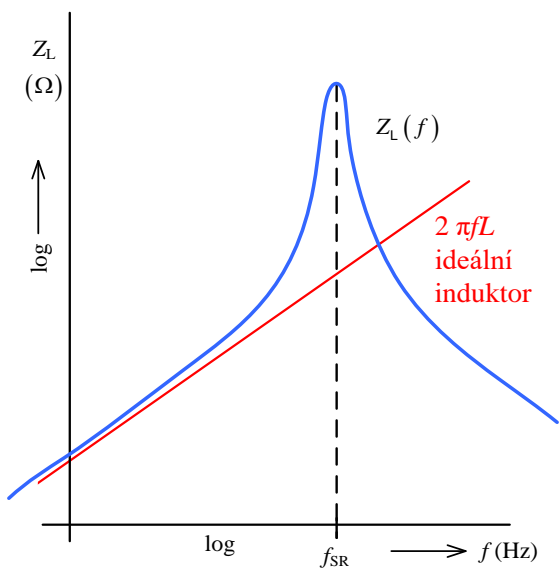

Obr. 7.34: Závislost modulu impedance na kmitočtu pro ideální a reálný induktor

Většina tlumivek či cívek se používá hluboko pod jejich vlastním rezonančním kmitočtem $\left(S R F=\right.$ self-resonant frequency), který nastane právě, když reaktance induktoru $X_{\mathrm{L}}=\omega L$ je rovna reaktanci kapacitoru $X_{\mathrm{C}}=1 / \omega C_{\mathrm{P}}$, tj. při kmitočtu

$$
S R F=f_{\mathrm{SR}} \approx \frac{1}{2 \pi \sqrt{L C_{\mathrm{P}}}} .
$$

U některých typů induktorů, jako např. u „feritových perel“ určených do vf filtrů pro potlačení šumu či impulsního rušení se vůbec neudává jmenovitá indukčnost, ale uvádí se většinou závislost impedance $\bar{Z}_{\mathrm{L}}$ na kmitočtu

$$
\bar{Z}_{\mathrm{L}}(f)=\operatorname{Re} \bar{Z}_{\mathrm{L}}(f)+\mathrm{j} \operatorname{Im} \bar{Z}_{\mathrm{L}}(f)=R(f)+\mathrm{j} X(f) .
$$

V katalogových listech jsou pak uvedeny kmitočtové závislosti modulu impedance $Z(f)$ společně s reálnou $R(f)$ a imaginární $X(f)$ složkou (viz Obr. 7.35).

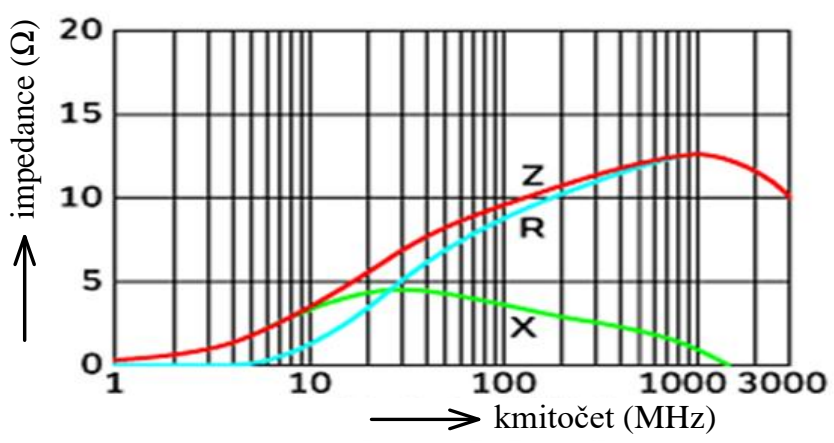

Obr. 7.35: Impedance induktoru typu „feritová perla“ (Ferrites Bead)

Náhradní model induktoru. Skutečnou impedanci induktoru můžeme pro nízké kmitočty modelovat ideálním induktorem o indukčnosti $L$ zapojeným v sérii se ztrátovým rezistorem o odporu $R_{\mathrm{S}}$ (viz Obr. 7.36 ). Přesnější model zahrnující parazitní kapacitor o kapacitě $C_{\mathrm{P}}$ je uveden na Obr. 7.36巾. Je však nutno podotknout, že model může být sestaven i jiným způsobem a že vyjadřuje vlastnosti cívky vždy jen pro určitý kmitočtový rozsah. 


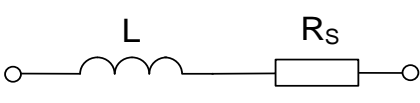

$\mathbf{a}$

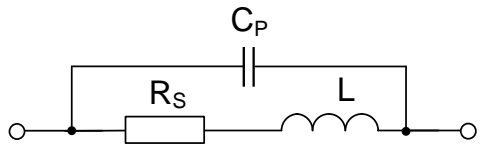

b

Obr. 7.36: a) Náhradní model cívky, b) náhradní model cívky s uvažováním parazitní kapacity

Vlastni kapacita induktoru někdy také označovaná jako parazitni kapacita induktoru je údaj, který je nutno znát pro přesné výpočty rezonančních obvodů. Při průtoku proudu cívkou se vytváŕí v okolí závitů (ve vzduchu nebo v jiném dielektrickém materiálu) elektrické pole. Energie v tomto poli má na cívku stejný vliv, jakoby k ní byla připojena paralelní kapacita. Vlastní kapacitu cívky si můžeme představit jako modelový kapacitor $\mathrm{C}_{\mathrm{P}}$ přripojený paralelně $\mathrm{k}$ induktoru (viz Obr. 7.36 ). Cívka tedy se svou vlastní kapacitou představuje rezonanční obvod, jehož kmitočet nazýváme vlastním rezonančním kmitočtem cívky. Změřením vlastního rezonančního kmitočtu cívky $f_{\mathrm{SR}}$ můžeme stanovit její vlastní kapacitu

$$
C_{\mathrm{P}} \approx \frac{1}{\left(2 \pi f_{\mathrm{SR}}\right)^{2} L},
$$

kde $C_{\mathrm{P}}$ je vlastní (parazitní) kapacita $[\mathrm{F}], \mathrm{L}$ indukčnost $[\mathrm{H}], f_{\mathrm{SR}}$ vlastní rezonanční kmitočet cívky [Hz]. Přitom předpokládáme, že cívka vykazuje malé ztráty. Přídavná kapacita, která se přidává do obvodu vlastní kapacitou cívky, zhoršuje její vf vlastnosti. Odtud vyplývá snaha po zmenšení této kapacity např. kř́žzovým vinutím vícevrstvých cívek. Vlastní kapacitu induktoru úplně odstranit nelze, poněvadž dva sousední závity budou mít vždy mezi sebou vlastní kapacitu. Způsobem provedení cívky lze však alespoň částečně vlastní kapacitu cívky potlačit.

Efektivní indukčnost induktoru představuje vyjádření vlivu vlastní (parazitní) kapacity na rezonanční obvod sestavený z reálného induktoru a vnějšího kapacitoru. Rezonanční kmitočet takového obvodu bude díky vlastní kapacitě o něco vyšší. To odpovídá efektivnímu zvýšení indukčnosti na vyšších kmitočtech. Na Obr. 7.37 je ukázán příklad zvyšování efektivní indukčnosti vícevrstvých SMD induktorů s keramickým jádrem v okolí vlastního rezonančního kmitočtu induktoru.

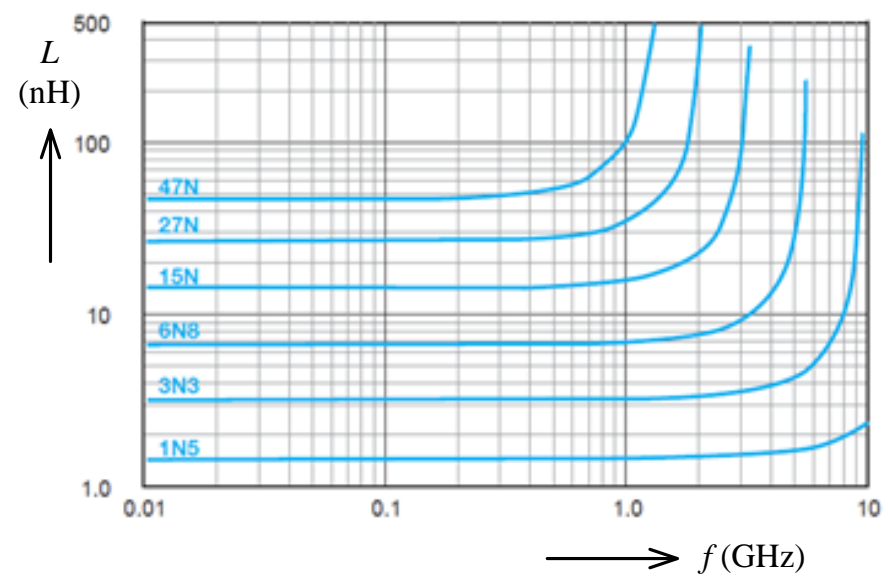

Obr. 7.37: Efektivní indukčnost vf vícevrstvé SMD cívky s keramickým jádrem 
Ztrátový odpor $R_{\mathrm{S}}$ induktoru zahrnuje nejen stejnosměrný odpor cívky, ale i činný odpor cívky a ztráty v dielektriku. Činný odpor závisí na efektivním prưřezu vodiče, tj. na ploše, $v$ jejímž rozmezí protéká proud. Stř́ídavý proud protékající vodičem totiž vytvárí uvnitř vodiče stř́́davé magnetické pole, což má za následek, že proud je ,vytlačován“ k povrchu vodiče. Čím vyšší je kmitočet, tím se koncentruje proud do tenčí vrstvy u povrchu vodiče. Tento jev se nazývá povrchový jev (skinefekt). Následkem zhuštění proudu u povrchu vodiče se zvětšuje v závislosti na kmitočtu i jeho ohmický odpor (zmenšuje se jeho efektivní průřez pro protékající proud). Kromě uvedeného jevu vzniká ve vodiči cívky ještě tzv. jev blízkosti, způsobený magnetickým polem ostatních závitů. Toto pole ovlivňuje průchod proudu ve vodiči tak, že se proud městná především k povrchu vodiče směrem od středu cívky, což má za následek, že činný odpor cívky vzrůstá mnohem více, než kdyby vodič nebyl stočen do cívky. To je jeden z důvodů, proč používáme pro induktory určené na velmi vysoké kmitočty tlusté vodiče s velkým povrchem.

Ztrátový činitel $(D F=$ Dissipation Factor $)$ je definován jako poměr ztrátového odporu $R_{\mathrm{S}}$ k reaktanci vlastní indukčnosti $X_{\mathrm{L}}$

$$
D F=\operatorname{tg} \delta=\frac{R_{\mathrm{S}}}{X_{\mathrm{L}}}=\frac{R_{\mathrm{S}}}{\omega L} .
$$

U vf cívek se ztrátový činitel pohybuje $\mathrm{v}$ mezích $10^{-2}$ až $10^{-3}$. činitele

Činitel jakosti $(Q F=$ Quality Factor) induktoru je dán převrácenou hodnotou ztrátového

$$
Q F=Q_{\mathrm{L}}=\frac{1}{\operatorname{tg} \delta}=\frac{X_{\mathrm{L}}}{R_{\mathrm{S}}}=\frac{\omega L}{R_{\mathrm{S}}} .
$$

Činitel jakosti se u vf cívek pohybuje v rozmezí od 100 do 1000 . U většiny cívek je činitel jakosti obvykle jen v rozmezí 100 až 200.

Díky změnám ztrátového odporu a efektivní hodnoty indukčnosti v závislosti na kmitočtu nebude ani činitel jakosti lineárně závislý na kmitočtu, jak by vyplývalo z rov. (7.20). Navíc mimo ztrát ve vodiči vykazují cívky i ztráty v dielektriku, které vznikají působením vlastního elektrického pole cívky. Dielektrické ztráty závisí na druhu dielektrika a na stupni vazby elektrického pole cívky s jejím jádrem. V cívkách s jádrem z feromagnetického materiálu závisí ztráty jak na konstrukci cívky, tak i na rozměrech jejího jádra. Přídavné ztráty, které vznikají vlivem viŕrivých proudů $\mathrm{v}$ jádře, vlivem hystereze a popř. i vlivem dielektrických ztrát $\mathrm{v}$ dielektriku pojícího materiálu, závisí na vlastnostech magnetického materiálu. Zmenšit ztráty tohoto druhu je možné jen pečlivou volbou vhodného magnetického materiálu.

$\mathrm{Na}$ Obr. 7.38 je zakreslena závislost činitele $Q_{\mathrm{L}}$ typických vícevrstvých SMD cívek na kmitočtu ve velmi širokém rozmezí kmitočtů. Je zřejmé, že v tomto rozmezí můžeme rozlišit celkem čtyři základní oblasti. V oblasti u velmi nízkých kmitočtů se vůbec neuplatňuje povrchový jev, ztrátový odpor cívky je stálý a proto činitel jakosti s kmitočtem lineárně narůstá. Od určitého kmitočtu začne dokonce $Q_{\mathrm{L}}$ díky zvětšování efektivní indukčnosti (viz Obr. 7.37) $\mathrm{s}$ kmitočtem narůstat. Pak ovšem začne vlivem povrchového jevu narůstat ztrátový odpor cívky a tedy její činitel $Q_{\mathrm{L}}$ se začne zvětšovat pomaleji a v oblasti kolem maxima průběhu se již začínají uplatňovat dielektrické ztráty a ty způsobují, že činitel $Q_{\mathrm{L}}$ se již dále nezvětšuje. $\mathrm{V}$ poslední části pak nastává strmý pokles průběhu činitele jakosti způsobený převládajícími dielektrickými ztrátami $\mathrm{v}$ jádře cívky. 


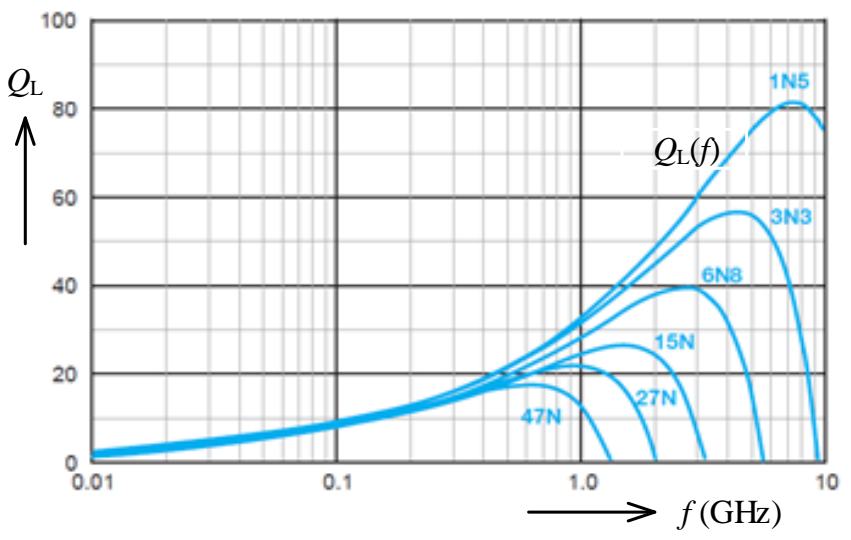

Obr. 7.38: Závislost činitele jakosti na kmitočtu u vf vícevrstvé SMD cívky s keramickým jádrem

Jmenovitý proud (Rated Current) někdy označovaný jako klidový ss proud (DC Bias Current) je maximální možný stejnosměrný proud, který ještě nezpůsobí přehřátí induktoru. Induktor je ještě schopen odvést teplo způsobené výkonovou ztrátou. Jak se tlumivka v závislosti na ss proudu $I_{\mathrm{DC}}$ ohřívá nad teplotu okolí o teplotu $\Delta T$ je vidět z Obr. 7.39. Současně s tím klesá indukčnost tlumivky. Př́činou poklesu indukčnosti jsou magnetické vlastnosti jádra. Tento jev se tedy neprojevuje u tzv. vzduchových cívek bez magnetického jádra.

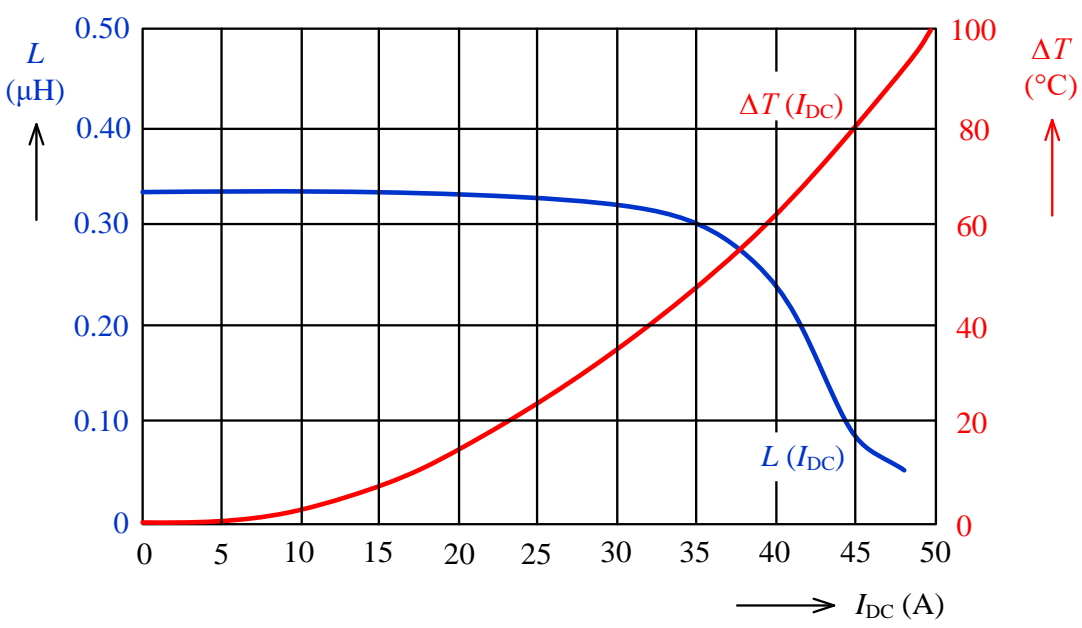

Obr. 7.39: Oteplení induktoru nad okolní teplotu a změna indukčnosti v závislosti na ss proudu

Klidový ss proud tekoucí induktorem při počátečním nulovém ss proudu neovlivňuje hodnotu indukčnosti induktoru. Pokud se však ss proud zvyšuje dojde k významnému poklesu indukčnosti (viz Obr. 7.39]. To platí především pro feritová jádra, která vykazují od určitého ss proudu velmi významný pokles indukčnosti. Induktory s práškovým železovým jádrem vykazují daleko mírnější pokles indukčnosti v závislosti na ss jmenovitém proudu. Rychlost s jakou indukčnost klesá je také funkcí tvaru jádra.

Nasycený proud (Saturation Current) je hodnota ss proudu induktorem, která způsobí pokles indukčnosti o $5 \%$ vůči počátečnímu nulovému ss jmenovitému proudu. Pro feritová jádra to bývá o $10 \%$, pro prášková železová jádra o $20 \%$. Provozování induktoru nad tuto hodnotu může zvýšit zvlnění proudu tekoucího do zátěže a tedy i zvlnění napětí na výstupu napájecího zdroje. 
Při použití tlumivky v impulsně regulovaném napájecím zdroji je proud $I_{\mathrm{DC}} \mathrm{v}$ podstatě dán proudem do připojené zátěže a nasycený proud pak představuje maximální proudové zatížení takovéhoto zdroje.

Zvlnění napětí (Ripple Voltage) je periodické střídavé napětí působící na induktor při použití ve spínaném zdroji. Hodnota zvlnění se udává jako povolený rozkmit napětí špičkašpička (peak-to-peak).

\section{Tř́dění induktorů}

Podle určení můžeme na induktory (cívky, tlumivky) rozčlenit do tří skupin:

- Vf induktory používané pro impedanční přizpůsobení, pro selektivní obvody, pro vf filtry nebo jako vf tlumivky.

- $\quad$ Nízkofrekvenční induktory používané pro nf filtry, nebo jako nf tlumivky.

- Výkonové induktory používané ve spínaných napájecích zdrojích, ve filtrech EMI pro potlačení elektromagnetického rušení, a akumulaci energie v napět'ových měničích (DC/DC Voltage Conversion) nebo jako výkonové tlumivky.

Při výběru parametrů induktoru musíme vždy přihlížet k uvažovanému použití. Přesnost, stabilita indukčnosti a vysoký činitel jakosti jsou prvořadými vlastnostmi induktorů určených pro filtrační či selektivní obvody nebo pro impedanční přizpůsobení. Menší nároky na tyto parametry jsou pak u odrušovacích tlumivek nebo induktorů užívaných pro potlačení elektromagnetického rušení, protože se jejich hodnoty volí vždy s určitou rezervou vyšší. V řadě případů se u těchto součástek ani výše uvedené parametry $\mathrm{v}$ katalozích neuvádějí a pouze je uveden průběh modulu impedance $Z(f)$ společně s jeho reálnou $R(f)$ a imaginární složkou $X(f)$. U induktorů určených pro filtraci nebo pro akumulaci energie ve výkonových spínacích zdrojích a napětových měničích je pak při jejich výběru kladen důraz na jmenovitý proud a na stejnosměrný odpor.

Podle provedení se induktory dělí na induktory bez feromagnetického jádra (Nonmaggnetic Core) tzv. vzduchové cívky (Air Coil), nebo induktory s feromagnetickým jádrem, kdy je obvykle použito feritové jádro (Ferrite Core). Pro většinu aplikací lze použít v principu jak cívky či tlumivky vzduchové, tak i s feromagnetickým jádrem. Ne vždy je však toto použití pro oba druhy stejně technicky a ekonomicky výhodné, každé provedení má své zásadní odlišnosti i okruh aplikací. Toto základní členění však představuje společný rys pro všechny druhy induktorů, bez ohledu na konkrétní aplikaci a detailní konstrukční uspořádání.

\section{Typy induktorů}

Sériově vyráběné cívky jsou určeny většinou k použití jako tlumivky a lze je pořídit v SMD i klasickém provedení. Monolitické SMD induktory jsou určeny zejména pro vf aplikace a to pro kmitočty vyšší než $100 \mathrm{MHz}$. K dispozici jsou i SMD induktory určené pro větší proudové zatížení, které se užívají v napájecích zdrojích či pro obecné užití pro kmitočty nižší než 100 MHz. Pro potlačení vf rušení v analogových i číslicových obvodech se používají tzv. feritové perly (korálky). Drátové induktory se podle provedení dělí na samonosné a vinuté na kostru, dále se dělí na induktory bez jádra (vzduchové) nebo s feromagnetickým jádrem. Cívky na kostře jsou mechanicky odolnější a stabilnější než cívky samonosné a navíc je lze vinout o libovolném počtu závitů. Vývodové induktory se člení na induktory s axiálními vývody (oba vývody ve směru osy součástky) a radiální (oba vývody jdou jedním směrem). Další členění může být podle tvaru použitého jádra, např. induktory toroidní, nebo hrníčkové. 


\begin{tabular}{|c|c|c|}
\hline SMD inductor & Vnitřní struktura & Vlastnosti \\
\hline & Jednovrstvový (Thin Film Type) & $\begin{array}{c}\text { vynikající QL,vysoký } \\
\text { SRF, vynikající } \\
\text { teplotní stabilita }\end{array}$ \\
\hline & Vícevrstvý (Multilayer Type) & pro běžně použití \\
\hline & Vrstvový (Film type) & $\begin{array}{l}\text { vysoké QL při } \\
\text { malých rozměrech }\end{array}$ \\
\hline & Horizontální vinutí (Horizontal Winding Type) & $\begin{array}{c}\text { vysoké QL na } \\
\text { kmitočtech řádově } \\
\text { GHz }\end{array}$ \\
\hline & $\begin{array}{l}\text { Drátový prof vf (Wire Wound Type for Radio } \\
\text { Frequency) }\end{array}$ & $\begin{array}{l}\text { velká indukčnost, } \\
\text { vysoké QL na vf }\end{array}$ \\
\hline
\end{tabular}

Obr. 7.40: Různé typy vf induktorů SMD 
Vfjednovrstvé SMD induktory (Thin Film Type) se vyrábějí fotolitografickým nanesením motivu cívky na keramický čip (viz Obr. 7.40). Keramický materiál má permeabilitu blízkou vzduchu a proto induktory s keramickým jádrem bývají označovány jako tzv. vzduchové cívky. Vyrábějí se obvykle v rozmezí indukčnosti 1 až $100 \mathrm{nH}$ s vysokou přesností v řadě E24, malé hodnoty s přsesností až $\pm 1 \mathrm{nH}$. Vykazují stabilní indukčnost a při vysokých kmitočtech, jejich vlastní resonanční kmitočet SRF je vysoký, řádově kolem GHz. Mají vynikající teplotní stabilitu a výborný činitel jakosti QL.

Vf vícevrstvé SMD induktory (Multilayer Type) jsou tvořeny vrstvami keramického materiálu s motivem cívky (viz různá provedení uprostřed Obr. 7.40. Změnou orientace osy motivu cívky do horizontální polohy (vodorovně s DPS) se dá dosáhnout filtračních účinků až do jednotek GHz. Vícevrstvé SMD induktory mají menší rozměry ve srovnání s drátovými SMD induktory. Činitel jakosti Q je však ve srovnání s drátovými induktory nižší. Hodnoty indukčností bývají v rozmezí $1 \mathrm{nH}$ až $270 \mathrm{nH}$, vyrábějí se v řadě E12, některé typy omezeně $\mathrm{i}$ $\mathrm{v}$ řadě E24.

Vf drátové SMD induktory (Wire Wound Type) jsou realizovány měděným vodičem navinutým ve tvaru spirály kolem jádra z nemagnetického keramického materiálu (viz Obr. 7.40. V principu jde o obdobu vzduchové cívky bez jádra. Cívka je realizována drátem s daleko větším průřezem, než je tomu u jednovrstvých či vícevrstvých SMD induktoru. Proto tento typ induktoru vykazuje daleko menší stejnosměrný odpor DCR (DC Resistance). Drátový SMD induktoru je schopen zpracovat daleko větší proudy a vykazuje extrémně vysoký činitel jakosti $Q_{\mathrm{L}}$. Indukčnost bývá v rozmezí $1 \mathrm{nH}$ až $470 \mathrm{nH}$.

Induktory pro napájecí rozvody a zdroje (Inductors for Power Lines) jsou výkonové tlumivky cíleně konstruovány tak, aby vykazovaly malou závislost na ss proudu tekoucím do zátěže napájecího zdroje a superponovaného zvlněného proudu a měly přitom přiměřenou velikost. Výkonové tlumivky mají tři hlavní aplikace:

- $\quad$ v nf filtrech pro potlačení šumu,

- ve filtrech pro EMC,

- $\quad \mathrm{k}$ akumulaci energie $\mathrm{v}$ DC/DC měničích.

Vrstvové induktory SMD pro napájecí rozvody jsou v podstatě stejné konstrukce jako monolitické induktory pro vf užití, liší se jen použitím feritového jádra (vizObr. 7.41). Vyrábějí se pro proudy do $1 \mathrm{~A}$, indukčnost bývá v rozmezí $0,47 \mu \mathrm{H}$ až $4,7 \mu \mathrm{H}$.

Pro větší proudy se vyrábějí drátové induktory s feritovým jádrem vhodným pro vyšší kmitočty. Vykazují malou závislost na ss proudu tekoucím do zátěže. Drátový SMD induktor s feritovým jádrem Obr. 7.41 uprostřed) je určen pro všeobecné užití. Vykazuje vysoký činitel jakosti Q na středních kmitočtech.

Pro impulsně regulované zdroje resp. pro DC/DC měniče s velkými proudy tekoucím do zátěže jsou k dispozici robustní drátové induktory SMD (viz Obr. 7.41 dole). Vykazují široký rozsah indukčností a vyznačují se malou závislostí indukčnosti na ss jmenovitém proudu tekoucím do zátěže zdroje. Rozsah indukčnosti bývá od $1 \mu \mathrm{H}$ do $330 \mu \mathrm{H}$. Jsou určeny podle provedení pro proudy do $0,5 \mathrm{~A}$ do $6 \mathrm{~A}$, někdy do $10 \mathrm{~A}$. Pro všeobecné užití jsou k dispozici obdobné induktory SMD s indukčností až 2,2 $\mathrm{mH}$ pro proudy do $1 \mathrm{~A}$. 


\begin{tabular}{|c|c|c|}
\hline SMD inductor & Vnitřní struktura & Vlastnosti \\
\hline & Vícevrstvý (Multilayer Type) & $\begin{array}{l}\text { malý ss odpor, malá } \\
\text { montážní výška, } \\
\text { malá hmotnost }\end{array}$ \\
\hline & $\begin{array}{l}\text { Drátový pro střední kmitočty } \\
\text { (Wire Wound Type for } \\
\text { Intermediate Frequency) }\end{array}$ & $\begin{array}{l}\text { vysoké Q na } \\
\text { středních kmitočtech }\end{array}$ \\
\hline & Drátový (Wire Wound Type) & $\begin{array}{c}\text { široký rozsah } \\
\text { indukčnosti, malá } \\
\text { závislost na ss } \\
\text { proudu }\end{array}$ \\
\hline
\end{tabular}

Obr. 7.41: Induktory pro napájecí zdroje a pro obecné užití - výkonové tlumivky

Odrušovací feritové perly či korálky (Ferrite Bead Inductors) jsou určeny jednak pro filtraci rušení na velmi vysokých kmitočtech až $1 \mathrm{GHz}$ jak v signálových spojích, tak i pro potlačení rušení, které se šiří po napájecích př́vodech. Princip feritové perly je trochu odlišný od klasické indukční cívky, protože slouží jako tlumivka pro rušivé signály na vysokých frekvencích, ovšem bez využití reaktanční složky. Prakticky dochází k přeměně vf signálu na teplo ve feritovém jádře díky vířivým proudům. Zahřívání je však minimální a odvod tepla není nutné řešit. Základem je feritový váleček (perla či perlička, korálek) s otvorem, kterým je provlečen vodič (Obr. 7.42 a). Vývodové feritové perly mají jen průchozí vodič, nebo má 2 až tři závity Obr. 7.42b). U SMD feritových perel Obr. 7.42屯) se dá dosáhnout vyšší impedance, než když jen vodič prochází perličkou. Její struktura je v podstatě stejná jako u monolitického čipu jednovrstvého induktoru. Rozdíl pouze spočívá v tom, že místo nemagnetické keramiky je použit feritový materiál, který se hodí lépe pro potlačení šumu na vysokých kmitočtech. SMD feritové perly mají podle typu a předpokládaného použití jmenovitý proud od $50 \mathrm{~mA}$ do $5 \mathrm{~A}$. 


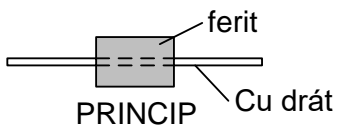

$\rightarrow-1$

SCHÉMATICKÁ ZNAČKA

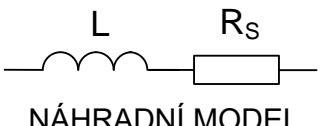

a
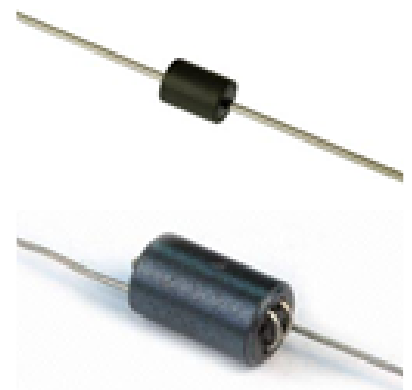

b

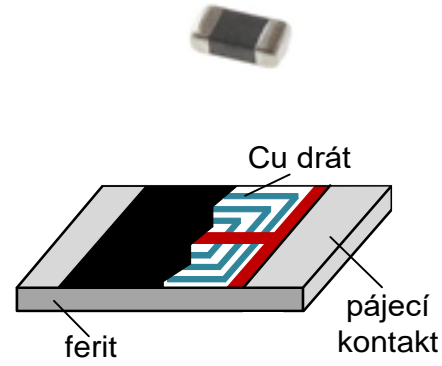

c

Obr. 7.42: Feritové perly: a) princip, schématická značka a náhradní model, b) vývodové perly, c) SMD perly

Činitel jakosti $Q_{\mathrm{L}}$ je feritových perel velmi nízký. V katalogu se ani neudává indukčnost, ale impedance při kmitočtu kde je její hodnota maximální, nebo hodnota impedance při nějakém referenčním kmitočtu, např. $100 \mathrm{MHz}$. Př́ípadně se uvádí závislost modulu impedance na kmitočtu. Přri aplikaci je vždy zapotřebí myslet také na to, že ss složka proudu $I_{\text {DS nasycuje }}$ jádro a tím impedance klesá (viz Obr. 7.43 ). Společně s blokačním kondenzátorem pak tvoří perličkový induktor v napájecím přívodu velmi kvalitní dolní propust, která spolehlivě potlačí vf rušení (viz Obr. 7.43 p).

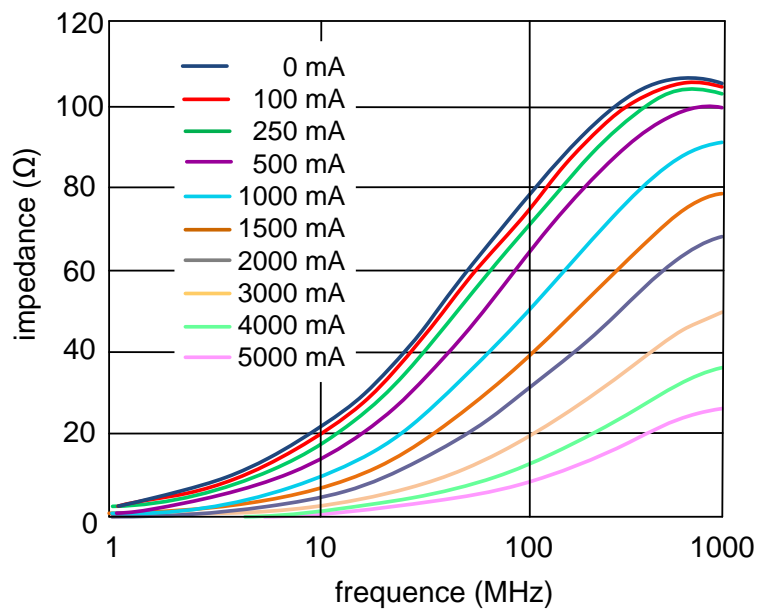

$\mathbf{a}$

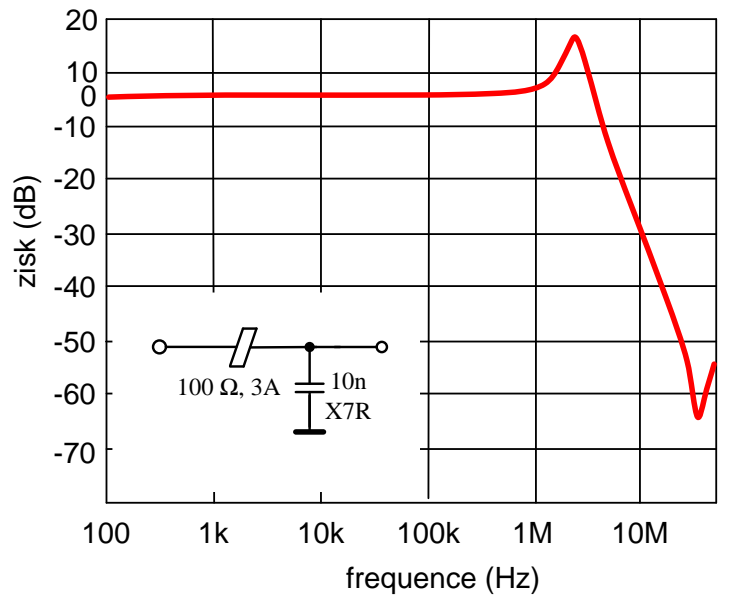

b

Obr. 7.43: a) závislost impedance feritové perly na kmitočtu, b) použití feritové perly v odrušovacím filtru

Vzduchová cívka či tlumivka (Air Coil) je z obvodového hlediska vhodná v podstatě pro všechny aplikace, pokud není přesycování feromagnetického jádra součástí její funkce (např́klad přesytky). Vzduchová cívka se vyznačuje svojí linearitou ve všech provozních stavech. Vzduch totiž představuje magnetický obvod s lineární magnetizační charakteristikou, kdy mezi elektrickým proudem a magnetickým tokem je lineární závislost bez ohledu na velikost proudu, indukčnost je konstantní. Lineární charakteristika je velikou výhodou vzduchové cívky ve srovnání s tlumivkou s feromagnetickým jádrem. Za tuto výhodu je ovšem nutno zaplatit relativně velkými rozměry. Pro vybuzení magnetického pole a dosažení požadované indukčnosti tlumivky je třeba většího počtu závitů cívek, než by tomu bylo u cívek s feromagnetickým jádrem. Vzduchové cívky se vyrábějí bud' jako samonosné, či na kostřičce 

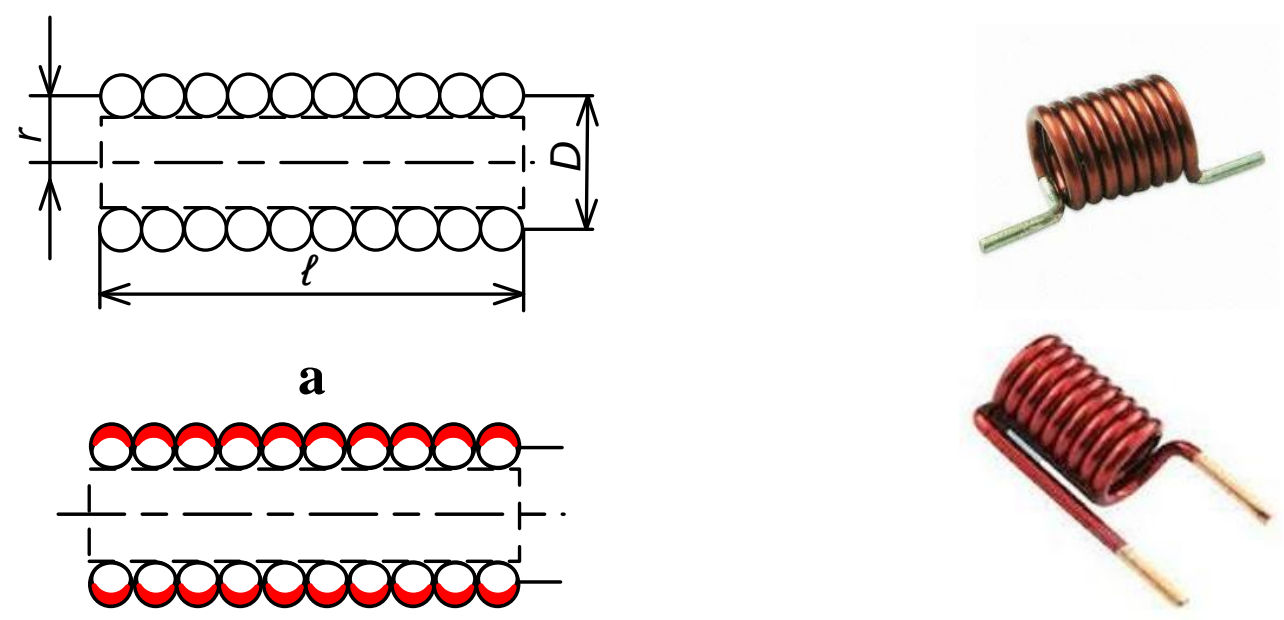

b

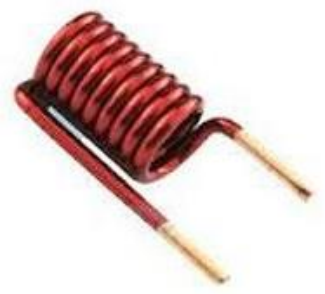

C

Obr. 7.44: a) K výpočtu jednovrstvé vzduchové cívky, b) vliv skinefektu, c) př́klady realizace

nebo i v provedení SMD. Nejjednodušší co do provedení jsou jednovrstvé vf válcové samonosné vzduchové cívky bez jádra Obr. 7.44 používané na vyšších kmitočtech (KV, VKV, UKV).

Pro výpočet indukčnosti jednovrstvých válcových cívek bez jádra (tzv. vzduchových) se udává řada vzorců. Za předkladu, že délka cívky je mnohem větší než její průměr (viz Obr. 7.44 q), lze použít jednoduchý a dostatečně přesný vztah

$$
L \approx \frac{0,41 r^{2} N^{2}}{9 r+10 l},
$$

kde $L$ je indukčnost $[\mu \mathrm{H}], r$ poloměr závitů $[\mathrm{cm}], l$ délka části s vinutím $[\mathrm{cm}], N$ počet závitů. Pro poměr $l>0,8 r$ (to je pro krátkovlnné cívky běžný prrípad), není třeba používat žádný opravný činitel. Z předchozího vztahu můžeme určit počet závitů pro požadovanou indukčnost cívky

$$
N \approx \sqrt{\frac{L(9 r+10 l)}{0,41 r^{2}}},
$$

kdy význam symbolů a jejich jednotky jsou stejné jako v předchozím př́padě.

Měděný vodič izolovaný lakovou vrstvou, ze kterého je cívka navinuta, mívá daleko větší průměr než by odpovídalo proudovému zatěžování cívky. Jedním z důvodů je zvýšení mechanické odolnosti vůči otřesům a druhým důvodem je pak skinefekt, kdy vlivem stř́davého magnetického pole dochází ke zmenšení efektivního prưřezu vodiče pro protékající proud (viz Obr. 7.44b). Pro zvětšení povrchové vodivosti bývá drát i někdy postř́břen. 


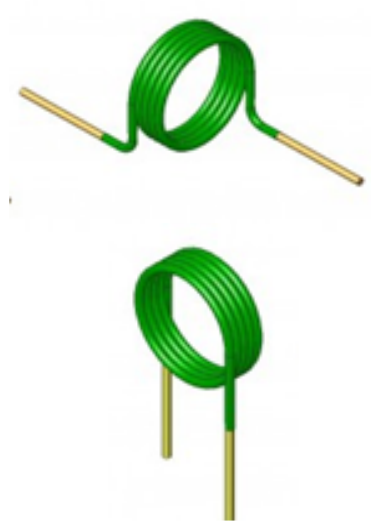

a

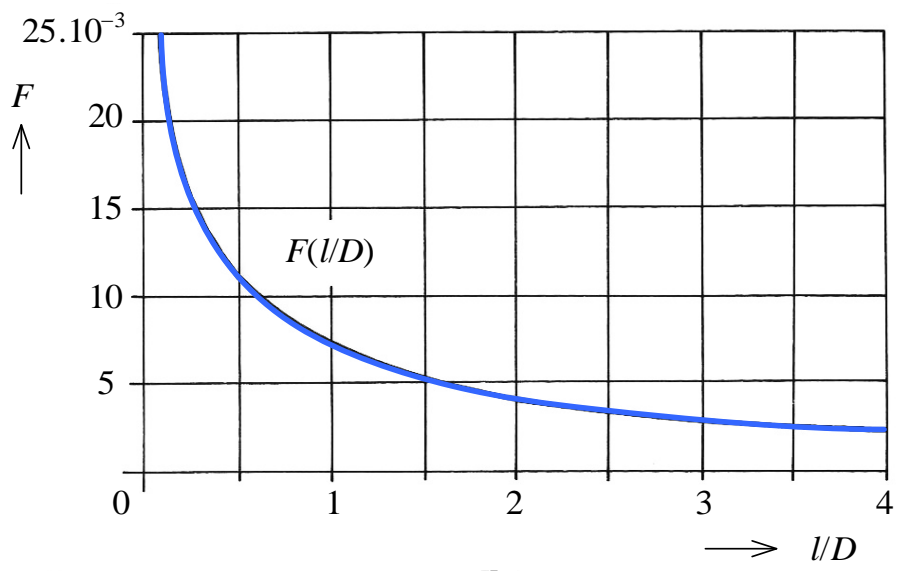

b

Obr. 7.45: a) Samonosná jednovrstvá cívka s průměrem větším než její délka, b) opravný činitel pro výpočet cívky s poměrně malou délkou vinutí a velkým průměrem

U cívky s poměrně malou délkou vinutí a velkým průměrem Obr. 7.45 je indukčnost cívky menší než vypočtená podle vztahu (7.22). K určení indukčnosti cívky, jejíž délka je srovnatelná s jejím průměrem, používáme opravný činitel tvaru cívky $F$ (viz Obr. 7.45), který závisí na poměru $l / D$. Tyto cívky bývají obyčejně samonosné nebo jsou navinuty na tělísku z takových materiálů, že pro zjednodušení můžeme předpokládat $\mu=1$. Vzorec má pak tvar

$$
L \approx F N^{2} D, \text { resp. } N \approx \sqrt{L / F D} .
$$

V těchto vztazích dosazujeme opět za $D$ v centimetrech a indukčnost je pak v $\mu \mathrm{H}$.

$\mathrm{K}$ dosažení větších indukčností se užívá vícevrstvých cívek (viz Obr. 7.46). Indukčnost takové cívky lze určit z rozměrů cívky Obr. 7.46 pomocí vzorce

$$
L \approx \frac{0,315 r^{2} N^{2}}{6 r+9 l+10 w}
$$

kde $L$ je indukčnost $[\mu \mathrm{H}], r$ poloměr středu tloušt'ky vinutí $[\mathrm{cm}], l$ délka cívky $[\mathrm{cm}], w$ tloušt'ka vinutí $[\mathrm{cm}], N$ počet závitů. Zajímá-li nás počet závitů pro potřebnou indukčnost, pak

$$
N \approx \sqrt{\frac{L(6 r+9 l+10 w)}{0,315 r^{2}}},
$$

přičemž veličiny mají stejný význam i rozměry jako v předchozím. Obvykle se však při zhotovení vícevrstvé cívky neobejdeme bez přeměření vlastností. 


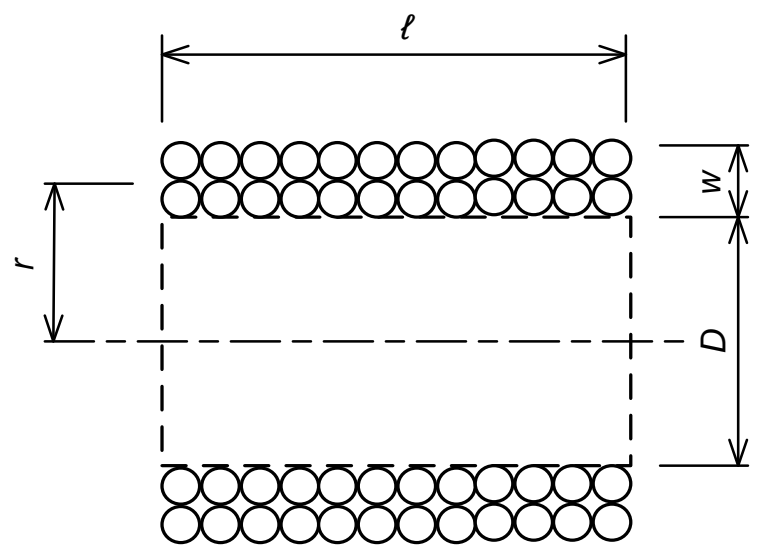

a

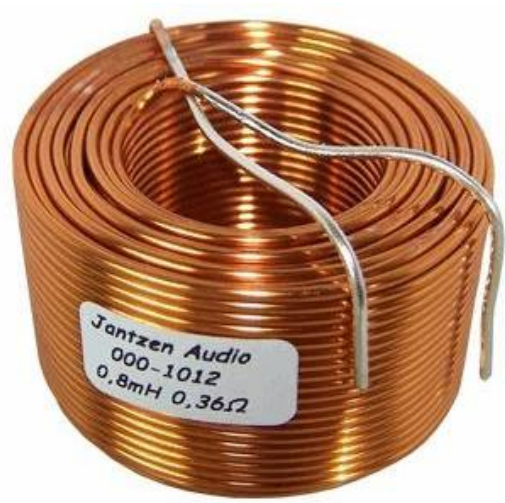

b

Obr. 7.46: Vícevrstvá vzduchová cívka

Cívka či tlumivka s feromagnetickým jádrem umožňuje realizovat větší indukčnost ve srovnání se vzduchovou cívkou se stejným počtem závitů. Indukčnost induktoru totiž závisí nejen na počtu závitů, ale i na permeabilitě vloženého jádra. Protože permeabilita feromagnetických jader je větší než jedna, mívají induktory s jádrem indukčnost větší než induktory bez jádra. Tímto způsobem je tedy možno zmenšovat rozměry cívek a zvětšovat jejich činitel jakosti, příp. zasouváním a vysouváním jádra v cívkovém tělísku je možné induktor doladit na žádanou indukčnost. U cívek s jádrem, jejichž tvary jsou voleny s cílem vytvořit uzavřené magnetické pole cívky, se magnetické pole soustředí hlavně v jádru, což vede nejen ke zvětšení indukčnosti, ale i ke značnému zeslabení vnějšího rozptylového pole. Př́kladem takového jádra s uzavřeným magnetickým polem je tzv. hrníčkové jádro, nebo jeho modifikace. Nejslabší rozptylové pole pak mají cívky toroidní, u nichž samotný tvar vinutí zabezpečuje velmi dobré zeslabení vnějšího rozptylového pole.

Snižování ztrát víŕivými proudy $\mathrm{v}$ klasickém jádru sestaveném $\mathrm{z}$ feromagnetických plechů je možné v podstatě dvěma způsoby: 1. zmenšováním tloušt'ky plechů, 2. zvětšením měrného odporu materiálu jádra. Při prvním způsobu hrají důležitou úlohu výrobní náklady, které stoupají se snižující se tloušt'kou plechů. To znamená, že existuje hranice tloušt'ky plechů, která je ještě ekonomicky únosná. Druhý způsob snižování ztrát vířivými proudy vedl ke hledání materiálů s vysokým měrným odporem. Došlo se až $\mathrm{k}$ nekovovým látkám, a to kysličníkům železa a feritům.

Nyní se jako jádra induktorů užívají výhradně ferity. Ferity jsou směsné oxidy obsahující jako hlavní složku oxid železitý $\left(\mathrm{Fe}_{2} \mathrm{O}_{3}\right)$. Jádra tohoto typu jsou mechanicky pevná a lze je vyrábět $\mathrm{v}$ nejrůznějších tvarech jako napřs. tyče, válečky, toroidy, hrníčková jádra nebo polouzavřená hrníčková jádra či jako jádra E. Ferity jsou odolné proti vlhkosti, atmosférickým a chemickým vlivům, ale jsou křehké a snadno se štípou nebo zlomí. Po vypálení je lze opracovávat jen broušením nebo je lze řezat diamantovými pilami. Proto se někdy místo feritu používá na jádra SMD induktorů feritový prášek spojený pryskyřicí. Vhodné druhy feritů je možno používat i pro kmitočty řádu několika set megahertzů.

Vložením feromagnetického jádra do cívky se zesiluje bohužel i účinek vnějších rušivých magnetických polí. Za všechny jeden prŕíklad z praxe. Výstupní signál oscilátoru byl nevysvětlitelně parazitně kmitočtově modulován $50 \mathrm{~Hz}$. Př́ŕčina byla nalezena ve feromagnetickém jádru cívky oscilátoru, které se nacházelo v rozptylovém poli sítového transformátoru. 
Nežádoucím jevem při aplikaci induktorů $\mathrm{s}$ feritovým jádrem, který může vést až k znehodnocení vlastností je vliv působení silného pulsního magnetického pole (např. v blízkosti hrotu klasické transformátorové páječky při jejím zapnutí či vypnutí), které může způsobit vratné i nevratné změny indukčnosti. Jev lze potlačit zapínáním a vypínáním páječky v dostatečné vzdálenosti od cívky, nebo nejlépe používat k pájení mikropáječku.

Sériově vyráběné cívky jsou určeny většinou k použití jako tlumivky a lze je pořídit $\mathrm{v}$ klasickém i SMD provedení. Axiální tlumivky SMCC (Obr. 7.46ła) připomínají svým pouzdrem rezistory a jsou k dostání $\mathrm{v}$ rozsahu indukčnosti $0,1 \mu \mathrm{H}$ až $10 \mathrm{mH}$ v řadě E12. Hodnota indukčnosti je na nich vyznačena barevnými proužky podobně jako na rezistorech, výsledná indukčnost je $\mathrm{v} \mu \mathrm{H}$. Tlumivky radiální Obr. 7.477) jsou vinuty na feritovém jádru a uzavřeny do plastového pouzdra. Vzhledem $\mathrm{k}$ robustnějšímu feritovému jádru dosahují i větších indukčností - řádově desítek $\mathrm{mH}$ a jsou opět v řadě E12.

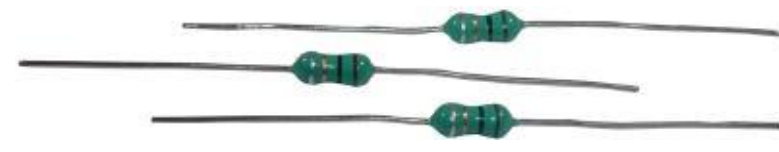

a

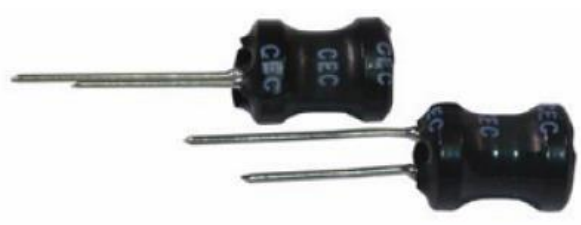

b

Obr. 7.47: Tlumivky na válečkovém toroidním jádře: a) axiální, b) radiální

U cívek s jádrem, jejichž tvary jsou voleny s cílem vytvořit uzavřené magnetické pole cívky, se magnetické pole soustředí hlavně v jádru, což vede nejen ke zvětšení indukčnosti, ale i ke značnému zeslabení rozptylového pole. Nejslabší rozptylové pole mají toroidní cívky (Wirewound Toroidal Choke), u nichž tvar vinutí zabezpečuje velmi dobré zeslabení vnějšího rozptylového pole $\mathrm{v}$ porovnání např. s cívkou válcovou. Na Obr. 7.47je uvedeno rozložení magnetického a elektrického pole kolem toroidní cívky. V obrázku je červenou barvou vyznačena největší intenzita a modrou barvou nejmenší intenzita těchto polí. Je zřejmé, že magnetické pole je soustředěno v jádru cívky (viz Obr. 7.47 a) a to blíže ke středu cívky. Kolem cívky se vyskytuje pouze elektrické pole (viz Obr. 7.47b), které se dá však jednoduše odstranit elektrostatickým stíněním.

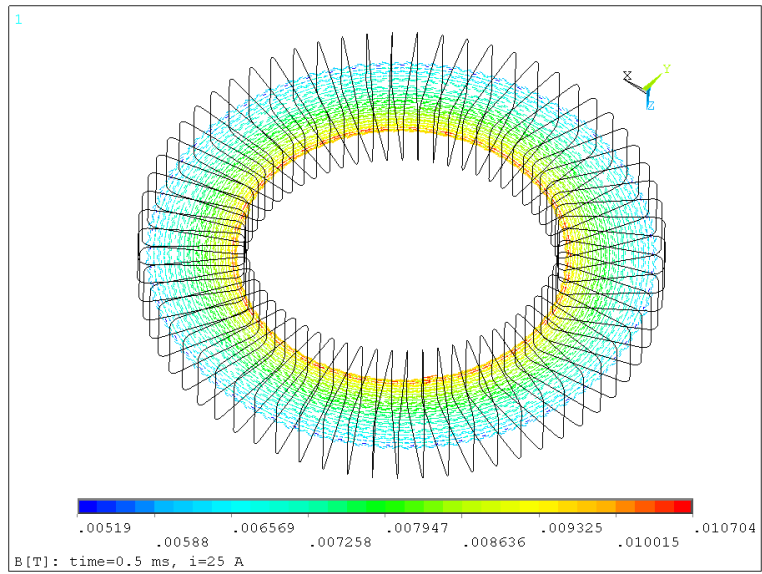

$\mathbf{a}$

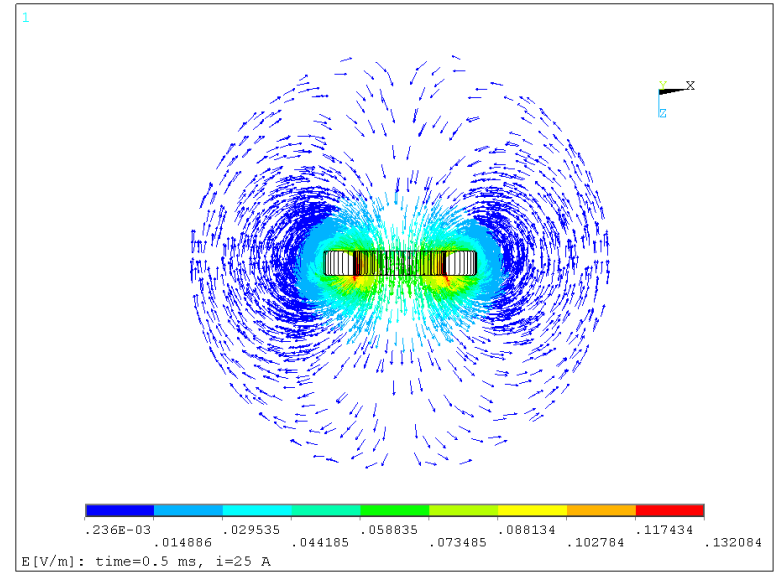

b

Obr. 7.48: a) Magnetická indukce toroidní cívky, b) intenzita elektrického pole v okolí toroidní cívky 
Z uvedených důvodů mají toroidní cívky jednak největší kvalitativní ukazatele a jednak slouží za měřítko pro určení permeability materiálu jádra. Provedení toroidní cívky je uvedeno na Obr. 7.49. Indukčnost toroidní cívky s jádrem (při nízkých kmitočtech) lze určit podle vztahu

$$
L \approx 6,28 \mu N^{2}\left(D-\sqrt{D^{2}-d^{2}}\right) 10^{-3},
$$

kde $L$ je indukčnost $[\mu \mathrm{H}], D$ osový průměr toroidu $[\mathrm{cm}], d$ střední průměr závitů $[\mathrm{cm}], \mu$ poměrná permeabilita toroidního jádra.

Při určování indukčnosti cívek s jádrem jiného tvaru bude stupeň vazby magnetického pole cívky s jádrem jiný a vliv takového jádra se bude lišit od vlivu jádra toroidního. Změny vazby magnetického pole cívky a jejího jádra pro různé konstrukce cívek nelze teoreticky vypočítat, a proto se Častěji se však pro výpočet indukčnosti cívky, zejména při použití feritového jádra, využívá údajů výrobce o tzv. měrné indukčnosti $A_{\mathrm{L}}$ (někdy také indukční konstanta nebo činitel indukčnosti). Je to indukčnost jednoho závitu na př́íslušném jádru a udává se v nH/závit ${ }^{2}$. Indukčnost cívky se pak stanoví jednoduše podle vztahu

$$
L \approx A_{L} N^{2},
$$

kde $L$ je indukčnost $[\mathrm{nH}]$ a $N$ počet závitů cívky. Př́slušný počet závitů stanovíme z předchozího vzorce, tj.

$$
N=\sqrt{L / A_{L}}
$$

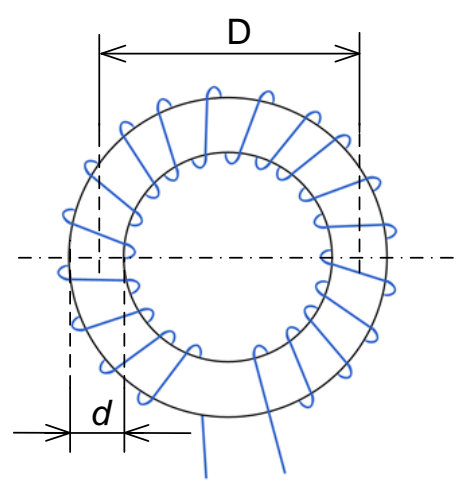

a

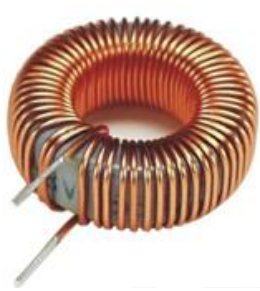

b

Obr. 7.49: a) K výpočtu toroidní cívky, b) př́klad realizace

Někteří výrobci uvádějí indukční konstantu $A_{\mathrm{L}} \mathrm{v} \mu \mathrm{H} / 100$ závitů (nebo též v mH/1000 závitů, takže ji nelze prímo dosadit do předchozích vztahů.

V současnosti nejpoužívanější typy feritových jader jsou uvedeny na Obr. 7.50. Nejjednodušší tvar mají jádra U a C Obr. 7.50^, b), která tvoří uzavřený magnetický obvod po dodání dalšího protikusu stejného tvaru nebo feritu ve tvaru I. Obr. 7.50\&, d, e ukazují různé varianty jader E, přičemž pro uzavření magnetického obvodu lze použít opět tentýž protikus nebo kus tvaru I. Klasické hrníčkové jádro Obr. 7.50]) vyzařuje do okolí nejmenší rušivé magnetické pole. $\mathrm{Na}$ Obr. $7.50 \mathrm{~g}$ je polouzavřené hrníčkové jádro typu EP, které se z obou stran nasadí na cívku umístěnou vodorovně nad DPS. Na Obr. 7.50h je pak nejrozšířenější tvar polouzavřeného hrníčkového jádra, a to tzv. RM jádro, které je stejně jako hrníčkové opatřeno 


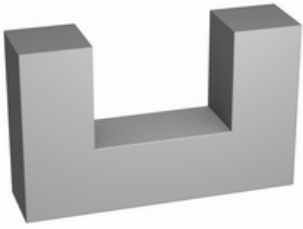

a

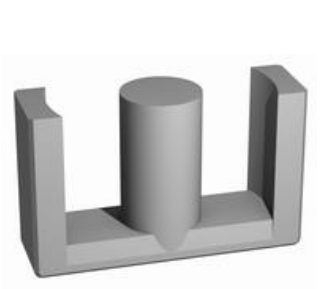

e

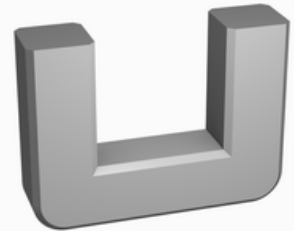

b

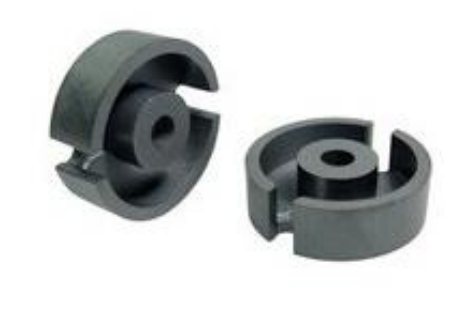

$\mathbf{f}$

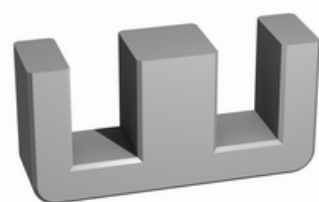

c

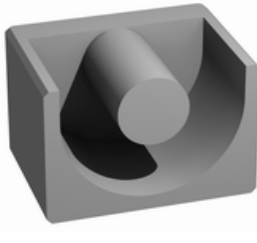

g

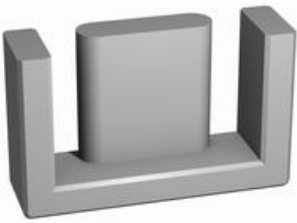

d

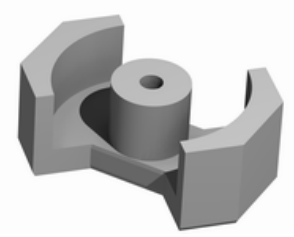

h

Obr. 7.50: a) Jádro U, b) jádro C, c) jádro E, d) jádro EFD, e) jádro ER, f) klasické hrníčkové jádro, g) jádro EP, h) jádro RM

otvorem pro upevnění pomocí šroubu. Připomeňme, že je nutno použít šroub z nemagnetického materiálu (mosazný či umělohmotný), protože železný by způsobil zhoršení vlastností vířivými proudy.

Vazba cívky s jádrem závisí nejen na tvaru jádra a cívky, ale i na jejich vzájemné poloze. Čím je vinutí tlustší v radiálním směru, tím bude vazba menší. Čím pevněji přiléhá cívka $\mathrm{k}$ jádru, tím více se vazba zvětšuje. Proto je výhodné používat pro cívku pokud možno tenkou kostřičku. Hustota magnetického pole má být rovnoměrná v celém objemu jádra. Protože průřrez toroidního jádra je všude stejný, je i hustota magnetického toku všude stejná. V hrníčkovém (resp. polouzavřeném hrníčkovém) jádře se má prưřez vnějšího válce přibližně rovnat ploše vnitřního trnu.

Induktory s hrníčkovými a či jádry RM lze obvykle dolad’ovat feritovými dolad'ovacími jadérky válcového tvaru, která se zašroubují do kruhového otvoru uprostřed. Finální výrobci elektronických zařízení dodávají armaturu k upevňování a stažení hrníčkových jader, popř. dodávají feritové dolad’ovací válečky vložené do plastového výlisku se závitem a drážkou. Při montáži hrníčkových a křižových jader je třeba dbát, aby dosedací plochy obou částí byly vždy dokonale čisté (očištění lihem, otření), cívková tělíska a vlastní cívky musí mít takové rozměry, aby uložením do hrníčkového jádra nevznikly vzduchové mezery, a při lepení je nutno dbát na to, aby lepidlo nevniklo mezi styčné plochy. Lepení se provádí zevně podél styčné plochy obou stisknutých feritových hrníčků.

Obr. 7.51 akazuje planární jádro typu E, které se používá pro konstrukci induktorů, které jsou př́mo tvořeny jednovrstvým nebo vícevrstvým plošným spojem. Princip takového planárního induktoru je zobrazen na Obr. 7.51巾, c. 


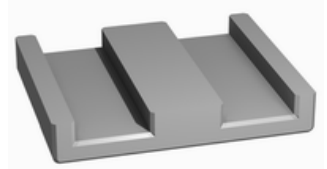

$\mathbf{a}$

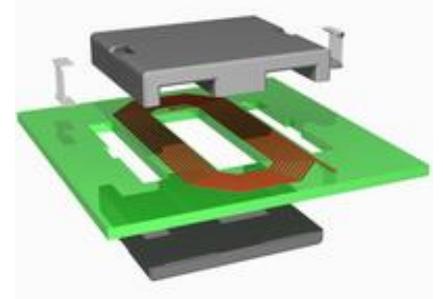

b

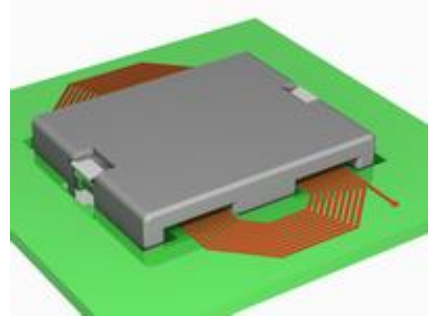

c

Obr. 7.51: a) Planární jádro E, b), c) planární induktor tvořený plošným spojem 


\section{Použitá literatura}

[1] TDK GROUP COMPANY: Film Capacitors. General technical information. EPCOS AG, 2018.

[2] MURATA: Basics of Noise Countermeasures. Lesson 4, Chip ferrite beads. Murata, 2011.

[3] MURATA: Basics of Noise Countermeasures. Lesson 5, Chip 3 terminal capacitors. Murata, 2011.

[4] MURATA: Basics of Noise Countermeasures. Lesson 8, Ferrite Cores. Murata 2012.

[5] MURATA: Basics of Noise Countermeasures. Lesson 11, Notes on the Use of Chip 3-Terminal Capacitors. Murata, 2013.

[6] KÁRNÍK, T. Niobium oxide for capacitor manufacturing, METAL 2008, 13.-15.5. 2008, Hradec nad Moravicí, 2008.

[7] MURATA: Three-terminal Capacitor Structure, No. TE04EA-1, Murata, 2012.

[8] COŽÍK, O. Použití blokovacích kondenzátorů při návrhu DPS. Slaboproudý obzor, roč. 69 (2013), č. 3, P1-P8.

[9] RENECAS: Choosing and Using Bypass Capacitors. Application Note AN 1325, Rev 1.00. Renecas, 2011.

[10] LATICE: Power Decoupling and Bypass Filtering for Programmable Devices. Technical Note TN1068, Lattice Semiconductor Corporation, 2004.

[11] MICRON: Bypass Capacitor Selection for High-Speed Design. Technical Note TN00-06. Micron 2011.

[12] HURST, L.: COMASCHI, A. Power Bypass Decoupling SHARC Processors. Engineer-to-Engineer Note EE-253. Analog Device 2006.

[13] MURATA: Birth of the BLM_E series chip ferrite beads. Entering unexplored BLM territory. Murata 2013.

[14] MURATA: Chip Inductors. Catalog. Murata 2013.

[15] MURATA: Basic Facts Inductors. Lesson 2, Roles of Inductors 1 - Inductors for highfrequency range. Murata 2011.

[16] MURATA: RF Inductor. Introducing the feature of Murata RF inductors and applications. Murata 2017.

[17] VISHAY: Inductors. Instructional Guide VMN-SG2139-1203. Vishay Technology 2012.

[18] LIMJOCO, A. S.; Eco, J. A. Ferrite Beads Demystified. Analog Dialoque 2016.

[19] VISHAY: Inductor and Magnetic Product Terminology. Vishay 2006.

[20] MURATA: EMI Suppressin Filter (for DC)/ Chip Inductors for Automotive. Catalog Murata 2016.

[21] MAXIM: Passives Aren't Really So Passive (Part 1): Capacitors. Application Note. Maxim 2017.

[22] FILKA, M.; VRBA, K. Telekomunikační projekty - specializované přednášky. Ediční středisko VUT v Brně, Brno 1990, ISBN 80-214-0176-1. 


\section{Piezoelektrické krystalové rezonátory}

\subsection{Základní vlastnosti piezoelektrických krystalů}

V přesných oscilátorech, mezifrekvenčních filtrech, v ultrazvukových generátorech atd. se užívají jako rezonátory piezoelektrické krystalové výbrusy. Využívá se u nich piezoelektrického jevu, který spočívá v tom, že při mechanickém namáhání některých krystalů nebo jejich výbrusů tlakem, tahem, ohybem či krutem se na jejich plochách objevují elektrické náboje - tzv. přímý piezoelektrický jev. U vratného piezoelektrického jevu, který se využívá v krystalových rezonátorech, dochází naopak k deformaci či rozkmitání krystalu, jestliže na jeho povrch přivedeme elektrický náboj.

Krystalová jednotka je nejčastěji tvořena vhodným výbrusem krystalu, na který jsou na obou stranách výbrusu naneseny kovové elektrody opatřené vývody. Úpravou elektrod a upevněním výbrusu v držáku se dosáhne toho, že po zapojení do elektrického obvodu, např̀. oscilátoru, se tento piezoelektrický rezonátor rozkmitá mechanicky na vlastním rezonančním kmitočtu (bud' sériovém, nebo paralelním) a elektrické kmity obvodu s velkou přesností udržuje. Krystalový rezonátor se tedy chová jako laděný obvod s velmi velkým činitelem jakosti $Q_{\text {C. }}$ Ten má u křemenných krystalových rezonátorů hodnotu od několika desítek tisíc do několika milionů (s vysoce leštěnými výbrusy, umístěnými ve vakuu a uchycenými pokud možno přesně v uzlech mechanického kmitání).

Způsob výroby krystalů a orientaci jednotlivých řezů k jednotlivým krystalografickým osám zde nebudeme rozebírat. Povšimneme si hlavně elektrických vlastností jednotlivých krystalových řezů. Schématická značka piezoelektrického krystalu je uvedena na Obr. 8.1a. Chování každého krystalu při rezonančním kmitočtu a jeho blízkém okolí můžeme popsat pomocí náhradního modelu, jehož obecný tvar je na Obr. 8.1p.
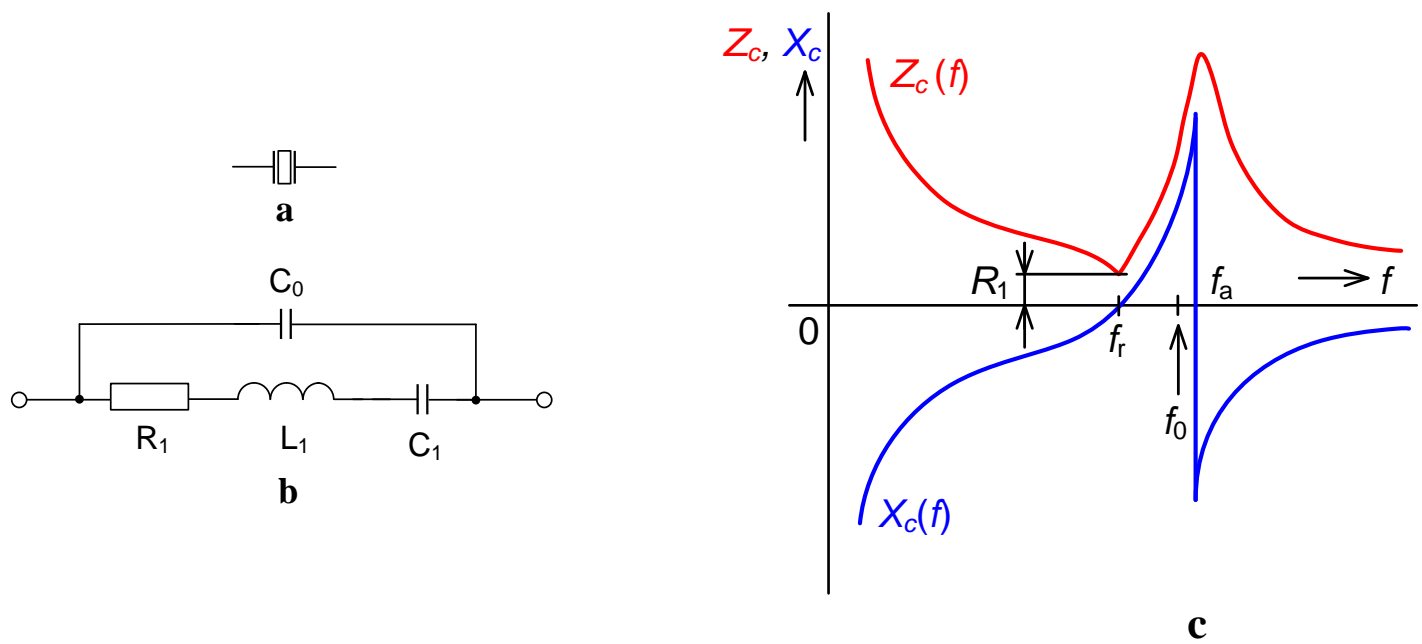

Obr. 8.1: a) Schématická značka krystalu, b) náhradní model krystalového rezonátoru, c) závislost impedance a reaktance krystalu na kmitočtu

Při kmitočtech značně nižších než kmitočet rezonanční se podle náhradního obvodu krystal chová jako prostý kapacitor s kapacitou $C_{\mathrm{p}}$, nebot' impedance cesty $\mathrm{L}_{1} \mathrm{R}_{1} \mathrm{C}_{1}$ je značně velká. Zvyšujeme-li kmitočet, nastává nezávisle na paralelní větvi nejprve sériová rezonance, která nastane právě, když reaktance induktoru $X_{\mathrm{L} 1}=\omega L_{1}$ je rovna reaktanci kapacitoru $X_{\mathrm{C} 1}=1 / \omega C_{1}, \mathrm{tj}$. při kmitočtu 


$$
f_{\mathrm{r}}=\frac{1}{2 \pi \sqrt{L_{1} C_{1}}},
$$

a při ještě vyšším kmitočtu pak nastává paralelní rezonance (tzv. kmitočet potlačení, nebo kmitočet při antirezonanci)

$$
f_{\mathrm{a}}=\frac{1}{2 \pi \sqrt{L_{1} C}}, \operatorname{kde} C=\frac{C_{1} C_{0}}{C_{1}+C_{0}} .
$$

Činitel jakosti krystalového rezonátoru (Quality Factor) je dán poměrem reaktance indukčnosti $X_{\mathrm{L} 1}$ při sériové rezonanci $f_{\mathrm{r}}$ ke ztrátovému odporu $R_{1}$

$$
Q F=Q_{\mathrm{C}}=\frac{X_{\mathrm{L} 1}}{R_{1}}=\frac{\omega_{\mathrm{r}} L_{1}}{R_{1}}=\frac{2 \pi f_{\mathrm{r}} L_{1}}{R_{1}} .
$$

Znalost parametrů elektrického náhradního modelu je důležitá, chceme-li rezonátor použít pro stabilizaci kmitočtu v různých zapojeních oscilátorů, při realizaci selektivních filtrů, př́padně $\mathrm{v}$ dalších aplikacích. Je třeba poznamenat, že v praxi nelze kmitající krystalový rezonátor nahradit odpovídajícím obvodem LC, protože skutečná cívka s indukčností $L_{1}$ danou náhradním obvodem by sama o sobě měla činný odpor mnohem větší, než odpovídá odporu $R_{1}$ krystalu a její vlastní kapacita by v daném kmitočtovém oboru potlačila její induktivní charakter. Právě ve vzájemném poměru jednotlivých parametrů náhradního obvodu, který se nedá realizovat kombinací reálných prvků, je mimořádný význam použití krystalových rezonátorů v elektrických obvodech. Kmitočet krystalového rezonátorů je závislý pouze na jeho geometrických rozměrech, tzn. čím vyšší je kmitočet rezonátoru tím je rezonátor menší.

Impedanci modelu krystalu můžeme zjednodušeně popsat vztahem $\bar{Z}_{C}=R_{1}+\mathrm{j} X_{C}$, kde $R_{1}$ značí sériových odpor a $X_{C}$ reaktanci krystalu. Průběhy modulu impedance a reaktance krystalu v závislosti na kmitočtu uvedené na Obr. 8.1 dávají názornou představu o chování krystalu. Rozmezí kmitočtů mezi $f_{\mathrm{r}}$ a $f_{\mathrm{a}}$ bývá označováno jako šířka pásma krystalu. V praxi je paralelní rezonanční kmitočet o něco málo nižší než $f_{\mathrm{a}}$, což je způsobeno kapacitním zatížením při nastavování kmitočtu při výrobě. VObr. 8.1 je tento kmitočet označen $f_{0}$.

Je zřejmé, že krystal použitý v oscilačním obvodu může pracovat ve dvou možných módech a to $\mathrm{v}$ sériové rezonanci nebo $\mathrm{v}$ paralelní rezonanci s připojenou kapacitní zátěží. Krystaly pracující $v$ různých módech jsou přitom fyzicky shodné, jen byly při výrobě kalibrovány na různé kmitočty. Jestliže byl krystal kalibrován při paralelní rezonanci při určitém kapacitním zatížení, bývá označován jako paralelní zatížený rezonátor (Paralle Load Resonant). Hodnota kapacitního zatížení $\mathrm{C}_{\mathrm{L}}$ pak musí být uvedena v katalogovém listě. Zatěžovací kapacita se uvádí v pF a sestává z vlastní kapacitní zátěže a z parazitních kapacit obvodu oscilátoru. Pokud se tato kapacitní zátěž nepřipojí, bude krystal kmitat na poněkud odlišném kmitočtu, než je uvedeno na pouzdru krystalu. Kalibrace krystalu na sériovou rezonanci nepředstavuje žádné kapacitní zatížení a takovýto krystal bývá označován jako sériových rezonátor (Series Resonant) a kapacitní zátěž není udávána.

\subsection{Parametry piezoelektrických krystalů}

Jmenovitý kmitočet (Nominal Frequency) je referenční či stř̌ední kmitočet krystalu, který byl nastaven při výrobě. Udává se typicky v kilohertzích $(\mathrm{kHz})$ nebo megahertzích $(\mathrm{MHz})$.

Tolerance kmitočtu (Frequency Tolerance, Calibration Accuracy), často nazývaná jako přesnost kalibrace kmitočtu krystalu, udává maximální $(+\Delta f)$ a minimální $(-\Delta f)$ odchylku 
kmitočtu vztaženou ke jmenovitému kmitočtu $f$ při pokojové teplotě $25^{\circ} \mathrm{C}$. Udává se obvykle $\mathrm{v}$ miliontinách

$$
\delta f=\frac{ \pm \Delta f}{f} \cdot 10^{6},[\mathrm{ppm}] .
$$

Stabilita kmitočtu v celém teplotním rozsahu (Frequency Stability Over Operating Temperature Range) udává maximální a minimální odchylku od kmitočtu v celém rozsahu pracovních teplot vztaženou ke jmenovitému kmitočtu př́i pokojové teplotě $25^{\circ} \mathrm{C}$. Udává se $\mathrm{v}$ procentech $(\%)$ nebo $\mathrm{v}$ miliontinách $(\mathrm{ppm})$.

Teplotní charakteristiky rezonátorů se dosti liší podle typu a úhlu řezu krystalem. Průběh teplotní závislosti kmitočtu některých krystalových řezů je naznačen na obr.Obr. 8.2. Teplotní charakteristiky jsou pro porovnání vlastností různých řezů vztaženy k teplotě obratu charakteristik $T_{0}$. Je zřejmé, že při určitých teplotách v okolí teploty obratu mohou být odchylky kmitočtu téměř nulové.

Velmi často je pro běžné aplikace používán řez AT a BT. Řez AT se užívá nejčastěji. Má teplotní charakteristiku typu kubické paraboly a je schopen pracovat s dobrou stabilitou kmitočtu v širokém rozmezí teplot $\left(-60\right.$ až $\left.+120^{\circ} \mathrm{C}\right)$. Řez AT se používá s kmitočty od $800 \mathrm{kHz}$ až do $300 \mathrm{MHz}$. Řez BT má parabolický průběh teplotní závislosti a je použitelný pro menší teplotní rozmezí $\left(-30^{\circ} \mathrm{C}\right.$ až $\left.+90^{\circ} \mathrm{C}\right)$. Pro velmi přesné účely pro provoz v termostatu s vnitřní teplotou nastavenou nad běžnou okolní teplotu je př́hodný řez ST s teplotou obratu $T_{0}=93^{\circ} \mathrm{C}$, nebo jeho vysokoteplotní modifikace s $T_{0}=103^{\circ} \mathrm{C}$.

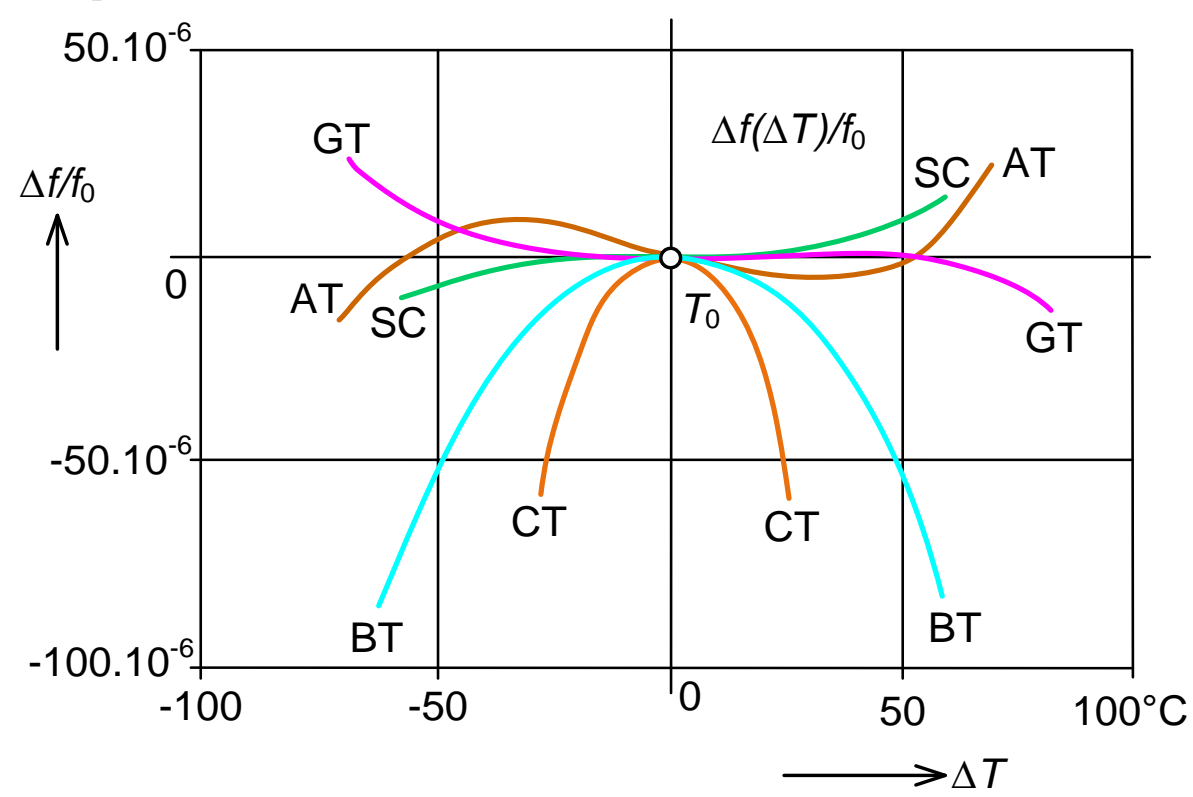

Obr. 8.2: Charakteristické průběhy teplotních závislostí kmitočtů řezů křemene; CT, BT $\left(T_{0}=20^{\circ} \mathrm{C}\right)$, AT $\left(T_{0}=25^{\circ} \mathrm{C}\right), \mathrm{SC}\left(T_{0}=93^{\circ} \mathrm{C}\right.$ nebo $T_{0}=103^{\circ} \mathrm{C}$ pro vysokoteplotní modifikaci), GT $\left(T_{0} \approx 40^{\circ} \mathrm{C}\right)$

Dlouhodobá stabilita kmitočtu je význačným parametrem pro přesná elektronická zařízení. Udává relativní odchylku kmitočtu vztaženou na časovou jednotku. Největší stabilita dosahovaná dnes ve světě se udává $1 \cdot 10^{-9} /$ týden.

Sériový rezonanční kmitočet (Series Resonant Frequency) je rezonanční kmitočet krystalu $f_{\mathrm{r}}$ pracujícího v sériovém módu, tj. bez kapacitní zátěže. Sériový rezonanční kmitočet $f_{\mathrm{r}} \mathrm{je}$ vždy 
nižší, než paralelní rezonanční kmitočet s kapacitní zátěží $f_{0}$. Hodnota kapacitní zátěže $C_{\mathrm{L}}$ není v tomto př́ipadě v katalogovém listu vůbec uvedena.

Paralelní rezonančni kmitočet při kapacitni zátěži (Parallel Load Resonance) je rezonanční kmitočet krystalu $f_{0}$ zjištění měřením při určité kapacitní zátěži $C_{\mathrm{L}}$. Tento kmitočet závisí na konstrukci krystalu a hodnotě zatěžovacího kapacitoru $\mathrm{C}_{\mathrm{L}}$. Pokud je krystal určen pro práci v paralelním režimu, musí být kapacita zatěžovacího kapacitoru uvedena v katalogovém listu.

Zatěžovací kapacita (Load Capacitance). Při kalibraci se kmitočet paralelní rezonance měří a přesně dostavuje s určitou kapacitní zátěží (obvykle 20 až 30 pF). Tato hodnota kapacitní zátěže bývá uvedena v katalogovém listě. Pokud nebudeme krystal provozovat za stejných podmínek, bude krystal kmitat na poněkud odlišném kmitočtu než je uvedeno na pouzdru. Paralelní rezonanční kmitočet $f_{0}$ totiž závisí na kapacitě kapacitní zátěže. Pokud je zatěžovací kapacita $\mathrm{C}_{\mathrm{L}}$ uvedena $\mathrm{v}$ katalogovém listu, je evidentní, že krystal je určen pro práci v paralelním módu.

Ekvivalentni sériový odpor ESR (Equivalent Series Resistance) je typický parametr uváděný výrobci. ESR je reálná část impedance krystalu zatíženého kapacitní zátěží $C_{\mathrm{L}}$, která se zjistí při sériovém resonančním kmitočtu $f_{\mathrm{r}}$. ESR je často chybně zaměňován s rezistorem $\mathrm{R}_{1} \mathrm{v}$ náhradním modelu rezonátoru (viz Obr. 8.1b). Jde však o ekvivalentní odpor, který krystal představuje při sériové rezonanci a souvisí s odporem rezistoru $\mathrm{R}_{1}$ přibližně podle vztahu

$$
E S R=R_{1}\left(1+C_{0} / C_{\mathrm{L}}\right)^{2}
$$

kde $C_{0}$ je paralelní kapacita v náhradním modelu a $C_{\mathrm{L}}$ je zatěžovací kapacita. Ekvivalentní sériový odpor se měří při sériovém rezonančním kmitočtu, nikoliv na paralelním rezonančním kmitočtu.

Zatížitelnost (Drive Level) krystalových rezonátorů je také důležitým údajem při výběru krystalu. Udává největší výkon, který se může trvale rozptýlit na výbrusu krystalové jednotky, aniž se zásadně změní její parametry. Dovolené zatížení závisí na provedení rezonátoru a na jeho kmitočtu. Bývá rozmezí $0,1 \mu \mathrm{W}$ až $20 \mathrm{~mW}$. Kmitočet oscilátoru řízeného krystalem je tím stabilnější, čím nižší je úroveň buzení.

\subsection{Typy piezoelektrických krystalů}

Konstrukce krystalového piezoelektrického rezonátoru je principiálně vždy obdobná. Jde o výbrus krystalu, který je po obou stranách opatřen napařenými elektrodami. Výbrus je uchycen do držáku a elektrody jsou připojeny k vývodům (viz Obr. 8.3. Způsob zapouzdření krystalu ovlivňuje dlouhodobou stabilitu kmitočtu krystalu. Kontaminace výbrusu krystalu uvnitř pouzdra při jeho výrobě totiž způsobuje jeho rychlejší stárnutí. 


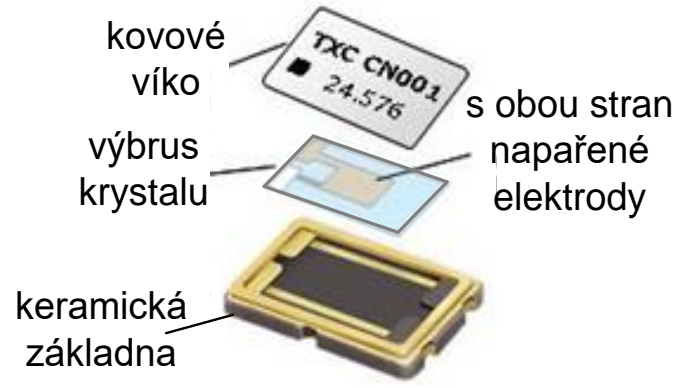

$\mathbf{a}$

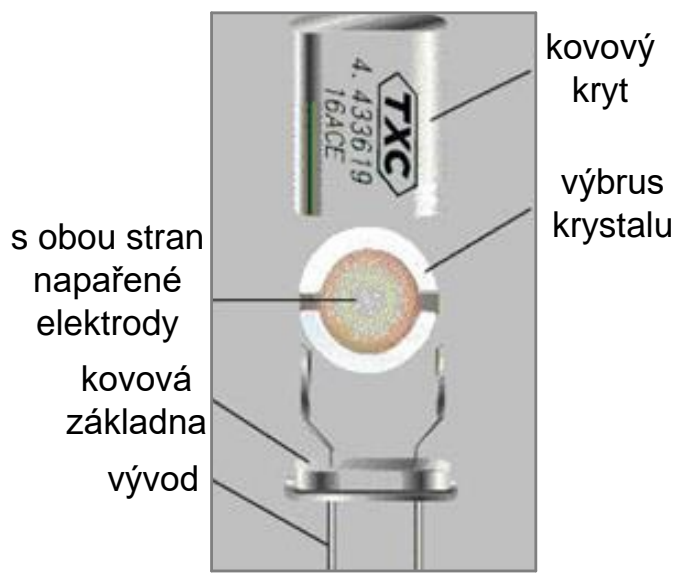

b

Obr. 8.3: Vnitřní provedení krystalového rezonátoru: a) SMD keramické pouzdro, b) vývodové kovové pouzdro

Z tohoto pohledu je nejméně šetrnou metodou zapouzdření zapájení kovového krytu k základně klasickou cínovou pájkou. Bohužel je to stále ještě jeden z často užívaných způsobů zapouzdření. $V$ tomto př́padě se dá očekávat horší dlouhodobá stabilita kmitočtu $\pm 10 \mathrm{ppm} / \mathrm{rok}$. Podobné vlastnosti mají i SMD krystaly v plastovém pouzdru určené pro běžné, průmyslové aplikace. U pouzder pájených $\mathrm{v}$ ochranné atmosfére nebo u SMD keramických pouzder lze očekávat dlouhodobou stabilitu $\pm 2 \mathrm{ppm} / \mathrm{rok}$. Nejlepších výsledků $\pm 0,5 \mathrm{ppm} /$ rok se dosahuje u krystalů zatavených do skleněného pouzdra. Vnější provedení jednotlivých typů krystalových rezonátorů jsou uvedeny na Obr. 8.4.

Teplotní vlastnosti, rozměry krystalu a oblast kmitočtového použití jsou dány polohou řezu krystalu vzhledem ke krystalografickým osám a přesným úhlem řezu. Typické vlastnosti často použivaných řezů shrnuje Tab 8.1.

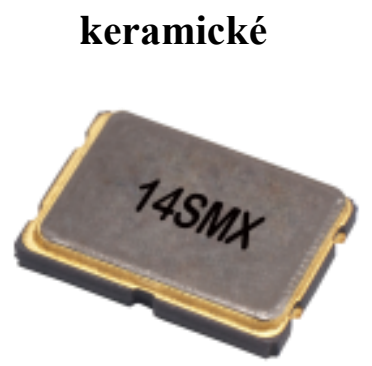

v plastu

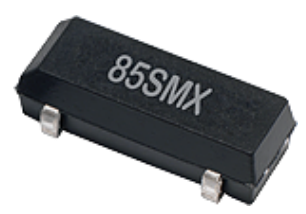

kovové

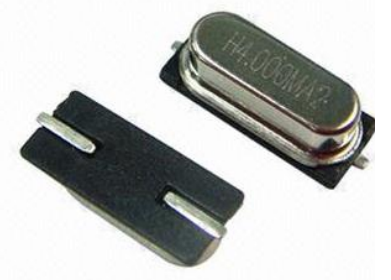

ultrastabilní

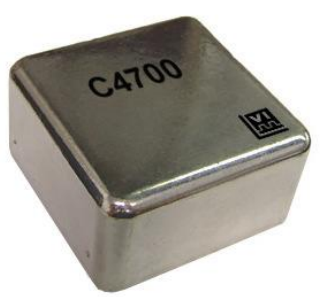

s drátovými vývody
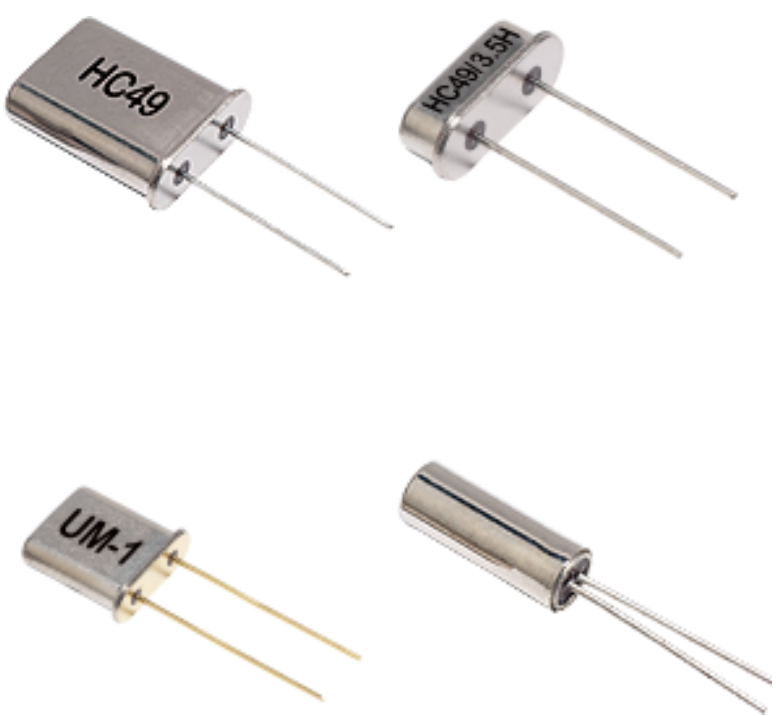

Obr. 8.4: Pizoelektrické krystalové rezonátory 
Tab 8.1: Vlastnosti krystalových rezonátorů

\begin{tabular}{|c|c|}
\hline Řez & Typické vlastnosti \\
\hline $\begin{array}{l}\text { AT } \\
500 \mathrm{kHz} \\
\text { až } \\
300 \mathrm{MHz}\end{array}$ & $\begin{array}{l}\text { Řez AT se u krystalových rezonátorů používá nejčastěji. Nacházejí aplikace } \\
\text { v elektronických př́strojích pro taktování digitálních obvodù. Dobré } \\
\text { teplotní vlastnosti v širokém rozmezí teplot a bod obratu teplotní } \\
\text { charakteristiky při }+25^{\circ} \mathrm{C} \text { je předurčuje pro práci bez termostatu. }\end{array}$ \\
\hline $\begin{array}{c}\text { SC } \\
500 \mathrm{kHz} \\
\text { až } \\
200 \mathrm{MHz}\end{array}$ & $\begin{array}{l}\text { Řez SC byl speciálně vyvinut pro přesné aplikace a pro umístění do } \\
\text { termostatového prostoru, kdy je zapotřebí uvnitř termostatu udržovat } \\
\text { teplotu podstatně vyšší než je teplota uvnitř přístroje. Řez SC vykazuje } \\
\text { vynikající stabilitu kmitočtu v okolí teploty } 93^{\circ} \mathrm{C} \text {, resp. teplotní modifikace } \\
\text { řezu SC má optimální stabilitu kmitočtu při teplotě } 103^{\circ} \mathrm{C} \text {. }\end{array}$ \\
\hline $\begin{array}{l}\text { BT } \\
500 \mathrm{kHz} \\
\text { až } \\
200 \mathrm{MHz}\end{array}$ & $\begin{array}{l}\text { Řez BT je podobný řezu AT, ale používá poněkud jiný úhel řezu vzhledem } \\
\text { ke krystalografickým osám. Stabilita kmitočtu však není tak vynikající jako } \\
\text { je tomu u řezu AT. }\end{array}$ \\
\hline $\begin{array}{c}\mathbf{X Y} \\
5 \mathrm{kHz} \\
\text { až } \\
100 \mathrm{kHz}\end{array}$ & $\begin{array}{l}\text { Řez XY je používán pro nízké kmitočty a obvykle jen pro kmitočet } 32,768 \\
\mathrm{kHz} \text {. Dělením dvěma se dá z takovéhoto kmitočtu krystalu odvodit časový } \\
\text { interval } 1 \mathrm{~s} \text {. Výhodou jsou velmi malé rozměry a malý poměr } \mathrm{C}_{0} / \mathrm{C}_{1} \text {. Má } \\
\text { podobnou teplotní charakteristiku jako řez } \mathrm{BT}, T_{0}=20^{\circ} \mathrm{C} \text {. }\end{array}$ \\
\hline $\begin{array}{l}\text { GT } \\
100 \mathrm{~Hz} \\
\text { až } \\
2,5 \mathrm{kHz}\end{array}$ & $\begin{array}{l}\text { Rez GT se vyznačuje tím, že v rozmezí teplot }+25 \text { až }+75^{\circ} \mathrm{C} \text { vykazuje téměř } \\
\text { nulovou teplotní závislost kmitočtu a je tedy vhodný pro provoz bez } \\
\text { termostatu. }\end{array}$ \\
\hline
\end{tabular}

\subsection{Aplikační doporučení}

Je známa celá řada zapojení oscilátorů s krystalovým rezonátorem. Obvykle se však užívají jedno či dvě osvědčená zapojení oscilátorů. Nejčastěji se užívá modifikace Colpittzova zapojení oscilátoru nazývaná Peirsův oscilátor. Prakticky všechny krystalové oscilátory užívané pro taktování číslicových obvodů jsou realisovány Piersovým zapojením, protože může být realizován s minimem obvodových komponentů. U tohoto zapojení budou ukázána některá úskalí, která mohou vést $\mathrm{k}$ nesprávně činnosti oscilátoru s krystalovým rezonátorem.

Jako aktivní prvek lze Piersově oscilátoru použít bipolární nebo unipolární tranzistor s mezním kmitočtem, tj. s kmitočtem kdy proudový zesilovací činitel tranzistoru poklesne na hodnotu jedna, alespoň desetkrát vyšším než je kmitočet krystalu. V dnešní době se však jako aktivní prvek nejčastěji použivá logický invertor, který je pomocí zpětnovazebního rezistoru $\mathrm{R}_{\mathrm{F}}$ nastaven do lineární oblasti Obr. 8.5. 


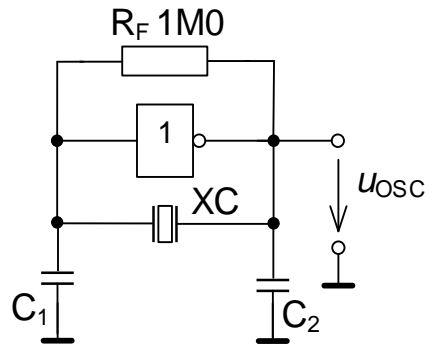

$\mathbf{a}$

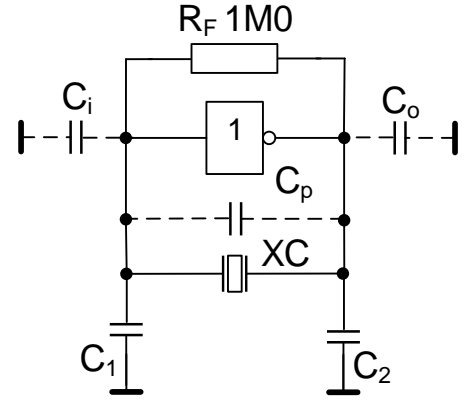

b

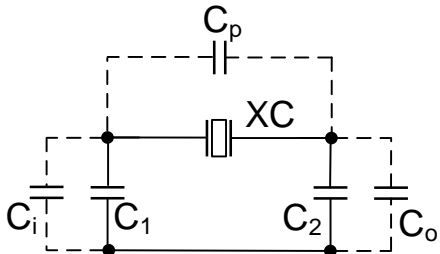

c

Obr. 8.5: Piersův oscilátor: a) zapojení, b) parazitní kapacity, c) k určení kapacitní zátěže krystalového rezonátoru

Předpokládejme, že invertor má vysokou vstupní impedanci a téměř nulovou výstupní impedanci. Rezistor $R_{F}$ pak nastavuje invertoru vstupní napětí shodně s výstupním napětím. Invertor pak nebude překlopen do úrovně $\mathrm{H}$ ani $\mathrm{L}$, ale bude pracovat $\mathrm{v}$ přechodové oblasti jako

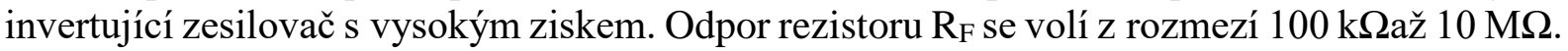
Obvykle se užívá hodnota $1 \mathrm{M} \Omega$.

Krystal v kombinaci $\mathrm{s}_{1}$ a $\mathrm{C}_{2}$ při paralelní rezonanci tvoří pásmovou zádrž, která při rezonanci vykazuje fázové natočení o $180^{\circ}$. Společně s fázovým natočením $180^{\circ}$ invertujícího zesilovače bude celkové natočení fáze ve smyčce zpětné vazby $360^{\circ}$ a oscilátor bude kmitat.

Paralelní rezonanční kmitočet krystalu je udáván pro kapacitní zátěž, která byla použita při měření kmitočtu během kalibrace. Pokud má tedy krystal kmitat na kmitočtu paralelní rezonance uvedené na pouzdru krystalu, musí být za provozu zatížen v oscilátoru stejnou kapacitní zátěží. Častou chybou při návrhu předepsané kapacitní zátěže je zanedbání vstupní a výstupní kapacity $\mathrm{C}_{\mathrm{i}}(3 \mathrm{až} 5 \mathrm{pF})$ a $\mathrm{C}_{\mathrm{o}}(5 \mathrm{až} 10 \mathrm{pF})$ invertoru, které celkem významně mohou změnit kapacity kapacitorů $\mathrm{C}_{1} \mathrm{a} \mathrm{C}_{2}$, protože jsou $\mathrm{k}$ těmto kapacitorům připojeny paralelně (viz Obr. 8.5p).

Vzhledem ke krystalovému rezonátoru se kapacitory $C_{1}$ a $C_{2}$ společně s kapacitory $C_{i} a$ $\mathrm{C}_{\mathrm{o}}$ jeví připojeny v sérii jako jeho zátěž. Započteme-li do kapacitní zátěže krystalu ještě vzájemnou parazitní kapacitu př́vodů na DPS společně s parazitní kapacitou mezi vstupem a výstupem invertoru $\mathrm{C}_{\mathrm{p}}(2$ až $4 \mathrm{pF})$, budou všechny tyto kapacitory představovat kapacitní zátěž krystalu Obr. 8.54). Skutečná kapacitní zátěž krystalu tedy bude dána nejen sériově spojenými kapacitami kapacitorů $\mathrm{C}_{1}$ a $\mathrm{C}_{2}$, ale i všemi parazitními kapacitami v obvodu

$$
C_{\mathrm{L}}=\frac{\left(C_{\mathrm{i}}+C_{1}\right)\left(C_{\mathrm{o}}+C_{2}\right)}{C_{\mathrm{i}}+C_{1}+C_{\mathrm{o}}+C_{2}}+C_{\mathrm{p}} .
$$

Předpokládejme, že krystalový rezonátor má v katalogovém listu předepsánu kapacitní zátěž $\mathrm{C}_{\mathrm{L}}=30 \mathrm{pF}$. Jestliže parazitní kapacity $C_{\mathrm{i}}$ a $C_{\mathrm{o}}$ nejsou přesně známy, tak odhad $5 \mathrm{pF}$ a pro $\mathrm{C}_{\mathrm{p}}$ odhad $3 \mathrm{pF}$ jsou dostatečně přesné pro prvotní výpočet. Jsou možné dva př́stupy k výpočtu $\mathrm{C}_{1}$ a $\mathrm{C}_{2} \mathrm{z}$ rov.(8.34), kdy v prvém př́padě se předpokládá $C_{1}=C_{2}=C$, nebo v druhém př́ípadě se zvolí $\mathrm{C}_{1}$ a vypočítává se $\mathrm{C}_{2}$. Pokud zvolíme první případ, pak pro předepsanou kapacitní zátěž $C_{\mathrm{L}}=30 \mathrm{pF}$ a uvažované parazitní kapacity bude $C_{1}=C_{2}=62 \mathrm{pF}$. Pokud odhad $C_{\mathrm{i}}$ a $C_{\mathrm{o}}$ nebyl přsesný, můžeme později oscilátor optimalizovat změnou počáteční hodnoty $C_{1}$ nebo $C_{2}$. 


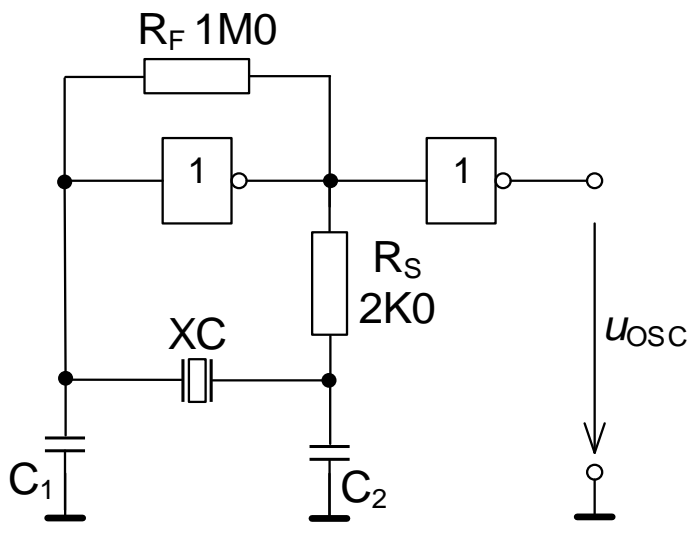

$\mathbf{a}$

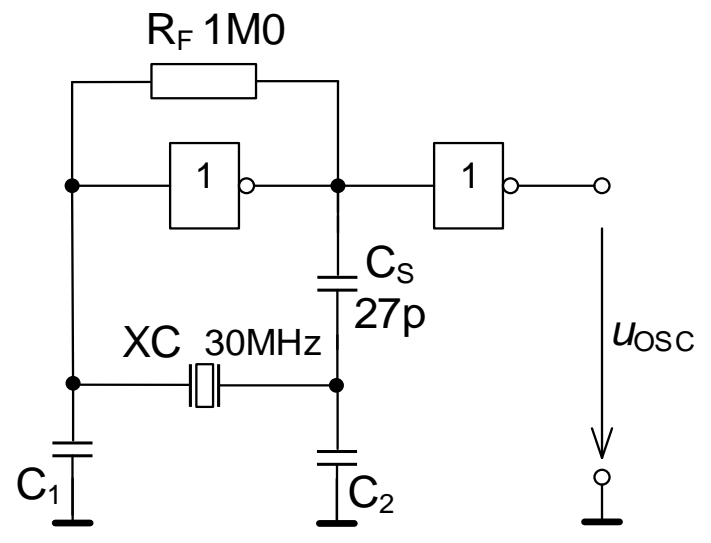

b

Obr. 8.6: a) Ochrana před rozkmitáním na jiném kmitočtu, b) modifikace zapojení pro práci na vyšších kmitočtech

Někteří autoři důrazně doporučují doplnit do série s výstupem invertoru sériový rezistor $\mathrm{R}_{\mathrm{S}}$ Obr. 8.6申), který společně $\mathrm{s} \mathrm{C}_{2}$ přidá do obvodu zpětné vazby další fázový posun a snižuje tak pravděpodobnost rozkmitání oscilátoru na nižším kmitočtu. Současně se tímto urychlí nasazení kmitů při zapnutí. Resistor $R_{S}$ zvyšuje výstupní odpor invertoru a jeho hodnota bývá v rozmezí $500 \Omega$ až $5 \mathrm{k} \Omega$. Pro zlepšení nástupních a sestupných hran a z důvodu větší zatížitelnosti se za oscilátor doplňuje vždy další oddělovací invertor (viz také Obr. 8.6 l). Typické uspořádání Piersova oscilátoru uvedené na Obr. 8.6 lze použít přibližně do jednotek MHz. Časové zpoždění hradla totiž representuje přídavné fázové natočení, což způsobí přebytek celkového fázového natočení ve zpětnovazební smyčce oscilátoru. Aby se zabránilo dodatečnému fázovému posuvu, který by mohl vést až k vysazení kmiti̊, doporučuje se rezistor $\mathrm{R}_{S}$ nahradit kapacitorem $\mathrm{C}_{S}$ Obr. 8.6). Kapacita tohoto kapacitoru se volí tak, aby při rezonančním kmitočtu krystalu $f_{0}$ byla jeho reaktance

$$
X_{\mathrm{S}}=\frac{1}{\omega_{0} C_{\mathrm{S}}}=\frac{1}{2 \pi f_{0} C_{\mathrm{S}}}
$$

rovna původnímu odporu $R_{\mathrm{S}}$ (obvykle $R_{\mathrm{S}}=2 \mathrm{k} \Omega$ ). Kapacita kapacitoru Cs však nemá být menší než $20 \mathrm{pF}$. Např. pro krystal s rezonančním kmitočtem $30 \mathrm{MHz}$ podle tohoto doporučení bude $\mathrm{C}_{\mathrm{S}}=27 \mathrm{pF}$.

Častou chybou při návrhu Piersova oscilátoru je výběr nevhodného typu krystalu z hlediska zvolené rezonance, při které byl při výrobě kalibrován. Piersův oscilátor totiž vždy nutí krystal kmitat v blízkosti paralelního rezonančního kmitočtu. To proto, že v blízkosti paralelního rezonančního kmitočtu krystal společně $\mathrm{s} \mathrm{R}_{\mathrm{S}}, \mathrm{C}_{1}$ a $\mathrm{C}_{2}$ Obr. 8.6ł) se chová jako pásmová zádrž, která je ve zpětné vazbě zapotřebí pro rozkmitání Piersova oscilátoru, kdežto při sériové rezonanci představuje pásmovou propust. Když tedy v Piersově oscilátoru použijeme krystal kalibrovaný pro provoz při sériové rezonanci (kdy se navíc užívá jiný způsob kalibrace), bude oscilátor kmitat o několik kHz výše, než je hodnota napsaná na pouzdře krystalu, tj. při paralelní rezonanci. Připomeňme, že u krystalů určených a kalibrovaných pro sériový mód se nikdy neuvádí hodnota kapacitní zátěže.

Složité číslicové obvody, které potřebují pro svoji činnost přesné taktování, mají obvykle připraveny $\mathrm{v}$ integrovaném obvodu dva invertory pro použití v generátoru taktovacích pulsů a $\mathrm{z}$ vnějšku se $\mathrm{k}$ obvodu připojí pouze krystal s pasivními prvky. Krystal s pasivními prvky se připojuje $\mathrm{k}$ integrovanému obvodu jen krátkými př́vody Obr. 8.7. Kapacitory $\mathrm{C}_{1}$ a $\mathrm{C}_{2}$ se doporučuje co nejkratším způsobem spojit prokoveným odporem s centrální vnitřní zemnicí 
vrstvou vícevrstvé DPS. Jinak se začne v obvodu oscilátoru uplatňovat i parazitní indukčnost tohoto spoje. Také se nedoporučuje v blízkosti obvodu oscilátoru (ani ve vnitřních vrstvách DPS) vést signálové spoje, kde dochází k prudkým změnám úrovní (např. logické signály).

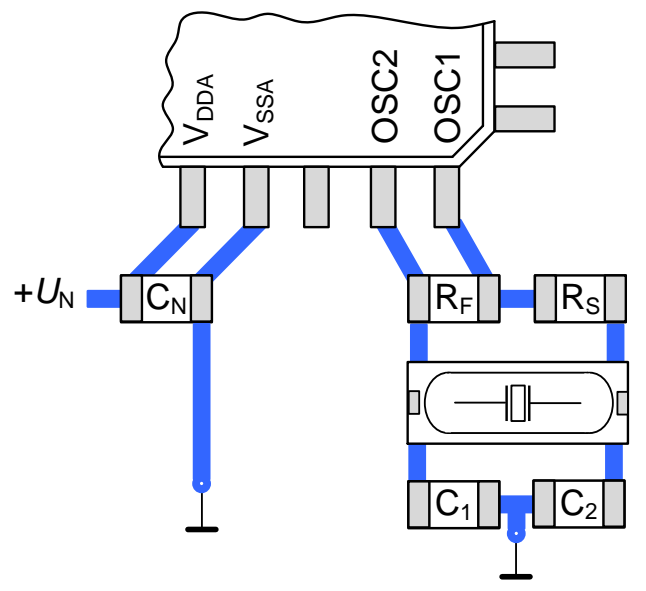

Obr. 8.7: Doporučené uspořádání krystalem řízeného oscilátoru na DPS 


\section{Použitá literatura}

[12] ERHART, J.; PŮlPÁN, P.; PUSTKA, M.: Piezoelectric Ceramic Resonators. Springer, Switzerland 2017, ISBN 978-3-319-42481-1.

[2] RADIO-ELECTRONIC. Quartz Crystal Cuts. Electronic Components (http: //www.radio-electronics.com/info/data/crystals/quartz-crystal-cuts-at-sc-ct.php).

[3] FAIRCHILD. HCMOS Crystal Oscillators. Application Note 340. Fairchild Semiconductor 1998.

[4] ECLIPTEK. Quartz Crystal Glossary of Terms. Ecliptec Corporation 2016.

[5] LOURENTS, R. Practical PICmicro Oscillator Analysis and Design, AN 943. Microchip Technology 2004.

[6] LAPTECH PRECISION. Mono Crystalline Quartz - The Piezoelectric Effect. Laptech Precision 2011.

[7] CERDA, R. Pierce-gate oscillator crystal load calculation. Crystek Crystal Corp. 2004.

[8] STATEK. What is frequency at load capacitance? Technical Note 33. Statek Corporation 2017.

[9] STATEK. Comparsion of Low Frequency Oscillator Designs. Technical Note 24. Statek Corporation 2016.

[10] STATEK. Practical Analysis of the Pierce Oscillator. Technical Note 31. Statek Corporation 2017.

[11] TXC CORPORATION. TXC Technical Terminology. TXC Corporation 2010.

[12] PAVLOVEC, V; ŠLAMAR, J. Krystalové jednotky a oscilátory. Amatérské rádio, B/2, 1987, s. 42-60. 


\section{Ochrana před přepětím a nadproudem}

V provozu může být elektronické zařízení vystaveno vnějšímu přepětí či nadproudům, které se mohou objevit přívodních na napájecích i na vstupních signálových vodičích zařízení. Aby nedošlo ke zničení citlivých elektronických obvodů či k návazným škodám na majetku (např. požáru), musí být každé zařízení proti těmto jevům chráněno. Všechny komerčně prodávané elektrické spotřebiče jsou proto ze zákona testovány, zda jsou dostatečně odolné (tzv. elektromagnetická kompatibilita). V této kapitole je uveden přehled nejběžnějších ochranných prvků, které se v praxi používají.

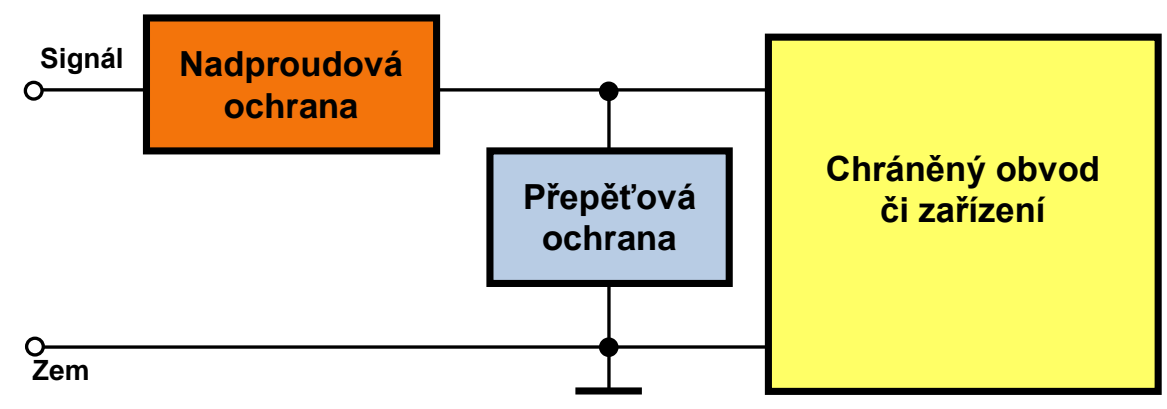

Obr. 9.1: Obvyklé připojení ochran na vstupu či výstupu zařízení

Jak ukazuje Obr. 9.1, nadproudová ochrana se zapojuje do signálového vodiče sériově s chráněným obvodem. Její funkcí je chráněný obvod při překročení povoleného proudu odpojit, nebo omezit poruchový proud na tak nízkou hodnotu, která chráněný obvod (ale i přepět'ovou ochranu) nepoškodí. Přepět’ová ochrana je pak zapojena paralelně mezi signálový vodič a zem. Její funkce je uzpůsobena k tomu, aby se přep̌tí omezilo nebo aby se pro přepětí ochrana chovala jako zkrat. Je zřejmé, že v obou případech musí být zemní rozvod konstruován tak, aby dokázal poruchové proudy spolehlivě odvést. V praxi se v zařízeních používá samostatně vedená „,poruchová zem“, která je s ostatními zeměmi spojena v jediném bodě. Díky tomu poruchové proudy nemohou ovlivnit citlivé elektronické součástky ve zbytku zařízení. V každém případě je nutné zajistit, aby poruchové proudy protékaly co nejkratší drahou a proto se obě ochrany umíst’ují co nejblíže vstupnímu konektoru.

\subsection{Přepět'ové a nadproudové jevy}

Pro lepší pochopení problematiky přepět’ové ochrany je nutné provést alespoň základní rozdělení přepětových jevů, které ukazuje Obr. 9.2. Dlouhodobá prepětí (permanent overvoltage) obvykle vznikají při poruše izolace. Typicky nastávají při souběžném vedení silových a komunikačních kabelů ve stoupačkách budov, kabelových žlabech, podzemních kolektorech apod. Při poškození izolace kabelů se na komunikačních vodičích objeví např. sítové napětí $230 \mathrm{~V}$ (v angličtině se tento stav označuje termínem power cross). Může též vzniknout poruchou externího napájecího zdroje zařízení apod. Pro efektivní ochranu proti trvalému přepětí je vždy nutné použít i prvky pro ochranu nadproudovou. 


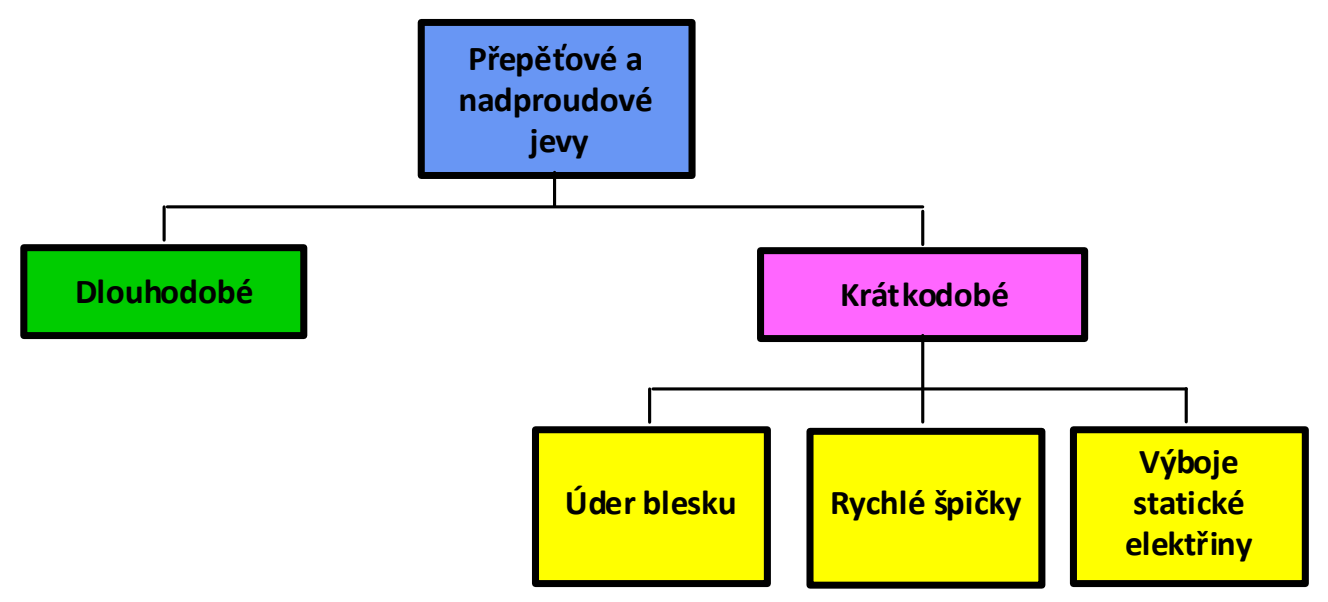

Obr. 9.2: Klasifikace přepět’ových a nadproudových jevů

U krátkodobých přepětí (transient overvoltage) je situace složitější, protože jejich napětí, proudy i rychlost se velmi výrazně liší podle toho, co je vyvolalo. V běžném provozu jsou častější výboje statické elektřiny (Electro Static Discharge, ESD), která se při pohybu hromadí na věcech denní potřeby (oblečení a obuv, nábytek, podlahové krytiny), ale i na samotných elektronických zařízeních. Mnohé z těchto věcí jsou přitom konstruovány z kvalitních izolanti̊ (plastů), takže jejich vzájemný potenciál může snadno přesáhnout $10 \mathrm{kV}$. Při vzájemném přiblížení pak dojde k přeskoku napětí (výboj, jiskra), který rozdíl potenciálů vyrovná. Tento děj je extrémně rychlý. Jak ukazuje Obr. 9.3a, náběžná hrana výboje má okolo $1 \mathrm{ns,} \mathrm{přičemž}$ špičková velikost proudu může dosáhnout až $30 \mathrm{~A}$. Celková energie výboje je nízká (jednotky $\mathrm{mJ}$ ), ale přesto jejich vysoká napětí spolehlivě zničí citlivé polovodičové součástky, zejména izolační bariéry hradel tranzistorů v CMOS obvodech. Bipolární polovodiče jsou proti ESD výrazně odolnější, ale ani ony nejsou zdaleka imunní.

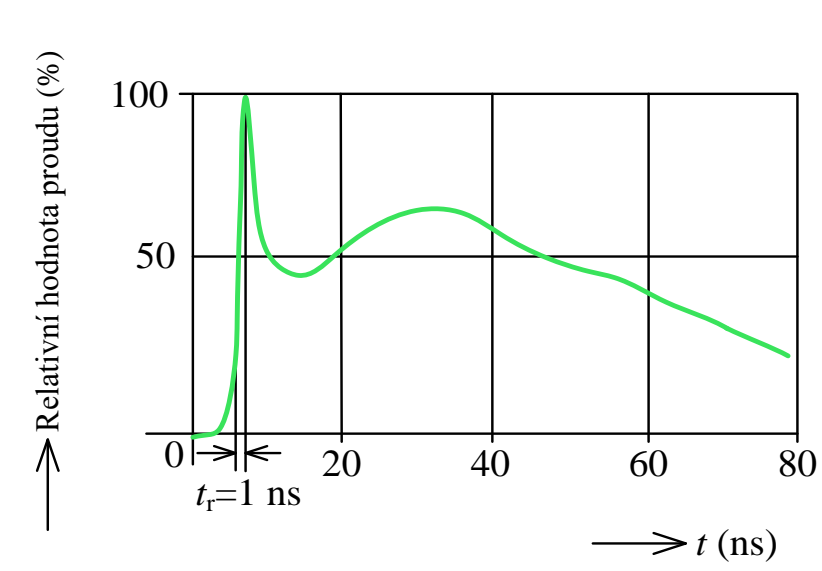

$\mathbf{a}$

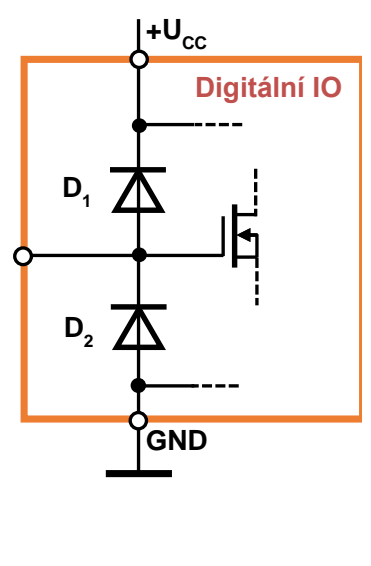

b

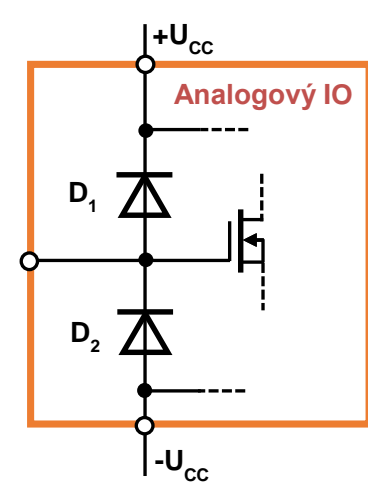

Obr. 9.3: a) Časový průběh ESD výboje, b) ochranné diody na vstupu digitálního CMOS IO, c) ochranné diody pro analogový CMOS IO

Každé na trh uváděné elektronické zařízení musí být ze zákona na ESD odolnost testováno. Testování se provádí podle různých norem, přičemž ESD se simuluje vybitím kondenzátoru nabitého na určité napětí do zkoušeného zařízení. Testují se všechny vstupy, 
výstupy a povrchy zařízení určitým počtem ESD výbojů obou polarit. Napětí a počet výbojů závisí na povaze zařízení. Např́íklad medicínské př́stroje musejí být výrazně odolnější, než běžná spotřební elektronika. V Tab 9.1 jsou pro ilustraci uvedena napětí používaná v testech dle normy IEC 61000-4-2, pro různá zařízení jsou předepsány různé ,úrovně“ testu.

Stojí za zmínku, že ve většině moderních logických CMOS integrovaných obvodech jsou př́mo na čipu ochranné diody, zapojené podle Obr. 9.3b. Pokud se na vstupu objeví napětí vyšší než $U_{\mathrm{CC}}+U_{\mathrm{D} 1}$ otevře se dioda $\mathrm{D}_{1}$ resp. pro napětí nižší než $U_{\mathrm{D} 2}$ se otevře $\mathrm{D}_{2}$ a vstup je proti přepětí chráněn. $\mathrm{V}$ př́ípadě analogového CMOS integrovaného obvodu Obr. 7.3 a) se ochranné diody otevřou při přepětí $U_{\mathrm{CC}}+U_{\mathrm{D} 1}$ nebo při - $\left(U_{\mathrm{CC}}+U_{\mathrm{D} 2}\right)$ Tyto diody však dokáží $\mathrm{IO}$ ochránit pouze před malými ESD výboji vznikajícími při běžné manipulaci (osazování na desky apod.). Výrobci obvykle udávají odolnost do $1,5 \mathrm{kV}$. Jinými slovy, neošetřené vstupy takto „chráněných“ CMOS IO nevydrží ani nejnižší úroveň IEC 61000-4-2 testu. Některé komunikační IO mohou mít ochranné diody na vyšší napětí, ale to vždy záleží na konkrétním typu.

Tab 9.1: Parametry testovacích ESD výbojů dle IEC 61000-4-2

\begin{tabular}{|c|c|c|c|c|c|}
\hline Úroveň IEC testu & $\begin{array}{c}\text { Testovací napětí, } \\
\text { kontaktní výboj } \\
{[\mathrm{kV}]}\end{array}$ & $\begin{array}{c}\text { Testovací napětí, } \\
\text { vzdušný výboj } \\
{[\mathrm{kV}]}\end{array}$ & $\begin{array}{c}\text { Špičkový } \\
\text { proud [A] }\end{array}$ & $\begin{array}{c}\text { Proud v } \\
\text { čase } 30 \text { ns } \\
{[\mathrm{A}]}\end{array}$ & $\begin{array}{c}\text { Proud v } \\
\text { čase } 60 \text { ns } \\
{[\mathrm{A}]}\end{array}$ \\
\hline 1 & 2 & 2 & 7,5 & 4 & 2 \\
\hline 2 & 4 & 4 & 15 & 8 & 4 \\
\hline 3 & 6 & 8 & 22,5 & 12 & 6 \\
\hline 4 & 8 & 15 & 30 & 16 & 8 \\
\hline
\end{tabular}

Do kategorie krátkodobých špiček patř́ i úder blesku (lighting surge) je ve skutečnosti výboj statické elektřiny, ovšem s extrémními parametry. Byly zaznamenány blesky, ve kterých špičkový proud přesahoval $200 \mathrm{kA}$ a rozdíl potenciálů pro jejich vznik se odhaduje stovky megavoltů. $V$ praxi se naštěstí nestává, že blesk udeří př́ímo do obnaženého ${ }^{1}$ vodiče, protože v cestě mu stojí různé ochrany (hromosvod) či překážky (zdivo, zemina, izolace, stínicí obal kabelu atd.). Úder blesku však ve svém okolí vyvolává silná elektromagnetická pole, která mohou ve vodičích nepřímo naindukovat velké proudy. Testování odolnosti zařízení proti těmto jevům se opět provádí podle různých norem, přičemž každá doporučuje jiné proudy a jiné tvary testovacích průběhů. Jeden z nejznámějších je tzv. 8/20 $\mu$ s průběh dle normy IEC 61000-4-5, který je uveden na Obr. 7.4 . Velikost špičkového proudu průběhu se mění v závislosti na povaze zařízení, např. pro zařízení připojená k venkovním kabelům je to až $1 \mathrm{kA}$. Ve stejné normě jsou definovány i přepětové testovací průběhy. Na Obr. 9.4b je pro ilustraci průběh napětí označovaný jako $1,2 / 50 \mu \mathrm{s}$. Špičkové testovací napětí se mění od $500 \mathrm{~V}$ do $4 \mathrm{kV}$, opět podle povahy testovaného zařízení. Nadproudy a přepětí vyvolané bleskem mají naštěstí zhruba $1000 \times$ pomalejší náběžnou hranu, než je tomu u ESD. Díky tomu je poměrně snadné je potlačit, i přes jejich značnou energii.

\footnotetext{
${ }^{1} \mathrm{U}$ rozvodů silové elektřiny někdy $\mathrm{k}$ přímému úderu blesku dochází. Taková zařízení se testují průběhem označovaným jako 10/350 $\mu$ s, kdy špičkový testovací proud má až 100 kA.
} 


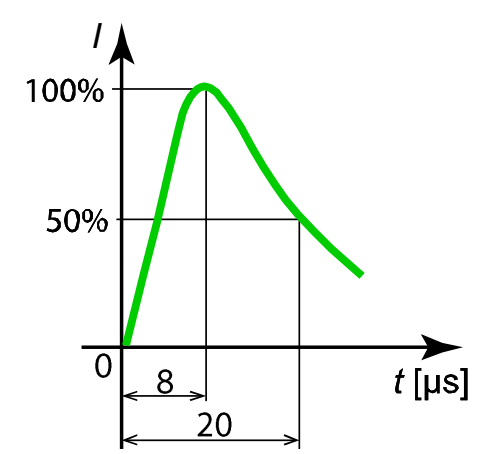

$\mathbf{a}$

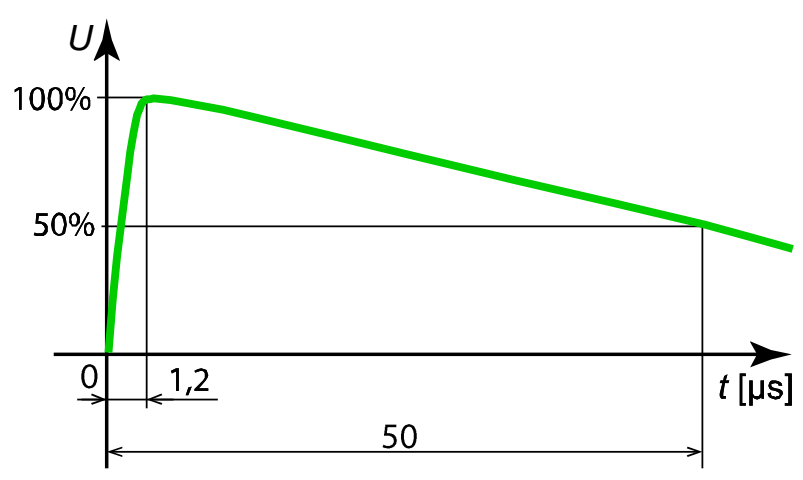

b

Obr. 9.4: Př́iklad testovacích průběhů nepřímého úderu blesku

Posledním typem krátkodobých poruchových jevi̊ z Obr. 9.2 jsou rychlé přepět'ové a nadproudové špičky (Electrical Fast Transients, EFT). Přepět'ové špičky vznikají nejčastěji při rozepínání induktivních zátěží, v sít’ovém rozvodu $230 \mathrm{~V}$ pak mohou špičky napětí vypadat např. jako na Obr. 9.5 ł. Špičky se prritom mohou i pravidelně opakovat, typicky v komutátorech sériových elektro motorů, což je způsobeno rychlým spínáním a odpojováním induktivních zátěží. Nadproudové špičky pak vznikají při zapínání velkých zátěží (inrush current), ale i ony se mohou pravidelně opakovat - typickým př́padem jsou neodrušené usměrňovače připojené prímo na rozvodnou sít', které z ní odebírají jen krátké proudové pulsy pro dobíjení filtračního kondenzátoru. Na tomto typu poruchových jevů je zákeřné, že mohou být velmi rychlé např́iklad přepět'ové špičky při rozepínání induktivních zátěží Obr. 9.5ł) mají náběžné hrany v nanosekundách a špičkové napětí může dosáhnout $1 \mathrm{kV}$. Díky ostrým hranám se pak mohou šiřit i nepř́mo přes různé kapacitní a induktivní vazby do signálových vodičů.

I odolnost zařízení proti těmto jevưm se pochopitelně testuje. V praxi se to provádí injektováním standardizované série pulsů (anglicky burst) přímo do testovaných vodičů, př́ípadně i nepřímo, za pomoci různých přípravků simulujících kapacitní a induktivní vazby. $\mathrm{Na}$ Obr. 9.5b je pro ilustraci nákres jedné testovací série pulsů podle normy IEC 61000-4-4. Samotný puls se vyznačuje ostrou náběžnou hranou a pozvolnější sestupnou hranou. Každé zařízení je testováno pro různý počet pulsů v jedné sérii, např̀. doba trvání pulsu $t_{\text {pulse }}$ se mění od 10 do $200 \mu$ s a čas $t_{\text {burst }}$ od 0,75 do 15 ms. Podle povahy testovaného zařízení se volí špičkové napětí pulsů, a to od $500 \mathrm{~V}$ do $4 \mathrm{kV}$. 


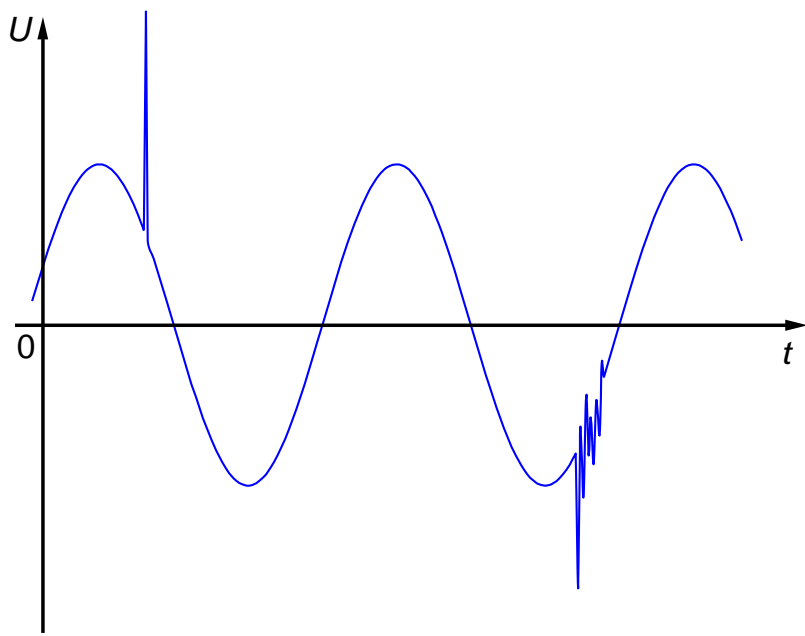

a

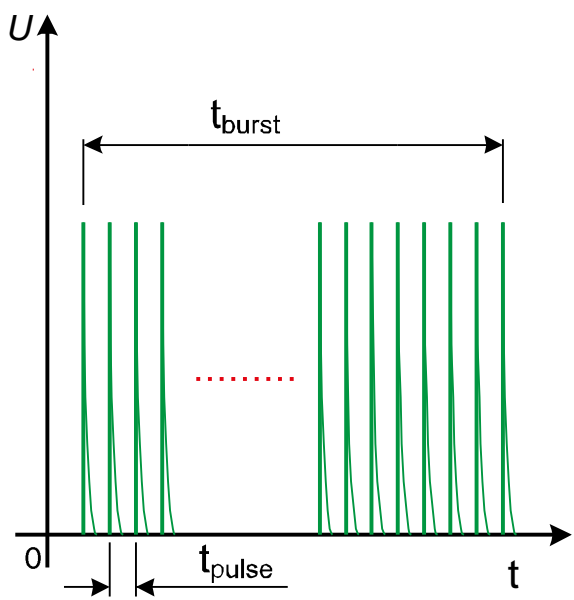

b

Obr. 9.5: Přepět’ové špičky v rozvodu $230 \mathrm{~V}$ a testovací série pulsů

Je zřejmé, že většina krátkodobých poruchových jevů má velmi široké kmitočtové spektrum; v praxi se proto pro jejich potlačení používá kombinace odrušovacích filtrů a ochranných prvků.

\subsection{Přepět'ové ochrany}

V zájmu prrehlednosti jsou přepětové ochranné prvky $\mathrm{v}$ této kapitole popisovány samostatně, v praxi se však vždy přepětí a nadproudy objevují současně. Je to ostatně logické, při zvýšení napětí na obvodu dochází i ke zvýšení protékajícího proudu (a naopak). Jak bude uvedeno dále, poruchový proud je u mnoha přepět'ových prvkủ důležitá veličina, kterou je nutné sledovat. V praxi se proto velmi často přepět'ové a nadproudové ochrany kombinují, jak bude na několika př́kladech ukázáno později. Pro rychlou orientaci jsou v Tab 9.2 vedeny typické elektrické parametry přepětových ochranných prvků a v Tab 9.3 pak jejich aplikační možnosti. V následujících podkapitolách jsou jednotlivé prvky rozebrány podrobněji. 
Tab 9.2: Přehled elektrických parametrů přepětových ochran

\begin{tabular}{|l|c|c|c|c|c|c|c|}
\hline \multicolumn{1}{|c|}{ Prvek } & $\begin{array}{c}\text { Jmenovité } \\
\text { napětí [V] }\end{array}$ & $\begin{array}{c}\text { Špičkový } \\
\text { poruchový } \\
\text { proud }\end{array}$ & $\begin{array}{c}\text { Rychlost } \\
\text { reakce }\end{array}$ & $\begin{array}{c}\text { Svodový } \\
\text { proud }\end{array}$ & $\begin{array}{c}\text { Parazitní } \\
\text { kapacita }\end{array}$ & Polarita & Typ reakce \\
\hline Bleskojistka & $70-1200$ & $40 \mathrm{kA}$ & $1 \mu \mathrm{s}$ & $<1 \mathrm{nA}$ & $<5 \mathrm{pF}$ & Bipolární & Spínač \\
\hline Varistor & $10-1000$ & $30 \mathrm{~A}$ & cca $100 \mathrm{~ns}$ & až $1 \mathrm{~mA}$ & $50-2000 \mathrm{pF}$ & Bipolární & Omezovač \\
\hline Polymerový varistor & $40-250$ & $30 \mathrm{~A}$ & $<1 \mathrm{~ns}$ & $<1 \mathrm{nA}$ & $<0,2 \mathrm{pF}$ & Bipolární & Omezovač \\
\hline Transil & $3-500$ & $1000 \mathrm{~A}$ & cca $1 \mathrm{ps}$ & typ. $1 \mu \mathrm{A}$ & $5-1000 \mathrm{pF}$ & Unip. i bip. & Omezovač \\
\hline Tyristorová ochrana & $5-600$ & $400 \mathrm{~A}$ & cca $1 \mathrm{~ns}$ & typ. $10 \mu \mathrm{A}$ & $5-200 \mathrm{pF}$ & Unip. i bip. & Spínač \\
\hline Zenerova dioda & $2-300$ & neudává se & neudává se & $10-100 \mu \mathrm{A}$ & $20-3000 \mathrm{pF}$ & Unipolární & Omezovač \\
\hline
\end{tabular}

Tab 9.3: Přehled doporučených aplikačních možností přepět’ových ochran

\begin{tabular}{|c|c|c|c|}
\hline Prvek & Oblast ochrany & Výhody & Nevýhody \\
\hline Bleskojistka & $\begin{array}{l}\text {-Úder blesku } \\
\text {-Dlouhodobé prepětí }\end{array}$ & $\begin{array}{l}\text {-Velmi vysoké poruchové proudy } \\
\text {-Spínací charakteristika (crowbar) } \\
\text {-Nízká parazitní kapacita } \\
\text {-Malé svodové proudy }\end{array}$ & $\begin{array}{l}\text {-Velké rozměry } \\
\text {-Pomalá reakce } \\
\text {-Vysoká cena } \\
\text {-Omezená životnost }\end{array}$ \\
\hline Varistor & $\begin{array}{l}\text {-Všechna přepětí } \\
\text {-Omezeně ESD }\end{array}$ & $\begin{array}{l}\text {-Nízká cena } \\
\text {-Velmi široká nabídka } \\
\text {-Vysoká pohlcená energie }\end{array}$ & $\begin{array}{l}\text {-Vysoká par. kapacita } \\
\text {-Vysoká impedance v aktivním stavu } \\
\text {-Omezená životnost }\end{array}$ \\
\hline $\begin{array}{l}\text { Polymerový } \\
\text { varistor }\end{array}$ & -Jen ESD & $\begin{array}{l}\text {-Nízká cena } \\
\text {-Velmi nízká parazitní kapacita } \\
\text {-Rychlá reakce }\end{array}$ & $\begin{array}{l}\text {-Dokáže ESD omezit jen na cca } 150 \mathrm{~V} \\
\text {-Vysoká impedance v aktivním stavu }\end{array}$ \\
\hline Transil & -Všechna přepětí & $\begin{array}{l}\text {-Extrémně rychlá reakce } \\
\text {-Přesnost jmenovitého napětí }( \pm 5 \%) \\
\text {-Nízká impedance } v \text { aktivním stavu } \\
\text {-Nízký svodový proud } \\
\text {-I typy s nízkou parazitní kapacitou } \\
\text {-Neomezená životnost }\end{array}$ & -Poměrně malá pohlcená energie \\
\hline $\begin{array}{l}\text { Tyristorová } \\
\text { ochrana }\end{array}$ & $\begin{array}{l}\text {-Úder blesku } \\
\text {-Dlouhodobé prepětí }\end{array}$ & $\begin{array}{l}\text {-Spínací charakteristika (crowbar) } \\
\text {-Neomezená životnost } \\
\text {-I typy s nízkou parazitní kapacitou }\end{array}$ & $\begin{array}{l}\text {-Nutný pečlivý výběr a testování } \\
\text {-Nedokáže reagovat na rychlé děje }\end{array}$ \\
\hline $\begin{array}{l}\text { Zenerova } \\
\text { dioda }\end{array}$ & $\begin{array}{l}\text {-Nízkonákladové } \\
\text { aplikace, hlavně ESD }\end{array}$ & $\begin{array}{l}\text {-Velmi nízká cena } \\
\text {-Přesnost jmenovitého napětí }( \pm 2 \%)\end{array}$ & $\begin{array}{l}\text {-Nedefinovaná pulsní zatížitelnost } \\
\text {-Nedefinovaná rychlost reakce } \\
\text {-Velké svodové proudy } \\
\text {-Vysoká parazitní kapacita }\end{array}$ \\
\hline
\end{tabular}

Z hlediska způsobu reakce na přepětí se ochranné prvky dělí do dvou velkých skupin:

1. Spínací ochranné prvky (crowbar device) při přepětí sepnou a začnou se chovat jako zkrat na vstupu zařízení ${ }^{2}$. Tím přepětí dokáží snížit na velmi nízké úrovně. Tuto charakteristiku bohužel mají pouze dva prvky, a to bleskojistky a tyristorové ochrany. NaObr. 9.6 je pro ilustraci reakce bleskojistky na napětový puls (blíže kapitola 0].

2. Omezovací ochranné prvky (clamping device) pouze nedovolí, aby přepětí překročilo určitou mez. Takto se chovají všechny ostatní přepětové ochrany popsané v tomto textu. $\mathrm{Na}$ Obr. 9.6 je prríklad typické reakce varistoru na napětový puls (blíže kapitola 0 .

\footnotetext{
${ }^{2}$ Z toho pochází i jejich anglické označení - prvek se chová, jako kdybychom obvod zkratovali pomyslným páčidlem (crowbar) či jiným masivním kusem kovu.
} 


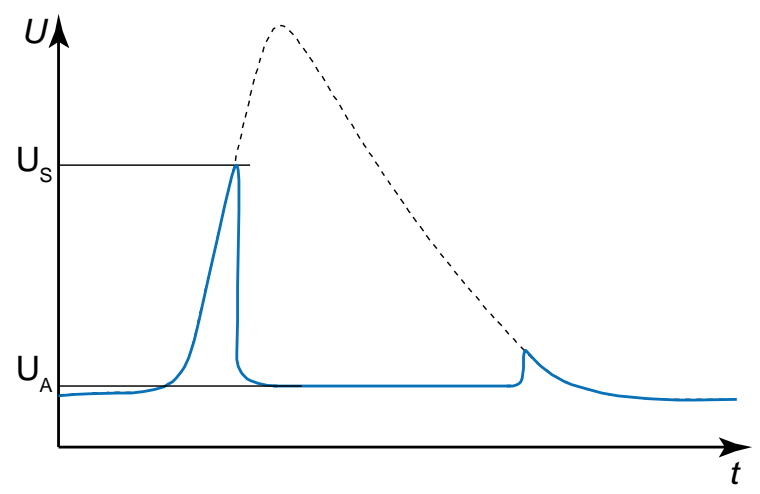

$\mathbf{a}$

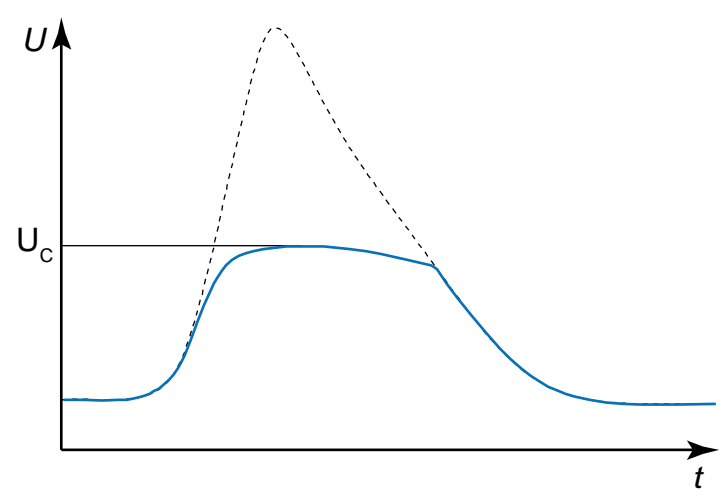

b

Obr. 9.6: Reakce ochrany na přepětový puls: a) spínacího prvku, b) omezovacího prvku

\section{Bleskojistky (GDT)}

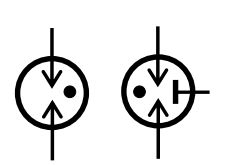

Bleskojistky (Gas Discharge Tube, GDT) mají podobu nevodivé (keramické) dutiny se dvěma elektrodami, která je vyplněna plynem o nízkém tlaku Obr. 9.7 ). Běžně dostupné jsou též dvojité bleskojistky pro ochranu dvou vodičů současně (viz Obr. 9.7b). V zásadě se jedná o doutnavku speciální konstrukce, která snese velké poruchové proudy. Při normálním provozu má bleskojistka velmi vysokou impedanci, typicky větší než $1 \mathrm{G} \Omega$. Se zvyšujícím se napětím postupně dochází k ionizaci plynu a tím ke snižování impedance; průběh ampérvoltové charakteristiky je naznačen na Obr. 9.74. Při dosažení jmenovitého zapalovacího napětí $U_{\mathrm{S}}$ (spark-over voltage) dojde mezi elektrodami k zapálení doutnavého výboje. Procházející proud sníží úbytek napětí na bleskojistce na $U_{\mathrm{GL}}$ (glow voltage). Doutnavý výboj však u moderních bleskojistek trvá velmi krátkou dobu ( 50 ns) a slouží jen jako pomocný mechanizmus pro stimulovanou emisi elektronů $\mathrm{z}$ povrchu elektrod. Tím dojde $\mathrm{k}$ masivní lavinové ionizaci plynu, jeho průrazu a mezi elektrodami bleskojistky začne hořet oblouk. Úbytek napětí na ní skokově klesne na velikost $\mathrm{U}_{\mathrm{A}}$ (arc voltage), což na Obr. 9.7ł naznačuje čárkovaná část charakteristiky. Po dobu hoření oblouku se tedy bleskojistka chová téměř jako zkrat (crowbar device). 


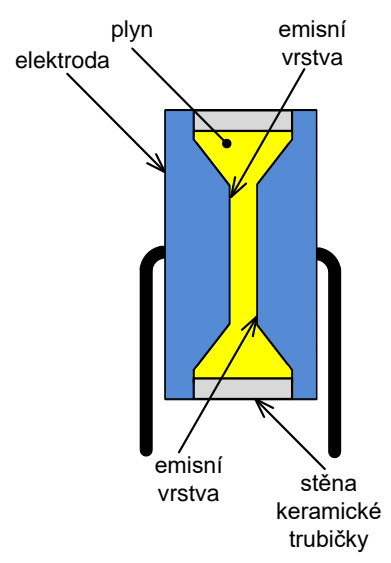

a

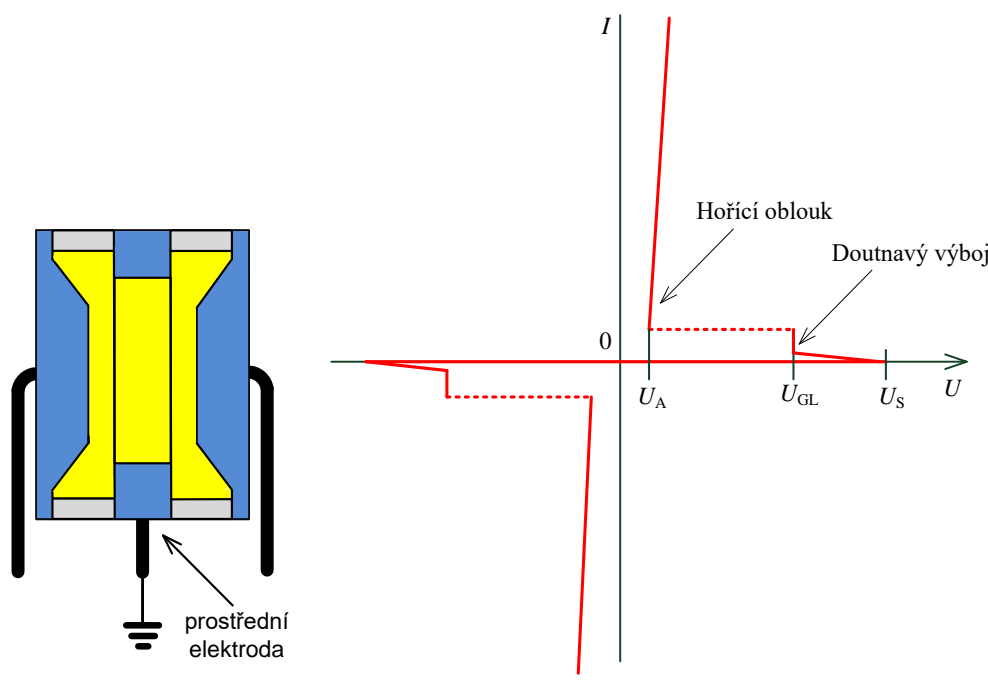

b

c

Obr. 9.7: a) Bleskojistka, b) dvojitá bleskojistka, c) AV charakteristika bleskojistky

Bleskojistky jsou součástky, které dokáží do země odvést velkou energii (běžné typy snesou poruchové proudy do $40 \mathrm{kA})$. Mají též malou parazitní kapacitu $(<5 \mathrm{pF})$, takže je lze použít ve vf aplikacích (ochrana svodů antén). Jsou však pomalé (reakční doba se pohybuje okolo $1 \mu \mathrm{s}$ ) a jejich zapalovací napětí se kus od kusu výrazně mění (tolerance $\pm 20 \%$ ). Používají se proto pouze jako hrubá ochrana proti těm největším přepětím, které mohou vzniknout po úderu blesku. V praxi je vždy nutné je kombinovat s dalšími ochranami přesnějšími a rychlejšími.

Každá aktivace bleskojistku postupně poškozuje, zejména její speciální vrstvu pro emisi elektronů na elektrodách (viz Obr. 9.7 ). Jejich životnost silně závisí na síle výbojů a podle toho je také nutné je při návrhu zařízení vybírat. Vyrábějí se v SMD i drátovém provedení, př́klady provedení bleskojistek jsou na Obr. 9.8 A, provedení dvojité bleskojistky je pak na Obr. 9.8b. V profesionálních zařízeních (informační systémy apod.) jsou bleskojistky často umístovány na samostatné panely (například na kabelové patch panely, viz Obr. 9.84), aby je bylo možné snadno zkontrolovat a vyměnit.

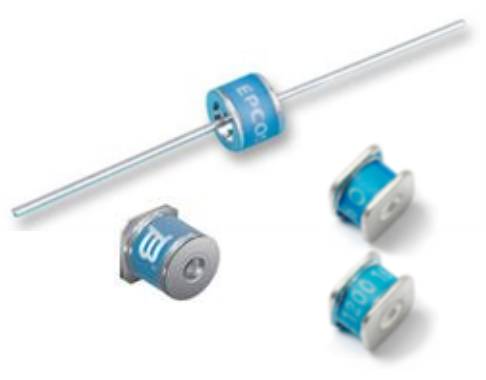

$\mathbf{a}$

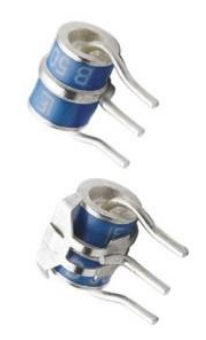

b

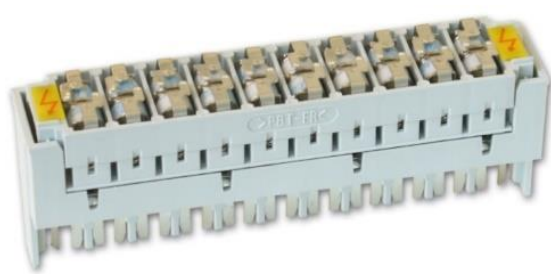

c

Obr. 9.8: a) Různá provedení bleskojistek, b) dvojité bleskojistky, c) držák bleskojistek do patch panelu 


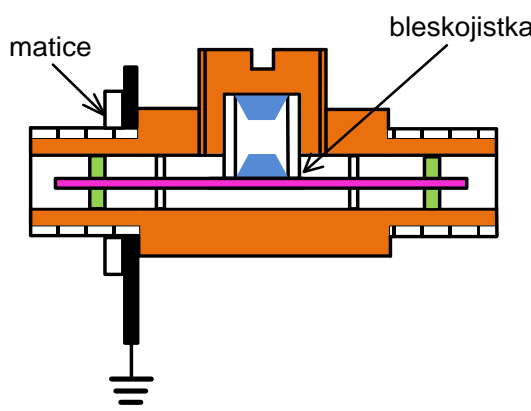

$\mathbf{a}$

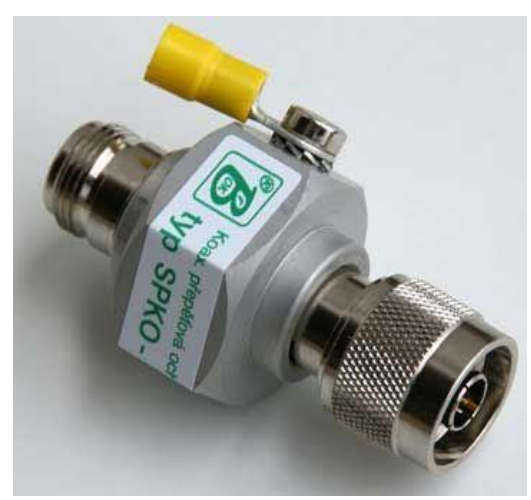

b

Obr. 9.9: a) Princip koaxiální bleskojistky, b) př́íklad provedení

Vyrábějí se i koaxiální bleskojistky, které se vkládají do koaxiálního anténního svodu (viz Obr. 9.9. Koaxiální bleskojistka je schopna uchránit zařízení při přímém úderu blesku do anténního svodu.

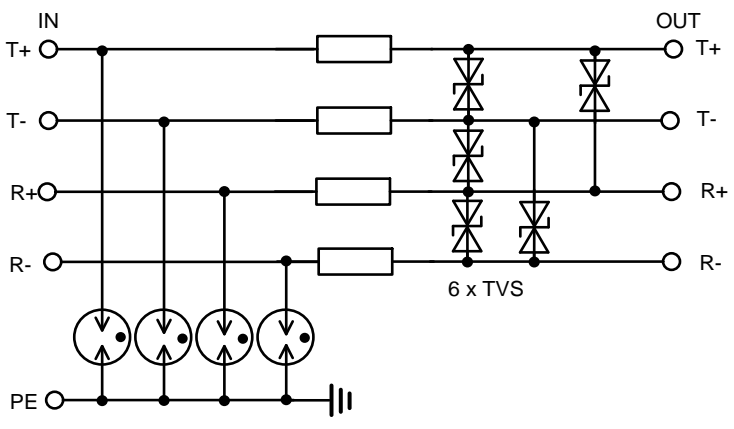

a

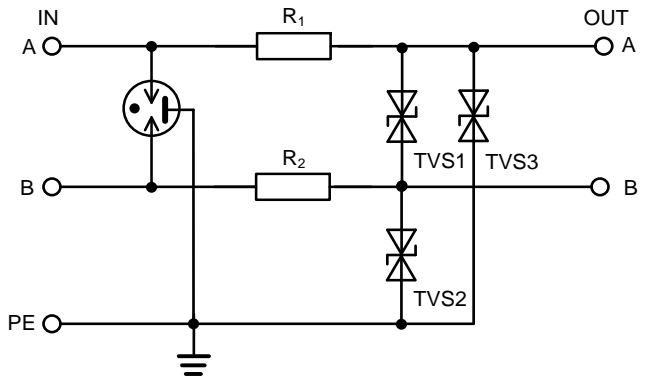

b

Obr. 9.10: Příklad použití bleskojistek pro ochranu sdělovacích vedení a komunikačních rozhraní ŕídicích systémů

Příklad použití bleskojistek pro ochranu sdělovacích datových a komunikačních rozhraní řídicích systémů pro měření a regulaci (MaR) nebo pro elektronické zabezpečovací systémy (EZS) či pro elektronickou požární signalizaci (EPS), zejména pak pro rozhraní RS485, RS422 či RS232, je uveden na Obr. 9.10 Al. Bleskojistky zde slouží k hrubé ochraně vodičů vůči zemní ochranné svorce $\mathrm{PE}$. K ochraně proti příčnému přep̌éí mezi vodiči pak slouží jemná ochrana $\mathrm{z}$ rezistorů a transilů (TVS).

$\mathrm{Na}$ Obr. 9.10b je pak uveden základní způsob použití dvojité bleskojistky pro ochranu dvouvodičových rozhraní ř́idicích systémů. Vnější elektrody jsou zapojeny mezi vodiče A, B a střední elektroda je pak zapojena na zcela samostatnou svorku, která je určena pro připojení na zemní vodič, nebo na PE svorku silového rozvodu. Vzhledem k tomu, že napět’ová špička od př́mého či nepřímého účinku blesku nemá zpravidla výraznou velikost mezi svorkami A a B navzájem, je připojení středu bleskojistky na zemní vodič velmi důležité. Datová sběrnice je pak ještě chráněna tzv. jemnou ochrannou sestavenou $\mathrm{z}$ rezistorů $\mathrm{R}_{1} \mathrm{a} \mathrm{R}_{2}$ a trŕ transilů. $V$ méně náročných zařízeních bývají transily TVS2 a TVS3 vynechány. 


\section{Varistory (MOV, MLV)}

Varistory jsou rezistory se silně nelineární závislostí odporu na napětí, což znázorňuje i jejich schématická značka. V současné době mají nejlepší poměr cena/výkon. Nejčastěji jsou vyráběny ze slisovaného prášku některých oxidů kovů, což reflektuje i jejich obvyklý anglický název Metal-oxide Varistor, MOV. Po slisování prášku mezi jednotlivými zrny vznikne velké množství polovodičových přechodů; na varistor je tedy možné pohlížet jako na velké množství diod zapojených sériově. Množstvím prášku, velikostí zrn, použitým materiálem a silou stlačení výrobci dokáží řídit velikost napětí, od kterého varistor začíná být vodivý. Do procesu však vstupuje mnoho náhodných faktorů, takže není možné dosáhnout tolerance jmenovitého napětí lepší než $\pm 10 \%$. Protože je orientace zrn (a tedy i přechodů) náhodná, varistory reagují vždy na obě polarity napětí (jsou to bipolární prvky), jak ukazuje ampérvoltová charakteristika na Obr.9.11 . Miniaturní SMD varistory nejsou vyráběny lisováním, ale strrídavým prokládáním vodivých a oxidových vrstev. Výrobci je obvykle označují jako vícevrstvý varistor (MLV = Multilayer Varistor), nicméně jejich vlastnosti jsou velmi podobné varistorům klasickým. Jsou vyráběny od miniaturního SMD provedení pro spotřební elektroniku až po několik centimetrů velké prvky pro ochranu výkonové elektroniky (Obr. 9.11日).

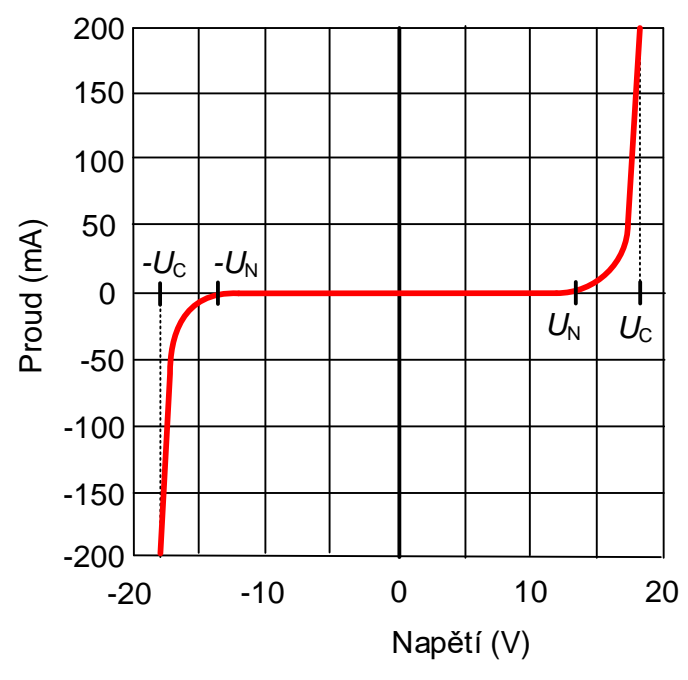

$\mathbf{a}$

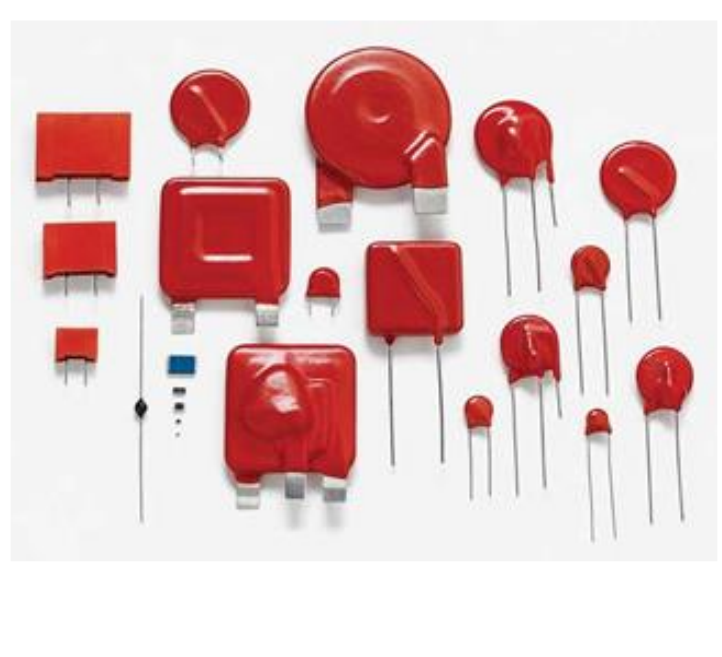

b

Obr. 9.11: Typická VA charakteristika a př́klady pouzder varistorů

Výrobci u varistoru vždy udávají dvě napětí: první je jmenovité napětí $U_{\mathrm{N}}$ (nominal voltage), které je vyznačeno na pouzdru. To je definováno jako úbytek napětí, který na varistoru vznikne při průchodu proudu $1 \mathrm{~mA}$. Při průchodu (velkého) poruchového proudu však na něm vznikne úbytek výrazně větší, obvykle je označován jako upínací napětí $U_{\mathrm{C}}$ (clamping voltage). Tuto situaci ilustruje detailněji charakteristika na Obr. 9.12 (pozor, v tomto obrázku je proud na vodorovné ose). Průběh na Obr. 9.12 je pro varistor o jmenovitém napětí $U_{\mathrm{N}}=12 \mathrm{~V}$ a jak je vidět, při proudu $1 \mathrm{~mA}$ je na něm skutečně úbytek $12 \mathrm{~V}$. Při průchodu poruchového proudu $10 \mathrm{~A}$ se na něm však objeví napětí $U_{\mathrm{C}}=18 \mathrm{~V}$. Tuto vlastnost je nutné při výběru varistoru zohlednit - obvykle je nutné změřit nebo vypočítat, jaký poruchový proud se může v daném obvodu objevit. Varistor je pak nutné vybrat tak, aby napětí $U_{\mathrm{C}}$ nepřekročilo nejvyšší přípustné napětí na chráněném obvodu. 


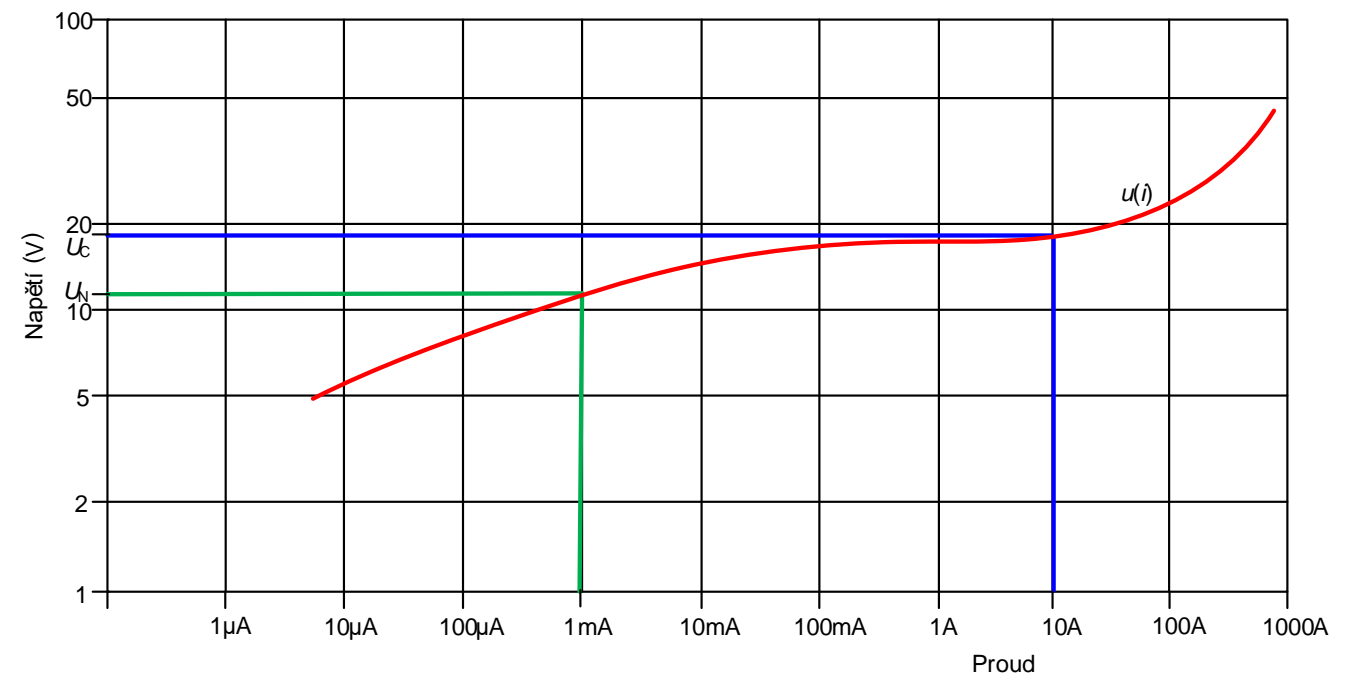

Obr. 9.12: Úbytek napětí na varistoru v závislosti na poruchovém proudu

Schopnost varistoru pohlcovat energii záleží hlavně na objemu slisovaného materiálu. SMD varistory snesou poruchové proudy v řádu stovek mA, běžné drátové typy do $100 \mathrm{~A}$ a průmyslové typy i přes $10 \mathrm{kA}$. Někteří výrobci udávají i celkovou pulsní energii, kterou je schopen varistor změnit na teplo, aniž dojde k jeho poškození. Varistory v provozu stárnou každá aktivace speče několik kovových zrn dohromady, takže jmenovité napětí varistoru postupně klesá. Nakonec mezi zrny vznikne vodivá cesta a varistor je tím pádem zničen. Přetěžování mimo katalogové údaje tento proces výrazně urychluje. Při překročení dovoleného proudu též rychle klesá schopnost varistoru omezit úbytek napětí, což je na Obr. 9.12 patrné u proudů nad $30 \mathrm{~A}$.

Mezi nevýhody varistorů patří zejména jejich velká parazitní kapacita (50 až 2000 pF, podle objemu slisovaného materiálu) a velký svodový proud v klidovém stavu (typicky okolo $10 \mu \mathrm{A}$, ale v mezním př́padě může dosáhnout až $1 \mathrm{~mA}$ ). To omezuje možnosti jejich nasazení v moderních vysokorychlostních přenosových systémech a měřicí technice. Jsou též poměrně pomalé, jejich reakční doba se pohybuje okolo $100 \mathrm{~ns}$. V dnešní době se proto varistory nejvíce používají pro základní ochranu výkonových obvodů (napájecí zdroje apod.) a obecně pro ochranu vstupů či výstupů, na kterých je v běžném provozu napětí nad $50 \mathrm{~V}$.

Základní zapojení varistoru pro ochranu vstupu zařízení velkým napětím je uvedeno na Obr. 9.13 A. V náročnějších případech se chrání obě vstupní svorky zařízení vůči zemnímu vodiči, nebo vůči svorce PE silového rozvodu (vizObr. 9.13b). Protože varistory jsou bipolární, chrání obvod jak proti překročení kladného vstupního napětí, tak i proti překročení napětí záporného. 


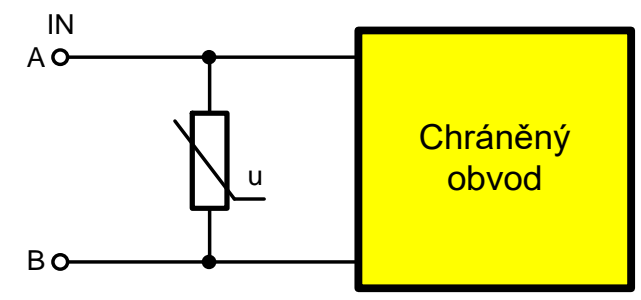

a

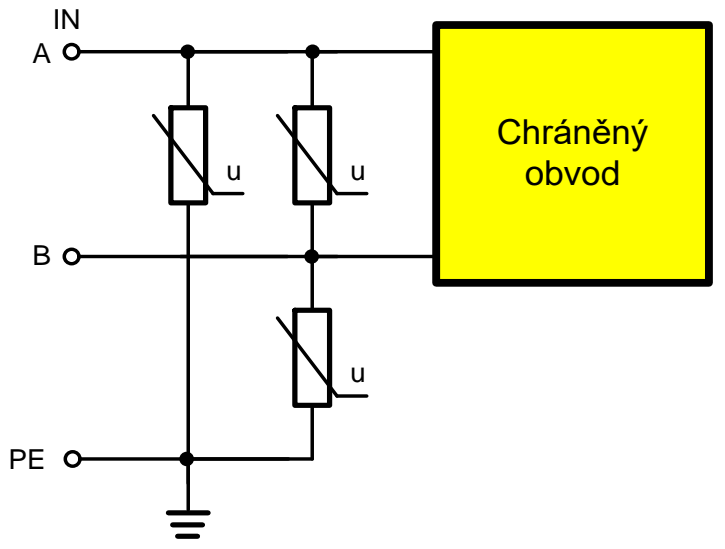

b

Obr. 9.13: a) Základní ochrana vstupu zařízení varistorem, b) ochrana vstupů varistory vůči ochrannému zemnímu vodiči

\section{Polymerové ESD varistory}

Polymerové ochranné prvky (polymer ESD suppressors) jsou varistory se speciální konstrukcí pro dosažení co nejnižší parazitní kapacity $(<0,2 \mathrm{pF})$. Oxidy kovů jsou $\mathrm{v}$ tomto př́padě rozptýleny v polymerovém nosiči a nanášejí se tenkovrstvou (thin film) technologií. Díky tomu je jejich reakční doba výrazně kratší $(<1$ ns) než u klasických varistorů. Jsou určeny výhradně pro ochranu vysokorychlostních sběrnic pro přenos dat (USB 3.0, HDMI, eSATA apod.) před výboji statické elektřiny, větší energie pohltit nedokáží. I když výrobci deklarují, že jsou určeny pro ochranu digitálních obvodů pracujících na 5 či 3,3 V, ve skutečnosti nedokáží napětí statického výboje omezit na méně, než cca $U_{\mathrm{C}}=40$ až $150 \mathrm{~V}$. Jejich úkolem je pohltit hlavní část energie ESD výboje, zbylou energii pak obvykle pohltí ESD diody prŕmo na čipu chráněného integrovaného obvodu Obr. 9.13b). Obvod na to ale pochopitelně musí být konstruován. Pro snížení celkové parazitní kapacity se vyrábějí pouze v SMD provedení Obr. 9.14 l). Vyrábějí se i tzv. pole varistorů ESD, v provedení SMD, kdy v jednom pouzdře jsou čtyři varistory. Použití polymerového ESD varistoru pro ochranu vstupu USB je uvedeno na Obr. 9.14b).

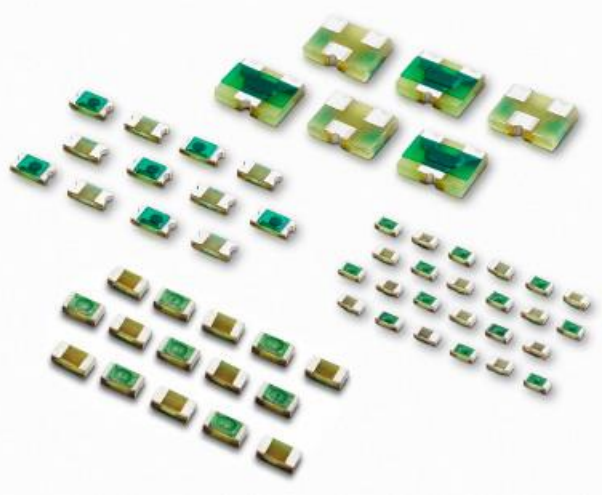

$\mathbf{a}$

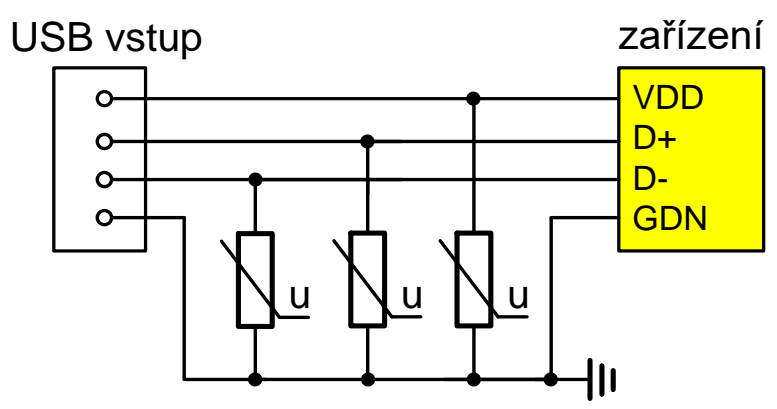

b

Obr. 9.14: a) Provedení polymerových ESD varistorů, b) jednoduchá ochrana vstupu USB pomocí polymerových ESD varistorů 


\section{Transily (TVS diody)}

Transily (Transient Voltage Suppressor Diode, TVS Diode, TransZorb) jsou
Unip. Boučasné době nejuniverzálnějším a nejvíce používaným prvkem pro
přepětovou ochranu. V zásadě to jsou lavinové Zenerovy diody speciální
konstrukce, která vydrží velké opakované poruchové proudy. Současně jsou
extrémně rychlé, jejich reakční doba je v pikosekundách a je dána v podstatě pouze parazitní indukčností vývodů. Jejich svodový proud v nevodivé oblasti se výrazně mění se jmenovitým napětím - u transilů na $15 \mathrm{~V}$ a více se pohybuje okolo $1 \mu \mathrm{A}$, u nižších jmenovitých napětí může dosahovat i stovek $\mu$ A. Při vhodném výběru je lze použít téměř ve všech rolích přepět'ové ochrany, od rychlých ESD výbojů až po omezení trvalých přepětí. Jsou však citlivější na překračování dovolených parametrů než varistory a i jejich cena je vyšší. Při správném výběru mají neomezenou životnost.

Podobně jako u varistorů, i u transilů je nutné hlídat jejich maximální proudovou zatížitelnost. Ta je definována jako maximální pulsní poruchový proud (maximum peak pulse current) a v katalogových listech se značí IPP. Pokud mají sloužit jako ochrana před trvalým přepětím, je též nutné sledovat jejich trvalý dovolený ztrátový výkon $P_{\mathrm{D}}$. Naopak pulsní ztrátový výkon $P_{\mathrm{PK}}$ (peak pulse power dissipation) je spíše reklamní údaj, který při návrhu není příliš užitečný (v katalogových listech lze nalézt dokonce hodnoty jako $1500 \mathrm{~W}$ ).

U transilů výrobci udávají dokonce tř̌i napětí (viz Obr. 9.15: První je pracovní závěrné napětí $U_{\mathrm{R}}$ (reverse stand-off voltage); je to napětí, při kterém transilem ještě teče jen minimální svodový proud $I_{\mathrm{R}}$, tj. obvykle do $1 \mu \mathrm{A}$. Současně je to jmenovité napětí transilu, které je vyznačeno na jeho pouzdru. Druhé je prahové napětí, při kterém transil přechází z nevodivého do vodivého stavu (,koleno křivky“); obvykle je označováno $U_{\mathrm{BR}}$ (breakdown voltage). Poslední je napětí, které se na transilu objeví při průchodu maximálního dovoleného poruchového proudu $I_{\mathrm{PP}}$. Toto napětí je označováno $U_{\mathrm{C}}$ (clamping voltage) a jeho význam je tedy stejný jako u varistorů. Vždy platí nerovnost $U_{\mathrm{R}}<U_{\mathrm{BR}}<U_{\mathrm{C}}$ a př́i návrhu ochranného obvodu je nutné ji vzít do úvahy. Transily mají vyšší přesnost jmenovitého napětí $U_{\mathrm{R}}$ než varistory, typická tolerance je $\pm 5 \%$.

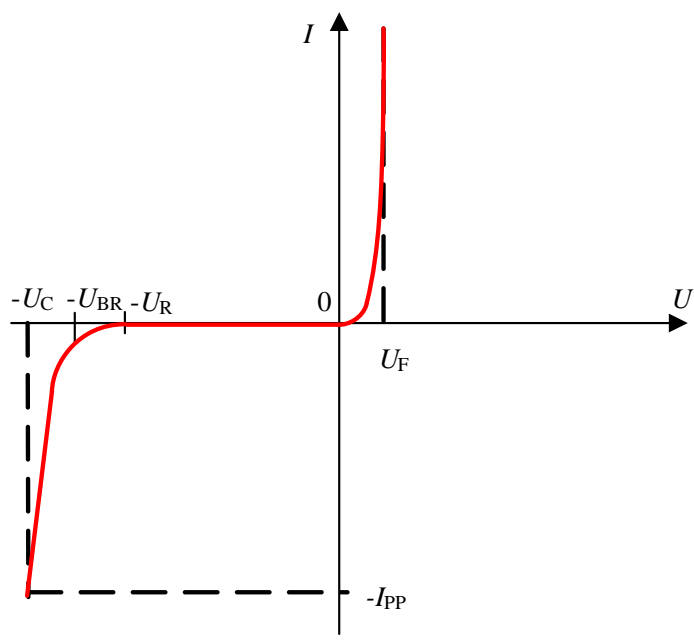

a

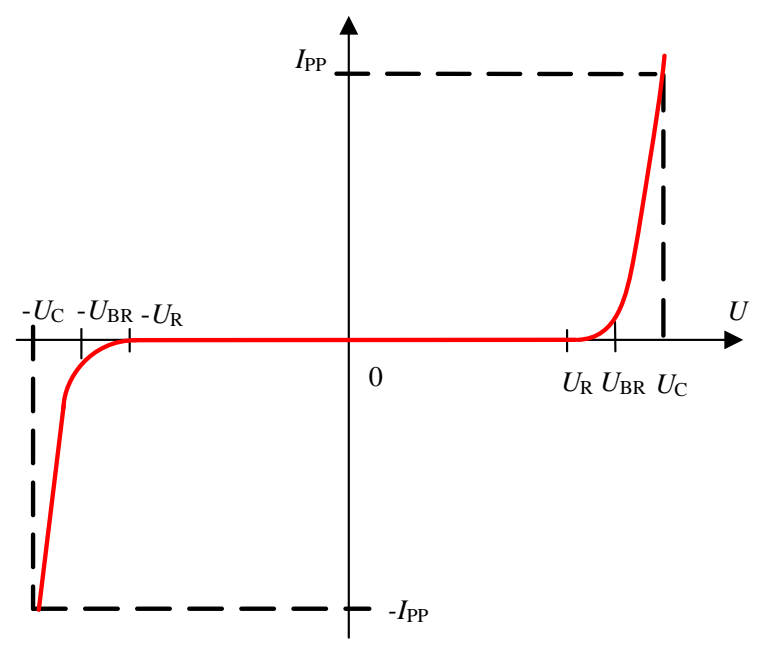

b

Obr. 9.15: AV charakteristiky transilu: a) unipolárního, b) bipolárního

Transily jsou dostupné v unipolárním i bipolárním provedení; unipolární transil má ampérvoltovou charakteristiku podobnou Zenerově diodě (Obr. 9.15 ), bipolární transil se pak chová podobně jako varistor Obr. 9.15B). Bipolární transily se ve skutečnosti vyrábějí anti- 
sériovým zapojením dvou unipolárních transilů, takže vždy mají o něco horší parametry zejména svodový proud. Různá provedení transilů jsou uvedena na Obr. 9.16ł.

Př́iklad použití transilů pro ochranu vstupů převodníku RS232/RS485 proti přepětí na datových vstupech a proti překročení izolační bariéry mezi galvanicky oddělenými částmi převodníku je uveden na Obr. 9.16b. Unipolární transily TVS1 a TVS2 zajišt'ují ochranu datových vstupů A a B přijímače a budiče linky RS485. Důležitý je pak z hlediska možného průrazu mezi galvanicky oddělenými částmi převodníku transil TVS3, který se otevře, když potenciál oddělených částí přesáhne povolené napětí.
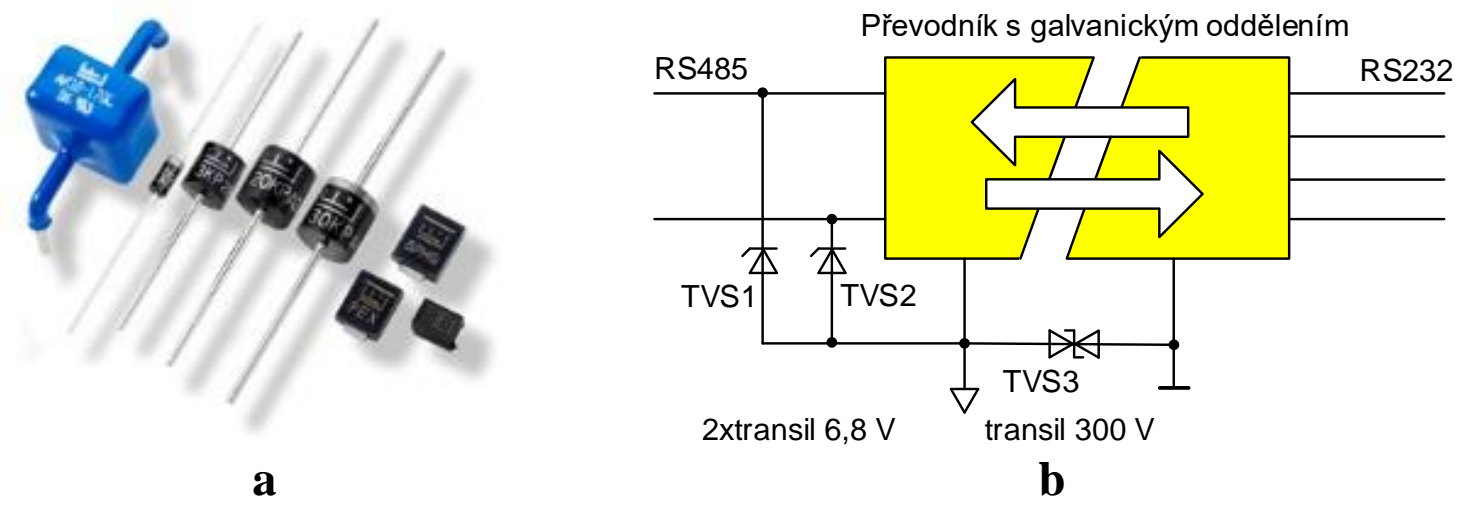

Obr. 9.16: a) Různá provedení transilů, b) př́iklad použití transilů pro ochranu převodníku RS232/RS422 s galvanickým oddělením

Nabídka transilů je ještě rozsáhlejší než u varistorů. Jejich výhodou také je, že se prodávají v integrované podobě po dvojicích, čtveřicích či osmicích Obr. 9.17ł), kdy jsou připraveny přímo pro konkrétní aplikaci (např. Ethernet nebo HDMI). Výrobci takové ochranné integrované obvody obsahující diody společně s transily obvykle nazývají TVS Diode Array. $\mathrm{Na}$ Obr. 9.17b je př́klad vnitřního zapojení čtyřnásobného unipolárního transilu v 6-vývodovém pouzdře, určeného pro ochranu budičů rozhraní (PHY) sítě Ethernet.

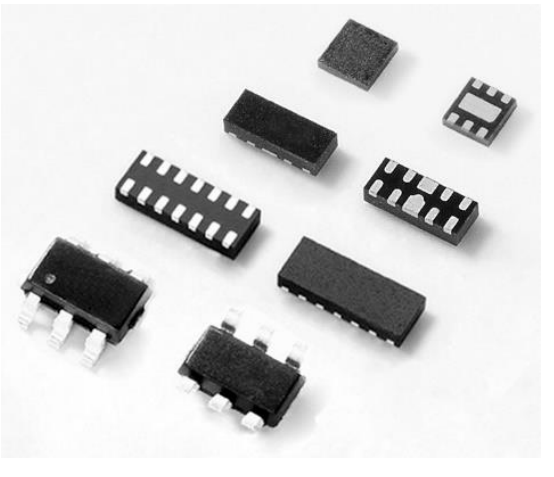

$\mathbf{a}$

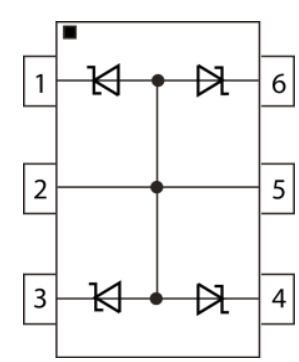

b

Obr. 9.17: a) Př́klad vícenásobných transilů, b) vnitřní zapojení vícenásobného transilu pro ochranu budičů rozhraní sítě Ethernet 


\section{Tyristorové ochrany}

$\pitchfork \frac{1}{7}$

Pro tyristorové ochrany prozatím neexistuje standardizovaná schématická značka, zde jsou uvedeny dvě nejčastěji užívané schematické značky. Tyristorové ochrany (thyristor surge protection device) mají spínací funkci jako bleskojistky (crowbar device), ale jedná se o čistě polovodičové prvky. Nesnesou ani zdaleka tak velké poruchové proudy jako bleskojistky (snesou maximálně asi $400 \mathrm{~A}$ ), ale zato mají mnohem vyšší přesnost napětí, při kterém reagují. Též jsou přibližně $1000 \times$ rychlejší, jejich reakční doba je v nanosekundách. Z těchto důvodů se velmi často používají jako ,jemný“ doplněk $\mathrm{k}$ bleskojistkám. Jsou nabízeny pod mnoha obchodními názvy např. Trisil, SIDAC, SIDACtor či TISP protector. Jejich základní princip je však vždy stejný, kdy základem je tyristor, který je př́mo na čipu doplněn o pomocné obvody pro vyhodnocování přiloženého napětí. Ty ovládají př́mo řídicí elektrodu tyristoru, takže prvek má pouze dva vývody. ${ }^{3}$

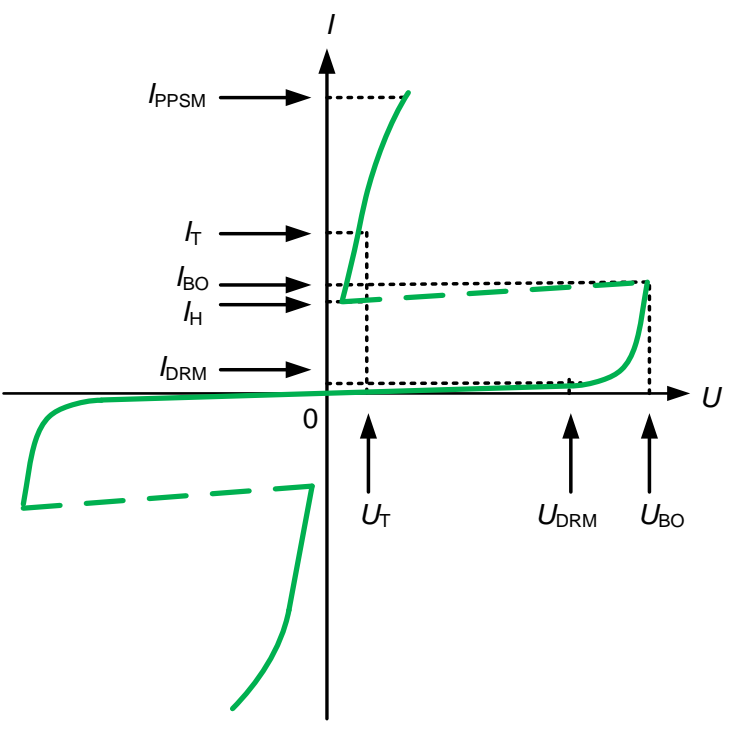

$\mathbf{a}$

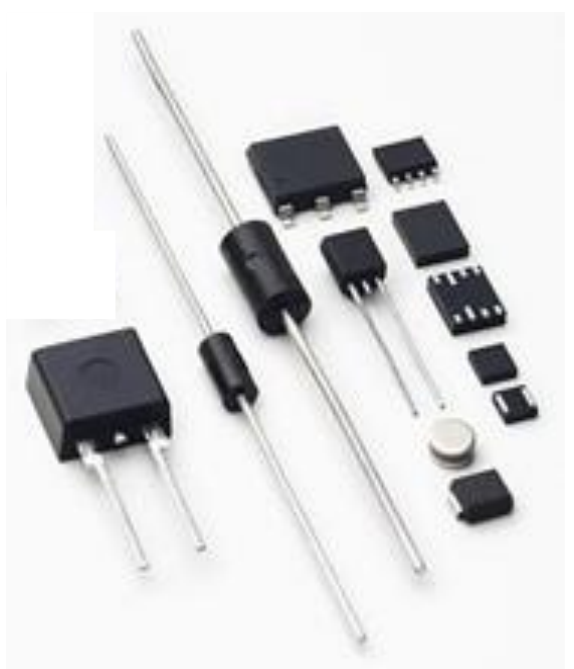

b

Obr. 9.18: a) Charakteristika bipolární tyristorové ochrany, b) různá provedení tyristorových ochran

Podobně jako transily se i tyristorové ochrany vyrábějí v unipolárním a i bipolárním provedení. Na Obr. 9.18 je uvedena charakteristika bipolárního prvku. Prvek je nevodivý v celém rozsahu doporučeného pracovního napětí $\pm U_{\text {DRM }}$ (repetitive peak off-state voltage) a teče jím jen svodový proud $I_{\mathrm{DRM}} \mathrm{o}$ velikosti okolo $\pm 10 \mu \mathrm{A}$. Při návrhu je nutné zajistit, aby při normálním provozu nebylo napětí $\pm U_{\text {DRM }}$ nikdy překročeno, protože poté svodový proud exponenciálně roste a navíc je jeho průběh silně nelineární. K vlastní aktivaci ochrany dojde až při překročení průrazného napětí $\pm U_{\mathrm{BO}}$ (breakover voltage) - tyristor sepne a úbytek napětí na prvku skokově klesne, což v Obr. 9.18 naznačují čárkované části charakteristiky. Napětí v sepnutém stavu $U_{\mathrm{T}}$ (on-state voltage) má hodnotu jednotek až desítek voltů, v závislosti na velikosti poruchového proudu. Tyristor zůstane otevřený, dokud přes něj teče proud větší než př́ídržný proud $I_{\mathrm{H}}$ (holding current). Prvek je schválně konstruován tak, aby byl proud $I_{\mathrm{H}}$ poměrně vysoký (150 až $900 \mathrm{~mA}$ ) a po odeznění přep̌èového jevu docházelo ke spolehlivému

\footnotetext{
${ }^{3}$ Pro telefonní a datové ústředny se vyrábějí „programovatelné“ tyristorové ochrany (programmable thyristor surge protector), které mají vývod navíc. Ten slouží k přivedení řídicího napětí, kterým lze změnit spouštěcí napětí prvku. Používají se v energeticky úsporných telefonních ústřednách, které dynamicky mění linkové napájecí napětí dle aktuální potřeby.
} 


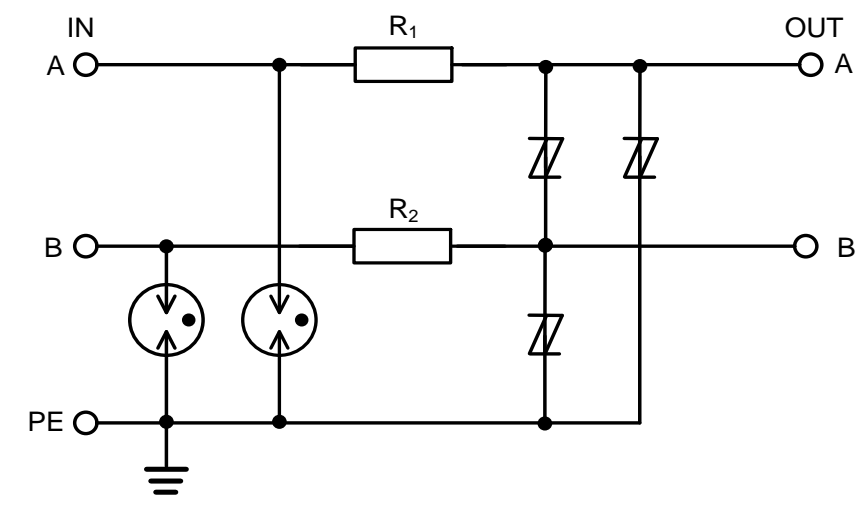

Obr. 9.19: Doplňková tyristorová ochrana pro komunikační rozhraní řídicích systémů

rozepnutí tyristoru. Kvůli tomuto chování jej nelze použít pro ochranu napájecích vstupů (napájecí napětí by je udržovalo sepnuté i po odeznění přepět'ového jevu). Přri návrhu je nutné dbát na to, aby nikdy nebyl překročen maximální dovolený proud I IPSM (non-repetitive peak impulse current). Pokud nejsou přetěžovány, mají tyristory neomezenou životnost. Vyrábějí se jak v provedení s vývody, tak i v pouzdru SMD (viz Obr. 9.18 ).

Tyristorové ochrany se nejvíce používají pro ochranu signálových vodičů komunikačních zařízení (např. zapojení na Obr. 9.19], takže jejich nabídka není zdaleka tak široká jako u transilů či varistorů. Velmi často mají podobu integrovaných obvodů obsahujících dvě či čtyři tyristorové ochrany současně. Nelze je použít pro ochranu vysokofrekvenčních obvodů kvůli jejich vysoké parazitní kapacitě, která se navíc silně nelineárně mění s přiloženým napětím (např. v rozmezí 50 až 300 pF).

\section{Ochranné Zenerovy diody}

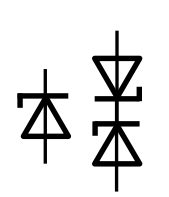

I obyčejné Zenerovy diody je možné použít jako unipolární či v anti-sériovém zapojení jako bipolární ochranu proti přepětí. Jejich hlavní výhodou je nízká cena a přesnost prahového napětí - běžně se vyrábějí s tolerancí $\pm 2 \%$, což většinou žádný jiný ochranný prvek nedosahuje. Jejich čipy však nejsou konstruovány pro pulsní zatěžování, takže v takových aplikacích mohou brzy selhat. Navíc nejsou konstruovány jako spínací prvek a jejich reakce na přepětí je značně pomalá. Jejich svodové proudy jsou pak znatelně vyšší, než u porovnatelných varistorů a transilů a jejich parazitní kapacita se může silně měnit s přiloženým napětím. Zenerovy diody se proto jako ochranné prvky používají pouze v nenáročných aplikacích, ve kterých je na prvním místě nízká cena, k omezení napětí externích napájecích zdrojů.

\section{Kapacitory pro prepět'ovou ochranu}

Kondenzátory mohou sloužit jako jednoznačně nejlevnější, ale také nejhorší ochranný prvek. Protože pouze kondenzátory malých kapacit jsou dostatečně levné, používají se kondenzátory výhradně pro jednoduchou ochranu před výboji statické elektřiny (ESD). Využívá se přitom závislost uchované energie $W$ na napětí $U$ tak, jak popisuje známý vztah

$$
W=\frac{1}{2} C \cdot U^{2}
$$

či při vyjádření napětí 


$$
U=\sqrt{\frac{2 W}{C}} .
$$

Snadným výpočtem pak zjistíme, že kondenzátor o kapacitě $10 \mathrm{nF}$ sníží energii ESD výboje o $3,2 \mathrm{~mJ}$ a omezí špičkové napětí $8 \mathrm{kV}$ (tzv. human body model) na $800 \mathrm{~V}$. To je pro citlivé polovodiče stále př́liš velké napětí, kondenzátory se proto vždy kombinují s rezistorem. Spolu pak tvoří integrační RC článek (dolní propust) a velká část energie výboje se změní v teplo v rezistoru. Nárůst napětí na kondenzátoru potom pochopitelně není tak dramatický, jako ve výše uvedeném výpočtu. Protože ESD výboje jsou rychlé děje, kondenzátor musí mít dobré vysokofrekvenční vlastnosti. Též musí být na poměrně vysoké jmenovité napětí, aby jej výboje brzy nezničily. V praxi se typicky používají SMD keramické kondenzátory $1 \mathrm{nF} / 200 \mathrm{~V}$ s dielektrikem NP0 v kombinaci se sériovým rezistorem okolo $220 \Omega$. Pokud by takto velká kapacita a odpor narušovaly funkci chráněného obvodu, je možné je zmenšit a paralelně ke kondenzátoru připojit Zenerovou diodou. Je však zřejmé, že tyto tři prvky zaberou na plošném spoji mnohem více místa než např́klad jeden transil, takže přínos takového řešení je diskutabilní.

\subsection{Nadproudové ochrany}

Jak bylo zmíněno na začátku kapitoly 9.1, přepět'ové jevy jsou vždy doprovázeny i vznikem nadproudů. Nadproudové ochrany však často plní i bezpečnostní funkci - např́íklad při poruše uvnitř zařízení jej odpojí od napájecího zdroje a tím zabrání dalším škodám. Pro rychlejší orientaci jsou v Tab 9.4 uvedeny nejdůležitější parametry nadproudových ochran, podrobnější popis funkce je pak v následujících podkapitolách.

Tab 9.4: Přehled elektrických parametrů nadproudových ochran

\begin{tabular}{|l|c|c|c|c|c|}
\hline \multicolumn{1}{|c|}{ Prvek } & $\begin{array}{c}\text { Jmenovitý } \\
\text { proud [A] }\end{array}$ & $\begin{array}{c}\text { Max. pracovní } \\
\text { napětí [V] }\end{array}$ & $\begin{array}{c}\text { Rychlost } \\
\text { reakce }\end{array}$ & $\begin{array}{c}\text { Zbytkový } \\
\text { odpor }\end{array}$ & Životnost \\
\hline Tavná pojistka & $0,01-\infty$ & $\infty$ & $\begin{array}{c}\text { částečně } \\
\text { volitelná }\end{array}$ & malý & 1 použití \\
\hline Termistorová vratná pojistka & $0,05-10$ & 250 & $>0,2 \mathrm{~s}$ & vysoký & omezená \\
\hline Polovodičová vratná pojistka & $0,05-1,5$ & 850 & cca $1 \mu \mathrm{s}$ & vysoký & neomezená \\
\hline Pojistný rezistor & dle odporu & 500 & $>1 \mathrm{~s}$ & odpor rezistoru & 1 použití \\
\hline
\end{tabular}

\section{Tavné pojistky}

Tavné pojistky jsou historicky nejstarším ochranným prvkem. Dnes mají nepřeberné množství podob, od miniaturních SMD čipových součástek až po metr dlouhé pojistky pro rozvody silové elektřiny. Stejně široký je i rozsah jmenovitých proudů, běžné typy jsou nabízeny od $10 \mathrm{~mA}$ do 100 A. Při použití pojistek pro malé proudy $(<100 \mathrm{~mA})$ je nutné dávat pozor na jejich zbytkový parazitní odpor, který může být i v řádu desítek $\Omega$. $\mathrm{Z}$ hlediska aplikace je též nutné správně vybrat rychlost jejich reakce. Ta je u pojistek na malá a nízká napětí označována zkratkami, které původně pocházejí z němčiny ${ }^{4}$ (viz Tab 9.5).

\footnotetext{
${ }^{4}$ Pojistky pro silové a vysokonapět'ové rozvody jsou značeny podrobněji a i zkratky jsou jiné.
} 
Tab 9.5: Zkratky pro značení rychlosti tavných pojistek

\begin{tabular}{|l|l|l|}
\hline Zkratka & Reakční charakteristika & Anglický název \\
\hline FF & Velmi rychlá (Flink Flink) & Very fast acting, ultrafast \\
\hline F & Rychlá (Flink) & Fast acting \\
\hline M & Středně rychlá (Mittelträge) & Medium acting \\
\hline T & Pomalá (Träge) & Antisurge, slow blow, time delay \\
\hline TT & Velmi pomalá (Träge Träge) & Long time lag \\
\hline
\end{tabular}

V praxi se nejvíce používají pojistky T a F, ostatní jsou obtížněji dostupné a i jejich cena bývá vyšší. Pojistky pomalé s charakteristikou T se zpravidla užívají v napájecích zdrojích - ty totiž obsahují kondenzátory, které způsobují velkou proudovou špičku po zapnutí (inrush current). Je proto nutné, aby se pojistka přepálila, až pokud nadproud trvá delší dobu. Pojistky FF se nejčastěji používají jako individuální ochrana drahých polovodičů, např́klad v kolektorových přívodech výkonových tranzistorů. Pro ostatní aplikace se pak používají pojistky s charakteristikou $\mathrm{F}$.

Zřejmě nejznámější jsou skleněné trubičkové pojistky o rozměrech Ø5×20 mm a $\varnothing 6,3 \times 32 \mathrm{~mm}$, jejich normalizovaných rozměrů je však více Obr. 9.20 ). Pro trubičkové pojistky se vyrábějí nejrůznější držáky, zejména do panelu Obr. 9.20巾), do kabelu Obr. 9.204) nebo do desky plošného spoje Obr. 9.20d). Trubičkové pojistky je však možné zapájet do DPS i prímo, k tomu jsou vyráběny typy s vývody (Obr. 9.20 1).

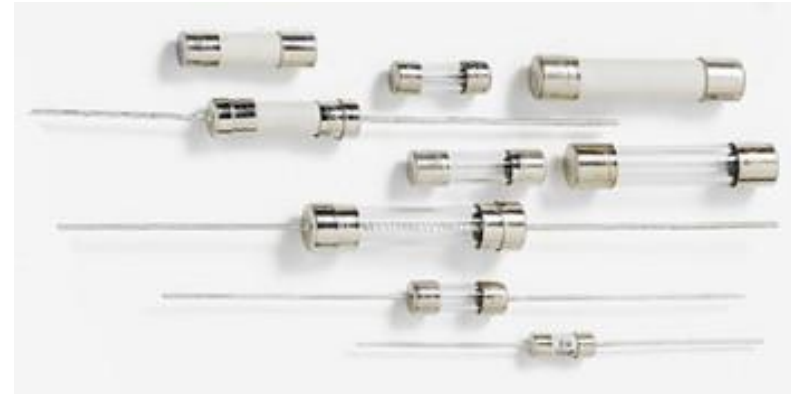

$\mathbf{a}$

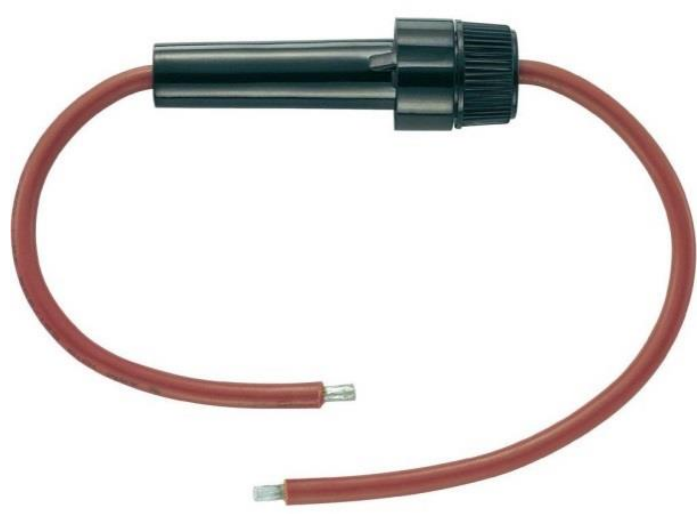

c

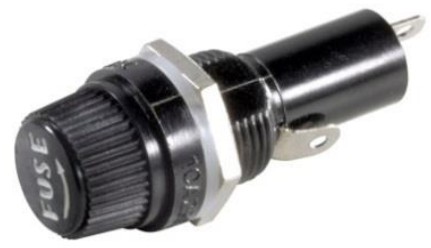

$\mathbf{b}$
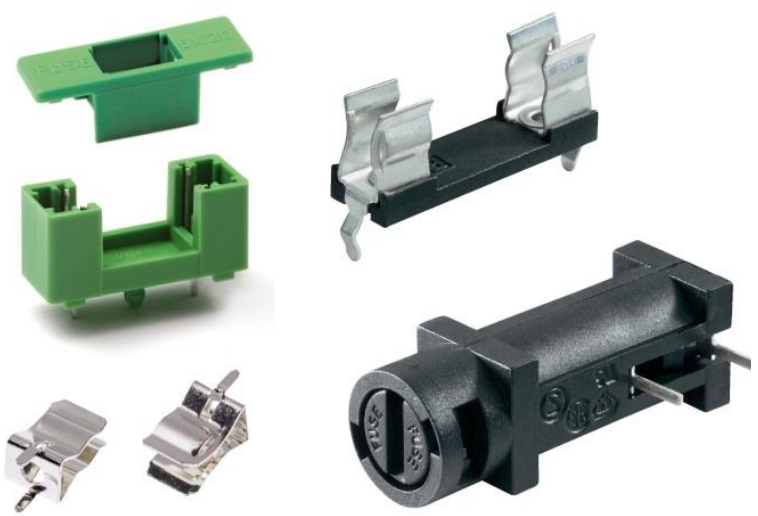

d

Obr. 9.20: Trubičkové pojistky a jejich držáky 


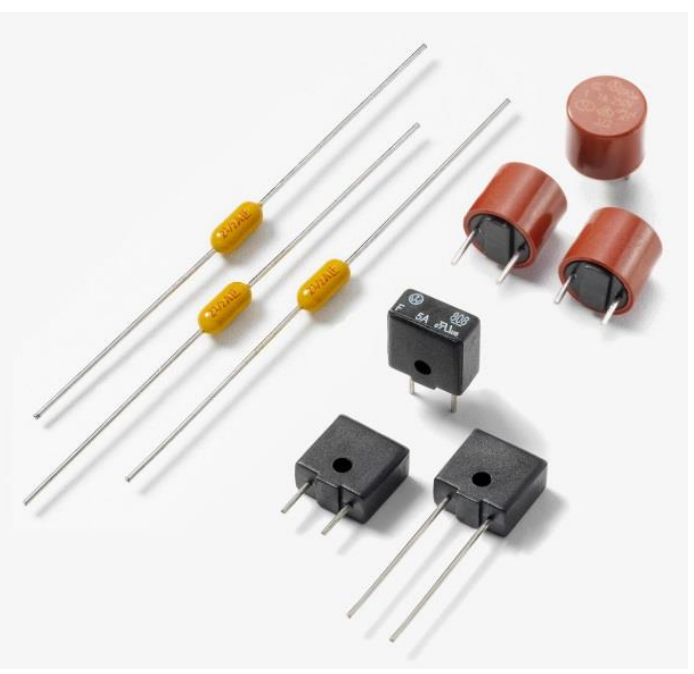

a

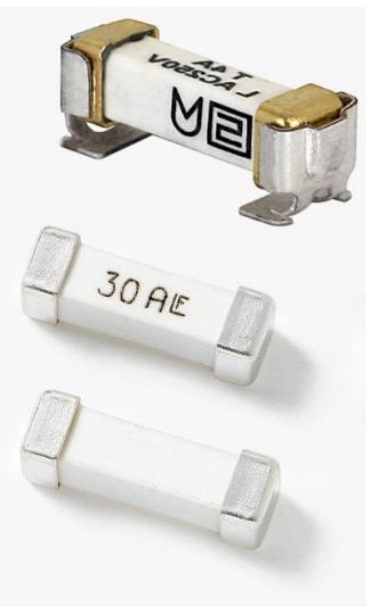

b

Obr. 9.21: Př́klady drátových a SMD pojistek

Při osazování na DPS jsou dnes skleněné pojistky vytlačovány modernějšími typy, které jsou vhodnější pro automatizovanou výrobu (nejsou křehké). Ty přitom mohou mít vývody umístěny i radiálně, což šetří místo na DPS (Obr. 9.21 a). K dispozici jsou pochopitelně i pojistky pro povrchovou montáž (SMD) v nejrůznějších velikostech Obr. 9.21b). Pro tyto pojistky existují i SMD pojistková pouzdra (viz Obr. 9.211 nahoře).

Př́klad nadproudové ochrany zařízení pomocí pojistky je uveden na Obr. 9.22. Pro přepět'ovou ochranu jsou zde použity varistory.

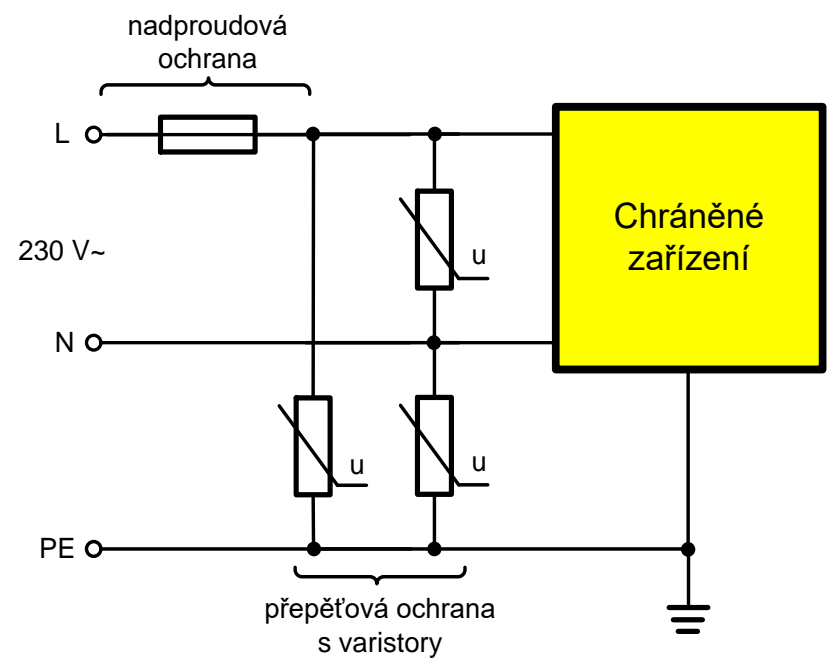

Obr. 9.22: Př́iklad nadproudové ochrany zařízení pojistkou 


\section{Termistorové vratné pojistky (PPTC)}

$y_{t}$

Hlavní výhodou vratných pojistek (resettable fuse) je, že dokáží na nadproudy reagovat opakovaně a po jejich odeznění přejít zpět do výchozího stavu. Používá se pro ně množství obchodních názvů, např. Polyfuse, PolySwitch, PolyTron, Multifuse či Semifuse. Ve skutečnosti jsou to termistory se silně nelineární kladnou závislostí odporu na teplotě, jak ukazuje Obr. 9.23. Jak je z grafu patrné,

do $100^{\circ} \mathrm{C}$ jejich odpor roste jen nepatrně, ale okolo teploty $120^{\circ} \mathrm{C}$ náhle vzroste o několik řádů. Jsou konstruovány ze speciálních polymerů s nelineární teplotní roztažností, do nichž jsou zamíchány vodivé (např. uhlíkové) částice; proto se také často označují zkratkou PPTC (polymer positive temperature coefficient thermistor). Při normálním provozu je polymer smrštěný a vodivé částice se na mnoha místech navzájem dotýkají, takže termistor má malý odpor $(0,1$ až $10 \Omega$, podle jmenovitého proudu). Procházející proud na něm způsobuje jen malý ztrátový výkon

$$
P=i^{2} \cdot R
$$

Př́i zvyšování proudu se ztrátový výkon zvyšuje se čtvercem proudu a termistorová pojistka se začne zahřívat. Tím se polymer roztáhne, některé vodivé částice ztratí kontakt a celkový odpor termistoru vzroste. Spolu s tím se však zvýší i ztrátový výkon, což termistor ohřeje ještě více atd. Jinými slovy, v termistorové pojistce dojde $\mathrm{k}$ tepelné kladné zpětné vazbě. Její odpor (a teplota) roste, až pro zdroj poruchového proudu představuje tak velkou impedanci, že proud obvodem poklesne. Tento proces (time to trip) je pomalý; v závislosti na mechanickém provedení termistoru a velikosti nadproudu může trvat 0,2 až 20 sekund. Termistorové pojistky jsou proto určeny výhradně pro omezení dlouhodobých nadproudů. Nicméně jakmile je porucha odstraněna, termistorová pojistka vychladne, polymer se smrští a odpor se vrátí (přibližně) na původní nízkou hodnotu.

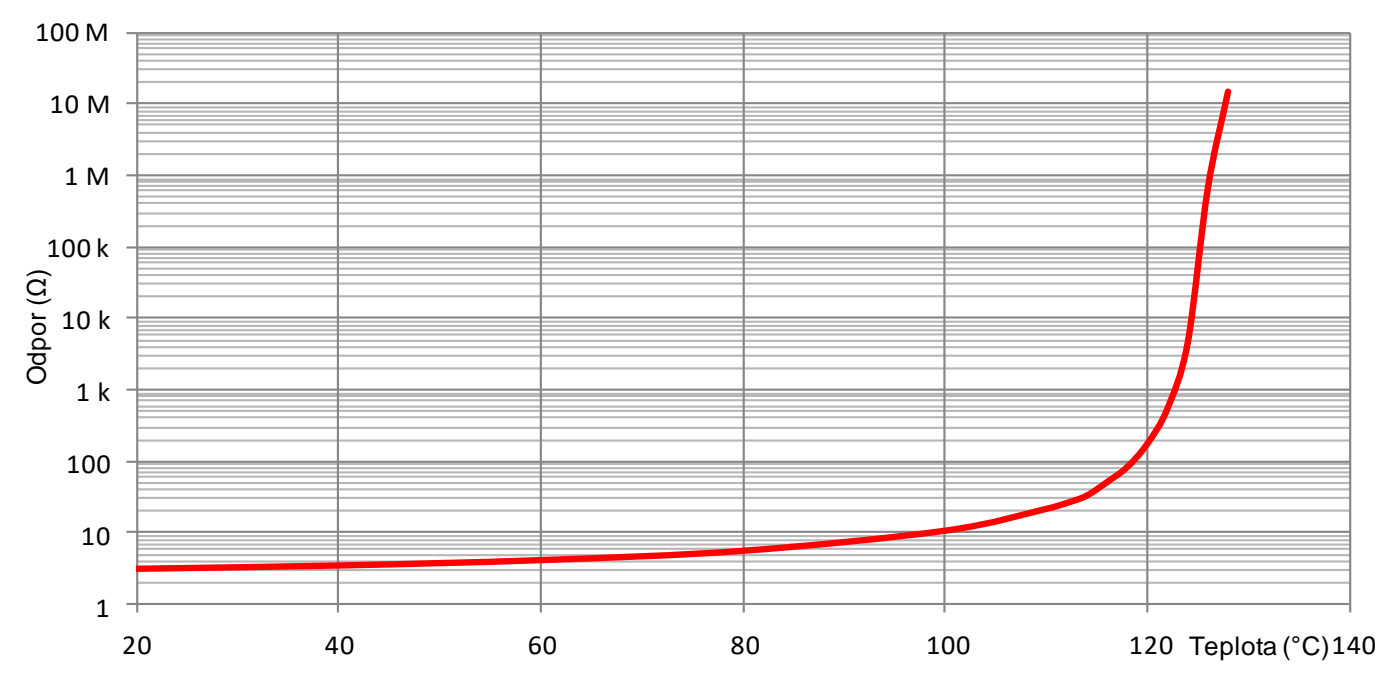

Obr. 9.23: Teplotní charakteristika polymerové termistorové pojistky

Je nutné si uvědomit, že po celou dobu poruchy pojistkou protéká proud, který ji udržuje ohřátou na teplotu okolo $125^{\circ} \mathrm{C}$ (tripped state). Výrobci obvykle udávají výkon $P_{\mathrm{D}}$, který je zapotřebí pro udržení polymerového termistoru v ohřátém stavu (tripped power dissipation). Jinými slovy, polymerové termistory pouze omezují velikost poruchového proudu, nedokáží jej zcela přerušit jako tavné pojistky. To s sebou přináší určité komplikace při návrhu, které jsou blíže vysvětleny v kapitole 9.3 . V blízkosti polymerových termistorů by též neměly být 
umist'ovány součástky citlivé na teplo (napřs. elektrolytické kondenzátory), zvláště pokud je výkon $P_{\mathrm{D}}$ značný.

Výrobci u polymerových termistorů udávají dva údaje: jmenovitý provozní proud $I_{\text {hold }}$ a spouštěcí proud $I_{\text {trip}}$, při kterém dojde k aktivaci prvku. Běžně se vyrábějí polymerové termistory se jmenovitým proudem $I_{\text {hold }}$ od $50 \mathrm{~mA}$ do $10 \mathrm{~A}$, přičemž u většiny typů přibližně platí $I_{\text {trip }} \approx 2 \cdot I_{\text {hold. }}$ Oba proudy se výrazně mění s teplotou okolí; např́iklad při $25^{\circ} \mathrm{C}$ je $I_{\text {hold }}=3 \mathrm{~A}$, ale při $80^{\circ} \mathrm{C}$ klesne na $1,8 \mathrm{~A}$. To představuje komplikaci při návrhu. Velkou nevýhodou polymerových termistorových pojistek je jejich nízké pracovní napětí, tj. jak velké napětí snesou v aktivním (rozepnutém) stavu. Většina současných polymerových termistorů snese maximálně $250 \mathrm{~V}$; pro některé speciální aplikace se vyrábějí i termistory na $600 \mathrm{~V}$, ale to je pouze několik výjimek. Pojistky mají omezenou životnost, která je obvykle udávána jako počet aktivačních cyklů. Podle velikosti nadproudů snesou 200 až 5000 cyklů, poté jejich odpor trvale vzroste natolik, že se již nedokáží vrátit do výchozího stavu.

Nabídka polymerových termistorových vratných pojistek je poměrně široká. Na Obr. 9.24 jsou př́klady drátových polymerových pojistek, které jsou bohužel provedením velmi podobné varistorům Obr. 9.11. Naštěstí v praxi je lze od sebe snadno rozeznat podle toho, jak jsou v obvodu zapojeny. Problémy s identifikací mohou nastat i u SMD polymerových pojistek Obr. 9.24b). Jak je na obrázku patrné, většina SMD typů má na kratších stranách pouzdra výřezy, ale neplatí to u všech výrobců. SMD polymerové termistory se nejčastěji nacházejí na základních deskách počítačů jako ochrana napájecích výstupů USB, FireWire a jiných externích portů před zkratem. V horní části Obr. 9.24b jsou pak speciální SMD polymerové pojistky pro ochranu telekomunikačních linek. Poněkud skrytou, avšak masově rozšířenou aplikací je ochrana akumulátorů, dnes nejčastěji Li-ion akumulátorů v mobilních telefonech, fotoaparátech, tabletech apod. Pro tyto účely jsou termistory vyráběny v tenkém provedení s páskovými vývody, aby $\mathrm{v}$ těle akumulátoru zabraly co nejméně místa, viz Obr. 9.244. Obvykle jsou zality přímo v plastu, který tvoří vnější obal akumulátoru. Protože se jedná o termistory, dokáží akumulátory ochránit nejen před nadproudem, ale současně i před přehřátím.

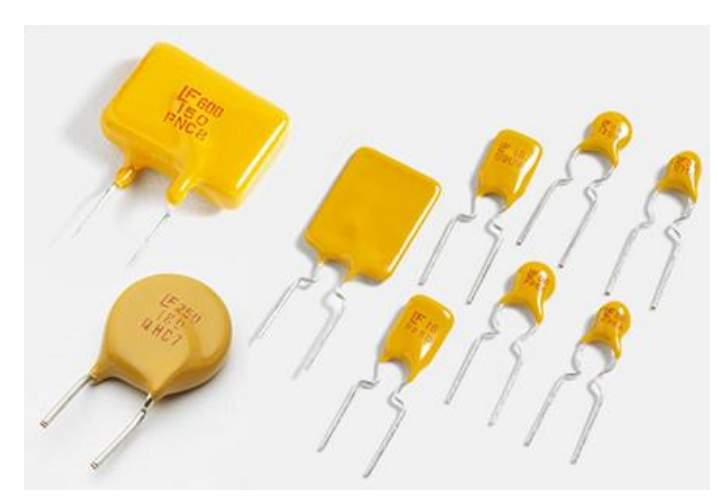

$\mathbf{a}$

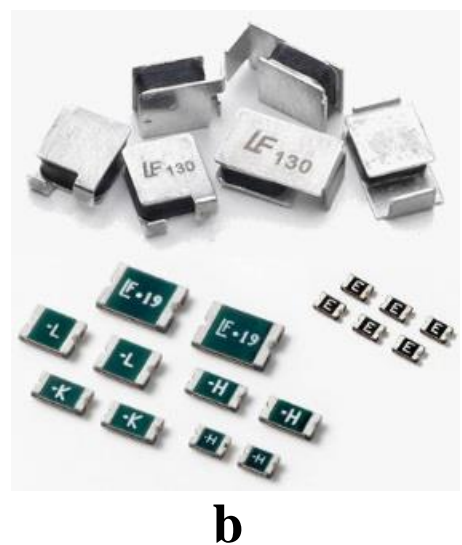

b

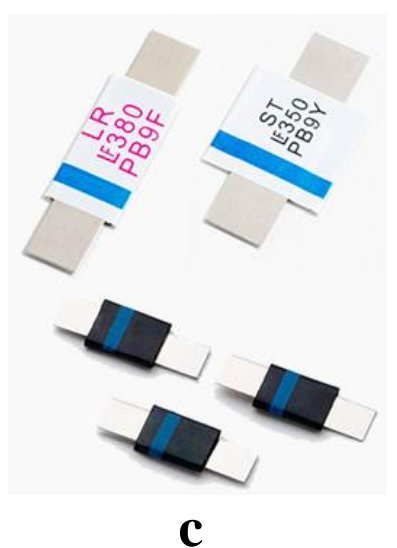

c

Obr. 9.24: Př́klady polymerových termistorových vratných pojistek

Př́iklad využití polymerového termistoru pro ochranu signálových vodičů nadproudem na Obr. 9.25. Dvojitá bleskojistka zde slouží jako tzv. hrubá ochrana a jako jemná přepětová ochrana je použita tyristorová ochrana. 


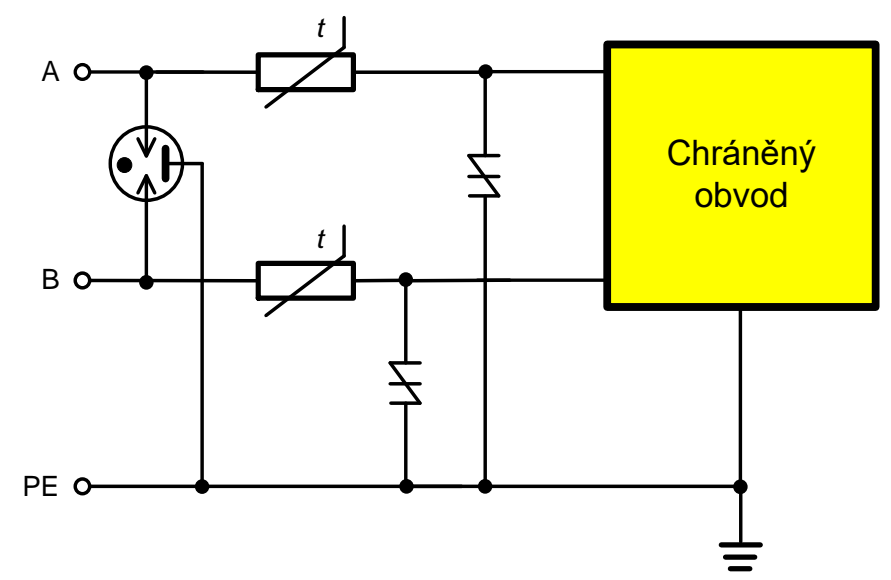

Obr. 9.25: Využití polymerového termistoru pro ochranu signálových vodičů proti nadproudu

\section{Polovodičové vratné pojistky}

目

Polovodičové vratné pojistky se do velké míry přibližují vlastnostem pojistek tavných. Na trh byly uvedeny teprve před několika lety, takže jejich název se ještě neustálil. Výrobci je označují jako High-Speed Electronic Current Limiter či Transient Blocking Unit (TBU). I když tyto pojistky mají jen dva vývody, ve skutečnosti jsou to integrované obvody, které na čipu obsahují výkonový spínací MOSFET tranzistor a pomocný obvod pro vyhodnocení protékajícího proudu a obsluhu spínacího tranzistoru. Obr. 9.26 ukazuje, jak pojistka na proud reaguje. Během normálním provozu je tranzistor sepnutý a pojistka má odpor $\mathrm{v}$ řádu jednotek $\Omega$, jak ukazuje strmá část křivky. Při překročení jmenovitého proudu ITRIG (trigger current) tranzistor rozepne a jeho odpor vzroste o několik řádů; zbytkový proud $I_{\mathrm{Q}}$ je typicky menší než $1 \mathrm{~mA}$. V tomto stavu pojistka setrvá, dokud na ní úbytek napětí neklesne pod $U_{\text {RESET }}$ (reset voltage reshold), pak se její odpor vrátí zpět na původní nízkou hodnotu.

Polovodičové pojistky jsou ze všech nadproudových ochran jednoznačně nejrychlejší, reagují do $1 \mu \mathrm{s}$. Další výhodou je, že se vyrábějí v unipolárním i bipolárním provedení. Unipolární propouštějí proud pouze jedním směrem (jako dioda), takže současně mohou sloužit

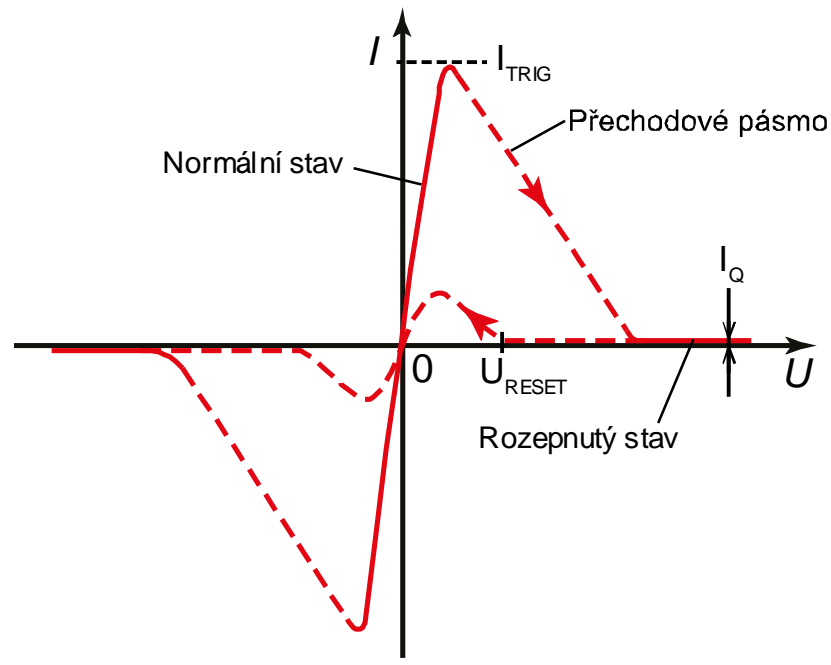

$\mathbf{a}$

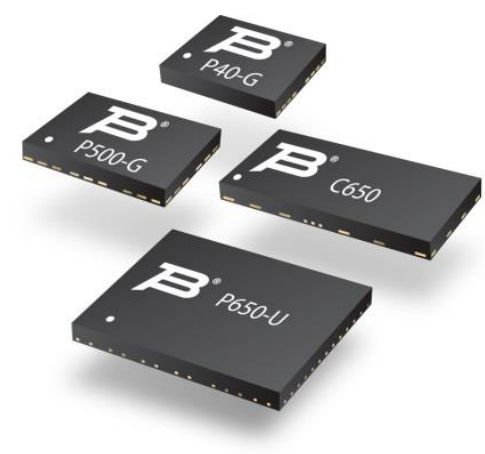

b

Obr. 9.26: a) VA charakteristika bipolární polovodičové pojistky, b) příklad provedení 
jako ochrana proti přepólování. Jejich nevýhodou je (prozatím) vysoká cena a malý rozsah jmenovitých proudů ( $50 \mathrm{~mA}$ až $1,5 \mathrm{~A})$. Přri návrhu je nutné počítat s vhodnou proudovou rezervou, výrobci doporučují 30\%. Pokud nejsou přetěžovány, mají neomezenou životnost. Jmenovitý proud ITRIG se mění s teplotou okolí, ale jeho změny nejsou tak výrazné, jako u termistorových pojistek.

Takřka všechny v současnosti vyráběné polovodičové pojistky jsou určeny pro ochranu signálových vodičů, jejich parazitní odpor je totiž $10 \times$ až $100 \times$ vyšší než u porovnatelných tavných pojistek. Navíc napětí $U_{\text {RESET }}$ je u většiny současných typů nízké (okolo $20 \mathrm{~V}$ ); pokud je na chráněném vodiči v běžném provozu napětí vyšší, nevrátí se pojistky spolehlivě zpět do vodivého stavu. Tyto důvody (prozatím) omezují možnosti jejich použití v napájecích obvodech. Př́klad provedení polovodičových pojistek pro SMD montáž je uveden na Obr. 9.26b.

\section{Rezistory a pojistné rezistory}

Obyčejné rezistory se často kombinují s přepětovými ochranami signálových vodičů, kdy se rezistor vloží do signálového vodiče před přepět'ovou ochranu. Jeho odpor se volí tak, aby nepříznivě neovlivňoval funkci zařízení (obvykle mezi 10 a $200 \Omega$ ). Např́iklad nadproud 1 A na rezistoru $100 \Omega$ způsobí úbytek napětí $100 \mathrm{~V}$ a následná přepět'ová ochrana nemusí být tak robustní (tj. může být levnější a menší). Rezistory jsou zvláště účinné pro potlačení krátkodobých poruchových jevů (velké proudy, ale po krátkou dobu). Pokud jsou vystaveny dlouhodobým nadproudům, tak obvykle dojde $\mathrm{k}$ jejich zničení, protože na nich vznikne velká výkonová ztráta dle vztahu (9.3). Nicméně i tato vlastnost je v praxi aktivně využívána, protože rezistor je jediná součástka, u které je zaručeno, že má po zničení velký odpor (open failure mode). U běžných rezistorů však není specifikováno, kdy ke zničení dojde a bylo by nutné tuto vlastnost složitě testovat. Proto existují tzv. pojistné rezistory (fusible resistor), u kterých je předem známo, při jakém ztrátovém výkonu dojde $\mathrm{k}$ jejich přepálení. Pro ilustraci, SMD pojistné rezistory v pouzdru 1206 na trvalý př́kon $0,125 \mathrm{~W}$ se spolehlivě přepálí při $2,5 \mathrm{~W}$. Jedná se tedy jen o velmi hrubou ochranu proti nadproudu.

\subsection{Př́íklady aplikací ochranných obvodů}

Konstrukce ochranných obvodů se značně mění podle toho, zda se jedná o napájecí či signálové vodiče, jaká jsou na nich napětí a proudy a jak zranitelné jsou obvody uvnitř chráněného zařízení. Je zřejmé, že výkonové součástky v sít’ovém zdroji toho snesou mnohem více, než integrovaný obvod vysokorychlostní komunikační linky. V této podkapitole je uveden pouze přehled nejčastějších řešení ochran, jsou však možné i jiné kombinace ochranných prvků.

Jak bylo zmíněno na začátku kapitoly 9 , v praxi se před uvedením zařízení na trh zvolené řešení ochran vždy ze zákona testuje. Výrobci obvykle postupují tak, že vyrobí několik vzorků zařízení a ty si ve svých laboratořích sami otestují (a př́ípadně ochrany posílí). Teprve až zařízení spolehlivě těmito interními testy projde, nechávají je certifikovat v (drahé) oficiální zkušebně.

\section{Ochrana napájecích zdrojů}

$\mathrm{Na}$ Obr. 9.27ł je typické řešení ochran klasických i spínaných sít'ových zdrojů pro zařízení Třídy I, které mají přivedený ochranný PE zemní vodič (například zdroje v PC). Přepět'ová ochrana je řešena pomocí varistorů a je tedy poměrně hrubá. To však nevadí, protože usměrňovač, vyhlazovací kondenzátor a další součástky zdroje jsou vždy dimenzovány na vyšší 
napětí, než je nezbytně nutné (jinak by zdroj v reálném nasazení př́liš dlouho nevydržel). Varistor MOV1 chrání zdroj před přepětovými špičkami mezi vodiči L a N. V praxi je nutné sít'ová zařízení chránit i proti přepětím, které mohou vzniknout mezi vodiči L či N a zemí (PE); to obstarávají varistory MOV2 a MOV3. V levnějších zdrojích často chybí, takže taková přepětí mohou brzy poškodit kondenzátory v odrušovacích obvodech. Tavná pojistka F1 pak slouží jako nadproudová ochrana při poruše zdroje (proražení odrušovacích či filtračních kondenzátorů, zničení usměrňovače apod.). Tavná pojistka je vždy pomalá (charakteristika T) a její jmenovitý proud se volí $2 \times$ až $3 \times$ vyšší, než je běžný odběr celého zařízení - nesmí reagovat na proudové špičky po zapnutí (inrush current) ani na běžné poruchové děje v rozvodné síti. Protože varistory reagují pomalu, zapojuje se za odrušovací obvody bipolární transil TVS1, který chrání usměrňovač a další polovodiče zdroje před rychlými špičkami.
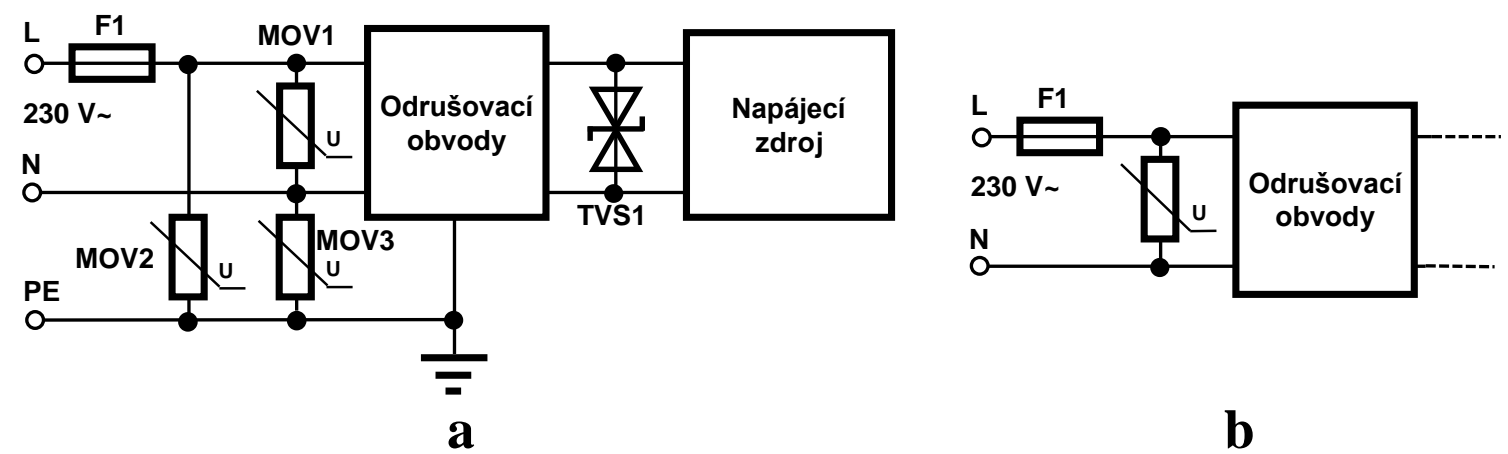

Obr. 9.27: Př́klad ochran sít’ových zdrojů: a) napájecí zdroj, b) malý spínaný zdroj

$\mathrm{Na}$ Obr. 9.27b je zapojení ochran používaných v malých spínaných zdrojích, jako jsou sítové adaptéry, nabíječky mobilních zařízení aj. Ty mají dvojitou izolaci (trrída ochrany 2), takže do nich není přiveden ochranný vodič. Též u nich bývá kladen důraz na nízkou cenu, takže jejich ochrana spočívá pouze $\mathrm{v}$ tavné pojistce a př́ípadně varistoru mezi vodiči $\mathrm{L}$ a $\mathrm{N}$. Uvedené zdroje též musejí mít ochranu proti přehřátí, která má obvykle podobu jednorázové tepelné pojistky. Po prvním velkém přetížení a/nebo přehřátí zdroj přestane fungovat a je nutné koupit nový.

Domácí spotřebiče obsahují velké množství induktivních zátěží napájených z $230 \mathrm{~V}$, typicky vinutí motorů různých typů a výkonů. Ty při rozepnutí generují velkou přepět'ovou špičku, která může poškodit spínací prvek (na Obr. 9.28 může dojít k oblouku a svaření kontaktů relé). Kontakty relé je možné ochránit paralelně připojeným varistorem, který přepět'ovou špičku omezí. Je též možné varistor připojit i př́ímo na induktivní zátěž a tím omezit špičky již u zdroje (nešírí se dál např. po vodičích). Polovodičové spínací prvky (napřs. triaky) jsou na přepětí citlivější a může být lepší pro jejich ochranu použít bipolární transily. Na Obr. 9.28 je dále použita polymerová termistorová pojistka, která motor chrání proti nadproudům. Pokud při nesprávné obsluze dojde k zablokování nebo přetížení motoru, termistor spolehlivě zareaguje, protože zablokovaný motor má velmi nízkou impedanci. Když uživatel svoji chybu napraví, termistor vychladne a spotřebič dál funguje bez nutnosti servisního zásahu. 


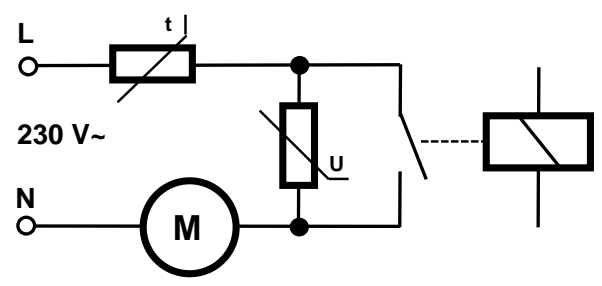

Obr. 9.28: Ochrana střídavého motoru a jeho spínacího prvku

Pro ochranu stejnosměrných napájecích vstupů pro připojení externího zdroje se dnes téměř výhradně používají unipolární transily, viz Obr. 9.29 a. Ty jsou totiž dostatečně přesné a současně rychlé, aby dokázaly ochránit polovodiče přímo prripojené na napájecí napětí. Zjednodušený obvod na Obr. 9.29 ašak není v praxi úplně dobrým řešením. U stejnosměrně napájených zařízení se totiž řeší i jejich ochrana proti přepólování. Tu na Obr. 9.29 dokáže zajistit př́mo sám unipolární transil - pokud je totiž na jeho katodu přiveden záporný potenciál, chová se jako obyčejná dioda a je na něm úbytek napětí do $1 \mathrm{~V}$. Potíž je v tom, že vzniklý nadproud přepálí tavnou pojistku, kterou je pak nutné vyměnit. Moderní elektronická zařízení navíc velmi často obsahují obvody, které generují rušení (DC/DC měniče, rychlé digitální obvody). Aby zařízení prošlo certifikací, nesmí se toto rušení šíriit ven po napájecím přívodu. Prakticky použitelný obvod proto vypadá spíše jako uspořádání na Obr. 9.29b. Dioda $\mathrm{D}_{1}$ zabezpečuje, že se při přepólování nepřepálí pojistka. Dále je doplněn vysokofrekvenční odrušovaný filtr $\mathrm{C}_{\mathrm{F}}-\mathrm{L}_{\mathrm{F}}-\mathrm{C}_{\mathrm{F}}$. Ten zabraňuje průniku vysokofrekvenční rušení oběma směry (ze zařízení i dovnitř). Kondenzátory $\mathrm{C}_{\mathrm{F}}$ musejí být účinné do vysokých kmitočtů, typicky se volí keramické např. $100 \mathrm{pF} / 200 \mathrm{~V}$ ze hmoty NP0. Pro vyrovnání proudového odběru se pak připojuje ještě větší blokovací kondenzátor $\mathrm{C}_{\mathrm{B}}$, například elektrolytický $100 \mu \mathrm{F}$.

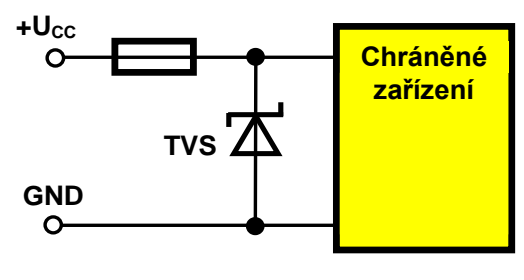

a

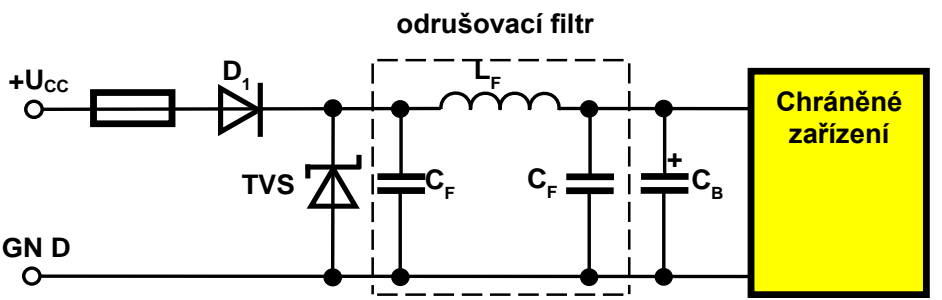

b

Obr. 9.29: Ochrana stejnosměrně napájených zařízení

Na tomto místě stojí za zmínku, že ve stejnosměrných napájecích ochranách je možné použít i polymerové termistorové pojistky, jsou s tím však spojeny určité obtíže. Jak již bylo zmíněno dříve, na termistorových pojistkách po aktivaci vzniká trvalá výkonová ztráta $P_{\mathrm{D}}$, která je udržuje v ohřátém stavu. Proud potřebný pro vytvoření této ztráty se však mění v závislosti na velikosti přepětí, které aktivaci pojistky způsobilo. Na Obr. 9.30 je pro příklad zařízení, které má být normálně napájeno napětím $U_{\mathrm{CC}}=24 \mathrm{~V}$ a odebírá proud $I_{\mathrm{CC}}=1 \mathrm{~A}$. Jako ochrana tedy bude použit transil se jmenovitým napětím $U_{\mathrm{R}}=24 \mathrm{~V}$ a termistorová pojistka se jmenovitým proudem $I_{\text {hold }}=1,5 \mathrm{~A}$. Pokud bude pojistka $\mathrm{v}$ SMD provedení, bude pro její udržení $\mathrm{v}$ ohřátém stavu zapotřebí výkon $P_{\mathrm{D}}=0,8 \mathrm{~W}$. 


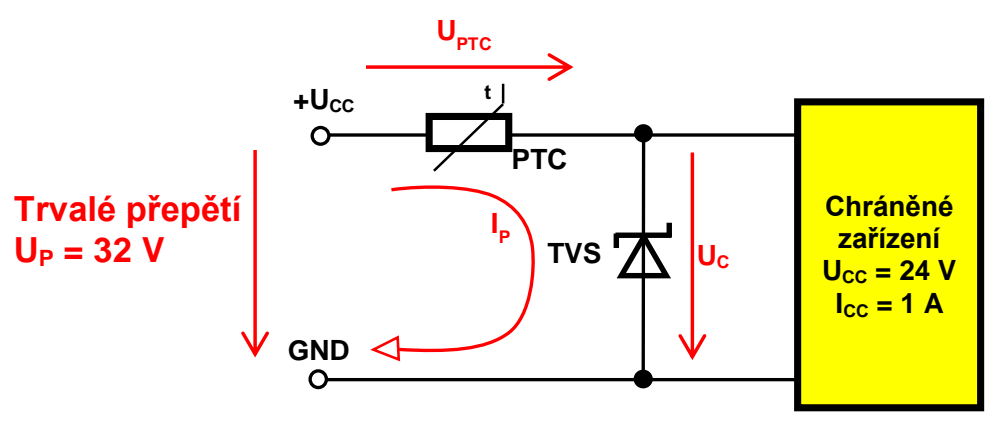

Obr. 9.30: K vysvětlení ztrátového výkonu termistoru a transilu

Při připojení přepětí např̀ o velikosti $U_{\mathrm{P}}=32 \mathrm{~V}$ zareaguje transil a omezí velikost napětí na chráněném obvodu přibližně na $U_{\mathrm{C}}=28 \mathrm{~V}$. Současně s tím začne přes termistor protékat velký proud $I_{\mathrm{P}}$, který jej postupně ohřeje. Na termistorové pojistce se poté objeví úbytek napětí

$$
U_{\mathrm{PTC}}=U_{\mathrm{P}}-U_{\mathrm{C}}=32-28=4 \mathrm{~V} .
$$

Snadným výpočtem zjistíte, že pro udržení v ohřátém stavu bude muset termistorovou pojistkou procházet proud

$$
I_{\mathrm{P}}=\frac{P_{\mathrm{D}}}{U_{\text {PTC }}}=\frac{0,8}{4}=0,2 \mathrm{~A} .
$$

Tím však na transilu vznikne poměrně velký ztrátový výkon

$$
P_{\mathrm{TVS}}=U_{\mathrm{C}} \cdot I_{\mathrm{P}}=28 \cdot 0,2=5,6 \mathrm{~W} .
$$

Transily, které dokáží takový ztrátový výkon trvale snést, jsou však rozměrné a drahé. Nicméně tyto problémy nastávají, pouze pokud je přepětí jen o něco málo vyšší, než je jmenovité napětí zařízení. Pokud by přepětí v Obr. 9.30 mělo velikost $U_{\mathrm{P}}=100 \mathrm{~V}$, bude mít poruchový proud velikost $I_{\mathrm{P}}=0,011 \mathrm{~A}$ a ztrátový výkon na transilu se (zdánlivě paradoxně) sníží na $P_{\mathrm{TVS}}=0,31 \mathrm{~W}$. Takový výkon přitom trvale snesou i miniaturní levné SMD transily. Při návrhu ochranných obvodů s termistorovými pojistkami je proto vždy nutné se zamyslet, jaká přepětí (a odpovídající poruchové proudy) lze na napájecím vstupu zařízení očekávat a podle toho použité prvky dimenzovat.

\section{Ochrana signálových spojů}

Signálová vedení jsou zpravidla velmi dlouhá a jsou vedena ve venkovním prostředí. Pokud v jejich okolí dojde k úderu blesku, mohou se do nich naindukovat vysoká napětí a proudy, které mohou snadno zničit koncová zařízení (telefonní či xDSL ústředny, datové modemy, rozvodny kabelové televize apod.). V budovách jsou pak signálové vodiče často vedeny souběžně se silovými kabely a při poruše izolace se na nich může trvale objevit sítové napětí $230 \mathrm{~V}$ (power cross). Jinými slovy, ochrana signálových spojů je jeden z nejnáročnějších úkolů, protože se na nich mohou objevit krátkodobé i dlouhodobé poruchové děje. Např. u moderních digitálních ústředen mohou škody dosáhnout velmi vysokých částek a proto je jejich ochraně věnována velká pozornost. Ochrana bývá vždy koncipována jako vícestupňová.

$\mathrm{Na}$ Obr. 9.31 je př́klad řešení ochran signálových spojů v obyčejné telefonní ústředně (POTS) a v koncovém telefonním př́stroji. Určitou komplikací návrhu je, že v běžném provozu jsou na telefonní lince i stejnosměrná napětí, napřr. vyzváněcí signál $25 \mathrm{~Hz}$ s amplitudou až $75 \mathrm{~V}$ je superponován na ss napětí $60 \mathrm{~V}$ a po zvednutí mikrotelefonu se z těchto $60 \mathrm{~V}$ napájí celý 
telefonní přístroj.. Na Obr. 9.31 je ochrana telefonního vedení dvoustupňová - bleskojistky pohlcují největší napět'ové a proudové špičky, které se na venkovním vedení mohou objevit po úderu blesku. Jako ,jemná“ ochrana obvodů vlastních linkových karet (SLIC) jsou použity unipolární tyristorové ochrany. Ty po sepnutí sníží poruchové napětí na jednotky voltů, čímž spolehlivě telefonní obvody ochrání. Současně jsou dostatečně rychlé, aby pohltily počáteční energii poruchového děje, než se stihnou aktivovat bleskojistky. Jak je v Obr. 9.31 naznačeno, bleskojistky bývají umístěny na samostatných patch panelech (viz Obr. 9.8๕), přičemž mezi nimi a linkovými kartami bývá vedení o délce okolo $10 \mathrm{~m}$. Parazitní odpor a indukčnost tohoto vedení se chová jako filtr (dolní propust), která omezuje strmost a velikost proudových pulsů, které přes tyristory protečou. Pro ochranu před trvalými poruchami jsou do obou vodičů vloženy termistorové pojistky. Jejich parazitní odpor též přispívá k výše zmíněnému filtračnímu efektu. Stojí za zmínku, že řešení dle Obr.9.31 je možné provést až s moderními tyristorovými ochranami, uvedenými na trh v nedávné době. Dříve nedostačoval jejich maximální špičkový proud $I_{\text {PPSM }}$ a přepět'ovou ochranu bylo nutné realizovat jako třístupňovou. Nejčastěji byl mezi termistory a tyristory přidán další stupeň $\mathrm{s}$ varistory a rezistory $(\sim 10 \Omega)$ pro další snížení napětových a proudových špiček.

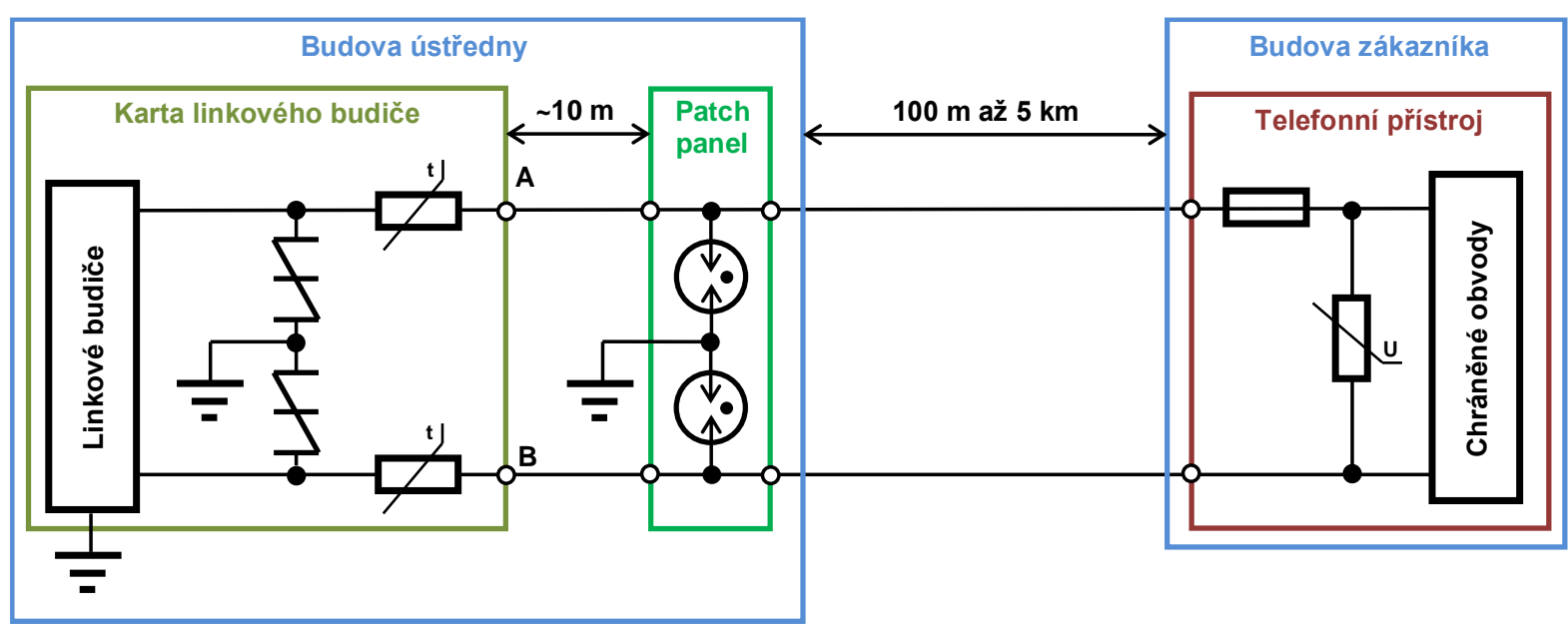

Obr. 9.31: Ochrana obyčejného telefonního vedení (POTS)

Ochrana koncových telefonních př́strojů je naopak velmi snadná, protože ty jsou plovoucí (nejsou propojeny se zemním vodičem). Nejčastěji je v nich jen varistor a tavná pojistka, jak ukazuje pravá část Obr. 9.31. Tyto ochrany jsou nutné víceméně jen pro certifikaci př́istroje; v praxi jsou telefonní vodiče vedeny těsně vedle sebe a je tedy nepravděpodobné, že by se na nich objevil velký rozdíl napětí. $\mathrm{V}$ dražších telefonech s rozšířenými funkcemi bývá místo varistoru osazena tyristorová ochrana, protože digitální obvody jsou na přepětí citlivější. Místo tavné pojistky může být použita pojistka termistorová, aby telefon po prvním dlouhodobém přepětí na lince nepřestal fungovat.

Technologie pro přenos dat po telefonních linkách (xDSL) mají ochrany koncipovány výrazně odlišně Obr. 9.32, protože na rozdíl od obyčejných hovorových linek (POTS) k přenosu používají výhradně střídavé signály. Vedení je od xDSL budičủ odděleno pomocí signálových transformátorů a kondenzátorů, které samy o sobě blokují většinu poruchových napětí. Jejich izolační schopnosti však nejsou neomezené (transformátory jsou testovány na $1500 \mathrm{~V}$ ) a proto je nutné je doplnit některými ochrannými prvky. Nejdůležitější jsou bleskojistky, které omezují napětí na vedení tak, aby nedošlo k průrazu izolace transformátorů. Některé časově proměnné poruchové děje se přes transformátor přece jen přenesou; aby nepoškodily xDSL budiče, je paralelně k primárnímu vinutí připojena bipolární tyristorová 
ochrana. V praxi se může stát, že opakovaná přepětí časem zničí (prorazí) sekundární vinutí transformátoru, oddělovací kondenzátor, nebo dokonce bleskojistku. Při trvalém přepětí by pak vedením po dlouhou dobu tekl velký proud. Aby nedošlo k jeho poškození, zapojují se před bleskojistky tavné pojistky.

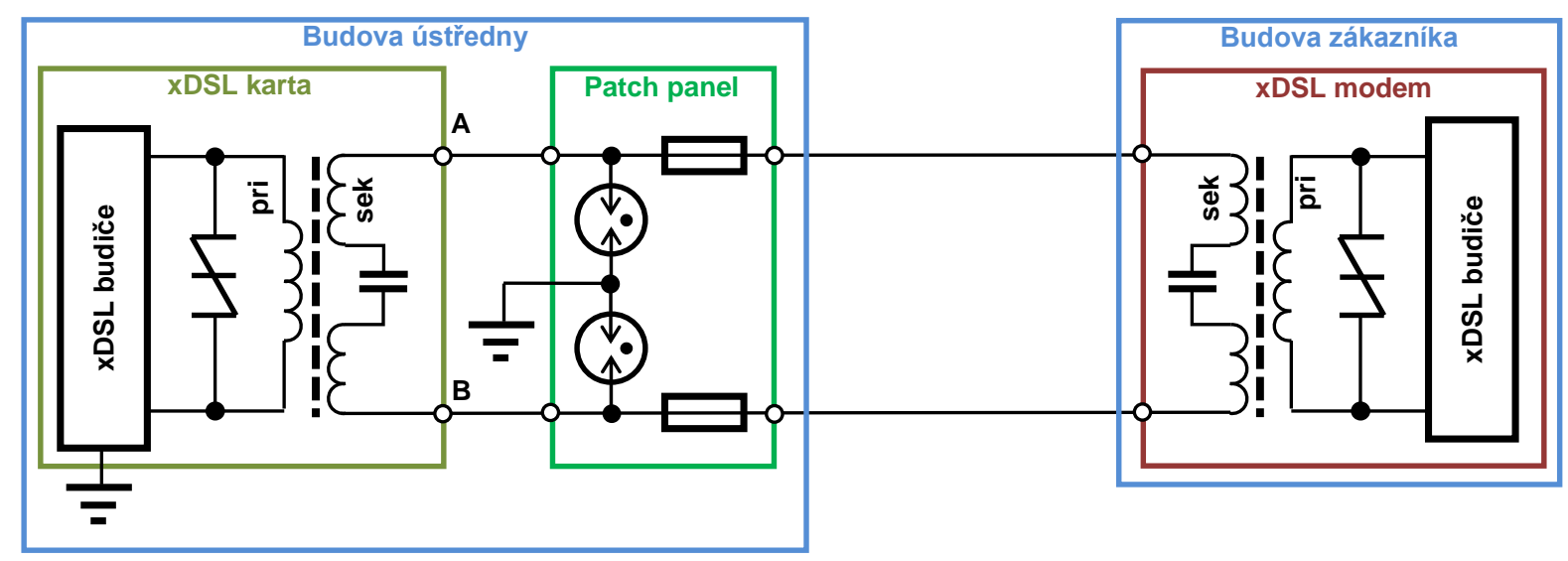

Obr. 9.32: К̌ Řšení ochran xDSL linky

Podobně jako v předchozím př́padě, ochrana běžných domácích xDSL modemů je výrazně jednodušší, protože jsou plovoucí. V levných modemech je typicky jen jediná bipolární tyristorová ochrana na primární straně signálového transformátoru. V dražších typech je pak možné nalézt nějaký ochranný prvek i na sekundární straně, např́íklad bipolární transil s nízkou parazitní kapacitou.

\section{Ochrana datových komunikačních rozhraní a porti̊}

Pro ochranu datových komunikačních rozhraní a portů neexistuje nějaké univerzální zapojení, protože jejich rychlosti a ostatní parametry se velmi výrazně mění. Zde se proto omezíme na několik př́kladů těch nejpoužívanějších. Například u rozhraní Ethernet pro rozvody uvnitř budov je velká část řešení standardizována, viz Obr. 9.33 . Mezi kabelem a řadičem je signálový transformátor, který je galvanicky odděluje. Rezistory $75 \Omega$ na kabelové straně jsou nutné pro impedanční přizpůsobení. Vysokonapětový kondenzátor $1 \mathrm{nF}$ pak odvádí rychlé poruchové děje (hlavně ESD) do země (PE). Současně zabezpečuje, aby do země netekly velké proudy při dlouhodobých poruchách (např. pokud se na kabelu objeví $230 \mathrm{~V}$ ). Na straně řadiče je zapotřebí pohltit pouze energii, která projde signálovým transformátorem (což je zlomek poruchové energie v kabelu). S tímto není nutné nějak experimentovat, dnes se k tomu používají 4-násobné unipolární transily, které jsou určeny přímo pro Ethernet (jako na Obr. 9.17b). Jiné velmi časté řešení integrovaných ochran je na Obr. 9.33b - každý signálový vodič je přes dvojici diod připojen mezi napájecí napětí $U_{\mathrm{CC}}$ a zem (GND). Diody tak zabezpečují, že napětí na signálovém vodiči nepřekročí velikost napájecího napětí řadiče. V pouzdru je současně integrován jeden transil, který zajišt'uje, aby se napájecí napětí nedostalo nad dovolenou mez. Pro různé varianty Ethernetu se tyto integrované ochrany vyrábějí s různými parametry; například pro průmyslový Ethernet jsou robustnější, pro Gigabit Ethernet mají nižší parazitní kapacity apod. Pokud existuje riziko, že by se do rozvodů Ethernetu mohlo naindukovat přepětí vyvolané úderem blesku, doplňují se na kabelovou stranu signálového transformátoru tyristorové ochrany. Požadavky na konstrukci a odolnost všech variant Ethernetu jsou standardizovány a podle toho je nutné vybrat i konkrétní ochranné prvky. 


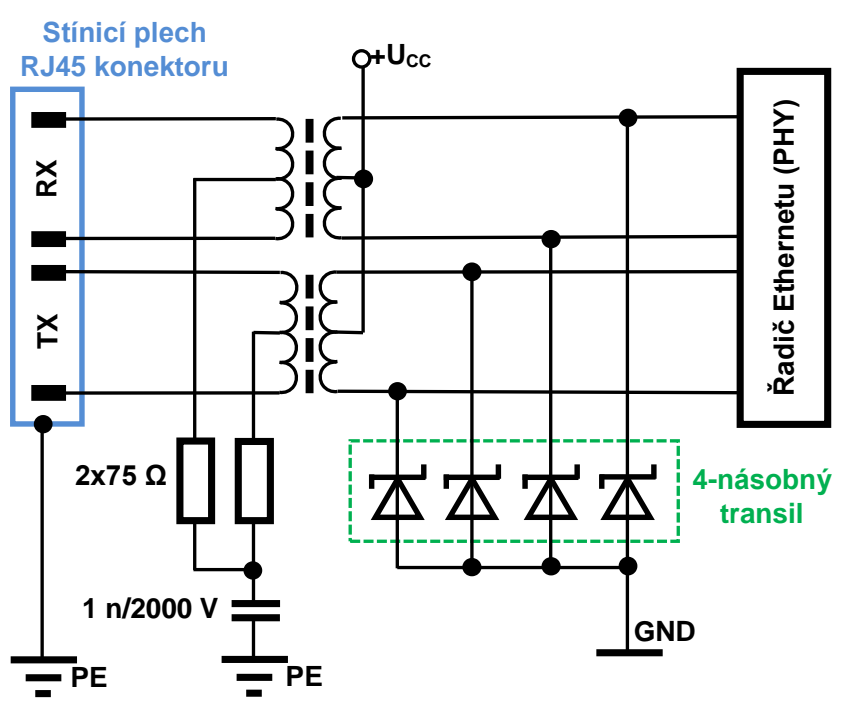

a

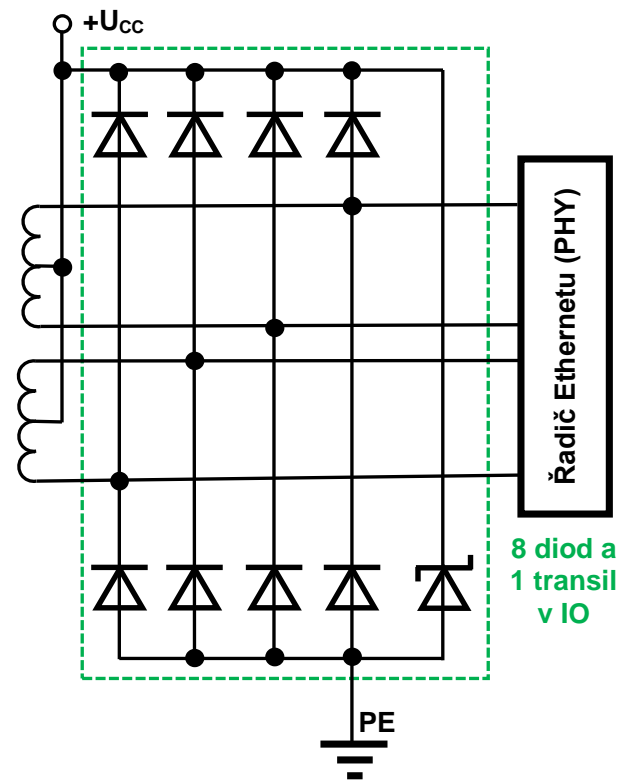

b

Obr. 9.33: Ochranné obvody 10/100 Ethernetu

Podobná situace je i s ochranami jiných masově používaných portů na spotřební elektronice, jako je USB, HDMI, DVI, FireWire apod. U nich se nepředpokládá, že by byly vystaveny dlouhodobým přepětím nebo dokonce úderům blesku; jsou však běžně vystavovány ESD výbojům. Ochrany jsou opět do velké míry standardizovány a výrobci nabízejí konkrétní výrobky pro konkrétní porty. $\mathrm{Na}$ Obr. 9.34 jsou pro ilustraci ochranné obvody USB 2.0 portu, které se používají na základní desce počítače. Vzhledem k vysokým rychlostem jsou datové vodiče vybaveny polymerovými ochranami, které mají minimální parazitní kapacitu. Ty dokáží omezit napětí z ESD výboje na přibližně $150 \mathrm{~V}$, zbylou energii odvedou ESD diody př́mo na čipu USB řadiče. USB porty (ale i FireWire či Thunderbolt) mají i vodiče pro napájení připojeného zařízení. Výstup napětí $+5 \mathrm{~V}$ z USB portu je přitom nutné ochránit nejen proti ESD, ale i proti zkratu - toto napětí je ovládáno př́ímo z USB řadiče, protože ten (mimo jiné) řídí i spotřebu připojeného zařízení. Koncepce ochrany záleží na jeho konstrukci, v praxi lze použít kombinaci unipolárního transilu a polovodičové vratné pojistky jako na Obr. 9.34. U méně zranitelných řadičů je možné použít i termistorovou pojistku, kdy je vhodné se ř́́dit doporučením výrobce řadiče. 


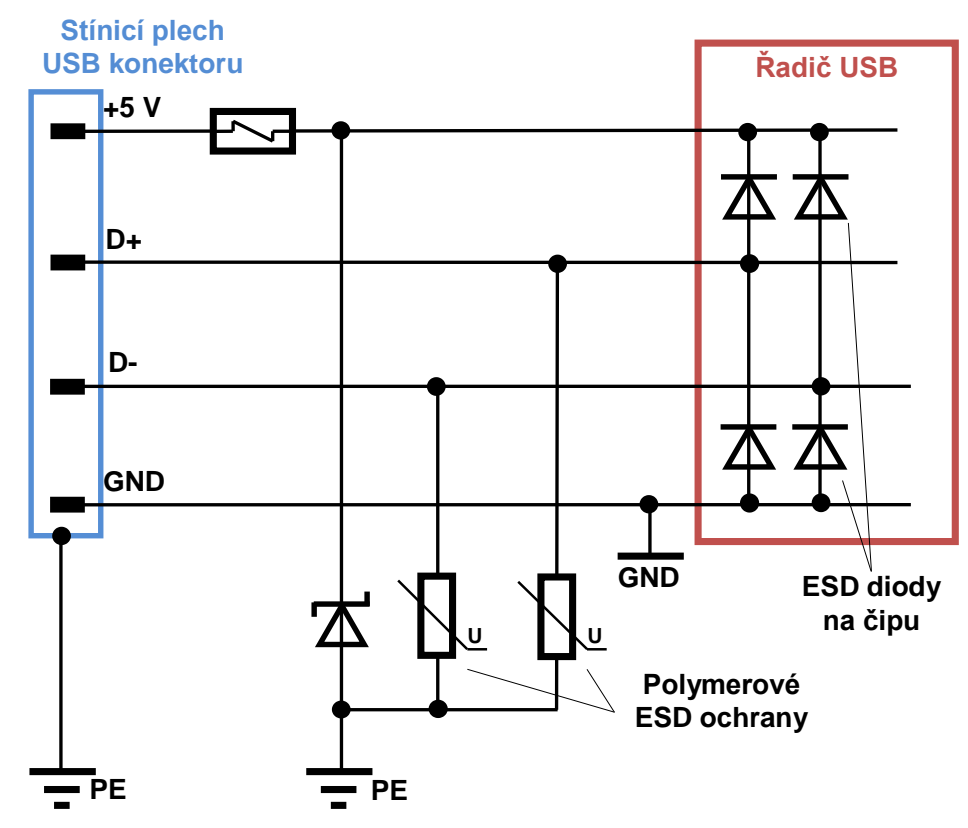

Obr. 9.34: Ochranné obvody portu USB 2.0

Obecně platí, že při výběru parametrů ochranných prvků datových komunikačních rozhraní je vždy nutné vzít do úvahy napětí, se kterými konkrétně použité obvody pracují. Např́klad integrovaný obvod řadiče Ethernetu $\mathrm{z}$ Obr. 9.33 může být napájen $\mathrm{z} 2,5 \mathrm{~V}$, $3,3 \mathrm{~V}$ nebo $5 \mathrm{~V}$ a podle toho je nutné vybrat i pracovní a napětí ochranných transilů. Současně je nutné zajistit, aby ochrany umožňovaly i zpětnou kompatibilitu. Např́iklad velká většina budičů sběrnice RS-232 dnes pracuje s logickými úrovněmi $\pm 10 \mathrm{~V}$ (obvody MAX232 a podobné). Oficiální napětový rozsah signálů na této sběrnici je však $\pm 25 \mathrm{~V}$, s čímž musejí ochrany počítat (typicky se používají bipolární transily se jmenovitým napětím $24 \mathrm{~V}$ ).

Bez ohledu na zvolené řešení však vždy platí, že ochranné prvky musí být umístěny co nejblíže vstupnímu konektoru, aby se rušivé vlivy nemohly šíriit dovnitř zařízení. Vodiče pro odvedení poruchových proudů do země musejí být dostatečně dimenzované, aby na nich nevznikaly velké úbytky napětí. V reálných zařízeních je pro ně zpravidla vyhrazena samostatná „,poruchová zem“, na kterou jsou kromě ochranných prvků zapojena i stínění konektorů (jako na Obr. 9.33 a abr. 9.34. Tato poruchová zem je pak v jednom bodě spojena $\mathrm{s}$ prívodem ochranného vodiče (kolík zásuvky). 


\section{Použitá literatura}

[13] SVAČINA, J.: Elektromagnetická kompatibilita: principy a poznámky. Vysoké učení technické v Brně, Brno 2001, ISBN 80-214-1873-7.

[2] SVAČINA, J.: Základy elektromagnetické kompatibility (EMC). Část 3: Způsoby omezování rušení - odrušovací prostředky a elektromagnetické stínění. Elektrorevue, Www.elektrorevue.cz. 2000/41-28. 11. 2000.

[3] SVAČINA, J.: Základy elektromagnetické kompatibility (EMC). Část 5: Elektromagnetická odolnost a její testování. Elektrorevue, www.elektrorevue.cz. 2001/25 - 4. 6. 2001.

[4] TDK: How to use ESD/surge Protection Devices: Surge Aresters. Application Note. TDK 2018.

[5] BOURNS: Fast Surge Protection for RF Ports in Handheld Instrumentation. Application Note. Bourns 2017.

[6] BREMOND, A.; KAROUI, C. Transient protection solutions: Transil diode versus varistor. Application note AN1826. STMicroelectronics 2004.

[7] LITTELFUSE: Littelfuse Varistors - Basic Properties, Terminology and Theory. Applicatin Note 10-89AN9767. Littelfuse, Inc. 1999.

[8] TDK: SIOV metal oxide varistors. Application notes. EPCOS AG 2018.

[9] BUSSMANN: Multilayer Varistor. Application Notes. Technical Note 4047. Eaton 2017.

[10] STMICROELECTRONICS: Transil clamping protection mode. Application note AN316. STMicroelectronics 2014.

[11] LITTELFUSE: Application Note: Transient Voltage Suppressors (TVS Diode). Littelfuse, Inc. 2015. 


\section{Aplikační pravidla pro aktivní elektronické obvodové prvky}

\subsection{Tranzistorové obvody}

V současné době se prakticky užívají jen křemíkové tranzistory. Nízkofrekvenční, vysokofrekvenční i spínací tranzistory s malým ztrátovým výkonem jsou obvykle montovány do miniaturního pouzdra z plastu pro montáž SMD nebo pro klasickou montáž do vývodového pouzdra z plastu nebo do kovového pouzdra. Uspořádání vývodů a jejich rozteč je v současné době standardizována. Nové typy jsou však přednostně v miniaturním plastikovém pouzdru.

Výkonové a spínací výkonové tranzistory jsou montovány do kovových plochých pouzder TO3, popř. některé typy pro menší výkony do plastikových pouzder TO220 s kovovou ploškou uzpůsobenou k připevnění na chladič. Kolektor je obvykle spojen s kovovým pouzdrem nebo kovovou ploškou tranzistoru. Všechny zásady a doporučení ke správnému návrhu obvodů s tranzistory není možno v tomto materiálu obsáhnout. Poukážeme alespoň na dvě skutečnosti, které musí mít konstruktér na paměti.

U zesilovačů, které zpracovávají malé napětové úrovně, vzniká nebezpečí, že rušivé napětí vnikne do smyček určitých částí obvodů, a zpưsobí zhoršení odstupu zařízení od šumu. $\mathrm{Na}$ Obr. 10.1 1 vidíme, že smyčka ve vstupním obvodu vlivem nesprávného umístění kapacitorů $\mathrm{C}_{1}$ a $\mathrm{C}_{2}$ je velká. Konstruktér se musí snažit, aby rozmístil součástky na plošném spoji tak, aby smyčka částí obvodů, které jsou choulostivé na rušivé napětí (mají malou úroveň užitečného signálu), byly co nejmenší. Příklad správného umístění vazebního kapacitoru $C_{1}$ a přemost'ovacího kapacitoru $\mathrm{C}_{2}$ je označen na Obr. 10.1b. Je zřejmé, že v tomto př́padě je plocha smyčky vstupního obvodu mnohem menší než na Obr. 10.1

Konstruktér musí uspořádat obvody na desce plošného spoje tak, aby mezi jednotlivými tranzistorovými zesilovacími stupni nevznikaly v zemním vodiči úbytky napětí, které by představovaly nežádoucí vazby (záporné nebo kladné) mezi stupni. Na Obr. 10.2 a je naznačeno nesprávné řešení tohoto problému. Tranzistorový zesilovač sestávající ze tř́ invertujících tranzistorových stupňů je napájen v bodech A, B. Vidíme, že střídavý okruh třetího stupně je uzavřen přes části zemního vodiče $1,2,3$, které jsou společné pro tranzistory $T_{1}$ a $T_{2}$. Úbytek na úseku 1 je ve fázi se vstupním napětím tranzistoru $\mathrm{T}_{1}$ (kladná vazba), na úseku $2 \mathrm{v}$ protifázi se vstupním napětím tranzistoru $\mathrm{T}_{2}$ (záporná vazba) a ve fázi se vstupním napětím tranzistoru $\mathrm{T}_{3}$ (kladná vazba).

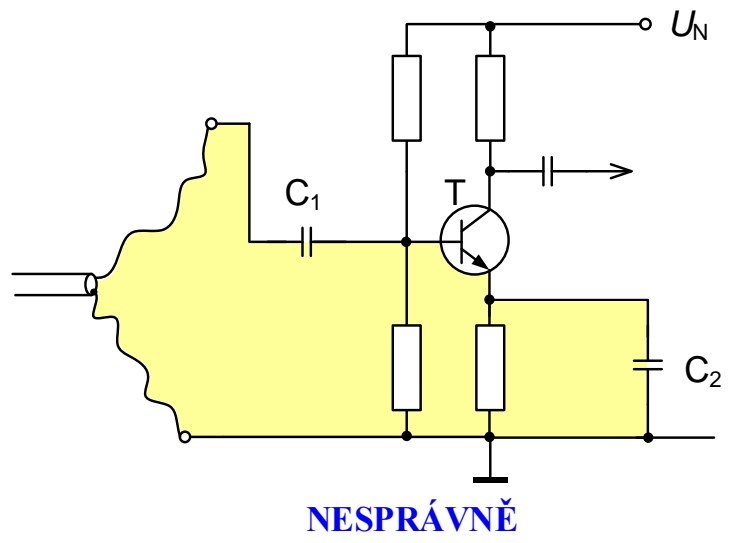

a

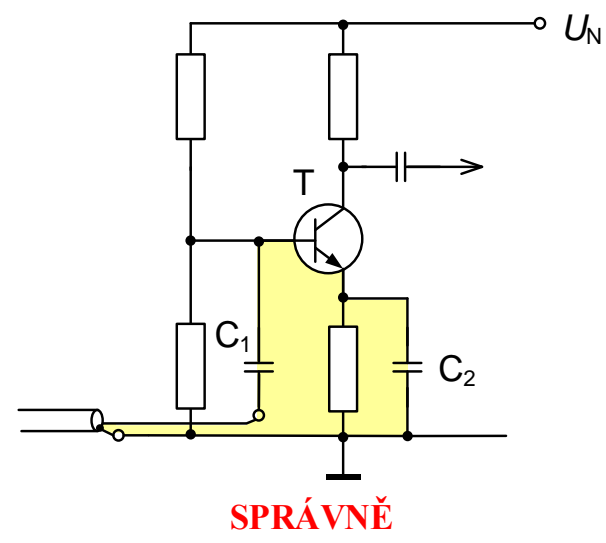

b

Obr. 10.1: Zapojení zesilovacího stupně z hlediska co nejmenší plochy vstupní smyčky 


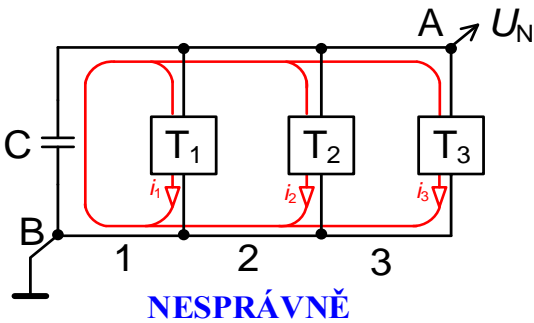

a

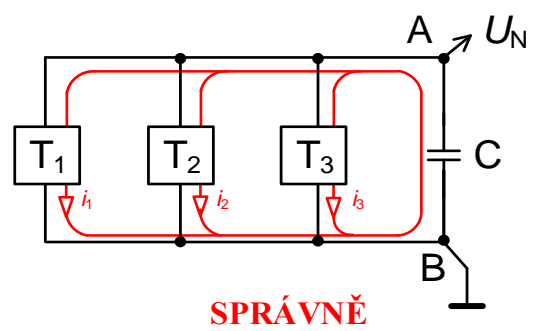

b

Obr. 10.2: Zapojení zesilovacích tranzistorových stupňů z hlediska správného připojení na zemní vodič

Uvedené vazby mohou způsobit nestabilitu zesilovače. Konstruktér musí proto zvolit napájecí body, jakož i rozmístění filtračních kapacitorů a emitorových rezistorů tranzistorových zesilovačů tak, aby stř́ídavý okruh jednotlivých stupňů byl co nejkratší a hlavně, aby proudy výkonnějších stupňů neprotékaly úseky vstupních okruhů. Takové řešení nám ukazuje uspořádání na Obr. 10.2b kde vidíme, že jsou vyloučeny nežádoucí vazby uplatňující se na Obr. 10.2 A. Proudy prvního a druhého stupně se sice uzavírají přes zemní vodič třetího stupně, ale tam se již př́liš neuplatní, protože signál je na výstupu třetího stupně zesílen.

\subsection{Operační zesilovače}

U invertujícího zapojení operačního zesilovače vystačíme se zesilovačem majícím jednoduchý invertující vstup, u neinvertujícího a rozdílového (odčítacího) zapojení musíme použít zesilovač s diferenčním vstupem. Až na několik speciálních výjimek jsou dnešní operační zesilovače opatřeny diferenčním vstupem. Výběr typu operačního zesilovače je nutno podřídit požadavkům jeho zamýšleného použití (přesnost, stálost parametrů, vstupní impedance, výstupní impedance, proud do zátěže, výkon, šiřrka pásma, rychlost přeběhu aj.) a kromě toho požadavkům ekonomickým (cena, provozní spolehlivost, snadná nahraditelnost). Při aplikaci operačního zesilovače obvykle uplatňuje celá řada hledisek současně.

\subsubsection{Aplikační zásady}

Charakter zpětnovazebni sitě. Charakter zpětnovazební sítě musíme vždy dát do relace $\mathrm{s}$ přenosovou charakteristikou operačního zesilovače, nebot' zanedbání těchto souvislostí vede téměř vždy $\mathrm{k}$ nestabilitě obvodu a tedy $\mathrm{k}$ jeho rozkmitání. Uvedeme si jednoduché kriterium použitelné k orientačnímu určení stability obvodu. Uvažujme elementární obvod uspořádaný podle Obr. 10.3 a, kde v operační síti zesilovače jsou zapojeny dva jednobrany $Z_{1}$ a $Z_{2}$, charakterizované impedancemi $\bar{Z}_{1}$ a $\bar{Z}_{2}$. Určíme tzv. zpětnovazební poměr (nebo také někdy činitel zpětné vazby) při rozpojené zpětnovazební smyčce $\bar{\beta}$. V podstatě jde o to určit, jaká část výstupního napětí $\bar{U}_{2}$ se při zkratované vstupní svorce a rozpojené zpětnovazební smyčce dostane na invertující vstup $\mathrm{OZ}$ přes impedanční dělič $\mathrm{Z}_{1}$ a $\mathrm{Z}_{2}$ (viz Obr. 10.3p)

$$
\bar{\beta}=\frac{\bar{U}_{\mathrm{i}}}{\bar{U}_{2}}=\frac{\bar{Z}_{1}}{\bar{Z}_{1}+\bar{Z}_{2}}
$$

V semilogaritmickém měřítku vyneseme do grafu na Obr. 10.3£ závislost 


$$
z_{\beta}(f)=20 \log |1 / \bar{\beta}|
$$

Do téhož grafu vyneseme závislost zisku zesilovače (bez zpětné vazby) na kmitočtu

$$
z(f)=20 \log A(f) .
$$

I když tato charakteristika není běžně udávána, lze ji u operačních zesilovačů se standardním poklesem přenosové charakteristiky $20 \mathrm{~dB} / \mathrm{dek}$ určit pomocí asymptot ze znalosti stejnosměrného zesílení a tranzitního kmitočtu $f_{\mathrm{T}}$.

Obvod bude zcela stabilní, pokud bude rychlost přibližování charakteristiky $z \beta(f)$ a $z(f)$ před jejich průsečíkem rovna nebo menší než $20 \mathrm{~dB} / \mathrm{dek}$. Ještě lze povolit přibližování charakteristik $30 \mathrm{~dB} /$ dek. Přri rychlosti přibližování $40 \mathrm{~dB} /$ dek je fázová bezpečnost $0^{\circ}$ a obvod se zcela jistě rozkmitá. Předpokládáme-li průběh převráceného zpětnovazebního poměru na kmitočtu $z_{\beta}(f)$ podle Obr. 10.3 , bude obvod při použití běžného operačního zesilovače stabilní, ale při použití širokopásmového operačního zesilovače s podstatně vyšším tranzitním kmitočtem již obvod stabilní nebude, protože rychlost přibližování charakteristik $z_{\beta}(f)$ a $z^{\prime}(f)$ nyní bude $40 \mathrm{~dB} /$ dek.
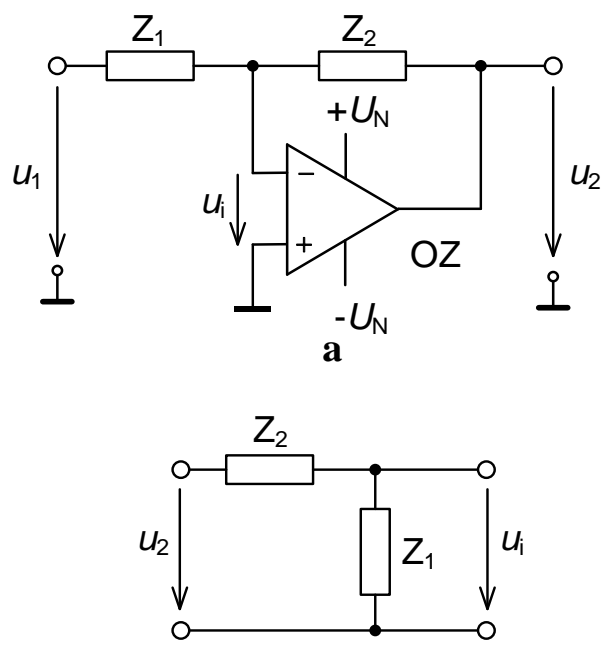

b

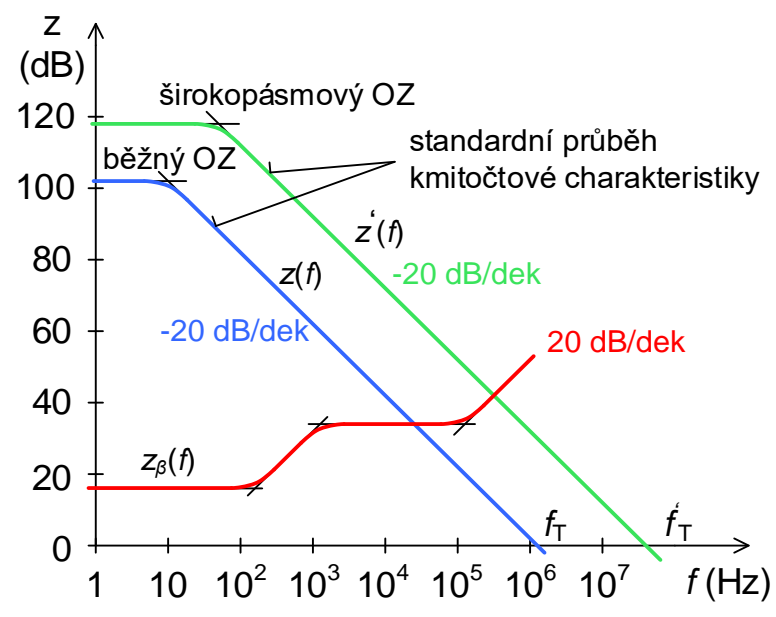

c

Obr. 10.3: a) Operační zesilovač s kmitočtově závislou zpětnou vazbou, b) k určení zpětnovazebního poměru, c) grafický způsob posouzení kmitočtové stability obvodu

K obdobné situaci může dojít i u zesilovače s čistě rezistorovou operační sítí, pokud operační zesilovač vykazuje na vysokých kmitočtech tzv. rychlý pokles kmitočtové charakteristiky. Tento př́pad je pro názornost uveden na Obr. 10.4a, kde je zapojení invertujícího zesilovače se zesílením $A_{\mathrm{U}}=-2$. Stanovíme-li zpětnovazební poměr $\beta=R_{1} /\left(R_{1}+R_{2}\right)$ a zakreslíme-li závislost $z_{\beta}(f)=20 \log \left(1+R_{2} / R_{1}\right)$ do grafu na Obr. 10.4 je nám okamžitě jasné, proč výrobce udává pro tento typ zesilovače $\left|A_{U}\right| \geq 5$. Rychlost přibližování charakteristik je totiž pro menší zesílení větší než $20 \mathrm{~dB} /$ dek a OZ bude na mezi stability, nebo se rozkmitá.

I když by se při prvním zběžném pohledu zdálo, že použití integračního kapacitoru ve zpětné vazbě integrátoru (viz Obr. 10.4b) musí vést ke zlepšení stability obvodu, není tomu tak 
vždy. Zpětnovazební poměr je v tomto případě komplexní $\bar{\beta}^{\prime}=R_{0} /\left(R_{0}+1 / \mathrm{j} \omega C_{1}\right)$, charakteristika $z_{\beta}^{\prime}(f)$ má jeden lom při kmitočtu $1 / 2 \pi R_{0} C_{1}$ a na vysokých kmitočtech se k charakteristice $z(f)$ operačního zesilovače s rychlým poklesem kmitočtové charakteristiky přibližuje rychlostí $40 \mathrm{~dB} / \mathrm{dek}$ Obr. 10.4. Je zřejmé, že použití operačního zesilovače s rychlým poklesem přenosové charakteristiky pro konstrukci integrátoru nebude obecně vhodné. Vždy je proto nutné $\mathrm{v}$ případě integrátoru použít operační zesilovač se standardním průběhem přenosové charakteristiky.
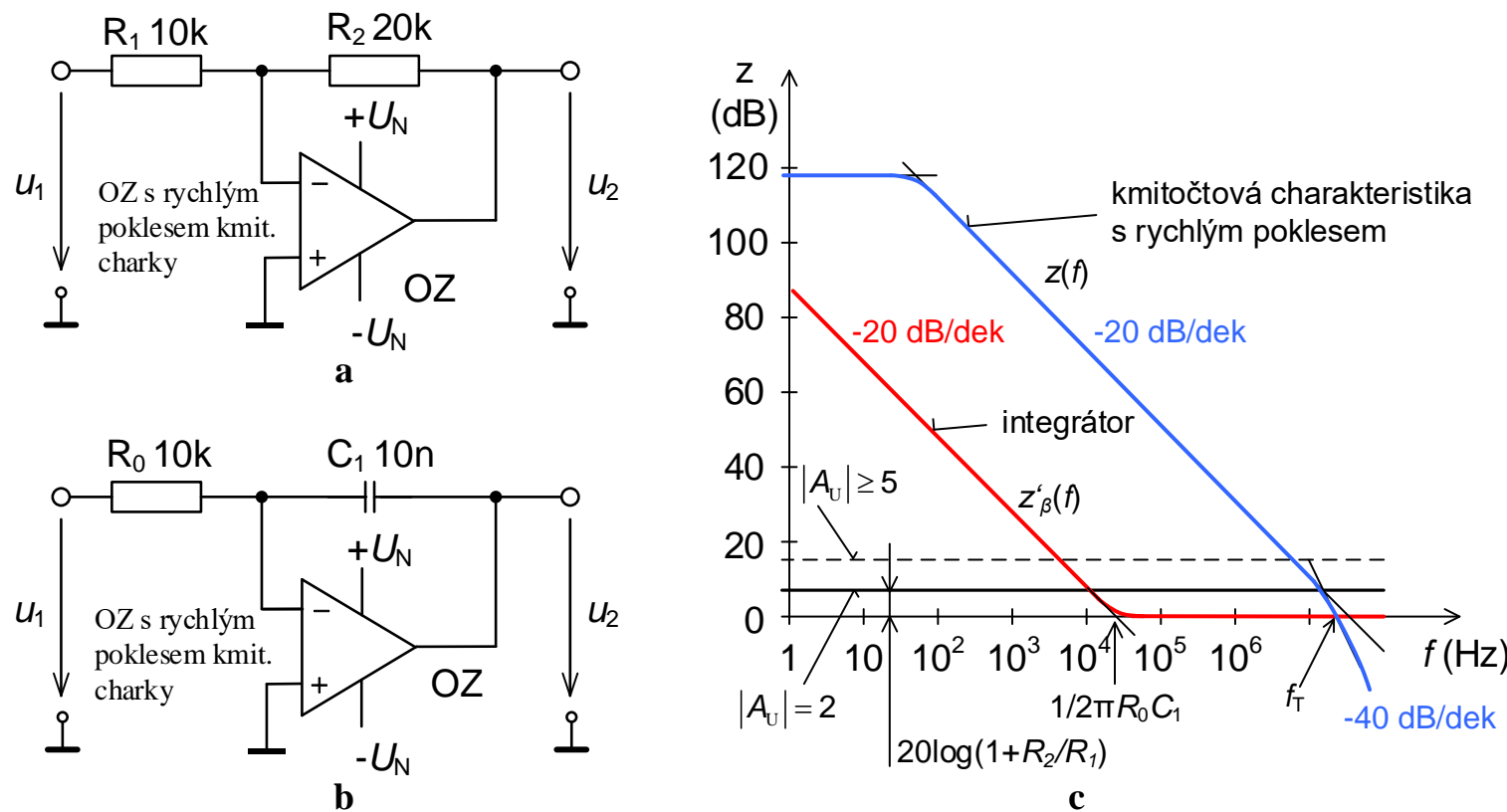

c

Obr. 10.4: K určení kmitočtové stability a) invertujícího zesilovače, b) integrátoru, c) grafické řešení

Bohužel i v př́ipadech, kdy by obvod měl být stabilní, může se bud' rozkmitávat, popř. může dojít k odtlumení obvodu, což způsobuje velký překmit při skokové změně vstupního napětí a dlouhé doznívání tlumených kmitů přechodného děje. Je to obvykle způsobeno některou parazitní veličinou, kterou jsme při prvním rozboru stability neuvažovali. $\mathrm{K}$ rozkmitání zesilovače, zapojeného v dané operační síti, může např. přispět rozptylová kapacita sčítacího bodu (invertující vstup OZ) zesilovače, zapojeného podle Obr. 10.5ł. Rozptylová kapacita, zahrnující kapacitu př́vodních vodičů, diferenční vstupní kapacitu $C_{\mathrm{i}}$ a souhlasnou vstupní kapacitu $C_{\mathrm{cm}}^{-}$operačního zesilovače, je pro názornost $\mathrm{v}$ zapojení modelována kapacitorem $C_{\mathrm{p}}$ o kapacitě asi $50 \mathrm{pF}$. Nebude-li ve zpětné vazbě zařazen korekční kapacitor $\mathrm{C}_{\mathrm{k}}$ bude zpětnovazební činitel

$$
\beta=\frac{R_{1}}{R_{1}+R_{2}} \frac{1}{1+j \omega C_{\mathrm{p}}\left(R_{1} \| R_{2}\right)}
$$

a může dojít k rozkmitání obvodu, protože se kmitočtové charakteristiky přibližují rychlostí 40 $\mathrm{dB} /$ dek (viz červený průběh $z_{\beta}(f) \mathrm{v}$ Obr. 10.5b). Přidaný korekční kapacitor $\mathrm{C}_{\mathrm{k}}$ upravuje zpětnovazební poměr do tvaru

$$
\beta=\frac{R_{1}}{R_{1}+R_{2}} \frac{1+\mathrm{j} \omega C_{\mathrm{k}} R_{2}}{1+\mathrm{j} \omega\left(C_{\mathrm{p}}+C_{\mathrm{k}}\right)\left(R_{1} \| R_{2}\right)}
$$


a charakteristika $z_{\beta}^{\prime}(f)=20 \log \left|1 / \beta^{\prime}\right|$ má již vzhledem $\mathrm{k}$ charakteristice $z(f)$ operačního zesilovače př́znivý průběh (modrý průběh na Obr. 10.5p). Optimální hodnota kapacity korekčního kapacitoru se určí obvykle experimentálně při buzení obvodu pravoúhlými kmity (viz Obr. 10.54). Zpravidla se ukáže, že tato optimální hodnota je menší než hodnota $C_{\mathrm{k}}=C_{\mathrm{p}}$ $R_{1} / R_{2}$, která príśsluší zcela vykompenzovanému zpětnovazebnímu děliči.
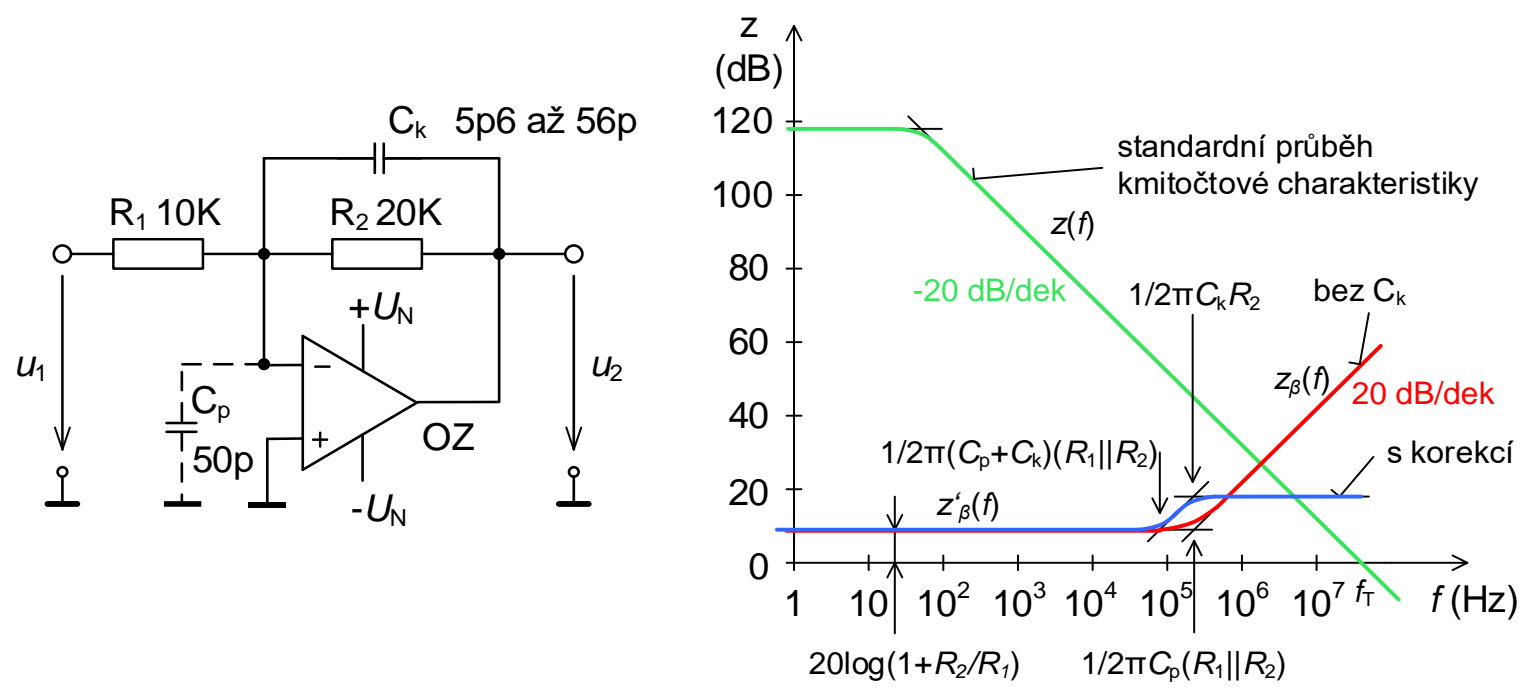

a

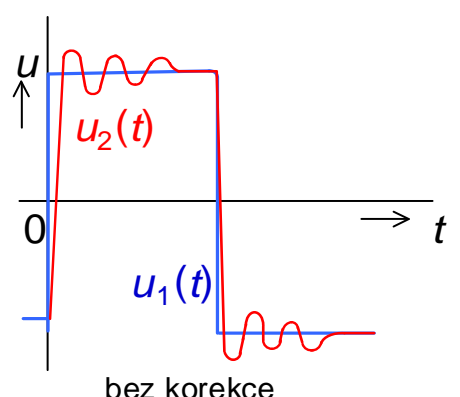

bez korekce

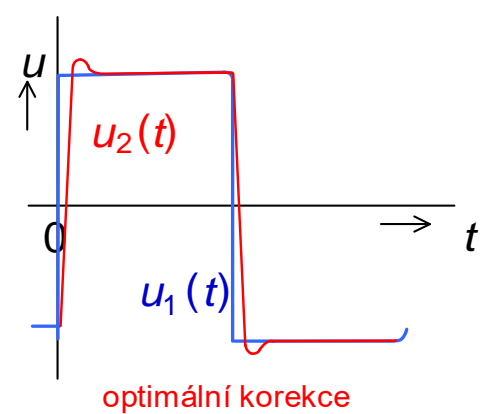

C

b

Obr. 10.5: Korekční kapacitor s malou kapacitou zapojený ve zpětné vazbě zlepší

kmitočtovou stabilitu obvodu

Použití malého zpětnovazebního kapacitoru má i další příznivé účinky: zkrátí se doba ustálení, zmenší se šumová šiř́ka pásma a odstraní se rezonanční zvětšení šumu. Jeho důležitost ani není možné docenit. I když se podaří zmenšit rozptylovou kapacitu spojů sčítacího bodu, zůstane neodstranitelná vstupní kapacita operačního zesilovače $C_{\mathrm{i}}+C^{-}{ }_{\mathrm{cm}}$, která stejně korekci vyžaduje. Zakreslení zpětnovazebního kapacitoru do schématu navržené operační sítě by mělo být samožrejmé, a to dokonce i tehdy, když se funkční vzorek obejde bez něho. Spíše jeho vynechání by mělo být podloženo úvahou a ověřením. Máme-li pochyby o vhodné hodnotě, předepíšeme $C_{\mathrm{k}}=15 \mathrm{pF}$. Cena levného keramického kapacitoru se vrátí v ušetřených hodinách, které bychom později strávili nad kmitajícím nebo šumícím vzorkem.

Jen v jednom případě nesmí být zpětnovazební korekční kapacitor zapojen: při použiti operačního zesilovače s rychlým poklesem kmitočtové charakteristiky v operační síti s velkým zesílením. Stabilita takové operační sítě předpokládá definované zeslabení ve zpětné vazbě, které by zpětnovazební kapacitor svoji malou reaktancí na vysokých kmitočtech zrušil. 
Zpětnovazební korekční kapacitor je samozřejmě zbytečný u napět'ového sledovače s přimým spojením výstupu a invertujícího vstupu operačního zesilovače.

Korekce kmitočtové charakteristiky. Většina operačních zesilovačů má interně korigovánu kmitočtovou charakteristiku tak, že na vysokých kmitočtech klesá rychlostí 20 $\mathrm{dB} /$ dek a její lom na $40 \mathrm{~dB} / \mathrm{dek}$ je až pod osou $0 \mathrm{~dB}$. V nabídce výrobců však stále existuje řada operačních zesilovačů s tzv. rychlým poklesem kmitočtové charakteristiky, u kterých je možno podle nastaveného zpětnovazebního zesílení připojit vnější korekční kapacitor. Při použití operačního zesilovače $s$ rychlým poklesem přenosové charakteristiky je nutno správně korigovat kmitočtovou charakteristiku celého zesilovače, aby se předešlo možnosti rozkmitání obvodu na vysokých kmitočtech. Korekční prvky - kapacitor (viz př́íklad na Obr. 10.6ł), někdy také sériová kombinace $\mathrm{RC}$ - se připojí k př́slušným vývodům zesilovače pokud možno krátkými spoji. Doporučenou kapacitu korekčního kapacitoru udává výrobce vždy pro určité zesílení nastavené zpětnovazební síti tak, aby rychlost přibližování charakteristiky $z_{\beta}(f)$ a korigované kmitočtové charakteristiky operačního zesilovače byla $20 \mathrm{~dB} / \mathrm{dek}$. Ve většině př́padi̊ je korekce kmitočtové charakteristiky provedena interně a nemusíme se tímto problémem zabývat. $\mathrm{V}$ tom príípadě výrobce uvádí, že OZ je stabilní i pro jednotkové zesílení.
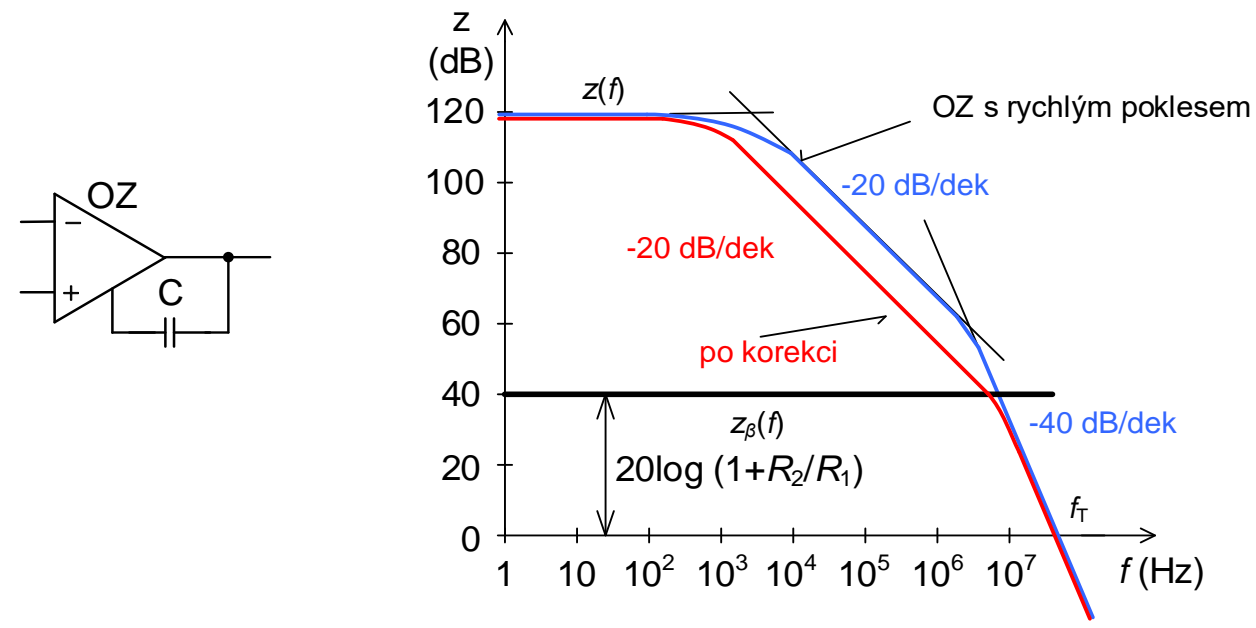

a

b

Obr. 10.6: Připojení vnějšího kapacitoru pro korekci kmitočtové charakteristiky OZ s rychlým poklesem kmitočtové charakteristiky, b) průběh kmitočtové charakteristiky před korekcí a po korekci

Charakter zdroje signálu. Volba zapojení operačního zesilovače (invertující či neinvertující zapojení) může být podstatně ovlivněna tím, zda je signál dodáván z tvrdých zdrojů (zdroj napětí s malým vnitřním odporem), popř. tím, jakou velikost (amplitudu) má zpracovávaný signál. Není-li vyžadováno zpracování stejnosměrné složky, je možno navíc vložit do cesty signálu oddělovací kapacitor; tím se současně dosáhne potlačení zbytkových napětí, jako napřs. napět'ové asymetrie (ofset) nebo ujíždění napět'ové nesymetrie (drift).

Charakter zátěže. Zátěží jsou dány nároky na výstupní napětí a proud. Nesmí se zapomínat na to, že část výstupního proudu teče do připojené zpětnovazební sítě. V př́padě, že parametry operačního zesilovače nestačí k pokrytí požadavků na napětí či proud dodávaný zátěží, je nutno použít napětový anebo proudový posilovač (booster). Velmi příhodně se dá ke zvýšení proudových schopností operačního zesilovače použít integrovaný posilovač nebo $\mathrm{v}$ náročných případech použít posilovač $\mathrm{z}$ diskrétních výkonových tranzistorů, který je schopen dodat do zátěže daleko větší proud. Zpoždění signálu, které posilovač ve smyčce zpětné vazby způsobí, má však stejné důsledky jako kapacitní zátěž. 
Kapacitní zátěž má mnohdy nežádoucí vliv na kmitočtovou charakteristiku a v důsledku toho na stabilitu zesilovače. Taková kapacitní zátěž se proto připojuje k výstupu operačního zesilovače přes rezistor s odporem několika desítek ohmů (viz Obr. 10.7ł). Vlastní korekci však provádí kapacitor $C_{k}$ o malé kapacitě zapojený mezi výstup operačního zesilovače a jeho invertující vstup. Zpětnovazební informace se nyní dostává na vstup operačního zesilovače dvěma cestami, stejnosměrnou a stř́idavou. Hlavní stejnosměrná smyčka uzavřená přes rezistor $\mathrm{R}_{2}$ reguluje výstupní napětí $\mathrm{v}$ místě spotřeby, tj. na zátěži, ale při rychlých změnách podává informaci zpožděnou a sama vede k rozkmitání. Tomu zabrání střídavá smyčka uzavřená přes korekční kapacitor $\mathrm{C}_{\mathrm{k}}$, který snímá fázově nezkreslené napětí na výstupu operačního zesilovače a přivádí je krátkou cestou na vstup. Vzhledem $\mathrm{k}$ malé reaktanci kapacitoru $\mathrm{C}_{\mathrm{k}}$ na vysokých kmitočtech převáží tato nezkreslená informace nad chybnou informací, kterou zprostředkuje rezistor $\mathrm{R}_{2}$. Obecné vztahy pro volbu korekčních prvků $\mathrm{R}_{0}$ a $\mathrm{C}_{\mathrm{k}}$ neuvádíme. Hodnoty uvedené $\mathrm{v}$ Obr. 10.7 ja jou typické a jejich zpřesnění pro konkrétní úlohu se provede nejlépe experimentálně. Sledujeme přitom osciloskopem výstupní signál obvodu při buzení pravoúhlými kmity a prvky vybereme tak, aby při skokových změnách nevznikaly na výstupním signálu zákmity, které jsou průvodním znakem odtlumené operační sítě (viz Obr. 10.5 ).

Obr. 10.7b ukazuje použití popsané korekce u napět'ového sledovače. Přidaný rezistor $\mathrm{R}_{1}$ izoluje zatěžovací kapacitor $\mathrm{C}_{\mathrm{z}}$ od invertujícího vstupu, modře kreslený rezistor $\mathrm{R}_{2}$ popřípadě slouží ke kompenzaci vstupního klidového proudu při použití bipolárního operačního zesilovače. Při použití unipolárního zesilovače jsou vstupní klidové proudy za normální teploty zanedbatelné a použitý kompenzační rezistor $\mathrm{R}_{2}$ by byl př́liš drahý a šumící.

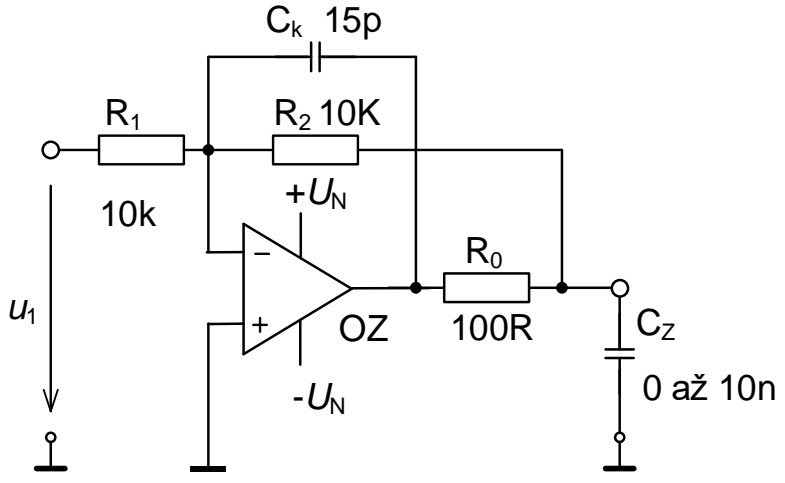

$\mathbf{a}$

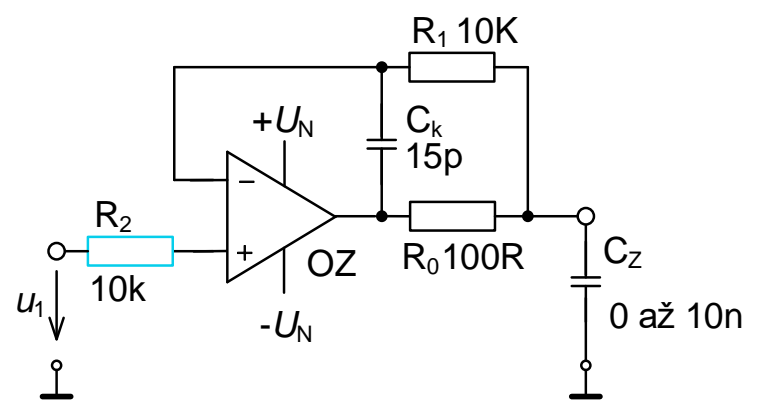

b

Obr. 10.7: Izolace kapacitní zátěže: a) invertujícího zesilovače, b) napět'ového sledovače

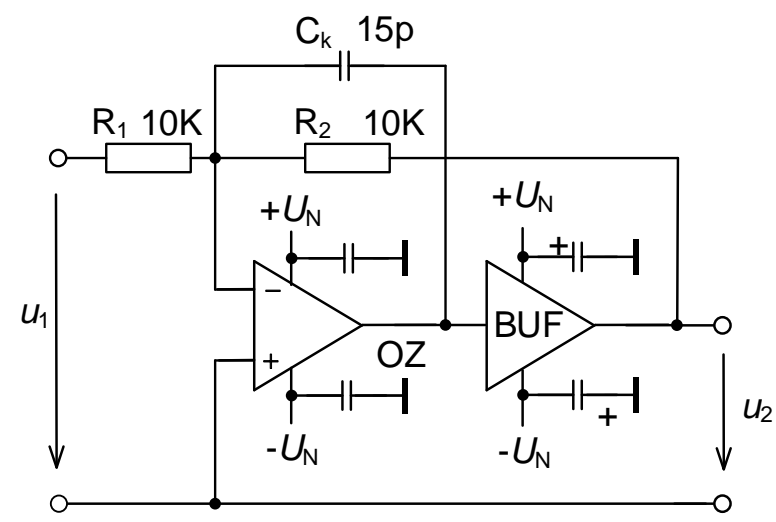

Obr. 10.8: Zajištění stability zesilovače s proudovým posilovačem 
Podstata popsané korekce, jak bylo již řečeno, se dá použít i v jiných situacích, napřs. při použití posilovače připojeného za výstup operačního zesilovače, kdy se na vložený posilovač nahlíží jako na zpožd’ovací článek, který se na vyšších kmitočtech překlene rychlou zpětnovazební smyčkou přes korekční kapacitor, podobně jako při izolaci kapacitní zátěže (viz Obr. 10.8).

\subsubsection{Další konstrukční doporučení}

Okolní podmínky. Operační zesilovač je nutno zvolit tak, aby byl schopen spolehlivě pracovat bez jakéhokoliv nastavování v daném rozmezí teplot a s danými napájecími napětími, a to po celou předpokládanou dobu provozu.

Činnost obvodů s operačními zesilovači je taktéž ovlivňována rušením z okolních zdrojů, které se projevuje jako tzv. interferenční šum či rušení. Interferenční rušení, pozorované na výstupu operační sítě, může být způsobeno elektrostatickou indukcí (kapacitní vazbou), elektromagnetickou indukcí (indukční vazbou), jiskřením kontakti̊, zvlněním či jehlovými impulsy v napájecích zdrojích. V náročných případech je pak nutno uvažovat ještě interferenční rušení způsobené mechanickým chvěním, fluktuací svodových proudů, fluktuací termoelektrických napětí, ionizujícím zářením a fotoelektrickými proudy. Za citlivá místa, kterými interferenční rušení vniká do operační sítě lze označit signálový zdroj, vstupní přívody, vstup operační sítě, vstupy operačního zesilovače, nulovací, korekční a napájecí vývody operačního zesilovače, zpětnovazební součástky a vodiče, plocha uzavřených smyček operační sítě a zemní rozvod. Nepostradatelným nástrojem pro identifikaci původu rušení je citlivý osciloskop.

Kapacitní vazba ze střídavého sítového rozvodu je nejčastější př́ičina brumu operační sítě. Na osciloskopu se pozná snadno podle periody $20 \mathrm{~ms}$. Kapacitní vazbou proniká do operační sítě také rušení blízkým rozhlasovým vysílačem. Jeho odlišení od autooscilací operační sítě je někdy obtížné. Napomáhají tomu dva př́iznaky:

- Amplituda vf kmitů se zvětšuje s přiblížením ruky beze změny kmitočtu. Doporučujeme tento postup ověření: levá ruka se uzemní dotknutím na kostru nebo zem, čímž se odstraní kapacitní sít’ový brum a pohyblivá pravá ruka funguje jako anténa s měnitelnou vazbou.

- V některých případech je při pozorování na osciloskopu zřejmá i amplitudová modulace signálu.

Ochrana je v obou případech snadná. Uzavřeme citlivý zesilovač do stínicí krabice (třeba tenké hliníkové), použijeme stíněné signálové přívody a elektrostaticky odstíníme sít'ové transformátory a v krajním případě použijeme napájení z baterií. Snad neškodí připomenout, že veškeré elektrostatické stínění musí být vždy uzemněno.

Indukční vazba bývá způsobena rozptylovým tokem sítového transformátoru a je druhým nejčastějším zdrojem rušení. Potlačení rozptylového toku je všeobecně obtížnější a nákladnější. Doporučuje se zmenšit plochy smyček jiným rozvržením plošného spoje, přemístit nastavovací prvky z panelu přímo na desku a nastavovat je např. číslicově, navzájem zkroutit dlouhé prŕvodní vodiče, oddálit vodiče od citlivé části, pootočit o $90^{\circ}$ nebo magneticky odstínit sít'ový transformátor.

Jiskření rozpínaných kontaktů je provázeno emisí série elektromagnetických vln $\mathrm{s}$ kmitočtem řádově $100 \mathrm{MHz}$, které proniknou nekontrolované všude. Č́ástečně pomáhá zmenšení rozměrů operační sítě. Úplně pomáhá likvidace jiskřícího kontaktu, jeho nasazení 
polovodičovým spínačem, nebo přenesení citlivého obvodu jinam. Podobně, ale pravidelně se projevují také radiolokační impulsy blízkých radiolokátorů.

V přesných metrologických aplikacích musíme uvažovat i další vlivy. Mechanické chvění se projevuje mnoha způsoby, a to mikrofoničností, přerušováním uvolněného pájeného spoje, piezoelektrickými projevy (generování náboje ohybem koaxiálního kabelu) a triboelektřinou (generování náboje třením kabelu), nebo indukcí způsobenou zemským magnetickým polem. Pomáhá oddálení zdroje chvění (motoru, větráku apod.), použití nízkošumových koaxiálních kabelů (grafitový povlak polyetylénového dielektrika pod stínicím pláštěm) a tuhá konstrukce s vysokým vlastním kmitočtem rezonance, popř. spojená s použitím mechanických tlumicích prvků.

Znečištěný nebo zvlhlý povrch plošného spoje s ekvivalentním svodovým odporem $10 \mathrm{G} \Omega$ mezi napájecím rozvodem a vstupem operačního zesilovače vyvolá vstupní svodový proud 1,5 nA, který presahuje 50-násobně nad vlastním vstupním klidovým proudem operačního zesilovače s tranzistory řízeným polem na vstupu. Dielektrická absorpce laminátu, nasáklého zbytky chemikálií z mokrých technologických procesů, vyvolá neočekávané časové konstanty, které zcela (napřr. o 3 dekadické ráády) znehodnotí dynamické chování operační sítě v časové oblasti. Nepř́ijemná pak také je fluktuující složka těchto svodových proudů. Ochrana proti těmto jevům zahrnuje očištění a vysušení svodových cest, použití zemního nebo aktivního ekviponenciálního stínění, použití teflonových opěrných bodů a teflonem izolovaných vodičů, přenesení kritických signálových cest mimo laminát a popř. použití kvalitního laminátu na bázi teflonu nebo použití hydrokarbon/keramického laminátu spojené s chemickým ošetřením DPS po ukončení technologických procesů.

Ionizující záření, nejčastěji tvrdé kosmické částice $\alpha$ (rychlá héliová jádra), ruší elektrometrické aplikace. Prolétlá částice zanechává stopu ionizovaného vzduchu. Zasáhne-li vzniklý prostorový náboj vstup zesilovače, projeví se náhodným krátkým impulsem - jehlou na pamětovém osciloskopu. Pomoc je dvojího druhu: 1) při měření objektů ve vakuu se do vakua vloží i zesilovač, 2) v ostatních méně výlučných př́ípadech se kolem vstupní části zesilovače vytvoří elektrostatické aktivní stíněni (guard) ve tvaru těsné mosazné nebo hliníkové krytky nasunuté přes elektrometrický rezistor a přes související vstup operačního zesilovače. Krytka absorbuje přitékající prostorový náboj a redukuje ionizační objem př́stroje na vnitřní objem krytky. Nedostatkem je zvětšená parazitní kapacita rezistoru.

Fotoelektrické proudy vznikají v operačním zesilovači (částečně průsvitné nekvalitní pouzdro) nebo i v signálovém zdroji. Mění se s denním svitem, s pohybem osob, s rozsvícením. Potlačí se optickým zastíněním. Běžně se ale tento problém nevyskytuje.

Konstrukční doporučení pro návrh DPS. Náchylnost operačního zesilovače k rozkmitání a k zesilování nežádoucích rušivých signálů se dá potlačit tak, že umístíme „sčítací bod“ zpětnovazební sítě co nejblíže invertujícímu vstupu zesilovače. Rozhodující rezistory zpětnovazební sítě musí být připojeny $\mathrm{k}$ vývodu invertujícího vstupu zesilovače co nejkratším spojem. Ostatní spoje (např. připojení zpětnovazebního rezistoru k výstupu operačního zesilovače, nebo připojení vstupního rezistoru ke zdroji zesilovaného signálu) mohou již být delší. V nutných př́ipadech použijeme stínění. Realizace sčítacího bodu na co nejmenší ploše a co nejblíže vstupu zesilovače zabraňuje vnikání nežádoucích rušivých signálů z okolí do zpracovávaného signálu. Umožňuje tedy také snížit parazitní kapacity sčítacího bodu a omezit svodové proudy, které by mohly způsobit chybu výstupního napětí zesilovače. Uvedená doporučení jsou zřejmá z př́kladu zapojení rozdílového obvodu s operačním zesilovačem na Obr. 10.9 . Všechny přívody k invertujícímu vstupu OZ musí být úplně co nejkratší Obr. 10.9 b), protože rušení či šum je zesilován celým zesílením operačního zesilovače. Př́ivody k neinvertujícímu vstupu již tak kritické nejsou, protože rušení či šum jsou zesilovány pouze 
zesílením $A_{\mathrm{U}}=1+R_{2} / R_{1}$. Pokud však dělič $\mathrm{R}_{3}, \mathrm{R}_{4}$ není dostatečně „tvrdý“ zdroj napětí a jeho výstupní odpor $R_{3} \| R_{4}>1 \mathrm{k} \Omega$, pak se doporučuje rezistory $\mathrm{R}_{3}$ a $\mathrm{R}_{4}$ připojit také blízko $\mathrm{OZ}$.

Aby se zabránilo nežádoucím vazbám, které mohou vést až $\mathrm{k}$ rozkmitání obvodu $\mathrm{s}$ operačním zesilovačem, je nutno mezi přívody napájecích napětí a společný vodič (zem) připojit bezindukční keramické kapacitory s kapacitou $10 \mathrm{nF}$ až $220 \mathrm{nF}$ a to u každého zesilovače. Tyto kapacitory, které představují zkrat pro vysokofrekvenční proudové složky, musí být umístěny těsně u operačního zesilovače tak, aby takto vytvořené spojení mezi společným vodičem a příslušnými vývody operačního zesilovače bylo co nejkratší. Př́ivody napájecích napětí musí mít dostatečně velký průřez, aby měly pokud možno malý odpor a (což je snad ještě důležitější) malou indukčnost.

Velká pozornost se při konstrukci zařízení s operačními zesilovači musí věnovat zemním spojům. Jak jsme podrobně ukázali v jiné kapitole, odděluje se tzv. signálová zem od výkonové země a zejména pak tyto analogové země nesmí být společné se zemí pro číslicové obvody. Spojení všech zemí se pak provede v zařízení jen v jednom vhodně zvoleném bodě.
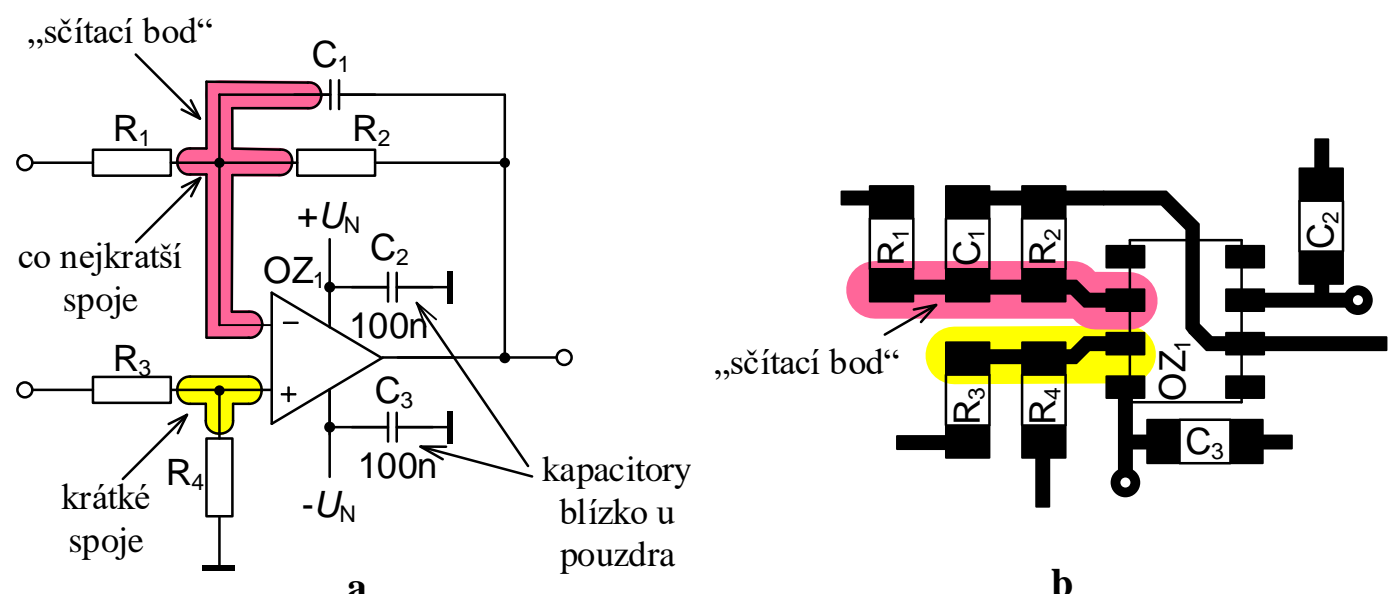

a

b

Obr. 10.9: Konstrukční doporučení při aplikaci operačního zesilovače

Nulování napětové nesymetrie. Většina moderních operačních zesilovačů má již z výroby nastavenu tak malou napětovou nesymetrii (offset), že přidání prvků pro jejich vynulování by bylo zbytečně drahé. Nulování napětové nesymetrie provádí výrobce před zapouzdřením laserovým trimováním, nastavením převodníku D/A aj. Napětová nesymetrie je pak jen desítky až stovky $\mu \mathrm{V}$. Navíc u složitějších zařízení se chyby způsobené napětovou nesymetrií kompenzují softwarově.

Existuje však stále ještě velká nabídka operačních zesilovačů, kdy jsou od výrobce připraveny svorky pro připojení potenciometrického trimru pro vynulování napětové nesymetrie. Tyto svorky jsou dalšími vstupními svorkami zesilovače. Jejich ss napětí je obvykle posunuto proti nulové úrovni a impedance je většinou menší než na „pravých“ vstupech. Citlivost na signál, přivedený na tyto svorky, může však být značná. Řada operačních zesilovačů má asi dvakrát větší zesíleni z nulovacího než z „pravého“ vstupu.

Povšimněme si v této souvislosti části zapojení nulovacího vstupu uvedeného na Obr. 10.10A. Bude-li běžec potenciometru $\mathrm{P}$ přibližně uprostřed dráhy tak, aby můstek $\mathrm{R}_{\mathrm{P} 1}, \mathrm{R}_{\mathrm{P} 2} \mathrm{a} \mathrm{R}_{\mathrm{A}}$, $\mathrm{R}_{\mathrm{B}}$ byl vyvážen, má napětí $\Delta U$ na vstupech $\mathrm{A}, \mathrm{B}$ stejnou velikost; působí tedy jako soufázový signál bez rozdílové složky. Jeho vliv na zesilovač je v tomto př́ípadě zanedbatelný. 
Jiné poměry nastanou, vyvážíme-li potenciometrem $\mathrm{P}$ napětovou nesymetrii zesilovače. Běžec již nebude uprostřed. Odpor potenciometrického trimru $R_{P}$ je obvykle $10 \mathrm{k} \Omega$. Pro představu předpokládejme, že vynulování napět'ové nesymetrie odpovídá $R_{P 1}=3 \mathrm{k} \Omega$ a $R_{P 2}=7$ $\mathrm{k} \Omega$. Rezistory $\mathrm{R}_{\mathrm{A}}$ a $\mathrm{R}_{\mathrm{B}}$ mají odpor $1 \mathrm{k} \Omega$. V tomto př́ípadě již můstek $\mathrm{R}_{\mathrm{P} 1}, \mathrm{R}_{\mathrm{P} 2}$ a $\mathrm{R}_{\mathrm{A}}, \mathrm{R}_{\mathrm{B}}$ není vyvážen a $\mathrm{v}$ úhlopříčce $\mathrm{A}-\mathrm{B}$ bude napětí $\Delta U / 8$. Vzhledem $\mathrm{k}$ dvojnásobnému zesílení $\mathrm{z}$ nulovacích svorek se projeví signál $\Delta U / 4$ mezi vstupními svorkami. Velikost $\Delta U$ je určena především velikostí odběru zesilovače ze záporného napájecího zdroje. Koncový stupeň zesilovače pracuje ve třídě B. To znamená, že odebírá proud ze záporného zdroje pouze při záporné půlvlně výstupního napětí. Výsledkem tedy je nelineární zkreslení výstupního signálu, jehož prŕíčinu bychom bez pochopení předchozích souvislostí obtížně hledali.

$\mathrm{Na}$ Obr. 10.10 je uvedeno správné připojení běžce potenciometru P pro nulování napět'ové nesymetrie (ofsetu). Běžec je připojen přímo na napájecí svorku zesilovače tak, aby byla potlačena uvedená nežádoucí závislost. Jednootáčkový potenciometrický trimr je použitelný pro nulování napět'ové nesymetrie přibližně pro zpětnovazební zesílení $\left|A_{U}\right| \leq 5$. Pro zesílení větší je nutno použít potenciometrický trimr víceotáčkový.

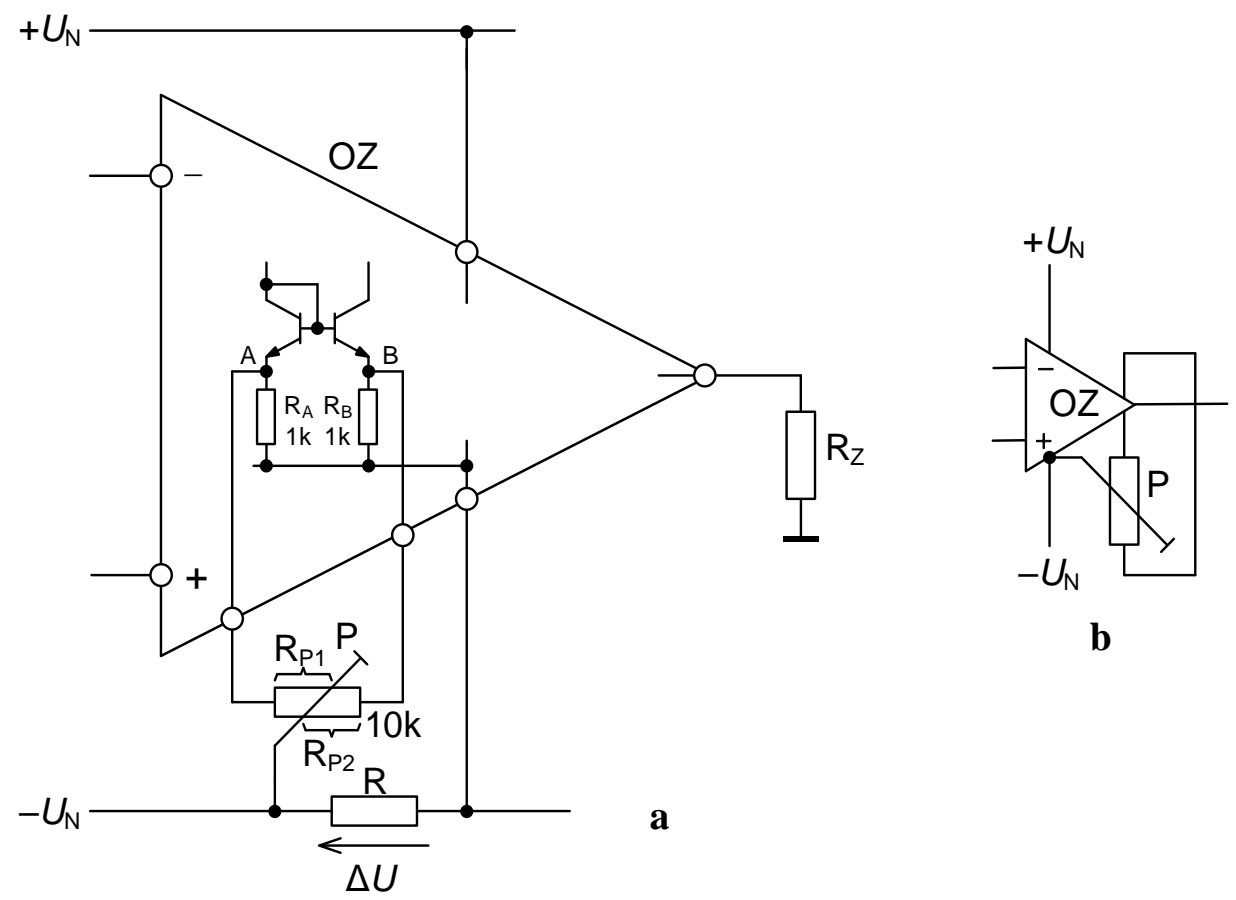

Obr. 10.10: a) K vysvětlení nesprávného způsobu připojení potenciometrického trimru ke svorkám pro nulování napět'ové nesymetrie, b) správné připojení běžce potenciometru pro nulování napět'ové nesymetrie

\subsubsection{Požadavky na napájecí zdroje}

Volba napájecích zdrojů. Volba typu napájecích zdrojů, tj. zda použít klasické napájecí zdroje se spojitou regulací, založené obvykle na dvoucestně usměrném napětí o sít'ovém kmitočtu $50 \mathrm{~Hz}$, či impulsně regulované zdroje, vždy záleží na konkrétní aplikaci. Pro běžné účely vystačíme s impulsně regulovanými zdroji, ale musíme počítat s tím, že úroveň impulsního rušení bude v signálové cestě vyšší a že bude nutno věnovat zvýšenou péči filtraci impulsního rušení v napájecích rozvodech. 
Klasické napájecí zdroje se spojitou regulací dosahují menšího zvlnění stabilizovaného napětí, přičemž při jednocestném usměrnění sít’ového napětí má zvlnění kmitočet $50 \mathrm{~Hz}$ anebo při dvoucestném usměrnění $100 \mathrm{~Hz}$. Tato skutečnost představuje velkou výhodu při napájení operačního zesilovače, protože pomalé změny je operační zesilovač schopen potlačit. Nevýhodou klasických zdrojů je jejich nižší účinnost $(40 \%)$ a větší rozměry (sítový transformátor).

Výhodou spínaných či impulsně regulovaných zdrojů je jejich vysoká účinnost a malé rozměry. Jejich nevýhodou je delší doba přechodného děje při změně zátěže a vysoký stupeň impulsního rušení, protože impulsní zdroje pracují na kmitočtech $20 \mathrm{kHz}$ až $200 \mathrm{kHz}$. Jehlové impulsy vznikající př̀i pulsní regulaci snadno proniknou do signálových cest přes parazitní kapacity.

Pokud bude zařízení obsahovat citlivé vstupní zesilovače, zpracovávat audiosignály, nebo generovat přesné měřicí signály nízkých úrovní (pod $100 \mathrm{mV}$ ), vyplatí se vždy tuto část zařízení napájet z klasických napájecích zdrojů se spojitou regulací. Samozřejmě výkonovou část zařízení, kdy již nedochází $\mathrm{k}$ velkému napět'ovému zesílení je již možné napájet $\mathrm{z}$ impulsně regulovaných zdrojů.

Symetrické napájecí zdroje. Pokud operační zesilovač používá symetrické napájení $\pm U_{\mathrm{N}}$, není zem voperačním zesilovači vyjádřena a stejnosměrně ji představuje střed mezi symetrickým napájecím napětím, tj. $0 \mathrm{~V}$. Nesymetrie napájecích zdrojů může tedy ovlivnit ss složku zpracovaného signálu. Při volbě velikosti napájecího napětí je třeba počítat $s$ tím, že rozkmit výstupního napětí $\mathrm{OZ}$ bude o něco menší než $\pm U_{\mathrm{N}}$. U klasického řešení $\mathrm{OZ}$ musíme počítat s tím, že rozkmit výstupního napětí bude asi $\pm\left(U_{N}-2 \mathrm{~V}\right)$. Operační zesilovače, u kterých se dá dosáhnout téměř rozkmitu $\pm U_{\mathrm{N}}$ jsou označovány jako operační zesilovače s plným rozkmitem (rail-to-rail).

Pro běžné aplikace vystačíme se symetrickými zdroji sestavenými ze stabilizátorů typové řady 7800 pro kladné napájecí napětí a 7900 pro záporné napájecí napětí. V řadě případů, např. pro napájení obvodů pro měřicí účely, nebo u zesilovačů s velkým ss zesílením je výhodné, aby rozdíl absolutní hodnoty obou napětí byl nulový. To se dá docílit např. tím, že jedno z napětí sleduje absolutní hodnotu druhého napětí. Tento požadavek se dá např. splnit uspořádáním symetrického stabilizátoru sledovacího typu, kdy výstupní napětí $U_{\mathrm{P}}$ se použije jako referenční napětí pro odvození záporného napětí $U_{\mathrm{N}}$.

Impedance napájecích zdrojů. Napájecí zdroje musí mít malé výstupní impedance. Nejsou-li totiž výstupní impedance obou napájecích zdrojů proti zemi malé v celém kmitočtovém rozsahu operačního zesilovače, mohou vzniknout potíže s vlastnostmi zesilovače. Nejde však jen o výstupní impedance samotných napájecích zdrojů, ale do těchto impedancí musíme zahrnout i celý napájecí rozvod až k vlastní součástce, který může při špatném provedení impedanci zdrojů zhoršit.

$\mathrm{Na}$ Obr. 10.11 je naznačeno zjednodušené zapojení klasického řešení operačního zesilovače, přičemž uvažujeme, že napájecí zdroj záporného napětí a přívodní vodiče vykazují impedanci $\bar{Z}$. Diferenční vstupní napětí se převádí na jednočinný signál vůči zápornému napájecímu zdroji ve vstupní části zesilovače, skládajícího se $\mathrm{z}$ diferenčního stupně $\mathrm{T}_{1}, \mathrm{~T}_{2} \mathrm{a}$ proudového zrcadla $T_{3}, T_{4}$. Další zesilovač $T_{5}$ je zapojen společně s korekčním kapacitorem $C_{K}$ jako jednoduchý integrátor. Tento integrátor má dvě vstupní svorky. Invertující, tvořená řídicí elektrodou tranzistoru $\mathrm{T}_{5}$, je připojena na proudové zrcadlo, neinvertující, emitor tranzistoru $\mathrm{T}_{5}$, je připojena př́mo na sběrnici záporného napájecího napětí. Změní-li se napětí záporného zdroje (např. skokem vlivem úbytku na vnitřním odporu zdroje způsobené odběrem jiného obvodu), zesilovač integrátoru přenáší tuto změnu ze své neinvertující vstupní svorky na výstup. Protože však celý zesilovač používáme ve zpětnovazebním zapojení, projeví se tato změna jako chybový signál, který je vlivem zpětné vazby potlačen. To však platí pro dostatečně pomalé změny napětí záporného napájecího zdroje. Rychlé změny, vyvolané napřs. vlivem 
spínání výkonových obvodů připojených $\mathrm{k}$ tomuto rozvodu napětí, nebo jehlové impulsy $\mathrm{z}$ impulsně regulovaného napájecího zdroje, které nestačí zesilovač vlivem omezené rychlosti přeběhu zpracovat, plně pronikají na výstup.
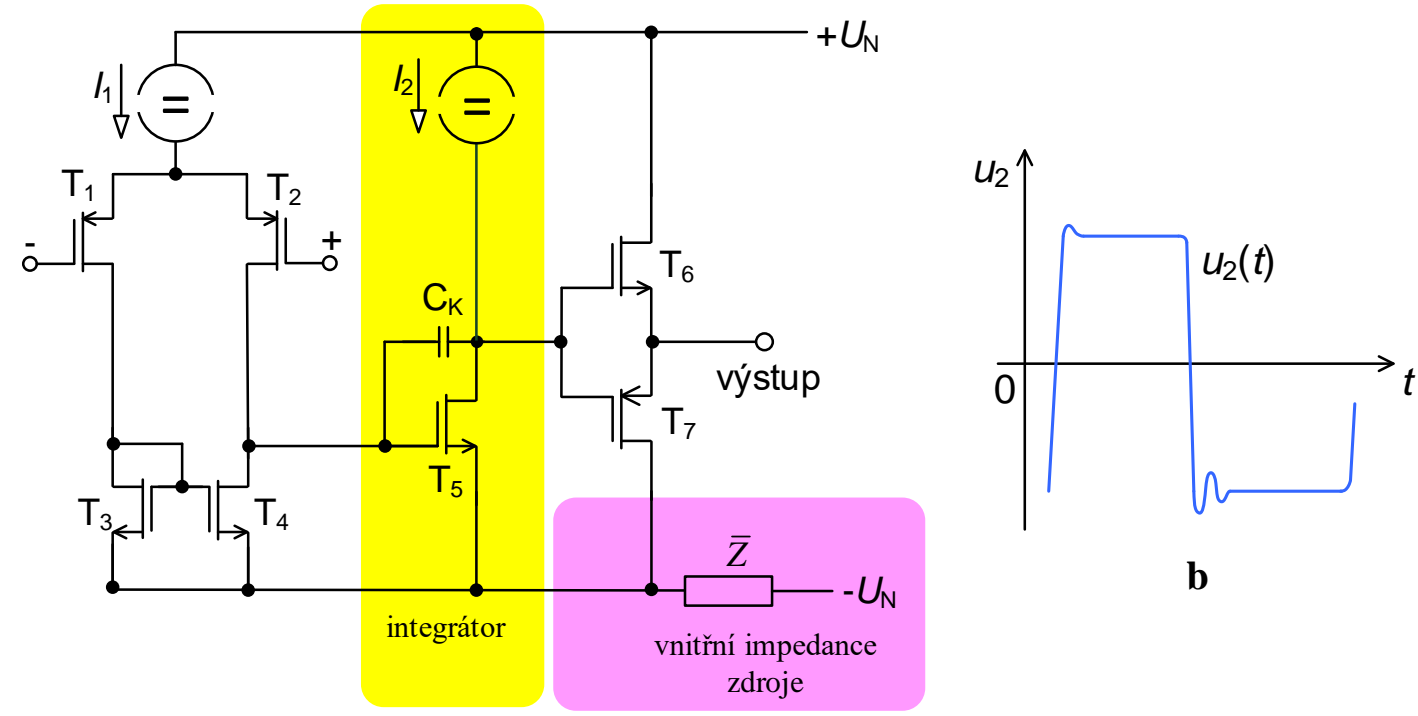

b

$\mathbf{a}$

Obr. 10.11: a) Zjednodušené zapojení operačního zesilovače, b) důsledek asymetrie impedancí v přechodové charakteristice zesilovače

Potlačení vlivu změny kladného napájecího napětí se zmenšuje se zvyšujícím se kmitočtem, ale vliv malých změn tohoto napětí je podstatně menší než u záporného napájecího napětí. Tím je způsobena asymetrie $\mathrm{v}$ přechodové charakteristice zesilovače. Impuls kladné polarity na výstupu zesilovače vyvolá proudový impuls z kladného napájecího zdroje. V důsledku dobrého potlačení vlivu kladného napájecího zdroje je tvar impulsu určen vlastnostmi zesilovače a zdroj má malý vliv na tvar výstupního impulsu. Naopak, impuls záporné polarity na výstupu zesilovače vyvolá impuls proudu ze záporného napájecího zdroje. Tento impuls vyvolá na vnitřní impedanci záporného napájecího zdroje zákmit, který se přenese na výstup zesilovače (viz Obr. 10.11b). Jestliže kladný výstupní impuls ukázal přechodové vlastnosti zesilovače, záporný výstupní impuls ukazuje nejen přechodové vlastnosti OZ, ale současně je zkreslen nenulovou vnitřní impedancí a vlivem poruch na napájecích svorkách záporného zdroje. Vlivem vnitřní impedance záporného napájecího zdroje je tedy přechodová charakteristika pro impulsy kladné a záporné polarity různá.

Blokování napájecích př́vodů. Pro blokování napájecích přívodů OZ při napájení z klasických napájecích zdrojů obvykle dostačuje zablokovat každý napájecí přívod vůči zemnímu vodiči keramickým kapacitorem $100 \mathrm{nF}$ až $220 \mathrm{nF}$ (viz Obr. 10.12 a). Aby přes napájecí přívody $\mathrm{OZ}$ nepronikalo rušení ostatních obvodů připojených ke stejným napájecím zdrojům, je důležitý konkrétní způsob připojení těchto blokovacích kapacitorů na DPS. 

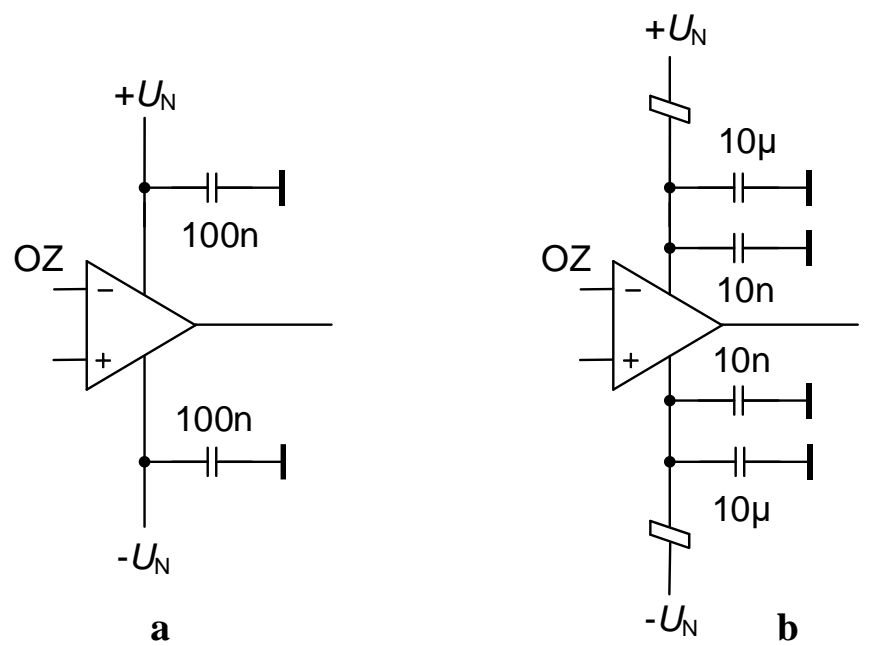

Obr. 10.12: a) Blokování napájení při použití klasických zdrojů, b) zařazení filtru LC při napájení z impulsně regulovaných zdrojů

Jak se impulsní rušení ze strany záporného napájecího zdroje může projevit na vstupní svorce zesilovače, závisí na tom, které zdroje rušení obsahuje smyčka uzavřená přes vodivý výstupní tranzistor zesilovače, zátěž a blokovací kapacitor. Způsob blokování uvedený na Obr. 10.13 nebude účinný. Ve smyčce A-B-C-D-E je rušivý signál $\mathrm{z}$ vodiče $\mathrm{C}-\mathrm{B}$ společného $\mathrm{s}$ jinými obvody přenášen př́mo na zápornou napájecí svorku $\mathrm{D}$ a přes parazitní kapacity tranzistoru se dostane na výstup zesilovače. V zapojení podle Obr. 10.13b je smyčka A-B-C pro vf složky proudu zátěže uzavřena nejkratším možným způsobem a kapacitor $C_{b}$ potlačuje vliv rušení z obvodů záporného zdroje. Vyplývá z toho poznatek, že blokovací kapacitor by měl být připojen co nejblíže k napájecímu vývodu OZ. To, co bylo uvedeno pro operační zesilovače pro záporný vývod zdroje, platí většinou i pro zdroj kladného napájecího napětí. Proto způsobu připojení blokovacích kapacitorů musíme věnovat patřičnou pozornost v obou napájecích př́vodech.

Zvlnění, jehlové impulsy šum a kolísání napětí napájecích zdrojů proniká do signálové cesty nejen přes napájecí svorky operačního zesilovače, ale i přes nulovací obvody a také přímo, jestliže z napájení je odvozena reference pro ss posunutí převodní charakteristiky obvodu. Zvlnění se pozná u klasicky řešeného zdroje jako brum s kmitočtem obvykle $100 \mathrm{~Hz}$. Vliv kolísání nekvalitně stabilizovaného klasického zdroje se ověří zkusmou záměnou napájecích zdrojů nebo napájením z akumulátorových baterií. Dobrý klasický napájecí zdroj nebručí a nešumí víc než $1 \mathrm{mV}$ a nekolísá o víc než $10 \mathrm{mV}$. 


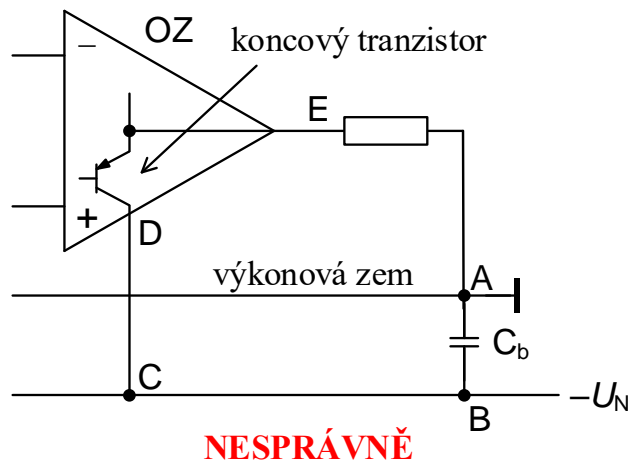

a

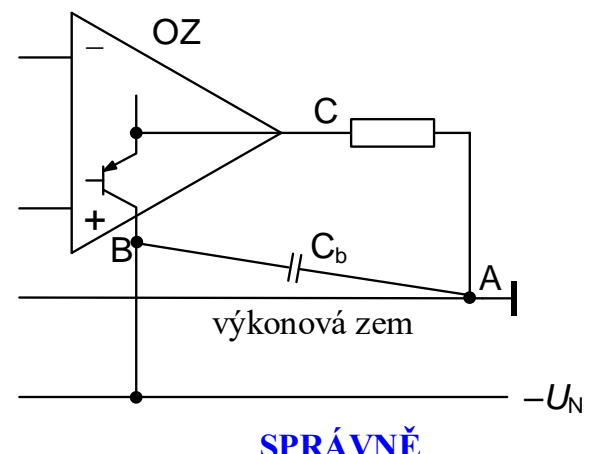

b

Obr. 10.13: a) Zapojení blokovacího kapacitoru do nevhodného místa není účinné,

b) správné zapojení blokovacího kapacitoru

Blokování napájení při použití impulsně regulovaných zdrojů. V př́ípadě použití impulsně řízených zdrojů pro napájení operačních zesilovačů je vhodné zařadit do napájecích př́vodů dolní propusti LC Obr. 10.12b). Filtr LC je realizován feritovou perlou (Ferrite Bead) a kapacitorem $1 \mu \mathrm{F}$, který je pro zlepšení vf vlastností doplněn kapacitorem $10 \mathrm{nF}$. Obvykle toto opatření dostačuje realizovat jednou hned za konektorem desky plošného spoje a operační zesilovače pak blokovat běžným způsobem jen kapacitory $100 \mathrm{nF}$. Pro zablokování celé desky se pak společně s feritovou perlou použije např. kapapacitor $10 \mu \mathrm{F}$ a paralelně s ním $10 \mathrm{nF}$.

Blokováni napájeni při neuzemněné zátěži. Složitější případ neuzemněné zátěže je naznačen na Obr. 10.14. Zátěží zesilovače $\mathrm{OZ}_{1}$, je neuzemněný rezistor $\mathrm{R}_{2}$ připojený $\mathrm{k}$ tzv. „virtuální nule“ $\mathrm{OZ}_{2}$. Proudu přes tranzistor $\mathrm{T}_{1}$ ze záporného zdroje odpovídá proud přes tranzistor $\mathrm{T}_{2} \mathrm{z}$ kladného zdroje. Kapacitor $\mathrm{C}_{\mathrm{b}}$ uzavírá nejkratší cestu mezi oběma zesilovači. Pokud by zesilovače byly napájeny $\mathrm{z}$ impulsně regulovaných zdrojů, bylo by nutné do napájecích př́vodů vložit feritové perly tak, jako v př́ípadě na Obr. 10.12 a kapacitor $\mathrm{C}_{\mathrm{b}}$ realizovat paralelní kombinací kapacitorů s kapacitou $1 \mu \mathrm{F}$ a $10 \mathrm{nF}$. Ve většině případů se však vystačí s blokováním obou napájecích přívodů proti zemi a problémy s neuzemněnou zátěží se řeší, až pokud vzniknou.

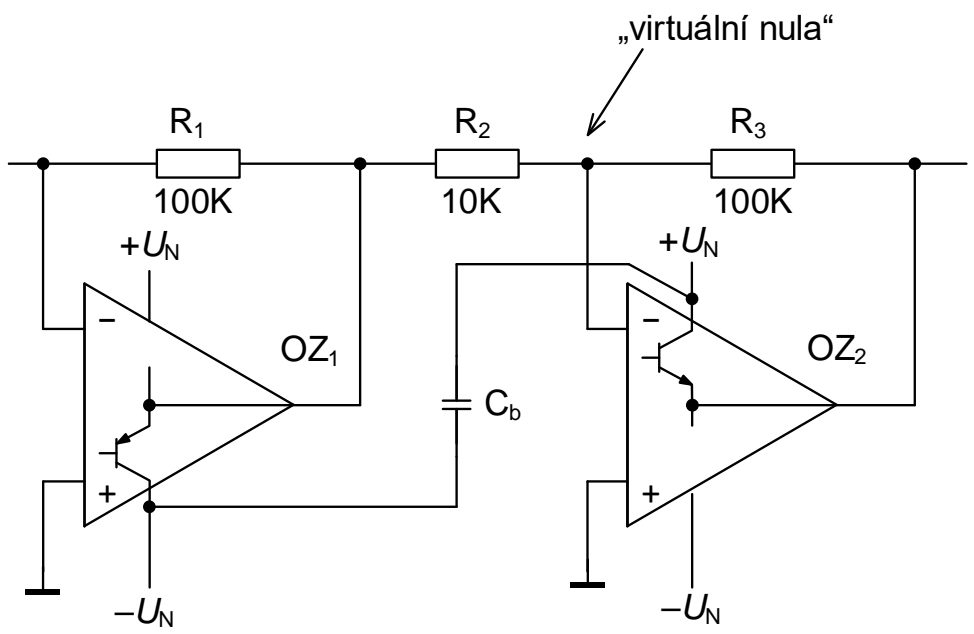

Obr. 10.14: Zapojení blokovacího kapacitoru $\mathrm{C}_{\mathrm{b}}$ pro neuzemněnou zátěž $\mathrm{R}_{2}$ 
Dalši doporučeni $k$ napájecím zdrojům: Odpory přívodů $\mathrm{k}$ napájecím zdrojům $\mathrm{u}$ složitějšího systému (např. milivoltmetru nebo stereofonního zesilovače apod.) mohou být, jak už bylo řečeno zdrojem nežádoucích vazeb. Obtíže jsou způsobeny tím, že výstupní proud zesilovače musí vždy protékat smyčkou, uzavřenou přes napájecí zdroj. Proud vyvolává úbytky napětí na vodičích napájecího vedení, které jsou superponovány na napájecí napětí a mohou se přenášet do nežádoucích míst zapojení. Abychom se zbavili těchto obtíží, snažíme se zmenšit možnost výskytu nežádoucí vazby některým z následujících opatření:

1. citlivé vstupní stupně napájíme ze samostatných zdrojů nebo stabilizátorů,

2. každý zesilovač napájíme po samostatném vedení od napájecího zdroje, nebo dokonce

3. každý zesilovač napájíme ze samostatného zdroje,

4. v kritických př́ípadech volíme bateriové napájení nebo napájení z akumulátorů.

Volba vhodného opatření závisí na složitosti a citlivosti zařízení. Ve velkých a náročných př́strojích se nemá šetřit na napájecích zdrojích, jejich provedení a stabilizaci, má-li být plně využito dosažitelných vlastností. Nejčastěji se použivají integrované zesilovače, které jsou svým principem širokopásmové. Jejich vlastnosti jsou definovány při napájení ze zdrojů s malým vnitřním odporem. Běžné stabilizátory napětí mají pro kmitočty vyšší než $100 \mathrm{kHz}$ výstupní impedanci indukčního charakteru, která se proti impedanci na nižších kmitočtech zvětšuje. Je to způsobeno zmenšením zisku v elektronické části stabilizátoru, který již nestačí udržet malý výstupní odpor zdroje a induktivním charakterem reaktance elektrolytických kondenzátorů na vyšších kmitočtech. Také přívody od zdroje delší než $10 \mathrm{~cm}$ se mohou projevit u širokopásmových zesilovačů svým induktivním charakterem. Proto znovu upozorňujeme na nutnost použít keramické blokovací kapacitory u každého zesilovače, a to co nejblíže $\mathrm{k}$ pouzdru.

Nesymetrické napájeni operačních zesilovačů. Operační zesilovač má obvykle invertující a neinvertující vstupní svorku a výstup, čtvrtou signálovou svorku představuje společný vodič, který je obvykle spojen s nulovým potenciálem, tj. se zemí. Tato signálová svorka je při symetrickém napájení (Dual-Supply Operation) operačního zesilovače pomyslná Obr. 10.15 ). Stejnosměrně představuje střed mezi symetrickým napájecím napětím, tj. $0 \mathrm{~V}$. Při symetrickém napájení nečiní obvykle aplikace operačního zesilovače problémy, všechna napětí jsou vztažena k nulovému potenciálu (k zemi).
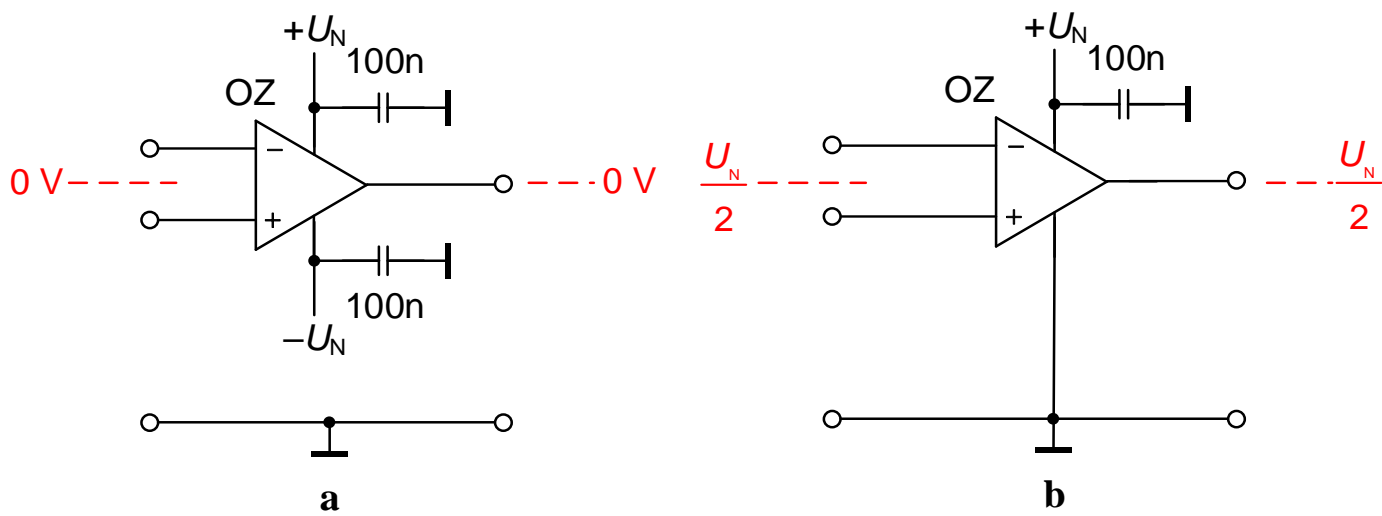

Obr. 10.15: a) Symetricky napájený operační zesilovač, b) operační zesilovač napájen z jednoho zdroje 
V př́ípadě nesymetrického napájení z jednoho zdroje (Single-Supply Operation) musíme počítat s tím, že vstupní i výstupní signál bude stejnosměrně posunut o $U_{\mathrm{N}} / 2$ (viz Obr. 10.15b). Rozkmit výstupního napětí nyní bude o něco menší a to v rozmezí $0 \mathrm{~V}$ až $U_{\mathrm{N}}$. Př́i napájení $\mathrm{OZ}$ z jednoho napájecího zdroje tedy musíme zpracovávaný signál ss posunout vytvořením „plovoucí země“ na potenciálu $U_{\mathrm{N}} / 2$, nebo v prŕípadě zpracování stř́idavých signálů (např. audiosignálů) provést stejnosměrné oddělení vstupního i výstupního signálu. I přes tyto nevýhody se OZ napájejí často jen z jednoho napájecího zdroje, protože to umožňuje jeho aplikace $\mathrm{v}$ bateriově napájených zařízeních, nebo v př́idavných kartách do počítačů, kdy je $\mathrm{k}$ dispozici obvykle jen napájecí napětí jedné polarity $(+12 \mathrm{~V},+5 \mathrm{~V}$, nebo dokonce jen $+3,3 \mathrm{~V})$. Obr. 10.16 ukazuje, jak se dá konvenční OZ, který je navržen pro symetrické napájení, napájet z jednoho napájecího zdroje $U_{\mathrm{N}}$. „Plovoucí zem“ je zde vytvořena referenční diodou, která by měla mít vybráno Zenerovo napětí přibližně $U_{\mathrm{N}} / 2$. Referenční dioda má nastaven pracovní bod pomocí rezistoru $\mathrm{R}_{0}$.

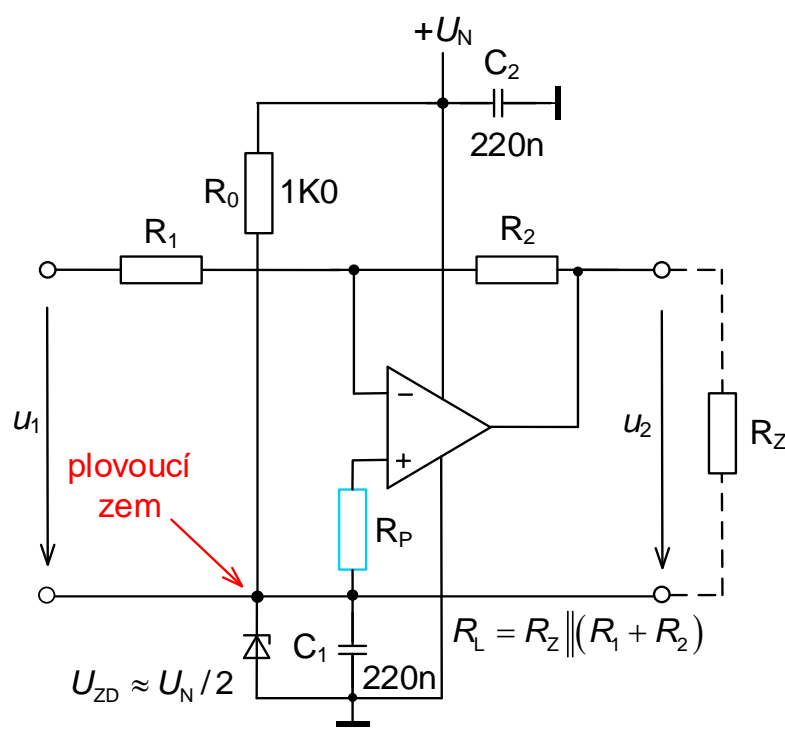

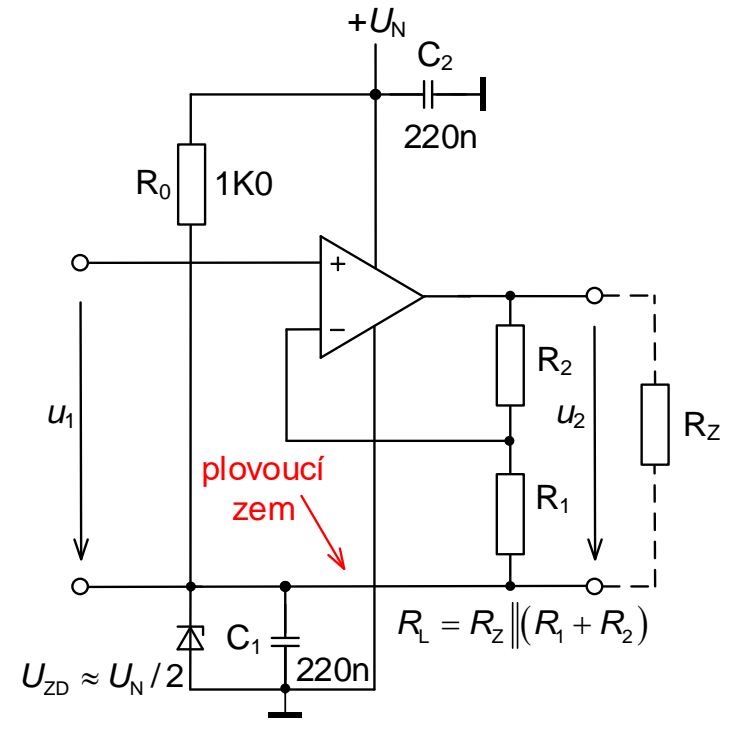

b

Obr. 10.16: Použití konvenčního OZ se symetrickým napájením při napájení z jednoho zdroje: a) invertující zesilovač, b) neinvertující zesilovač

Odpor rezistoru $R_{\mathrm{p}} \approx R_{1} \| R_{2}$ (ve schématu vyznačen modře) slouží ke kompenzaci vstupního klidového proudu. $\mathrm{V}$ př́ípadě unipolárního $\mathrm{OZ}$ se volí $\mathrm{R}_{\mathrm{p}}=0 \Omega$. Vzhledem $\mathrm{k}$ tomu, že vstupní i výstupní svorka jsou vztaženy ke stejné „plovoucí zemi“, která je na potenciálu $U_{Z D}$, není přesnost a stabilita Zenerova napětí kritická. Na vstupu i výstupu nyní mohou být vzhledem $\mathrm{k}$,plovoucí zemi“ bipolární signály. Provoz je podobný provozu se symetrickým napájením. Proud zátěží $R_{\mathrm{L}}=R_{\mathrm{Z}} \|\left(R_{1}+R_{2}\right)$ však teče do „plovoucí země“, kde se bude přidávat $\mathrm{k}$ proudu referenční diodou (záporný zatěžovací proud se bude odečítat od proudu nastavujícího pracovní bod referenční diody). Referenční dioda a proud nastavující její pracovní bod musí být proto zvolen tak, aby referenční dioda byla provozována v závěrném směru při všech způsobech zatížení OZ.

Neinvertující zesilovač napájený z jednoho napájecího zdroje je uveden na Obr. 10.16 . Opět uvažujeme použití konvenčního OZ, navrženého pro symetrické napájení. V tomto př́padě bude výstup zatížen stejně jako $\mathrm{v}$ předchozím, $\mathrm{tj} . R_{\mathrm{L}}=R_{\mathrm{Z}} \|\left(R_{1}+R_{2}\right)$ a proud touto zátěží se bude přidávat k proudu referenční diodou. 
Někdy se v jednoduché aplikaci pro odvození napětí „plovoucí země“ použije odporový dělič (viz Obr. 10.17ł). Jeho výstupní impedance a tedy i výstupní impedance takového pomocného zdroje je $R_{\mathrm{A}} \| R_{\mathrm{B}}$.

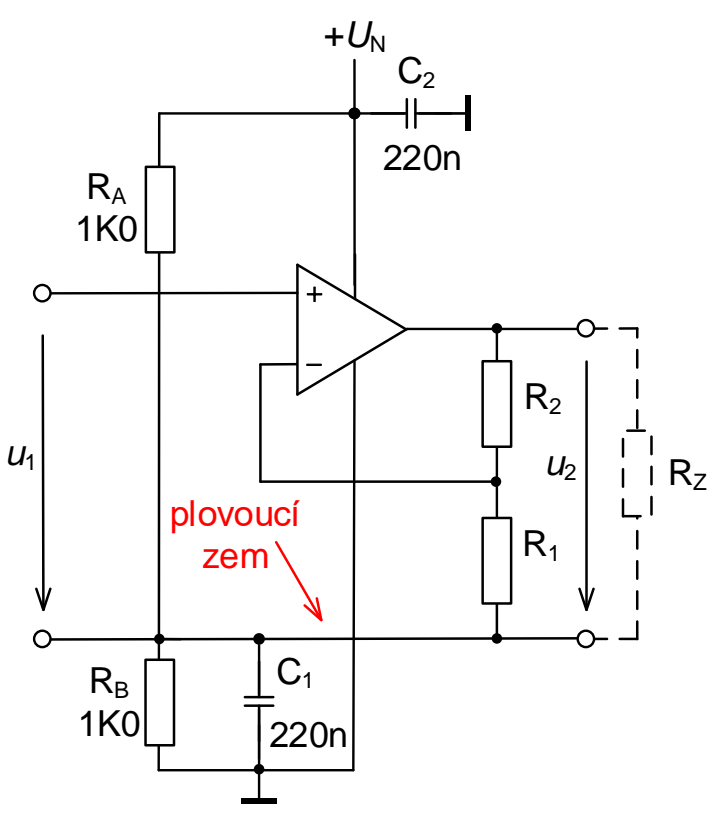

$\mathbf{a}$

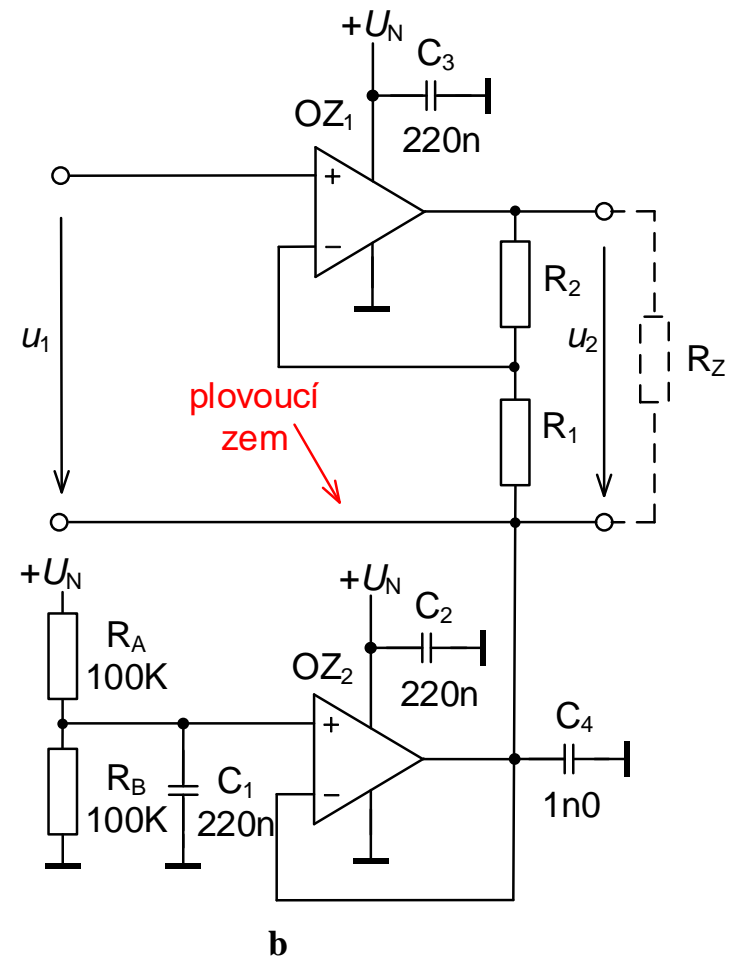

b

Obr. 10.17: Vytvoření „plovoucí země“a) pomocí děliče, b) pomocí děliče a oddělovacího zesilovače

I přesto, že výstupní odpor děliče $\mathrm{R}_{\mathrm{A}}, \mathrm{R}_{\mathrm{B}}$ je zapojen $\mathrm{v}$ sérii $\mathrm{s}$ rezistorem $\mathrm{R}_{1}$, je zesílení obvodu stále určeno jen odpory rezistorů $\mathrm{R}_{1}$ a $\mathrm{R}_{2}$. Vzhledem $\mathrm{k}$ tomu, že vstupní $\mathrm{i}$ výstupní napětí jsou vztaženy $\mathrm{k}$,plovoucí zemi“ nemá tato impedance vliv na zesílení obvodu. Proud zátěží $R_{\mathrm{L}}=R_{\mathrm{Z}} \|\left(R_{1}+R_{2}\right)$ teče výstupním odporem děliče $\mathrm{R}_{\mathrm{A}} \| \mathrm{R}_{\mathrm{B}}$ a může způsobit posunutí napětí „plovoucí zeměc. Protože je zapotřebí, aby dělič $R_{A}, R_{B}$ byl dostatečně „tvrdý“ zdroj napětí, je nutno jeho odpory volit malé. To však klade zvýšené nároky na napájecí zdroj.

Zvláště náročné aplikace mohou vyžadovat velmi malý proudový odběr z napájecího zdroje, přičemž vnitřní odpor posuvného zdroje má být malý. Jeden způsob je naznačen naObr. 10.17b. Vstupní napětí oddělovacího zesilovače $\mathrm{OZ}_{2} \mathrm{~s}$ jednotkovým přenosem může být vytvořeno různými způsoby uvedenými dříve. Zde je použit dělič $\mathrm{R}_{\mathrm{A}}, \mathrm{R}_{\mathrm{B}}$. Oddělovací zesilovač se $100 \%$ zápornou zpětnou vazbou vytváří velmi kvalitní „,plovoucí zem“, protože výstupní impedance takovéhoto zdroje je pro ss signály menší než $1 \Omega$. Kmitočtová charakteristika a výstupní impedance $\mathrm{OZ}$ bez zpětné vazby určují výstupní impedanci oddělovacího zesilovače na vysokých kmitočtech. Přemostěním výstupu oddělovacího zesilovače kapacitorem $\mathrm{C}_{4}$ můžeme výstupní impedanci na vysokých kmitočtech ještě snížit, ale jeho impedance nesmí překročit povolenou kapacitní zátěž $\mathrm{OZ}$, protože by mohlo dojít k rozkmitání oddělovacího zesilovače.

Napájení operačního zesilovače z baterie umožňuje vytvořit plovoucí zem rozdělením napájecího napětí $U_{N}$ pomocí děliče $R_{A}, R_{B}$ na polovinu (viz Obr. 10.18). Kapacitor $C_{1}$ slouží $\mathrm{k}$ potlačení šumu rezistorového děliče. Zesilovač $\mathrm{s} \mathrm{OZ}_{1}$ má jednotkový přenos a pouze slouží $\mathrm{k}$ oddělení děliče $\mathrm{R}_{\mathrm{A}}, \mathrm{R}_{\mathrm{B}}$. Oddělovací zesilovač s $\mathrm{OZ}_{1}$ i neinvertující zesilovač $\mathrm{s} \mathrm{OZ}_{2}$ je pak napájen symetrickým napětím. Pokud se použije nízkovoltová baterie, např. 3,0 V je použití 


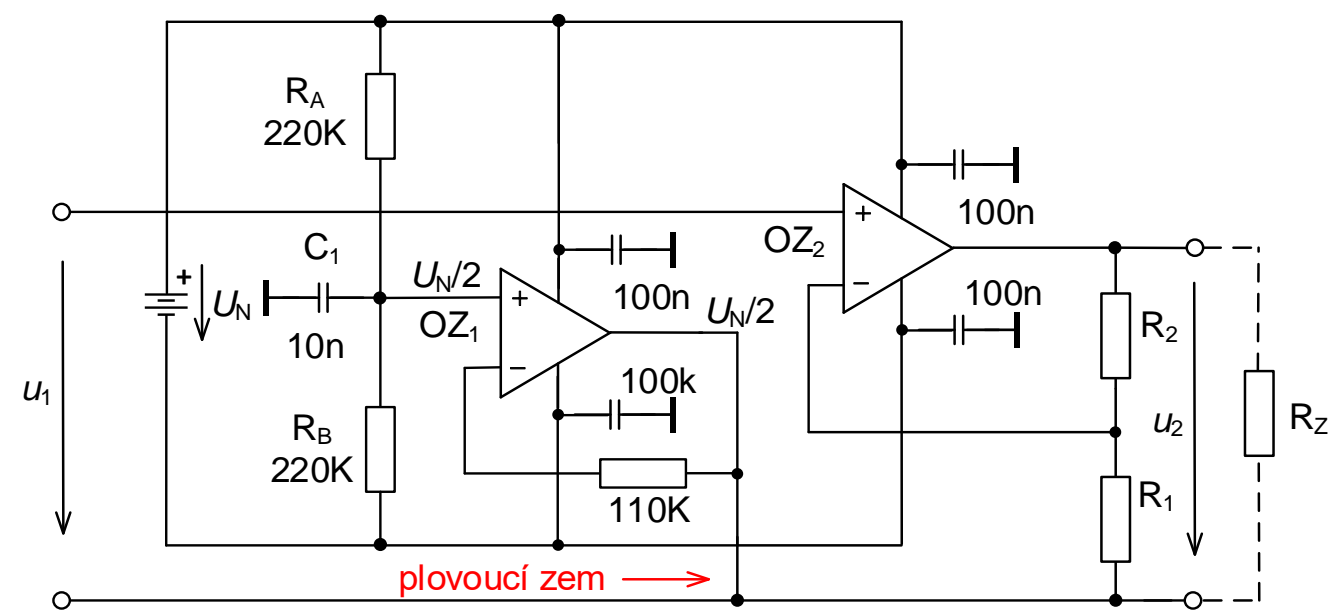

Obr. 10.18: Užití operačního zesilovače pro vytvoření plovoucí země neinvertujícího zesilovače napájeného $\mathrm{z}$ baterie

operačních zesilovačů umožňujících pracovat s plným rozkmitem výstupního napětí („rail-torail“) nezbytné.

Při zpracování strrídavých signálů lze užít i jiné způsoby využití OZ napájeného z jednoho zdroje. Základní princip je schematicky naznačen na Obr. 10.19. Na vstup zesilovače je přivedeno ss napětí $U_{N} / 2$, které je odvozeno $z$ napájecího napětí $U_{N}$. To může vést ke zhoršení šumových poměrů, protože impulsní rušení z impulsně regulovaného zdroje, nebo zvlnění klasického zdroje se podělí děličem s odpory $R_{\mathrm{A}}=R_{\mathrm{B}}$ na polovinu, tzn., že rušení či zvlnění zdroje bude potlačeno pouze o $6 \mathrm{~dB}$.

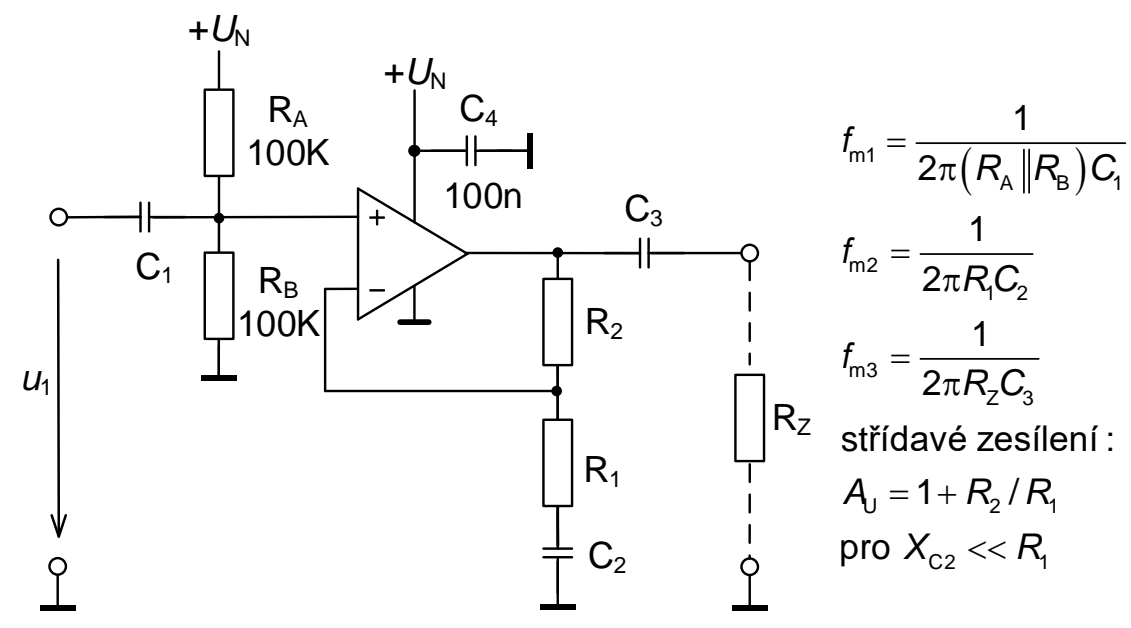

Obr. 10.19: Základní princip nastavení předpětí na vstupu OZ může vést ke zhoršení šumových poměrů nesymetricky napájeného střídavého zesilovače

Řešení tohoto problému nabízí modifikace zapojeníObr. 10.20. Výstup děliče $R_{A}, R_{B} j e$ nyní pro stř́davé signály přemostěn kapacitorem $\mathrm{C}_{4}$. Ten se př̀i použití klasického napájecího zdroje volí elektrolytický tak, aby platilo $f_{\mathrm{m} 1}<f_{\mathrm{m} 2} / 10$. V př́ípadě impulsně regulovaného zdroje se na pozici kapacitoru $\mathrm{C}_{4}$ použijí tři paralelně zapojené $\mathrm{SMD}$ kapacitory např. $10 \mu \mathrm{F}, 1 \mu \mathrm{F}$ a 1 $\mathrm{nF}$. 


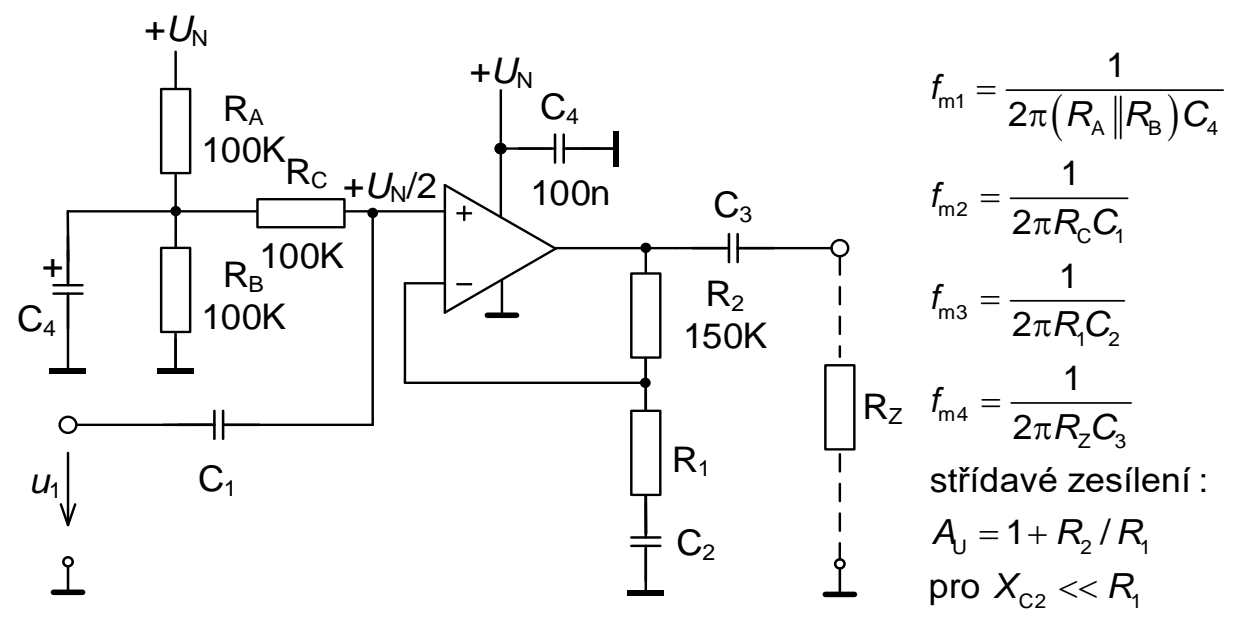

Obr. 10.20: Střídavý neinvertující zesilovač s OZ napájeným jediným napájecím napětím

Povšimněme si, že zesílení pro ss signály je jednotkové (kapacitor $\mathrm{C}_{2}$ má pro ss signály vysokou impedanci) a $\mathrm{OZ}$ má pro ss signály ve zpětné vazbě pouze rezistor $\mathrm{R}_{2}$. Dále musíme vzít v úvahu, že výstupní odpor děliče $\mathrm{R}_{\mathrm{A}}, \mathrm{R}_{\mathrm{B}}$ společně s odporem rezistoru $\mathrm{R}_{\mathrm{C}}$ zapojeným před neinvertujícím vstupem $\mathrm{OZ}$ je značný $R_{\mathrm{A}} \| R_{\mathrm{B}}+R_{\mathrm{C}}$. Pokud nebudou odpory v invertujícím a neinvertujícím vstupu přibližně shodné, mohou vstupní klidové odpory OZ vyvolat ss posunutí jeho výstupního napětí. To však potřebujeme udržet přibližně na hodnotě $U_{N} / 2$, protože jinak může dojít k omezení rozkmitu výstupního napětí. Z tohoto důvodu se volí $R_{2}=R_{\mathrm{A}} \| R_{\mathrm{B}}+R_{\mathrm{C}}$.

Při napájení z jednoho zdroje $12 \mathrm{~V}$ představují odpory děliče $100 \mathrm{k} \Omega$ rozumný kompromis mezi proudovým odběrem z napájecího zdroje a chybou vyvolanou vstupním klidovým proudem. Při napájení $+5 \mathrm{~V}$ je možné odpory děliče zvolit $42 \mathrm{k} \Omega$. V případě napájení ze zdroje 3,3 V je nezbytné použít OZ s plným rozkmitem výstupního napětí („rail-to-rail“) a odpory děliče lze snížit na $27 \mathrm{k} \Omega$.

Samozřejmě problémům se vstupními klidovými proudy se můžeme vyhnout použitím unipolárního zesilovače. Chceme-li však zařízení provozovat v širokém teplotním rozsahu je vyrovnání odporů v invertujícím a neinvertujícím vstupu $\mathrm{OZ}$ příhodné i pro tento prŕípad.

Invertující uspořádání stř́ídavého zesilovače s OZ napájeným z jednoho zdroje je uvedeno na Obr. 10.21. V tomto př́padě bude vliv vstupních klidových proudů eliminován při $R_{2}=R_{\mathrm{A}} \| R_{\mathrm{B}}$. Aby se potlačil průnik rušivých signálů $\mathrm{z}$ napájecího zdroje je dělič $\mathrm{R}_{\mathrm{A}}, \mathrm{R}_{\mathrm{B}}$ zablokován kapacitorem $\mathrm{C}_{2}$ a pro dolní propust tvořenou výstupním odporem děliče $R_{\mathrm{A}} \| R_{\mathrm{B}} \mathrm{a}$ kapacitou $\mathrm{C}_{2}$ musí platit $f_{\mathrm{m} 1}<f_{\mathrm{m} 2} / 10$. 


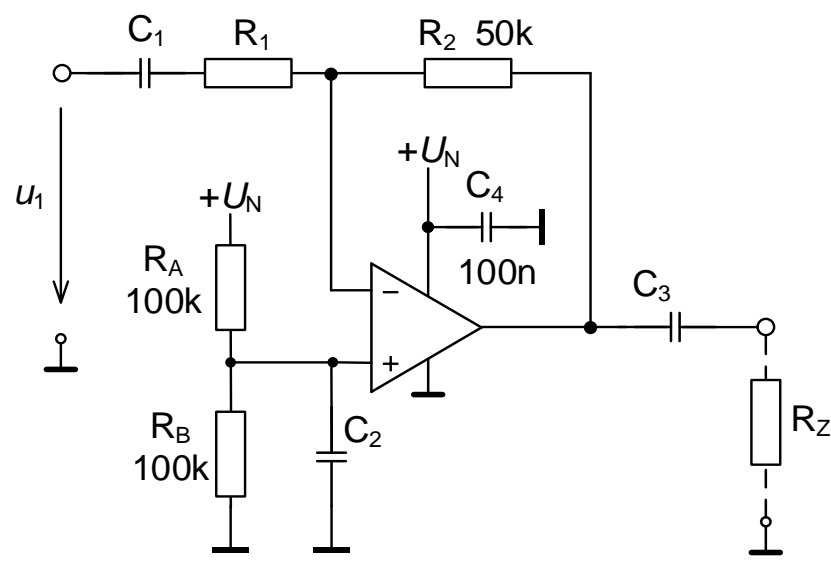

$$
\begin{aligned}
& f_{\mathrm{m} 1}=\frac{1}{2 \pi\left(R_{\mathrm{A}} \| R_{\mathrm{B}}\right) C_{2}} \\
& f_{\mathrm{m} 2}=\frac{1}{2 \pi R_{1} C_{1}} \\
& f_{\mathrm{m} 3}=\frac{1}{2 \pi R_{\mathrm{Z}} C_{3}} \\
& \text { stř́idavé zesílení : } \\
& A_{\mathrm{U}}=-R_{2} / R_{1} \\
& \text { pro } X_{\mathrm{C} 1}<<R_{1}
\end{aligned}
$$

Obr. 10.21: Střídavý invertující zesilovač s OZ napájený jediným napájecím napětím

\subsection{Vzorkovače a sledovače s pamětí}

Při digitalizaci analogového signálu je nutno provést vzorkování signálu, ale často také zapamatování tohoto vzorku po určitou dobu, protože převedení do digitálního tvaru jistou dobu trvá. Pro správnou činnost A/D převodníku je proto často nutné, aby se vstupní napětí během převodu $\mathrm{A} / \mathrm{D}$ neměnilo. K definovanému odběru a uchování vozku z časově proměnného analogového signálu se používají vzorkovače s pamětí $(\mathrm{S} / \mathrm{H}$ amplifier $=$ sample and hold amplifier) nebo sledovače s pamětí $(\mathrm{T} / \mathrm{H}$ amplifier $=$ track and hold amplifier). Obvody se vzájemně liší pouze tím, po jakou dobu se analogový signál vzorkuje.

Princip vzorkovače resp. sledovače s pamětí je naznačen na Obr. 10.22. Vlastní vzorkovací obvod tvoří elektronický spínač $\mathrm{S}$ (např. tranzistor řízený polem) s pamět’ovým kapacitorem $\mathrm{C}_{\mathrm{P}}$. Zesilovač $\mathrm{OZ}_{1} \mathrm{~s}$ jednotkovým přenosem pouze odděluje zdroj budicího signálu od vlastního vzorkovacího obvodu, protože při sepnutí elektronického spínače $\mathrm{S}$ teče do pamět'ového kapacitoru velký nabíjecí proud a tento proud musí být schopen zesilovač $\mathrm{OZ}_{1}$ dodat. Druhý zesilovač $\mathrm{OZ}_{2} \mathrm{~s}$ jednotkovým přenosem odděluje pamět'ový kapacitor $\mathrm{C}_{\mathrm{P}}$ od zátěže (představovanou vstupním odporem následujícího převodníku $\mathrm{A} / \mathrm{D}$ ), protože by docházelo v době pamatování $\mathrm{k}$ nežádoucímu vybíjení pamět'ového kapacitoru.

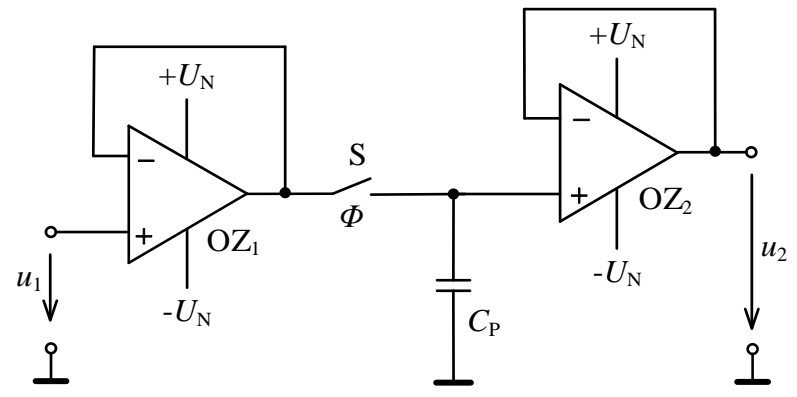

a

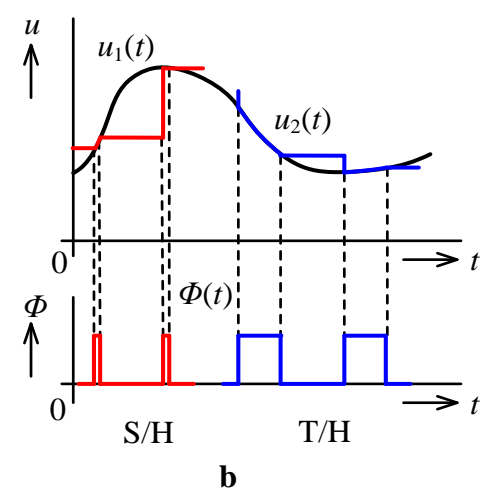

Obr. 10.22: a) Princip vzorkovače/sledovače s pamětí, b) časové průběhy při vzorkování a pamatování $(\mathrm{S} / \mathrm{H})$, resp. při vzorkování a sledování $(\mathrm{T} / \mathrm{H})$ 
Ideální vzorkovač s pamětí by měl vzorkovat analogový vstupní signál tak, že doba na odebrání vlastního vzorku by měla být co nejkratší (viz červené průběhy na Obr. 10.22b). Přitom se požaduje, aby i během této krátké doby vzorkování odpovídal vzorek okamžité hodnotě vzorkovaného signálu. V režimu pamatování by měl být zapamatovaný vzorek signálu na výstupu vzorkovače $\mathrm{k}$ dispozici beze změny alespoň po dobu, kterou potřebuje následující převodník $\mathrm{A} / \mathrm{D}$ pro převod analogového signálu do číslicového tvaru.

Režim sledovače se užívá při vzorkování velmi pomalých změn zpracovávaného signálu. Sledovač s pamětí v podstatě trvale sleduje měřený signál a poslední hodnotu si pamatuje pouze po dobu, kterou následující převodník $\mathrm{A} / \mathrm{D}$ potřebuje pro převod do digitálního tvaru (viz modré průběhy na Obr. 10.22p).

Uved’me ještě, že vlastní obvod může být proveden v různých variantách. Především nemusí pracovat jako „klasický“ sledovač napětí s jednotkovým prrenosem, ale jeho zesílení ve sledovacím provozu může být různé od jedné, pro zvýšení přesnosti může být užito zpětné vazby, obvod může i invertovat. Vzorkovače s pamětí a sledovače s pamětí jsou prakticky shodné obvody, jen se u nich liší doba vzorkování a pamatování. Aplikační zásady jsou proto stejné.

Výběr pamětového kapacitoru. Integrované vzorkovače či sledovače pro všeobecné použití mají většinou možnost připojení vnějšího pamět'ového kapacitoru. Pokud ke vzorkovači či sledovači s pamětí připojujeme vnější pamětový kapacitor, musíme při jeho výběru věnovat velkou pozornost jeho vlastnostem. Použité dielektrikum (keramika, nebo izolační fólie z polystyrenu či polyetylenu aj.) není ideální izolací a reálné vlastnosti kapacitoru ještě zhoršuje materiál vnějšího pláště (termoplast, ochranný tmel, izolační lak apod.). Tyto ztráty se modelují v náhradním zapojení kapacitoru jako izolační nebo svodový odpor $R_{i}$ připojený paralelně ke kapacitoru C. Izolační odpor pamětového kapacitoru by měl být $10^{11}$ až $10^{12} \Omega$. U některých kapacitorů pak navíc další ztráty způsobuje trvalý průchod tzv. zbytkového stejnosměrného proudu. Z tohoto důvodu jsou jako pamět'ový prvek zcela nevhodné elektrolytické kondenzátory.

Velkou pozornost je nutno také věnovat dielektrické absorbci pamět’ového kapacitoru. Jak bylo již uvedeno dříve, nabije-li se kapacitor na určité napětí, část náboje se váže s dielektrikem a nelze ho při vzorkování následující hodnoty úplně odstranit. Nevhodný výběr kapacitoru s velkou dielektrickou absorbcí může způsobit velkou chybu zapamatovaného napětí řádově $\mathrm{mV}$. Jako materiál dielektrika se doporučuje volit polystyrén nebo polypropylen, které vykazují součinitel dielektrické absorbce lepší než 0,02 \%. Špatné dielektrické vlastnosti mají kapacitory s keramickým dielektrikem. Bohužel dielektrická absorbce se liší kus od kusu a některé série kondenzátorů s polystyrenovým či polypropylenovým dielektrikem mohou vykazovat velkou dielektrickou absorbci. Proto se vyplatí investovat 30 až $50 \%$ ceny navíc a pro vzorkovače koupit kapacitory se zaručenou malou dielektricku absorbcí.

Promyšlený návrh plošného spoje. Velká pozornost se musí také věnovat návrhu plošného spoje vzorkovače či sledovače s pamětí, protože u těchto obvodů je na závadu pronikání svodových proudů po znečištěném povrchu plošného spoje do citlivé svorky pamět’ového kapacitoru. Nosným prostředím těchto svodových proudů je elektrolytická kaše na povrchu plošného spoje vzniklá z prachu, ze zbytků pájedel, poutanou vlhkostí či vlhkostí ze zkondenzovaných par. Svodové proudy mohou být minimalizovány promyšleným použitím vodivého izolačního prstence, který obklopuje citlivý uzel a je na stejném potenciálu jako tento uzel. Vzhledem k tomu, že mezi nimi pak není žádný rozdíl potenciálů, nemůže mezi nimi téci žádný svodový proud. Poznamenejme ještě, že svodové proudy tekoucí po povrchu plošného spoje jsou daleko větší než vnitřní objemové proudy tekoucí izolačním materiálem a proto se doporučuje izolační prstence provést na obou stranách plošného spoje a v případě vícevrstvého plošného spoje i ve všech vnitřních vrstvách. 
Připojení prstence na vhodný potenciál musí být velmi dobře promyšleno a je zapotřebí znát alespoň zjednodušené vnitřní zapojení integrovaného vzorkovače. Např. ve zpětnovazebním zapojení na Obr. 10.23 se citlivý uzel pamětového kapacitoru $\mathrm{C}_{\mathrm{p}}$ nachází na stejném potenciálu, jaký je na výstupu napětového sledovače s $\mathrm{OZ}_{2}$. Aby byl tento uzel chráněn proti svodovým proudům tekoucím po povrchu desky plošného spoje, je nutno prstenec připojit na výstup napět'ového sledovače $\mathrm{s} \mathrm{OZ}_{2} \mathrm{~s}$ jednotkovým přenosem, který představuje „tvrdý“ zdroj napětí (s malým vnitřním odporem) a je tedy schopen svodové proudy absorbovat.

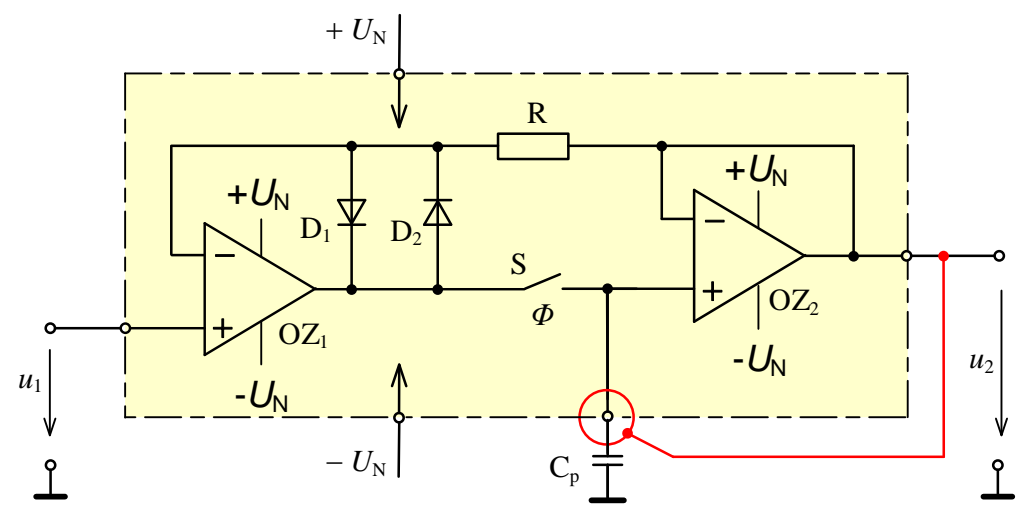

Obr. 10.23: Aktivní izolace pamětového kapacitoru na desce plošného spoje

Jiná situace je v př́ípadě vzorkovače s integrátorem (viz Obr. 10.24), protože citlivý uzel pamět’ového kapacitoru je nyní na nulovém potenciálu, který se udržuje na invertující vstupní svorce $\mathrm{OZ}_{2}$ (tzv. „virtuální nula“). V tomto př́ípadě se ochranný prstenec připojí na nulový potenciál.

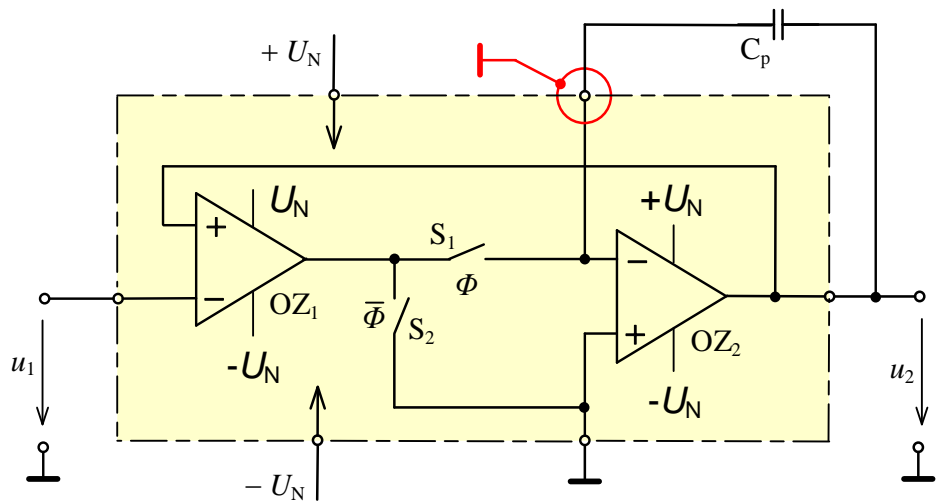

Obr. 10.24: Izolace pamět’ového kapacitoru uzemněným prstencem

\subsection{Komparátory}

Komparátory jsou integrované obvody, které slouží pro porovnávání dvou napětí. V zásadě je možné je považovat za nejjednodušší $A / D$ převodník (s rozlišením 1 bit). Elementární zapojení komparátoru pro vyhodnocení zda vstupní napětí $u_{1}$ je větší či menší než komparační napětí $U_{\mathrm{K}}$ je uvedeno na Obr. 10.25. Vstupní část komparátoru je analogová, kdežto na výstupu je bud' kladné saturační napětí $U_{2 \mathrm{p}}$ nebo záporné saturační napětí $U_{2 \mathrm{n}}$. Budeli vstupní napětí $u_{1}<U_{\mathrm{K}}$ bude výstup komparátoru v kladné saturaci $u_{2}=U_{2 \mathrm{p}}$ a pro $u_{1}>U_{\mathrm{K}}$ bude $\mathrm{v}$ záporné saturaci $u_{2}=U_{2 \mathrm{n}}$. 

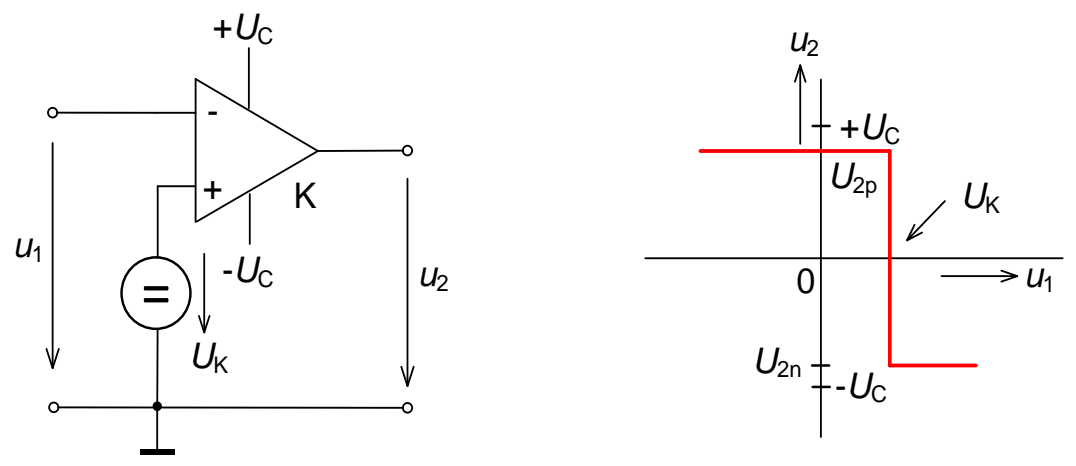

Obr. 10.25: Základní zapojení komparátoru a jeho převodní charakteristika

Navenek jsou komparátory podobné operačním zesilovačům bez zapojené zpětné vazby, tzn. mají diferenciální vstup, velké zesílení, nízkou výstupní impedanci atd. Mohlo by se tedy zdát, že je možné místo komparátoru použít obyčejný operační zesilovač, ale v praxi se takový postup důrazně nedoporučuje. Důvodů je hned několik:

- Vstupní obvody komparátorů jsou sice analogové, podobně jako u diferenčních operačních zesilovačů, ale diferenční zesilovač na vstupu má jen malé zesílení (asi 1000), ale vyznačuje se velkou rychlostí přeběhu.

- Výstupy komparátorů jsou digitální (je na nich úroveň H či L) a jejich výstupní napětové úrovně jsou většinou uzpůsobeny tak, aby je bylo možné prŕmo propojit s logickými obvody CMOS, TTL, LVDS apod. To u operačních zesilovačů neplatí.

- OZ jsou uzpůsobeny k provozu se silnou zápornou zpětnou vazbou, bez ní jsou velmi náchylné ke kmitání. Naopak komparátory jsou určeny k provozu bez ZV.

- Diferenciální vstup OZ předpokládá, že na něm je rozdíl napětí blízký nule (virtuální nula). Naopak vstupy komparátoru snesou i velké rozdíly vstupního napětí.

- Když se výstup OZ dostane do saturace, jen těžko a pomalu se z ní dostává ven. Komparátory tímto netrpí, jejich výstup je $\mathrm{k}$ takovému provozu př́mo konstruován, výstup se chová stejně jako výstup logického obvodu.

\subsubsection{Základní vlastnosti komparátorů}

Klasické řešení komparátoru má symetrické napájení a společnou zem analogové a číslicové části Obr. 10.26 ). Mohou mít př́mý i inverzní výstup jako např. komparátor $\mathrm{s}$ diferenčním výstupem na Obr. 10.26b. Podobně jako A/D převodníky, komparátory obvykle mají samostatné napájecí vstupy pro vstupní (analogovou) část a výstupní (digitální) část. Je to ostatně logické, rychlé přepínání výstupu generuje rušení, které se nesmí šiřit do analogového napájecího rozvodu. Díky samostatným napájecím vstupům též mohou být použita různá napájecí napětí, což v praxi nastává velmi často. Typický př́pad je, že analogová část je napájena symetrickým napětím $\pm 15 \mathrm{~V}$ a výstupní část je napájena $\mathrm{z}+3,3 \mathrm{~V}$ pro logické obvody, jak ukazuje Obr. 10.264. 


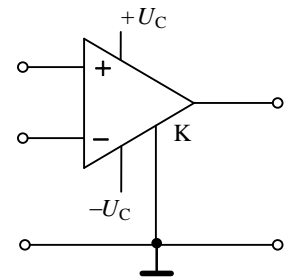

a

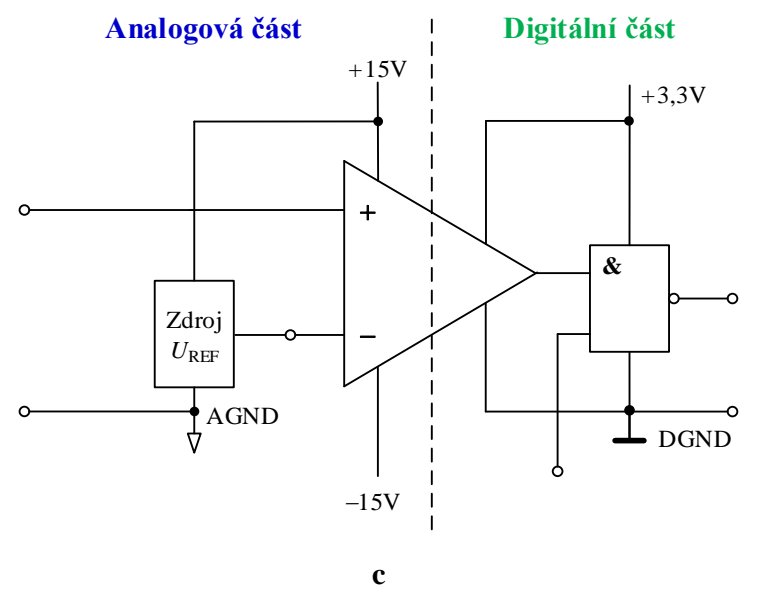

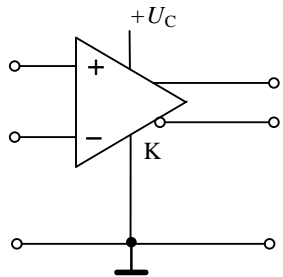

b

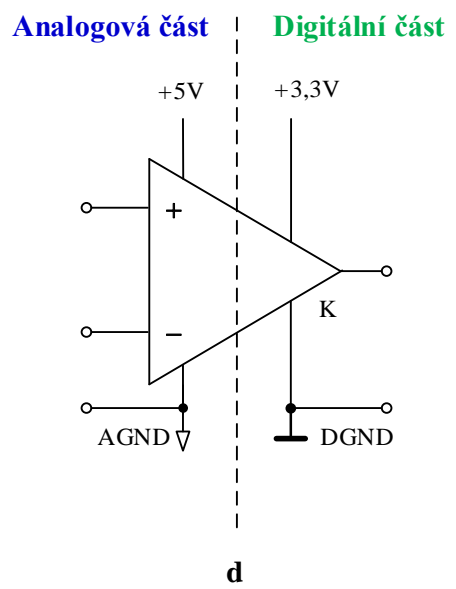

Obr. 10.26: Typická zapojení komparátorů

Nicméně symetrické napájení je dnes luxus, který má opodstatnění pouze v měřicí a audio technice. Pro běžnou spotřební elektroniku se vyrábí obrovské množství komparátorů, kterým dostačuje nesymetrické analogové napájení jako na Obr. 10.26", a někdy mají i dva vývody pro zem, jeden pro analogovou (AGND) a druhý pro digitální (DGND) tak, jak je znázorněno na Obr. 10.26 d. Účelem opět je, zamezit průniku rušení z digitální části do analogových obvodů.

Některé parametry komparátorů mají stejný význam jako u OZ, např. vstupní napět’ová a proudová nesymetrie (input offset voltage/current) či citlivost na souhlasné napětí (common mode rejection ratio, CMMR). Protože komparátory jsou určeny k jinému účelu než OZ, je nutné při jejich výběru sledovat zcela jiné parametry:

- Vstupní napět'ový rozsah (input voltage range) je u některých komparátorů omezený, s čímž se výrobci př́liš nechlubí. Omezení přitom může být celá řada, záleží na konstrukci vstupního zesilovače. Např́iklad komparátor napájený $\mathrm{z} \pm 15 \mathrm{~V}$ může být schopen zpracovat vstupní napětí $u_{\mathrm{P}}$ či $u_{\mathrm{N}}$ pouze v rozsahu $\pm 5 \mathrm{~V}$ proti zemi (viz Obr. 10.27ł). Pokud napětí na některém vstupu tento rozsah překročí, komparátor se dostane do hluboké saturace, ze které se dostává jen pomalu (reakční doba $t_{\mathrm{PD}}$ se prodlouží). Jiné komparátory zase snesou vstupní napětí v celém rozsahu napájení, ale jejich vzájemný rozdíl $u_{\mathrm{P}}-u_{\mathrm{N}}$ nesmí překročit napřr. 7,5 V. Na druhou stranu však existují i komparátory, které na vstupu snesou celý rozsah napájecího napětí (rail-to-rail input).

- Doba zpoždění $t$ PD (propagation delay) je nejdůležitější údaj, od kterého se odvíjí i cena komparátoru. Jeho interní obvody nejsou nekonečně rychlé, vždy nějakou dobu trvá, než výstup zareaguje na změnu vstupního napětí. Na Obr. 10.27b je pro ilustraci časová odezva komparátoru při přechodu vstupního napětí $u_{\mathrm{i}}$ přes nulu (ze záporných do kladných hodnot). Společně se jmenovitou reakční dobou $t_{\mathrm{PD}}$ je vždy udáván i rozdíl napětí na vstupu (overdrive voltage), který je nutný pro její dosažení (na Obr. 10.27b je označen jako $\left.U_{0 v}\right)$. Pokud je tento rozdíl menší, je i reakce komparátoru pomalejší. Na tuto 
skutečnost je tedy také nutné dávat při výběru komparátoru pozor. Dnes jsou běžně dostupné komparátory, které mají $t_{\mathrm{PD}}$ kratší než 0,2 ns.

- Rychlost přeběhu výstupu (slew rate), obvykle udává strmost náběžné a sestupné hrany (rise time $t_{\mathrm{R}}$ resp. fall time, $t_{\mathrm{F}}$, viz Obr. 10.27b. Zde záleží na konstrukci budiče výstupu, nicméně informace o strmosti hran je obvykle podobná reakční době $t_{\mathrm{PD}}$ (pomalý komparátor nepotřebuje rychlý výstup a naopak). Kapacitní zátěž na výstupu strmost hran zhoršuje (doba trvání hran se prodlužuje), což je nutné při aplikacích zohlednit.

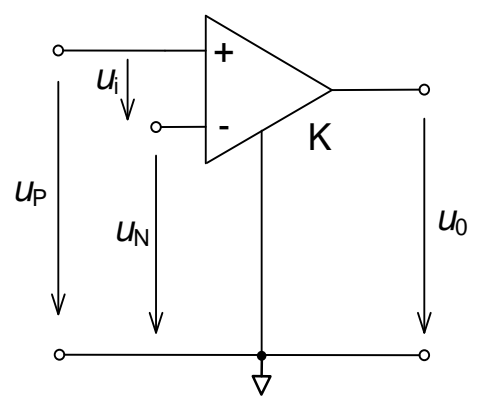

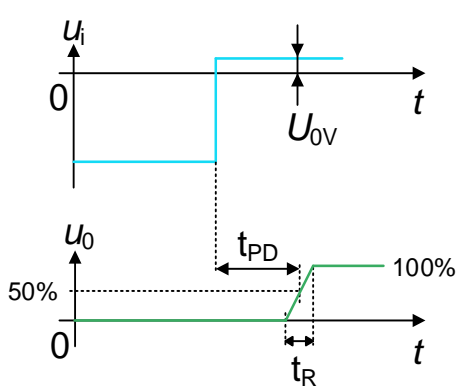

b

Obr. 10.27: K významným parametrům komparátorů

- Maximální výstupní proud (output current capability) úzce souvisí s výše zmíněnými kapacitními zátěžemi na výstupu - čím větší proud je výstup schopen dodat, tím rychleji dokáže kapacitní zátěž nabít a tedy dosáhnout strmějších hran. K dispozici jsou i komparátory speciálně konstruované pro buzení velkých kapacitních zátěží.

- Vnitřní hysterezní obvody (internal hysteresis) - téměř všechny vysokorychlostní komparátory mají hysterezi realizovanou př́mo na čipu. U některých typů je nastavena napevno, zpravidla okolo 10 až $20 \mathrm{mV}$ (fixed hysteresis). U jiných typů je nastavitelná $\mathrm{z}$ venku (adjustable hysteresis), typicky v rozsahu 0 až $200 \mathrm{mV}$.

- Synchronizační/aktivační vstup (latch enable) - protože komparátory jsou ve skutečnosti jednobitovými A/D převodníky, je často v praxi nutné jejich překlápění synchronizovat $\mathrm{s}$ hodinovým signálem $\mathrm{z}$ nadřazeného digitálního systému. Některé typy $\mathrm{k}$ tomu mají př́imo na čipu synchronizační obvody a samostatný digitální vstup.

- Vstup pro řízení spotřeby (shutdown input) - některé komparátory mají vstup, kterým lze komparátor vypnout a tím radikálně snížit jeho spotřebu. To se typicky používá v zařízeních napájených z baterií.

Mezi další významné aplikační vlastnosti lze zařadit i konstrukci výstupu (output stage type). Výstup komparátoru je digitální, takže i jeho konstrukce a napětové úrovně se mohou lišit podle logických obvodů, pro které je určen. Dnes jsou vyráběny komparátory se třemi druhy výstupů:

1. Dvojčinný výstup (push-pull output) se použíá pro připojení k běžným logickým obvodům CMOS, TTL apod. (viz Obr. 10.28ł). Je to klasický logický výstup, který $\mathrm{v}$ úrovni H dokáže proud dodávat do zátěže a $\mathrm{v}$ úrovni $\mathrm{L}$ jej ze zátěže odebírat.

2. Výstup s otevřeným kolektorem (open collector/drain output) umožňuje připojit zátěž $\mathrm{R}_{\mathrm{L}}$ napájenou z vnějšího napětí $U_{\mathrm{EXT}}$ (viz Obr. 10.28b). Takový výstup dokáže proud pouze ze zátěže odebírat, ale napětí $U_{\mathrm{EXT}}$ může být menší i větší, než je napájecí napětí

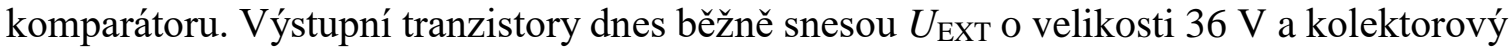
proud $20 \mathrm{~mA}$, takže jimi lze prímo spínat i poměrně velké zátěže (LED, relé, optotriaky apod). Výstupy s otevřeným kolektorem je také možné zapojovat paralelně jako na 
Obr. 10.28\&, takže jednu zátěž lze ovládat $\mathrm{z}$ více komparátorů současně (zapojení plní logickou funkci OR). Toho lze mj. využít při konstrukci okénkového komparátoru (viz dále).

3. Diferenční výstup (differential output) či komplementární výstupy (complementary outputs) se užívají u všech vysokorychlostních komparátorů ( $\left.t_{\mathrm{PD}}<10 \mathrm{~ns}\right)$. Takové komparátory jsou vždy určeny pro konkrétní standard vysokorychlostních logických obvodů a nelze je použít nikde jinde. Dnes jsou nejčastěji k dispozici výstupy pro standardy LVDS (Low-Voltage Differential Signalling), ECL (Emitter-Coupled Logic), PECL (Positive Emitter-Coupled Logic) a CML (Current-Mode Logic). Všechny diferenční výstupy musí být připojeny na vedení o definované vlnové impedanci (např. u LVDS je to $100 \Omega$ ) a vedení musí být na konci předepsaným způsobem zakončeno. Komparátory též musí být napájeny napětím, které je pro daný logický standard předepsáno. Na Obr. 10.29 je př́klad zapojení komparátoru s LVDS diferenciálním výstupem.

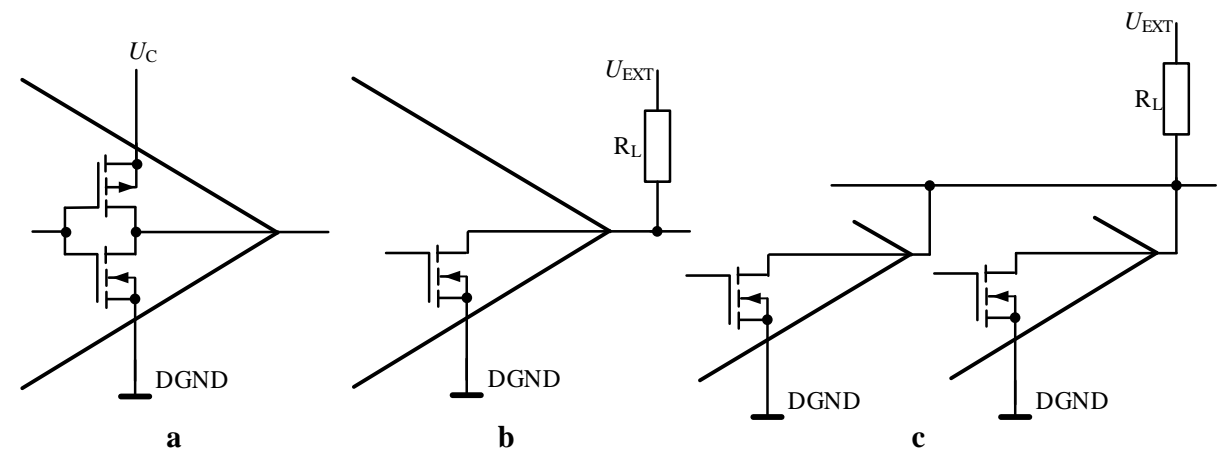

Obr. 10.28: Dvojčinný výstup a otevřený kolektor

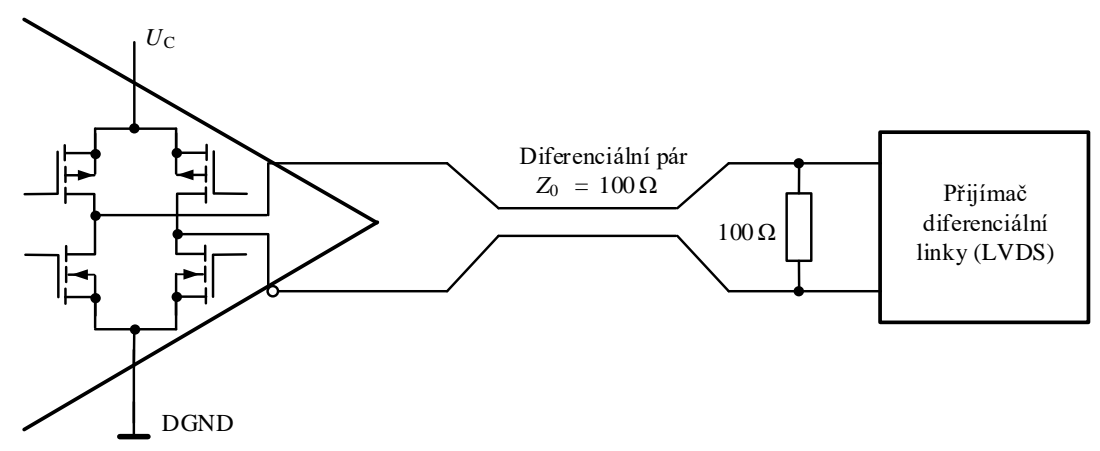

Obr. 10.29: Př́iklad zapojení diferenčního výstupu komparátoru (LVDS standard)

Při použití komparátorů je nutné vyloučit parazitní vazby mezi vstupem a výstupem komparátoru, jinak dojde k jeho samovolnému rozkmitání. Situaci vysvětluje Obr. 10.30a, na kterém je mezi výstupem a invertujícím vstupem parazitní kapacita $C_{\mathrm{PAR}}$ o kapacitě pouhého $1 \mathrm{pF}$. Při každém překlopení komparátoru se na jeho výstupu objeví velmi ostrá hrana $-\mathrm{u}$ moderních komparátorů mají běžně strmost (rychlost přeběhu) $\Delta u / \Delta t=100 \mathrm{~V} / \mu \mathrm{s} \mathrm{i}$ více. Snadným výpočtem zjistíte, že po dobu trvání hrany bude parazitní kapacitou procházet proud

$$
i_{\mathrm{PAR}}=C_{\mathrm{PAR}} \frac{\Delta u}{\Delta t}=1 \cdot 10^{-12} \cdot \frac{100}{1 \cdot 10^{-6}}=100 \mu \mathrm{A} .
$$

Tento proud na vstupní impedanci zdroje signálu $\mathrm{R}_{\mathrm{i}}=100 \Omega$ vyvolá špičkový úbytek napětí okolo $10 \mathrm{mV}$, který se přičte k užitečnému signálu. Taková změna však dokáže spolehlivě 
komparátor překlopit zpět a celý proces se může opakovat - komparátor začne kmitat na vysoké frekvenci ${ }^{5}$. Výrobci komparátorů o tomto problému pochopitelně vědí a záměrně vstupy a výstupy umist'ují na opačné strany pouzdra IO. To je vidět i na Obr. 10.30b, ve kterém parazitní kapacita $C_{\mathrm{PAR}}$ vznikla nesprávným vedením spojů - takové uspořádání by zaručeně vedlo ke kmitání. Naopak na Obr. 10.30 je správné provedení, kdy jsou vstupní a výstupní spoje vedeny co nejdále od sebe. Pro další potlačení vzájemných vazeb jsou pod IO vedeny zemní plochy, které slouží jako stínění.

Z podobného důvodu se doporučuje vstupní přívody komparátoru po celé délce chránit zemními plochami proti pronikání takovýchto špiček ze všech sousedících vodičů, které přenášejí digitální signály. Aby se omezila úroveň pronikajících špiček přes zbylé parazitní kapacity, doporučuje se vstupy komparátoru budit $\mathrm{z}$ „tvrdých“ zdrojů napětí, tj. ze zdrojů s výstupním odporem menším než $1 \mathrm{k} \Omega$.

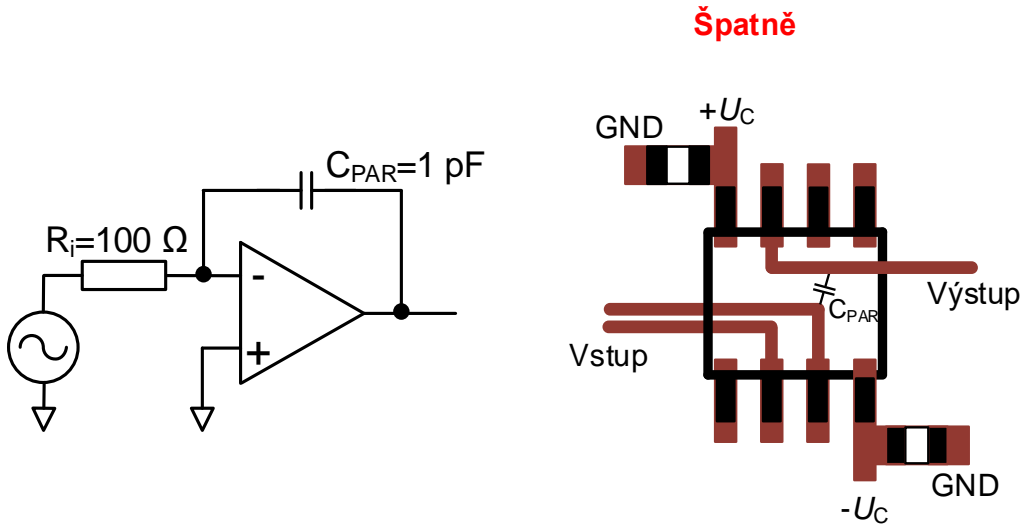

$\mathbf{a}$

b

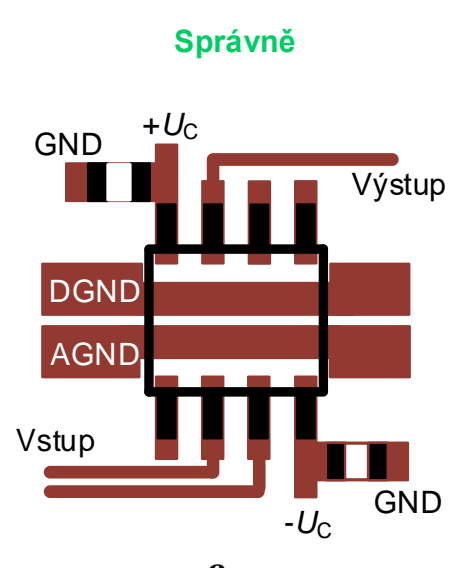

c

Obr. 10.30: Vedení spojů komparátoru

Rychlé komparátory využívají pro rychlé překlopení vydatnějších zdrojů proudu pro nabíjení parazitních kapacitorů uvnitř integrovaného obvodu. To způsobuje špičkové odběry proudu z napájecích zdrojů. Napájecí rozvody proto musí být masivní a musí být velmi kvalitně zablokovány. Výběr blokovacích kondenzátorů se odvíjí od rychlosti komparátoru - pro potlačení ostřejších proudových špiček jsou zapotřebí i kondenzátory na vyšší pracovní kmitočty. Dnes se k tomuto účelu téměř výhradně používají keramické kondenzátory. Pro vysokorychlostní komparátor je možné použít například paralelní kombinaci tří kondenzátorů: $10 \mu \mathrm{F}$ a $100 \mathrm{nF}$ z materiálu X7R a $1 \mathrm{nF}$ z materiálu NP0. Každý z nich je nejúčinnější v jiném kmitočtovém pásmu a navzájem se doplňují. Přitom platí, že čím menší (SMD) pouzdro se použije, tím lepší jsou frekvenční vlastnosti kondenzátoru. Kondenzátor $1 \mathrm{nF}$ musí být co nejblíže pouzdra a ostatní dva v jeho těsné blízkosti. Kondenzátory musí být umístěny a propojeny tak, aby byla co nejkratší proudová smyčka do země. Doporučené zapojení blokovacích kapacitorů včetně řešení plošného spoje je uvedeno na Obr. 10.31. Země jsou rozděleny na signálovou analogovou AGND, číslicovou DGND a na výkonovou GND. Země se vzájemně propojí až v centrálním zemnicím uzlu celého zařízení. V případě, že vstupní analogová část je napájena ze symetrického zdroje a výstupní digitální část z nesymetrického napájecího zdroje, dostačuje takto kvalitně blokovat pouze výstupní část obvodu komparátoru

\footnotetext{
${ }^{5}$ U klasického komparátoru (tj. s dvojčinným výstupem jako na Obr. 10.30 ) je ke vzniku tohoto jevu náchylný právě invertující vstup. Existují však i komparátory s obrácenou logikou výstupu, u kterých je pak naopak náchylnější neinvertující vstup. Nicméně v obou případech je pronikání špiček do vstupního signálu nežádoucí, takže je snahou $C_{\mathrm{PAR}}$ minimalizovat.
} 
(viz Obr. 10.31b). Protože každý komparátor má jiné parametry a rozmístění vývodů na pouzdru, je vhodné se při výběru blokovacích kondenzátorů a jejich umíst'ování řídit doporučením výrobce.
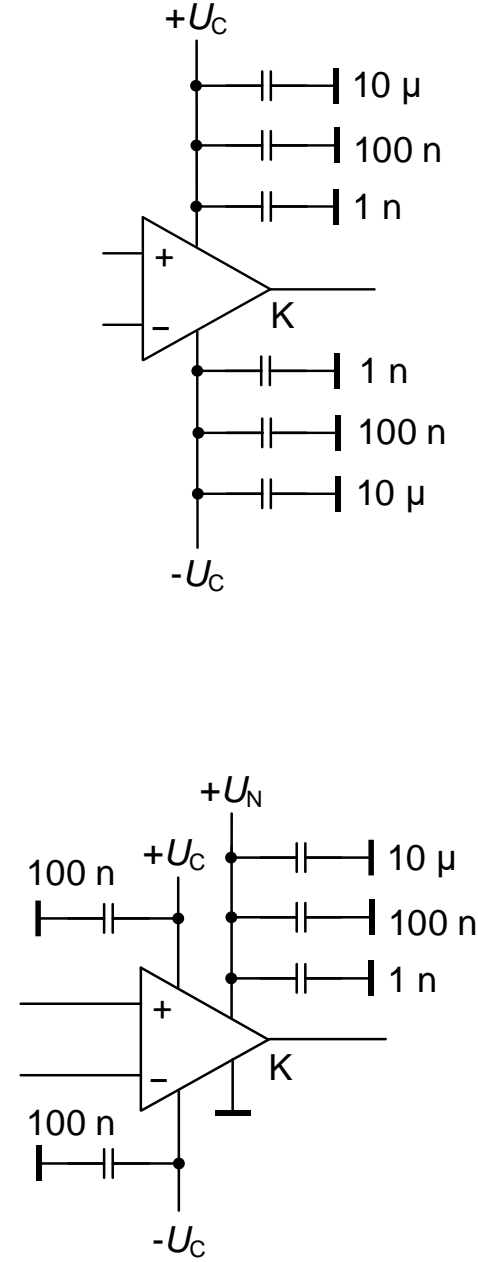

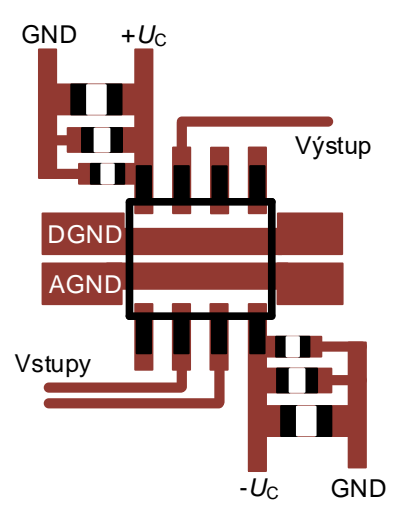

a

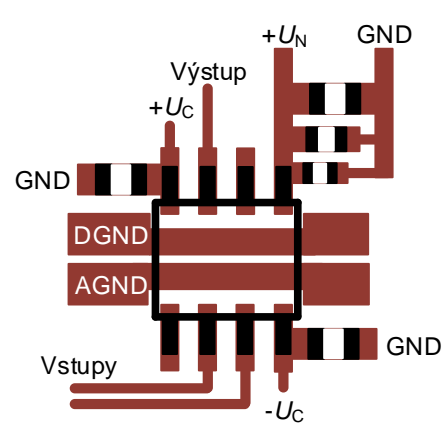

b

Obr. 10.31: Blokování napájecích přívodů rychlých komparátorů: a) při napájení vstupní i výstupní části ze symetrických zdrojü, b) při napájení vstupní části ze symetrických zdrojů a výstupní části z nesymetrického zdroje

\subsubsection{Komparátory s hysterezí}

Pokud se vstupní signál mění pomalu, superponovaný šum a vnitřní šum komparátoru způsobí, že v oblasti průchodu přes komparační hladinu se jeho výstup několikrát rychle překlopí. Na Obr. 10.32 je pro ilustraci př́klad, jak by komparátor reagoval na silně zašuměný vstupní signál $U_{\mathrm{IN}}$. Takovéto zákmity na výstupu jsou přitom nežádoucí, protože výstupní signál komparátorů je zpravidla zpracováván digitálními obvody, které zákmity nesprávně vyhodnotí jako řádně logické signály. U vysokorychlostních komparátorů $\left(t_{\mathrm{PD}}<10 \mathrm{~ns}\right)$ někdy výrobci dokonce předepisují minimální strmost hran vstupního signálu tak, aby k tomu nedocházelo. Toto však lze zaručit pouze u některých vybraných aplikací a v praxi 


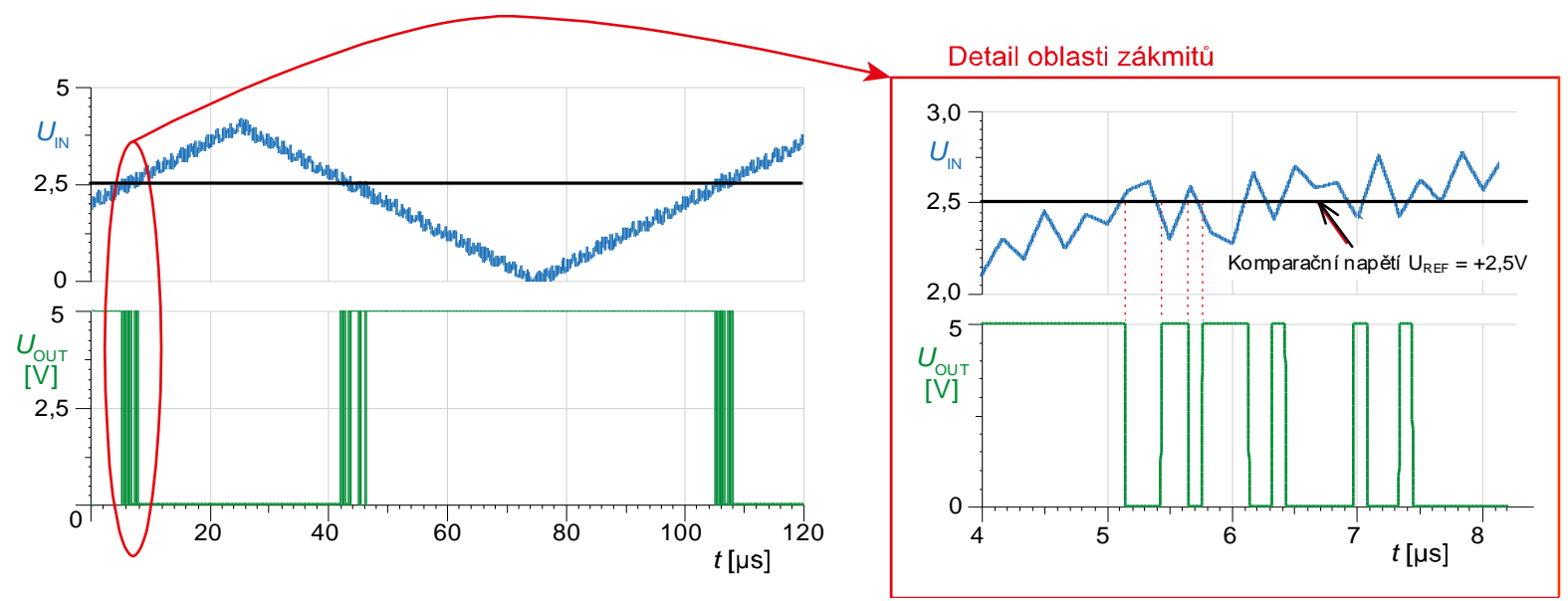

Obr. 10.32: Zákmity komparátoru při pomalém a/nebo zašuměném vstupním signálu

se proto u komparátorů zavádí hystereze. Jak bylo zmíněno výše, ta je u některých typů implementována př́imo na čipu, ale většinou je nutné ji realizovat vnějšími prvky.

V praxi se nejčastěji užívá pro vytvoření hystereze obvod uvedený na Obr. 10.33a. Hysterezi zajištuje kladná zpětná vazba přes rezistorový dělič $\mathrm{R}_{1}, \mathrm{R}_{2}$. Komparační napětí na neinvertujícím vstupu se mění $\mathrm{v}$ závislosti na stavu výstupního napětí komparátoru $u_{2}$, které nabývá dvou hodnot $U_{\mathrm{L}}$ a $U_{\mathrm{H}}$. Např. na výstupu komparátoru CMOS napájeného $\mathrm{z}+5 \mathrm{~V}$ je ve stavu $\mathrm{L}$ napětí $U_{\mathrm{L}} \approx 0,3 \mathrm{~V}$ a ve stavu $\mathrm{H}$ napětí $U_{\mathrm{H}} \approx 4,5 \mathrm{~V}$.

Napětí na neinvertujícím vstupu komparátoru stanovíme obecně např. pomocí metody superpozice Obr. 10.33b)

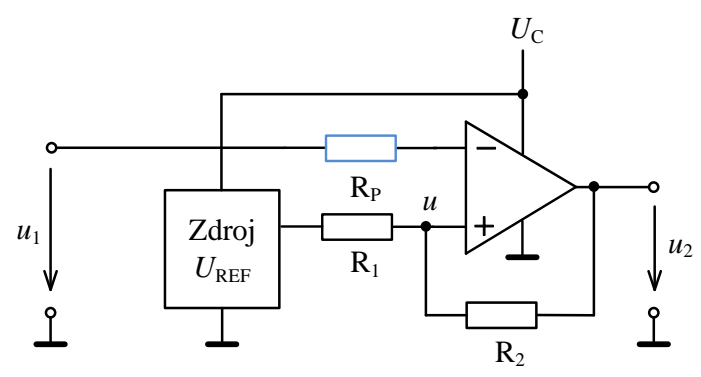

a
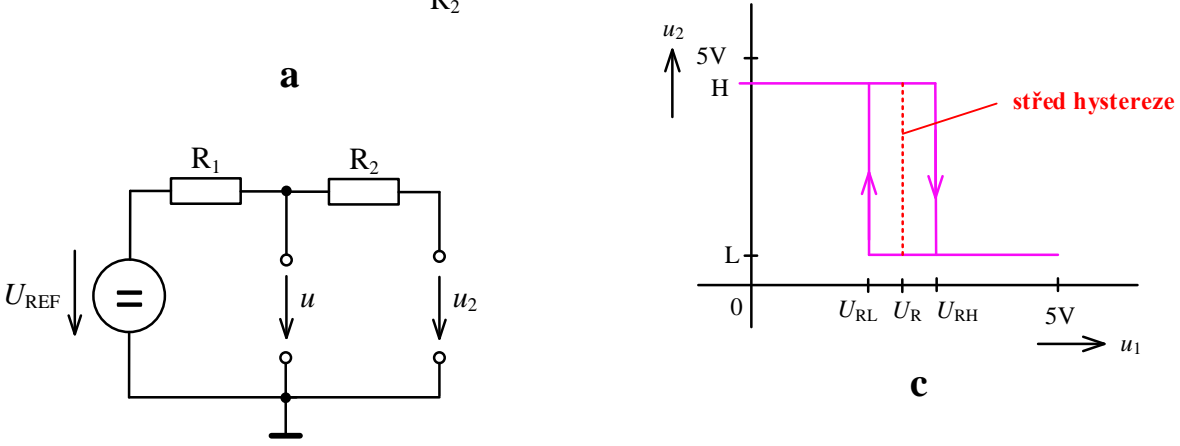

b

Obr. 10.33: Komparátor s hysterezí: a) zapojení, b) k určení hystereze, c) hysterezní charakteristika 


$$
u=\frac{R_{2}}{R_{2}+R_{1}} U_{\mathrm{REF}}+\frac{R_{1}}{R_{2}+R_{1}} u_{2}=\frac{U_{\mathrm{REF}} R_{2}+u_{2} R_{1}}{R_{2}+R_{1}} .
$$

Bude-li na výstupu komparátoru úroveň $\mathrm{H}$, bude $u_{2}=U_{\mathrm{H}}$ a horní komparační hladina podle rov. 10.9 bude

$$
U_{\mathrm{RH}}=\frac{U_{\mathrm{REF}} R_{2}+U_{\mathrm{H}} R_{1}}{R_{2}+R_{1}}
$$

a podobně pro výstupní úroveň $\mathrm{L}$ bude $u_{2}=U_{\mathrm{L}}$ a dolní komparační hladina

$$
U_{\mathrm{RL}}=\frac{U_{\mathrm{REF}} R_{2}+U_{\mathrm{L}} R_{1}}{R_{2}+R_{1}}
$$

Z požadavku na hysterezi charakteristiky $U_{\mathrm{RH}}-U_{\mathrm{RL}}$ můžeme určit vztah pro výpočet rezistorů

$$
\frac{R_{2}}{R_{1}}=\frac{U_{\mathrm{H}}-U_{\mathrm{L}}}{U_{\mathrm{RH}}+U_{\mathrm{RL}}}-1 \text {. }
$$

Převodní charakteristika takovéhoto komparátoru shysterezí je nakreslena na Obr. 10.33 . Hysterezní křivka bude symetricky rozložena kolem napětí

$$
U_{\mathrm{R}}=U_{\mathrm{RL}}+\frac{U_{\mathrm{RH}}-U_{\mathrm{RL}}}{2}=\frac{R_{2}}{R_{1}+R_{2}} U_{\mathrm{REF}}+\frac{1}{2} \frac{R_{1}}{R_{1}+R_{2}}\left(U_{\mathrm{L}}+U_{\mathrm{H}}\right) .
$$

Odtud můžeme dopočítat požadovanou hodnotu referenčního napětí

$$
U_{\mathrm{REF}}=\frac{2 U_{\mathrm{R}}\left(R_{1}+R_{2}\right)-R_{1}\left(U_{\mathrm{L}}+U_{\mathrm{H}}\right)}{2 R_{2}} .
$$

V praxi se integrované referenční zdroje vyrábějí pouze v určité napět'ové řadě, je tedy nutné zvolit vhodný kompromis. Poznamenejme však, že přesnost obvodu je primárně určena saturačními úrovněmi $U_{\mathrm{L}}$ a $U_{\mathrm{H}}$ a proto nároky na referenční zdroj nejsou kritické a napětí $U_{\mathrm{REF}}$ se běžně odvozuje $z$ napájecího napětí rezistorovým děličem doplněným oddělovacím zesilovačem s OZ s jednotkovým přenosem.

Odpor rezistoru $\mathrm{R}_{1}$ se volí malý (stovky $\Omega$ ) tak, aby výstupní impedance děliče $R_{1} \| R_{2}$ nebyla větší než $1 \mathrm{k} \Omega$. Pro vyrovnání impedancí na vstupech komparátoru se do invertujícího vstupu zapojuje rezistor $R_{\mathrm{P}}$ o stejném odporu jako $R_{1} \| R_{2}$ (na Obr. 10.33 naznačen modře).

U vysokorychlostních komparátorů $\left(t_{\mathrm{PD}}<10 \mathrm{~ns}\right)$ je praktická realizace hysterezní zpětné vazby velmi náročná. Reálné obvody totiž vždy mají parazitní kapacity, a jak bylo ukázáno na Obr. 10.30A, a i velmi malé kapacity mohou způsobit rozkmitání komparátoru. To je také hlavní důvod, proč dnes rychlé komparátory mají interní hysterezní obvody přímo na čipu.

\subsubsection{Okénkové komparátory}

V praxi je často nutné sledovat, jestli nějaká veličina nevybočuje ze zadaných mezí. $\mathrm{K}$ tomu lze použít tzv. okénkový komparátor (window comparator), který je možné vytvořit vhodným zapojením dvou „obyčejných“ komparátorů. Jeden z nejčastějších příkladů je na Obr. 10.34 a Rezistorový dělič zapojený mezi napájení $U_{\mathrm{C}}$ a zem vyrábí dvě referenční 
napětí pro komparátory; na Obr. 10.34 jsou rezistory shodné, takže referenční napětí jsou $U_{\mathrm{C}} / 3$ a $2 U_{\mathrm{C}} / 3$. Pokud je vstupní napětí větší než $2 U_{\mathrm{C}} / 3$, zareaguje horní komparátor $\mathrm{K}_{1}$ a na jeho výstupu se objeví úroveň $H$. Naopak, pokud je vstupní napětí menší než $U_{\mathrm{C}} / 3$, zareaguje dolní komparátor $K_{2}$. Jinými slovy, na výstupech obou komparátorů je úroveň $L$ pouze pokud se vstupní napětí pohybuje mezi $U_{\mathrm{C}} / 3$ a $2 U_{\mathrm{C}} / 3$. Pro praktické aplikace je zapotřebí výstupy komparátorů sloučit, což se provádí logickou funkcí OR - na Obr. 10.34 đe ke tomu použito logické hradlo. Výstupní napětí $u_{2}$ celého okénkového komparátoru je pak znázorněno na Obr. 10.34p.

Protože rezistorový dělič pro vytvoření komparačních hladin je př́mo napojen na napájecí zdroj, vyplatí se zablokovat vstup komparátoru $K_{1}$ kondenzátorem $C_{B}$, jak je naznačeno na Obr. 10.34 a. Pro dosažení dobrých kmitočtových vlastností je možné použít např́klad paralelní kombinaci keramických kondenzátorů $10 \mu \mathrm{F}$ a $10 \mathrm{nF}$ z materiálu X7R. Jestliže to přesnost úlohy vyžaduje, je možné horní rezistor děliče odpojit a invertující vstup komparátoru $K_{1}$ připojit na vnější zdroj referenčního napětí se stabilitou lepší než má napájecí napětí $U_{\mathrm{C}}$. Blokovací kondenzátory jsou v takovém př́ipadě zbytečné.
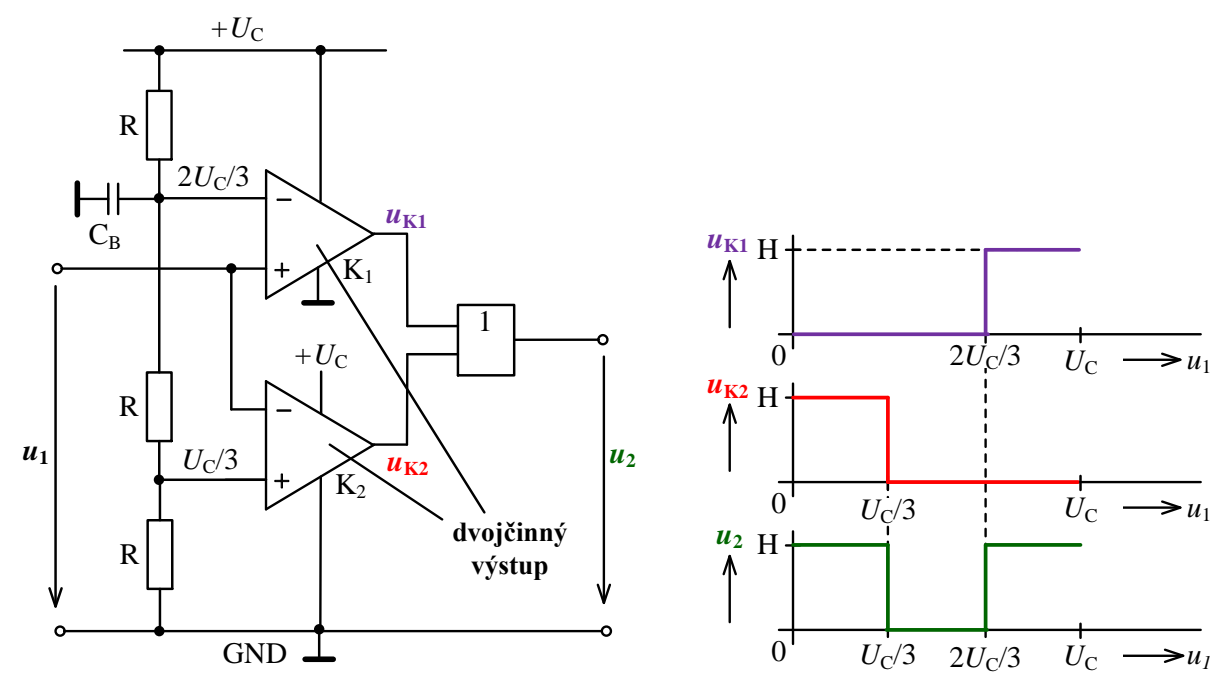

Obr. 10.34: Okénkový komparátor

Jiným velmi oblíbeným řešením je použití komparátorů s otevřeným kolektorem, jak ukazuje Obr. 10.35 . Jak bylo vysvětleno u Obr. 10.28\&, jejich výstupy jsou prímo konstruovány pro paralelní spojování, takže spojením obou výstupů a rezistoru $\mathrm{R}_{\mathrm{L}}$ se dá realizovat tzv. montážní NEBO. Ovšem pozor, kolektorový výstup má nyní opačnou logiku než je na Obr. 10.34b (místo úrovně H bude na výstupu úroveň L, protože výstupní tranzistor se sepne a přidrží napětí $u_{2} \mathrm{k}$ zemi). Výstupní napětí samotných nespojených komparátorů a výstupní napětí celého okénkového komparátoru je uvedeno na Obr. 10.35. 

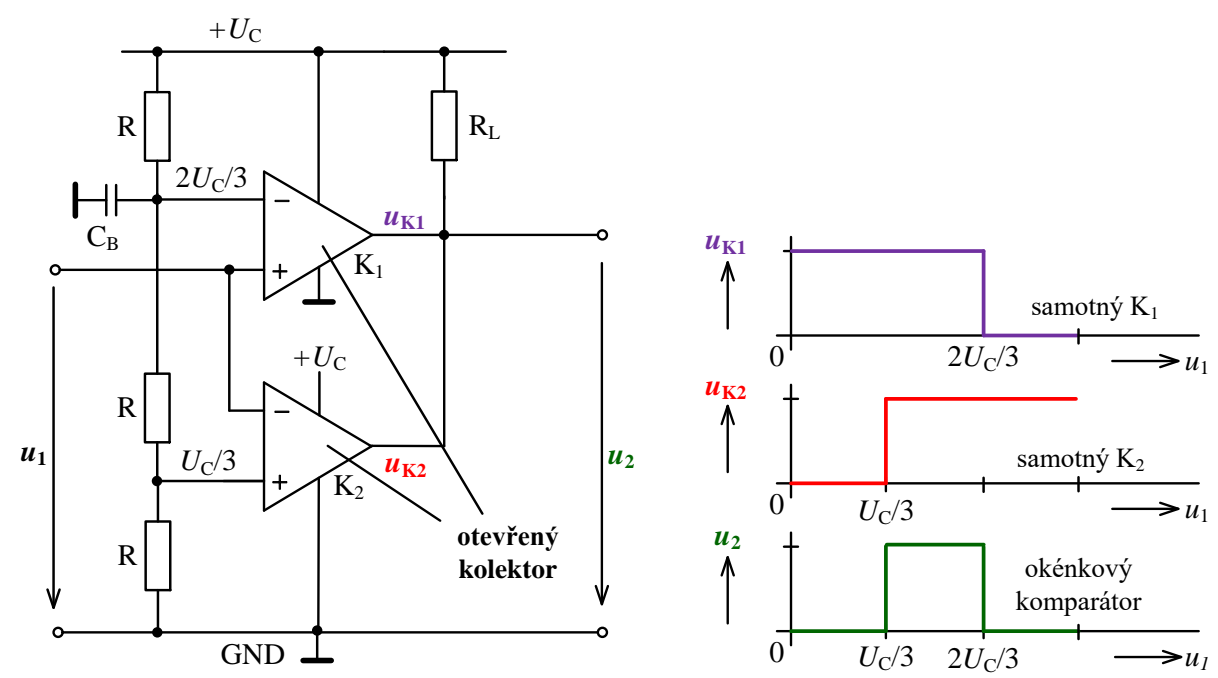

Obr. 10.35: Jiné zapojení okénkového komparátoru

I u okénkového komparátoru je možné zavést hysterezi, přičemž pro každý komparátor je nutné toto opatření udělat samostatně, protože každý z komparátorů reaguje při jiném vstupním napětí. Vždy však záleží na konkrétní situaci a impedanci zdrojů vstupního a referenčních napětí. V praxi je obvykle jednodušší použít komparátory s interní hysterezí nebo vybrat některý ze specializovaných integrovaných obvodů.

Okénkové komparátory nacházejí použití v podstatě ve všech výkonnějších napájecích zdrojích. Tam hlídají, aby výstupní napětí zdrojů nevybočilo z předem stanovených tolerancí (např. u zdrojů v PC je to $\pm 5 \%$ ). Pokud k tomu dojde, na výstupu okénkového komparátoru podle Obr. 10.34 se objeví úroveň $\mathrm{H}$ a řídicí obvody zdroj vypnou, aby přepětí či podpětí nepoškodilo zbytek počítače. Pro podobné masové aplikace se okénkové komparátory vyrábějí $\mathrm{v}$ integrované podobě, prričemž jich může být $\mathrm{v}$ jednom pouzdru i několik (pro hlídání více různých napětí). Mohou obsahovat interní zdroje referenčních napětí, složitější logické obvody pro vyhodnocování, časovače pro odměřování délky poruchových stavů apod. Prodávají se pod obchodními názvy jako Power Supply Supervisor, Under/Over-Voltage Detector, Voltage Monitor apod. Aplikační doporučení pro okénkové komparátory jsou podobné, jako je tomu u obyčejných komparátorů.

\subsubsection{Shrnutí zásad při aplikaci komparátorů}

Při použití komparátorů je tedy nutné dodržovat následující zásady:

1. Nikdy nepoužívejte zbytečně rychlé komparátory - jsou náchylnější ke kmitání, jejich spotřeba je vždy vyšší a jejich použití je náročnější.

2. Vstupní a výstupní spoje musejí být vedeny na DPS co nejdále od sebe, viz Obr. 10.30屯.

3. U komparátorů s drátovými vývody nesmí být použity patice, protože výrazně zvyšují parazitní kapacity mezi vývody.

4. V př́padě potřeby je vhodné zavést hysterezi nebo použít komparátor s interní hysterezí.

5. Komparátory při překlápění vyvolávají proudové špičky v zemním rozvodu. V př́padě komparátorů s oddělenými zeměmi (AGND, DGND) se proudové špičky vyskytují zejména v digitální části komparátoru. Rozvod zemí by proto měl být masivní, u rychlých komparátorů se obvykle doporučuje použít souvislé plochy mědi. Ty by měly vést i mezi vstupy a výstupem, jak ukazuje Obr. 10.30\&. U velmi rychlých komparátorů je doporučeno použít čtyřvrstvý plošný spoj, kdy v první vnitřní vrstvě je souvislá zemní plocha a v druhé 
vnitřní vrstvě je masivní rozvod napájení. Ovšem pozor, takové plochy současně zvyšují kapacity signálových spojů proti zemi, což může degradovat rychlost překlopení komparátoru.

6. Stejné proudové špičky se objevují i v napájecích př́ivodech. Jak bylo zmíněno výše, u velmi rychlých komparátorů musí být jejich napájecí rozvod masivní, aby měl nízkou impedanci. Obvykle jsou opět požadovány souvislé plochy ve vnitřních vrstvách DPS.

7. Napájecí vstupy komparátorů proto musí být velmi kvalitně blokovány v blízkosti pouzdra komparátoru. Pro blokování napájení se užívají kapacitory určené pro vyšší pracovní kmitočty a napájení rychlých komparátorů se nejlépe zablokuje třemi paralelně zapojenými kapacitory $10 \mu \mathrm{F}, 100 \mathrm{nF}$ a vf kapacitoru $1 \mathrm{nF}$.

8. Oba vstupy by měly být buzeny ze zdrojů o podobné impedanci. Pro jejich vyrovnání je možné do vstupu sériově zapojit rezistory (jako $R_{P}$ na Obr. 10.33).

\subsection{Aplikační doporučení pro časovače}

Do kategorie časovačů se řadí generátory periodicky se pakujících pravoúhlých kmitů, tzv. multivibrátory a dále obvody, které generují jednorázové impulsy po přesně definovanou dobu, tzv. nonostabilní klopné obvody. Ve většině př́ípadů jsou založeny na nabíjení resp. vybíjení kapacitoru, kdy napětí na kapacitoru je porovnáváno s referenčním napětím pomocí komparátoru či komparátorů. Výstupní napětí časovačů má většinou logické úrovně a proto bývají často zařazovány do kategorie číslicových obvodů. Ve skutečnosti tomu tak není a při aplikaci časovačů se musí pracovat obezřetně. Úskalí při aplikacích si vysvětlíme na př́kladu časovače na Obr. 10.36 zapojeného jako multivibrátor.

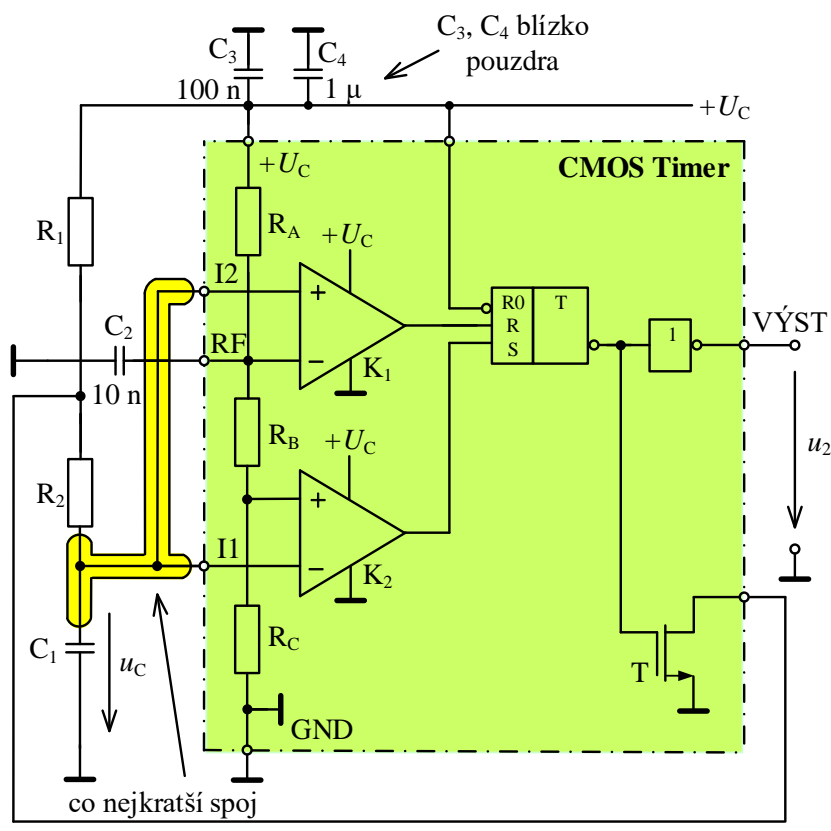

a

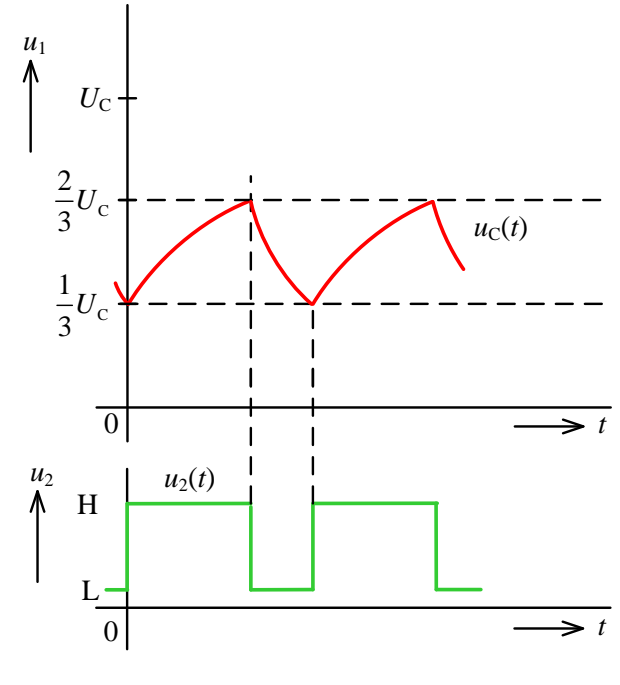

b

Obr. 10.36: Časovač zapojený jako multivibrátor

$\mathrm{Na}$ Obr. 10.36 je záměrně rozkresleno zjednodušené vnitřní zapojení integrovaného časovače, aby bylo zcela zřejmé, které vstupy obvodu jsou citlivé na pronikání rušivých signálů. Přívodní vodiče k oběma komparátorům musí být velice krátké. Kromě toho může snadno dojít k průniku rušivých napětí na kapacitor $C_{1}$, a to parazitní kapacitní vazbou z okolních vodičů 
vykazující prudké změny úrovní signálu (např. číslicové signály). Může tak nastat strhávání kmitočtu multivibrátoru. Proto od tohoto uzlu odkloníme i ve vnitřních vrstvách desky plošného spoje zejména ty vodiče, kterými jdou signály vyznačující se velkými skokovými změnami. V kritických př́ípadech můžeme tento bod chránit elektrostatickou bariérou spojenou se zemí, popř. na horní straně desky ponechat pod pouzdrem komparátoru souvislou zemní vrstvu plošného spoje. Napájecí vývod je zapotřebí zablokovat opět co nejblíže pouzdra elektrolytickým či vícevrstvým kondenzátorem $1 \mu \mathrm{F}$ a k němu paralelně připojit keramický vf kapacitor $100 \mathrm{nF}$. Protože vnitřní dělič sestávající ze tří rezistorů se shodnými odpory je napájen př́mo z napájecího rozvodu, doporučuje se vstup RF zablokovat keramickým kapacitorem 10 nF. V př́ipadě, že chceme docílit větší přesnosti, je možné na svorku RF připojit vnější zdroj referenčního napětí se stabilitou lepší než má napájecí zdroj. Pak je ovšem kapacitor $\mathrm{C}_{2}$ zbytečný.

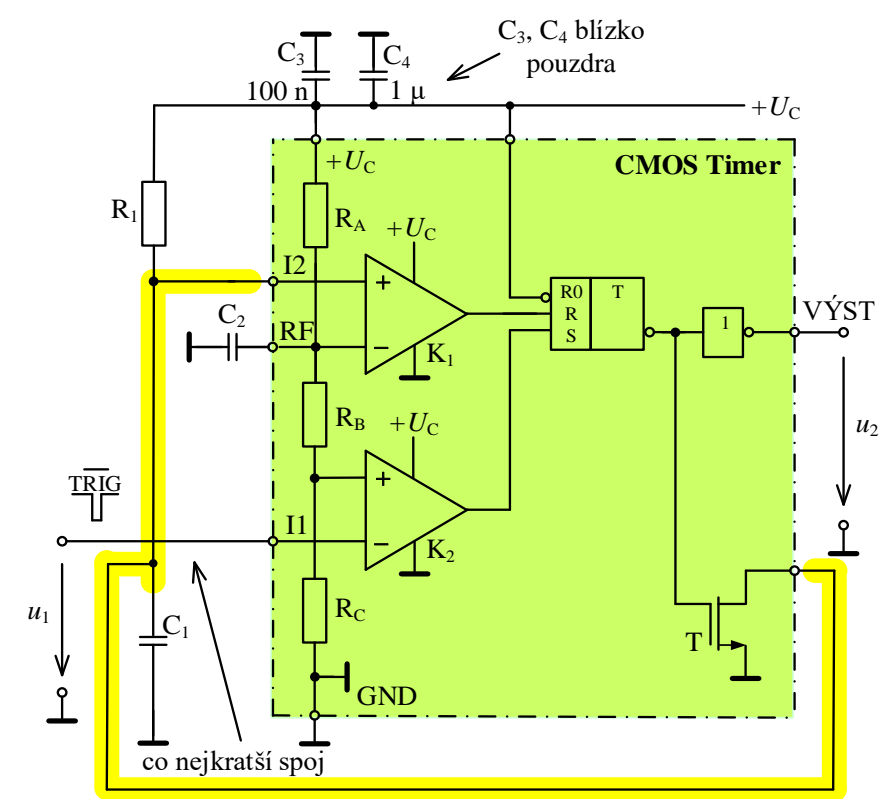

a

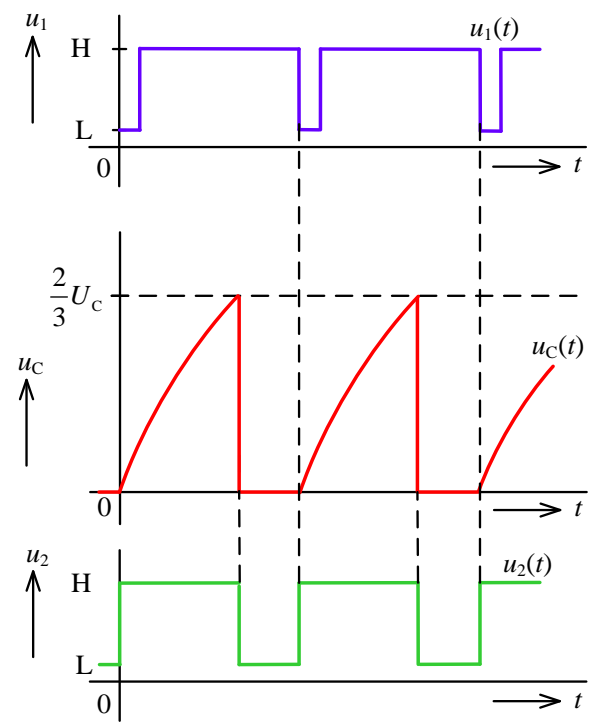

b

Obr. 10.37: Časovač zapojený jako monostabilní klopný obvod

Ještě větší péči při návrhu plošného spoje vyžaduje zapojení monostabilního klopného obvodu s časovačem na Obr. 10.37. Zde navíc musí být i krátký spoj vedený z kapacitoru $\mathrm{C}_{1}$ na vývod spínacího tranzistoru T. I v tomto případě se kapacitor $C_{1}$ chová jako tzv. „měkký zdroj napětí“ a veškeré rušivé signály, které se dostanou do tohoto uzlu, mohou způsobit zkrácení či prodloužení časového intervalu generovaného impulsu. Doporučené řešení plošného spoje pro tento monostabilní klopný obvod je uvedeno na Obr. 10.38. 


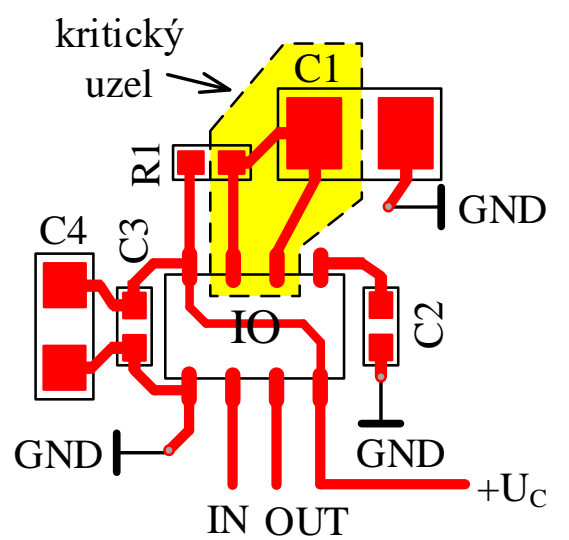

Obr. 10.38: Doporučený plošný spoj pro zapojení monostabilního klopného obvodu $\mathrm{s}$ časovačem

Jiný typ jednoúčelového monostabilního klopného obvodu uvedený na Obr. 10.39je všemi výrobci jednoznačně zařazen do kategorie logických obvodů. Z principiálního zapojení je však zřejmé, že má svoji analogovou část, která je citlivá na vnější vlivy.

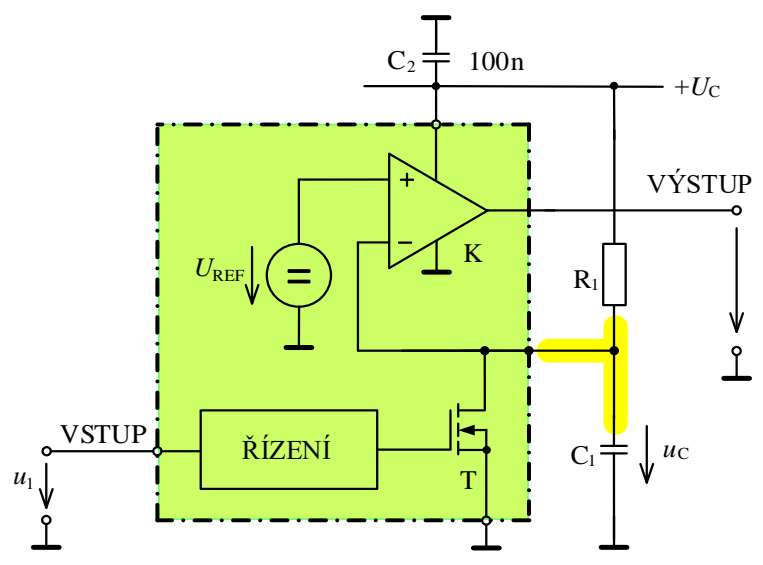

Obr. 10.39: Monostabilní klopný obvod

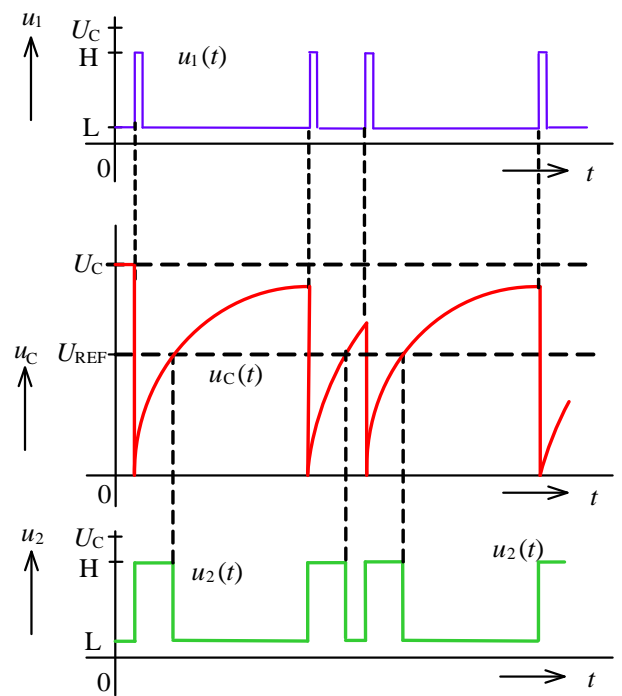

V klidu je tranzistor $\mathrm{T}$ rozpojen a kapacitor je nabit na napětí $U_{\mathrm{C}}$. Jestliže je na vstup časovače přiveden časovací impuls, řídicí obvod na krátký okamžik sepne tranzistor $\mathrm{T}$ a kapacitor $\mathrm{C}_{1}$ se rychle vybije a pak se začne nabíjet $\mathrm{s}$ časovou konstantou $\mathrm{R}_{1} \mathrm{C}_{1}$ na napájecí napětí. Výstupní napětí komparátoru má v této době hodnotu H. Jakmile napětí na kapacitoru

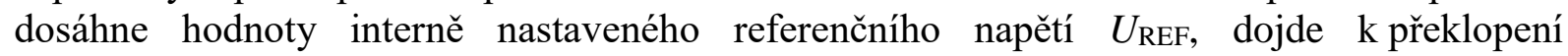
komparátoru a na jeho výstupu bude L.

Je zřejmé, že kritickým uzlem je zde vstup komparátoru připojený $\mathrm{k} \mathrm{R}_{1}$ a $\mathrm{C}_{1}$. Kolem tohoto uzlu se nedoporučuje vést žádné logické signály, protože průnik rušení do tohoto obvodu může způsobit zkrácení či prodloužení výstupních impulsů monostabilního obvodu. Tento uzel má být co nejmenší a v kritických př́padech se doporučuje pod integrovaným obvodem a v jeho okolí rozvést zemnicí plochy.

Většina multivibrátorů či monostabilních klopných obvodů pracuje na stejném principu založeném na nabíjení kapacitoru v RC obvodu. Vzhledem k tomu, že se používají externí rezistory a kapacitory, bude přesnost těchto obvodů určena zejména výrobními a tepelnými 
tolerancemi těchto obvodových prvků. Rezistory do RC článku vybíráme přesné a stabilní $\mathrm{s}$ nízkým teplotním koeficientem lepším než $\pm 15 \mathrm{ppm} /{ }^{\circ} \mathrm{C}$. Kapacitory volíme taktéž přesné a stabilní třídy 1, nejlépe s nulovým teplotním součinitelem (COG/NPO aj.). Kapacitor by měl vykazovat malou dielektrickou absorbci lepší než $0,2 \%$.

\subsection{Aplikační pravidla pro D/A a A/D převodníky}

$\mathrm{A} / \mathrm{D}$ a $\mathrm{D} / \mathrm{A}$ převodníky, stejně jako komparátory patř́ $\mathrm{k}$ jedněm $\mathrm{z}$ nejobtížněji aplikovaným obvodům. Spadají do kategorie tzv. systémů se smíšenými signály (mixed - signal systems), které pracují na rozhraní analogových a číslicových signálů.

Dříve byly $\mathrm{D} / \mathrm{A}$ a $\mathrm{A} / \mathrm{D}$ převodníky považovány za obvody s vysokou přesností a nízkou rychlostí. Kritériem byla doba převodu potřebná pro vzájemný $\mathrm{D} / \mathrm{A}$ nebo $\mathrm{A} / \mathrm{D}$ převod signálu. Dnešní $\mathrm{D} / \mathrm{A}$ a $\mathrm{A} / \mathrm{D}$ převodníky však většinou pracují jako vysokorychlostní a proto s nimi musí být také tak zacházeno. Všechny vzorkovací A/D převodníky (se zabudovaným vzorkovačem $\mathrm{S} / \mathrm{H}$ ), i když se jejich doba převodu zdá být nízká, je nutno považovat za vysokorychlostní obvody. Např. 12-bitový středně rychlý A/D převodník s postupnou aproximací s dobou převodu $500 \mathrm{kS} / \mathrm{s}$ může pracovat s interním taktovacím kmitočtem $10 \mathrm{MHz}$. Podobně převodníky sigma-delta je nutno díky jejich vysokému převzorkovacímu kmitočtu považovat za vysokorychlostní obvody. Např. A/D převodníky s rozlišením 24 bitů určené pro převod nf analogových signálů ( $10 \mathrm{~Hz}$ až 7,5 kHz) pracují s interním taktovacím kmitočtem $5 \mathrm{MHz}$ nebo i vyšším. Kromě toho se některé integrované $\mathrm{A} / \mathrm{D}$ a D/A prevevodníky vyznačují relativně malými interními digitálními proudy, jiné pak mají digitální proudy velké. Ve většině př́ípadů musí být tyto dva typy převodníků ošetřeny odlišně.

\subsubsection{A/D a D/A převodníky pracující s velkými digitálními proudy}

Je realitou, že digitální obvody jsou zdrojem velkého vf rušení. Saturační logika způsobuje v napájení a tedy i v zemním vodiči velké a rychlé proudové špičky, které na odporu a indukčnosti zemního vodiče způsobují chybové napětí. Přitom analogové obvody jsou velmi citlivé na rušení $\mathrm{v}$ př́ivodech napájecího napětí a zejména pak na společném zemním vodiči. $\mathrm{Z}$ těchto důvodů má většina $\mathrm{A} / \mathrm{D}$ či $\mathrm{D} / \mathrm{A}$ převodníků oddělené napájení analogové a digitální části včetně samostatných zemních př́ivodů.

Jako př́klad je na Obr. 10.40 uvedeno vnitřní uspořádání paralelního D/A převodníku s váhovými zdroji proudu. Aby bylo dosaženo požadované přesnosti převodu, musí být vstup operačního zesilovače či zdroj referenčního napětí připojeny na přesný nulový potenciál. Proto jsou země převodníku rozděleny na analogovou (AGND) a digitální zem (DGND). Aby nedošlo v analogové zemi ke vzniku rušivého napětí při připojení všech zdrojů váhových proudů (které právě nejsou v činnosti) na nulový potenciál, je tzv. doplňkový proud IC odveden do výkonové země, i když jde o váhové proudy z analogové části převodníku. U A/D převodníků jsou pak na přesný nulový potenciál připojeny i další referenční zdroje či komparátory. Pokud bychom spojili výkonovou zem s analogovou zemí, pak proudové špičky vzniklé přepínáním zdrojů proudu způsobí na analogovém zemním vodiči napětové špičky, které následně proniknou do výstupu převodníku. Většinou je výkonová zem proto spojena uvnitř převodníku s digitální zemí. 


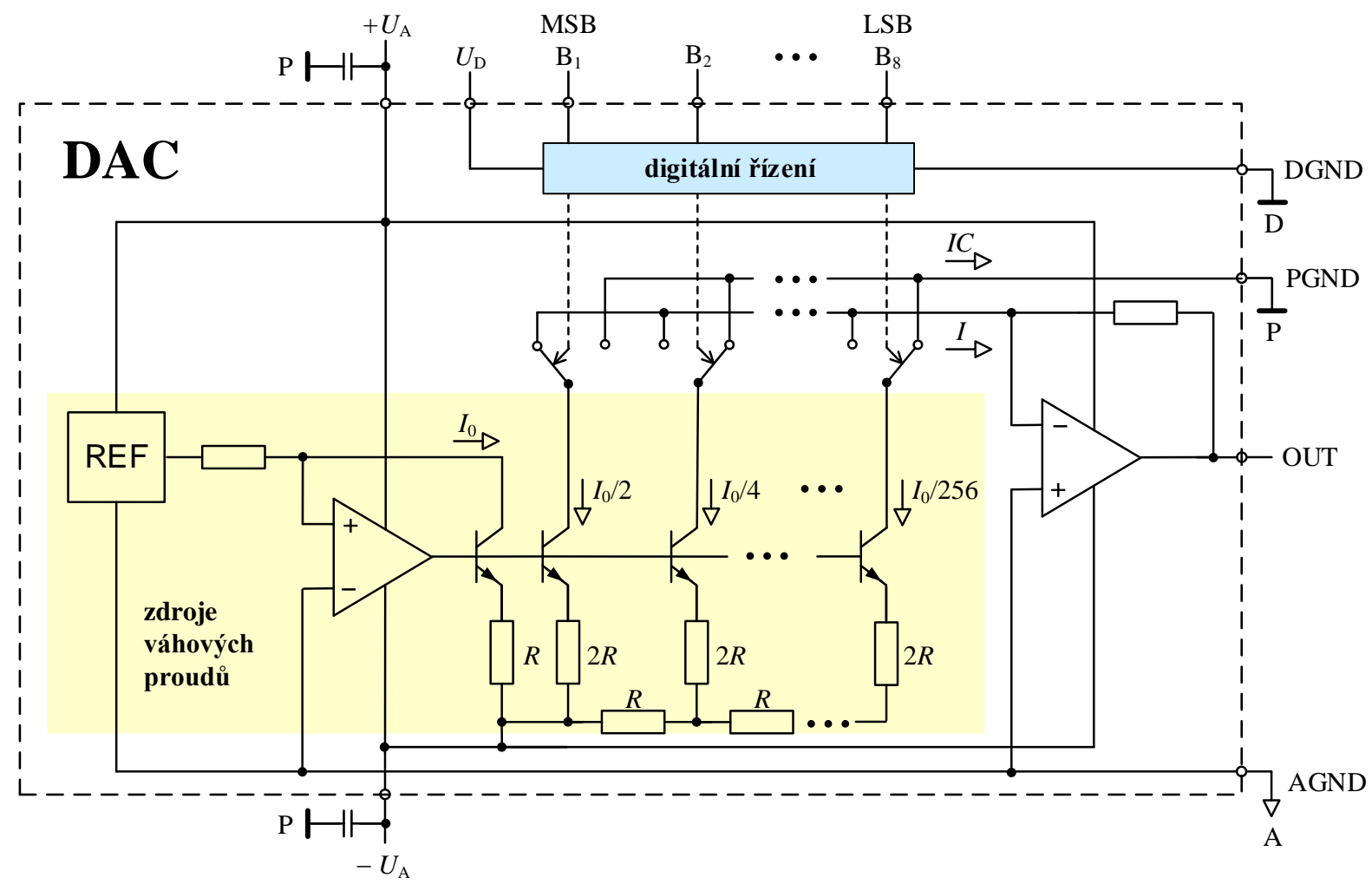

Obr. 10.40: Př́klad vnitřního zapojení paralelního D/A převodníku s váhovými proudy

Rušení z digitální části zařízení může pronikat do analogové části i z dalších důvodů v případech, kdy digitální signálové spoje jsou vedeny společně s analogovými signály. Prudké změny logického signálu se pak snadno přenesou do analogové části prostřednictvím parazitních kapacit a vzájemných indukčností mezi plošnými vodiči jako derivační špičky. Proto se doporučuje obvody na DPS striktně rozdělit na analogovou a digitální část a pod každou částí realizovat na druhé straně, či ve vnitřní vrstvě DPS, analogovou a digitální zemnicí vrstvu (viz Obr. 10.41. Analogová a digitální část by měly mít svůj vlastní napájecí zdroj včetně samostatného zpětného zemního vodiče.

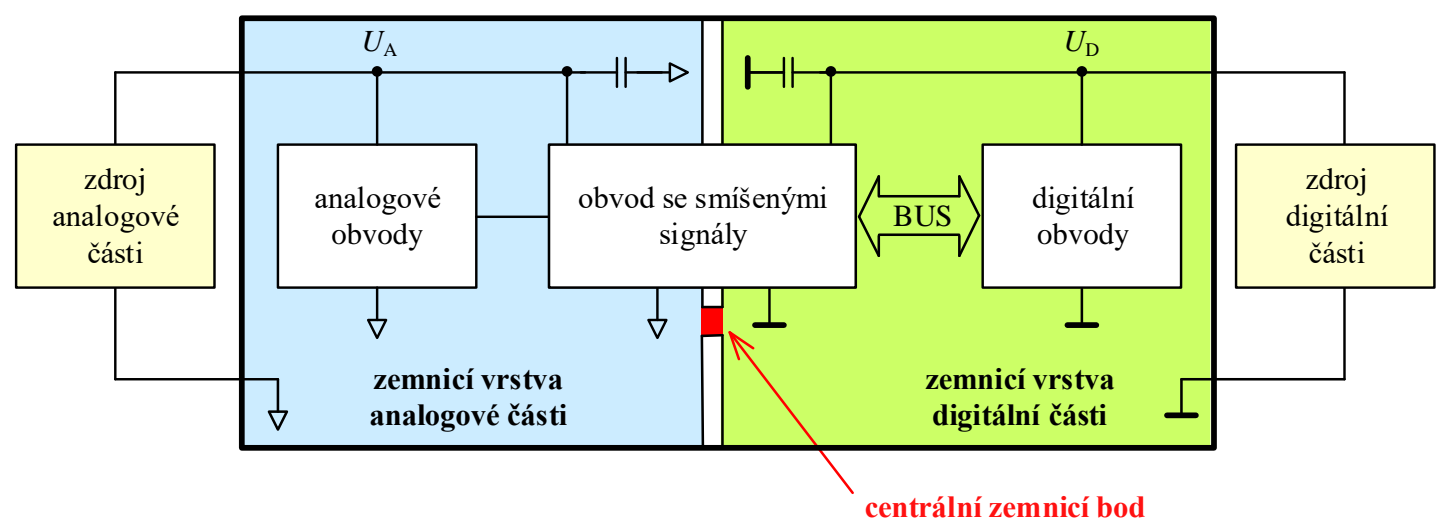

Obr. 10.41: Způsob rozdělení DPS na analogovou a digitální část a volba centrálního zemnicího bodu v př́ípadě užití jediného $\mathrm{D} / \mathrm{A}$ nebo $\mathrm{A} / \mathrm{D}$ převodníku (typická vývojová či testovací deska) 
Jako společný bod pro spojení obou zemí se volí analogová zemní svorka převodníku. Tímto způsobem se zajistí, aby rušivé zemní proudy z digitální části neovlivnily přesnost převodu převodníku. Stejnou filosofii rozdělení zemí a bod jejich spojení volíme u všech obvodů se smíšenými signály, tj. jak $\mathrm{v}$ př́ípadě $\mathrm{D} / \mathrm{A}$ převodníků, tak $\mathrm{i} \mathrm{v}$ př́padě $\mathrm{A} / \mathrm{D}$ převodníků.

Tento způsob volby centrálního zemnicího bodu je doporučován ve většině aplikačních listů. Je však třeba si uvědomit, že takto lze volit centrální zemnicí bod pouze v případě, že $\mathrm{v}$ zařízení je použit jediný $\mathrm{D} / \mathrm{A}$ nebo jediný $\mathrm{A} / \mathrm{D}$ převodník. Jamile bude $\mathrm{v}$ zařízení několik $\mathrm{D} / \mathrm{A}$ a několik $\mathrm{A} / \mathrm{D}$ převodníků, které jsou navíc na různých zásuvných kartách, nelze tento způsob aplikovat. Pak je nutno použít tzv. ,jednobodový“ hvězdicový zemnicí systém, kdy analogová a digitální zem jsou v celém zařízení vedeny odděleně a centrální zemnicí bod se obvykle zvolí u zemní svorky výkonově nejvíce namáhaného napájecího zdroje.

Př́́klad uspořádání zásuvné karty osazené jak A/D tak i D/A převodníky pracujícími s velkými digitálními proudy je uveden na Obr. 10.42. Zemnicí vrstvy jsou pod převodníky rozděleny tak, aby analogové signály včetně napájení analogové části byly vedeny nad analogovou zemnicí vrstvou a podobně digitální signály jsou vedeny nad digitální zemnicí vrstvou. Analogová zem převodníku je spojena se zemnicí vrstvou analogové části, digitální zem je spojena se zemnicí vrstvou digitální části. Mezi obě zemnicí vrstvy na zásuvné kartě je antiparalelně zapojena dvojice rychlých Schottkyho diod, které omezí př́padné vf rušení mezi zemními vodiči na max $\pm 0,3 \mathrm{~V}$. Současně tyto diody chrání převodníky proti průrazu, protože některé obvodové prvky převodníku (např. komparátory) jsou připojeny mezi oba napájecí systémy $U_{\mathrm{A}}, U_{\mathrm{D}}$ a mohly by se neopatrnou manipulací, např. při zasunutí karty do propojovací desky pod napětím, zničit.

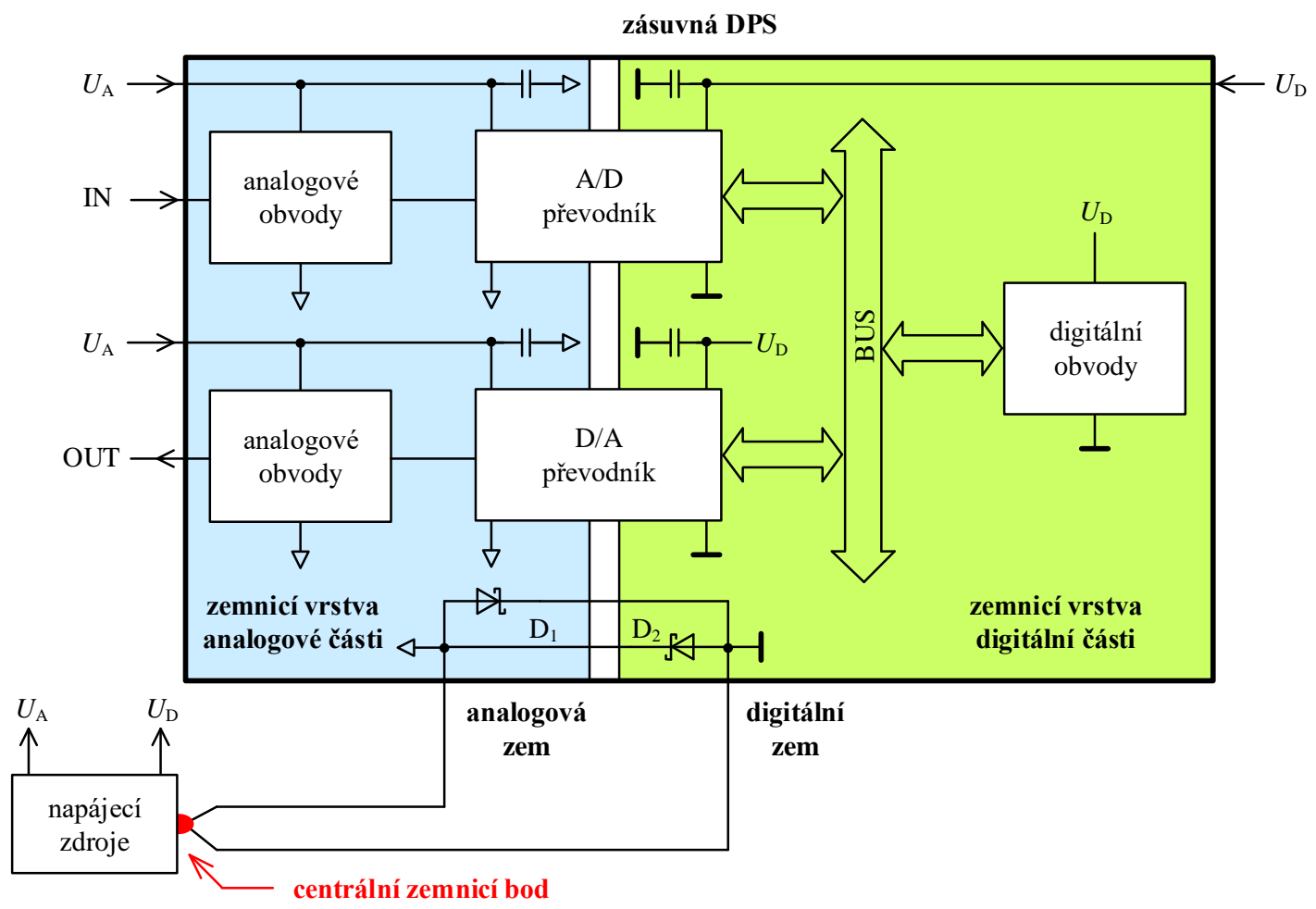

Obr. 10.42: Rozdělení na analogovou a digitální část v př́ípadě převodníků $\mathrm{A} / \mathrm{D}$ nebo $\mathrm{D} / \mathrm{A}$ s velkými digitální proudy 
Ve vysoce přesných aplikacích se vyplatí analogovou zem ještě rozdělit na signálovou a výkonovou zem, přičemž analogová zem A/D nebo D/A převodníku se připojí na signálovou zem, kdežto blokovací kondenzátory v napájení analogové části se připojí na výkonovou zem.

\subsubsection{A/D a D/A převodníky pracující s malými digitálními proudy}

Analogové obvody, jako jsou zesilovače nebo zdroje referenčního napětí či proudu, které jsou citlivé na vf rušení, se vždy vztahují a blokují vzhledem k analogové zemi. Podobně jako s analogovými obvody by se mělo zacházet i s A/D a D/A převodníky (a i s dalšími obvody pracujícími se smíšeným signálem), které se vyznačují malými digitálními proudy. Tento typ převodníku se pak uzemňuje a jejich napájení blokuje jen k analogové zemi.

Na první pohled se to může zdát nesmyslné, protože převodník má svoji analogovou a digitální část a obvykle má samostatné vývody analogové (AGND) a digitální (DGND) země. Proč tomu tak je, osvětlíme pomocí zapojení na Obr. 10.43, kde je uvedeno nepř́liš vhodné uspořádání zemí obvodu se smíšenými signály s malými interními digitálními proudy. Aby se uvnitř integrovaného obvodu zabránilo pronikání vf rušení z digitálních obvodů do analogových obvodů, jsou jejich zemní vodiče zcela odděleny. Rychlé změny digitálních proudů $\mathrm{v}$ zemním vodiči DGND vyvolají napětí $\mathrm{v}$ bodě $\mathrm{B}$, které se přenese přes parazitní kapacitu $\mathrm{C}_{\mathrm{par}}$ do bodu $\mathrm{A}$ analogových obvodů. Pokud bude vývod DGND připojen $\mathrm{k}$ jakékoliv další impedanci digitální země, kterou navíc protékají velké vf rušivé proudy externě připojených digitálních obvodů, zvedne se úroveň rušení v bodě $\mathrm{B}$ a tedy $\mathrm{i}$ úroveň digitálního rušení v bodě A.

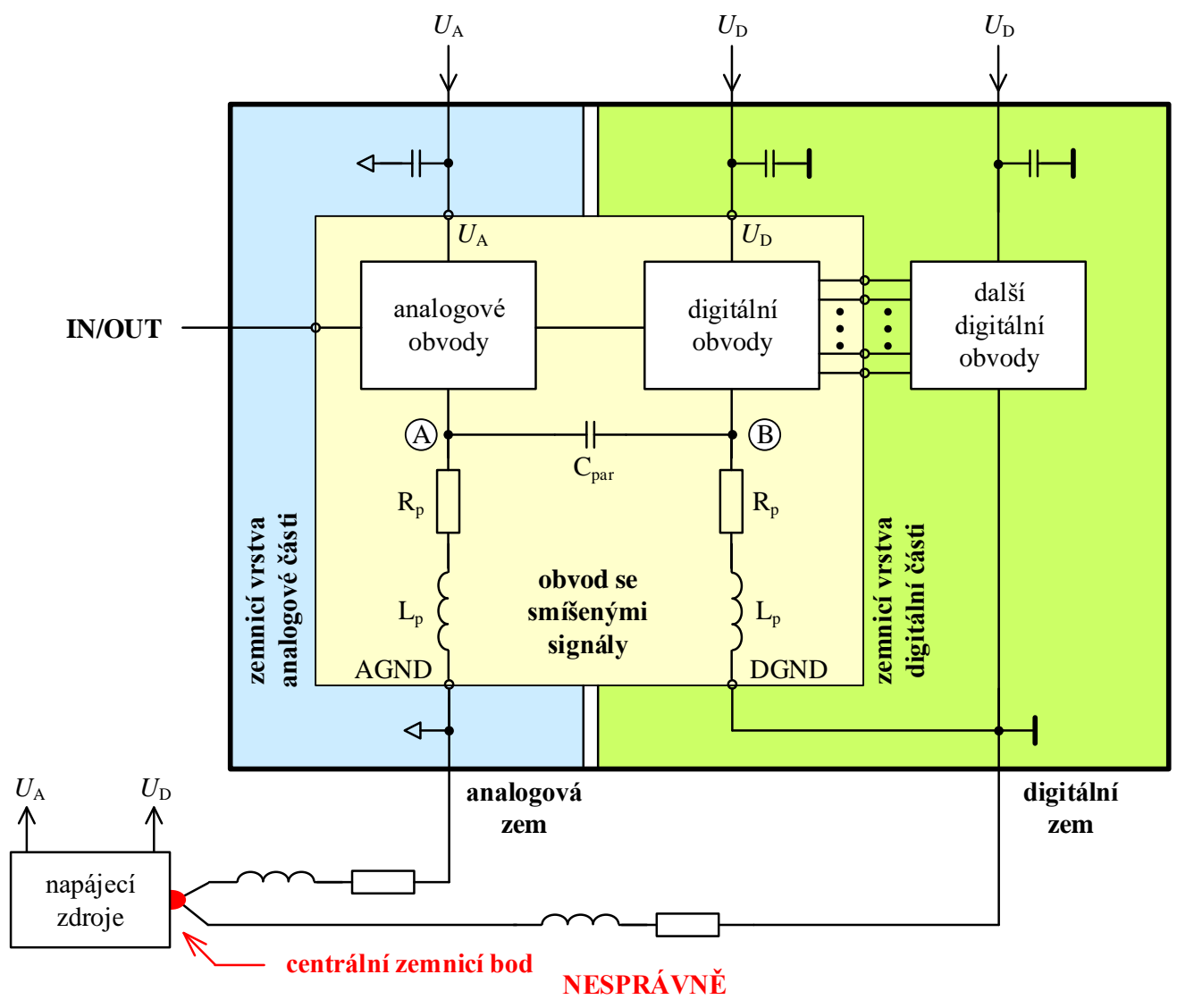

Obr. 10.43: Nevhodné zapojení obvodu se smíšenými signály s malými interními digitálními proudy 
Označení vývodu DGND nám ale pouze říká, na který vývod integrovaného obvodu je vyvedena interní zem jeho digitálních obvodů, nikoliv, že tento vývod musí být nutně připojen $\mathrm{k}$ digitální zemi celého systému.

Doporučené řešení pro $\mathrm{A} / \mathrm{D}$ převodník s malými interními digitálními proudy (technologie CMOS) je uvedeno na Obr. 10.44. Vývod digitální země DGND je co nejkratším způsobem propojen s vývodem analogové země AGND. Je pravdou, že toto uspořádání může injektovat malé množství digitálního šumu do analogové země, ale pokud budou interní digitální proudy malé, bude šum daleko menší, než digitální šum od dalších připojených digitálních systémů pracujících s velkými digitálními proudy.

Digitální část převodníku s malými digitálními proudy se v tomto př́padě napájí $\mathrm{z}$ napájecího zdroje analogové části. Aby nedošlo $\mathrm{k}$ přenosu digitálního rušení $\mathrm{z}$ napájecího př́vodu digitální části převodníku do př́ivodu napájení analogové části, jsou vývody $U_{\mathrm{A}}$ a $U_{\mathrm{D}}$ odděleny feritovou perlou, která pro vf proudy vykazuje velkou impedanci. Interní rušivé digitální proudy se pak budou uzavírat krátkou cestou přes blokovací kondenzátor $\mathrm{C}_{2}$. Tato cesta je na Obr. 10.44 znázorněna červeně. Rušivé vf proudy způsobené digitální částí převodníku se proto na vnější analogové zemi převodníku neprojeví a jsou omezeny jen na malou smyčku přes blokovací kondenzátor $\mathrm{C}_{2}$ a vývod DGND. Blokovací keramický kondenzátor $\mathrm{C}_{2}$ o kapacitě $10 \mathrm{nF}$ až $100 \mathrm{nF}$ s malou parazitní indukčností by měl být namontován co nejblíže převodníku tak, aby se minimalizovala parazitní indukčnost plošného spoje.

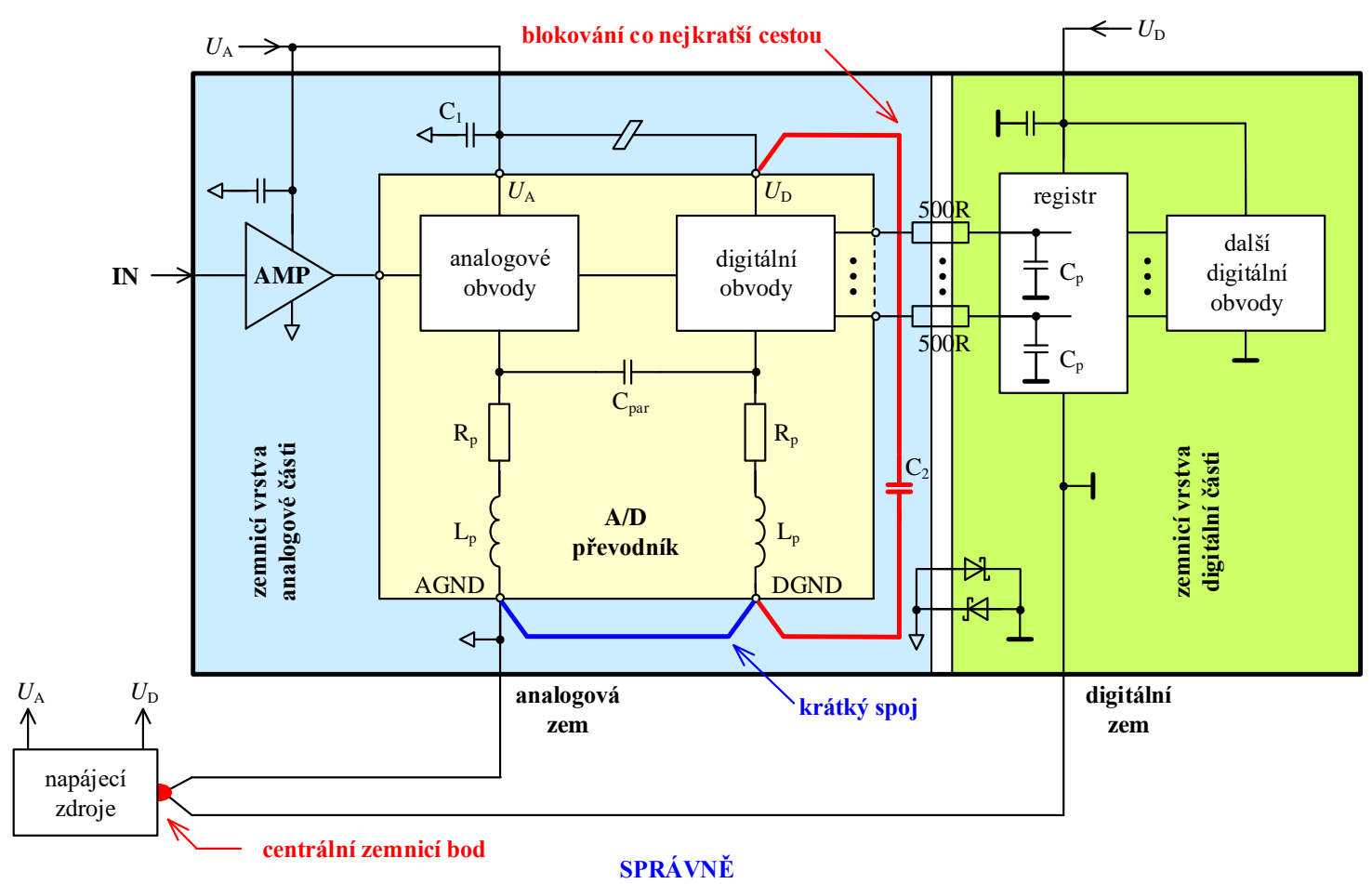

Obr. 10.44: Doporučené zapojení A/D převodníku s malými interními digitálními proudy

Aby změny interních digitálních proudů zůstaly skutečně malé, doporučuje se také mezi vlastní převodník a další digitální obvody vložit oddělovací registr s malými vstupními proudy, nebo oddělovací hradla CMOS. Pro omezení prudkých změn v odběru proudu v digitální části převodníku se navíc doporučuje do přívodů k oddělovacímu registru vložit rezistory o odporu $500 \Omega$, které společně se vstupními parazitními kapacitami $C_{p}$ vytvoří RC článek, který zmenší prudké změny výstupních proudů při nabíjení těchto parazitních kapacit. Rezistor $500 \Omega$ se vstupní parazitní kapacitou $\mathrm{C}_{\mathrm{p}} \approx 10 \mathrm{pF}$ způsobí zpoždění nástupné či sestupné hrany logického 
signálu přibližně o 11 ns. I když celá řada převodníků je vybavena třístavovou logikou pro př́mou komunikaci s datovou sběrnicí, je vložení oddělovacího registru mezi převodník a datovou sběrnici osvědčenou praxí.

Na závěr je třeba ještě zdůraznit, že i když analogová část i digitální část převodníku bude pracovat se shodným napájecím napětím $+5 \mathrm{~V}$, neznamená to, že analogovou část převodníku můžeme napájet ze stejného napájecího zdroje $+5 \mathrm{~V}$, ze kterého je napájen mikroprocesor, dynamické RAM, elektrický ventilátor a další zařízení s vysokým proudovým odběrem. Každá část zařízení musí mít samostatné napájecí zdroje.

\subsection{Logické obvody}

První fází konstrukčního řešení digitálního (číslicového) systému je bezesporu sestavení logického schématu z dostupných integrovaných obvodů. Konstruktér vychází z potřebných logických funkcí, které realizuje $\mathrm{z}$ daného sortimentu typů integrovaných obvodů př́slušné řady. Tato problematika ale není předmětem této publikace. Zde pouze uvádíme zásady týkající se výběru typové řady logických obvodů, připojování nevyužitých vstupů, ošetření signálů z mechanických kontaktů, připojení nestandardních zátěží, přizpůsobení úrovní pro vzájemné propojení obvodů TTL a CMOS apod.

\subsubsection{Přehled a základní vlastnosti vyráběných typových řad}

Historicky se vývoj digitálních obvodů ubíral dvěma základními směry určenými technologií výroby. Jako první se začaly používat digitální obvody TTL realizované bipolární technologií. Snížení cen a příkonu digitálních obvodů pak přinesla technologie CMOS, která také umožnila výrazné snížení napájecích napětí. Bipolární technologii však technologie CMOS dosud nedokázala překonat, pokud se týká některých parametrů či sortimentu a proto se oba typy stále užívají. Jako poslední se na trhu objevily obvody vyráběné technologií BiCMOS, které dosahují srovnatelné zpoždění jako bipolární technologie, ale jejich příkon je daleko nižší.

$\mathrm{V}$ dnešní době se logické obvody vyrábějí ve velkém množství různých typových variant. Je to dáno tím, že některé technologie musí podporovat zpětnou kompatibilitu s již stávajícími obvody, jiné jsou naopak zaměřeny na nízký příkon hradla, malé napájecí napětí nebo malé zpoždění signálu při průchodu hradlem. Mezi primární rozhodnutí při konstrukci zařízení proto patří výběr vhodné typové řady. V následujícím přehledu jsou uvedeny často používané produktové řady bipolárních a unipolárních logických obvodů.

\section{Bipolární logické obvody TTL}

Užívání bipolárních logických obvodů TTL se velmi rychle rozšśřilo po celém světě. Šlo především o obvody označované SN74, které od roku 1963 vyráběla firma Texas Instruments a později pod různým označením mnoho dalších výrobců. Původní obvody této řady (nazývané klasické nebo standardní) jsou již léta považovány za zastaralé. Nevyhovují současným požadavkům z hlediska rychlosti i spotřeby. Starší typové řady se již nedoporučuje užívat pro nové konstrukce. Uvedeme zde proto pouze přehled v dnešní době nejužívanějších typových rad.

$\boldsymbol{A L S}$ (Advanced Low power Schottky) řada byla vyvinuta pro aplikace s nízkým př́konem a dostatečnou rychlostí. Jsou schopny zpracovat kmitočty přesahující $5 \mathrm{GHz}$. Řada ALS představuje cenově dostupný typ bipolárních digitálních obvodů $z$ hlediska běžně 
uplatňovaných požadavků na rychlost a malou spotřebu a na dostatečný sortiment jednotlivých typů obvodů. Zpoždění hradla je lepší než 11 ns.

$\boldsymbol{F}$ popř. $\boldsymbol{F A S T}$ (Fairchild Advanced Schottky TTL) je podobná řadě ALS, vyznačuje se poněkud vyšší rychlostí než řada ALS při dodržení nízké spotřeby energie, zpoždění hradla je lepší než 7 ns. Obvodově se nijak výrazně neliší od řady ALS. Navíc je zde užit nelineární rezistor („,dynamický odpor“), jehož úkolem je další zrychlení obvodu především při přechodu do stavu $\mathrm{H}$ na výstupu. U této řady je $\mathrm{k}$ dispozici největší sortiment nejrůznějších obvodů (registry, čítače, dekodéry aj.).

$\boldsymbol{L V T}$ (Low Voltage TTL) jsou logické obvody TTL, jejichž řešení bylo navrženo tak, aby je bylo možné napájet napětím 3,3 V. Přitom logické úrovně zůstaly shodné jako u klasických obvodů TTL napájených napětím $5 \mathrm{~V}$. Tento alternativní způsob řešení přinesl zkrácení zpoždění signálu, které je u hradla lepší než 4,1 ns.

Poznámka: Obvody jednotlivých řad bipolárních logických obvodů mohou být použivány současně, jsou signálově slučitelné. Existuje zde však jeden problém - nebo spíše existuje vždy $\mathrm{v}$ době, kdy se určitá řada začíná vyrábět a není k dispozici dostatečný sortiment typů obvodů. Postupné nahrazování jednotlivých typů jedné řady obvody jiné řady není pro uživatele výhodné. Důvodem je, že při návrhu zařízení je nutné počítat vždy s horšími parametry obou řad. Výhodnějším řešením je proto při novém návrhu přejít kompletně na novou řadu, až bude sortiment typu obvodů dostatečně rozsáhlý.

\section{Unipolární logické obvody CMOS}

Brzy po nástupu logických obvodů TTL byly vyvinuty logické obvody CMOS typové řady CD4000 popř. 74C. Vyznačovaly se pro běžné aplikace dostačující rychlostí, nízkým př́konem, velkým rozsahem napájecích napětí a vysokou šumovou imunitou. Další typové řady logických obvodů CMOS pak přinesly zlepšení řady parametrů a typová řada CD4000/74C se dnes považuje za zastaralou. Pro nové konstrukce se doporučuje používat níže uvedené typové r̆ady logických obvodů CMOS.

$\boldsymbol{H C} / \boldsymbol{H C T}(\mathrm{HC}=$ High speed CMOS, HCT = High speed CMOS - TTL inputs) jsou rychlé logické obvody, které patří k nejužívanějším obvodům posledních let. Mohou spolupracovat i s jinými typovými řadami obvodů CMOS (HC mají vstupy kompatibilní s logikou CMOS), popř. s logickými obvody TTL (HCT mají vstupy kompatibilní s TTL). Př́íkon obvodů 74HC je velmi nízký, ale významně se zvyšuje v dynamickém režimu. Velký vliv na zvýšení př́íkonu má také teplota. Např́iklad při zvýšení teploty z 25 na $85^{\circ} \mathrm{C}$ se při napájecím napětí $U_{\mathrm{N}}=6$ V napájecí proud zvětší z $2 \mu \mathrm{A}$ na $20 \mu \mathrm{A}$ (prríkon se zvětší z $12 \mu \mathrm{W}$ na $120 \mu \mathrm{W}$ ). Další zvýšení na maximální př́pustnou teplotu $125^{\circ} \mathrm{C}$ se projeví napájecím proudem $40 \mu \mathrm{A}$ a odpovídajícím ztrátovým výkonem $240 \mu \mathrm{W}$.

Obvody řady 74HCT jsou určeny $\mathrm{k}$ přímé návaznosti na obvody TTL. Jejich vstupní obvody jsou navrženy tak, aby respektovaly vstupní napětí $U_{\mathrm{IL}}<0,8 \mathrm{~V}$ a $U_{\mathrm{IH}}>2 \mathrm{~V}$ pro napět'ové vstupní úrovně. V obou případech vstupní proudy nepřesáhnou hodnotu $1 \mu \mathrm{A}$. Proto mohou obvody 74HCT snadno nahradit obvody 74LS pouhou záměnou, přitom se ztrátový výkon redukuje až na pětinu. Je nutno upozornit, že se poněkud změní dynamické parametry a v kritických aplikacích je nutná kontrola.

Typické vlastnosti obvodů HC/HCT:

- velmi nízký prríkon, ve statickém režimu je př́íkon v průměru $10 \mu \mathrm{W}$ na jedno elementární hradlo,

- vykazují vysokou šumovou imunitu, 
- zpoždění na jedno hradlo je kolem 18 ns, jsou tedy až 5x rychlejší než obvody $74 C$,

- nízká cena.

AHC/AHCT $(\mathrm{AHC}=$ Advanced High speed CMOS, AHCT = Advanced High speed CMOS - TTL inputs) jsou pokročilejší než obvody HC/HCT, vykazují výbornou šumovou imunitu, ale zejména mají pouze poloviční př́kon oproti obvodům $\mathrm{HC} / \mathrm{HCT}$.

Typické vlastnosti obvodů AHD/AHCT:

- přibližně poloviční spotřeba než u obvodů $\mathrm{HC}$,

- vynikají nízkým šumem,

- $\quad$ zpoždění je asi 8,5 ns (jsou tedy více než 2x rychlejší než obvody HC)

- výstupní proud $8 \mathrm{~mA}$ (pro napájecí napětí $5 \mathrm{~V}$ ),

- může pracovat při napájecím napětí 3,3 i $5 \mathrm{~V}$,

- při použití napájecího napětí 3,3 V jsou vstupy díky ochranným diodám odolné vůči napětí přsesahující $3,3 \mathrm{~V}$.

$\boldsymbol{A C} / \boldsymbol{A C T}(\mathrm{AC}=$ Advanced CMOS, ACT $=$ Advanced CMOS - TTL input $)$ jsou pokročilé CMOS logické obvody s vynikající nízkou spotřebou, ale zároveň jsou schopné pracovat s velkým výstupním proudem. Vstupy obvodů AC jsou kompatibilní s CMOS logikou a ACT umožňuje navázání logických obvodů TTL. Řada 74AC představuje skupinu rychlých obvodů CMOS se vstupními úrovněmi CMOS a posílenými výstupy, které mohou budit zátěž proudy až 24 mA. Doba zpoždění signálu je stejná nebo kratší než u obvodů ALS TTL, avšak obvody mohou mít až trojnásobně vyšší hodinový kmitočet. Obvody se vyznačují velkou odolností vůči kapacitní zátěži.

Typické vlastnosti obvodů AC/ACT:

- velmi nízká spotřeba,

- typické zpoždění $5 \mathrm{~ns}$,

- napájecí napětí 1,5 V až 5,5 V (AC), popř. 4,5 V až 5,5 V (ACT),

- $\quad$ výstupní proud až $24 \mathrm{~mA}$.

$\boldsymbol{L V} / \boldsymbol{L} \boldsymbol{V C}$ (Low Voltage CMOS) jsou logické obvody CMOS umožňující pracovat s velmi nízkým napájecím napětím, ale i s napájecím napětím $5 \mathrm{~V}$.

Typické vlastnosti obvodů LV/LVC:

- Široký rozsah napájecího napětí 1,0 až $5,5 \mathrm{~V}$,

- typické zpoždění $9 \mathrm{~ns}$ pro $U_{\mathrm{N}}=3 \mathrm{~V}$,

- pro napájecí napětí 4,5 V umožňují dosáhnout dvojnásobné rychlosti, než řada HCMOS,

- výstupní proud je asi $8 \mathrm{~mA}$ pro $U_{\mathrm{N}}=3 \mathrm{~V}$ a $12 \mathrm{~mA}$ pro $U_{\mathrm{N}}=4,5 \mathrm{~V}$,

- $\quad$ snadná náhrada obvodů HCMOS, umožňují snížení napájecího napětí z $5 \mathrm{~V}$ na 3,3 V při zachování rychlosti.

$\boldsymbol{A L V C}$ (Advanced Low Voltage CMOS) jsou CMOS logické obvody s vynikající rychlostí a nízkou spotřebou, které pracují i při nízkém napájecím napětí. Využívány jsou zejména pro konstrukci výpočetní techniky a jejich periferií.

Typické vlastnosti obvodů ALVC jsou:

- velmi nízká spotřeba, 
- typické zpoždění 2 ns,

- $\quad$ výstupní proud až $24 \mathrm{~mA}$,

- rozsah napájecích napětí 1,2 až 3,6 V,

- vstupy jsou odolné vůči napětí až $5 \mathrm{~V}$.

$\boldsymbol{A} \boldsymbol{V C}$ (Advanced Very low voltage CMOS) logické obvody umožňující dosáhnout velmi malého zpoždění kolem 2 ns při nízkém napájecím napětí $2,5 \mathrm{~V}$. Do zátěže jsou schopny dodat proud až $24 \mathrm{~mA}$.

Typické vlastnosti AVC jsou:

- napájecí napětí 1,2 až 3,6 V,

- $\quad$ zpoždění 1,7 ns pro napájecí napětí 3,3 V a 3,2 ns pro 1,8 V,

- nízký statický a dynamický př́íkon,

- $\quad$ vstupy jsou odolné vůči napětí do 3,6 V,

- $\quad$ standardní maximální výstupní proud $24 \mathrm{~mA}$,

- funkce snížené spotřeby.

$\boldsymbol{A} \boldsymbol{U} \boldsymbol{C}$ (Advanced Ultra low voltage CMOS) jsou vylepšením technologie logických obvodů AVC, které umožňují snížit napájecí napětí až na $0,8 \mathrm{~V}$.

\section{BiCMOS logické obvody}

Technologie BiCMOS (Bipolar CMOS) je technologií, která na jednom čipu využívá prvky TTL a CMOS. Uvedená technologie se využívá zejména k výrobě mikroprocesorů, budičů sběrnice a vyrovnávacích pamětí. Technologie BiCMOS přinesla spoustu možností, protože dokáže kombinovat vysokou hustotu integrace unipolární technologie se schopností bipolárních tranzistorů dodat do zátěže velký proud. Proto obvody BiCMOS vykazují solidní rychlosti i při velkých kapacitních zátěžích, což je výhodou např. u budičů sběrnice nebo pamětí, kde se může vyskytnout neočekávaný vyšší odběr z výstupu. Dobrých spínacích rychlostí při kapacitních zátěžích lze samozřejmě dosáhnout i u technologie CMOS, ale obvody jsou mnohem složitější, dražší a mají obvykle i vyšší spotřebu. Je pak na zvážení, která z obou technologií je výhodnější. Níže je uvedeno několik základních typů obvodů BiCMOS.

$\boldsymbol{B C T}$ (BiCMOS - TTL input) jsou logické obvody kompatibilní s TTL obvody. Napájecí napětí může být z rozmezí 4,5 až 5,5 V, vstupy jsou kompatibilní s logikou LVTTL/TTL, výstupy TTL, maximální proud do zátěže $15 \mathrm{~mA}$, zpoždění 6,6 ns při napájení $5 \mathrm{~V}$. Používají se jako přijímač/vysílač sběrnice, nebo jako vyrovnávací pamět'.

$\boldsymbol{A B T}$ (Advanced BiCMOS Technology) jsou pokročilejší obvody BiCMOS, rychlejší než BCT. Napájecí napětí může být 4,5 až 5,5 V, vstupy jsou kompatibilní s logikou LVTTL/TTL, výstupy TTL, maximální proud do zátěže $32 \mathrm{~mA}$, zpoždění 4,6 ns při napájení $5 \mathrm{~V}$. Používají se zejména jako vyrovnávací pamět', nebo jako tř́stavový budič sběrnice.

$\boldsymbol{L V T}$ (Low Voltage CMOS - TTL input) jsou logické obvody technologie BiCMOS s nízkým napájecím napětím. Maximální provozní napájecí napětí $2,7 \mathrm{~V}$, kompatibilita vstupů LVTTL/TTL, kompatibilita výstupu LVTTL, maximální proud do zátěže $20 \mathrm{~mA}$, zpoždění při kapacitní zátěži 50 pF maximálně 6,9 ns. 
Celá rodina dnes užívaných digitálních obvodů představuje v současnosti více než 20 různých typů a je tudíž obtížné vytvořit obecně platné aplikační zásady. Je proto vždy nutné respektovat konkrétní doporučení výrobců.

\subsubsection{Základní aplikační doporučení}

\section{Bipolární logické obvody TTL}

Pro běžné aplikace se užívají obvody řady 74ALS popř. 74F, které jsou určeny pro práci při provozních teplotách 0 až $+70{ }^{\circ} \mathrm{C}$. Pro větší teplotní rozsahy $-55^{\circ} \mathrm{C}$ až $125{ }^{\circ} \mathrm{C}$ jsou pak určeny obvody 54ALS, resp. 54F. Všechny obvody řady 74ALS/54ALS, resp. 74F/54F mají být napájeny ze zdroje napětí $U_{\mathrm{N}}=+5 \mathrm{~V}$, změny napájecího napětí jsou povoleny $\pm 5 \%$. Na napájecím rozvodu může být krátkodobě až $+7 \mathrm{~V}$. Nedodržením doporučených napětí vzniká nebezpečí, že nebudou dodrženy zaručované logické úrovně. Logické obvody mohou zpracovávat pouze signály, které svými parametry vyhovují kritériím předepsaným pro daný typ. Pro obvody ALS resp. F je předepsáno $U_{\mathrm{IL}}=0 \mathrm{~V} \min$ až $0,8 \mathrm{~V} \max$ a $U_{\mathrm{IH}}=2 \mathrm{~V} \min$ až 5 $\mathrm{V}$ max při vstupních proudech $I_{\mathrm{IL}}=-0,1 \mathrm{~mA}, I_{\mathrm{IH}}=20 \mu \mathrm{A}$ (znaménko plus značí, že proud teče do vstupu, znaménko mínus značí, že teče ze vstupu ven). Výstupní proud při úrovni H je $I_{\mathrm{OH}}$ $=-0,4 \mathrm{~mA}$ a při úrovni L pak $I_{\mathrm{OL}}=8 \mathrm{~mA}$. Minimální strmost přechodových hran u obvodů ALS je $2 \mathrm{~V} / \mu \mathrm{s}$.

Logické obvody 74LVT mají doporučené napájecí napětí $U_{\mathrm{N}}=+3,3 \mathrm{~V}$, maximálně může toto napětí být $+3,6 \mathrm{~V}$. Obvody řady LVT mají vstupní logické úrovně typicky $U_{\mathrm{IL}}=0 \mathrm{~V}$ min až $0,8 \mathrm{~V} \max , U_{\mathrm{IH}}=2 \mathrm{~V} \min$ až $+5,5 \mathrm{~V} \max$, takže jsou schopny spolupracovat se všemi typy obvodů TTL napájených napětím $U_{\mathrm{N}}=+5 \mathrm{~V}$ bez přizpůsobení napětových úrovní.

Rozvod napájení k logickým obvodům, zemění, blokování napájení a výběr typů blokovacích kondenzátorů byl již podrobně rozveden dříve a proto zájemce odkazujeme na předchozí kapitoly. Logické obvody TTL jsou velmi odolné a při osazování desek plošných spojů nebo při oživování zařízení nevyžadují žádné zvláštní zacházení.

\section{Digitální obvody CMOS}

Integrované obvody využívající prvků řízených polem mají v mnoha směrech výhodnější vlastnosti oproti bipolárním technologiím. Zejména jsou to integrované obvody s komplementárními tranzistory MOSFET, označované všeobecně jako obvody CMOS. Ve srovnání s technologií TTL mají velkou výhodu v tom, že nespotřebovávají prakticky žádný příkon, když je obvod ve stavu L nebo H. Př́kon ve statickém režimu je nepatrný (řádově $10 \mu \mathrm{W}$ na hradlo). Vyznačují se velmi nízkými vstupními proudy, resp. mají velký vstupní odpor (ř́dově $10^{14} \Omega$ ).

Rozsah napájecích napětí je větší, přičemž jsou nižší požadavky na stabilizaci napájecího napětí. Vykazují velkou šumovou imunitu, která je prakticky 30 až 45 \% napájecího napětí. Všechny vstupy a výstupy jsou chráněny před přepětím.

Jejich pracovní rychlost je obvykle nižší než u bipolárních obvodů a dále klesá již při nevelké kapacitní zátěži. Proto pro přenos signálu po vedení do dalšího obvodu, což představuje kapacitní zátěž, je lépe použít bipolární oddělovací stupeň. Činnost tranzistorů MOS je mnohem méně ovlivňována radioaktivním zářením než u bipolárních tranzistorů.

V současné době se nejčastěji užívají CMOS logické obvody řady 74HC (High-speed CMOS), v níž je číselné označení typů i rozložení vývodů shodné s řadou TTL. Pokud záleží na vysoké rychlosti obvodů, je možné užít pokročilejší řadu 74AHC, která je oproti řadě 74HC více než dvakrát rychlejší. Velmi často se také užívají obvody CMOS 74ACT, které se 
vyznačují vysokou rychlostí při zachování ultranízké spotřeby. Mají posílené výstupy CMOS, které mohou dodat proudy do zátěže až $24 \mathrm{~mA}$ a jsou proto vhodné i pro buzení sběrnic. Změny napájecího napětí mohou být až $\pm 10 \%$, napájecí napětí nesmí překročit napětí $+7 \mathrm{~V}$.

\section{Zásady práce s logickými obvody CMOS}

Práce s obvody CMOS vyžaduje odlišný přístup a dodržování náročnějších pravidel než u obvodů TTL. Třebaže jsou u většiny součástek uvnitř systému ochranné obvody, které chrání součástku před poškozením vlivem statické elektřiny, musí se dodržet pokyny výrobce pro manipulaci a práci s obvody CMOS. Je totiž známo, že výboj statické elektřiny nemusí viditelně poškodit integrovaný obvod, avšak přitom podstatně ohrozí jeho spolehlivost $\mathrm{v}$ dalším provozu.

Při montáži, oživování i zahořování elektronických zařízení, obsahujících integrované obvody CMOS, je třeba pracovat v prostředí s vyšší relativní vlhkostí vzduchu - zavést „vodivé podlahy“, pracovní stoly opatřit vodivým povrchem, používat vodivou obuv a nesyntetické oblečení, pracovní zásobníky používat z vodivých materiálů a provést uzemnění obsluhy kovovými náramky spojené odporem nejvýše 50 až $100 \mathrm{k} \Omega$ se zemí, nejlépe na společný zemnicí bod. Vyvarovat se dotyku prŕvodů pokud nejsou všechny zkratovány. Zkratovat výstupní konektor u desek osazených součástkami CMOS po montáži a při přepravě. Současně je nutno zajistit, aby k manipulaci s deskami docházelo pouze při odpojeném napětí. Musí-li být realizována výměna DPS pod napětím, je nutno zajistit, aby zemní vodič byl odpojen jako poslední a připojen jako první. Logické signály smí být přivedeny na DPS až po připojení napájecího napětí.

Při montáži integrovaných obvodů CMOS pájením přímo do desek je nutno dodržovat zásady výrobce a nepřekračovat dobu ani teplotu pájení, používat neagresivní doporučená tavidla, zavést řádné mytí po pájení a používat ochranné lakování. Pájení je dovoleno jen na dolní zúžené části vývodu. Při ručním pájení je třeba používat uzemněné páječky na malé napětí. Při teplotě hrotu páječky $300^{\circ} \mathrm{C}$ je doba pájení maximálně $10 \mathrm{~s}$, při teplotě hrotu páječky 300 až $400{ }^{\circ} \mathrm{C}$ se zkracuje na $5 \mathrm{~s}$. Přri vypájení obvodů má být teplota hrotu páječky $260{ }^{\circ} \mathrm{C} \mathrm{a}$ doba pájení maximálně $5 \mathrm{~s}$. Při vkládání a vyjímání obvodů CMOS z desek s plošnými spoji musí být odpojeny všechny napájecí zdroje. Měřicí přístroje používané při oživování musí být také uzemněny.

Při oživování desek osazených obvody CMOS je nutno zajistit, aby nebylo pájeno na vývodech při připojeném napětí, nebot' vlivem tepla i jiných vlivů dojde většinou ke zničení obvodu nebo ke zhoršení jeho vlastností. Kromě možnosti bezprostředního zničení obvodu přetížením diod vstupních ochran je zde nebezpečí vyvolání tzv. tyristorového jevu, při němž obvod prestane fungovat a jeho odběr prudce stoupne. Pokud se obvod zvýšeným odběrem nezničí, napřr. přepálením některých vývodů na čipu, je po vypnutí a opětném zapnutí napájecího napětí jeho činnost obnovena, ovšem nelze již zaručit jeho spolehlivost.

\section{Integrované obvody BiCMOS}

V současné době stále více světových firem přichází na trh s novou technologií BiCMOS (Bipolar CMOS), která v sobě sdružuje výhody bipolárních (velká rychlost, velký výstupní výkon) a unipolárních obvodů (malá spotřeba v klidovém stavu). Obvody BiCMOS jsou více než dvakrát rychlejší ve srovnání s ekvivalentními obvody CMOS a jejich zpoždění (doba průchodu) je na rozdíl od obvodů CMOS téměř nezávislé na zatížení. Nejužívanějšími logickými obvody BiCMOS jsou v současné době obvody 74ABT, které vykazují zpoždění na hradlo jen asi 4 ns. Integrované obvody BiCMOS vyžadují zvláštní zacházení, stejně jako je tomu u obvodi̊ CMOS. 


\subsubsection{Ošetření nevyužitých vstupů}

\section{Bipolární logické obvody TTL}

U všech typů bipolárních obvodů TTL (zkráceně obvody TTL) je př́ípustné nevyužité vstupy nechat nezapojené. Nezapojený vstup totiž zaujme takovou napětovou úroveň, jaká nepřekáží správné činnosti obvodu při ovládání ostatními vstupy. Nezapojené vstupy automaticky zaujímají neagresivní logickou hodnotu. V praxi se však vždy snažíme nevyužité vstupy připojit na korektní hodnotu logické úrovně $\mathrm{H}$ nebo $\mathrm{L}$ a to tak, aby ošetřený vstup neovlivnil vlastní činnost logického obvodu. Důvody jsou dva:

Impedance nezapojeného vstupu je střední nebo vysoké hodnoty, takže existuje určité nebezpečí přenosu rušivých impulsů ze sousedních vodičů kapacitní vazbou.

Další důvod je ale závažnější. Uvažujme pro vysvětlení jednoduchý příklad třívstupového hradla na Obr. 10.45 A, přičemž budeme uvažovat i parazitní kapacity vstupů. Předpokládejme, že vstup A budíme $\mathrm{z}$ výstupu jiného logického obvodu, přičemž vstupy $\mathrm{B}, \mathrm{C}$ nejsou nikam připojeny. Protože neprripojené vstupy $\mathrm{B}, \mathrm{C}$ jsou spojeny $\mathrm{s}$ emitory vstupního tranzistoru $\mathrm{T}_{1}$ hradla (Obr. 10.451), a ty jsou všechny spojeny uvnitř společné bázové oblasti, musí při změnách logických úrovní na vstupu A zaujmout potenciál báze $\mathrm{T}_{1}$ i vstupy $\mathrm{B}, \mathrm{C}$. Potenciál báze přitom (se stejnosměrným posuvem několika desetin voltů na přechodu báze - emitor) sleduje potenciál vstupu A. Jestliže byla na vstupu A úroveň L, potenciál všech vstupů $A, B, C$ bude blízký nule a kapacity $C_{\mathrm{A}}, C_{\mathrm{B}}, C_{\mathrm{C}}$ se vybijí. Pokud se nyní na vstupu A úroveň skokem změní na úroveň $H$, musí se nejprve všechny parazitní kapacitory nabít, aby tranzistor $T_{1}$ mohl přjejít ze sepnutého stavu do vypnutého. Protože vstup A je buzen z výstupu invertoru, nabije se parazitní kapacita $C_{\mathrm{A}}$ velmi rychle proudem dodaným z výstupu invertoru. Budou-li parazitní kapacity $C_{\mathrm{A}}=C_{\mathrm{B}}=C_{\mathrm{C}}=1 \mathrm{pF}$ a budeme-li předpokládat vnitřní odpor budicího zdroje $R_{\mathrm{O}}=100$ $\Omega$, bude nabíjecí časová konstanta $R_{\mathrm{O}} C_{\mathrm{A}}=100$ ps. Doba nabíjení kapacity $C_{\mathrm{A}}$ bude zanedbatelná vůči době trvání přechodové hrany logického signálu a na činnost obvodu nebude mít vliv. Jinak je tomu u kapacit $C_{\mathrm{B}}$ a $C_{\mathrm{C}}$. Ty se rovněž nabíjí na úroveň $\mathrm{H}$, ale jejich nabíjení probíhá přes rezistor v bázi tranzistoru $\mathrm{T}_{1}$, který má odpor $R_{\mathrm{B}}=4 \mathrm{k} \Omega$. Časová konstanta nabíjení $C_{\mathrm{B}}, C_{\mathrm{C}}$ tedy bude $\left(C_{\mathrm{B}}+C_{\mathrm{C}}\right) R_{\mathrm{B}}=8 \mathrm{~ns}$. I když uvážíme, že pro dosažení překlápěcí úrovně $U_{\mathrm{T}}$ $=1,3$ až $1,5 \mathrm{~V}$, což představuje jen přibližné nabití kapacitorů asi na $25 \%$, způsobí nezapojené vstupy zpoždění odezvy asi o 2 ns. Toto zpoždění může být již na závadu, zejména pokud se neošetřené vstupy objeví v cestě logického signálu vícekrát, protože se tato zpoždění sčítají. Obecné pravidlo tedy je, že na každý nezapojený vstup musíme počítat s př́ídavným zpožděním $1 \mathrm{~ns}$.
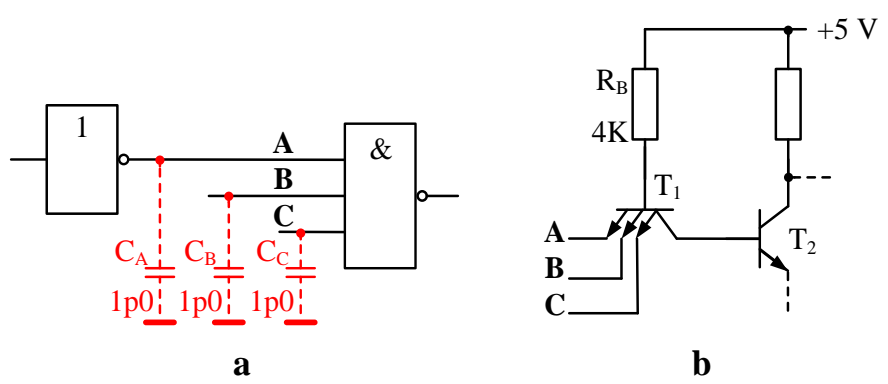

Obr. 10.45: a) Důsledek neošetřených vstupů hradla TTL, b) detail zapojení vstupních obvodů hradla 
Při práci s logickými obvody TTL proto platí zásada neponechávat vstupy logických obvodů nepřipojeny. $\mathrm{Na}$ Obr. 10.46 ji jou nakresleny základní způsoby ošetření nevyužitých vstupů. V zásadě připojíme nevyužitý vstup na zdroj napětí definované úrovně H nebo L, a to tak, aby logická funkce ošetřovaného obvodu nebyla narušena.

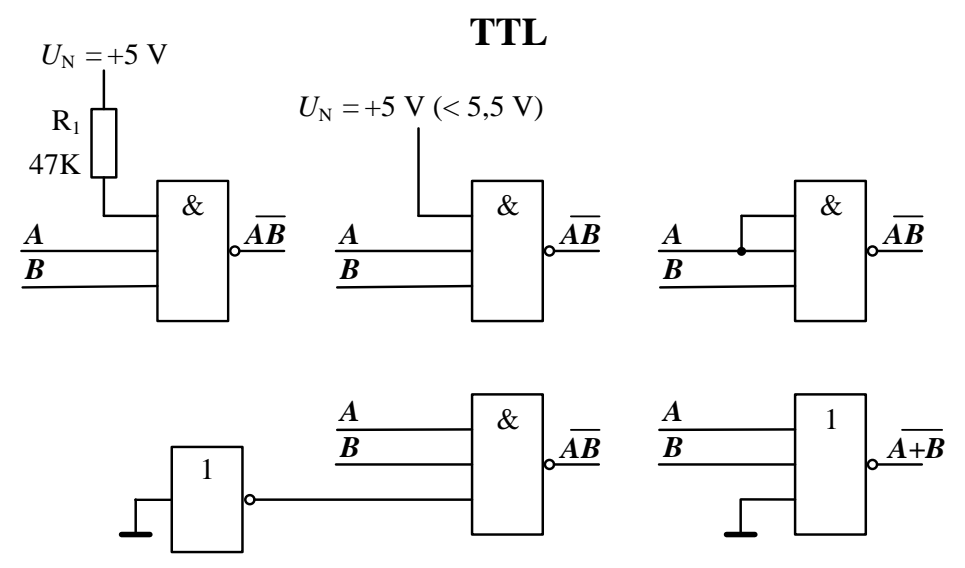

$\mathbf{a}$

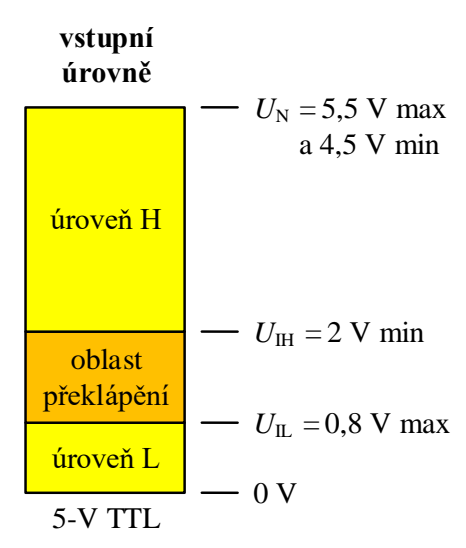

b

Obr. 10.46: a) Ošetření nepoužitých vstupů, b) vstupní úrovně obvodů typové řady ALS

Nejjednodušší způsob je připojit nevyužitý vstup přes rezistor $\mathrm{R}_{1}$ na napájecí napětí $U_{\mathrm{N}}$ (tzv. „Pull-up Resistor“). Odpor rezistoru musí být zvolen tak, aby úbytek napětí vytvořený proudem do vstupu hradla snížil napájecí napětí $U_{\mathrm{N}}$ na úroveň $H$. Jako př́klad jsou na Obr. 10.46 uvedeny logické úrovně pro obvody TTL typové řady ALS. Napětí $U_{\mathrm{IH}}=2,0 \mathrm{~V}$ je minimální vstupní napětí, které vstup identifikuje jako úroveň $\mathrm{H}$ a $U_{\mathrm{I}}=0,8 \mathrm{~V}$ je maximální vstupní napětí garantované pro úroveň L. Vstupní napětí mezi $0,8 \mathrm{~V}$ a $2,0 \mathrm{~V}$ je pak rozpoznáno bud' jako L nebo $H$. Pro návrh odporu rezistoru $\mathrm{R}_{1}$ je podstatná informace, že vstupní napětí z rozmezí 2,0 V až 5,0 V bude identifikováno jako úroveň $\mathrm{H}$. Protože vstupní proud je při úrovni $\mathrm{H}$ u obvodů ALS typicky $I_{\mathrm{IH}}=20 \mu \mathrm{A}$, může být odpor rezistoru

$$
R_{\mathrm{IMAX}}=\frac{U_{\mathrm{N}}-U_{\mathrm{IHMIN}}}{I_{\mathrm{IH}}}=\frac{5,0-2,0}{20 \cdot 10^{-6}}=150 \mathrm{k} \Omega .
$$

V zarušeném prostředí však pro ošetření jednoho vstupu hradla volíme raději hodnoty $50 \mathrm{k} \Omega$ až $100 \mathrm{k} \Omega$. Pokud bude k rezistoru $\mathrm{R}_{1}$ připojeno $n$ nepoužitých vstupů, musí se volit odpor samozřjmě nižší, protože pak

$$
R_{\mathrm{IMAX}}=\frac{U_{\mathrm{N}}-U_{\mathrm{IHMIN}}}{n \cdot I_{\mathrm{IH}}} .
$$

Nevyužité vstupy můžeme také připojit na rozvod napájecího napětí $U_{\mathrm{N}}=+5 \mathrm{~V}$, je-li zaručeno, že napájecí napětí v žádném případě nepřekročí mezní hodnotu pro úroveň $\mathrm{H}$, tj. 5,5 V a to ani při zapnutí či vypnutí napájecích zdrojů. Je to však riskantní, protože po napájecím vedení se často šíří nekontrolovatelné poruchy ve tvaru přepět'ových impulsů.

K ošetření nevyužitých vstupů můžeme využít i jiný způsob. Pokud nevyužité vstupy tvoří s ostatními (tj. využitými) vstupy téhož obvodu logický součet nebo součin, můžeme je prostě spojit paralelně se vstupy již využitými. Zde je ovšem nutné kontrolovat, zda zvětšení 
vstupní kapacity nebude na závadu z hlediska rychlosti. Zpravidla zde však na problémy nenarážíme, problémy však mohou nastat u extrémně rychlých obvodů. V této souvislosti je nutné poznamenat, že v obvodech s víceemitorovým vstupním tranzistorem paralelní spojení několika vstupů (emitorů tohoto tranzistoru) je z hlediska logického zisku ekvivalentní pouze jedné standardní zátěži, protože celý proud vstupu v logické úrovni L je dán pouze odporem rezistoru v bázi vstupního tranzistoru, a ne počtem paralelně spojeným vstupních emitorů.

$\mathrm{Na}$ druhé straně však při spojení několika vstupů téhož víceemitorového tranzistoru do několika různých budicích výstupů je nutné jednotlivé emitory pro každý z budicích obvodů počítat samostatně jako plné jednotkové standardní zátěže, protože podle okamžitého logického stavu jednotlivých výstupů budicích obvodů může libovolným vstupním emitorem protékat celý vstupní proud.

Pokud v integrovaném logickém obvodě s invertory jeden invertor zbyl, můžeme nevyužitý vstup či více vstupů připojit i k výstupu nepoužitého invertoru. $\mathrm{V}$ tom prŕpadě vstup invertoru připojíme na nulový potenciál, aby se na jeho výstupu nastavila úroveň $\mathrm{H}$.

U obvodů NOR však nemůžeme nepoužité vstupy připojit na úroveň $H$, ale musíme je připojit na společný zemní vodič, aby nebyla narušena logická funkce obvodu.

\section{Ořetrení nevyužitých logických obvodi̊ TTL}

Při návrhu digitálního systému se může stát, že na DPS zůstane nevyužito jedno nebo dokonce více hradel. Také v těchto prrípadech je vhodné připojit vstupy těchto nevyužitých obvodů na takovou úroveň, aby spotřeba těchto obvodů byla minimální. Např́klad obvod NAND má typickou proudovou spotřebu asi $0,5 \mathrm{~mA}$ při výstupní úrovni $\mathrm{H}$ a spotřebu asi 1,5 mA při výstupní úrovni L. Proto je vhodné vstupy nevyužitých obvodů NAND připojit na úroveň L (na společný zemní vodič), čímž šetříme $1 \mathrm{~mA}$ na každé nepoužité hradlo. V ostatních př́padech volíme vstupní úroveň tak, aby výstup nepoužitého obvodu byl na úrovni, která vykazuje menší proudovou spotřebu.

\section{CMOS logické obvody}

V př́padě logických obvodů CMOS je třeba dodržet zásadu, že všechny vstupy obvodu a tedy i všechny nepoužité vstupy musí být připojeny na definovanou úroveň $L$ nebo $H$. V prŕípadě nevyužitých vstupů se podle typu obvodu připojí tyto vstupy přímo na napájecí napětí $U_{\mathrm{N}}$ nebo na $0 \mathrm{~V}$. Na rozdíl od obvodů TTL, které většinou vyhodnotí nepřipojený vstup jako by byl připojen na úroveň $\mathrm{H}$, se u obvodů CMOS nastaví na nepřipojeném vstupu nedefinované napětí $\mathrm{z}$ intervalu $0 \mathrm{~V}$ až $U_{\mathrm{N}}$. $\mathrm{Z}$ tohoto důvodu se u obvodů CMOS doporučuje důsledně všechny nevyužité vstupy ošetřit.

Je třeba upozornit, že v souvislosti se spojováním vstupů hradel obvodů CMOS, např. u typové řady 74HC (NOR a NAND), dochází v závislosti na počtu vzájemně spojených vstupů ke změně přenosových charakteristik a tím i ke změnám v odstupu rušivých signálů. Názorně tuto okolnost ukazuje Obr. 10.47, kdy křivky A a B platí, pokud je nevyužitý vstup logického členu NAND připojen na úroveň $\mathrm{H}$, resp. na napájecí napětí $U_{\mathrm{N}}$. Prahová úroveň, kdy dojde k překlopení hradla, se však výrazně změní, pokud oba vstupy spojíme (křivka C). Požadavky na prahovou úroveň potřebnou pro spolupráci s dalšími obvody jsou však $\mathrm{i} v$ tomto príípadě splněny. Další obvody řady $74 \mathrm{HC}$ a všechny obvody $74 \mathrm{HCT}$ mají vstupy vyvážené, tzn. že prahová hodnota určující vstupní napětí rozhodné pro překlopení obvodu není ovlivněna logickými stavy jiných vstupů. 


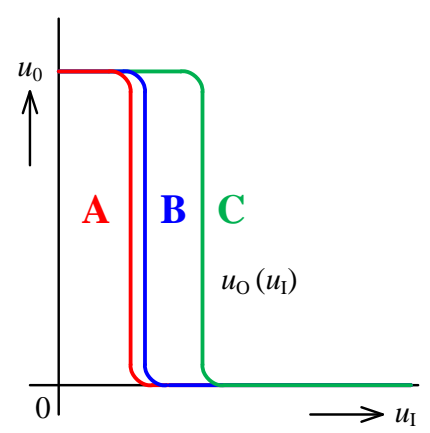

\section{CMOS}

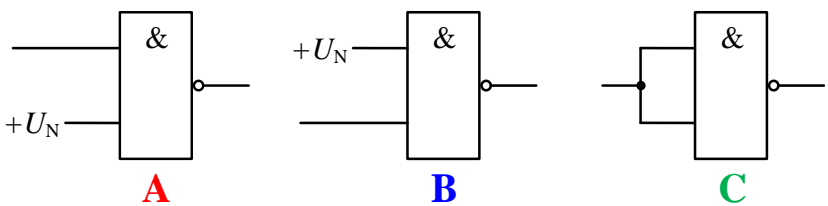

Obr. 10.47: Změna přenosových charakteristik hradla CMOS podle způsobu ošetření nevyužitých vstupů

\section{Ošetření nevyužitých logických obvodi̊ CMOS}

U nevyužitých logických obvodů CMOS jsou úvahy o snížení proudové spotřeby obvodu zbytečné. At' prripojíme vstupy na zem nebo na rozvod napájecího napětí $U_{\mathrm{N}}$, vždy je alespoň jeden z koncových spínacích tranzistorů zahrazen, takže obvodem teče jen nepatrný klidový proud, logické členy pracují ve statickém režimu a mají proto zanedbatelně malý př́íkon.

\subsubsection{Přizpůsobení napětových úrovní}

Při konstrukci zařízení obvykle narazíme na skutečnost, že ve vybrané typové řadě logických obvodů některé typy chybí a musíme vybrat obvody z jiné typové řady, nebo logické obvody musí komunikovat s mikroprocesorem vyrobeným jinou technologií. Základní porovnání napět'ových úrovní různých typů logických obvodů je uvedeno na Obr. 10.48. Zde $U_{\text {IH }}$ značí minimální vstupní napětí, které je vyhodnoceno jako logické úrovně $\mathrm{H}$, podobně $U_{\mathrm{IL}}$ je maximální vstupní napětí pro úroveň L. $U_{\mathrm{T}}$ značí přibližnou úroveň, kdy dojde k překlopení obvodu a $U_{\mathrm{OH}}$ a $U_{\mathrm{OL}}$ jsou zaručená výstupní napětí pro úroveň $\mathrm{H}$ a $\mathrm{L}$.

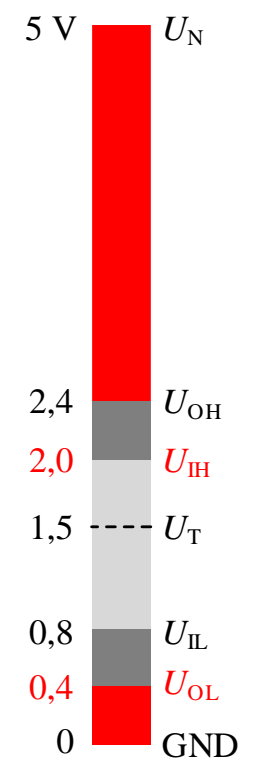

5 V TTL

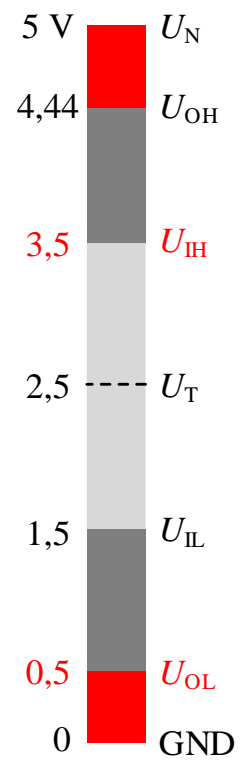

5 V CMOS
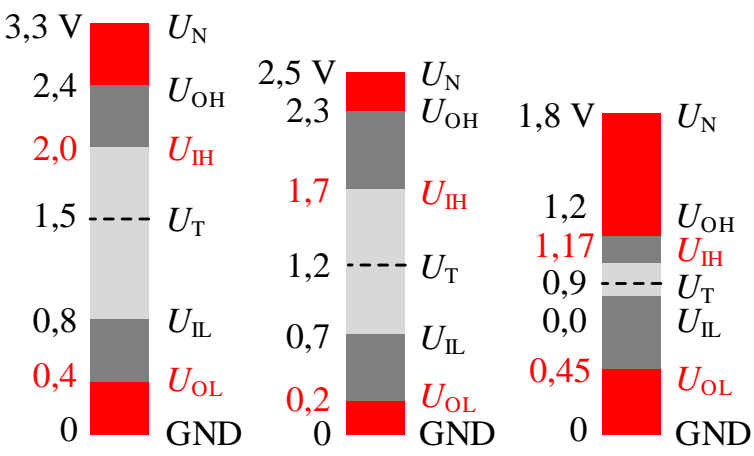

3,3 V LVTTL

\section{2,5 V CMOS}

1,8 V CMOS

Obr. 10.48: Napět'ové úrovně různých typových řad logických obvodů 
Pro přizpůsobení napět'ových úrovní je na trhu celá řada obvodů. Jako př́íklad uvedeme převodník logických úrovní (Logic Level Shifter) napájený jediným napájecím napětím (viz Obr. 10.49. Jde o CMOS pozitivní hradlo NOR, jehož výstupní logické úrovně jsou určeny napájecím napětím $U_{\mathrm{N}}$. Obvod umí převést nízké úrovně na vyšší (Up Level Shifting), popř. vy̌šśi logické úrovně převede na nižší (Down Level Shifting). Obě možnosti jsou uvedeny na Obr. 10.49.

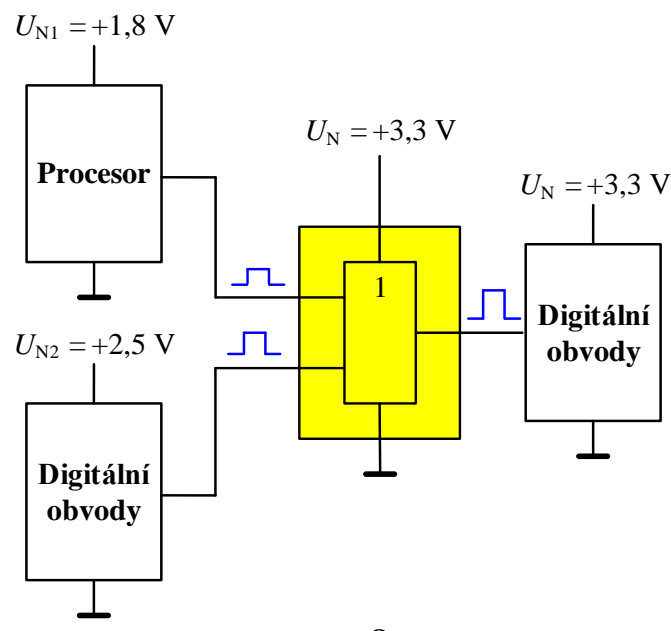

a

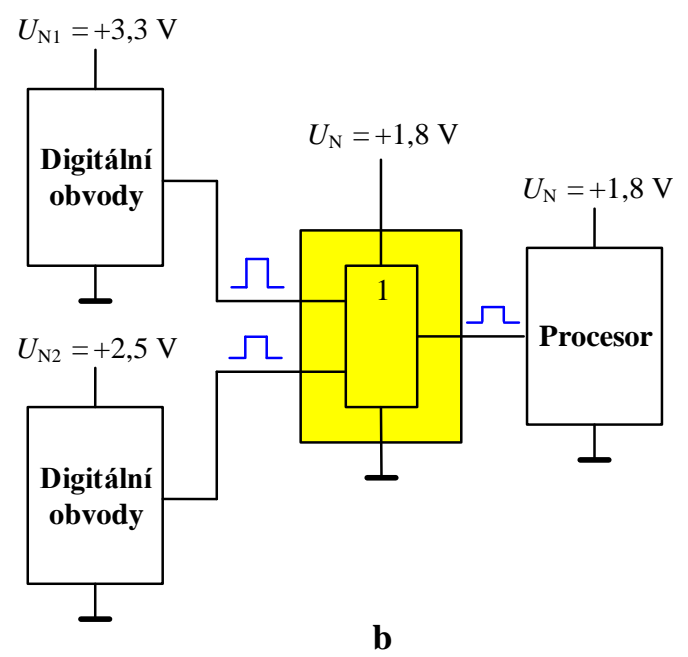

b

Obr. 10.49: Příklady přizpůsobení napětových úrovní převodníkem s jedním napájením

a) převod na vyšší logickou úroveň, b) převod na nižší logickou úroveň

Jiné typy převodníků (Voltage Level Translators) pracují se dvěma napájecími napětími. Př́iklad jednosměrného jednobitového převodníku napětí s dvojitým napájením je uveden na Obr. 10.50. Obvod lze použít jak ke zvýšení logické úrovně napětí, tak i pro její snížení. Zařízení pracuje se dvěma napájecími napětími $U_{\mathrm{N} 1}$ a $U_{\mathrm{N} 2}$, přičemž každé z těchto napájecích napětí může být z rozmezí $1,65 \mathrm{~V}$ až $3,60 \mathrm{~V}$. Napětí $U_{\mathrm{N} 1}$ definuje úrovně napětí na vstupu $\mathrm{A}$, kdežto úrovně napětí na výstupu B definuje napájecí napětí $U_{\mathrm{N} 2}$. Převodník je vhodný pro převod napětových úrovní mezi systémy napájenými $1,8 \mathrm{~V}, 2,5 \mathrm{~V}$ a 3,3 $\mathrm{V}$.

Existují i sofistikovanější obousměrné převodníky, u kterých je možno řídit směr přenosu, nebo převodníky s automatickým vyhodnocením směru přenosu. Uvedené obvody jsou však již nad rámec této kapitoly.

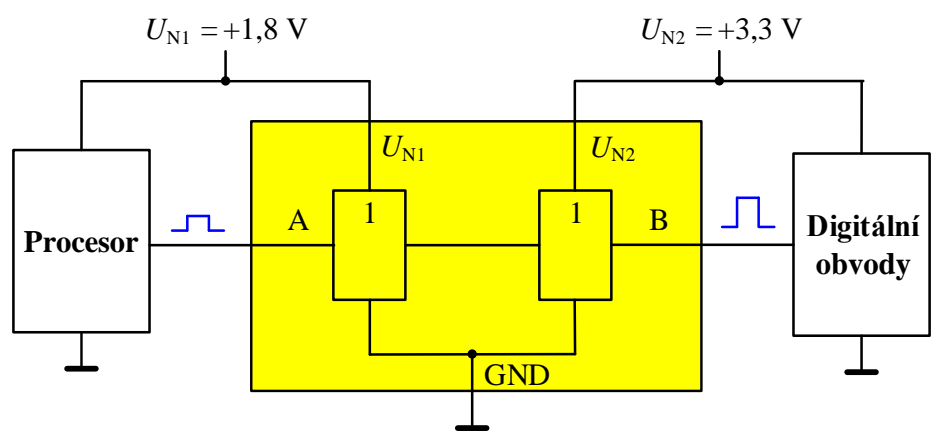

Obr. 10.50: Převodník napětových úrovní se dvěma napájecími napětími 
Při připojování vstupů logických obvodů se největší problémy vyskytují s připojením na obvody, jejichž výstupní signál má jiné úrovně signálu, než potřebují standardní logické obvody. Na Obr. 10.51 je nakresleno zapojení, u kterého se k omezení vstupního napětí $U>U_{\mathrm{N}}$ na př́pustnou hodnotu $U_{\mathrm{N}}+U_{\mathrm{P}}=U_{\mathrm{N}}+0,4$ používá Schottkyho dioda (s prahovým napětím $\left.U_{\mathrm{P}}=0,4 \mathrm{~V}\right)$ připojená na napájecí napětí $U_{\mathrm{N}}$.

Pokud jsou vstupní úrovně přesně známy, stačí na vstup hradla zařadit odporový dělič, který hodnotu vstupního napětí $U$ sníží na prríslušnou hodnotu pro úroveň H (viz Obr. 10.51b).

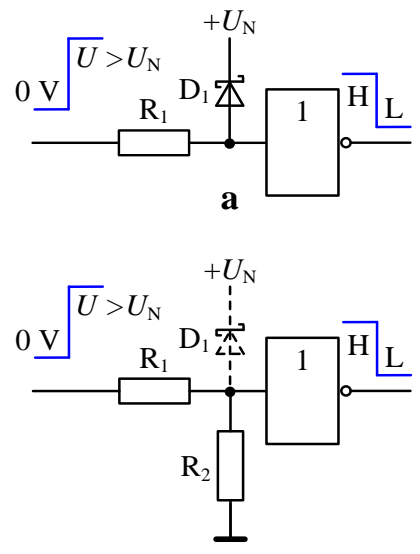

b

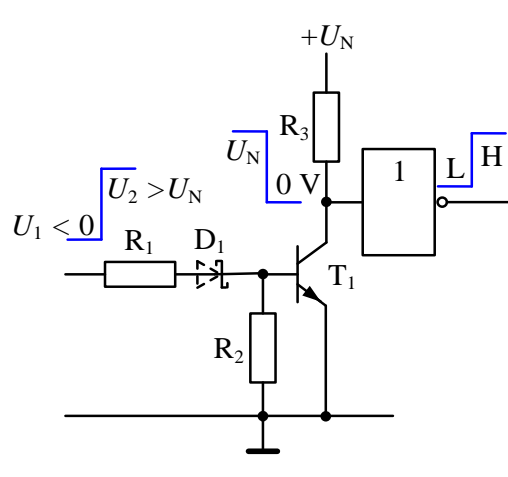

c

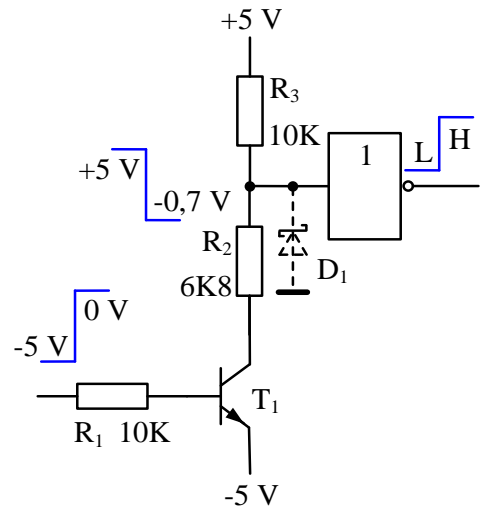

d

Obr. 10.51: Př́iklady přizpůsobení nestandardních logických úrovní pro obvody typové řady ALS

Pokud by ovšem mohlo dojít k překročení povolené hodnoty vstupního napětí hradla, doporučuje se taktéž zapojit ochrannou diodu $\mathrm{D}_{1}$.

Zapojení podle Obr. 10.51థ používá k převodu úrovní $U_{1}<0 \mathrm{~V}$ a $U_{2}>U_{\mathrm{N}}$ spínací tranzistor v zapojení se společným emitorem. Č́árkovaně naznačená dioda $\mathrm{D}_{1}$ se musí použít při $U_{1}<-5 \mathrm{~V}$, nebot' by mohlo dojít k proražení emitorového přechodu tranzistoru při malém odporu rezistoru $R_{1}$. Tranzistor invertuje vstupní napětí a transformuje je do úrovní $0 \mathrm{~V}$ a $U_{\mathrm{N}}$.

Musíme-li navázat obvody ALS na část číslicového systému se zápornou logikou (např. s úrovněmi $-5 \mathrm{~V}$ a $0 \mathrm{~V}$ ), můžeme použít přizpůsobovací obvod podle Obr. 10.51d. Spínací tranzistor $\mathrm{T}_{1}$ má emitor připojen na záporné napájecí napětí $-5 \mathrm{~V}$. Rezistorový dělič $\mathrm{R}_{2}, \mathrm{R}_{3}$ v jeho kolektoru je navržen tak, aby napětí na výstupu děliče odpovídalo při otevřeném tranzistoru $\mathrm{T}_{1}$ úrovni $\mathrm{L}$. Rezistor $\mathrm{R}_{2}$ musí tedy mít takový odpor, aby tato podmínka byla splněna i při reálném proudu $I_{\text {IL }}$ připojeného invertoru. V některých př́padech zapojujeme i ochrannou diodu $\mathrm{D}_{1}$ pro omezení záporných napětí na vstupu invertoru. Pozor na to, že tranzistor $\mathrm{T}_{1}$ invertuje procházející signál.

\subsubsection{Ošetření pomalých přechodových hran}

Pro správnou činnost digitálních obvodů je zapotřebí, aby se vstupní napětí nenacházelo „př́iliš dlouho“ “v rostoucí či klesající části přechodové hrany, tzn. vstupní signál musí mít v čase krátkou nástupnou či sestupnou hranu. Pokud tomu tak není a hrany jsou př́liš pomalé, může 
šum superponovaný na vstupní signál vyvolat několikanásobné překlopení výstupního napětí (viz Obr. 10.52ł).

Dále je nutno vzít v úvahu, že hradlo v přechodové oblasti pracuje jako zesilovač, a že mezi vstupem a výstupem existuje parazitní kapacitní vazba. Pokud se působením vnějšího signálu obvod dostane do oblasti rozhodovací úrovně $U_{\mathrm{T}}$ a bude v ní př́liš dlouho, může být splněna podmínka kladné zpětné vazby a obvod se rozkmitá. Na výstupu se pak objeví náhodná série logických úrovní $\mathrm{L}$ a $\mathrm{H}$, která způsobí nesprávnou funkci dalších návazných obvodů. $\mathrm{Z}$ tohoto důvodu by měla být rychlost přechodových hran větší než $1 \mathrm{~V} / \mu \mathrm{s}$. Konkrétní hodnota záleží na použité řadě logických obvodů.
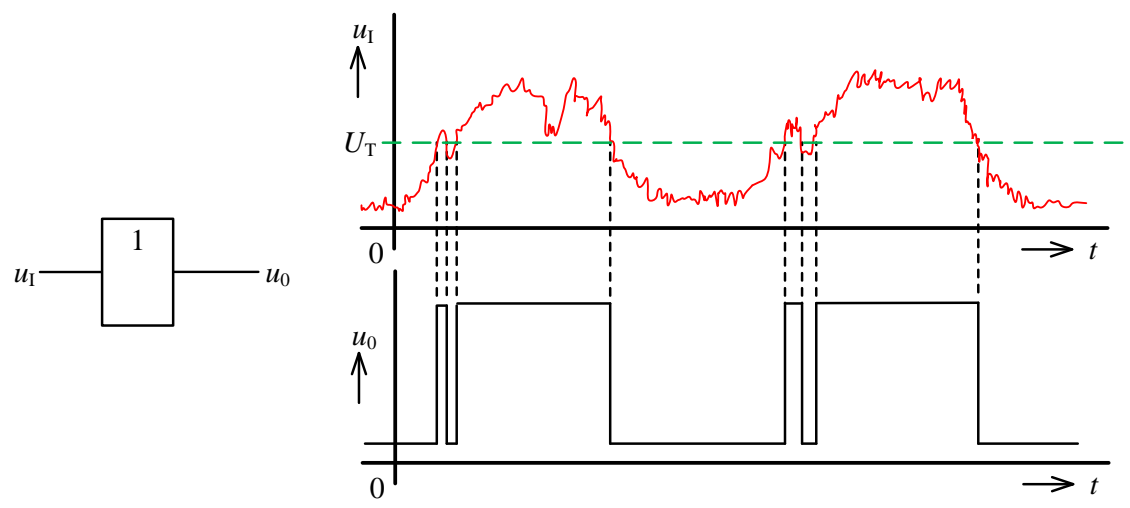

a
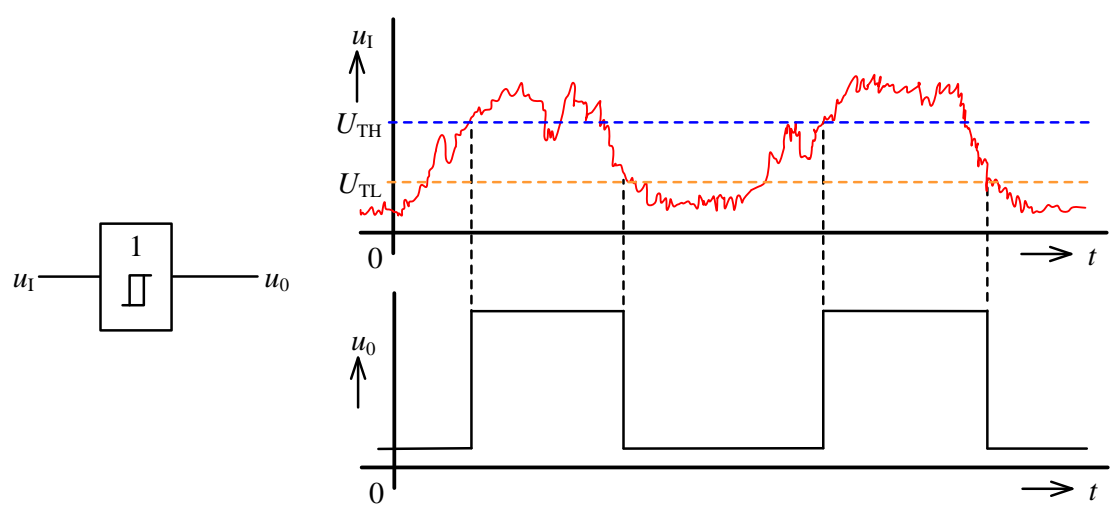

b

Obr. 10.52: Vliv pomalých přechodových hran: a) běžné hradlo, b) hradlo se Schmittovým obvodem na vstupu

U běžných logických obvodů dochází $\mathrm{k}$ překlopení ve stejném bodě jako v př́padě náběžné, tak i sestupné hrany. Pokud se napětí hrany mění jen pomalu, je také pravděpodobné, že dojde k otevření obou výstupních tranzistorů hradla současně, čímž v obvodu vznikne krátkodobý požadavek na větší napájecí proud ze zdroje $\left(U_{\mathrm{N}}\right)$. Pokud však takový proud není $\mathrm{k}$ dispozici (např́klad vlivem nedostatečných či nevhodně navržených blokovacích kondenzátorů), dojde ke krátkodobému poklesu napájecího napětí. Tím však také dojde k posunu rozhodovacích úrovní vstupů a logický prvek se překlopí zpět do předchozího stavu. V tu chvíli napájecí napětí opět stoupne a celý proces se opakuje. Výsledkem je kmitání obvodu, které se samozřejmě přenese i do rozvodu napájení.

Pro zpracování pomalu se měnících signálů je proto nezbytné použít logické obvody s hysterezí mající na vstupu Schmittův klopný obvod (Schmitt trigger). Je to v podstatě komparátor s kladnou zpětnou vazbou a se dvěma rozhodovacími úrovněmi, které se přepínají 
podle okamžitého stavu na výstupu. Přesnost nastavení těchto úrovní nemusí být ani nijak velká. Schmittův obvod na vstupu logického obvodu dokáže jednoznačně zajistit spolehlivé překlopení výstupu obvodu a odstranění nežádoucích zákmitů.

Pokud přivedeme na vstup hradla se zabudovaným Schmittovým obvodem rostoucí vstupní napětí (viz.Obr. 10.52b), hradlo se překlopí až v okamžiku, kdy vstupní napětí dosáhne horní rozhodovací úrovně $U_{\mathrm{TH}}$. Tím ovšem Schmittův klopný obvod na vstupu hradla přejde na dolní rozhodovací úroveň $U_{\text {TL }}$. Proto se hradlo nepřiklopí, i když se vstupní napětí dostane pod úroveň $U_{\mathrm{TH}}$. Uvedený mechanismus přepínání rozhodovacích úrovní v závislosti na stavu výstupu účinně brání tomu, aby se obvod náhodně překlopil. Tento typ vstupu lze nalézt u celé řady logických obvodů a mikrokontrolerů.

\subsubsection{Zpracování signálů z mechanických kontaktů}

Celá řada číslicových systémů musí zpracovávat i signály, které dodávají zařízení s mechanickými kontakty (spínače, přepínače, relé, klávesnice apod.). Výstupní signál mechanického kontaktu v okamžiku sepnutí nebo rozepnutí může být doprovázen po dobu až několika milisekund zákmity, které se pochopitelně dostávají na vstup připojených logických obvodů. Vzhledem k rychlosti číslicových obvodů je zřejmé, že tato série krátkých impulsů pronikne do logických obvodů a může mít nežádoucí důsledky. Proto je nutné v kritických př́padech signál z mechanických kontaktů upravit speciálními obvody. I když vstupní obvody logických obvodů CMOS jsou konstruovány naprosto odlišně od obvodů TTL, jsou zásady ošetřrování kontaktů $\mathrm{v}$ mnoha prrípadech totožné. Jen je při návrhu konkrétních hodnot součástek nutno počítat s tím, že vstupní proudy obvodů CMOS jsou podstatně nižší, než je tomu u obvodů TTL.

$\mathrm{Na}$ Obr. 10.53 je několik př́kladů zapojení pro korekci signálů z mechanických kontaktů, které využívají invertor se Schmittovým obvodem na vstupu. Zapojení mají za spínačem integrační člen $\mathrm{RC} \mathrm{k}$ časovému překlenutí přechodného děje při sepnutí nebo rozpojení kontaktů. Časová konstanta se volí řádově několik milisekund. Pokud při sepnutí spínače dojde k odskočení kontaktů, pouze se pozastaví vybíjení či nabíjení kapacitoru $\mathrm{C}_{1}$ a k překlopení hradla dojde až v okamžiku, kdy napětí na kapacitoru $\mathrm{C}_{1}$ dosáhne hodnoty rozhodné pro překlopení Schmittova klopného obvodu.

Hodnoty součástek $\mathrm{v}$ př́padě zapojení na Obr. 10.53飞 jsou zvoleny s přihlédnutím na použitý invertor CMOS. Funkce obvodu je ale obdobná. V klidu je na vstupu invertoru napětí odpovídající úrovni L. Po stlačení tlačítka se vstupní napětí invertoru přibližně exponenciálně zvětšuje a invertor se překlopí. Díky nepatrným vstupním proudům je dimenzování RC článku pro časové konstanty řádově desítky milisekund snadné. Odpory pracovních rezistorů můžeme volit řádu desítek až stovek $\mathrm{k} \Omega$, kapacitor $\mathrm{C}_{1}$ má pak kapacitu nejvýše stovky $\mathrm{nF}$. 

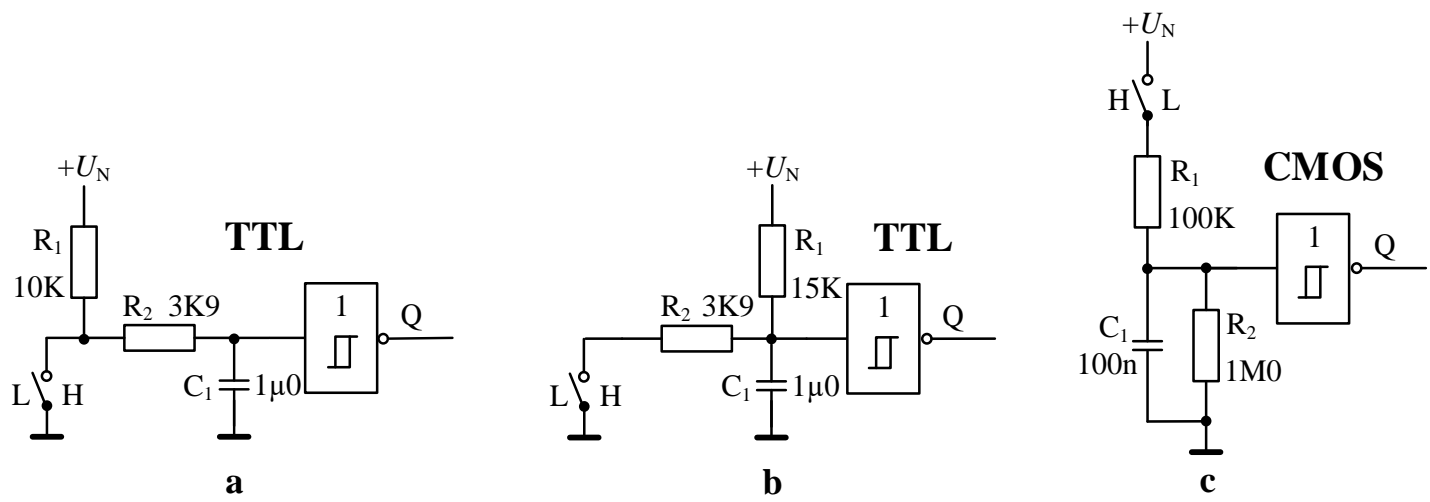

Obr. 10.53: Zpracování signálu ze spínače s využitím invertoru

$\mathrm{Na}$ Obr. 10.54 jsou nakreslena zapojení klasických korekčních obvodů pro ošetření signálů z mechanických kontaktů využívající klopné obvody $\overline{\mathbf{R S}}$. V př́padě zapojení na Obr. 10.54 astupní přepínač budí klopný obvod $\overline{\mathrm{RS}}$, sestavený ze dvou hradel NAND. Oba vstupy obvodu $\overline{\mathrm{RS}}$ reagují na sestupnou hranu přiváděného signálu za předpokladu, že druhý vstup má konstantní klidovou úroveň H. Odskoky kontaktů při přepínání nejsou naprosto na závadu, nebot' signál na výstupu Q se jednoznačně změní na požadovanou úroveň při prvním dotyku přepínače na druhý kontakt a další př́ípadné impulsy, způsobené odskočením kontaktu, jen potvrdí stav výstupu Q. Použijeme-li např. hradla typové řady 74ALS se vstupním proudem $I_{\mathrm{IH}}=20 \mu \mathrm{A}$ a požadujeme-li, aby při napájení $U_{\mathrm{N}}=5 \mathrm{~V}$ byla na vstupu hradla spolehlivě úroveň $\mathrm{H}$, zvolíme $U_{\mathrm{IH}}=3,5 \mathrm{~V}$. Potom

$$
R_{1}=R_{2}=\frac{U_{\mathrm{N}}-U_{\mathrm{IH}}}{I_{\mathrm{IH}}}=\frac{5-3,5}{20 \cdot 10^{-6}}=75 \mathrm{k} \Omega .
$$

Zapojení lze samozřejmě použít i pro logické obvody CMOS, jen odpory rezistorů $\mathrm{R}_{1}$ a $\mathrm{R}_{2} \mathrm{je}$ nutno volit jinak.

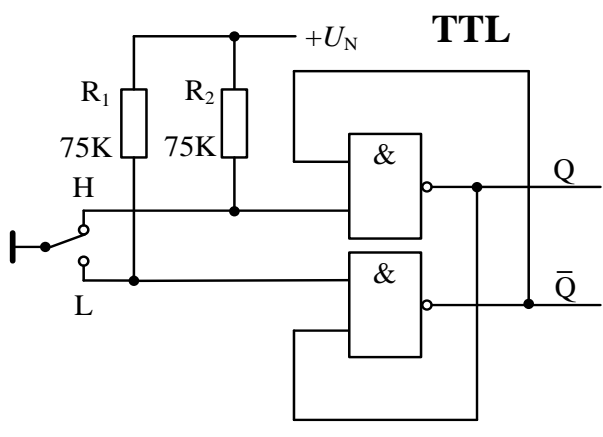

a

\section{CMOS}

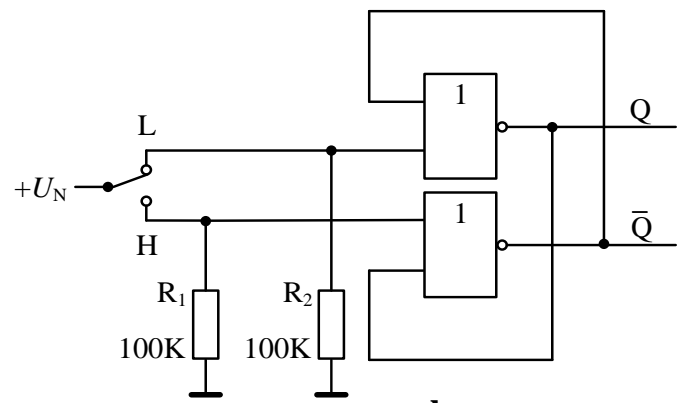

b

Obr. 10.54: Zpracování signálu mechanických tlačítek pomocí klopných obvodů $\overline{\mathbf{R S}}$

$\mathrm{Na}$ Obr. 10.54 je nakresleno jiné schéma obvodu pro ošetření signálu z mechanických tlačítek. Stlačením tlačítka do polohy $\mathrm{H}$, které může být doprovázeno několika zákmity, hned prvním stykem obou jeho kontaktů se výstup Q klopného obvodu s hradly NOR nastaví na úroveň H. Přechodný děj se zákmity se na výstupu Q neuplatní. Stlačením tlačítka do polohy $\mathrm{L}$ 
se obdobným způsobem výstup Q klopného obvodu nastaví na úroveň L. Ani v tomto případě se přechodné děje na tlačítku neuplatní. Odpory rezistorů $R_{1} a R_{2}$ mohou mít velkou hodnotu díky nepatrnému vstupnímu proudu hradel CMOS.

\subsubsection{Připojení nestandardních zátěží}

Při připojování výstupů logických obvodů jsme vázáni mezními hodnotami výstupního napětí $U_{\mathrm{OH}}, U_{\mathrm{OL}}$ a proudu $I_{\mathrm{OH}}, I_{\mathrm{OL}}$, které udává a zaručuje výrobce pro daný typ logických obvodů. Pokud výstup logického obvodu zatěžujeme pouze přiměřením počtem vstupů logických obvodů stejného typu, nemusíme se výstupními charakteristikami obvodu př́liš zabývat. Zátěží však může být dioda LED, elektromechanické relé, logické obvody jiného typu, nebo jakýkoliv jiný obvodový prvek. V tom př́ípadě již musíme vzít $\mathrm{v}$ úvahu specifika výstupních obvodů konkrétních typů logických obvodů.

\section{Typy výstupů logických obvodi̊}

U většiny logických obvodů se užívá dvojčinné zapojení se dvěma výstupními tranzistory, přičemž vždy vede pouze jeden z obou tranzistorů. Na Obr. 10.55 dva příklady provedení koncových stupňů pro obvody TTL a CMOS. Je zřejmé, že u obvodu TTL Obr. 10.55 ) budou značné rozdíly v povolených hodnotách výstupního proudu. Při úrovni $\mathrm{L}$ na výstupu (tranzistor $\mathrm{T}_{2}$ rozpojen, $\mathrm{T}_{3}$ sepnut) zřejmě problém $\mathrm{s}$ výstupním proudem tekoucím ze zátěže do tranzistoru $T_{3}$ nebude. Při úrovni $H$ ( $T_{2}$ sepnut, $T_{3}$ rozpojen) však proud tekoucí do zátěže vyvolá úbytek napětí na rezistoru $\mathrm{R}_{3}$. Proto výstupní proud v úrovni $\mathrm{H}$ bude menší než v úrovni L. Např. u obvodů 74ASL se povoluje $I_{\mathrm{OH}}=-0,4 \mathrm{~mA}$ (proud teče do zátěže), kdežto $I_{\mathrm{OL}}=8 \mathrm{~mA}$ (proud teče ze zátěže).
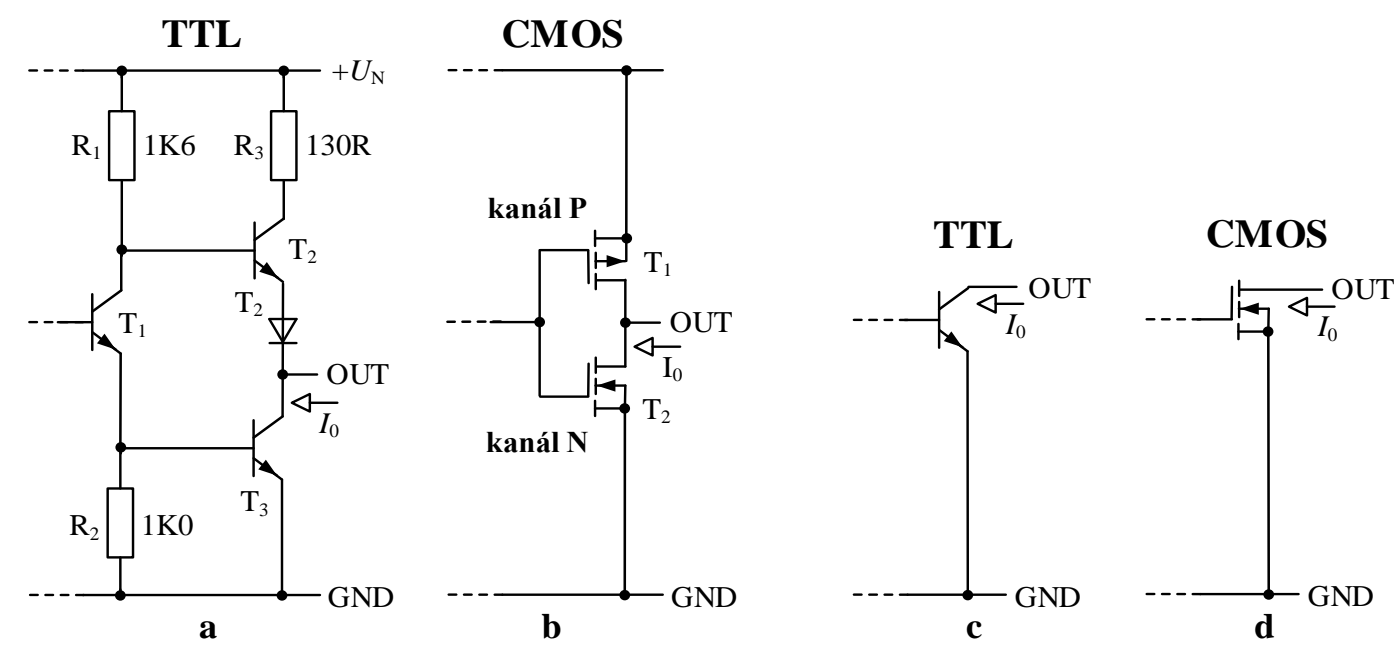

Obr. 10.55: Koncové stupně logických obvodů: a), b) dvojčinný výstup, c), d) výstup s otevřeným kolektorem

V př́padě koncového stupně s tranzistory CMOS Obr. 10.55b) budou vlastnosti výstupu obdobné, jak pro úroveň $\mathrm{H}$, tak i pro úroveň L. Doporučený výstupní proud se uvádí shodně, jak pro výstupní úroveň $\mathrm{H}$, tak i pro úroveň L. Např. u obvodů $74 \mathrm{HC}$ je doporučený výstupní proud maximálně $I_{\mathrm{O}}= \pm 5,2 \mathrm{~mA}$. Drobná odlišnost je pouze ve výstupním odporu př́ úrovni $\mathrm{H}$ 
a při úrovni $\mathrm{L}$, protože sepnutý tranzistor $\mathrm{T}_{1} \mathrm{~s}$ kanálem $\mathrm{P}$ vykazuje v sepnutém stavu odpor $R_{\mathrm{OH}}$ $\approx 100 \Omega$, kdežto tranzistor $\mathrm{T}_{2} \mathrm{~s}$ kanálem $\mathrm{N}$ má odpor $R_{\mathrm{OL}} \approx 50 \Omega$.

Pro buzení zátěží větším proudem jsou prakticky ve všech technologiích digitálních obvodů k dispozici invertory či hradla NAND s otevřeným kolektorem, jejichž proudová zatížitelnost výstupu je několikanásobně větší než u běžných typů. Pro obsluhu nestandardních zátěží se proto nejčastěji užívají digitální obvody s otevřeným kolektorem, kdy místo obvyklého dvojčinného zapojení se dvěma výstupními tranzistory je použit pouze jeden spínací tranzistor, jehož emitor (resp. source) je připojen na společný zemní vodič a kolektor (resp. drain) je vyveden z obvodu (viz Obr. 10.55ধ,d). Pro další využití je nezbytně nutné kolektor (drain) spojit přes rezistor či jinou zátěž s rozvodem napájecího napětí. Ve většině př́ípadů je možné připojit zátěž na vyšší napětí, než je napájecí napětí samotného logického obvodu.

Pro úplnost ještě poznamenejme, že existuje ještě tzv. tř́istavový výstup, který umožňuje uzavřít oba výstupní tranzistory tak, že výstup logického obvodu je zcela odpojen. Tyto obvody jsou určeny pro konstrukci digitálních sběrnic.

\section{Připojování zátěží při aktivní úrovni H}

$\mathrm{Na}$ Obr. 10.56 jou uvedeny příklady připojování zátěží k výstupům logických obvodů, kdy aktivním stavem je úroveň H na těchto výstupech. NaObr. 10.56 je ukázána možnost, jak pro větší proud tekoucí do zátěže použít pomocný spínací tranzistor. Pokud totiž potřebujeme zátěž budit $\mathrm{z}$ výstupu obvodu 74ASL, může do báze tranzistoru téct $\mathrm{v}$ úrovni $\mathrm{H}$ maximálně proud $I_{\mathrm{B}}=0,4 \mathrm{~mA}$. Protože tranzistor sepne při napětí $U_{\mathrm{BE}} \approx 0,7 \mathrm{~V}$, určí se odpor $R_{\mathrm{B}}$ podle vztahu $R_{\mathrm{B}}=\left(U_{\mathrm{OH}}-U_{\mathrm{BE}}\right) / I_{\mathrm{B}} \approx\left(U_{\mathrm{OH}}-0,7\right) / I_{\mathrm{B}}$. Aby bylo saturační napětí na sepnutém tranzistoru co nejmenší $U_{\mathrm{CES}} \approx 0,2 \mathrm{~V}$, doporučuje se volit $I_{\mathrm{B}} \approx(0,05$ až 0,1$) I_{\mathrm{C}}$. Odtud vyplývá, že proud LED diodou $I_{\mathrm{D}}$ může zvolit maximálně $I_{\mathrm{D}} \approx I_{\mathrm{B}} / 0,05=0,4 \mathrm{~mA} / 0,05=8 \mathrm{~mA}$. Odpor $R_{\mathrm{O}}$ pak určíme podle vztahu $R_{\mathrm{O}}=\left(U_{\mathrm{N}}-U_{\mathrm{D}}-U_{\mathrm{CES}}\right) / I_{\mathrm{D}}$.

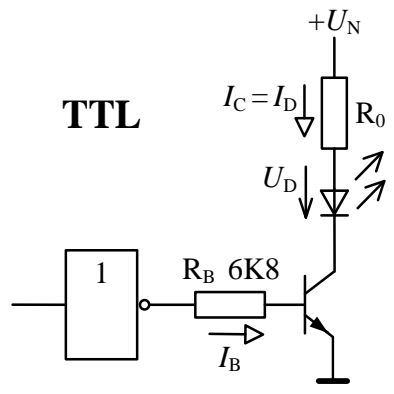

$\mathbf{a}$

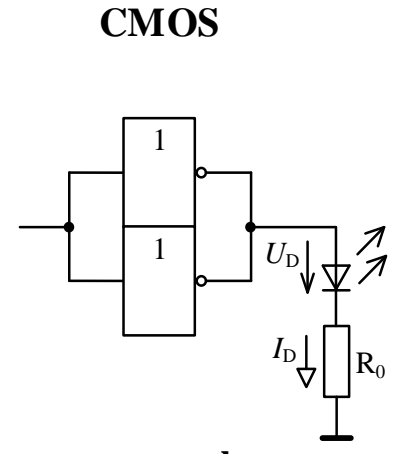

b

\section{CMOS}

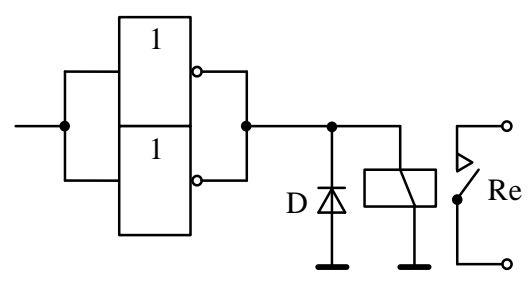

c

Obr. 10.56: Připojování zátěží při aktivní úrovni H na výstupu logického obvodu

Pokud máme větší zátěž připojit k obvodům CMOS, můžeme výstupní proud zvýšit paralelním spojením s dalším výstupem. Musíme však použít stejný typ obvodu a paralelně spojit nejen výstupy, ale i vstupy, aby bylo zaručeno časové krytí při přepínání paralelně spojených výstupů Obr. 10.56, c). Pokud použijeme např. obvody $74 \mathrm{HC}$ s výstupním proudem $I_{\mathrm{OH}} \approx 5,2 \mathrm{~mA}$, může pak do zátěže téct proud až $10,4 \mathrm{~mA}$. V prŕípadě spínání LED diody na Obr. 10.567 je tedy nutno volit proud diodou $I_{\mathrm{D}} \leq 10,4 \mathrm{~mA}$. Odpor $R_{\mathrm{O}}$ se pak určí podle vztahu $R_{\mathrm{O}}=\left(U_{\mathrm{OH}}-U_{\mathrm{D}}\right) / I_{\mathrm{D}}$. 
Pokud úrovní H chceme budit elektromechanické relé Obr. 10.56屯), musíme jej vybrat tak, aby proud ze spojených výstupů dokázal relé spolehlivě sepnout. Dioda D slouží jako ochrana proti přepětí na cívce relé v okamžiku, kdy se výstup logického obvodu př̀ene do úrovně L.

\section{Připojování zátěží při aktivní úrovni $L$}

$\mathrm{Na}$ Obr. 10.57 jsou nakresleny př́klady zapojení k výstupům logických úrovní, u nichž je aktivním stavem úroveň L. Na Obr. 10.57 je LED dioda ř́zena ze spojených výstupů logických obvodů. Rezistor Ro omezuje proud diodou na hodnotu $I_{\mathrm{D}}=\left(U_{\mathrm{N}}-U_{\mathrm{D}}-U_{\mathrm{OL}}\right) / R_{\mathrm{O}}$. $\mathrm{V}$ př́ipadě obvodů $74 \mathrm{HC}$ může téci diodou maximálně proud $I_{\mathrm{D}} \leq 2 I_{\mathrm{OL}} \approx 2 \cdot 5,2 \mathrm{~mA}=10,4 \mathrm{~mA}$.

Při požadavku na větší proud diodou LED použijeme některý logický obvod s otevřeným kolektorem nebo s otevřeným drainem (viz Obr. 10.57b). Jestliže je na tranzistor na výstupu logického obvodu rozpojen, teče diodou LED jen malý proud, který ji nerozsvítí. Pokud se výstupní tranzistor v logickém obvodu sepne, bude na výstupu napětí $U_{\mathrm{OL}} \approx 0,25$ až $0,5 \mathrm{~V}$ a proud LED diodou $I_{\mathrm{D}}$ bude určen rezistorem $R_{\mathrm{O}}=\left(U_{\mathrm{N}}-U_{\mathrm{D}}-U_{\mathrm{OL}}\right) / I_{\mathrm{D}}$.

Některé typy logických obvodů s otevřeným kolektorem dovolují připojení zátěže na vyšší napětí, než je napájení samotného logického obvodu (viz Obr. 10.57๕). Proud cívkou relé je omezen maximálním výstupním proudem logického obvodu. Paralelně k indukční zátěži je zapojena ochranná dioda $\mathrm{D}$, která ochrání výstup logického obvodu proti napětové špičce vznikající při odpojení indukční zátěže.

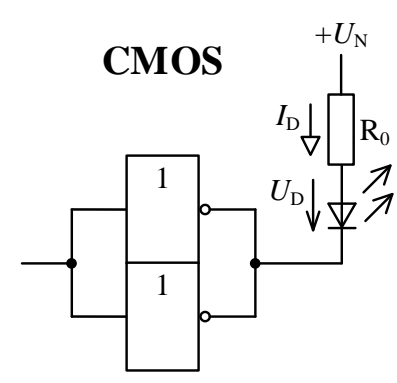

a

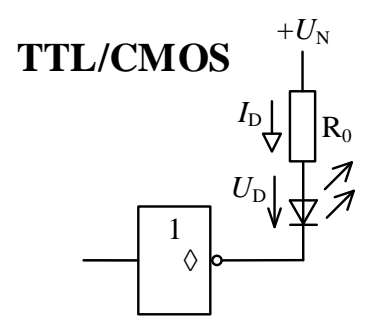

b

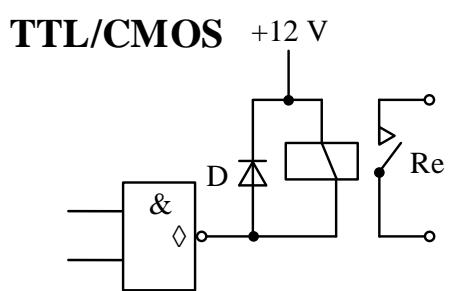

c

Obr. 10.57: Připojování zátěží při aktivní úrovni L na výstupu logického obvodu

\section{Spínání výkonových zátěží}

Zapojení na Obr. 10.58 používá pro spínání větších proudů do zátěže Darlingtonovo uspořádání malovýkonového $\left(\mathrm{T}_{1}\right)$ a výkonového $\left(\mathrm{T}_{2}\right)$ tranzistoru. Jako budicí obvod je použit logický obvod NAND s výstupem $\mathrm{s}$ otevřeným kolektorem, který aktivuje přes rezistor $\mathrm{R}_{0}$ budicí proud $I_{\mathrm{B}}$ do Darlingtonovy dvojice tranzistorů, pokud je výstupní tranzistor logického obvodu rozpojen. Aby byly tranzistory $\mathrm{T}_{1}$ a $\mathrm{T}_{2}$ dobře sepnuty, doporučuje se, aby $I_{\mathrm{B}}=(0,0025$ až 0,005$) I_{Z}$. Poznamenejme, že výstupní napětí logického obvodu bude $2 U_{\mathrm{BE}} \approx 2 \cdot 0,7=1,4$ $\mathrm{V}$ a není proto možné $\mathrm{z}$ výstupu logického obvodu budit vstupy jiných logických obvodů. Aby se tranzistor $\mathrm{T}_{2}$ rychleji zavíral, je $\mathrm{k}$ jeho přechodu $\mathrm{BE}$ paralelně zapojen rezistor $\mathrm{R}_{1}$, který urychluje odvod náboje $\mathrm{z}$ báze tranzistoru. 


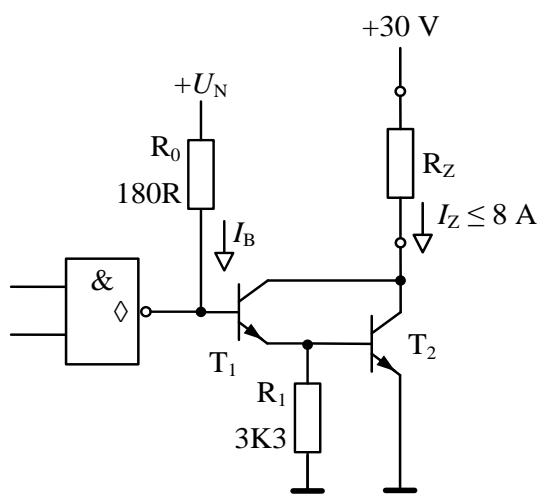

a

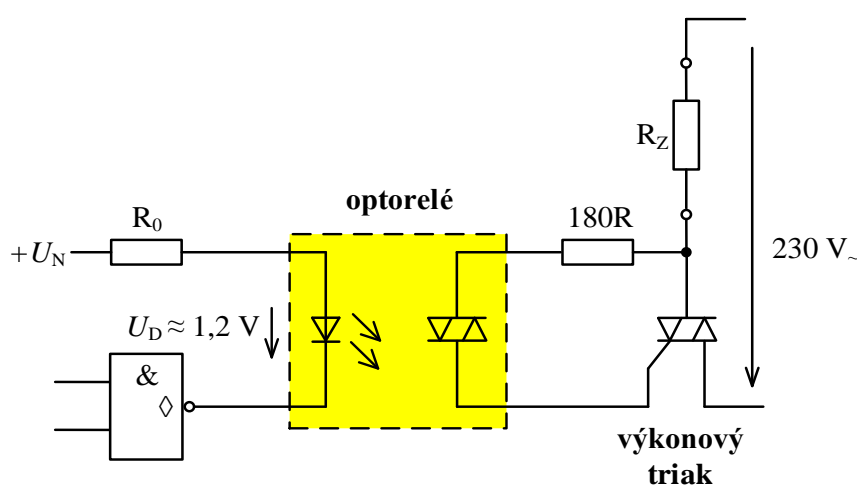

b

Obr. 10.58: Spínání výkonových zátěží

Pro spínání velkých proudů do zátěže je možné také použít výkonové tyristory nebo triaky. Na Obr. 10.58b je př́klad zapojení pro připojení zátěže $\mathrm{R}_{\mathrm{Z}} \mathrm{k}$ sít’ovému zdroji $230 \mathrm{~V}_{\sim}$ pomocí výkonového triaku. Ten je spínán pomocí optorelé, které obsahuje diodu LED a malovýkonový triak. Dioda LED se spíná logickým obvodem s otevřeným kolektorem. 


\section{Použitá literatura}

[1] TIETZE, U.; SCHENK, CH.; GAMM, E. Electronic Circuits: handbook for design and application. 2nd ed. New York: Springer-Verlag Berlin Heidelberg, 2008. ISBN 978-3540-00429-5.

[2] TIETZE, U.; SCHENK, CH. Electronic circuits: design and applications. Berlin: Springer-Verlag, 1991. ISBN 354050608x.

[3] DOSTÁL, J. Operational amplifiers. New York: Elsevier/North-Holland, 1981. ISBN 0444417133.

[4] DOSTÁL, J. Operační zesilovače. Praha: BEN - technická literatura, 2005. ISBN 8073000490.

[5] DOSTÁL, J. Operační zesilovače. Praha: SNTL Nakladatelství technické literatury, 1981.

[6] KESTER, W.; BRYANT, J.; BYRNE, M. Grounding Data Converters and Solving the Mystery of „AGND“ and „DGND“. MT-031 Tutorial, Analog Devices, 2008.

[7] FORTUNATO, M. Successful PCB grouding with mixed-signal chips-follow the path of least impedance. Tutorial 5450, Maxim Integrated 2017.

[8] ZUMBAHLEN, H.: Staying Well Grounded. Analog Devices, 2017.

[9] WAKERLY, J.F.: Digital design - principles and practices. Prentice Hall, 2001, ISBN 0-13-089896-1.

[10] BALCH, M.: Complete digital desigh. McGraw-Hill, 2003, ISBN 0-07-140927-0

[11] COLLIER, M. Digital Circuit Design: Principles and Practice, reateSpace Independent Publishing Platform; 1 edition 2014, ISBN-10: 1499686900.

[12] HALL, S.H., High-Speed Digital System Design: A Handbook od Interconnect Theory and Design Practices 1st Edition, Wiley-IEEE Press; 1 edition, 2000, ISBN-10: 0471360902.

[13] KAY A., GREEN, T. Pocket Reference, Ebook, WWW.TI.COM/ANALOGREFGUIDE, Fourth Edition, 2015 Download eBook.

[14] STTEFFAN, P.; VRBA R. Návrh systémů s digitálními integrovanými obvody a mikroprocesory pro integrovanou výuku VUT a VŠB-TUO, BRNO, 2014.

[15] MUSIL, V.; ŠTEFFAN, P. Digitální integrované obvody. Skriptum FEKT VUT v Brně, BRNO, 2006.

[16] TEXAS INSTRUMENT. Single-bit Dual-supply Buffered Voltage Signal Converter 2N7001T-Q1. Data sheet, Texas Instrument, 2020.

[17] TEXAS INSTRUMENT. Single Power Supply 2-Input Positive NOR Gate CMOS Logic Level Shifter. Data sheet, Texas Instruments, 2014.

[18] TEXAS INSTRUMENTS. Configurable Multiple-Function Gate SN74LVC1G57 and SN74LVC1G58. Texas Instruments, 2013.

[19] GLEN, Ch. A. Configurable logic gates' Schmitt inputs make versatile monostables. EDN Magazine, May 25, 2006, p. $94-96$.

[20] TEXAS INSTRUMENTS. HCMOS Design Consideration. Texas Instruments, 2002.

[21] TEXAS INSTRUMENTS. Design With Logic. Texas Instruments, 1997. 